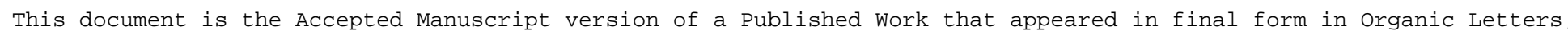

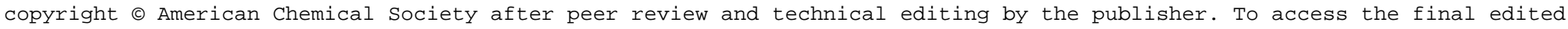
and published work see https://pubs.acs.org/doi/10.1021/acs.orglett.0c01150

\title{
Copper-Catalyzed Oxyvinylation of Diazo Compounds
}

\author{
Guillaume Pisella, Alec Gagnebin and Jerome Waser*
}

Laboratory of Catalysis and Organic Synthesis, Institut des Sciences et Ingénierie Chimique, Ecole Polytechnique Fédérale de Lausanne, CH-1015, Lausanne, Switzerland

Supporting Information Placeholder

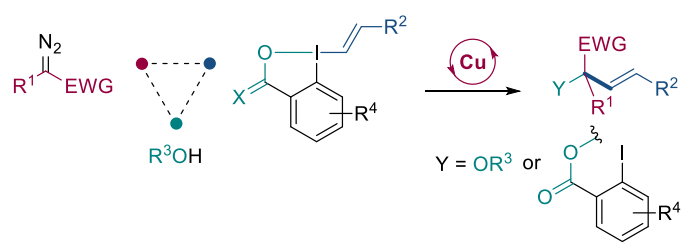

\begin{abstract}
A copper(I)-catalyzed vinylation of diazo compounds with VinylBenziodoXolone reagents (VBX) as partners is reported. The transformation tolerates diverse functionalities on both reagents delivering polyfunctionalized vinylated products. The strategy was successfully extended to a three-component/intermolecular version with alcohols. The obtained products contain synthetically versatile functional groups, such as an aryl iodide, an ester and an allylic leaving group, enabling further modification.
\end{abstract}

Metal carbenes obtained from diazo compounds have been extensively used in synthetic chemistry ${ }^{1}$ and their gem-difunctionalization is a powerful method to access complex products (Scheme 1A). ${ }^{2}$ The formation of at least one new C-C bond in this process has been realized for alkylation, arylation and alkynylation reactions using palladium, ${ }^{3}$ copper $^{4}$ and rhodium ${ }^{5}$ catalysis. The most successful approaches involve cross-coupling through carbene migratory insertion (path a), ${ }^{2 \mathrm{~b}}$ or trapping of transient ylides with carbon electrophiles (path b). ${ }^{2 a}$

The introduction of an olefin in such processes has been limited to the formation of a $\mathrm{C}$-alkenyl and a $\mathrm{C}-\mathrm{H}$ bond, ${ }^{6}$ with the exception of a palladium-catalyzed cross-coupling combining vinylhalides and nucleophiles (Scheme 1B). ${ }^{7}$ The reaction proceeds via a $\pi$-allyl palladium species, resulting in a 1,3 relationship between the nucleophile and the vinyl group. We considered a reverse approach to develop an unprecedented 1,1-oxyvinylation: Addition of an oxygen nucleophile first, followed by reaction with an electrophilic hypervalent iodine vinylation reagent (Scheme 1C). Our group established an efficient coppercatalyzed 1,1-oxyalkynylation of diazo compounds based on the use of electrophilic ethynylbenziodoxolone (EBX) hypervalent iodine reagents. ${ }^{8,9}$ To develop the first direct vinylation of diazo compounds, we envisaged the use of the corresponding vinylbenziodoxolone (VBX) reagents recently reported by Olofsson and co-workers. ${ }^{10}$

In this work, we report a copper-catalyzed insertion of diazo compounds into VBX reagents proceeding with broad scope at room temperature. The transformation was successfully extended to the synthesis of allylic ethers using alcohols as external nucleophiles.
Scheme 1. General difunctionalization of metal carbenes (A) and vinylation of diazo compounds ( $B$ and $C$ ).

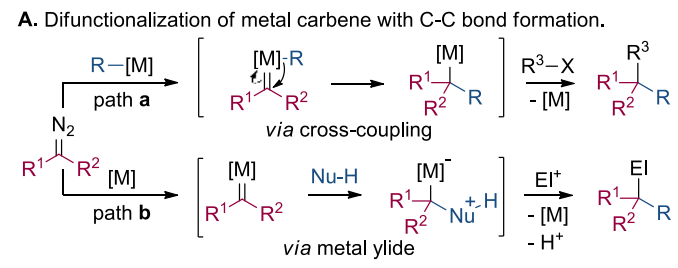

B. Palladium-catalyzed vinylation via $\pi$-allyl intermediates.

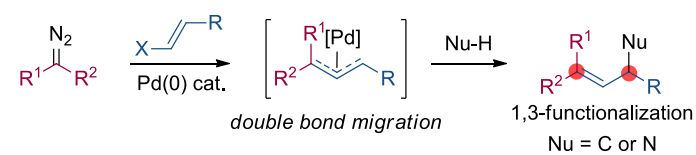

C. This Work: Direct vinylation of diazo compounds.

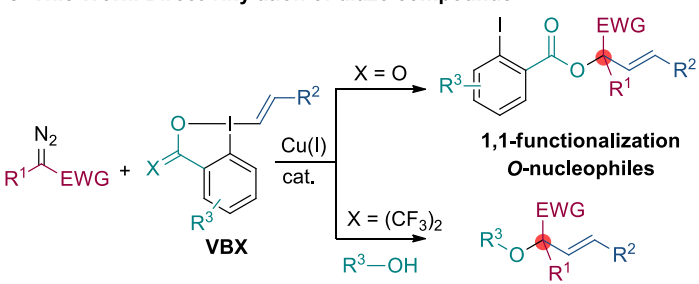

We started our optimization by reacting Ph-VBX (1a) with ethyl diazoacetate (2a) (Table 1; See Supporting Information for other tested conditions, Table S1). No desired product was isolated without copper catalyst or ligand (entries 1 and 2). Allylic ester $\mathbf{4 a}$ was formed in $90 \%$ yield when $\mathrm{Cu}\left(\mathrm{CH}_{3} \mathrm{CN}\right)_{4} \mathrm{BF}_{4}$ (4 mol\%) was used in combination with diimine $\mathbf{3 a}(5 \mathrm{~mol} \%)$ (entry 3). ${ }^{8 a}$ A lower yield was obtained with more electron-rich VBX 1c (entry 4). No reaction occurred using the alkyl-substituted substrate $\mathbf{1 j}$ even at a higher temperature (entry 5). We therefore investigated bisoxazoline (BOX) ligands, which had 
also been successful in our previous work. ${ }^{8 \mathrm{~b}}$ Using $t \mathrm{Bu}-\mathrm{BOX}$ ligand $\mathbf{3 b}$ the reaction could be performed in one hour at room temperature to give $\mathbf{4 a}$ in $95 \%$ yield as a racemate (entry 6 ). The non-chiral ligand 3c gave a similar result (entry 7). These conditions performed well with the more electron-rich and aliphatic substrates (entries 8 and 9), but were not successful for substituted diazo compound $\mathbf{2 b}$ (entry 10). Product $5 \mathbf{a}$ could be obtained in $80 \%$ yield using ligand $\mathbf{3 a}$ (entry 11 ). In all reactions, only the $E$-olefin was obtained.

Table 1. Optimization of the insertion of diazo compounds 2a and $2 b$ into $\operatorname{VBX}(1){ }^{a}$

2b, $\mathrm{R}^{1}=\mathrm{Ph}$
ntry ligand

${ }^{\text {aReactions on }} 0.10 \mathrm{mmol}$ scale with 2.0 equiv. of $2,4 \mathrm{~mol} \%$ of $\mathrm{Cu}\left(\mathrm{CH}_{3} \mathrm{CN}\right)_{4} \mathrm{BF}_{4}, 5 \mathrm{~mol} \%$ of ligand in DCE $(0.04 \mathrm{M})$. ' Isolated yields. ${ }^{\mathrm{c}}$ Without $\mathrm{Cu}\left(\mathrm{CH}_{3} \mathrm{CN}\right)_{4} \mathrm{BF}_{4} .{ }^{\mathrm{d}} \mathrm{On} 0.20 \mathrm{mmol}$ scale. $\mathrm{Ph}=$ phenyl, Cy = cyclohexyl, PMP = para-methoxyphenyl.

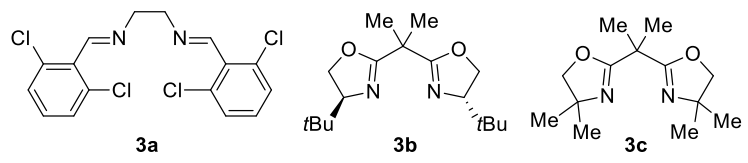

Diverse aryl-substituted VBXs were then explored with ethyl diazoacetate (2a) (Scheme 2A). ${ }^{11}$ Electron donating ether and alkyl groups on the arene afforded products $\mathbf{4 b - c}$ in $81 \%$ and $92 \%$ yields. Fluorinated compounds $\mathbf{4 d}$ and $\mathbf{4 e}$ were obtained in $72 \%$ and $66 \%$ yield. A naphthyl-substituted VBX led to the formation of $\mathbf{4 f}$ in $81 \%$ yield. A slightly diminished yield was obtained for thiophene-substituted $\mathbf{4 g}$ (76\% yield). Both electronrich and -poor substituents on the benziodoxolone backbone were tolerated affording $\mathbf{4 h}$ and $\mathbf{4 i}$. Next, we turned our attention to alkyl-substituted VBX reagents (Scheme 2B). VBXs bearing aliphatic chains $(\mathrm{Cy}, \mathrm{Bn}$ and $n \mathrm{Pr}$ ) provided allylic esters $\mathbf{4 j - 1}$ in $90-99 \%$ yield. The incorporation of an ester (4m) or a chloride (4n) group could also be achieved. Trisubstituted alkene 40 was accessed in 97\% yield. VBXs with amines, silyl ethers, and chlorides in allylic position delivered the corresponding products $\mathbf{4 p - r}$. A lower yield was obtained for $\mathbf{4 p}$ and 4r, maybe due to the low solubility of the corresponding VBX reagents in DCE. $\pi$-Conjugated systems were readily incorporated (Scheme 2C). An isoprene skeleton was introduced to give $\mathbf{4 s}$ in $82 \%$ yield. Conjugated diene $\mathbf{4 t}$ and enyne $\mathbf{4 u}$ were also successfully synthesized.

\section{Scheme 2. Scope of VBX reagents.}
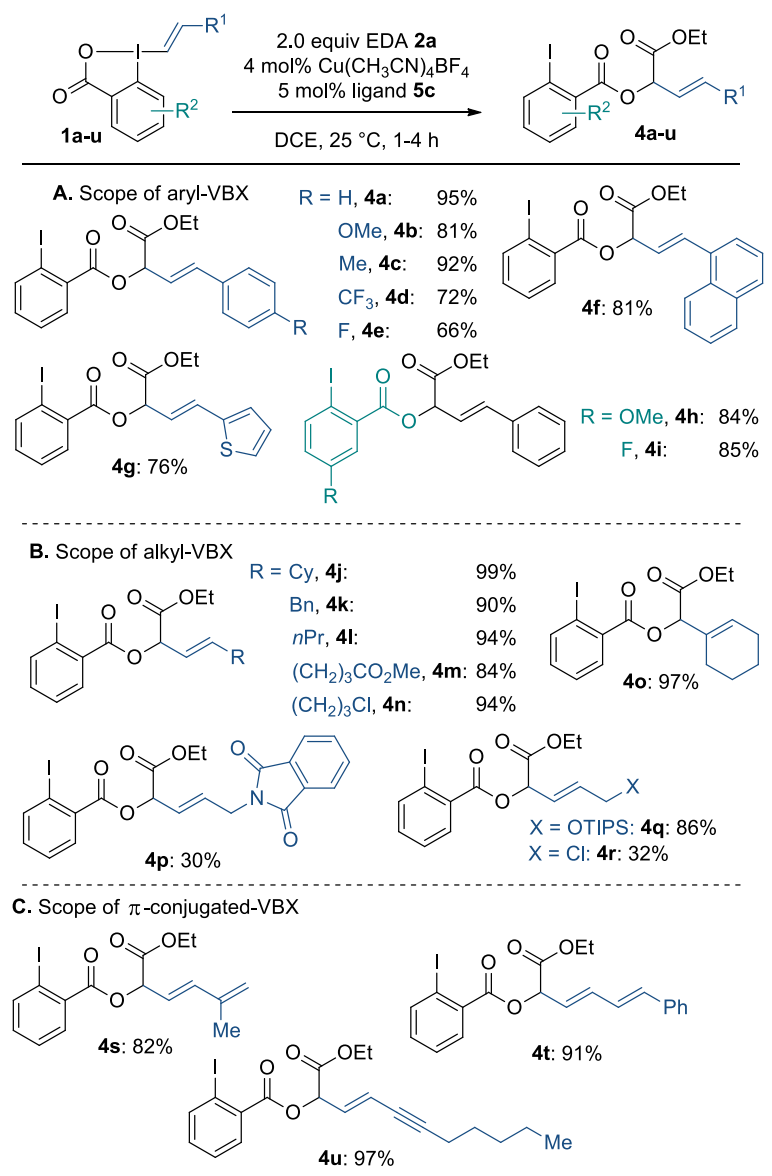

Reactions using VBX $1(0.2 \mathrm{mmol})$ and $\mathbf{2 a}(0.4 \mathrm{mmol})$ in DCE (0.04 M).

We next investigated the scope of the acceptor substituent on the diazo compounds (Scheme 3A). Various esters such as $t \mathrm{Bu}$ or BHT were tolerated giving $\mathbf{5 b}$ and $\mathbf{5 c}$ in quantitative yield. ${ }^{12}$ Product 5d bearing a benzyl group was obtained in $92 \%$ yield and 5e with an allyl group in 91\%. 2-Diazo- $N, N$-diethylacetamide provided $\mathbf{5 f}$ in $94 \%$ yield. Weinreb amide derivative $\mathbf{5 g}$ was isolated in $99 \%$ yield. Sulfonate- and phosphonate-diazo compounds were efficient coupling partners, generating products $\mathbf{5 h}$ and $\mathbf{5 i}$ in quantitative yields. ${ }^{13}$ Unfortunately, diazoketones underwent degradation through Wolff rearrangement $(\mathbf{5 j})$ and no conversion was obtained using trimethylsilyldiazomethane $(\mathbf{5 k}$, $0 \%$ yield). However, compound $\mathbf{5 l}$ incorporating a trifluoromethyl group was isolated in quantitative yield. Organofluorine compounds are important for the pharmaceutical, agrochemical and materials industry. ${ }^{14}$ Other less stable diazo compounds lacking an electron-withdrawing group were not yet investigated. Finally, the reaction of disubstituted diazo compounds was investigated using diimine ligand 3a (Scheme 3B). Products $\mathbf{5 a}$ and $\mathbf{5 m}$ with tertiary allylic centers were formed in 71 and $89 \%$ yield. A second electron-withdrawing group suppressed the reactivity $(\mathbf{5 n}, 0 \%$ yield). A cyclic diazo compound afforded the desired product $\mathbf{5 0}$ in $90 \%$ yield. Diene product $\mathbf{5 p}$ could be obtained in good yield when starting from a vinyl diazo precursor. Attack of the nucleophile at the vinylogous center was favored. ${ }^{15}$ 
Scheme 3. Scope of diazo compounds 2 .

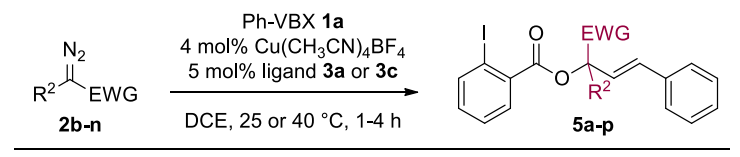

A. Scope of acceptor substituent EWG on diazo compound ${ }^{\mathrm{a}}$

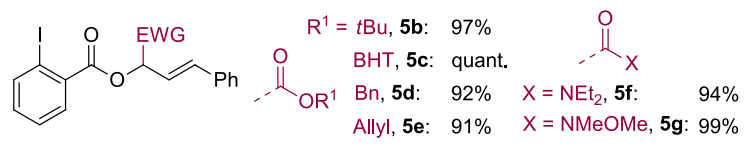

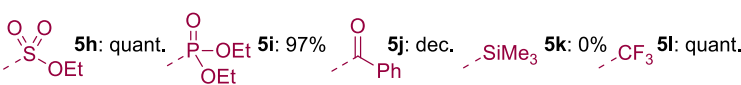

B. Scope of substituent $\mathrm{R}^{2}$ on diazo compound ${ }^{\mathrm{b}}$

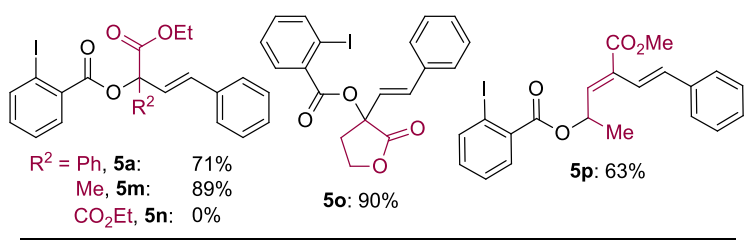

Reactions using Ph-VBX (1a) $(0.2 \mathrm{mmol})$ and $2(0.4 \mathrm{mmol})$ in DCE $(0.04 \mathrm{M}) .{ }^{\mathrm{a}} 3 \mathrm{C}$ as ligand at $25^{\circ} \mathrm{C}$. ${ }^{\mathrm{b}} 3 \mathrm{a}$ as ligand at $40{ }^{\circ} \mathrm{C}$.

We then investigated an enantioselective version of the reaction. Testing various substrates, chiral ligands and reaction conditions, we achieved a maximum of 75:25 er with ligand 3d for the formation of $\mathbf{5 c}$ (See Table S3 for details). ${ }^{16}$ Interestingly, with tert-amyl alcohol as co-solvent, we observed ${ }^{1} \mathrm{H}$ NMR signals tentatively assigned to allylic ether product $\mathbf{6 a}$ in the crude reaction mixture, in addition to expected $\mathbf{4 a}$ for the reaction of VBX 1a and 2a (Scheme 4A).

\section{Scheme 4. Extension to three-component reaction.}

A. Initial observation of a three-component diazovinylation reaction
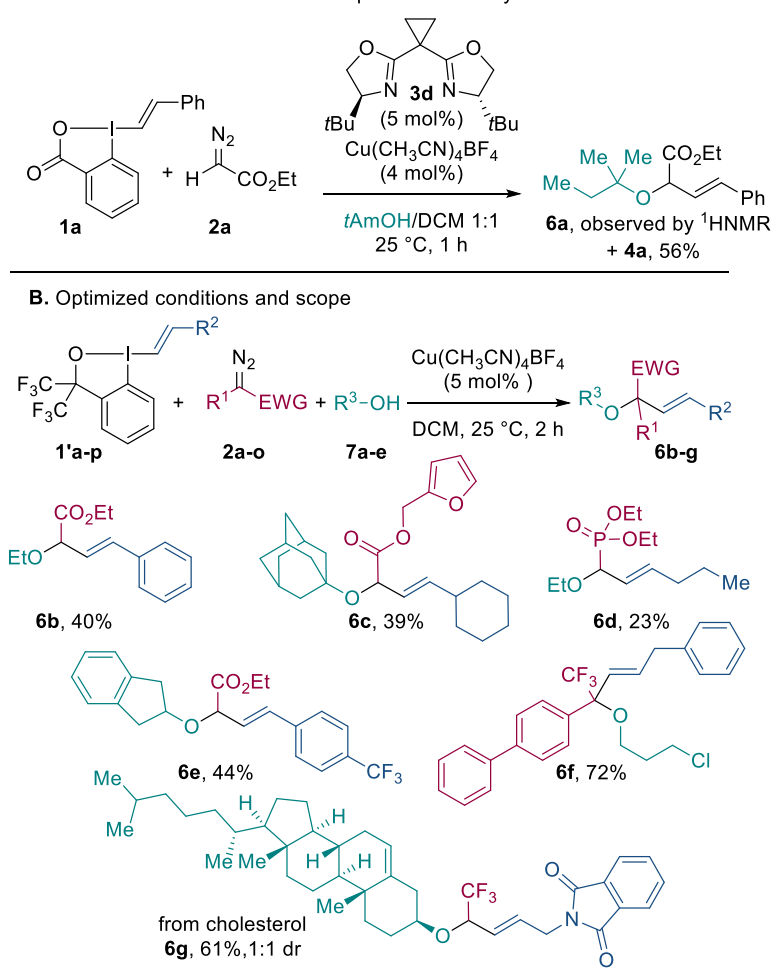

Reactions using VBX (1v-z) $(0.3 \mathrm{mmol})$ and $\mathrm{R}^{3} \mathrm{OH}(0.9 \mathrm{mmol})$ in DCM (0.075 M). Diazo 2 (0.6 mmol, 0.6 M in DCM) added via syringe pump over $1 \mathrm{~h}$.

To favor the three-component reaction, we used less nucleophilic bis-trifluoromethyl benziodoxole VBX 1' and removed the ligand (See Table S2 for details). ${ }^{17}$ With 3 equivalents of alcohol, the three-component products were obtained in 23 $72 \%$ yield (Scheme 4B). Primary, secondary and tertiary alcohols were combined with different VBXs and diazo compounds leading to functionalized allylic ethers bearing esters $(\mathbf{6 b}, \mathbf{6 c}$ and $\mathbf{6 e})$, phosphonate (6d), chloride (6f), furan (6c), indanyl (6e), adamantyl (6c) or trifluoromethyl (6e and $\mathbf{6 f})$ groups. The vinylation of cholesterol was achieved in $61 \%$ yield affording 6g with a trifluoromethyl and a phthalimide group.

Product 4a was synthesized on $2.0 \mathrm{mmol}$ scale using a lower catalyst loading at higher concentration (Scheme 5A). The esters groups in $\mathbf{4 a}$ were readily reduced with $\mathrm{LiAlH}_{4}$ to produce diol $\mathbf{8}$ (Scheme 5B). Butenolide 9 resulting from the formation of an $\alpha$-keto ester followed by dimerization was formed under basic conditions. Treatment of $\mathbf{4 a}$ with $\mathrm{TiCl}_{4}$ and allyl-TMS led to the formation of conjugated ester 10. Propargyl-TMS could also be used as nucleophile giving allene-containing product $\mathbf{1 1}$. The introduction of an azide was accomplished using $\mathrm{TMSN}_{3}$ to form 12, which isomerizes spontaneously. ${ }^{18}$ A Heck reaction between $\mathbf{5 m}$ and methyl acrylate afforded 13 in $66 \%$ yield. Hydrogenolysis of the iodoarene was achieved with hydrogen and poisoned $\mathrm{Pd} / \mathrm{C}$ to give product $\mathbf{1 4}$ in $77 \%$ yield. Visible light photoredox catalysis gave access to the deiodinated product $\mathbf{1 5}$ in $82 \%$ yield with $E$ to $Z$ isomerization of the olefin.

Scheme 5. Scale-up synthesis and product modifications.

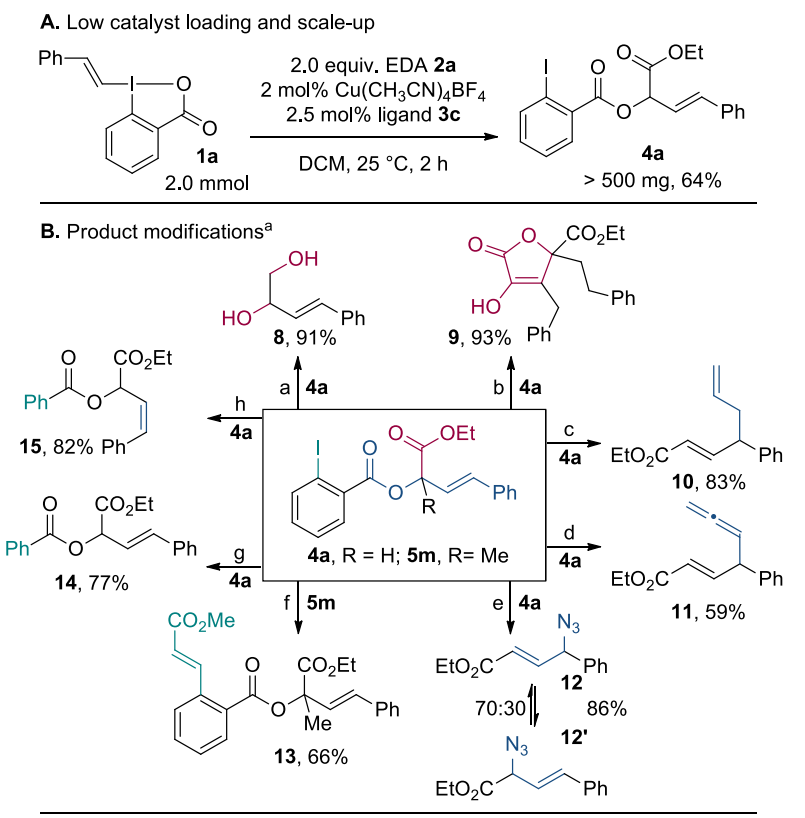

aReaction conditions: a) $\mathrm{LiAlH}_{4}$ (3.00 equiv.), THF, $0{ }^{\circ} \mathrm{C}$ to rt, 1 h, $91 \%$; b) DBU (10 equiv.), $\mathrm{MeOH}, 50{ }^{\circ} \mathrm{C}, 6 \mathrm{~h}, 93 \%$; c) AllylTMS (1.5 equiv.), $\mathrm{TiCl}_{4}$ (1.05 equiv.), $\mathrm{DCM}, 0^{\circ} \mathrm{C}, 15 \mathrm{~min}, 83 \%$; d) Propargyl-TMS (2.0 equiv.), $\mathrm{TiCl}_{4}$ (1.05 equiv.), $\mathrm{DCM},-78{ }^{\circ} \mathrm{C}$ to $0{ }^{\circ} \mathrm{C}, 59 \%$; e) $\mathrm{TMSN}_{3}$ ( 1.5 equiv.), $\mathrm{TiCl}_{4}$ (1.05 equiv.), DCM, $20{ }^{\circ} \mathrm{C}$ to $0{ }^{\circ} \mathrm{C}, \mathbf{1 2} / \mathbf{1 2}$ 70:30, 86\%; f) methyl acrylate (5.0 equiv.), $\mathrm{PdCl}_{2}\left(\mathrm{PPh}_{3}\right)_{3}(5 \mathrm{~mol} \%), \mathrm{PPh}_{3}(5 \mathrm{~mol} \%), \mathrm{Et}_{3} \mathrm{~N}, 80{ }^{\circ} \mathrm{C}, 24 \mathrm{~h}, 66 \%$; g) $\mathrm{H}_{2}, \mathrm{Pd} / \mathrm{C}(10 \mathrm{~mol} \%, 10 \% \mathrm{w} / \mathrm{w}), \mathrm{DABCO}$ (10 equiv.), $\mathrm{MeOH}, \mathrm{rt}$, 
$10 \mathrm{~min}, 77 \%$; h) $\mathrm{fac}-\operatorname{Ir}(\mathrm{ppy})_{3}(2.5 \mathrm{~mol} \%), \mathrm{NBu}_{3}$ (10 equiv.), $\mathrm{HCO}_{2} \mathrm{H}$ (10 equiv.), blue LED, MeCN, $40{ }^{\circ} \mathrm{C}, 18 \mathrm{~h}, 82 \%$.

Based on literature precedence and our work on the coppercatalyzed oxy-alkynylation reaction, ${ }^{8 a-c}$ a tentative reaction mechanism would involve an electrophilic copper-carbene generated from the diazo compound (See Scheme S1 in the Supporting Information). Nucleophilic attack of the carboxylate part of the VBX reagent or the alcohol nucleophile would generate an ylide intermediate, which is then vinylated.

In summary, we have developed a copper-catalyzed insertion of diazo compounds into vinylbenziodoxolone (VBX) reagents. The transformation provides access to a broad scope of functionalized allylic esters. ${ }^{19}$ Extension of the strategy to a threecomponent reaction with alcohol nucleophiles allowed the synthesis of structurally diverse allylic ethers. The obtained products can be further modified to give important building blocks. Ongoing research is focused on the elucidation of the reaction mechanism and the development of the asymmetric version of the transformation based on our preliminary results.

\section{ASSOCIATED CONTENT}

\section{Supporting Information}

Supplementary tables and schemes, experimental procedures and characterization data (NMR, IR, MS, X-ray). The Supporting Information is available free of charge on the ACS Publications website. Raw NMR, IR and MS data is available at zenodo.org, DOI: 10.5281/zenodo.3764827.

\section{AUTHOR INFORMATION}

\section{Corresponding Author}

*jerome.waser@epfl.ch

\section{ACKNOWLEDGMENT}

We thank ERC (European Research Council, Starting Grant iTools4MC, number 334840) and the Swiss National Science Foundation (SNSF, grant 200020_182798). We thank Dr R. Scopelliti and Dr F. F. Tirani from ISIC at EPFL for X-ray analysis. We thank Dr Durga Prasad Hari (University of Bristol) for insightful discussions during the project.

\section{REFERENCES}

(1) (a) Doyle, M. P.; Duffy, R.; Ratnikov, M.; Zhou, L. Catalytic Carbene Insertion into $\mathrm{C}-\mathrm{H}$ Bonds. Chem. Rev. 2010, 110, 704. (b) Ford, A.; Miel, H.; Ring, A.; Slattery, C. N.; Maguire, A. R.; McKervey, M. A. Modern Organic Synthesis with $\alpha$-Diazocarbonyl Compounds. Chem. Rev. 2015, 115, 9981 .

(2) (a) Guo, X.; Hu, W. Novel Multicomponent Reactions via Trapping of Protic Onium Ylides with Electrophiles. Acc. Chem. Res. 2013 46, 2427. (b) Xia, Y.; Qiu, D.; Wang, J. Transition-Metal-Catalyzed Cross-Couplings through Carbene Migratory Insertion. Chem. Rev. 2017, 117, 13810.

(3) Selected examples: (a) Chen, Z.-S.; Duan, X.-H.; Zhou, P.-X.; Ali, S.; Luo, J.-Y.; Liang, Y.-M. Palladium-Catalyzed Divergent Reactions of $\alpha$-Diazocarbonyl Compounds with Allylic Esters: Construction of Quaternary Carbon Centers. Angew. Chem. Int. Ed. 2012, 51, 1370. (b) Zhou, P.-X.; Zhou, Z.-Z.; Chen, Z.-S.; Ye, Y.-Y.; Zhao, L.-B.; Yang, Y.-F.; Xia, X.-F.; Luo, J.-Y.; Liang, Y.-M. Palladium-Catalyzed Insertion of $\alpha$-Diazocarbonyl Compounds for the Synthesis of Cyclic Amino Esters. Chem. Commun. 2013, 49, 561. (c) Qin, G.; Li, L.; Li, J.; Huang, H. Palladium-Catalyzed Formal Insertion of Carbenoids into Aminals via C-N Bond Activation. J. Am. Chem. Soc. 2015, 137 , 12490. (d) Liu, Z.; Tan, H.; Fu, T.; Xia, Y.; Qiu, D.; Zhang, Y.; Wang, J. Pd(0)-Catalyzed Carbene Insertion into Si-Si and Sn-Sn Bonds. $J$.
Am. Chem. Soc. 2015, 137, 12800. (e) Dai, Q.; Jiang, Y.; Guo, S.; Yu, J.-T.; Cheng, J. 3-Aza $\pi$-Allyl Palladium Derived from Imino Migration in Palladium-Carbene: MCRs toward Multiple Substituted Indole Skeleton. Chem. Commun. 2015, 51, 14781. (f) Gutiérrez-Bonet, Á.; Juliá-Hernández, F.; de Luis, B.; Martin, R. Pd-Catalyzed C(sp³)-H Functionalization/Carbenoid Insertion: All-Carbon Quaternary Centers via Multiple C-C Bond Formation. J. Am. Chem. Soc. 2016, 138, 6384. (g) Pérez-Gómez, M.; Hernández-Ponte, S.; Bautista, D.; GarcíaLópez, J.-A. Synthesis of Spiro-Oxoindoles through Pd-Catalyzed Remote $\mathrm{C}-\mathrm{H}$ Alkylation Using $\alpha$-Diazocarbonyl Compounds. Chem. Commun. 2017, 53, 2842.

(4) Selected examples: (a) Zhu, Y.; Zhai, C.; Yang, L.; Hu, W. Copper(II)-Catalyzed Highly Diastereoselective Three-Component Reactions of Aryl Diazoacetates with Alcohols and Chalcones: An Easy Access to Furan Derivatives. Chem. Commun. 2010, 46, 2865. (b) Wang, C.; Ye, F.; Wu, C.; Zhang, Y.; Wang, J. Construction of All-Carbon Quaternary Centers through Cu-Catalyzed Sequential Carbene Migratory Insertion and Nucleophilic Substitution/Michael Addition. J. Org. Chem. 2015, 80, 8748. (c) Lefebvre, Q.; Fava, E.; Nikolaienko, P.; Rueping, M. Hydrotrifluoromethylthiolation of $\alpha$-Diazo Esters - Synthesis of $\alpha-\mathrm{SCF}_{3}$ Substituted Esters. Chem. Commun. 2014, 50, 6617. (d) Lv, X.; Kang, Z.; Xing, D.; Hu, W. Cu(I)-Catalyzed Three-Component Reaction of Diazo Compound with Terminal Alkyne and Nitrosobenzene for the Synthesis of Trifluoromethyl Dihydroisoxazoles. Org. Lett. 2018, 20, 4843. (e) Alavala, G. K. R.; Sajjad, F.; Shi, T.; Kang, Z.; Ma, M.; Xing, D.; Hu, W. Diastereoselective Synthesis of Isochromans via the $\mathrm{Cu}$ (II)-Catalysed Intramolecular Michael-Type Trapping of Oxonium Ylides. Chem. Commun. 2018, 54, 12650.

(5) Selected examples: (a) Huang, H.; Guo, X.; Hu, W. Efficient Trapping of Oxonium Ylides with Imines: A Highly Diastereoselective Three-Component Reaction for the Synthesis of $\beta$-Amino- $\alpha$-Hydroxyesters with Quaternary Stereocenters. Angew. Chem. Int. Ed. 2007, 46, 1337. (b) Hu, W.; Xu, X.; Zhou, J.; Liu, W.-J.; Huang, H.; Hu, J.; Yang, L.; Gong, L.-Z. Cooperative Catalysis with Chiral Brønsted Acid$\mathrm{Rh}_{2}(\mathrm{OAc})_{4}$ : Highly Enantioselective Three-Component Reactions of Diazo Compounds with Alcohols and Imines. J. Am. Chem. Soc. 2008, 130, 7782. (c) Guan, X.-Y.; Yang, L.-P.; Hu, W. Cooperative Catalysis in Multicomponent Reactions: Highly Enantioselective Synthesis of $\gamma$ Hydroxyketones with a Quaternary Carbon Stereocenter. Angew. Chem. Int. Ed. 2010, 49, 2190. (d) Jia, S.; Xing, D.; Zhang, D.; Hu, W. Catalytic Asymmetric Functionalization of Aromatic C-H Bonds by Electrophilic Trapping of Metal-Carbene-Induced Zwitterionic Intermediates. Angew. Chem. Int. Ed. 2014, 53, 13098. (e) Tsoi, Y.-T.; Zhou, Z.; Yu, W.-Y. Rhodium-Catalyzed Cross-Coupling Reaction of Arylboronates and Diazoesters and Tandem Alkylation Reaction for the Synthesis of Quaternary $\alpha, \alpha$-Heterodiaryl Carboxylic Esters. Org. Lett. 2011, 13, 5370. (f) Hyster, T. K.; Ruhl, K. E.; Rovis, T. A Coupling of Benzamides and Donor/Acceptor Diazo Compounds To Form $\gamma$-Lactams via Rh(III)-Catalyzed C-H Activation. J. Am. Chem. Soc. 2013, 135, 5364. (g) Ye, B.; Cramer, N. Asymmetric Synthesis of Isoindolones by Chiral Cyclopentadienyl-Rhodium(III)-Catalyzed $\mathrm{C}-\mathrm{H}$ Functionalizations. Angew. Chem. Int. Ed. 2014, 53 , 7896. (h) Xia, Y.; Liu, Z.; Liu, Z.; Ge, R.; Ye, F.; Hossain, M.; Zhang, Y.; Wang, J. Formal Carbene Insertion into C-C Bond: $\mathrm{Rh}(\mathrm{I})$-Catalyzed Reaction of Benzocyclobutenols with Diazoesters. J. Am. Chem. Soc. 2014, 136, 3013. (i) Xia, Y.; Feng, S.; Liu, Z.; Zhang, Y.; Wang, J. Rhodium(I)Catalyzed Sequential C $(\mathrm{sp})-\mathrm{C}\left(\mathrm{sp}^{3}\right)$ and $\mathrm{C}\left(\mathrm{sp}^{3}\right)-\mathrm{C}\left(\mathrm{sp}^{3}\right)$ Bond Formation through Migratory Carbene Insertion. Angew. Chem. Int. Ed. 2015, 54, 7891. (j) Yada, A.; Fujita, S.; Murakami, M. Enantioselective Insertion of a Carbenoid Carbon into a C-C Bond To Expand Cyclobutanols to Cyclopentanols. J. Am. Chem. Soc. 2014, 136, 7217. (k) Alamsetti, S. K.; Spanka, M.; Schneider, C. Synergistic Rhodium/Phosphoric Acid Catalysis for the Enantioselective Addition of Oxonium Ylides to $\mathrm{Or}$ tho-Quinone Methides. Angew. Chem. Int. Ed. 2016, 55, 2392.

(6) (a) Brown, H. C.; Salunkhe, A. M. Stereoselective Synthesis of cis- and trans- $\beta, \gamma$-Unsaturated Carboxylic Esters via Reaction of 1Alkenyldichloroboranes with Ethyl Diazoacetate. Synlett 1991, 1991, 684. (b) Peng, C.; Zhang, W.; Yan, G.; Wang, J. Arylation and Vinylation of $\alpha$-Diazocarbonyl Compounds with Boroxines. Org. Lett. 2009, 11, 1667. (c) Pérez-Aguilar, M. C.; Valdés, C. Olefination of Carbonyl Compounds through Reductive Coupling of Alkenylboronic Acids and 
Tosylhydrazones. Angew. Chem. Int. Ed. 2012, 51, 5953. For a review, see: (d) Li, H.; Zhang, Y.; Wang, J. Reaction of Diazo Compounds with Organoboron Compounds. Synthesis 2013, 45, 3090.

(7) Selected examples: (a) Devine, S. K. J.; Van Vranken, D. L. Palladium-Catalyzed Carbene Insertion into Vinyl Halides and Trapping with Amines. Org. Lett. 2007, 9, 2047. (b) Devine, S. K. J.; Van Vranken, D. L. Palladium-Catalyzed Carbene Insertion and Trapping with Carbon Nucleophiles. Org. Lett. 2008, 10, 1909. (c) Kudirka, R.; Devine, S. K. J.; Adams, C. S.; Van Vranken, D. L. Palladium-Catalyzed Insertion of $\alpha$-Diazoesters into Vinyl Halides To Generate $\alpha, \beta$ Unsaturated $\gamma$-Amino Esters. Angew. Chem. Int. Ed. 2009, 48, 3677. (d) Khanna, A.; Maung, C.; Johnson, K. R.; Luong, T. T.; Van Vranken, D. L. Carbenylative Amination with $N$-Tosylhydrazones. Org. Lett. 2012, 14, 3233. (e) Zhou, P.-X.; Ye, Y.-Y.; Liang, Y.-M. Palladium-Catalyzed Insertion of $N$-Tosylhydrazones and Trapping with Carbon Nucleophiles. Org. Lett. 2013, 15, 5080. (f) Xia, Y.; Xia, Y.; Zhang, Y.; Wang, J. Palladium-Catalyzed Coupling of $N$-Tosylhydrazones and $\beta$-Bromostyrene Derivatives: New Approach to $2 \mathrm{H}$ Chromenes. Org. Biomol. Chem. 2014, 12, 9333.

(8) (a) Hari, D. P.; Waser, J. Copper-Catalyzed Oxy-Alkynylation of Diazo Compounds with Hypervalent Iodine Reagents. J. Am. Chem. Soc. 2016, 138, 2190. (b) Hari, D. P.; Waser, J. Enantioselective Copper-Catalyzed Oxy-Alkynylation of Diazo Compounds. J. Am. Chem. Soc. 2017, 139, 8420. (c) Pisella, G.; Gagnebin, A.; Waser, J., ThreeComponent Reaction for the Synthesis of Highly Functionalized Propargyl Ethers. Chem. Eur. J. 2020, DOI: 10.1002/chem.202001317. For other examples of multi-functionalization of diazo compounds with hypervalent iodine reagents, see: (d) Tao, J.; Tran, R.; Murphy, G. K. Dihaloiodoarenes: $\alpha, \alpha$-Dihalogenation of Phenylacetate Derivatives. $J$. Am. Chem. Soc. 2013, 135, 16312. (e) Yuan, W.; Eriksson, L.; Szabó, K. J. Rhodium-Catalyzed Geminal Oxyfluorination and OxytrifluoroMethylation of Diazocarbonyl Compounds. Angew. Chem. Int. Ed. 2016, $55,8410$.

(9) (a) Ochiai, M.; Masaki, Y.; Shiro, M. Synthesis and Structure of 1-Alkynyl-1,2-Benziodoxol-3(1H)-ones. J. Org. Chem. 1991, 56, 5511. (b) Zhdankin, V. V.; Kuehl, C. J.; Krasutsky, A. P.; Bolz, J. T.; Simonsen, A. J. 1-(Organosulfonyloxy)-3(1H)-1,2-benziodoxoles: Preparation and reactions with alkynyltrimethylsilanes. J. Org. Chem. 1996, 61, 6547. (c) Zhdankin, V. Benziodoxole-Based Hypervalent Iodine Reagents in Organic Synthesis. Curr. Org. Synth. 2005, 2, 121. (d) Yoshimura, A.; Zhdankin, V. V. Advances in Synthetic Applications of Hypervalent Iodine Compounds. Chem. Rev. 2016, 116, 3328. (e) Li, Y.; Hari, D. P.; Vita, M. V.; Waser, J. Cyclic Hypervalent Iodine Reagents for Atom-Transfer Reactions: Beyond Trifluoromethylation. Angew. Chem. Int. Ed. 2016, 55 , 4436. (f) Hari, D. P.; Caramenti, P.; Waser, J. Cyclic Hypervalent Iodine Reagents: Enabling Tools for Bond Disconnection via Reactivity Umpolung. Acc. Chem. Res. 2018, 51,3212 .

(10) (a) Stridfeldt, E.; Seemann, A.; Bouma, M. J.; Dey, C.; Ertan, A.; Olofsson, B. Synthesis, Characterization and Unusual Reactivity of Vinylbenziodoxolones-Novel Hypervalent Iodine Reagents. Chem.
Eur. J. 2016, 22, 16066. For further applications of the reagents, see: (b) Boelke, A.; Caspers, L. D.; Nachtsheim, B. J. $\mathrm{NH}_{2}$-Directed C-H Alkenylation of 2-Vinylanilines with Vinylbenziodoxolones. Org. Lett. 2017, 19, 5344. (c) Davies, J.; Sheikh, N. S.; Leonori, D. Photoredox Imino Functionalizations of Olefins. Angew. Chem. Int. Ed. 2017, 56, 13361; (d) Le Vaillant, F.; Garreau, M.; Nicolai, S.; Gryn'ova, G.; Corminboeuf, C.; Waser, J. Fine-Tuned Organic Photoredox Catalysts for Fragmentation-Alkynylation Cascades of Cyclic Oxime Ethers. Chem. Sci. 2018, 9, 5883.

(11) Aryl-VBX reagents were obtained in good yields using Olofsson's protocol (Ref. 10a). This method gave alkyl-VBX reagents in low yield only and a new method was developed to access this class of compounds. See Supporting Information for details.

(12) The structure of $\mathbf{5} \mathbf{c}$ was confirmed by X-ray analysis. The data is available at the Cambridge Crystallographic Data Center (ccdc number 1897009).

(13) (a) Enders, D.; Vignola, N.; Berner, O. M.; Harnying, W. Efficient Asymmetric Synthesis of $\alpha$-Alkylated Benzylic Methyl Sulfonates. Tetrahedron 2005, 61 , 3231. (b) Le Flohic, A.; Meyer, C.; Cossy, J. Reactivity of Unsaturated Sultones Synthesized from Unsaturated Alcohols by Ring-Closing Metathesis. Application to the Racemic Synthesis of the Originally Proposed Structure of Mycothiazole. Tetrahedron 2006, 62, 9017. (c) Rowe, B. J.; Spilling, C. D. Stereospecific $\mathrm{Pd}(0)$-Catalyzed Arylation of an Allylic Hydroxy Phosphonate Derivative: Formal Synthesis of (S)-(+)-ar-Turmerone. J. Org. Chem. 2003, 68, 9502. (d) Yan, B.; Spilling, C. D. Synthesis of Cyclopentenones via Intramolecular HWE and the Palladium-Catalyzed Reactions of Allylic Hydroxy Phosphonate Derivatives. J. Org. Chem. 2008, 73, 5385.

(14) Organofluorine Chemistry; Banks, R. E., Smart, B. E., Tatlow, J. C., Eds.; Springer US: Boston, MA, 1994.

(15) Hansen, J. H.; Davies, H. M. L. Vinylogous Reactivity of Silver(I) Vinylcarbenoids. Chem. Sci. 2011, 2, 457.

(16) This result contrasts with the excellent e.r. obtained in the corresponding alkynylation using a very similar catalyst system. Nevertheless, this is not so surprising, considering that the geometry of the alkenyl and the alkynyl reagents, as well as in a lesser measure their reactivity, are very different, leading to different interactions with the ligands in the transition state. Obviously, another type of ligands will be needed to achieve high enantioinduction in this case.

(17) This approach was also successful for the development of the first three-component oxylalkynylation of diazo compounds (Ref. 8c).

(18) Sawama, Y.; Nagata, S.; Yabe, Y.; Morita, K.; Monguchi, Y.; Sajiki, H. Iron-Catalyzed Chemoselective Azidation of Benzylic Silyl Ethers. Chem. Eur. J. 2012, 18, 16608.

(19) This part of the work has previously appeared in a preprint: Pisella, G.; Gagnebin, A.; Waser, J. Copper-Catalyzed Insertion of Diazo Compounds into Vinyl Hypervalent Iodine Reagents to Generate Allylic Esters. ChemRxiv. 2019, Preprint. https://doi.org/10.26434/chemrxiv.7892513.v1. 


\title{
Copper-Catalyzed Oxyvinylation of Diazo Compounds
}

\author{
Guillaume Pisella, Alec Gagnebin and Jerome Waser \\ Laboratory of Catalysis and Organic Synthesis, Ecole Polytechnique Fédérale de Lausanne, \\ EPFL SB ISIC LCSO, BCH 4306, 1015 Lausanne, Switzerland.
}

Supporting Information

(159 pages)

Author contributions: G. P. performed and planned the experiments and prepared the manuscript and the experimental part, A. G. performed the experiments as a laboratory technician in formation under the supervision of G. P., J. W. supervised the project, prepared the manuscript and corrected the experimental part.

Table of Contents

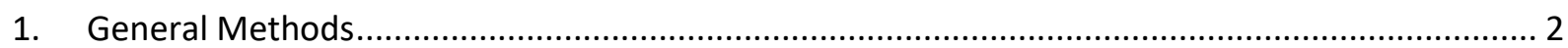

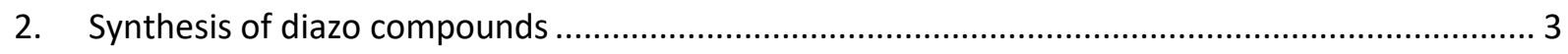

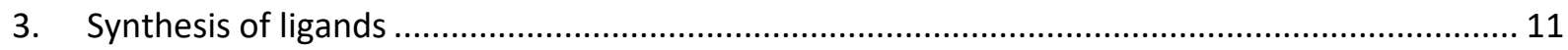

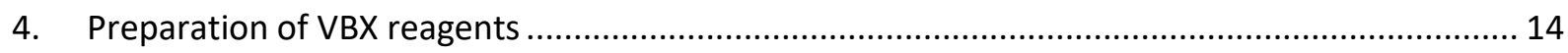

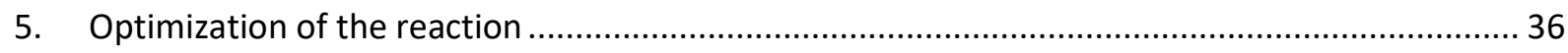

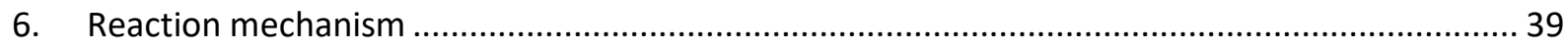

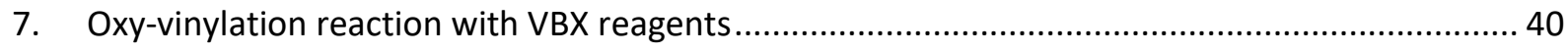

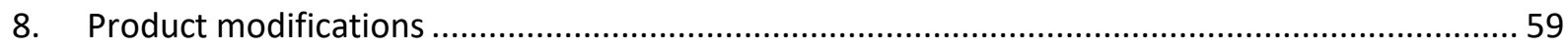

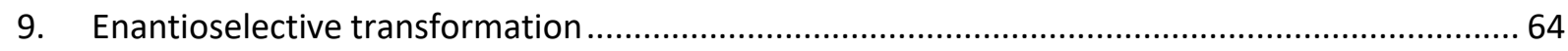

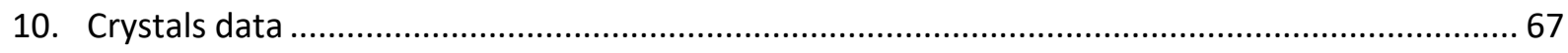

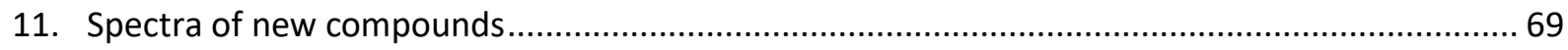




\section{General Methods}

All reactions were carried out in oven dried glassware under an atmosphere of nitrogen, unless stated otherwise. Heating was realized using heating blocks/mantles with external temperature control, unless indicated otherwise. For quantitative flash chromatography technical grade solvents were used. For flash chromatography for analysis, HPLC grade solvents from Sigma-Aldrich were used. THF, Et ${ }_{2} \mathrm{O}$, $\mathrm{CH}_{3} \mathrm{CN}$, toluene, hexane and $\mathrm{CH}_{2} \mathrm{Cl}_{2}$ were dried by passage over activated alumina under nitrogen atmosphere $\left(\mathrm{H}_{2} \mathrm{O}\right.$ content $<10 \mathrm{ppm}$, Karl-Fischer titration). The solvents were degassed by FreezePump-Thaw method when mentioned. All chemicals were purchased from Acros, Aldrich, Fluka, VWR, Aplichem or Merck and used as such unless stated otherwise. Chromatographic purification was performed as flash chromatography using Macherey-Nagel silica 40-63, $60 \AA$, using the solvents indicated as eluent with 0.1-0.5 bar pressure. TLC was performed on Merck silica gel 60 F254 TLC aluminium plates and visualized with UV light, permanganate stain, CAN stain or Anisaldehyde stain. Melting points were measured on a Büchi B-540 melting point apparatus using open glass capillaries, the data is uncorrected. ${ }^{1} \mathrm{H}$ NMR spectra were recorded on a Brucker DPX-400 $400 \mathrm{MHz}$ spectrometer in $\mathrm{CDCl}_{3}$, DMSO- $d_{6}$ or $\mathrm{CD}_{3} \mathrm{OD}$, all signals are reported in ppm with the internal chloroform signal at 7.26 $\mathrm{ppm}$, the internal DMSO signal at $2.50 \mathrm{ppm}$ or the internal methanol signal at $3.30 \mathrm{ppm}$ as standard. The data is being reported as $(\mathrm{s}=$ singlet, $\mathrm{d}=$ doublet, $\mathrm{t}=$ triplet, $\mathrm{q}=$ quadruplet, qi = quintet, $\mathrm{m}=$ multiplet or unresolved, $\mathrm{br}=$ broad signal, $\mathrm{app}=$ apparent, coupling constant(s) in $\mathrm{Hz}$, integration, interpretation). ${ }^{13} \mathrm{C}$ NMR spectra were recorded with ${ }^{1} \mathrm{H}$-decoupling on a Brucker DPX-400 $100 \mathrm{MHz}$ spectrometer in $\mathrm{CDCl}_{3}, \mathrm{DMSO}-d_{6}$ or $\mathrm{CD}_{3} \mathrm{OD}$, all signals are reported in ppm with the internal chloroform signal at $77.0 \mathrm{ppm}$, the internal DMSO signal at $39.5 \mathrm{ppm}$ or the internal methanol signal at $49.0 \mathrm{ppm}$ as standard. Infrared spectra were recorded on a JASCO FT-IR B4100 spectrophotometer with an ATR PRO410-S and a ZnSe prisma and are reported as $\mathrm{cm}^{-1}$ ( $\mathrm{w}=$ weak, $\mathrm{m}=$ medium, $\mathrm{s}=\mathrm{strong}$, $\mathrm{br}=$ broad). High resolution mass spectrometric measurements were performed by the mass spectrometry service of ISIC at the EPFL on a MICROMASS (ESI) Q-TOF Ultima API (Waters) or (APPI) LTQ Orbitrap ELITE ETD (Thermo Fisher). The raw data obtained from the Q-TOF Waters instrument does not take into account the mass of the electron for the ion, the obtained raw data has been therefore corrected by removing the mass of the electron $(5 \mathrm{mDa})$. HPLC measurements were done on a Agilent 1260 Infinity autosampler using a CHIRALPAK IA, IB, IC or ID column from DAICEL Chemical. The diffraction data for crystal structures were collected at low temperature using $\mathrm{Cu}(323)$ or Mo (520) $K_{\alpha}$ radiation on a Rigaku SuperNova dual system in combination with Atlas type CCD detector. The data reduction and correction were carried out by CrysAlis ${ }^{\text {Pro }}{ }^{1}$ The solutions and refinements were performed by SHELXT ${ }^{2}$ and $S H E L X L^{3}$, respectively. The crystal structures were refined using full-matrix least-squares based on $F^{2}$ with all non-H atoms defined in anisotropic manner. Hydrogen atoms were placed in calculated positions by means of the "riding" model. The blue LEDs were bought on www.conrad.ch/fr (Ruban LED avec câble à extrémités ouvertes Barthelme Y51516414 18240524 V 502 cm bleu 1 pc(s)).

\footnotetext{
${ }^{1}$ CrysAlis $^{\text {Pro }}$, Rigaku Oxford Diffraction, release 1.171.40.68a, 2019.

${ }^{2}$ SHELXT - Integrated space-group and crystal-structure determination, G. M. Sheldrick, Acta Crystallogr., Sect. A 2015, 71, 3.

${ }^{3}$ SHELXL - Crystal structure refinement, G. M. Sheldrick, Acta Crystallogr., Sect. C 2015, 71, 3.
} 


\section{Synthesis of diazo compounds}

CAUTION: Diazo compounds are toxic and potentially explosive and should be handled with care in a well-ventilated hood. ${ }^{4}$

Ethyl 2-diazoacetate (2a), tert-butyl 2-diazoacetate (2c) and benzyl 2-diazoacetate (2e) were directly purchased from Sigma Aldrich.<smiles>CCOC(=O)C=[W]</smiles>

2a<smiles>CC(C)(C)OC(=O)C=[W]</smiles>

2c<smiles>N=CC(=O)OCc1ccccc1</smiles>

$2 \mathrm{e}$

Ethyl 2-diazo-2-phenylacetate (4b)<smiles>CCOC(=O)Cc1ccccc1</smiles>

16

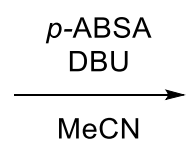

$\mathrm{MeCN}$<smiles>CCOC(=O)C(=N)c1ccccc1</smiles>

2b

Following a reported procedure, ${ }^{5} \mathrm{DBU}(1.50 \mathrm{~mL}, 10.0 \mathrm{mmol}, 2.00$ equiv) was added slowly to a stirred solution of ethyl 2-phenylacetate (16) $(0.80 \mathrm{~mL}, 5.0 \mathrm{mmol}, 1.00$ equiv) and p-ABSA (1.80 g, $7.50 \mathrm{mmol}$, 1.50 equiv) in dry $\mathrm{MeCN}(20 \mathrm{~mL})$ at $0{ }^{\circ} \mathrm{C}$. The reaction mixture was then allowed to warm to room temperature. After stirring for $14 \mathrm{~h}$, the reaction mixture was quenched with water $(15 \mathrm{~mL})$, and extracted with diethyl ether $(3 \times 15 \mathrm{~mL})$. The organic layers were combined and washed with $10 \% \mathrm{NH}_{4} \mathrm{Cl}$ $(20 \mathrm{~mL})$, brine $(20 \mathrm{~mL})$, dried over $\mathrm{MgSO}_{4}$, filtered and concentrated under reduced pressure. The crude product was purified by column chromatography using EtOAc:pentane 3:97 as mobile phase affording the corresponding ethyl 2-diazo-2-phenylacetate (2b) as a red oil $(0.80 \mathrm{~g}, 4.2 \mathrm{mmol}, 84 \%)$. ${ }^{1} \mathrm{H} \mathrm{NMR}(400$ $\left.\mathrm{MHz}, \mathrm{CDCl}_{3}\right): \delta 7.53-7.45(\mathrm{~m}, 2 \mathrm{H}, \mathrm{ArH}), 7.43-7.35(\mathrm{~m}, 2 \mathrm{H}, \operatorname{ArH}), 7.22-7.14(\mathrm{~m}, 1 \mathrm{H}, \mathrm{ArH}), 4.34(\mathrm{q}, J=$ $\left.7.1 \mathrm{~Hz}, 2 \mathrm{H}, \mathrm{OCH}_{2} \mathrm{CH}_{3}\right), 1.35\left(\mathrm{t}, J=7.1 \mathrm{~Hz}, 3 \mathrm{H}, \mathrm{OCH}_{2} \mathrm{CH}_{3}\right) .{ }^{13} \mathrm{C} \mathrm{NMR}\left(101 \mathrm{MHz}, \mathrm{CDCl}_{3}\right): \delta 165.2,128.8$, $125.6,125.6,124.0,61.1,14.6$. The values of the NMR spectra are in accordance with reported literature data. ${ }^{6}$ One carbon was not resolved at $101 \mathrm{MHz}$.

\section{2,6-Di-tert-butyl-4-methylphenyl 2-diazoacetate (2d)}<smiles>Cc1cc(C(C)(C)C)c(O)c(C(C)(C)C)c1</smiles>

16<smiles>CC1=CC(=O)OC(C)(C)O1</smiles>

17<smiles>CC(=O)CC(=O)Oc1c(C(C)(C)C)cc(C)cc1C(C)(C)C</smiles>

18

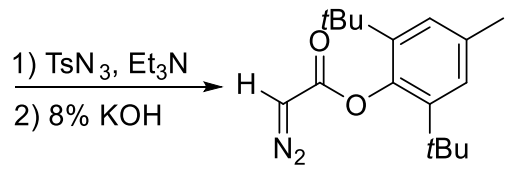

2d

Following a reported procedure, ${ }^{7}$ a mixture of 2,6-di-tert-butyl-4-methylphenol (16) $(5.51 \mathrm{~g}, 25.0$ mmol, 1.00 equiv), 2,2,6-trimethyl-4H-1,3-dioxin-4-one (17) (3.32 mL, $25.0 \mathrm{mmol}, 1.00$ equiv), and xylene $\left(5 \mathrm{~mL}\right.$ ) was stirred at $140{ }^{\circ} \mathrm{C}$ for $1.5 \mathrm{~h}$. After cooling to room temperature, the reaction mixture was directly loaded on silica and was purified by column chromatography using EtOAc:pentane 2:98 as mobile phase to afford 2,6-di-tert-butyl-4-methylphenyl 3-oxobutanoate (18) as a white solid (5.77 g,

\footnotetext{
${ }^{4}$ S. P. Green, K. M. Wheelhouse, A. D. Payne, J. P. Hallett, P. W. Miller and J. A. Bull, Org. Process Res. Dev. 2020, 24, 67.

${ }^{5}$ O. A. Davis, R. A. Croft and J. A. Bull, Chem. Commun., 2015, 51, 15446.

${ }^{6}$ H. Keipour and T. Ollevier, Org. Lett., 2017, 19, 5736.

${ }^{7}$ P. Müller and P. Polleux, Helv. Chim. Acta 1994, 77, 645.
} 
$19.0 \mathrm{mmol}, 76 \%)$. colorless thick oil $(5.00 \mathrm{~g}, 19.1 \mathrm{mmol}, 76 \%) .{ }^{1} \mathrm{H} \mathrm{NMR}\left(400 \mathrm{MHz}, \mathrm{CDCl}_{3}\right): \delta 12.08$ (s, $0.22 \mathrm{H}, \mathrm{OH}$ of enol form), $7.31-7.24(\mathrm{~m}, 1 \mathrm{H}, \mathrm{ArH}$ of enol and keto form), $7.24-7.18(\mathrm{~m}, 2 \mathrm{H}, \mathrm{ArH}$ of enol and keto form), $5.38\left(\mathrm{~s}, 0.2 \mathrm{H}\right.$, vinyl $\mathrm{H}$ of enol form), $3.81\left(\mathrm{~s}, 1.56 \mathrm{H}, \mathrm{CH}_{3} \mathrm{COCH}_{2}\right.$ of keto form), 3.03 (m, $2 \mathrm{H}, 2 \times \mathrm{CH}\left(\mathrm{CH}_{3}\right)_{2}$ of enol and keto form), $2.41\left(\mathrm{~s}, 2.32 \mathrm{H}, \mathrm{CH}_{3} \mathrm{COCH}_{2}\right.$ of keto form), 2.08 (s, $0.6 \mathrm{H}, \mathrm{CH}_{3}$ of enol form), $\left.1.28-1.21\left(\mathrm{~m}, 12 \mathrm{H}, 2 \times \mathrm{CH}\left(\mathrm{CH}_{3}\right)_{2}\right) ;{ }^{13} \mathrm{C} \mathrm{NMR} \mathrm{(101} \mathrm{MHz}, \mathrm{CDCl}_{3}\right)$, Enol form: $\delta$ 177.7, 171.5, $144.5,140.5,126.5,123.9,88.7,23.7,22.7,21.4 ;{ }^{13} \mathrm{C} \mathrm{NMR}\left(101 \mathrm{MHz}, \mathrm{CDCl}_{3}\right)$, Keto form: $\delta$ 199.9, 165.7, $145.1,140.2,126.8,124.0,49.6,30.4,27.4,27.3$. The values of the NMR spectra are in accordance with reported literature data. ${ }^{8}$

Following a reported procedure, ${ }^{7}$ to a solution of 2,6-di-tert-butyl-4-methylphenyl 3-oxobutanoate (18) $(5.48 \mathrm{~g}, 18.00 \mathrm{mmol}, 1.00$ equiv) in MeCN (22 mL) was added triethylamine ( $3.26 \mathrm{~mL}, 23.40 \mathrm{mmol}$, 1.30 equiv). The reaction mixture was cooled in an ice bath and a solution of tosyl azide ( $3.9 \mathrm{~g}, 19.8$ mmol, 1.1 equiv) in MeCN ( $22 \mathrm{~mL}$ ) was added slowly. The reaction mixture was allowed to warm to room temperature and stirred for $20 \mathrm{~h} .8 \%$ aqueous $\mathrm{KOH}$ solution $(90 \mathrm{~mL})$ was added and stirred vigorously for $4 \mathrm{~h}$. The reaction mixture was diluted with water $(50 \mathrm{~mL})$, extracted with diethyl ether $(3 \times 100 \mathrm{~mL})$. The combined organic layers were dried over $\mathrm{MgSO}_{4}$ and concentrated under reduced pressure. The crude product was purified by column chromatography using $\mathrm{Et}_{2} \mathrm{O}$ :pentane 2:98 as mobile phase to afford 2,6-di-tert-butyl-4-methylphenyl 2-diazoacetate (2d) as a yellow solid (4.80 g, $16.64 \mathrm{mmol}, 92 \%) .{ }^{1} \mathrm{H} \mathrm{NMR}\left(400 \mathrm{MHz}, \mathrm{CDCl}_{3}\right): \delta 7.12(\mathrm{~s}, 2 \mathrm{H}, \mathrm{ArH}), 5.00\left(\mathrm{~s}, 1 \mathrm{H}, \mathrm{CHN}_{2}\right), 2.32\left(\mathrm{~s}, 3 \mathrm{H}, \mathrm{ArCH}_{3}\right)$, $1.36(\mathrm{~s}, 18 \mathrm{H}, 2 \times t \mathrm{Bu}) ;{ }^{13} \mathrm{C} \mathrm{NMR}\left(101 \mathrm{MHz}, \mathrm{CDCl}_{3}\right): \delta 166.3,145.1,142.4,134.8,127.0,47.3,35.3,31.5$, 21.5. The values of the NMR spectra are in accordance with reported literature data. ${ }^{9}$

Allyl 2-diazoacetate (2f)

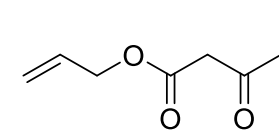

19

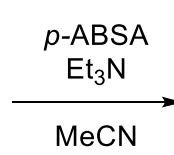

$\mathrm{MeCN}$<smiles>C=CCOC(=O)C(=N)C(C)=O</smiles>

20

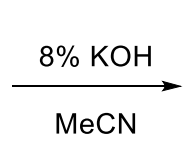

$\mathrm{MeCN}$

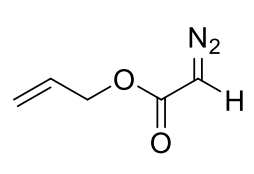

$2 f$

Following a reported procedure,,$^{10}$ to a solution of allyl acetoacetate (19) $(1.10 \mathrm{~mL}, 8.00 \mathrm{mmol}, 1.00$ equiv) and 4-acetamidobenzenesulfonyl azide $\left(2.11 \mathrm{~g}, 8.80 \mathrm{mmol}, 1.10\right.$ equiv) in $\mathrm{MeCN}(40 \mathrm{~mL})$ at $0{ }^{\circ} \mathrm{C}$ was added dropwise $\mathrm{Et}_{3} \mathrm{~N}(2.23 \mathrm{~mL}, 16.0 \mathrm{mmol}, 2.00$ equiv). The reaction mixture was allowed to warm to room temperature and stirred for $3 \mathrm{~h}$. The solvent was removed under reduced pressure. The residue was suspended in diethyl ether $(50 \mathrm{~mL})$ and the solid removed by filtration. The solvent was removed under reduced pressure. . The crude product was purified by column chromatography using EtOAc:pentane 15:85 as mobile phase to afford) allyl 2-diazo-3-oxobutanoate (20) as a yellow oil (1.23 g, $7.34 \mathrm{mmol}, 92 \%) .{ }^{1} \mathrm{H}$ NMR $\left(400 \mathrm{MHz}, \mathrm{CDCl}_{3}\right): \delta 5.94$ (ddt, $J=17.2,10.4,5.8 \mathrm{~Hz}, 1 \mathrm{H}, \mathrm{CHCH}_{2}$ ), $5.40-$ $5.26\left(\mathrm{~m}, 2 \mathrm{H}, \mathrm{CHCH}_{2}\right), 4.73\left(\mathrm{dt}, J=5.8,1.3 \mathrm{~Hz}, 2 \mathrm{H}, \mathrm{CH}_{2} \mathrm{O}\right), 2.48\left(\mathrm{~s}, 3 \mathrm{H}, \mathrm{CH}_{3}\right) ;{ }^{13} \mathrm{C} \mathrm{NMR}\left(101 \mathrm{MHz}, \mathrm{CDCl}_{3}\right): \delta$ $190.2,161.2,131.6,119.3,66.0,28.4$. One carbon was not resolved at $101 \mathrm{MHz}$. The values of the NMR spectra are in accordance with reported literature data. ${ }^{10}$

To a solution of allyl 2-diazo-3-oxobutanoate (20) $(0.840 \mathrm{~g}, 5.00 \mathrm{mmol}, 1.00$ equiv) in MeCN (15 mL) was added $8 \%$ aqueous $\mathrm{KOH}$ solution $(25 \mathrm{~mL})$ and the reaction mixture was stirred at room temperature for $4 \mathrm{~h}$. The reaction mixture was diluted with water $(15 \mathrm{~mL})$, extracted with diethyl ether $\left(3 \times 30 \mathrm{~mL}\right.$ ). The combined organic layers were dried over $\mathrm{MgSO}_{4}$ and concentrated under reduced pressure. The crude product was purified by column chromatography using EtOAc:pentane 10:90 as

\footnotetext{
${ }^{8}$ D. P. Hari and J. Waser, J. Am. Chem. Soc., 2017, 139, 8420.

${ }_{9}^{9}$ M. P. Doyle, V. Bagheri, T. J. Wandless, N. K. Harn, D. A. Brinker, C. T. Eagle and K. L. Loh, J. Am. Chem. Soc. 1990, 112, 1906.

${ }^{10}$ P. Müller, Y. F. Allenbach and S. Grass, Tetrahedron: Asymmetry, 2005, 16, 2007.
} 
mobile phase to afford allyl 2-diazoacetate (2f) as a yellow oil (154 mg, $1.22 \mathrm{mmol}, 24 \%) .{ }^{1} \mathrm{H}$ NMR (400 $\mathrm{MHz}, \mathrm{CDCl}_{3}$ ): $\delta 5.92$ (ddt, $\left.J=17.2,10.4,5.7 \mathrm{~Hz}, 1 \mathrm{H}, \mathrm{CHCH}_{2}\right), 5.38-5.20\left(\mathrm{~m}, 2 \mathrm{H}, \mathrm{CHCH}_{2}\right), 4.77(\mathrm{~s}, 1 \mathrm{H}$, $\left.\mathrm{CHN}_{2}\right), 4.65\left(\mathrm{dt}, J=5.7,1.5 \mathrm{~Hz}, 2 \mathrm{H}, \mathrm{CH}_{2} \mathrm{O}\right) ;{ }^{13} \mathrm{C} \mathrm{NMR}\left(101 \mathrm{MHz}, \mathrm{CDCl}_{3}\right): \delta 166.6,132.4,118.5,65.2,46.4$. The values of the NMR spectra are in accordance with reported literature data. ${ }^{11}$

\section{2-Diazo- $N, N$-diethylacetamide (2g)}

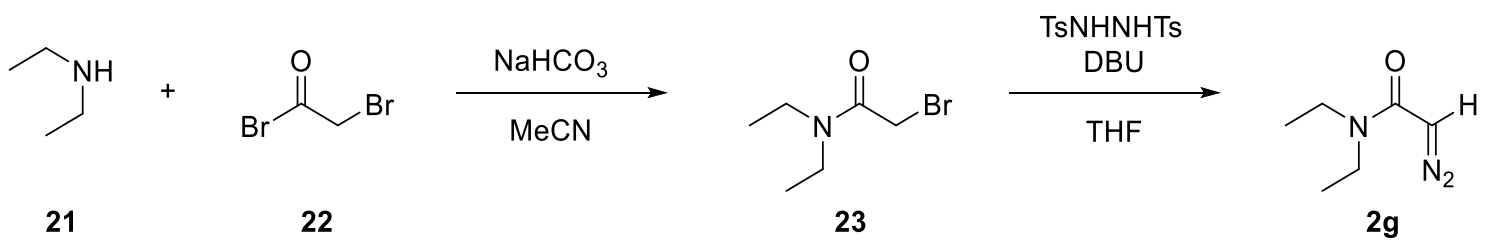

Following a reported procedure, ${ }^{12}$ diethyl amine (21) $\left(0.73 \mathrm{~g}, 10 \mathrm{mmol}, 1.0\right.$ equiv) and $\mathrm{NaHCO}_{3}(2.52 \mathrm{~g}$, $30.0 \mathrm{mmol}, 3.00$ equiv) were dissolved in dry $\mathrm{CH}_{2} \mathrm{Cl}_{2}(20 \mathrm{~mL})$ and bromoacetyl bromide (22) $(1.75 \mathrm{~mL}$, $20.0 \mathrm{mmol}, 2.00$ equiv) was added slowly at $0{ }^{\circ} \mathrm{C}$ and the reaction was stirred for $6 \mathrm{~h}$ at room temperature, quenched with $100 \mathrm{~mL}$ of $\mathrm{H}_{2} \mathrm{O}$ and the solution was extracted with $\mathrm{CH}_{2} \mathrm{Cl}_{2}(3 \times 50 \mathrm{~mL})$. The combined organic layers were washed with water $(100 \mathrm{~mL})$ and dried over $\mathrm{MgSO}_{4}$, the solvent was evaporated and the residue was used in the next step without purification. The resulting 2-bromo- $\mathrm{N}, \mathrm{N}$ diethylacetamide (23) and $N, N^{\prime}$-ditosylhydrazine $(2.10 \mathrm{~g}, 6.08 \mathrm{mmol}, 0.60$ equiv) were dissolved in dry THF $(20 \mathrm{~mL})$ and cooled down to $0{ }^{\circ} \mathrm{C}$, then DBU $(2.30 \mathrm{~mL}, 15.2 \mathrm{mmol}, 1.52$ equiv) was added dropwise and stirred at room temperature for $1 \mathrm{~h}$ and then quenched with saturated solution of $\mathrm{NaHCO}_{3}(50$ $\mathrm{mL}$ ) and extracted with diethyl ether $(3 \times 50 \mathrm{~mL})$. The combined organic layers were dried over anhydrous $\mathrm{MgSO}_{4}$. The solvent was removed under reduced pressure and purified by column chromatography using EtOAc:pentane 30:70 as mobile phase affording the corresponding 2-diazo$\mathrm{N}, \mathrm{N}^{\prime}$-diethylacetamide $(\mathbf{2 g})$ as a yellow oil $(0.725 \mathrm{~g}, 5.14 \mathrm{mmol}, 52 \%) .{ }^{1} \mathrm{H} \mathrm{NMR}\left(400 \mathrm{MHz}, \mathrm{CDCl}_{3}\right): \delta 4.92$ (s, $1 \mathrm{H}, \mathrm{CHN}_{2}$ ), 3.26 (br s, $\left.\left.4 \mathrm{H}, 2 \times \mathrm{CH}_{2} \mathrm{CH}_{3}\right), 1.14\left(\mathrm{t}, J=7.2 \mathrm{~Hz}, 6 \mathrm{H}, 2 \times \mathrm{CH}_{2} \mathrm{CH}_{3}\right) ;{ }^{13} \mathrm{C} \mathrm{NMR} \mathrm{(101} \mathrm{MHz,} \mathrm{CDCl}\right)_{3}$ : $165.8,46.4,41.4,13.9$. The values of the NMR spectra are in accordance with reported literature data. ${ }^{13}$

\section{2-Diazo- $N$-methoxy-N-methylacetamide (2h)}

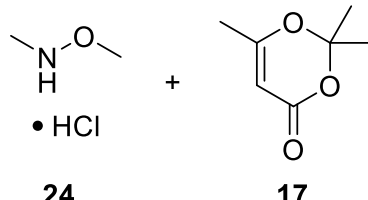

17
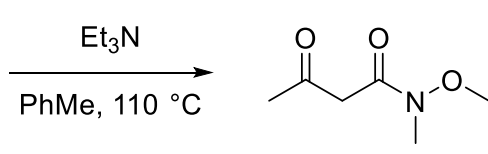

25

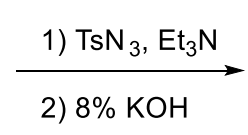

2) $8 \% \mathrm{KOH}$

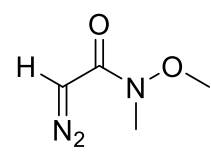

$2 \mathrm{~h}$

Following a reported procedure, ${ }^{14}$ a mixture of $\mathrm{N}, \mathrm{O}$-dimethylhydroxylamine hydrochloride (24) $(2.44$ g, $25.0 \mathrm{mmol}, 1.00$ equiv), 2,2,6-trimethyl-4H-1,3-dioxin-4-one (17) ( $5.00 \mathrm{~mL}, 37.5 \mathrm{mmol}, 1.50$ equiv) and triethylamine $(3.85 \mathrm{~mL}, 27.5 \mathrm{mmol}, 1.10$ equiv) was dissolved in toluene $(75 \mathrm{~mL})$ and refluxed for $2 \mathrm{~h}$. The reaction mixture was cooled to room temperature and washed with aqueous hydrochloric acid $(90 \mathrm{~mL}, 1.0 \mathrm{M})$ and the aqueous layer was extracted with ethyl acetate $(3 \times 100 \mathrm{~mL})$. The combined organic layers were dried over $\mathrm{MgSO}_{4}$ and the solvent was evaporated under reduced pressure. The crude product was purified by column chromatography using EtOAc:pentane 50:50 as mobile phase to afford $\mathrm{N}$-methoxy- $\mathrm{N}$-methyl-3-oxobutanamide (25) as a yellow oil $(2.40 \mathrm{~g}, 16.5 \mathrm{mmol}, 66 \%) .{ }^{1} \mathrm{H}$ NMR $\left(400 \mathrm{MHz}, \mathrm{CDCl}_{3}\right): \delta 13.65(\mathrm{~s}, 0.13 \mathrm{H}, \mathrm{OH}$ of enol form), $5.32(\mathrm{~s}, 0.13 \mathrm{H}$, vinyl $H$ of enol form) $3.60(\mathrm{~s}, 3 \mathrm{H}$, $\left.\mathrm{OCH}_{3}\right), 3.50\left(\mathrm{~s}, 1.74 \mathrm{H}, \mathrm{CH}_{3} \mathrm{COCH}_{2}\right.$ of keto form), $3.13\left(\mathrm{~s}, 2.6 \mathrm{H}, \mathrm{N}-\mathrm{CH}_{3}\right.$ of keto form), 3.11 (s, $0.4 \mathrm{H}$, enol

\footnotetext{
${ }^{11}$ M. Bolsønes, H. T. Bonge-Hansen and T. Bonge-Hansen, Synlett, 2014, 25, 221.

${ }^{12}$ S. Chanthamath, S. Thongjareun, K. Shibatomi and S. Iwasa, Tetrahedron Lett. 2012, 53, 4862.

${ }^{13}$ D. Gauthier, R. H. Dodd and P. Dauban, Tetrahedron 2009, 65, 8542.

${ }^{14}$ S. Müller, F. Sasse and M. E. Maier, Eur. J. Org. Chem. 2014, 1025.
} 
form of $\left.\mathrm{N}-\mathrm{CH}_{3}\right), 2.17\left(\mathrm{~s}, 2.6 \mathrm{H}, \mathrm{CH}_{3} \mathrm{COCH}_{2}\right.$ of keto form), 1.89 (s, $0.4 \mathrm{H}$, enol form of $\left.\mathrm{CH}_{3}\right) ;{ }^{13} \mathrm{C} \mathrm{NMR} \mathrm{(101}$ $\left.\mathrm{MHz}, \mathrm{CDCl}_{3}\right): \delta$ 201.7, 167.8, 61.1, 48.3, 31.8, 30.0; Enol form, $\left.{ }^{13} \mathrm{C} \mathrm{NMR} \mathrm{(101} \mathrm{MHz,} \mathrm{CDCl}_{3}\right): \delta 175.0$, $172.2,86.5,21.6$. Two carbons were not resolved at $101 \mathrm{MHz}$. The characterization data corresponded to the reported values. ${ }^{14}$

Following a reported procedure, ${ }^{7}$ to a solution of $\mathrm{N}$-methoxy- $\mathrm{N}$-methyl-3-oxobutanamide (25) $(0.73 \mathrm{~g}$, $5.0 \mathrm{mmol}, 1.0$ equiv) in MeCN (6 mL) was added triethylamine $(660 \mathrm{mg}, 6.50 \mathrm{mmol}, 1.30$ equiv). The reaction mixture was cooled in an ice bath and a solution of tosyl azide ( $1.1 \mathrm{~g}, 5.5 \mathrm{mmol}, 1.1$ equiv) in MeCN ( $6 \mathrm{~mL}$ ) was added slowly. The reaction mixture was allowed to warm to room temperature and stirred for 20 h. $8 \%$ aqueous $\mathrm{KOH}$ solution $(25 \mathrm{~mL})$ was added and stirred vigorously for $4 \mathrm{~h}$. The reaction mixture was diluted with water $(15 \mathrm{~mL})$, extracted with diethyl ether $(3 \times 30 \mathrm{~mL})$. The combined organic layers were dried over $\mathrm{MgSO}_{4}$ and concentrated under reduced pressure. The crude product was purified by column chromatography using EtOAc:pentane 50:50 as mobile phase to afford 2-diazo- $N$-methoxy- $N$-methylacetamide (2h) as a yellow oil (350 mg, $2.71 \mathrm{mmol}, 54 \%) .{ }^{1} \mathrm{H}$ NMR (400 $\left.\mathrm{MHz}, \mathrm{CDCl}_{3}\right): \delta 5.30\left(\mathrm{~s}, 1 \mathrm{H}, \mathrm{CHN}_{2}\right), 3.60\left(\mathrm{~s}, 3 \mathrm{H}, \mathrm{OCH}_{3}\right), 3.12\left(\mathrm{~s}, 3 \mathrm{H}, \mathrm{CH}_{3}\right) ;{ }^{13} \mathrm{C} \mathrm{NMR}\left(101 \mathrm{MHz}, \mathrm{CDCl}_{3}\right): \delta$ 168.1, 61.3, 46.1, 33.0. The values of the NMR spectra are in accordance with reported literature data. ${ }^{15}$

\section{Ethyl diazomethanesulfonate (2i)}

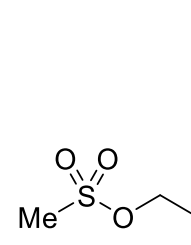

26
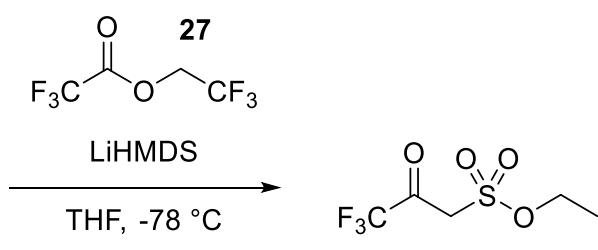

28
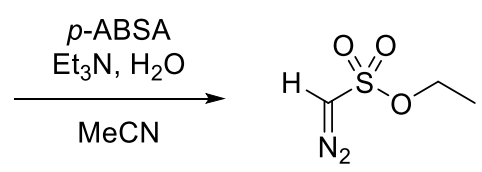

2i

Following a reported procedure, ${ }^{16}$ to a solution of ethyl methanesulfonate (26) $(1.86 \mathrm{~g}, 15.0 \mathrm{mmol}$, 1.00 equiv) in dry THF ( $50 \mathrm{~mL}$ ) was added a $1 \mathrm{M}$ LiHMDS solution in hexane $(18 \mathrm{~mL}, 18 \mathrm{mmol}, 1.2$ equiv) at $-78{ }^{\circ} \mathrm{C}$. After stirring the reaction mixture for $30 \mathrm{~min}$ at this temperature, 2,2,2-trifluoroethyl trifluoroacetate (27) $(2.4 \mathrm{~mL}, 18 \mathrm{mmol}, 1.2$ equiv) was added rapidly in one portion via syringe. After $10 \mathrm{~min}$, the reaction mixture was poured into a solution of diethyl ether $(20 \mathrm{~mL})$ and $5 \% \mathrm{HCl}(50 \mathrm{~mL})$. The mixture was extracted with diethyl ether $(3 \times 50 \mathrm{~mL})$, washed with brine $(50 \mathrm{~mL})$, dried over $\mathrm{MgSO}_{4}$, filtered and concentrated under reduced pressure to give a yellow oil. The resulting ethyl 3,3,3trifluoro-2-oxopropane-1-sulfonate (28) was immediately dissolved in dry MeCN (30 mL). To this solution was added $p$-ABSA ( $4.32 \mathrm{~g}, 18.0 \mathrm{mmol}, 1.20$ equiv), $\mathrm{Et}_{3} \mathrm{~N}(2.5 \mathrm{~mL}, 18 \mathrm{mmol}, 1.2$ equiv), and water $(0.27 \mathrm{~mL}, 15 \mathrm{mmol}, 1.0$ equiv). After stirring the reaction mixture overnight at room temperature, the solvent was removed under reduced pressure and the residue was filtered on short plug of silica gel and washed with a mixture of ethyl acetate $(100 \mathrm{~mL})$ and hexane $(100 \mathrm{~mL})$. The filtrate was concentrated under vacuum and the residue was purified by column chromatography using EtOAc:pentane 10:90 as mobile phase affording the corresponding ethyl diazomethanesulfonate (2i) as a yellow oil $(0.9 \mathrm{~g}, 6 \mathrm{mmol}, 40 \%) .{ }^{1} \mathrm{H}$ NMR $\left(400 \mathrm{MHz}, \mathrm{CDCl}_{3}\right): \delta 5.25\left(\mathrm{~s}, 1 \mathrm{H}, \mathrm{CHN}_{2}\right), 4.26(\mathrm{q}, J=7.1 \mathrm{~Hz}$, $\left.\left.2 \mathrm{H}, \mathrm{CH}_{2} \mathrm{CH}_{3}\right), 1.41\left(\mathrm{t}, J=7.1 \mathrm{~Hz}, 3 \mathrm{H}, \mathrm{CH}_{2} \mathrm{CH}_{3}\right) ;{ }^{13} \mathrm{C} \mathrm{NMR} \mathrm{(101} \mathrm{MHz}, \mathrm{CDCl}_{3}\right): \delta 67.4,52.4,14.6$. The values of the NMR spectra are in accordance with reported literature data. ${ }^{16}$

\footnotetext{
${ }^{15}$ H. Mao, A. Lin, Y. Shi, Z. Mao, X. Zhu, W. Li, H. Hu, Y. Cheng and C. Zhu, Angew. Chem., Int. Ed. 2013, 52, 6288.

${ }^{16}$ Ye T., Zhou C., New J. Chem. 2005, 29, 1159.
} 
Diethyl (diazomethyl)phosphonate (2j)<smiles>CCOP(=O)(CC)CC(C)=O</smiles>

29

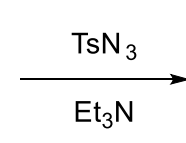<smiles>CCO[P+](=O)C(=[W])C(C)=O</smiles>

30

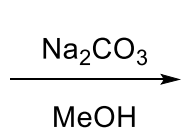

$\mathrm{H}_{\mathrm{O}}^{\mathrm{N}_{2}}$

2j

Following a reported procedure, ${ }^{17}$ a mixture of diethyl (2-oxopropyl)phosphonate (29) $(1.15 \mathrm{~mL}, 6.00$ mmol, 1.00 equiv), tosyl azide $(1.3 \mathrm{~g}, 6.6 \mathrm{mmol}, 1.10$ equiv) and triethylamine $(6 \mathrm{~mL})$ was stirred at room temperature for $18 \mathrm{~h}$. After evaporation of the triethylamine under reduced pressure, the residue was dissolved in diethyl ether $(50 \mathrm{~mL})$. The precipitate was filtered off, the filtrate was evaporated and the residue was purified by column chromatography using EtOAc:pentane 50:50 as mobile phase affording the corresponding diethyl (1-diazo-2-oxopropyl)phosphonate (30) as a yellow oil (0.810 g, $3.68 \mathrm{mmol}, 61 \%) .{ }^{1} \mathrm{H} \mathrm{NMR}\left(400 \mathrm{MHz}, \mathrm{CDCl}_{3}\right): \delta 4.04-4.19\left(\mathrm{~m}, 4 \mathrm{H}, 2 \times \mathrm{CH}_{2} \mathrm{CH}_{3}\right) 2.19(\mathrm{~s}, 3 \mathrm{H}$, $\left.\mathrm{CH}_{3}\right), 1.30\left(\mathrm{t}, J=7.0 \mathrm{~Hz}, 6 \mathrm{H}, 2 \times \mathrm{CH}_{2} \mathrm{CH}_{3}\right) ;{ }^{13} \mathrm{C} \mathrm{NMR}\left(101 \mathrm{MHz}, \mathrm{CDCl}_{3}\right): \delta 190.1(\mathrm{~d}, J=13.2 \mathrm{~Hz}), 63.4(\mathrm{~d}, J=$ $5.6 \mathrm{~Hz}), 27.1,16.0(\mathrm{~d}, J=6.8 \mathrm{~Hz})$. The values of the NMR spectra are in accordance with reported literature data. ${ }^{14}$

Following a reported procedure, ${ }^{8}$ to a solution of diethyl (1-diazo-2-oxopropyl)phosphonate (30) (694 $\mathrm{mg}, 3.15 \mathrm{mmol}, 1.00$ equiv) in $\mathrm{MeOH}(9.0 \mathrm{~mL})$ was added $\mathrm{Na}_{2} \mathrm{CO}_{3}(401 \mathrm{mg}, 3.78 \mathrm{mmol}, 1.20$ equiv). The mixture was stirred at room temperature for $15 \mathrm{~min}$. The precipitate was filtered off, the filtrate was evaporated and the residue was purified by column chromatography using EtOAc:pentane 50:50 as mobile phase affording the corresponding diethyl (diazomethyl)phosphonate (2j) as a yellow oil (533 $\mathrm{mg}, 2.99 \mathrm{mmol}, 95 \%) .{ }^{1} \mathrm{H} \mathrm{NMR}\left(400 \mathrm{MHz}, \mathrm{CDCl}_{3}\right): \delta 4.17-4.08\left(\mathrm{~m}, 4 \mathrm{H}, 2 \times \mathrm{CH}_{2} \mathrm{CH}_{3}\right), 3.75(\mathrm{~d}, J=11.1 \mathrm{~Hz}$, $\left.1 \mathrm{H}, \mathrm{CHN}_{2}\right), 1.34\left(\mathrm{td}, J=7.1,0.7 \mathrm{~Hz}, 6 \mathrm{H}, 2 \times \mathrm{CH}_{2} \mathrm{CH}_{3}\right) ;{ }^{13} \mathrm{C} \mathrm{NMR}\left(101 \mathrm{MHz}, \mathrm{CDCl}_{3}\right): \delta 62.6(\mathrm{~d}, J=5.3 \mathrm{~Hz})$, $16.1(\mathrm{~d}, J=6.9 \mathrm{~Hz})$. The values of the NMR spectra are in accordance with reported literature data. ${ }^{14}$ One carbon was not resolved at $101 \mathrm{MHz}$.

\section{2,2,2-Trifluorodiazoethane (2k)}<smiles>NCC(F)(F)F</smiles>

31

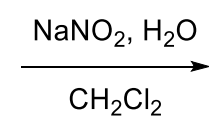

Following a reported procedure, ${ }^{18}$ under argon, 2,2,2-trifluoroethanamine hydrochloride (31) (0.678 g, $5.00 \mathrm{mmol}, 1.00$ equiv) and sodium nitrite $(0.379 \mathrm{~g}, 5.50 \mathrm{mmol}, 1.10$ equiv) were dissolved in degassed $\mathrm{CH}_{2} \mathrm{Cl}_{2}(10 \mathrm{~mL})$. Degassed water $\left(1.00 \mathrm{~mL}, 55.5 \mathrm{mmol}, 11.1\right.$ equiv) was added slowly at $0{ }^{\circ} \mathrm{C}$. The solution was stirred for $2 \mathrm{~h}$ at $0{ }^{\circ} \mathrm{C}$ and $1 \mathrm{~h}$ at room temperature. The aqueous layer was frozen in the freezer overnight $\left(-18{ }^{\circ} \mathrm{C}\right)$ and the organic layer was dried over a plug of potassium carbonate, transferred into a vial, sealed and stored at $-18{ }^{\circ} \mathrm{C}$. The concentration of the obtained solution was determined to be $0.37 \mathrm{M}$ by ${ }^{19} \mathrm{~F}$ NMR analysis (according to an internal reference, $\left.\mathrm{PhCF}_{3}\right) .{ }^{19} \mathrm{~F} \mathrm{NMR} \mathrm{(377}$ $\left.\mathrm{MHz}, \mathrm{CH}_{2} \mathrm{Cl}_{2}\right) \delta-55.56$. The values of the NMR spectra are in accordance with reported literature data. ${ }^{18}$

\footnotetext{
${ }^{17}$ S. Chanthamath, S. Ozaki, K. Shibatomi and S. Iwasa, Org. Lett. 2014, 16, 3012.

${ }^{18}$ S. Hyde, J. Veliks, B. Liégault, D. Grassi, M. Taillefer and V. Gouverneur, Angew. Chem. Int. Ed., 2016, 55, 3785 .
} 
Ethyl 2-diazopropanoate (2I)<smiles>CCOC(=O)C(C)C(C)=O</smiles>

32

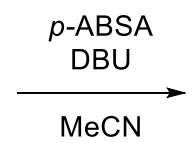

$\mathrm{MeCN}$<smiles>CCOC(=O)C(C)=[W]</smiles>

21

Following a reported procedure, ${ }^{19} \mathrm{DBU}(1.8 \mathrm{~mL}, 12 \mathrm{mmol}, 3.0$ equiv) was added slowly to a stirred solution of ethyl 2-methylacetoacetate (32) $(0.60 \mathrm{~mL}, 4.0 \mathrm{mmol}, 1.0$ equiv) and $p$-ABSA (1.4 g, 6.0 mmol, 1.5 equiv) in MeCN $(80 \mathrm{~mL})$ at $0{ }^{\circ} \mathrm{C}$. The reaction mixture was then allowed to warm to room temperature. After stirring for $12 \mathrm{~h}$, the reaction mixture was quenched with $1 \mathrm{M} \mathrm{HCl}(8 \mathrm{~mL})$, and extracted with hexane $(3 \times 40 \mathrm{~mL})$. The organic layers were combined, washed with a saturated solution of $\mathrm{NaHCO}_{3}(40 \mathrm{~mL})$, brine $(40 \mathrm{~mL})$, dried over $\mathrm{MgSO}_{4}$, filtered and concentrated under reduced pressure. The crude product was purified by column chromatography using $\mathrm{Et}_{2} \mathrm{O}$ :pentane 2:98 as mobile phase affording the corresponding ethyl 2-diazopropanoate (2I) as a yellow oil (241 mg, 1.88 $\mathrm{mmol}, 47 \%) .{ }^{1} \mathrm{H}$ NMR $\left(400 \mathrm{MHz}, \mathrm{CDCl}_{3}\right): \delta 4.20$ (q, $\left.J=7.1 \mathrm{~Hz}, 2 \mathrm{H}, \mathrm{CH}_{2} \mathrm{CH}_{3}\right), 1.94\left(\mathrm{~s}, 3 \mathrm{H}, \mathrm{N}_{2} \mathrm{CCH}_{3}\right), 1.25$ (t, $\left.J=7.1 \mathrm{~Hz}, 3 \mathrm{H}, \mathrm{CH}_{2} \mathrm{CH}_{3}\right) ;{ }^{13} \mathrm{C}$ NMR $\left(101 \mathrm{MHz}, \mathrm{CDCl}_{3}\right): \delta 167.9,60.7,14.5,8.4$. The values of the NMR spectra are in accordance with reported literature data. ${ }^{20}$ One carbon was not resolved at $101 \mathrm{MHz}$.

\section{3-Diazodihydrofuran-2(3H)-one (2m)}

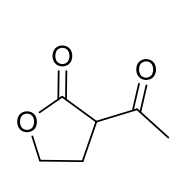

33

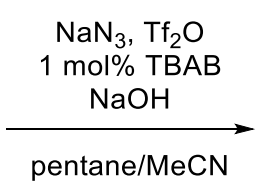

pentane/MeCN

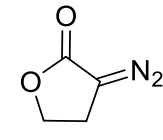

$2 m$

Following a reported procedure, ${ }^{21}$ sodium azide $(2.42 \mathrm{~g}, 37.2 \mathrm{mmol}, 4.00$ equiv), sodium hydroxide (78 $\mathrm{mL}, 2 \mathrm{M}$ in water), tetrabutylammonium bromide $(30.0 \mathrm{mg}, 0.09 \mathrm{mmol}, 0.01$ equiv) and pentane (40 $\mathrm{mL}$ ) were mixed in a $250 \mathrm{~mL}$ round-bottom flask with magnetic stir bar open to the air and allowed to cool to $0{ }^{\circ} \mathrm{C}$. With vigorous stirring, $\mathrm{Tf}_{2} \mathrm{O}(3.10 \mathrm{~mL}, 18.6 \mathrm{mmol}, 2.00$ equiv) was added dropwise. After $10 \mathrm{~min}$, a solution of 2-acetyl-butyrolactone (33) $(1.00 \mathrm{~mL}, 9.30 \mathrm{mmol}, 1.00$ equiv) in $\mathrm{MeCN}(35 \mathrm{~mL})$ was poured into the round-bottom flask through a funnel, followed by an additional $\mathrm{MeCN}(10 \mathrm{~mL})$ to complete the transfer. The initially colorless reaction mixture immediately turned yellow. After allowing to stir for $30 \mathrm{~min}$ at $0{ }^{\circ} \mathrm{C}$, the mixture was diluted with ice water $(25 \mathrm{~mL})$ and chilled EtOAc $(25$ $\mathrm{mL}$ ) and transferred to a separatory funnel. After phase separation and removal of the organic layer, the aqueous layer was washed with cold EtOAc $(2 \times 50 \mathrm{~mL})$. The combined organic layers were dried over $\mathrm{MgSO}_{4}$, filtered, and concentrated under reduced pressure. The crude product was purified by column chromatography using EtOAc:pentane 50:50 as mobile phase affording the corresponding 3diazodihydrofuran-2(3H)-one $(2 \mathrm{~m})$ as a bright yellow crystalline solid $(0.32 \mathrm{~g}, 2.8 \mathrm{mmol}, 30 \%) .{ }^{1} \mathrm{H}$ NMR $\left(400 \mathrm{MHz}, \mathrm{CDCl}_{3}\right): \delta 4.38\left(\mathrm{t}, J=8.0 \mathrm{~Hz}, 2 \mathrm{H}, \mathrm{CH}_{2}\right), 3.36\left(\mathrm{t}, \mathrm{J}=8.0 \mathrm{~Hz}, 2 \mathrm{H}, \mathrm{CH}_{2}\right) ;{ }^{13} \mathrm{C} \mathrm{NMR}\left(101 \mathrm{MHz}, \mathrm{CDCl}_{3}\right)$ : $170.6,65.3,49.4,23.1$. The values of the NMR spectra are in accordance with reported literature data. $^{21}$

\footnotetext{
${ }^{19}$ T. Hashimoto, Y. Naganawa and K. Maruoka, J. Am. Chem. Soc. 2011, 133, 8834.

${ }^{20}$ L. Huang and W. D. Wulff J. Am. Chem. Soc. 2011, 133, 8892.

${ }^{21}$ E. S. Sattely, S. J. Meek, S. J. Malcolmson, R. R. Schrock and A. H. Hoveyda, J. Am. Chem. Soc. 2009, $131,943$.
} 
Methyl (E)-2-diazopent-3-enoate (2n)

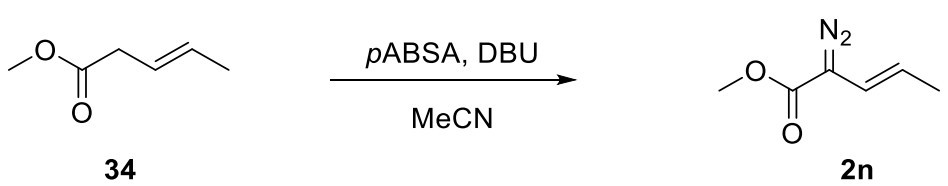

Following a reported procedure, ${ }^{22}$ to a stirring solution of methyl trans-pent-3-enoate (34) $(1.00 \mathrm{~g}, 8.76$ mmol, 1.00 equiv) and $p$-ABSA $\left(3.16 \mathrm{~g}, 13.1 \mathrm{mmol}, 1.50\right.$ equiv) in dry $\mathrm{MeCN}(20 \mathrm{~mL})$ at $0{ }^{\circ} \mathrm{C}$, was added $\mathrm{DBU}\left(2.65 \mathrm{~mL}, 17.5 \mathrm{mmol}, 2.00\right.$ equiv) slowly in $5 \mathrm{~min}$. The reaction mixture was stirred at $0{ }^{\circ} \mathrm{C}$ for $1 \mathrm{~h}$ and then $12 \mathrm{~h}$ at room temperature. The reaction mixture was quenched with $\mathrm{NH}_{4} \mathrm{Cl}$ (saturated solution, $20 \mathrm{~mL})$. The aqueous layer was extracted with $\mathrm{Et}_{2} \mathrm{O}(3 \times 40 \mathrm{~mL})$ and the combined organic layers were washed with brine $(40 \mathrm{~mL})$, dried over $\mathrm{MgSO}_{4}$, filtered and concentrated under reduced pressure. The crude product was purified by column chromatography using pentane as mobile phase affording the corresponding methyl (E)-2-diazopent-3-enoate (2n) as an orange oil (950 $\mathrm{mg}, 6.78$ mmol, 77\%). ${ }^{1} \mathrm{H}$ NMR (400 MHz, $\left.\mathrm{CDCl}_{3}\right): \delta 5.73\left(\mathrm{dd}, J=15.8,1.7 \mathrm{~Hz}, 1 \mathrm{H}, \mathrm{CH}_{3} \mathrm{CHCH}\right), 5.38-5.29(\mathrm{~m}, 1 \mathrm{H}$, $\mathrm{CH}_{3} \mathrm{CHCH}$ ), $3.79\left(\mathrm{~s}, 3 \mathrm{H}, \mathrm{OCH}_{3}\right), 1.84\left(\mathrm{dd}, J=6.7,1.7 \mathrm{~Hz}, 3 \mathrm{H}, \mathrm{CH}_{3} \mathrm{CHCH}\right) ;{ }^{13} \mathrm{C} \mathrm{NMR}\left(101 \mathrm{MHz}, \mathrm{CDCl}_{3}\right): \delta$ $166.1,120.4,112.6,52.0,18.2$. The values of the NMR spectra are in accordance with reported literature data. ${ }^{22}$ One carbon was not resolved at $101 \mathrm{MHz}$.

\section{Furan-2-ylmethyl 2-diazoacetate (20)}
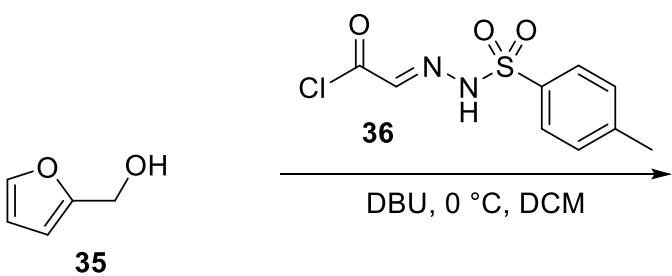

Following a reported procedure,$^{23}$ to a solution of $p$-toluenesulfonylhydrazone of glyoxylic acid chloride (36) $\left(1.30 \mathrm{~g}, 5.00 \mathrm{mmol}, 1.00\right.$ equiv.) in $\mathrm{CH}_{2} \mathrm{Cl}_{2}(10 \mathrm{~mL})$ were added furfuryl alcohol (35) (475 $\mu \mathrm{L}, 5.50$ mmol, 1.10 equiv.) and then $\mathrm{DBU}\left(1.89 \mathrm{~mL}, 12.5 \mathrm{mmol}, 2.50\right.$ equiv.) dropwise at $0{ }^{\circ} \mathrm{C}$. After stirring for $2 \mathrm{~h}$ at the same temperature, the reaction was stirred $30 \mathrm{~min}$ at room temperature and then poured into saturated $\mathrm{NH}_{4} \mathrm{Cl}$ solution $(10 \mathrm{~mL})$. The organic layer was then extracted with $\mathrm{CH}_{2} \mathrm{Cl}_{2}(3 \times 10 \mathrm{~mL})$, washed with brine $(20 \mathrm{~mL})$, dried over $\mathrm{MgSO}_{4}$, filtered and concentrated under reduced pressure. The crude product was purified by column chromatography using EtOAc/pentane 3:97 as eluent to afford furan-2-ylmethyl 2-diazoacetate (2o) as a yellow oil (534 mg, $3.21 \mathrm{mmol}, 64 \%) .{ }^{1} \mathrm{H} \mathrm{NMR} \mathrm{(400} \mathrm{MHz}$, $\left.\mathrm{CDCl}_{3}\right) \delta 7.42(\mathrm{dd}, J=1.9,0.9 \mathrm{~Hz}, 1 \mathrm{H}, \mathrm{ArH}), 6.42(\mathrm{dd}, J=3.3,0.8 \mathrm{~Hz}, 1 \mathrm{H}, \mathrm{ArH}), 6.36(\mathrm{dd}, J=3.3,1.8 \mathrm{~Hz}$, $\left.1 \mathrm{H}, \mathrm{ArH}), 5.14\left(\mathrm{~s}, 2 \mathrm{H}, \mathrm{CH}_{2} \mathrm{O}\right), 4.78\left(\mathrm{br} \mathrm{s}, 1 \mathrm{H}, \mathrm{CN}_{2} \mathrm{H}\right) ;{ }^{13} \mathrm{C} \mathrm{NMR} \mathrm{(101} \mathrm{MHz}, \mathrm{CDCl}_{3}\right) \delta 166.6,149.5,143.5$, $111.0,110.7,58.3,46.5$. The values of the NMR spectra are in accordance with reported literature data. $^{24}$

\footnotetext{
${ }^{22}$ H. M. L. Davies and A. M. Walji, Angew. Chem., Int. Ed. 2005, 44, 1733.

${ }^{23}$ T. Hashimoto, N. Uchiyama and K. Maruoka, J. Am. Chem. Soc. 2008, 130, 14380.

${ }^{24}$ S. Bew, P.-A. Ashford and D. Bachera, Synthesis 2013, 45, 903.
} 


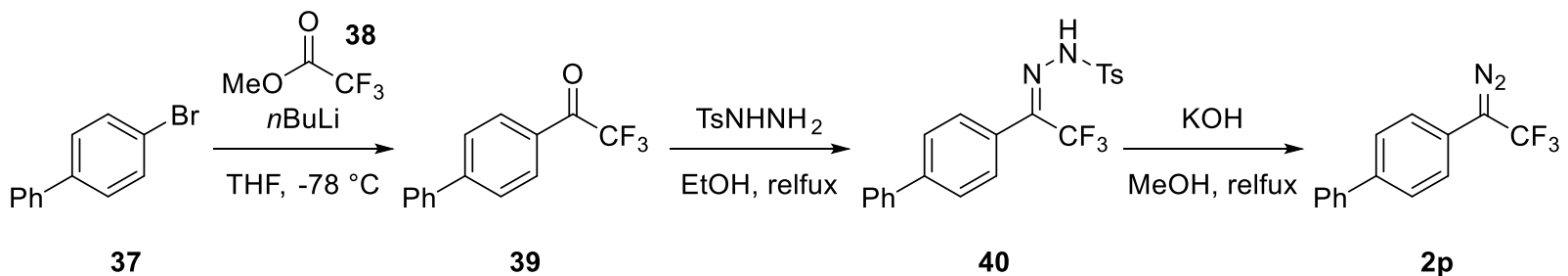

Following a reported synthesis, ${ }^{25}$ a solution of 4-bromo-biphenyl (37) (4.66 g, 20.0 mmol, 1.00 equiv.) in anhydrous THF $(100 \mathrm{~mL})$ was cooled to $-78^{\circ} \mathrm{C}$. Then, a $2.5 \mathrm{M}$ solution of $n$-butyllithium $(9.60 \mathrm{~mL}$, $24.0 \mathrm{mmol}, 1.20$ equiv.) in hexanes was added dropwise. The mixture was stirred for $1 \mathrm{~h}$, followed by the dropwise addition of methyl 2,2,2-trifluoroacetate (38) $(2.21 \mathrm{~mL}, 22.0 \mathrm{mmol}, 1.10$ equiv.) in 30 min. The mixture was allowed to warm up to room temperature, stirred for $18 \mathrm{~h}$ and then quenched with saturated aqueous ammonium chloride solution $(50 \mathrm{~mL})$. Diethyl ether $(50 \mathrm{~mL})$ was added and the layers were separated. The aqueous layer was extracted with diethyl ether $(2 \times 25 \mathrm{~mL})$. The combined organic layers were washed with brine $(50 \mathrm{~mL})$, dried over $\mathrm{MgSO}_{4}$, filtrated and concentrated under reduced pressure. The residue was purified by silica gel chromatography using pentane/EtOAc 90:10 as eluent to afford 1-([1,1'-biphenyl]-4-yl)-2,2,2-trifluoroethanone (39) as a slight yellow oil $(3.37 \mathrm{~g}, 13.5 \mathrm{mmol}, 67 \%) .{ }^{1} \mathrm{H}$ NMR $\left(400 \mathrm{MHz}, \mathrm{CDCl}_{3}\right) \delta 8.20-8.10(\mathrm{~m}, 2 \mathrm{H}, \mathrm{ArH}), 7.81-$ $7.74(\mathrm{~m}, 2 \mathrm{H}, \mathrm{ArH}), 7.68-7.62(\mathrm{~m}, 2 \mathrm{H}, \mathrm{ArH}), 7.54-7.41(\mathrm{~m}, 3 \mathrm{H}, \mathrm{ArH}) ;{ }^{13} \mathrm{C} \mathrm{NMR}\left(101 \mathrm{MHz}, \mathrm{CDCl}_{3}\right) \delta 180.3$ ( $q, J=34.8 \mathrm{~Hz}$ ), 148.4, 139.3, 130.9 (q, $J=2.2 \mathrm{~Hz}$ ), 129.3, 129.1, 128.7, 127.8, 127.5, 116.9 (q, $J=291.4$ $\mathrm{Hz}) ;{ }^{19} \mathrm{~F} \mathrm{NMR}\left(376 \mathrm{MHz}, \mathrm{CDCl}_{3}\right) \delta-71.3$. The values of the NMR spectra are in accordance with reported literature data. ${ }^{26}$

Following a reported procedure, ${ }^{26}$ 1-([1,1'-biphenyl]-4-yl)-2,2,2-trifluoroethanone (39) (3.36 g, 13.5 mmol, 1.05 equiv.) was added to $\mathrm{EtOH}(9 \mathrm{~mL})$ at room temperature followed by $p$ toluenesulfonylhydrazide $(2.40 \mathrm{~g}, 12.9 \mathrm{mmol}, 1.00$ equiv.) in one portion. A condenser was then attached and the contents were heated to reflux for $12 \mathrm{~h}$. After this time, the solvent was removed under reduced pressure until the beginning of the formation of a solid. Then, pentane $(200 \mathrm{~mL})$ was added and the precipitate was collected by filtration and washed with pentane. The solid obtained was used in the next step without purification.

Following a reported procedure, ${ }^{26} \quad N^{\prime}-\left(1-\left(\left[1,1^{\prime}\right.\right.\right.$-biphenyl]-4-yl)-2,2,2-trifluoroethylidene)-4methylbenzenesulfonohydrazide (40) was disolved in a $0.4 \mathrm{M}$ solution of potassium hydroxide $(3.37 \mathrm{~g}$, $60.0 \mathrm{mmol}, 2.00$ equiv.) in $\mathrm{MeOH}(17.5 \mathrm{~mL})$. A condenser was attached and the reaction mixture was stirred at reflux for $0.5 \mathrm{~h}$. Then, the reaction was cooled to room temperature and diluted with water $(20 \mathrm{~mL})$. The product was extracted with $\mathrm{Et}_{2} \mathrm{O}(3 \times 30 \mathrm{~mL})$, dried over $\mathrm{MgSO}_{4}$, filtered and concentrated under reduced pressure. The crude oil was purified by silica gel chromatography using pentane as eluent to afford 4-(1-diazo-2,2,2-trifluoroethyl)-1,1'-biphenyl (2p) as a red solid (1.42 g, $5.44 \mathrm{mmol}$, $50 \%)$. The compound was kept at $-18{ }^{\circ} \mathrm{C} . \mathrm{R}_{\mathrm{f}}=0.70$ (pentane); ${ }^{1} \mathrm{H}$ NMR $\left(400 \mathrm{MHz}, \mathrm{CDCl}_{3}\right) \delta 7.68-7.62$ $(\mathrm{m}, 2 \mathrm{H}, \mathrm{ArH}), 7.62-7.55(\mathrm{~m}, 2 \mathrm{H}, \mathrm{ArH}), 7.45(\mathrm{dd}, J=8.4,6.9 \mathrm{~Hz}, 2 \mathrm{H}, \mathrm{ArH}), 7.41-7.34(\mathrm{~m}, 1 \mathrm{H}, \mathrm{ArH}), 7.17$ $(\mathrm{d}, J=8.2 \mathrm{~Hz}, 2 \mathrm{H}, \mathrm{ArH}) ;{ }^{13} \mathrm{C} \mathrm{NMR}\left(101 \mathrm{MHz}, \mathrm{CDCl}_{3}\right) \delta 140.2,139.0,129.1,128.2,127.7,127.0,125.8$ (q, $J=269.6 \mathrm{~Hz}), 122.7,122.4 ;{ }^{19} \mathrm{~F} \mathrm{NMR}\left(376 \mathrm{MHz}, \mathrm{CDCl}_{3}\right) \delta$-57.3. One carbon was not resolved at 101 $\mathrm{MHz}$. The values of the NMR spectra are in accordance with reported literature data. ${ }^{26}$

\footnotetext{
${ }^{25}$ A. S. Golubev, A. F. Shidlovskii, A. S. Peregudov and N. D. Kagramanov, Russ Chem Bull. 2014, 63, 2264.

${ }^{26}$ E. Emer, J. Twilton, M. Tredwell, S. Calderwood, T. L. Collier, B. Liégault, M. Taillefer and V. Gouverneur, Org. Lett. 2014, 16, 6004.
} 


\section{Synthesis of ligands}

Ligand 3a was synthesized using a simple reported procedure. ${ }^{27} \mathbf{3 b}$ was purchased directly from TCl. 3f was purchased directly from Sigma-Aldrich.

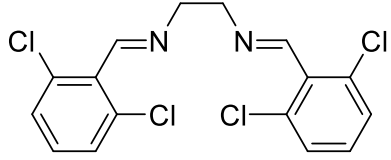

$3 \mathbf{a}$<smiles>CC(C)(C1=NC(C(C)(C)C)CO1)C1=NC(C(C)(C)C)CO1</smiles>

3b<smiles>c1ccc(-c2ccccn2)nc1</smiles>

$3 f$

\section{2,2'-(propane-2,2-diyl)bis(4,4-dimethyl-4,5-dihydrooxazole) (3c)}

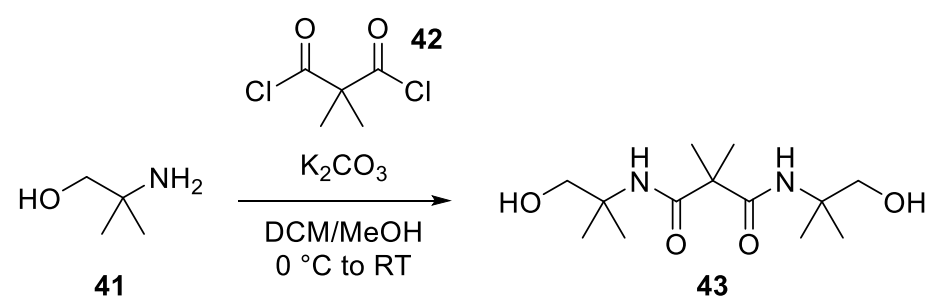

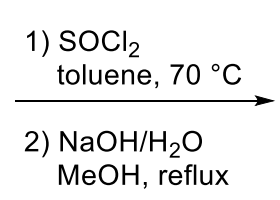

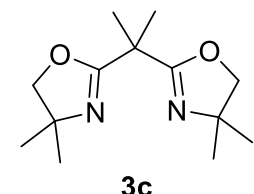

Following a reported procedure, ${ }^{28}$ 2-amino-2-methylpropan-1-ol (41) $(0.952 \mathrm{~mL}, 10.5 \mathrm{mmol}, 2.1$ equiv) was added to a suspension of $\mathrm{K}_{2} \mathrm{CO}_{3}\left(2.76 \mathrm{~g}, 20.0 \mathrm{mmol}, 4.0\right.$ equiv) $\mathrm{DCM}(50 \mathrm{~mL})$ at $0{ }^{\circ} \mathrm{C}$ under argon. A solution of dimethylmalonyl dichloride (42) $(0.660 \mathrm{~mL}, 5.00 \mathrm{mmol}, 1.0$ equiv) in DCM (10 mL) was added dropwise to the cold mixture. The mixture was allowed to warm to room temperature and stirred for $16 \mathrm{~h}$. $\mathrm{MeOH}(50 \mathrm{~mL})$ was added and the mixture was stirred for $2 \mathrm{~h}$. The whole reaction mixture was filtered through Celite $(5 \mathrm{~g})$ and rinsed twice with $\mathrm{MeOH}(2 \times 10 \mathrm{~mL})$. The solvent was removed under reduce pressure. The crude N1,N3-bis(1-hydroxy-2-methylpropan-2-yl)-2,2dimethylmalonamide (43) was obtained as a white residue $(1.42 \mathrm{~g})$ and was used directly into the next step without further purification.

The crude bisamide (43) was dissolved in toluene $(30 \mathrm{~mL})$ and heated to $70{ }^{\circ} \mathrm{C}$ under argon. Thionyl chloride ( $1.50 \mathrm{~mL}, 20.0 \mathrm{mmol}, 4.0$ equiv) was added in one portion and the resulting mixture was stirred at $70{ }^{\circ} \mathrm{C}$ for $5 \mathrm{~h}$. The reaction was cooled to $0{ }^{\circ} \mathrm{C}$ and quenched with a saturated $\mathrm{NaHCO}_{3}$ solution (15 $\mathrm{mL})$. The mixture was extracted with DCM $(5 \times 30 \mathrm{~mL})$ and the combined organic layers were dried over $\mathrm{MgSO}_{4}$, filtered and the solvent was removed under reduced pressure to furnish a pale yellow oil. The residue was dissolved in $17.0 \mathrm{~mL}$ of a $5 \%$ methanolic $\mathrm{NaOH}$ solution $(0.830 \mathrm{~g}$ of $\mathrm{NaOH}$ was completely dissolved in $0.850 \mathrm{~mL} \mathrm{H} 2 \mathrm{O}$ and then diluted with $16.1 \mathrm{~mL} \mathrm{MeOH}$ ) and heated to reflux for $2 \mathrm{~h}$ under argon. The solvent was removed under reduced pressure and the resulting residue was partitioned between DCM $(10 \mathrm{~mL})$ and $\mathrm{H}_{2} \mathrm{O}(10 \mathrm{~mL})$. The aqueous layer was extracted with DCM $(5 \times$ $10 \mathrm{~mL}$ ). The combined organic layers were dried over $\mathrm{MgSO}_{4}$, filtered and the solvent was removed under reduced pressure to furnish afford 2,2'-(propane-2,2-diyl)bis(4,4-dimethyl-4,5-dihydrooxazole) (3c) as a pale yellow wax (471 mg, $\left.2.00 \mathrm{mmol}, 40 \%) .{ }^{1} \mathrm{H} \mathrm{NMR} \mathrm{(400} \mathrm{MHz}, \mathrm{CDCl}_{3}\right) \delta 3.92\left(\mathrm{~s}, 4 \mathrm{H}, 2 \times \mathrm{CH}_{2} \mathrm{O}\right)$, $1.49\left(\mathrm{~s}, 6 \mathrm{H}, 2 \times \mathrm{CH}_{3}\right), 1.27\left(\mathrm{~s}, 12 \mathrm{H}, 4 \times \mathrm{CH}_{3}\right) ;{ }^{13} \mathrm{C} \mathrm{NMR}\left(101 \mathrm{MHz}, \mathrm{CDCl}_{3}\right) \delta 167.6,79.4,67.0,38.2,28.0$, 25.4. The values of the NMR spectra are in accordance with reported literature data. ${ }^{29}$

\footnotetext{
${ }^{27}$ H. Liu, H.-L. Zhang, S.-J. Wang, A.-Q. Mi, Y.-Z. Jiang and L.-Z. Gong, Tetrahedron-Asymmetry, 2005, 16, 2901.

${ }^{28}$ M. C. Paderes and S. R. Chemler, Eur. J. Org. Chem., 2011, 2011, 3679.

${ }^{29}$ K. M. Partridge, I. A. Guzei and T. P. Yoon, Angew. Chem. Int. Ed., 2010, 49, 930.
} 


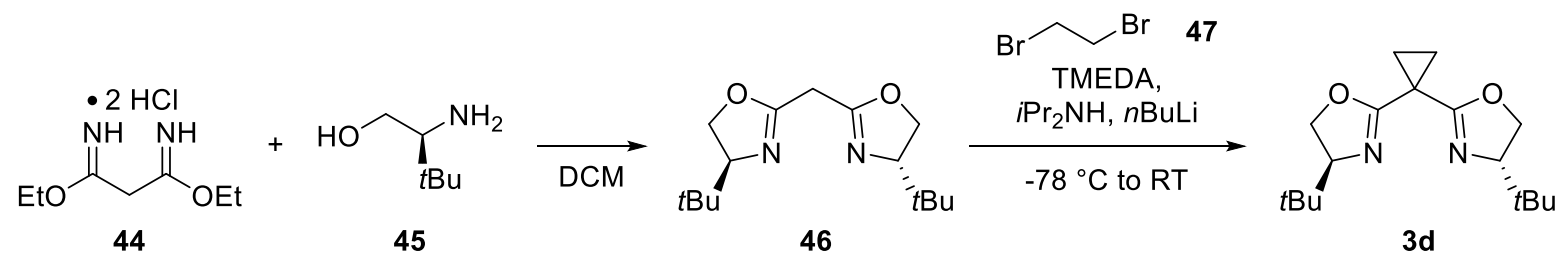

Following a reported procedure, ${ }^{30}$ to a solution of (S)-tert-leucinol (45) $(0.94 \mathrm{~g}, 8.0 \mathrm{mmol}, 2.0$ equiv) in DCM $(40 \mathrm{~mL})$ was added diethyl malonimidate dihydrochloride (44) $(0.93 \mathrm{~g}, 4.0 \mathrm{mmol}, 1.0$ equiv). The resulting cloudy solution was stirred at room temperature for $36 \mathrm{~h}$. The reaction mixture was diluted with water $(8 \mathrm{~mL})$ and extracted with DCM $(3 \times 20 \mathrm{~mL})$. The combined organic layers were washed with brine $(40 \mathrm{~mL})$, dried over $\mathrm{MgSO}_{4}$, and concentrated. The resulting oily residue was distilled bulb-tobulb (Kugelrohr distillation, $150{ }^{\circ} \mathrm{C}$ at $0.2 \mathrm{mbar}$ ) to afford bis((S)-4-(tert-butyl)-4,5-dihydrooxazol-2$\mathrm{yl})$ methane (46) as a white solid $(0.600 \mathrm{~g}, 2.84 \mathrm{mmol}, 71 \%) .{ }^{1} \mathrm{H} \mathrm{NMR}\left(400 \mathrm{MHz}, \mathrm{CDCl}_{3}\right) \delta 4.13$ (dd, $\mathrm{J}=$ 10.1, 8.7 Hz, $\left.2 \mathrm{H}, 2 \times \mathrm{OCH}_{a}\right), 4.02\left(\mathrm{dd}, J=8.7,7.7 \mathrm{~Hz}, 2 \mathrm{H}, 2 \times \mathrm{C}\left(\mathrm{CH}_{3}\right)_{3} \mathrm{CH}\right), 3.81(\mathrm{ddt}, J=10.1,7.8,1.1 \mathrm{~Hz}$, $\left.2 \mathrm{H}, 2 \times \mathrm{OCH}_{b}\right), 3.27\left(\mathrm{t}, \mathrm{J}=1.2 \mathrm{~Hz}, 2 \mathrm{H}, \mathrm{O}(\mathrm{C}=\mathrm{N}) \mathrm{CH}_{2}\right), 0.82\left(\mathrm{~s}, 18 \mathrm{H}, 2 \times \mathrm{C}\left(\mathrm{CH}_{3}\right)_{3}\right) ;{ }^{13} \mathrm{C} \mathrm{NMR}\left(100 \mathrm{MHz}, \mathrm{CDCl}_{3}\right)$ $\delta 161.5,76.0,69.1,34.0,28.4,26.0$. The values of the NMR spectra are in accordance with reported literature data. ${ }^{30}$

Following a reported procedure, ${ }^{30}$ to a solution of bis((S)-4-(tert-butyl)-4,5-dihydrooxazol-2yl)methane (46) (75 mg, $0.28 \mathrm{mmol}, 1.0$ equiv) in THF ( $5 \mathrm{~mL})$ in a $20 \mathrm{~mL}$ microwave vial, was added TMEDA ( $85 \mu \mathrm{L}, 0.56 \mathrm{mmol}, 2.0$ equiv) and $i-\mathrm{Pr}_{2} \mathrm{NH}(40 \mathrm{~mL}, 0.28 \mathrm{mmol}, 1.0$ equiv). The solution was cooled to $-78{ }^{\circ} \mathrm{C}$ and $n$-BuLi $(0.38 \mathrm{~mL}, 1.5 \mathrm{M}$ in hexane, $0.56 \mathrm{mmol}, 2.0$ equiv) was added. The reaction mixture was warmed to $-20^{\circ} \mathrm{C}$ and stirred at that temperature for 30 minutes. The solution was cooled back to $-78^{\circ} \mathrm{C}$ and 1,2-dibromoethane (47) $(25 \mu \mathrm{L}, 0.28 \mathrm{mmol}, 2.0$ equiv) was added. After the addition, the cold bath was removed and the reaction mixture was allowed to stir at room temperature for an additional $16 \mathrm{~h}$. The reaction mixture was quenched by the addition of sat. aq. $\mathrm{NH}_{4} \mathrm{Cl}(2.5 \mathrm{~mL})$ and diluted with water $(2 \mathrm{~mL})$ to dissolve the resulting salts. The mixture was extracted with diethyl ether $(3 \times 10 \mathrm{~mL})$. The combined organic layers were washed with brine $(10 \mathrm{~mL})$, dried over $\mathrm{MgSO}_{4}$, and concentrated. The resulting oily residue was purified by column chromatography using EtOAc/pentane $1: 2$ to $1: 1$ as mobile phase to afford $(4 S, 4 ' S)$-2,2'-(cyclopropane-1,1-diyl)bis(4-(tert-butyl)-4,5dihydrooxazole) (3d) as a white solid (42 mg, $0.14 \mathrm{mmol}, 51 \%) .{ }^{1} \mathrm{H} \mathrm{NMR}\left(400 \mathrm{MHz}, \mathrm{CDCl}_{3}\right): \delta 4.18$ (dd,

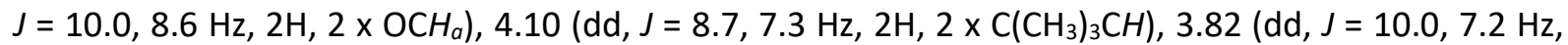
$\left.2 \mathrm{H}, 2 \times \mathrm{OCH}_{b}\right), 1.52-1.47\left(\mathrm{~m}, 2 \mathrm{H}, 2 \times \mathrm{CH}_{a}\right.$ of $\left.\mathrm{CyP}\right), 1.30-1.24\left(\mathrm{~m}, 2 \mathrm{H}, 2 \times \mathrm{CH}_{b}\right.$ of $\left.\mathrm{CyP}\right), 0.86(\mathrm{~s}, 18 \mathrm{H}, 2 \mathrm{x}$ $\left.\mathrm{C}\left(\mathrm{CH}_{3}\right)_{3}\right) ;{ }^{13} \mathrm{C} \mathrm{NMR}\left(100 \mathrm{MHz}, \mathrm{CDCl}_{3}\right): \delta 165.4,75.2,69.1,33.8,25.7,18.2,15.1$. The values of the NMR spectra are in accordance with reported literature data. ${ }^{30}$

\section{2,2'-(Propane-2,2-diyl)bis(4,5-dihydrooxazole) (3e)}

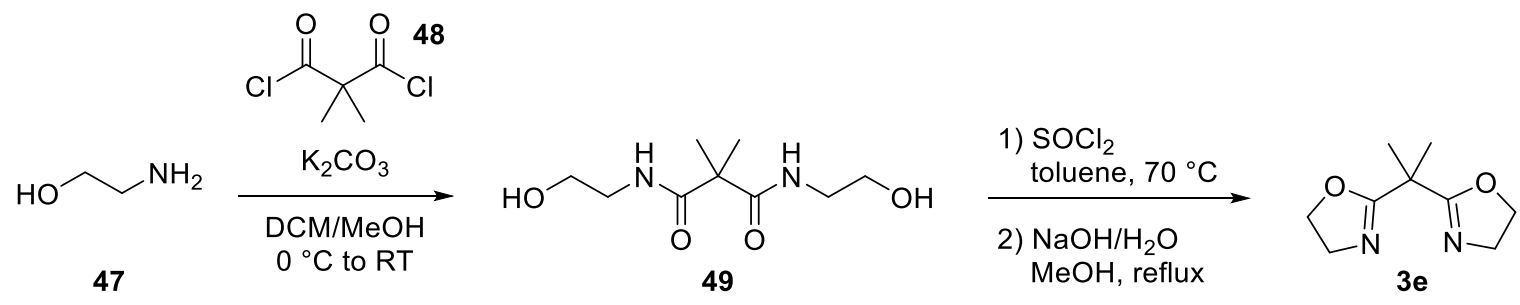

Following a reported procedure, ${ }^{31} \mathrm{~K}_{2} \mathrm{CO}_{3}(2.76 \mathrm{~g}, 20.0 \mathrm{mmol}, 4.0$ equiv) was suspended in $\mathrm{DCM}(50 \mathrm{~mL})$ at $0{ }^{\circ} \mathrm{C}$ under argon and then ethanolamine $(47)(0.63 \mathrm{~mL}, 10.5 \mathrm{mmol}, 2.1$ equiv) was added. A solution

\footnotetext{
${ }^{30}$ S. E. Denmark and C. M. Stiff, J. Org. Chem., 2000, 65, 5875.

${ }^{31}$ L. Miao, I. Haque, M. R. Manzoni, W. S. Tham and S. R. Chemler, Org. Lett., 2010, 12, 4739.
} 
of dimethylmalonyl dichloride (48) $(0.660 \mathrm{~mL}, 5.00 \mathrm{mmol}, 1.0$ equiv) in $\mathrm{DCM}(10 \mathrm{~mL})$ was added dropwise to the cold mixture. The mixture was allowed to warm to room temperature and stirred for $16 \mathrm{~h}$. $\mathrm{MeOH}(50 \mathrm{~mL})$ was added and the mixture was stirred for $2 \mathrm{~h}$. The whole reaction mixture was filtered through Celite $(5 \mathrm{~g})$ and rinsed twice with $\mathrm{MeOH}(2 \times 10 \mathrm{~mL})$. The solvent was removed under reduce pressure. The crude $N^{1}, N^{3}$-bis(2-hydroxyethyl)-2,2-dimethylmalonamide (49) was obtained as a white residue $(1.12 \mathrm{~g})$ and was used directly into the next step without further purification.

The crude bisamide (49) was dissolved in toluene $(30 \mathrm{~mL})$ and heated to $70{ }^{\circ} \mathrm{C}$ under argon. Thionyl chloride ( $1.46 \mathrm{~mL}, 20.0 \mathrm{mmol}, 4.0$ equiv) was added in one portion and the resulting mixture was stirred at $70{ }^{\circ} \mathrm{C}$ for $5 \mathrm{~h}$. The reaction was cooled to $0{ }^{\circ} \mathrm{C}$ and quenched with a saturated $\mathrm{NaHCO}_{3}$ solution (15 $\mathrm{mL})$. The mixture was extracted with DCM $(5 \times 30 \mathrm{~mL})$ and the combined organic layers were dried over $\mathrm{MgSO}_{4}$, filtered and the solvent was removed under reduced pressure to furnish a pale yellow oil. The residue was dissolved in $17.0 \mathrm{~mL}$ of a $5 \%$ methanolic $\mathrm{NaOH}$ solution $(0.830 \mathrm{~g}$ of $\mathrm{NaOH}$ was completely dissolved in $0.850 \mathrm{~mL} \mathrm{H} \mathrm{H}_{2} \mathrm{O}$ and then diluted with $16.1 \mathrm{~mL} \mathrm{MeOH}$ ) and heated to reflux for $2 \mathrm{~h}$ under argon. The solvent was removed under reduced pressure and the resulting residue was partitioned between DCM $(10 \mathrm{~mL})$ and $\mathrm{H}_{2} \mathrm{O}(10 \mathrm{~mL})$. The aqueous phase was extracted with $\mathrm{DCM}(5 \times$ $10 \mathrm{~mL}$ ). The combined organic layers were dried over $\mathrm{MgSO}_{4}$, filtered and the solvent was removed under reduced pressure to furnish afford 2,2'-(propane-2,2-diyl)bis(4,5-dihydrooxazole) (3e) as a pale yellow wax (412 mg, $2.26 \mathrm{mmol}, 45 \%) .{ }^{1} \mathrm{H} \mathrm{NMR}\left(400 \mathrm{MHz}, \mathrm{CDCl}_{3}\right) \delta \delta 4.28\left(\mathrm{t}, J=9.5 \mathrm{~Hz}, 4 \mathrm{H}, 2 \times \mathrm{CH}_{2} \mathrm{O}\right)$, $3.87\left(\mathrm{t}, J=9.5 \mathrm{~Hz}, 4 \mathrm{H}, 2 \times \mathrm{CH}_{2} \mathrm{~N}\right), 1.51\left(\mathrm{~s}, 6 \mathrm{H}, 2 \times \mathrm{CH}_{3}\right) ;{ }^{13} \mathrm{C} \mathrm{NMR}\left(101 \mathrm{MHz}, \mathrm{CDCl}_{3}\right) \delta 170.0,68.2,54.5$, $38.8,24.4$. The values of the NMR spectra are in accordance with reported literature data. ${ }^{31}$ 


\section{Preparation of VBX reagents}

trans-2-Phenylvinylboronic acid (50a), trans-2-(4-Methoxyphenyl)vinylboronic acid (50b), trans-2-(4Methylphenyl)vinylboronic acid (50c), trans-2-(4-Fluorophenyl)vinylboronic acid (50d), trans-2-[4(Trifluoromethyl)phenyl]vinylboronic acid (50e), 2-Cyclohexylvinylboronic acid (50j), trans-3-Phenyl1-propen-1-ylboronic acid (50k), 1-Penten-1-ylboronic acid (50l), 1-Cyclohexenylboronic acid (500), and trans-2-Chloromethylvinylboronic acid (50r) were directly purchased from Sigma Aldrich.<smiles>COc1ccc(/C=C/[Mg]OC(=O)c2ccccc2)cc1</smiles><smiles></smiles><smiles></smiles><smiles>O/C=C/c1ccc(C(F)(F)F)cc1</smiles><smiles>Oc1ccccc1</smiles><smiles>OC=CCc1ccccc1O</smiles><smiles>CCCC=C[Hg]O</smiles>

501<smiles>O=C(OCCOCCO)C1=CCCCC1</smiles><smiles>ClC/C=C/Br</smiles>

The ${ }^{13} \mathrm{C}$ NMR signal for carbons attached to boron was broad or did not appear in the collected spectra due to the quadrupolar splitting of ${ }^{11} \mathrm{~B} \cdot{ }^{32}$

All boronic acids analyzed under electrospray ionization-MS analysis gave complex ionization pathways. ${ }^{33}$ Faint signals could be obtained using APPI-MS.

\section{(E)-(2-(Naphthalen-1-yl)vinyl)boronic acid (50f)}<smiles>C#Cc1cccc2ccccc12</smiles>

Following a reported procedure ${ }^{34}$ catecholborane (52) $(640 \mu \mathrm{l}, 6.00 \mathrm{mmol}, 1.20$ equiv) was added dropwise to stirring neat 1-ethynylnaphthalene (51) (711 $\mu \mathrm{l}, 5.00 \mathrm{mmol}, 1.00$ equiv) at $0{ }^{\circ} \mathrm{C}$ under inert atmosphere. The reaction mixture was stirred at room temperature until the gas evolution had ceased and, then was heated to $70^{\circ} \mathrm{C}$ and stirred for $3 \mathrm{~h}$. The resulting thick oil was dissolved in THF $(8 \mathrm{~mL})$ and then slowly added to an ice-cold mixture of 1:1 Et ${ }_{2} \mathrm{O} /$ water $(25 \mathrm{~mL})$ and stirred for an additional 30 minutes. The two layers were separated and the aqueous layer was extracted with $\mathrm{Et}_{2} \mathrm{O}(2 \times 15 \mathrm{~mL})$. The combined organic layers were washed with water $(5 \times 15 \mathrm{~mL})$, dried over $\mathrm{MgSO}_{4}$, filtered and the solvent was evaporated under reduced pressure. The resulting crude residue was dissolved in boiling water $(70 \mathrm{~mL})$. The insoluble materials were discarded by hot filtration and the aqueous filtrate was allowed to cool to room temperature. The precipitate was collected by filtration to give $(E)$ - (2(naphthalen-1-yl)vinyl)boronic acid (50f) as a white solid (324 mg, $1.60 \mathrm{mmol}, 33 \%) .{ }^{1} \mathrm{H} \mathrm{NMR}(400 \mathrm{MHz}$, DMSO- $\left.d_{6} / \mathrm{D}_{2} \mathrm{O} 9: 1\right) \delta 8.21(\mathrm{~d}, J=8.3 \mathrm{~Hz}, 1 \mathrm{H}, \mathrm{ArH}), 8.09(\mathrm{~d}, J=18.2 \mathrm{~Hz}, 1 \mathrm{H}, \mathrm{BCHCH}), 7.93-7.82(\mathrm{~m}, 2 \mathrm{H}$, $\operatorname{ArH}), 7.73(\mathrm{~d}, J=7.2 \mathrm{~Hz}, 1 \mathrm{H}, \operatorname{ArH}), 7.62-7.44(\mathrm{~m}, 3 \mathrm{H}, \operatorname{ArH}), 6.20(\mathrm{~d}, J=18.2 \mathrm{~Hz}, 1 \mathrm{H}, \mathrm{BCHCH}) ;{ }^{13} \mathrm{C} \mathrm{NMR}$ (101 MHz, DMSO- $d_{6} / \mathrm{D}_{2} \mathrm{O}$ 9:1) $\delta$ 143.5, 135.6, 134.0, 131.3, 129.4, 129.3, 127.3, 126.9, 126.6, 124.2, 124.0; ${ }^{11} \mathrm{~B}$ NMR (128 MHz, DMSO- $\left.d_{6} / \mathrm{D}_{2} \mathrm{O} 9: 1\right) \delta 29.0$. The ${ }^{13} \mathrm{C}$ NMR signal for the carbon attached to

\footnotetext{
32 B. Wrackmeyer, Prog. Nucl. Magn. Reson. Spectrosc. 1979, 12, 227.

${ }^{33}$ L. Wang, C. Dai, S. K. Burroughs, S. L. Wang and B. Wang, Chem. Eur. J., 2013, 19, 7587.

${ }^{34}$ T. Haddad, R. Gershman, R. Dilis, D. Labaree, R. B. Hochberg and R. N. Hanson, Bioorg. Med. Chem. Lett., 2012, 22, 5999.
} 
boron did not appear due to the quadrupolar splitting of ${ }^{11} \mathrm{~B}$. The values of the NMR spectra are in accordance with reported literature data. ${ }^{34}$

\section{(E)-(2-(Thiophen-2-yl)vinyl)boronic acid (50g)}

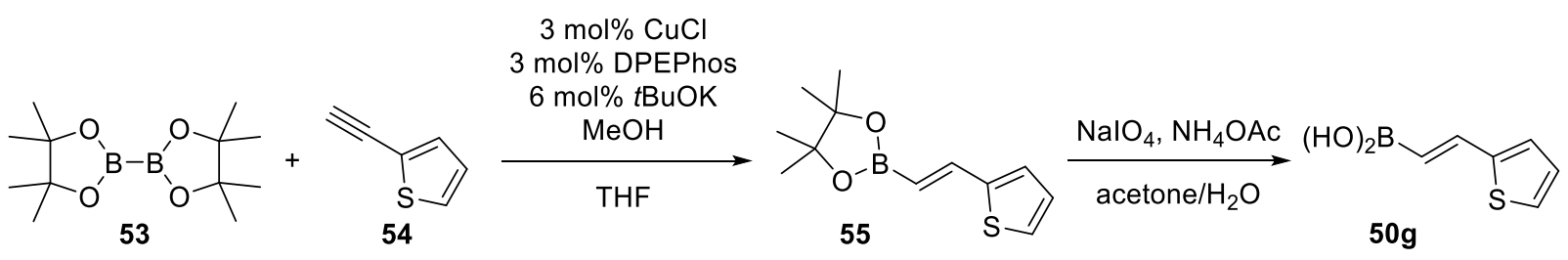

Following a reported procedure, ${ }^{35} \mathrm{CuCl}(15.0 \mathrm{mg}, 0.150 \mathrm{mmol}, 0.03$ equiv), $\mathrm{NaOtBu}$ ( $29.0 \mathrm{mg}, 0.300$ mmol, 0.06 equiv) and DPEPhos ( $81.0 \mathrm{mg}, 0.150 \mathrm{mmol}, 0.03$ equiv) were dissolved in THF ( $5 \mathrm{~mL}$ ) under argon. The reaction mixture was stirred for $30 \mathrm{~min}$ at room temperature and then, bis(pinacolato)diboron (53) $(1.40 \mathrm{~g}, 5.50 \mathrm{mmol}, 1.10$ equiv) and THF (2.5 mL) were added and the reaction mixture was stirred for another $10 \mathrm{~min}$ and then 2-ethynylthiophene (54) $(0.475 \mathrm{~mL}, 5.00$ mmol, 1.00 equiv) was added, followed by $\mathrm{MeOH}(0.405 \mathrm{~mL}, 10.0 \mathrm{mmol}, 2.00$ equiv). The reactor wall was washed with THF (1.5 mL), sealed, and stirred for $4 \mathrm{~h}$. The reaction mixture was filtered through a pad of Celite, washed with EtOAc and the solvent was removed under reduced pressure. The resulting oil was purified by column chromatography using EtOAc/pentane 5:95 as mobile phase affording $(E)$ 4,4,5,5-tetramethyl-2-(2-(thiophen-2-yl)vinyl)-1,3,2-dioxaborolane (55) as a clear yellow oil (1.07 g, $4.53 \mathrm{mmol}, 91 \%) .{ }^{1} \mathrm{H} \mathrm{NMR}\left(400 \mathrm{MHz}, \mathrm{CDCl}_{3}\right) \delta 7.47$ (d, J = $\left.18.1 \mathrm{~Hz}, 1 \mathrm{H}, \mathrm{CHCHB}\right), 7.24$ (d, J = 5.1, $\left.1 \mathrm{H}, \mathrm{ArH}\right)$, $7.11-7.05(\mathrm{~m}, 1 \mathrm{H}, \operatorname{ArH}), 6.99$ (dd, $J=5.1,3.6 \mathrm{~Hz}, 1 \mathrm{H}, \operatorname{ArH}), 5.91(\mathrm{~d}, J=18.1 \mathrm{~Hz}, 1 \mathrm{H}, \mathrm{CHCHB}), 1.30$ (s, $\left.12 \mathrm{H}, 4 \times \mathrm{CH}_{3}\right) ;{ }^{13} \mathrm{C}$ NMR $\left(101 \mathrm{MHz}, \mathrm{CDCl}_{3}\right) \delta 144.1,141.9,127.8,127.8,126.4,83.5,24.9$. The ${ }^{13} \mathrm{C} \mathrm{NMR}$ signal for the carbon attached to boron did not appear due to the quadrupolar splitting of ${ }^{11} \mathrm{~B}$. The values of the NMR spectra are in accordance with reported literature data. ${ }^{35}$

Following a reported procedure, ${ }^{35} \quad(E)$-4,4,5,5-tetramethyl-2-(2-(thiophen-2-yl)vinyl)-1,3,2dioxaborolane (55) (1.00 g, $4.23 \mathrm{mmol}, 1.00$ equiv), $\mathrm{NH}_{4} \mathrm{OAc}\left(1.63 \mathrm{~g}, 21.2 \mathrm{mmol}, 5.00\right.$ equiv), $\mathrm{NalO}_{4}$ ( $4.53 \mathrm{~g}, 21.2 \mathrm{mmol}, 5.00$ equiv) were suspended in a mixture $1: 1$ acetone/water $(42 \mathrm{~mL})$. The resulting slurry was stirred at room temperature for $16 \mathrm{~h}$. It was then diluted with EtOAc $(30 \mathrm{~mL})$, washed successively with water $(2 \times 20 \mathrm{~mL})$ and brine $(20 \mathrm{~mL})$, dried over $\mathrm{MgSO}_{4}$, filtered, and concentrated under reduced pressure. The crude yellow oil was dissolved with diethyl ether $(20 \mathrm{~mL})$ then shaken 5 min with a basic aqueous solution of sorbitol $\left(25 \mathrm{~mL}, 1 \mathrm{M}\right.$ sorbitol, $1 \mathrm{M} \mathrm{Na}_{2} \mathrm{CO}_{3}$ ), the aqueous layer was re-acidified with $4 \mathrm{M} \mathrm{HCl}(25 \mathrm{~mL}, \mathrm{pH}=2)$ and extracted with diethyl ether $(35 \mathrm{~mL})$. The organic layer was dried over $\mathrm{MgSO}_{4}$, filtered and the solvent was removed under reduced pressure affording $(E)-(2-$ (thiophen-2-yl)vinyl)boronic acid (50g) as a clear yellow solid (0.416 g, $2.70 \mathrm{mmol}, 64 \%)$. M.p. 118-120 ${ }^{\circ} \mathrm{C} ;{ }^{1} \mathrm{H}$ NMR (400 MHz, DMSO- $d_{6} / \mathrm{D}_{2} \mathrm{O}$ 9:1) $\delta 7.47(\mathrm{~d}, J=5.1 \mathrm{~Hz}, 1 \mathrm{H}, \mathrm{ArH}), 7.36$ (d, J=18.1 Hz, $\left.1 \mathrm{H}, \mathrm{CHCHB}\right)$, $7.14(\mathrm{~m}, 1 \mathrm{H}, \mathrm{ArH}), 7.04$ (dd, $J=5.1,3.5 \mathrm{~Hz}, 1 \mathrm{H}, \mathrm{ArH}), 5.80(\mathrm{~d}, J=18.1 \mathrm{~Hz}, 1 \mathrm{H}, \mathrm{CHCHB}) ;{ }^{13} \mathrm{C}$ NMR (101 $\left.\mathrm{MHz}, \mathrm{DMSO}-d_{6} / \mathrm{D}_{2} \mathrm{O} 9: 1\right) \delta 144.0,138.8,128.2,127.6,126.4,122.6$ (br); ${ }^{11} \mathrm{~B}$ NMR (128 MHz, DMSO$d_{6} / D_{2} \mathrm{O}$ 9:1) $\delta$ 28.5. The ${ }^{13} \mathrm{C}$ NMR signal for the carbon attached to boron was broad due to the quadrupolar splitting of ${ }^{11} \mathrm{~B}$. The values of the NMR spectra are in accordance with reported literature data. $^{36}$

\section{(E)-(6-Methoxy-6-oxohex-1-en-1-yl)boronic acid (50m)}

\footnotetext{
${ }^{35}$ C. Feng, H. Wang, L. Xua and P. Li, Org. Biomol. Chem., 2015, 13, 7136.

${ }^{36}$ S. Liu and L. S. Liebeskind, J. Am. Chem. Soc., 2008, 130, 6918.
} 

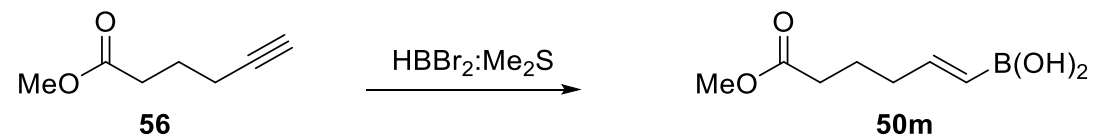

Following a reported procedure, ${ }^{37}$ a solution of $1 \mathrm{M}$ dibromoborane dimethyl sulfide complex in DCM $(6.00 \mathrm{~mL}, 6.00 \mathrm{mmol}, 1.2$ equiv) was added dropwise to neat methyl hex-5-ynoate (56) $(631 \mathrm{mg}, 5.00$ $\mathrm{mmol}, 1.00$ equiv) at $0{ }^{\circ} \mathrm{C}$. The resulting solution was allowed to warm to room temperature. After stirring for $4 \mathrm{~h}$, the solution was transferred slowly to an ice-cooled mixture of 2:1 diethyl ether/water $(18 \mathrm{~mL})$ and stirred vigorously for $15 \mathrm{~min}$. The mixture was diluted with diethyl ether $(20 \mathrm{~mL})$ and extracted with water $(2 \times 10 \mathrm{~mL})$. The organic layer was then shaken 5 min with a basic aqueous solution of sorbitol ( $25 \mathrm{~mL}, 1 \mathrm{M}$ sorbitol, $1 \mathrm{M} \mathrm{Na}_{2} \mathrm{CO}_{3}$ ), the aqueous layer was re-acidified with $4 \mathrm{M} \mathrm{HCl}$ $(25 \mathrm{~mL}, \mathrm{pH}=2)$ and extracted with diethyl ether $(35 \mathrm{~mL})$. The organic layer was dried over $\mathrm{MgSO}_{4}$, filtered and the solvent was removed under reduced pressure affording ( $E$ )-(6-methoxy-6-oxohex-1en-1-yl)boronic acid (50m) as a light brown oil $(517 \mathrm{mg}, 3.01 \mathrm{mmol}, 60 \%) .{ }^{1} \mathrm{H}$ NMR (400 MHz, DMSO$d_{6} / \mathrm{D}_{2} \mathrm{O}$ 9:1) $\delta 6.38\left(\mathrm{dt}, J=17.9,6.4 \mathrm{~Hz}, 1 \mathrm{H}, \mathrm{CHCHCH}_{2}\right), 5.30(\mathrm{dt}, J=17.9,1.6 \mathrm{~Hz}, 1 \mathrm{H}, \mathrm{BCHCH}), 3.55(\mathrm{~s}$, $\left.3 \mathrm{H}, \mathrm{OCH}_{3}\right), 2.26\left(\mathrm{t}, J=7.4 \mathrm{~Hz}, 2 \mathrm{H}, \mathrm{CH}_{2} \mathrm{CO}_{2} \mathrm{Me}\right), 2.10-2.00\left(\mathrm{~m}, 2 \mathrm{H}, \mathrm{CH}_{2} \mathrm{BCC}\right), 1.59(\mathrm{p}, J=7.4 \mathrm{~Hz}, 2 \mathrm{H}$, $\mathrm{CH}_{2} \mathrm{CH}_{2} \mathrm{CH}_{2}$ ); ${ }^{13} \mathrm{C}$ NMR (101 MHz, DMSO- $\left.d_{6} / \mathrm{D}_{2} \mathrm{O} 9: 1\right) \delta 174.4,150.1,125.2$ (br), 51.8, 34.5, 33.0, 23.6. The ${ }^{13} \mathrm{C}$ NMR signal for the carbon attached to boron was broad due to the quadrupolar splitting of ${ }^{11} \mathrm{~B}$. The values of the NMR spectra are in accordance with reported literature data. ${ }^{37}$

(E)-(5-Chloropent-1-en-1-yl)boronic acid (50n)

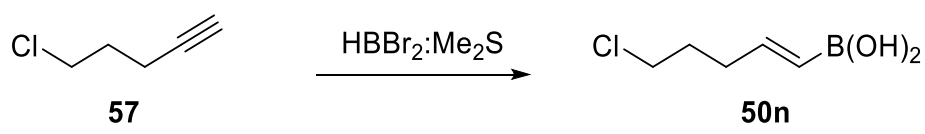

A solution of $1 \mathrm{M}$ dibromoborane dimethyl sulfide complex in DCM (6.00 mL, $6.00 \mathrm{mmol}, 1.2$ equiv) was added dropwise to neat 5-chloropent-1-yne (57) $\left(0.523 \mathrm{~mL}, 5.00 \mathrm{mmol}, 1.0\right.$ equiv) at $0{ }^{\circ} \mathrm{C}$. The resulting solution was allowed to warm to room temperature. After stirring for $4 \mathrm{~h}$, the solution was transferred slowly to an ice-cooled mixture of 2:1 diethyl ether/water $(18 \mathrm{~mL})$ and stirred vigorously for $15 \mathrm{~min}$. The mixture was diluted with diethyl ether $(20 \mathrm{~mL})$ and extracted with water $(2 \times 10 \mathrm{~mL})$. The organic layer was then shaken $5 \mathrm{~min}$ with a basic aqueous solution of sorbitol ( $25 \mathrm{~mL}, 1 \mathrm{M}$ sorbitol, $\left.1 \mathrm{M} \mathrm{Na}_{2} \mathrm{CO}_{3}\right)$, the aqueous layer was re-acidified with $4 \mathrm{M} \mathrm{HCl}(25 \mathrm{~mL}, \mathrm{pH}=2)$ and extracted with diethyl ether ( $35 \mathrm{~mL}$ ). The organic layer was dried over $\mathrm{MgSO}_{4}$, filtered and the solvent was removed under reduced pressure affording (E)-(5-chloropent-1-en-1-yl)boronic acid (50n) as a light yellow oil (461 mg, $3.11 \mathrm{mmol}, 62 \%$ ). ${ }^{1} \mathrm{H}$ NMR (400 MHz, DMSO- $\left.d_{6} / \mathrm{D}_{2} \mathrm{O} 9: 1\right) \delta 6.40$ (dt, $J=17.9,6.5 \mathrm{~Hz}, 1 \mathrm{H}, \mathrm{CHCHCH}_{2}$ ), 5.35 (dt, J = 17.9, $1.5 \mathrm{~Hz}, 1 \mathrm{H}, \mathrm{BCHCH}), 3.60$ (t, J $=6.5 \mathrm{~Hz}, 2 \mathrm{H}, \mathrm{CH}_{2} \mathrm{Cl}$ ), 2.19 (dtd, $J=7.8,6.6,1.6 \mathrm{~Hz}, 2 \mathrm{H}$, $\mathrm{CHCH}_{2} \mathrm{CH}_{2}$ ), 1.79 (dq, $J=8.4,6.6 \mathrm{~Hz}, 2 \mathrm{H}, \mathrm{CH}_{2} \mathrm{CH}_{2} \mathrm{Cl}$ ); ${ }^{13} \mathrm{C} \mathrm{NMR}\left(101 \mathrm{MHz}\right.$, DMSO-d $d_{6} / \mathrm{D}_{2} \mathrm{O}$ 9:1) $\delta$ 149.0, 125.8 (br), 45.3, 32.4, 31.3; ${ }^{11} \mathrm{~B}$ NMR (128 MHz, DMSO-d $/ \mathrm{D}_{2} \mathrm{O}$ 9:1) $\delta 27.3$; IR $\left(\mathrm{v}_{\max }, \mathrm{cm}^{-1}\right) 2961(\mathrm{~m}), 2922$ $(\mathrm{w}), 1634(\mathrm{~m}), 1347(\mathrm{~s}), 1305(\mathrm{~m}), 1225(\mathrm{~m}), 1051(\mathrm{w}), 998(\mathrm{~m}), 691(\mathrm{~m}), 652(\mathrm{~m})$; HRMS (APPI/LTQOrbitrap) calcd for $\mathrm{C}_{5} \mathrm{H}_{9} \mathrm{BClO}_{2}^{-}\left[\mathrm{M}^{-}\right]$147.0390; found 147.0394. The ${ }^{13} \mathrm{C}$ NMR signal for the carbon attached to boron was broad due to the quadrupolar splitting of ${ }^{11} \mathrm{~B}$.

\footnotetext{
${ }^{37}$ D. Kontokosta, D. S. Mueller, H.-Y. Wang and L. L. Anderson, Org. Lett., 2013, 15, 4830.
} 


\section{(E)-(3-(1,3-Dioxoisoindolin-2-yl)prop-1-en-1-yl)boronic acid (50p)}

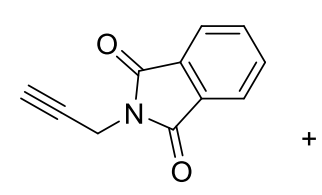

58

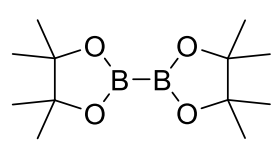

53

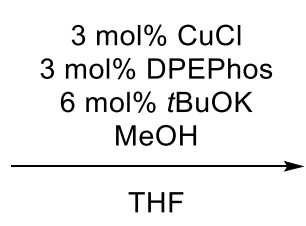<smiles>CC1(C)OB(/C=C/CN2C(=O)c3ccccc3C2=O)OC1(C)C</smiles>

59 $\mathrm{NaIO}_{4}, \mathrm{NH}_{4} \mathrm{OAC}$ acetone $/ \mathrm{H}_{2} \mathrm{O}$<smiles>O=C1c2ccccc2C(=O)N1C/C=C/[PbH2]</smiles>

Following a reported procedure, ${ }^{35} \mathrm{CuCl}(15.0 \mathrm{mg}, 0.150 \mathrm{mmol}, 0.03$ equiv), NaOtBu (29.0 mg, 0.300 mmol, 0.06 equiv) and DPEPhos ( $81.0 \mathrm{mg}, 0.150 \mathrm{mmol}, 0.03$ equiv) were dissolved in THF ( $5 \mathrm{~mL}$ ) under argon. The reaction mixture was stirred for $30 \mathrm{~min}$ at room temperature and then, bis(pinacolato)diboron (53) $(1.40 \mathrm{~g}, 5.50 \mathrm{mmol}, 1.10$ equiv) and THF (2.5 mL) were added and the reaction mixture was stirred for another $10 \mathrm{~min}$ and then $N$-propargylphtalimide (58) $(0.926 \mathrm{~g}, 5.00$ mmol, 1.00 equiv) was added, followed by $\mathrm{MeOH}(0.405 \mathrm{~mL}, 10.0 \mathrm{mmol}, 2.00$ equiv). The reactor wall was washed with THF (1.5 mL), sealed, and stirred for $4 \mathrm{~h}$. The reaction mixture was filtered through a pad of Celite, washed with EtOAc and the solvent was removed under reduced pressure. The resulting oil was purified by column chromatography using EtOAc/pentane 15:85 as mobile phase affording $(E)$ 2-(3-(4,4,5,5-tetramethyl-1,3,2-dioxaborolan-2-yl)allyl)isoindoline-1,3-dione (59) as a white solid (1.49 g, $4.75 \mathrm{mmol}, 95 \%) .{ }^{1} \mathrm{H}$ NMR $\left(400 \mathrm{MHz}, \mathrm{CDCl}_{3}\right) \delta 7.85$ (dd, $\left.J=5.4,3.1 \mathrm{~Hz}, 2 \mathrm{H}, \mathrm{ArH}\right), 7.72(\mathrm{dd}, J=5.5,3.1$ $\mathrm{Hz}, 2 \mathrm{H}, \mathrm{ArH}), 6.59(\mathrm{dt}, J=18.0,4.5 \mathrm{~Hz}, 1 \mathrm{H}, \mathrm{CHCHB}), 5.48(\mathrm{dt}, J=18.0,1.9 \mathrm{~Hz}, 1 \mathrm{H}, \mathrm{CHCHB}), 4.38$ (dd, $J=$ 4.6, $\left.1.8 \mathrm{~Hz}, 2 \mathrm{H}, \mathrm{CH}_{2} \mathrm{~N}\right), 1.22\left(\mathrm{~s}, 12 \mathrm{H}, 4 \times \mathrm{CH}_{3}\right) ;{ }^{13} \mathrm{C} \mathrm{NMR}\left(101 \mathrm{MHz}, \mathrm{CDCl}_{3}\right) \delta 167.9,145.4,134.2,132.2$, $123.5,83.5,41.1,24.9$. The ${ }^{13} \mathrm{C}$ NMR signal for the carbon attached to boron did not appear due to the quadrupolar splitting of ${ }^{11} \mathrm{~B}$. The values of the NMR spectra are in accordance with reported literature data. ${ }^{35}$

Following a reported procedure, ${ }^{35}$ (E)-2-(3-(4,4,5,5-tetramethyl-1,3,2-dioxaborolan-2yl)allyl)isoindoline-1,3-dione (59) (1.49 g, $4.75 \mathrm{mmol}), \mathrm{NH}_{4} \mathrm{OAc}\left(1.83 \mathrm{~g}, 23.7 \mathrm{mmol}, 5.00\right.$ equiv), $\mathrm{NalO}_{4}$ $(5.08 \mathrm{~g}, 23.7 \mathrm{mmol}, 5.00$ equiv) were suspended in a mixture 1:1 acetone/water $(46 \mathrm{~mL})$. The resulting slurry was stirred at room temperature for $16 \mathrm{~h}$. It was then diluted with EtOAc $(30 \mathrm{~mL})$, washed successively with water $(2 \times 20 \mathrm{~mL})$ and brine $(20 \mathrm{~mL})$, dried over $\mathrm{MgSO}_{4}$, filtered, and concentrated under reduced pressure affording (E)-(3-(1,3-dioxoisoindolin-2-yl)prop-1-en-1-yl)boronic acid (50p) as a white solid (0.805 g, $3.48 \mathrm{mmol}, 73 \%)$. M.p. $145-147{ }^{\circ} \mathrm{C} ;{ }^{1} \mathrm{H}$ NMR (400 MHz, DMSO- $d_{6} / \mathrm{D}_{2} \mathrm{O}$ 9:1) $\delta 7.95$ - $7.77(\mathrm{~m}, 4 \mathrm{H}, \mathrm{ArH}), 6.41(\mathrm{dt}, J=18.0,4.3 \mathrm{~Hz}, 1 \mathrm{H}, \mathrm{CHCHB}), 5.24(\mathrm{dt}, J=18.0,1.9 \mathrm{~Hz}, 1 \mathrm{H}, \mathrm{CHCHB}), 4.22$ (dd, $J=4.3,1.9 \mathrm{~Hz}, 2 \mathrm{H}, \mathrm{CH}_{2} \mathrm{~N}$ ); ${ }^{13} \mathrm{C}$ NMR (101 MHz, DMSO- $d_{6} / \mathrm{D}_{2} \mathrm{O}$ 9:1) $\delta 168.2,143.2,135.2,131.9$, $124.4(\mathrm{br}), 123.7,41.0 ;{ }^{11} \mathrm{~B}$ NMR (128 MHz, DMSO- $d_{6} / \mathrm{D}_{2} \mathrm{O}$ 9:1) $\delta 26.8$; IR $\left(\mathrm{v}_{\max }, \mathrm{cm}^{-1}\right) 2985(\mathrm{~m}), 2904$ (m), $1773(\mathrm{~m}), 1716(\mathrm{~s}), 1427(\mathrm{~m}), 1395$ (s), $1343(\mathrm{~m}), 1071$ (s), 1055 (s), 726 (m); HRMS (APPI/LTQOrbitrap) calcd for $\mathrm{C}_{11} \mathrm{H}_{11} \mathrm{BNO}_{4}{ }^{+}[\mathrm{M}+\mathrm{H}]^{+}$232.0776; found 232.0775. The ${ }^{13} \mathrm{C}$ NMR signal for the carbon attached to boron was broad due to the quadrupolar splitting of ${ }^{11} \mathrm{~B}$. 


\section{(E)-(3-((Triisopropylsilyl)oxy)prop-1-en-1-yl)boronic acid (50q)}

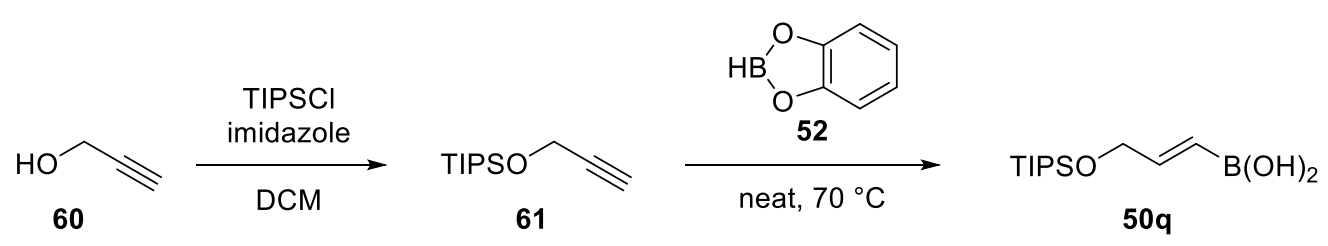

Following a reported procedure,,$^{38}$ a solution of propargyl alcohol $(60)(1.04 \mathrm{~mL}, 17.8 \mathrm{mmol}, 1.00$ equiv), imidazole ( $3.04 \mathrm{~g}, 44.7 \mathrm{mmol}, 2.50$ equiv), and triisopropylchlorosilane $(5.73 \mathrm{~mL}, 26.8 \mathrm{mmol}, 1.50$ equiv) in DCM $(30 \mathrm{~mL})$ was stirred at room teperature for $16 \mathrm{~h}$. The reaction mixture was diluted with DCM $(30 \mathrm{~mL})$ and quenched with water $(10 \mathrm{~mL})$. The aqueous layer was separated and extracted with DCM $(2 \times 15 \mathrm{~mL})$. The combined organic layers were washed successively with water $(2 \times 15 \mathrm{~mL})$ and brine $\left(15 \mathrm{~mL}\right.$ ), dried over $\mathrm{MgSO}_{4}$, filtered and concentrated under reduced pressure. The crude product was purified by column chromatography using pentane as mobile phase providing triisopropyl(prop-2-yn-1-yloxy)silane (61) as a colorless oil (3.23 g, $15.2 \mathrm{mmol}, 85 \%) .{ }^{1} \mathrm{H} \mathrm{NMR}(400 \mathrm{MHz}$, $\left.\mathrm{CDCl}_{3}\right) \delta 4.38\left(\mathrm{~d}, J=2.4 \mathrm{~Hz}, 2 \mathrm{H}, \mathrm{CH}_{2} \mathrm{O}\right), 2.39(\mathrm{t}, J=2.4 \mathrm{~Hz}, 1 \mathrm{H}, \mathrm{CCH}), 1.26-0.99(\mathrm{~m}, 21 \mathrm{H}, \mathrm{TIPS}) ;{ }^{13} \mathrm{C} \mathrm{NMR}$ $\left(101 \mathrm{MHz}, \mathrm{CDCl}_{3}\right) \delta 82.5,72.7,51.7,17.8,12.0$. The values of the NMR spectra are in accordance with reported literature data. ${ }^{38}$

Catecholborane (52) (1.71 mL, $16.0 \mathrm{mmol}, 1.05$ equiv) was added dropwise to stirring neat triisopropyl(prop-2-yn-1-yloxy)silane (61) $\left(3.23 \mathrm{~g}, 15.2 \mathrm{mmol}, 1.00\right.$ equiv) at $0{ }^{\circ} \mathrm{C}$ under inert atmosphere. The reaction mixture was stirred at room temperature until the gas evolution had ceased and, then was heated to $70{ }^{\circ} \mathrm{C}$ and stirred for $4 \mathrm{~h}$. After cooling to room temperature, the reaction mixture was diluted in $\mathrm{Et}_{2} \mathrm{O}(150 \mathrm{~mL})$ and $1 \mathrm{~N} \mathrm{NaOH}(45 \mathrm{~mL}, 45 \mathrm{mmol})$ was added. After vigorous stirring for $10 \mathrm{~min}$, the mixture was transferred to a separatory funnel and the layers were separated. The organic layer was washed with $1 \mathrm{~N} \mathrm{NaOH}(60 \mathrm{~mL})$, water $(3 \times 60 \mathrm{~mL})$ and 1:1 water/brine $(60 \mathrm{~mL})$. The organic layer was dried over $\mathrm{MgSO}_{4}$, filtered, and concentrated under reduced pressure. The crude product was purified by column chromatography using $\mathrm{Et}_{2} \mathrm{O}$ /pentane $50: 50$ as mobile phase affording (E)-(3-((triisopropylsilyl)oxy)prop-1-en-1-yl)boronic acid (50q) as a colorless oil $(2.12 \mathrm{~g}, 8.21 \mathrm{mmol}$, 54\%). TLC (Et ${ }_{2} \mathrm{O} /$ pentane, 50:50): $\mathrm{Rf}=0.37, \mathrm{KMnO} ;{ }^{1} \mathrm{H}$ NMR (400 MHz, DMSO- $\left.d_{6} / \mathrm{D}_{2} \mathrm{O} 9: 1\right) \delta 6.46$ (dt, $J$ $=17.9,3.7 \mathrm{~Hz}, 1 \mathrm{H}, \mathrm{CHCHB}$ ), 5.59 (dt, $J=17.9,2.0 \mathrm{~Hz}, 1 \mathrm{H}, \mathrm{CHCHB}$ ), 4.22 (dd, $J=3.7,2.0 \mathrm{~Hz}, 2 \mathrm{H}, \mathrm{CH}_{2} \mathrm{O}$ ), 1.05 - $0.94(\mathrm{~m}, 21 \mathrm{H}, \mathrm{TIPS}) ;{ }^{13} \mathrm{C}$ NMR (101 MHz, DMSO- $\left.d_{6} / \mathrm{D}_{2} \mathrm{O} 9: 1\right) \delta$ 149.6, 122.0 (br), 65.1, 18.5, 12.1; ${ }^{11} \mathrm{~B}\left(128 \mathrm{MHz}, \mathrm{DMSO}-d_{6} / \mathrm{D}_{2} \mathrm{O}\right.$ 9:1) $\delta$ 26.1; IR $\left(\mathrm{v}_{\max }, \mathrm{cm}^{-1}\right) 2942(\mathrm{~m}), 2895(\mathrm{~m}), 2867(\mathrm{~m}), 1638(\mathrm{~m}), 1462$ $(\mathrm{m}), 1372(\mathrm{~s}), 1344(\mathrm{~s}), 1291(\mathrm{~s}), 1258(\mathrm{~m}), 1131(\mathrm{~s}), 1107(\mathrm{~s}), 1055(\mathrm{~m}), 1017(\mathrm{~m}), 994(\mathrm{~m}), 953(\mathrm{~m}), 882$ (s), $771(\mathrm{~m}), 681$ (s), 663 (s), 653 (s); HRMS (APPI/LTQ-Orbitrap) calcd for $\mathrm{C}_{12} \mathrm{H}_{26} \mathrm{BO}_{3} \mathrm{Si}^{-}$[M"] 257.1750; found 257.1749. The ${ }^{13} \mathrm{C}$ NMR signal for the carbon attached to boron was broad due to the quadrupolar splitting of ${ }^{11} \mathrm{~B}$.

\section{(E)-(3-Methylbuta-1,3-dien-1-yl)boronic acid (50s)}

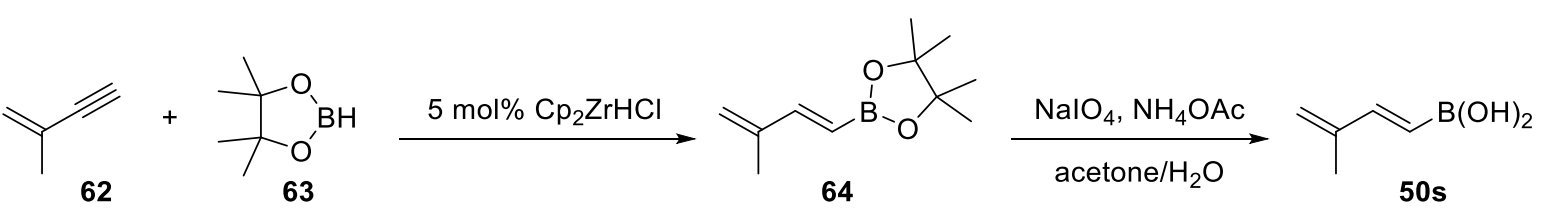

Following a reported procedure, ${ }^{39}$ to a flask containing $\mathrm{Cp}_{2} \mathrm{ZrHCl}(64.0 \mathrm{mg}, 0.250 \mathrm{mmol}, 0.05$ equiv) at $0{ }^{\circ} \mathrm{C}$ under argon atmosphere was added pinacolborane (63) $(0.798 \mathrm{~mL}, 5.50 \mathrm{mmol}, 1.10$ equiv) then dropwise 2-methylbut-1-en-3-yne (62) $(0.485 \mathrm{~mL}, 5.00 \mathrm{mmol}, 1.00$ equiv). The resulting mixture was

\footnotetext{
${ }^{38}$ M. S. Oderinde, H. N. Hunter and M. G. Organ, Chem. Eur. J., 2012, 18, 10817.

${ }^{39}$ A. Cannillo, S. Norsikian, P. Retailleau, M.-E. T. H. Dau, B. I. Iorga and J.-M. Beau, Chem. Eur. J., 2013, 19, 9127.
} 
stirred at $0{ }^{\circ} \mathrm{C}$ for $30 \mathrm{~min}$ and then at room temperature for $24 \mathrm{~h}$. The crude reaction was directly purified by column chromatography using EtOAc/pentane 2:98 as mobile phase affording 4,4,5,5tetramethyl-2-[(1E)-3-methylbuta-1,3-dien-1-yl]-1,3,2-dioxaborolane (64) as a colorless oil (789 mg, $4.05 \mathrm{mmol}, 81 \%) .{ }^{1} \mathrm{H}$ NMR $\left(400 \mathrm{MHz}, \mathrm{CDCl}_{3}\right) \delta 7.10$ (d, J=18.2 Hz, $\left.1 \mathrm{H}, \mathrm{CHCHB}\right), 5.56(\mathrm{~d}, J=18.2 \mathrm{~Hz}, 1 \mathrm{H}$, $\mathrm{CHCHB}), 5.21-5.13\left(\mathrm{~m}, 2 \mathrm{H}, \mathrm{CCH}_{2}\right), 1.85\left(\mathrm{t}, J=1.1 \mathrm{~Hz}, 3 \mathrm{H}, \mathrm{CCH}_{3}\right), 1.28\left(\mathrm{~s}, 12 \mathrm{H}, 4 \times \mathrm{CH}_{3}\right) .{ }^{13} \mathrm{C}$ NMR (101 $\left.\mathrm{MHz}, \mathrm{CDCl}_{3}\right) \delta 152.3,143.2,120.3,116.7(\mathrm{br}), 83.4,24.9,17.9$. The ${ }^{13} \mathrm{C}$ NMR signal for the carbon attached to boron was broad due to the quadrupolar splitting of ${ }^{11} \mathrm{~B}$. The values of the NMR spectra are in accordance with reported literature data. ${ }^{39}$

Following a reported procedure, ${ }^{39}$ to a stirred solution of 4,4,5,5-tetramethyl-2-[(1E)-3-methylbuta1,3-dien-1-yl]-1,3,2-dioxaborolane (64) $(772 \mathrm{mg}, 3.98 \mathrm{mmol}, 1.00$ equiv) in acetone (125 mL) were added an aqueous solution of $\mathrm{NH}_{4} \mathrm{OAc}\left(79 \mathrm{~mL}, 0.1 \mathrm{M}, 1.50\right.$ equiv) and $\mathrm{NalO}_{4}(2.55 \mathrm{~g}, 11.9 \mathrm{mmol}, 3.0$ equiv). The cloudy mixture was stirred at room temperature for $24 \mathrm{~h}$. After cautious acidification with aqueous $2 \mathrm{M} \mathrm{HCl}(\mathrm{pH}=2)$, the aqueous layer was extracted with AcOEt $(2 \times 80 \mathrm{~mL})$. The combined organic layers were dried over $\mathrm{MgSO}_{4}$, filtered and the solvent was removed under reduced pressure affording (E)-(3-methylbuta-1,3-dien-1-yl)boronic acid (50s) as a light yellow solid (200 mg, $1.79 \mathrm{mmol}$, 36\%). ${ }^{1} \mathrm{H}$ NMR (400 MHz, $\left.\mathrm{CDCl}_{3}\right) \delta 7.42$ (d, J = $\left.17.8 \mathrm{~Hz}, 1 \mathrm{H}, \mathrm{CHCHB}\right), 5.68$ (d, J=17.9 Hz, $\left.1 \mathrm{H}, \mathrm{CHCHB}\right)$, $5.29\left(\mathrm{~s}, 1 \mathrm{H}, \mathrm{CCH}_{2}\right), 5.27\left(\mathrm{~s}, 1 \mathrm{H}, \mathrm{CCH}_{2}\right), 1.92\left(\mathrm{~s}, 3 \mathrm{H}, \mathrm{CCH}_{3}\right) ;{ }^{13} \mathrm{C} \mathrm{NMR}\left(101 \mathrm{MHz}, \mathrm{CDCl}_{3}\right) \delta 154.9,143.2$, 121.6, $120.0(\mathrm{br}), 18.1 ;{ }^{11} \mathrm{~B}$ NMR (128 MHz, DMSO- $d_{6} / \mathrm{D}_{2} \mathrm{O}$ 9:1) $\delta 19.38$. The ${ }^{13} \mathrm{C}$ NMR signal for the carbon attached to boron was broad due to the quadrupolar splitting of ${ }^{11} \mathrm{~B}$. The values of the NMR spectra are in accordance with reported data. ${ }^{39}$

\section{((1E,3E)-4-Phenylbuta-1,3-dien-1-yl)boronic acid (50t)}

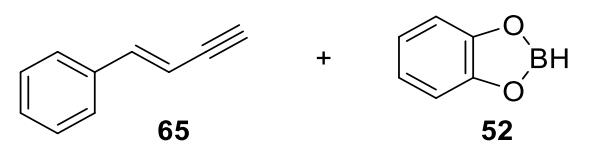

neat, $70^{\circ} \mathrm{C}$

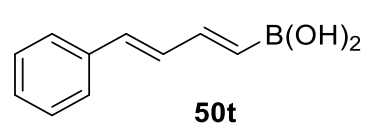

$50 t$

Catecholborane (52) (533 $\mu \mathrm{l}, 5.00 \mathrm{mmol}, 1.00$ equiv) was added dropwise to stirring neat (E)-but-1-en3-yn-1-ylbenzene (65) $\left(641 \mathrm{mg}, 5.00 \mathrm{mmol}, 1.00\right.$ equiv) at $0{ }^{\circ} \mathrm{C}$ under inert atmosphere. The reaction mixture was stirred at room temperature until the gas evolution had ceased and, then was heated to $70{ }^{\circ} \mathrm{C}$ and stirred for $1 \mathrm{~h}$. The reaction was cooled to $0{ }^{\circ} \mathrm{C}$ and quenched by dropwise addition of water $(3 \mathrm{~mL})$. The solid was suspended in water $(20 \mathrm{~mL})$ and vigorously stirred at room temperature for $18 \mathrm{~h}$. The mixture was extracted with diethyl ether $(2 \times 20 \mathrm{~mL})$ and washed with water $(5 \times 20 \mathrm{~mL})$. The organic layer was then shaken $5 \mathrm{~min}$ with a basic aqueous solution of sorbitol $(25 \mathrm{~mL}, 1 \mathrm{M}$ sorbitol, 1 $\left.\mathrm{M} \mathrm{Na}_{2} \mathrm{CO}_{3}\right)$, the aqueous layer was re-acidified with $4 \mathrm{M} \mathrm{HCl}(25 \mathrm{~mL}, \mathrm{pH}=2)$ and extracted with diethyl ether $\left(35 \mathrm{~mL}\right.$ ). The organic layer was dried over $\mathrm{MgSO}_{4}$, filtered and the solvent was removed under reduced pressure affording ((1E,3E)-4-phenylbuta-1,3-dien-1-yl)boronic acid (50t) as a off-white solid (461 mg, $3.11 \mathrm{mmol}, 62 \%$ ). M.p. $110-112{ }^{\circ} \mathrm{C} ;{ }^{1} \mathrm{H}$ NMR (400 MHz, DMSO- $d_{6} / \mathrm{D}_{2} \mathrm{O}$ 9:1) $\delta 7.54-7.48(\mathrm{~m}$, 2H), $7.38-7.30(\mathrm{~m}, 2 \mathrm{H}), 7.30-7.22(\mathrm{~m}, 1 \mathrm{H}), 7.08-6.87(\mathrm{~m}, 2 \mathrm{H}), 6.69(\mathrm{~d}, J=15.4 \mathrm{~Hz}, 1 \mathrm{H}), 5.65(\mathrm{~d}, J=$ $17.3 \mathrm{~Hz}, 1 \mathrm{H}) ;{ }^{13} \mathrm{C}$ NMR $\left(101 \mathrm{MHz}\right.$, DMSO- $d_{6} / \mathrm{D}_{2} \mathrm{O}$ 9:1) $\delta 146.9,137.0,134.7,131.4,129.1,128.6(\mathrm{br})$, 128.4, 127.0; ${ }^{11} \mathrm{~B}$ NMR (128 MHz, DMSO- $\left.d_{6} / \mathrm{D}_{2} \mathrm{O} 9: 1\right) \delta$ 29.2; IR $\left(\mathrm{v}_{\max }, \mathrm{cm}^{-1}\right) 2967(\mathrm{~m}), 2912(\mathrm{~m}), 1622$ $(\mathrm{m}), 1427(\mathrm{~m}), 1456(\mathrm{~s}), 1082(\mathrm{~s}), 1021$ (s); HRMS (APPI/LTQ-Orbitrap) calcd for $\mathrm{C}_{10} \mathrm{H}_{11} \mathrm{BO}_{2}{ }^{+}\left[\mathrm{M}^{+}\right]$ 174.0847; found 174.0847. The ${ }^{13} \mathrm{C}$ NMR signal for the carbon attached to boron was broad due to the quadrupolar splitting of ${ }^{11} \mathrm{~B}$. 


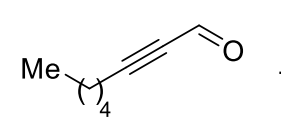

66

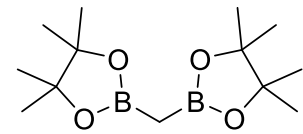

67

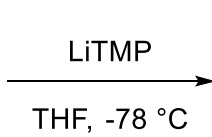

THF, $-78^{\circ} \mathrm{C}$

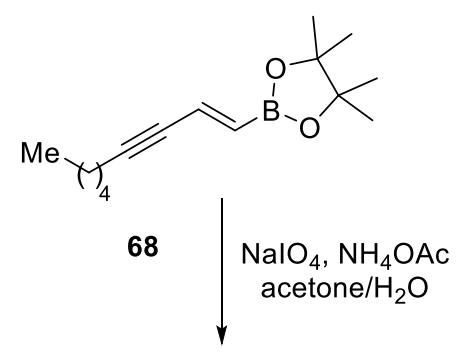

$\mathrm{Me}_{\mathrm{H}_{4}} \mathrm{B(OH)_{2 }}$

Following a reported procedure,,$^{40}$ a $100 \mathrm{~mL}$ flask was charged with LiTMP ( $883 \mathrm{mg}, 6.00 \mathrm{mmol}, 1.20$ equiv), sealed with a septum cap, and removed from the glovebox. The reaction flask was cooled to 0 ${ }^{\circ} \mathrm{C}$, and dry THF ( $\left.6 \mathrm{~mL}\right)$, followed by a solution of bis[(pinacolato)boryl]methane (67) $(1.60 \mathrm{~g}, 6.00 \mathrm{mmo}$, 1.20 equiv) in THF (12 mL) were added. The reaction was stirred for 5 minutes at $0{ }^{\circ} \mathrm{C}$ and then was cooled to $-78{ }^{\circ} \mathrm{C}$, and a solution of oct-2-ynal (66) $(0.735 \mathrm{~mL}, 5.00 \mathrm{mmol}, 1.00$ equiv) in THF (6.00 mL) was added slowly. The reaction was stirred at $-78{ }^{\circ} \mathrm{C}$ for $4 \mathrm{~h}$ and the solvent was removed under reduced pressure. The crude reaction mixture was purified by column chromatography using EtOAc/pentane 2:98 as mobile phase affording (E)-4,4,5,5-tetramethyl-2-(non-1-en-3-yn-1-yl)-1,3,2dioxaborolane (68) as a clear yellow oil (805 mg, $\left.3.24 \mathrm{mmol}, 65 \%) ;{ }^{1} \mathrm{H} \mathrm{NMR} \mathrm{(400} \mathrm{MHz,} \mathrm{CDCl}_{3}\right) \delta 6.42$ (dt, $J=18.3,2.1 \mathrm{~Hz}, 1 \mathrm{H}, \mathrm{CHCHB}), 5.92$ (dd, $J=18.3,0.6 \mathrm{~Hz}, 1 \mathrm{H}, \mathrm{CHCHB}$ ), 2.32 (tdd, $J=7.2,2.2,0.6 \mathrm{~Hz}$, $\left.2 \mathrm{H}, \mathrm{CCH}_{2}\right), 1.56-1.48\left(\mathrm{~m}, 2 \mathrm{H}, \mathrm{CH}_{2}\right), 1.42-1.27\left(\mathrm{~m}, 4 \mathrm{H}, 2 \times \mathrm{CH}_{2}\right), 1.26\left(\mathrm{~s}, 12 \mathrm{H}, 4 \times \mathrm{CH}_{3}\right.$ pinacol), 0.89 (t, J $\left.=7.1 \mathrm{~Hz}, 3 \mathrm{H}, \mathrm{CH}_{2} \mathrm{CH}_{3}\right) ;{ }^{13} \mathrm{C} \mathrm{NMR}\left(101 \mathrm{MHz}, \mathrm{CDCl}_{3}\right) \delta 130.5,95.4,83.6,81.0,31.2,28.4,24.9,22.3,19.7$, 14.1. The ${ }^{13} \mathrm{C}$ NMR signal for the carbon attached to boron did not appear due to the quadrupolar splitting of ${ }^{11} \mathrm{~B}$. The values of the NMR spectra are in accordance with reported literature data. ${ }^{40}$

(E)-4,4,5,5-Tetramethyl-2-(non-1-en-3-yn-1-yl)-1,3,2-dioxaborolane (68) $(0.805 \mathrm{~g}, 3.24 \mathrm{mmol}, 1.00$ equiv), $\mathrm{NH}_{4} \mathrm{OAc}$ ( $1.250 \mathrm{~g}, 16.22 \mathrm{mmol}, 5.00$ equiv) and $\mathrm{NalO}_{4}$ ( $3.470 \mathrm{~g}, 16.22 \mathrm{mmol}, 5.00$ equiv) were suspended in a mixture 1:1 acetone/water $(30 \mathrm{~mL})$. The resulting slurry was stirred at room temperature for $16 \mathrm{~h}$. It was then diluted with EtOAc $(30 \mathrm{~mL})$, washed successively with water $(2 \times 20$ $\mathrm{mL}$ ) and brine $(20 \mathrm{~mL})$, dried over $\mathrm{MgSO}_{4}$, filtered, and concentrated under reduced pressure. The resulting yellow oil was dissolved in diethyl ether $(20 \mathrm{~mL})$ then shaken 5 min with a basic aqueous solution of sorbitol ( $25 \mathrm{~mL}, 1 \mathrm{M}$ sorbitol, $1 \mathrm{M} \mathrm{Na}_{2} \mathrm{CO}_{3}$ ), the aqueous layer was re-acidified with $4 \mathrm{M} \mathrm{HCl}$ $(25 \mathrm{~mL}, \mathrm{pH}=2)$ and extracted with diethyl ether $(35 \mathrm{~mL})$. The organic layer was dried over $\mathrm{MgSO}_{4}$, filtered and the solvent was removed under reduced pressure affording $(E)$-non-1-en-3-yn-1-ylboronic acid $(\mathbf{5 0 u})$ as a yellow oil $(0.365 \mathrm{~g}, 2.20 \mathrm{mmol}, 68 \%) .{ }^{1} \mathrm{H}$ NMR (400 MHz, DMSO- $\left.d_{6} / \mathrm{D}_{2} \mathrm{O} 9: 1\right) \delta 6.27(\mathrm{dt}$, $J=18.3,2.1 \mathrm{~Hz}, 1 \mathrm{H}, \mathrm{CHCHB}), 5.83(\mathrm{~d}, J=18.4 \mathrm{~Hz}, 1 \mathrm{H}, \mathrm{CHCHB}), 2.32\left(\mathrm{td}, J=7.0,2.2 \mathrm{~Hz}, 2 \mathrm{H}, \mathrm{CCH}_{2}\right), 1.46$ $\left(\mathrm{m}, 2 \mathrm{H}, \mathrm{CH}_{2}\right), 1.38-1.23\left(\mathrm{~m}, 4 \mathrm{H}, 2 \times \mathrm{CH}_{2}\right), 0.86\left(\mathrm{t}, \mathrm{J}=7.0 \mathrm{~Hz}, 3 \mathrm{H}, \mathrm{CH}_{2} \mathrm{CH}_{3}\right) ;{ }^{13} \mathrm{C}$ NMR (101 MHz, DMSO$\left.d_{6} / \mathrm{D}_{2} \mathrm{O} 9: 1\right) \delta 136.6(\mathrm{br}), 126.6,93.7,81.2,30.6,27.9,21.7,18.7,14.0 ;{ }^{11} \mathrm{~B}$ NMR (128 MHz, DMSO$\left.d_{6} / D_{2} \mathrm{O} 9: 1\right) \delta$ 27.2; IR ( $\left.v_{\max }, \mathrm{cm}^{-1}\right) 2985(\mathrm{~m}), 2904(\mathrm{~m}), 1773(\mathrm{~m}), 1716(\mathrm{~s}), 1427(\mathrm{~m}), 1395(\mathrm{~s}), 1343(\mathrm{~m})$, 1071 (s), 1055 (s), 726 (m); HRMS (APPI/LTQ-Orbitrap) m/z: [M] ${ }^{+}$Calcd for $\mathrm{C}_{9} \mathrm{H}_{15} \mathrm{BO}_{2}{ }^{+}$166.1160; found 166.1161. The ${ }^{13} \mathrm{C}$ NMR signal for the carbon attached to boron was broad due to the quadrupolar splitting of ${ }^{11} \mathrm{~B}$.

\footnotetext{
40 J. R. Coombs, L. Zhang and J. P. Morken, Org. Lett., 2015, 17, 1708.
} 
<smiles>O=C(O)c1ccccc1I</smiles>

$69 a$ 由a

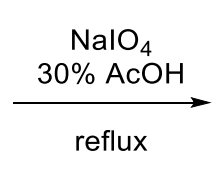

reflux<smiles>O=C1OI(O)c2ccccc21</smiles>

$70 a$

Following a reported procedure, ${ }^{41} \mathrm{NaIO}_{4}(18.1 \mathrm{~g}, 85.0 \mathrm{mmol}, 1.05$ equiv) and 2-iodobenzoic acid (69a) (20.0 g, $81.0 \mathrm{mmol}, 1.00$ equiv) were suspended in $30 \%$ (v/v) aq. AcOH (160 mL). The mixture was vigorously stirred under reflux for $4 \mathrm{~h}$ and allowed to cool to room temperature. The precipitate was collected by filtration, washed on the filter with ice water $(3 \times 40 \mathrm{~mL})$ and acetone $(45 \mathrm{~mL})$, and airdried in the dark to give 2-iodosylbenzoic acid (70a) as a white solid (20.8 g, $79.0 \mathrm{mmol}, 98 \%) .{ }^{1} \mathrm{H} \mathrm{NMR}$ (400 MHz, DMSO-d $)$ : $\delta 8.02(\mathrm{dd}, J=7.7,1.4 \mathrm{~Hz}, 1 \mathrm{H}, \mathrm{ArH}), 7.97(\mathrm{~m}, 1 \mathrm{H}, \operatorname{ArH}), 7.85(\mathrm{dd}, J=8.2,0.7 \mathrm{~Hz}$, $1 \mathrm{H}, \mathrm{ArH}), 7.71$ (td, $J=7.6,1.2 \mathrm{~Hz}, 1 \mathrm{H}, \mathrm{ArH}) ;{ }^{13} \mathrm{C}$ NMR $\left(100 \mathrm{MHz}, \mathrm{DMSO}-d_{6}\right): \delta 167.7,134.5,131.5,131.1$, $130.4,126.3,120.4$. The values of the NMR spectra are in accordance with reported literature data. ${ }^{41}$

\section{1-Hydroxy-5-methoxy-1 $\lambda^{3}$-benzo[d][1,2]iodaoxol-3(1H)-one (70b)}<smiles>COc1ccc(I)c(C(=O)O)c1</smiles>

$69 b$

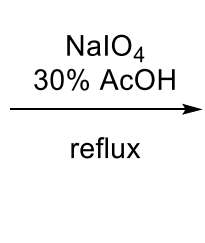<smiles>COc1ccc(O)c(C(=O)O)c1</smiles>

Following a reported procedure, ${ }^{42} \mathrm{NalO}_{4}(2.25 \mathrm{~g}, 10.5 \mathrm{mmol}, 1.05$ equiv) and 2-iodo-5-methoxybenzoic acid (69b) (2.78 g, $10.0 \mathrm{mmol}, 1.00$ equiv) were suspended in $30 \%$ (v/v) aq. AcOH ( $27 \mathrm{~mL})$. The mixture was vigorously stirred under reflux for $4 \mathrm{~h}$ and allowed to cool to room temperature. The precipitate was collected by filtration, washed on the filter with ice water $(3 \times 8 \mathrm{~mL})$ and acetone $(3 \times 6 \mathrm{~mL})$, and air-dried in the dark to give 1-hydroxy-5-methoxy-1 $\lambda^{3}$-benzo[d][1,2]iodaoxol-3(1H)-one (70b) as a white solid (2.31 g, $7.90 \mathrm{mmol}, 79 \%)$. ${ }^{1} \mathrm{H}$ NMR (400 MHz, DMSO-d $\left.)\right) 8.00(\mathrm{~s}, 1 \mathrm{H}, \mathrm{ArH}), 7.72-7.61(\mathrm{~m}$, $1 \mathrm{H}, \mathrm{ArH}), 7.59-7.47(\mathrm{~m}, 1 \mathrm{H}, \mathrm{ArH}), 3.88\left(\mathrm{~s}, 3 \mathrm{H}, \mathrm{OCH}_{3}\right) ;{ }^{13} \mathrm{C} \mathrm{NMR}\left(101 \mathrm{MHz}, \mathrm{DMSO}-d_{6}\right) \delta 167.9,162.0$, $133.5,127.6,122.0,115.4,109.5,56.4$. The values of the NMR spectra are in accordance with reported literature data. ${ }^{42}$

\section{5-Fluoro-1-hydroxy-1 $\lambda^{3}$-benzo[d][1,2]iodaoxol-3(1H)-one (70c)}<smiles>CC(C)(C)OC(=O)c1cc(F)ccc1I</smiles>

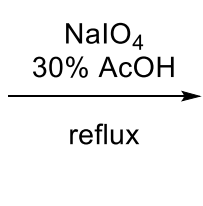<smiles>O=C1OI(O)c2ccc(F)cc21</smiles>

Following a reported procedure, ${ }^{42} \mathrm{NaIO}_{4}(2.25 \mathrm{~g}, 10.5 \mathrm{mmol}, 1.05$ equiv) and 5-fluoro-2-iodobenzoic acid (69c) (2.70 g, $10.0 \mathrm{mmol}, 1.00$ equiv) were suspended in $30 \%$ (v/v) aq. AcOH ( $27 \mathrm{~mL})$. The mixture was vigorously stirred under reflux for $4 \mathrm{~h}$ and allowed to cool to room temperature. The precipitate was collected by filtration, washed on the filter with ice water $(3 \times 8 \mathrm{~mL})$ and acetone $(3 \times 6 \mathrm{~mL})$, and air-dried in the dark to give 5-fluoro-1-hydroxy-1 $\lambda^{3}$-benzo[ $\left.d\right][1,2]$ iodaoxol-3(1H)-one $(70 \mathrm{c})$ as a white solid (2.62 g, $9.30 \mathrm{mmol}, 93 \%) .{ }^{1} \mathrm{H}$ NMR (400 MHz, DMSO-d $) \delta 8.21(\mathrm{~s}, 1 \mathrm{H}, \operatorname{Ar} H), 7.89-7.78(\mathrm{~m}, 2 \mathrm{H}$,

\footnotetext{
${ }^{41}$ L. Kraszkiewicz and L. Skulski, Arkivoc. 2003, 6, 120.

${ }^{42}$ S. Bertho, R. Rey-Rodriguez, C. Colas, P. Retailleau and I. Gillaizeau, Chem. Eur. J., 2017, 23, 17674.
} 
$\operatorname{ArH}), 7.78-7.72(\mathrm{~m}, 1 \mathrm{H}, \operatorname{ArH}) ;{ }^{13} \mathrm{C}$ NMR (101 MHz, DMSO- $\left.d_{6}\right) \delta 166.5,164.0$ (d, J = 248.3 Hz), 134.2 (d, $J=7.3 \mathrm{~Hz}$ ), $128.4(\mathrm{~d}, J=8.6 \mathrm{~Hz}), 121.8(\mathrm{~d}, J=24.0 \mathrm{~Hz}), 117.5(\mathrm{~d}, J=23.5 \mathrm{~Hz}), 114.3 ;{ }^{19} \mathrm{~F} \mathrm{NMR}(376 \mathrm{MHz}$, DMSO- $\left.d_{6}\right) \delta-112.7$. The values of the NMR spectra are in accordance with reported literature data. ${ }^{42}$

\section{1-Acetoxy-1,2-benziodoxol-3-(1H)-one (71)}

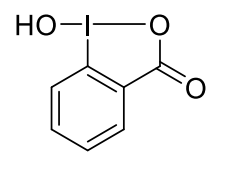

$70 a$

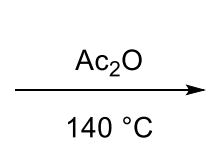

$140^{\circ} \mathrm{C}$<smiles>CC(=O)OI1OC(=O)c2ccccc21</smiles>

71

Following a reported procedure, ${ }^{43}$ 2-iodosylbenzoic acid (70a) $(20.8 \mathrm{~g}, 79.0 \mathrm{mmol}, 1.00$ equiv) was suspended in acetic anhydride $\left(75.0 \mathrm{~mL}, 788 \mathrm{mmol}, 10.0\right.$ equiv) and heated to reflux $\left(140{ }^{\circ} \mathrm{C}\right)$ until complete dissolution (about $15 \mathrm{~min}$ ). The resulting clear solution was allowed to cool to room temperature and then cooled to $5{ }^{\circ} \mathrm{C}$ overnight. The white crystals were filtered, washed with pentane $(3 \times 30 \mathrm{~mL})$ and dried under reduced pressure to afford 1-acetoxy-1,2-benziodoxol-3-(1H)-one (71) as a white solid (22.3 g, $73.0 \mathrm{mmol}, 92 \%) .{ }^{1} \mathrm{H} \mathrm{NMR}\left(\mathrm{CDCl}_{3}, 400 \mathrm{MHz}\right) \delta 8.24$ (dd, $\left.J=7.6,1.6 \mathrm{~Hz}, 1 \mathrm{H}, \mathrm{ArH}\right)$, $8.00(\mathrm{dd}, J=8.3,1.0 \mathrm{~Hz}, 1 \mathrm{H}, \mathrm{ArH}), 7.92(\mathrm{ddd}, J=8.4,7.2,1.6 \mathrm{~Hz}, 1 \mathrm{H}, \mathrm{ArH}), 7.71(\mathrm{td}, J=7.3,1.1 \mathrm{~Hz}, 1 \mathrm{H}$, $\mathrm{ArH}), 2.25\left(\mathrm{~s}, 3 \mathrm{H}, \mathrm{COCH}_{3}\right) ;{ }^{13} \mathrm{C} \mathrm{NMR}\left(\mathrm{CDCl}_{3}, 100 \mathrm{MHz}\right) \delta 176.5,168.2,136.2,133.3,131.4,129.4,129.1$, $118.4,20.4$. The values of the NMR spectra are in accordance with reported literature data. ${ }^{44}$

\section{1,1,1,3,3,3-Hexafluoro-2-(2-iodophenyl)propan-2-ol (69')}<smiles>OC(c1ccccc1)(c1ccccc1)C(F)(F)F</smiles>

72

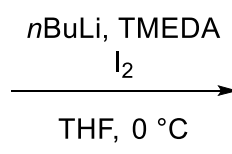

$\mathrm{THF}, 0^{\circ} \mathrm{C}$<smiles>OC(c1ccccc1F)(c1ccccc1C(F)(F)F)C(F)(F)F</smiles>

69'

Following a reported procedure, ${ }^{45}$ TMEDA ( $1.27 \mathrm{~mL}, 8.40 \mathrm{mmol}, 0.20$ equiv.) was added to a solution of $n$-BuLi ( $37.0 \mathrm{~mL}, 92.0 \mathrm{mmol}, 2.20$ equiv., $2.5 \mathrm{M}$ in hexanes). After $15 \mathrm{~min}$, the cloudy solution was cooled to $0^{\circ} \mathrm{C}$ and 1,1,1,3,3,3-hexafluoro-2-phenylpropan-2-ol (72) $(7.07 \mathrm{~mL}, 42.0 \mathrm{mmol}, 1.00$ equiv.) in THF $(6.0 \mathrm{~mL})$ was added dropwise. The reaction was stirred $30 \mathrm{~min}$ at $0{ }^{\circ} \mathrm{C}$ and then $18 \mathrm{~h}$ at room temperature. Then, THF $(30.0 \mathrm{~mL})$ was added, followed by the portionwise addition of $\mathrm{I}_{2}(11.3 \mathrm{~g}, 44.5$ mmol, 1.05 equiv.) at $0{ }^{\circ} \mathrm{C}$ and the mixture was stirred at $0{ }^{\circ} \mathrm{C}$ for $30 \mathrm{~min}$ and $4 \mathrm{~h}$ at room temperature. The reaction was quenched with saturated aqueous $\mathrm{NH}_{4} \mathrm{Cl}(50 \mathrm{~mL})$ and extracted with diethyl ether (3 $x 30 \mathrm{~mL}$ ). The combined organic layers were washed with water, brine, dried over $\mathrm{MgSO}_{4}$, filtered and the solvent was removed under reduced pressure. The crude product was purified by column chromatography using EtOAc/pentane 3:97 as eluent to afford 1,1,1,3,3,3-hexafluoro-2-(2iodophenyl)propan-2-ol (69') as a colorless oil $(13.9 \mathrm{~g}, 37.5 \mathrm{mmol}, 89 \%) .{ }^{1} \mathrm{H} \mathrm{NMR}\left(400 \mathrm{MHz}, \mathrm{CDCl}_{3}\right) \delta$ $8.13(\mathrm{dd}, J=7.9,1.4 \mathrm{~Hz}, 1 \mathrm{H}, \operatorname{ArH}), 7.63(\mathrm{~d}, J=8.2 \mathrm{~Hz}, 1 \mathrm{H}, \operatorname{ArH}), 7.43(\mathrm{dt}, J=8.4,1.4 \mathrm{~Hz}, 1 \mathrm{H}, \operatorname{ArH}), 7.11$ (dt, $J=8.0,1.5 \mathrm{~Hz}, 1 \mathrm{H}, \mathrm{ArH}), 4.23(\mathrm{~s}, 1 \mathrm{H}, \mathrm{OH}) ;{ }^{13} \mathrm{C} \mathrm{NMR}\left(101 \mathrm{MHz}, \mathrm{CDCl}_{3}\right) \delta 144.7,131.4,130.0,129.7$, 128.0, 122.6 (q, $J=291.4 \mathrm{~Hz}), 90.6,78.9(\mathrm{q}, J=32.1 \mathrm{~Hz}) ;{ }^{19} \mathrm{~F} \mathrm{NMR}\left(376 \mathrm{MHz}, \mathrm{CDCl}_{3}\right) \delta-73.4$. The values of the NMR spectra are in accordance with reported literature data. ${ }^{45}$

\footnotetext{
${ }^{43}$ P. Caramenti, S. Nicolai and J. Waser, Chem. Eur. J., 2017, 23, 14702.

${ }^{44}$ P. Eisenberger, S. Gischig, A. Togni, Chem. Eur. J., 2006, 12, 2579.

45 J. Cvengroš, D. Stolz and A. Togni, Synthesis 2009, 2818.
} 


\section{3,3-Bis(trifluoromethyl)-1 $\lambda^{3}$-benzo[d][1,2]iodaoxol-1(3H)-yl acetate (71')}<smiles>OC(F)(F)C(F)(F)c1ccccc1F</smiles>

69'

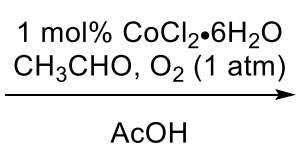<smiles>CC(=O)OI1OC(C(F)(F)F)c2ccccc21</smiles>

$7^{\prime}$

Following a reported procedure, ${ }^{46}$ a $500 \mathrm{~mL}$ flask was charged with glacial acetic acid $(188 \mathrm{~mL})$, 1,1,1,3,3,3-hexafluoro-2-(2-iodophenyl)propan-2-ol (69') (13.9 g, $37.5 \mathrm{mmol}, 1.00$ equiv.) and cobalt(II) chloride hexahydrate $\left(89.0 \mathrm{~g}, 0.375 \mathrm{mmol}, 0.01\right.$ equiv.). The reaction vessel was purged with $\mathrm{O}_{2}$ for 5 min before acetaldehyde $(21.4 \mathrm{~mL}, 379 \mathrm{mmol}, 10.0$ equiv.) was added in one portion. The reaction mixture was stirred under $1 \mathrm{~atm}$ of $\mathrm{O}_{2}$, delivered by inflated balloon, at room temperature for $12 \mathrm{~h}$. Acetaldehyde ( $21.4 \mathrm{~mL}, 379 \mathrm{mmol}, 10.0$ equiv.) was added and the reaction continued for $6 \mathrm{~h}$. The solvent was removed under reduced pressure and the residue was dissolved in DCM. The organic layer was washed with distilled water $(50 \mathrm{~mL})$ and extracted with DCM $(3 \times 50 \mathrm{~mL})$. The organic layer was dried over $\mathrm{MgSO}_{4}$, filtered and the solvent was removed under reduced pressure. The obtained residue was triturated in pentane for $0.5 \mathrm{~h}$, filtered and washed with pentane (operation repeated 2 times) to afford 3,3-bis(trifluoromethyl)-1 $\lambda^{3}$-benzo[d] [1,2]iodaoxol-1(3H)-yl acetate (71') as a white solid (9.91 g, $23.2 \mathrm{mmol}, 62 \%) .{ }^{1} \mathrm{H}$ NMR (400 MHz, DMSO- $\left.d_{6}\right) \delta 7.93$ (ddd, $\left.J=8.4,7.1,1.6 \mathrm{~Hz}, 1 \mathrm{H}, \mathrm{ArH}\right), 7.85-7.69$ $(\mathrm{m}, 3 \mathrm{H}, \mathrm{ArH}), 2.19\left(\mathrm{~s}, 3 \mathrm{H},(\mathrm{O}) \mathrm{CCH}_{3}\right) ;{ }^{13} \mathrm{C}$ NMR $\left(101 \mathrm{MHz}\right.$, DMSO- $\left.d_{6}\right) \delta 174.4,134.2,131.4,131.0,130.8$, $129.5-129.0(\mathrm{~m}), 123.1(\mathrm{q}, J=289.5 \mathrm{~Hz}), 116.1,84.5-83.7(\mathrm{~m}), 20.0 ;{ }^{19} \mathrm{~F}$ NMR $\left(376 \mathrm{MHz}, \mathrm{DMSO}-d_{6}\right) \delta$ -75.1. The values of the NMR spectra are in accordance with reported literature data. ${ }^{47}$

\section{General procedure A: Synthesis of VBX reagents:}
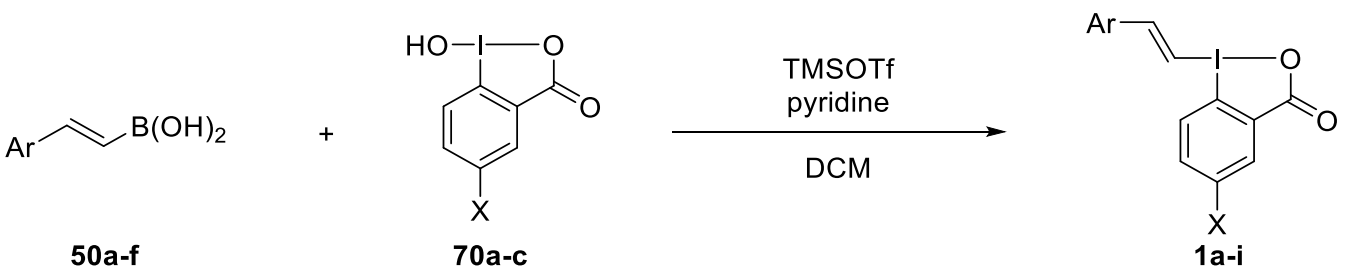

To a suspension of 2-iodosylbenzoic acid (70a-c) $(1.30 \mathrm{mmol}, 1.00$ equiv) in dry DCM (13 mL) was added TMSOTf ( $0.270 \mathrm{~mL}, 1.50 \mathrm{mmol}, 1.15$ equiv) dropwise over $10 \mathrm{~min}$ and stirred for $30 \mathrm{~min}$ at room temperature. Afterwards, the corresponding vinyl boronic acid (50a-i) $(1.50 \mathrm{mmol}, 1.15$ equiv) was added and the reaction mixture was stirred until the reaction was completed ( $1 \mathrm{ho} 8 \mathrm{~h}$, monitored by TLC, MeOH/DCM 5:95). Pyridine ( $0.121 \mathrm{~mL}, 1.50 \mathrm{mmol}, 1.15$ equiv) was added and after further stirring for $10 \mathrm{~min}$ at room temperature, the solvent was removed under reduced pressure. The resulting solid was dissolved in $\mathrm{DCM}(20 \mathrm{~mL})$ and washed with $1 \mathrm{M} \mathrm{HCl}(10 \mathrm{~mL})$. The aqueous layer was extracted with DCM $(3 \times 20 \mathrm{~mL})$. The organic layers were combined, washed successively with a saturated solution of $\mathrm{NaHCO}_{3}(40 \mathrm{~mL})$ and water $(3 \times 20 \mathrm{~mL})$, dried over $\mathrm{MgSO}_{4}$, filtered and the solvent was removed under reduced pressure. The resulting solid was dissolved again in DCM (minimum amount until dissolution) and precipitated in $\mathrm{Et}_{2} \mathrm{O}$ (ca. $150 \mathrm{~mL}$ ). After precipitation at $4{ }^{\circ} \mathrm{C}$ for $2 \mathrm{~h}$, the solid was filtered and washed with $\mathrm{Et}_{2} \mathrm{O}$ to afford the corresponding VBX reagent.

\footnotetext{
${ }^{46}$ A. Maity, S.-M. Hyun and D. C. Powers, Nat. Chem. 2018, 10, 200.

${ }^{47}$ P. Eisenberger, S. Gischig and A. Togni, Chem. Eur J. 2006, 12, 2579.
} 
General procedure B: Synthesis of VBX reagents:

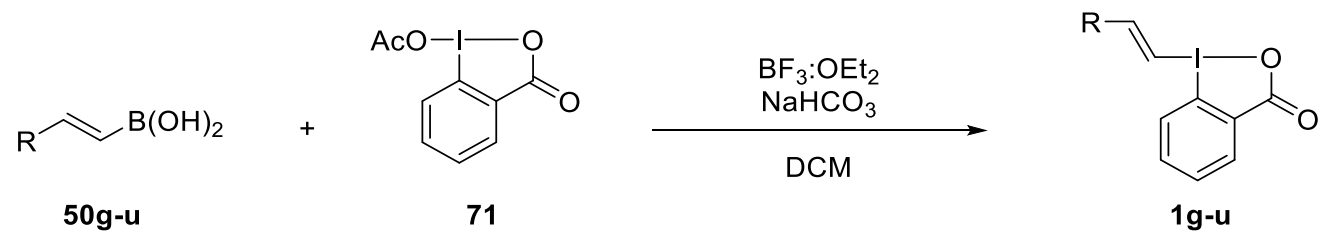

To a solution of the corresponding vinyl boronic acid $(50 \mathrm{~g}-\mathrm{u})(1.30 \mathrm{mmol}, 1.00$ equiv) in dry DCM (13 $\mathrm{mL}$ ) was added $\mathrm{BF}_{3}: \mathrm{OEt}_{2}\left(0.198 \mathrm{~mL}, 1.56 \mathrm{mmol}, 1.20\right.$ equiv) dropwise at $0{ }^{\circ} \mathrm{C}$. After 15 minutes, 1 acetoxy-1,2-benziodoxol-3-(1H)-one (71) $(477 \mathrm{mg}, 1.56 \mathrm{mmol}, 1.20$ equiv) was added in one portion at $0{ }^{\circ} \mathrm{C}$. The reaction mixture was allowed to warm up to room temperature and stirred until the reaction was completed ( 4 to $24 \mathrm{~h}$, monitored by TLC using MeOH/DCM 5:95). The reaction was then quenched with a saturated solution of $\mathrm{NaHCO}_{3}(13 \mathrm{~mL})$ and stirred vigorously for $1 \mathrm{~h}$. The resulting suspension was filtered and the filtrate was extracted with DCM $(3 \times 20 \mathrm{~mL})$. The combined organic layers were washed with water $(3 \times 20 \mathrm{~mL})$, dried over $\mathrm{MgSO}_{4}$, filtered and the solvent was removed under reduced pressure. The resulting solid was dissolved in DCM (minimum amount until dissolution) and precipitated in $\mathrm{Et}_{2} \mathrm{O}$ (ca. $150 \mathrm{~mL}$ ). After precipitation at $4{ }^{\circ} \mathrm{C}$ for $2 \mathrm{~h}$, the solid was filtered and washed with $\mathrm{Et}_{2} \mathrm{O}$ to afford the corresponding $\mathrm{VBX}$ reagent.

\section{General procedure C: Synthesis of VBX reagents:}

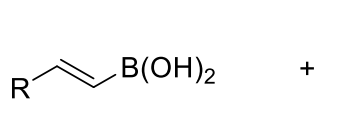

50a-p

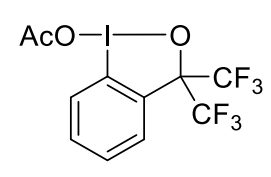

$7^{\prime}$

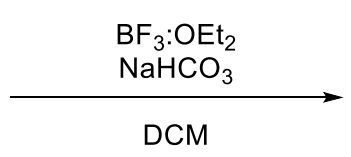

1 'a-p

To a solution of the corresponding vinyl boronic acid (50a-50p) $(1.00 \mathrm{mmol}, 1.00$ equiv) in dry DCM $(10 \mathrm{~mL})$ was added $\mathrm{BF}_{3}: \mathrm{OEt}_{2}\left(0.152 \mathrm{~mL}, 1.20 \mathrm{mmol}, 1.20\right.$ equiv) dropwise at $0{ }^{\circ} \mathrm{C}$. After 15 minutes, 3,3bis(trifluoromethyl)-1 $1 \lambda^{3}$-benzo[d][1,2] iodaoxol-1(3H)-yl acetate (71') (514 mg, $1.20 \mathrm{mmol}, 1.20$ equiv.) was added in one portion at $0{ }^{\circ} \mathrm{C}$. The reaction mixture was allowed to warm up to room temperature and stirred for $1 \mathrm{~h}$. The reaction mixture was then quenched with saturated aqueous $\mathrm{NaHCO}_{3}$ solution and extracted with dichloromethane (3 times). The combined organic extracts were dried over $\mathrm{MgSO}_{4}$, filtered and concentrated under reduced pressure. The residue was purified by column chromatography using EtOAc/pentane as eluent to give the corresponding VBX reagent.

\section{(E)-1-Styryl-1 $\lambda^{3}$-benzo[d][1,2]iodaoxol-3(1H)-one (1a)}

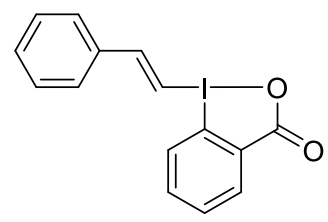

$1 \mathrm{a}$

Following general procedure A, starting from trans-2-phenylvinylboronic acid (50a) (221 mg, 1.50 $\mathrm{mmol}$ ) and 2-iodosylbenzoic acid (70a) (343 mg, $1.30 \mathrm{mmol}$ ), afforded (E)-1-styryl-1 $\lambda^{3}$ benzo[d][1,2]iodaoxol-3(1H)-one (1a) as a white solid (351 mg, $1.00 \mathrm{mmol}, 77 \%) .{ }^{1} \mathrm{H}$ NMR $(400 \mathrm{MHz}$, MeOD) $\delta 8.32-8.25(\mathrm{~m}, 1 \mathrm{H}, \mathrm{ArH}), 7.97(\mathrm{~d}, J=15.5 \mathrm{~Hz}, 1 \mathrm{H}, \mathrm{ICHCHPh}), 7.77-7.63(\mathrm{~m}, 6 \mathrm{H}, \mathrm{ArH}$ and ICHCHPh), $7.54-7.45$ (m, 3H, ArH). ${ }^{13} \mathrm{C}$ NMR (101 MHz, MeOD) $\delta$ 170.1, 155.8, 136.7, 135.3, 134.5, 
$133.3,132.1,131.8,130.2,129.0,129.0,115.5,100.0$. The values of the NMR spectra are in accordance with reported literature data. ${ }^{48}$

The reaction was scaled up to trans-2-phenylvinylboronic acid (50a) $(1.48 \mathrm{~g}, 10.0 \mathrm{mmol})$ and 2iodosylbenzoic acid (70a) $(2.30 \mathrm{~g}, 8.70 \mathrm{mmol})$ affording $(E)$-1-styryl-1 $\lambda^{3}$-benzo[d][1,2]iodaoxol-3(1H)one (1a) $(2.20 \mathrm{~g}, 6.30 \mathrm{mmol}, 72 \%)$.

(E)-1-(4-Methoxystyryl)-1 $\lambda^{3}$-benzo[d][1,2]iodaoxol-3(1H)-one (1b)<smiles>COc1ccc(/C=C/I2OC(=O)c3ccccc32)cc1</smiles>

1b

Following general procedure $A$, starting from trans-2-(4-methoxyphenyl)vinylboronic acid (50c) (266 $\mathrm{mg}, 1.50 \mathrm{mmol}$ ) and 2-iodosylbenzoic acid (70a) (343 mg, $1.30 \mathrm{mmol}$ ), afforded (E)-1-(4methoxystyryl)-1 $\lambda^{3}$-benzo[d] [1,2] iodaoxol-3(1H)-one (1) b) as a white solid (306 mg, $0.805 \mathrm{mmol}, 62 \%$ ). ${ }^{1} \mathrm{H}$ NMR $(400 \mathrm{MHz}, \mathrm{MeOD}) \delta 8.29(\mathrm{dt}, J=5.8,3.5 \mathrm{~Hz}, 1 \mathrm{H}, \mathrm{ArH}), 7.89(\mathrm{~d}, J=15.3 \mathrm{~Hz}, 1 \mathrm{H}, \mathrm{ICHCHPh}), 7.78$ - $7.60(\mathrm{~m}, 5 \mathrm{H}, \mathrm{ArH}), 7.45(\mathrm{~d}, J=15.4 \mathrm{~Hz}, 1 \mathrm{H}, \mathrm{ICHCHPh}), 7.12-6.95(\mathrm{~m}, 2 \mathrm{H}, \mathrm{ArH}), 3.87\left(\mathrm{~s}, 3 \mathrm{H}, \mathrm{OCH}_{3}\right) ;{ }^{13} \mathrm{C}$ NMR (101 MHz, MeOD) $\delta 170.1,163.7,155.8,135.2,134.5,133.3,131.8,130.8,129.4,128.9,115.6$, $115.5,95.9,56.0$. The values of the NMR spectra are in accordance with reported literature data. ${ }^{48}$

(E)-1-(4-Methylstyryl)-1 $\lambda^{3}$-benzo[d][1,2]iodaoxol-3(1H)-one (1c)<smiles>Cc1ccc(/C=C/I2OC(=O)c3ccccc32)cc1</smiles>

$1 c$

Following general procedure A, starting from trans-2-(4-methylphenyl)vinylboronic acid (50b) $(242 \mathrm{mg}$, $1.50 \mathrm{mmol}$ ) and 2-iodosylbenzoic acid (70a) (343 mg, $1.30 \mathrm{mmol}$ ), afforded (E)-1-(4-methylstyryl)- $1 \lambda^{3}$ benzo[d][1,2]iodaoxol-3(1H)-one (1c) as a white solid (335 mg, $0.920 \mathrm{mmol}, 71 \%) .{ }^{1} \mathrm{H} \mathrm{NMR}(400 \mathrm{MHz}$, MeOD) $\delta 8.32$ - $8.25(\mathrm{~m}, 1 \mathrm{H}, \mathrm{ArH}), 7.92(\mathrm{~d}, J=15.4 \mathrm{~Hz}, 1 \mathrm{H}, \mathrm{ICHCHPh}), 7.76-7.64(\mathrm{~m}, 3 \mathrm{H}, \mathrm{ArH}), 7.62-$ $7.54\left(\mathrm{~m}, 3 \mathrm{H}, \mathrm{ArH}\right.$ and ICHCHPh), $7.31(\mathrm{~d}, J=7.9 \mathrm{~Hz}, 2 \mathrm{H}, \mathrm{ArH}), 2.42\left(\mathrm{~s}, 3 \mathrm{H}, \mathrm{CH}_{3}\right) ;{ }^{13} \mathrm{C} \mathrm{NMR}(101 \mathrm{MHz}$, MeOD) $\delta 169.9,155.7,142.8,135.0,134.3,133.8,133.1,131.6,130.6,128.8,128.7,115.3,98.1,21.3$. The values of the NMR spectra are in accordance with reported literature data. ${ }^{48}$

(E)-1-(4-(Trifluoromethyl)-1 $\lambda^{3}$-benzo[d][1,2]iodaoxol-3(1H)-one (1d)

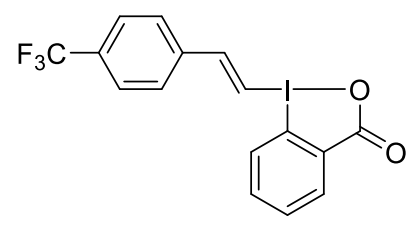

$1 d$

Following general procedure $A$, starting from trans-2-[4-(trifluoromethyl)phenylvinylboronic acid (50d) (323 mg, $1.50 \mathrm{mmol}$ ) and 2-iodosylbenzoic acid (70a) (343 mg, $1.30 \mathrm{mmol}$ ), afforded (E)-1-(4(trifluoromethyl)-1 $\lambda^{3}$-benzo[d][1,2]iodaoxol-3(1H)-one (1d) as a white solid (275 $\mathrm{mg}, 0.658 \mathrm{mmol}$,

\footnotetext{
${ }^{48}$ E. Stridfeldt, A. Seemann, M. J. Bouma, C. Dey, A. Ertan and B. Olofsson, Chem. Eur. J., 2016, 22, 16066.
} 
51\%). ${ }^{1} \mathrm{H}$ NMR (400 MHz, MeOD) $\delta 8.30(\mathrm{~m}, 1 \mathrm{H}, \mathrm{ArH}), 8.05$ (d, J=15.5 Hz, 1H, ICHCHPh), $7.93-7.84(\mathrm{~m}$, $3 \mathrm{H}, \mathrm{ArH}$ and ICHCHPh), $7.81(\mathrm{~m}, 2 \mathrm{H}, \mathrm{ArH}), 7.74(\mathrm{~m}, 3 \mathrm{H}, \mathrm{ArH}) ;{ }^{13} \mathrm{C} \mathrm{NMR}(101 \mathrm{MHz}, \mathrm{MeOD}) \delta$ 170.6, 154.1, 140.6, 136.0, 134.4, 133.8, 133.7 (q, $J=37.7 \mathrm{~Hz}), 132.4,129.9,129.7,127.5$ (q, $J=3.8 \mathrm{~Hz}), 125.8$ (q, $J=$ $271.5 \mathrm{~Hz}$ ) 115.9, 104.1; ${ }^{19} \mathrm{~F}$ NMR (376 MHz, MeOD) $\delta$-64.4. The values of the NMR spectra are in accordance with reported literature data. ${ }^{48}$

(E)-1-(4-Fluorostyryl)-1 $\lambda^{3}$-benzo[d][1,2]iodaoxol-3(1H)-one (1e)

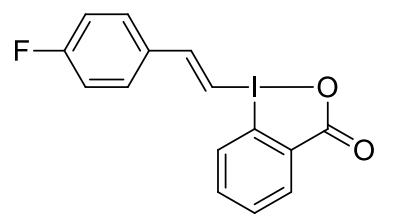

$1 \mathrm{e}$

Following general procedure A, starting from trans-2-(4-fluorophenyl)vinylboronic acid (50e) $(248 \mathrm{mg}$, $1.50 \mathrm{mmol}$ ) and 2-iodosylbenzoic acid (70a) (343 mg, $1.30 \mathrm{mmol}$ ), afforded (E)-1-(4-fluoroystyryl)- $1 \lambda^{3}$ benzo[d][1,2]iodaoxol-3(1H)-one (1e) as a white solid (424 mg, $1.152 \mathrm{mmol}, 89 \%)$. M.p. 146-148 ${ }^{\circ} \mathrm{C}$; $\mathrm{R}_{\mathrm{f}}$ $=0.11(\mathrm{MeOH} / \mathrm{DCM} 5: 95) ;{ }^{1} \mathrm{H}$ NMR $(400 \mathrm{MHz}, \mathrm{MeOD}) \delta 8.38-8.31(\mathrm{~m}, 1 \mathrm{H}, \mathrm{ArH}), 8.02(\mathrm{~d}, J=15.2 \mathrm{~Hz}$, 1H, ICHCHPh), $7.85-7.71(\mathrm{~m}, 5 \mathrm{H}, \mathrm{ArH}), 7.66(\mathrm{~d}, J=15.3,1 \mathrm{H}, \mathrm{ICHCHPh}), 7.30-7.22(\mathrm{~m}, 2 \mathrm{H}, \mathrm{ArH}) ;{ }^{13} \mathrm{C}$ NMR (101 MHz, MeOD) $\delta 170.9,166.4(\mathrm{~d}, J=251.2 \mathrm{~Hz}), 155.9,137.0,134.2,133.3(\mathrm{~d}, J=3.0 \mathrm{~Hz}), 132.6$, $132.2,131.9(\mathrm{~d}, J=8.7 \mathrm{~Hz}), 130.4,117.7(\mathrm{~d}, J=22.3 \mathrm{~Hz}), 115.7,98.2 ;{ }^{19} \mathrm{~F} \mathrm{NMR}(376 \mathrm{MHz}, \mathrm{MeOD}) \delta-$ 110.9; IR ( $\left.\mathrm{v}_{\max }, \mathrm{cm}^{-1}\right) 3018(\mathrm{~s}), 2946(\mathrm{~s}), 2858(\mathrm{~m}), 1750$ (s), 1731 (s), $1542(\mathrm{~s}), 1512(\mathrm{~s}), 1319$ (s), 1271 $(\mathrm{s}), 1243(\mathrm{~s}), 1200(\mathrm{~s}), 1165(\mathrm{~s}), 1124(\mathrm{~s}), 968(\mathrm{~s}), 838(\mathrm{~m})$; HRMS (ESI) calcd for $\mathrm{C}_{15} \mathrm{H}_{11} \mathrm{FIO}_{2}{ }^{+}[\mathrm{M}+\mathrm{H}]^{+}$ 368.9782; found 368.9785 .

\section{(E)-1-(2-(Naphthalen-1-yl)-1 $\lambda^{3}$-benzo[d][1,2]iodaoxol-3(1H)-one (1f)}

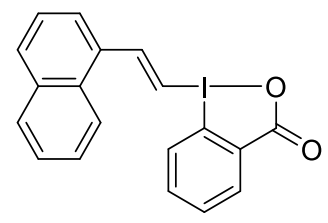

$1 f$

Following general procedure A, starting from (E)-(2-(naphthalen-1-yl)vinyl)boronic acid (50f) (296 mg, $1.50 \mathrm{mmol}$ ) and 2-iodosylbenzoic acid (70a) $(343 \mathrm{mg}, 1.30 \mathrm{mmol})$, afforded (E)-1-(2-(naphthalen-1-yl)$1 \lambda^{3}$-benzo[d][1,2]iodaoxol-3(1H)-one (1f) as a white solid (316 mg, $\left.0.790 \mathrm{mmol}, 61 \%\right)$. M.p. 164-166 ${ }^{\circ} \mathrm{C} ; R_{\mathrm{f}}=0.20$ (MeOH/DCM 5:95); ${ }^{1} \mathrm{H}$ NMR (400 MHz, MeOD) $\delta 8.79$ (d, J=15.1 Hz, 1H, ICHCHPh), 8.33 - $8.28(\mathrm{~m}, 1 \mathrm{H}, \mathrm{ArH}), 8.27$ - $8.23(\mathrm{~m}, 1 \mathrm{H}, \mathrm{ArH}), 8.05$ - $7.89(\mathrm{~m}, 3 \mathrm{H}, \mathrm{ArH}), 7.85$ - $7.79(\mathrm{~m}, 1 \mathrm{H}, \mathrm{ArH}), 7.74$ $7.66\left(\mathrm{~m}, 3 \mathrm{H}, \mathrm{ArH}\right.$ and ICHCHPh), $7.65-7.55(\mathrm{~m}, 3 \mathrm{H}, \mathrm{ArH}) ;{ }^{13} \mathrm{C}$ NMR $(101 \mathrm{MHz}, \mathrm{MeOD}) \delta 168.7,151.7$, 133.9, 133.8, 133.1, 132.6, 131.9, 131.0, 130.8, 130.4, 128.5, 127.7, 127.0, 126.2, 125.2, 122.8, 114.3, 101.2, 78.1; IR ( $\left.v_{\max } \mathrm{cm}^{-1}\right) 2985(\mathrm{~s}), 2906(\mathrm{~s}), 1390(\mathrm{~m}), 1247(\mathrm{~m}), 1227(\mathrm{~m}), 1065(\mathrm{~s}), 1051(\mathrm{~s}), 896(\mathrm{~m})$, $867(\mathrm{~m})$; HRMS (ESI) calcd for $\mathrm{C}_{19} \mathrm{H}_{13} \mathrm{INaO}_{2}{ }^{+}[\mathrm{M}+\mathrm{Na}]^{+} 422.9852$; found 422.9851 . 
(E)-1-(2-(Thiophen-2-yl)vinyl)-1 $\lambda^{3}$-benzo[d][1,2]iodaoxol-3(1H)-one (1g)<smiles>O=C1OI(/C=C/c2cccs2)c2ccccc21</smiles>

$1 \mathrm{~g}$

Following general procedure $B$, with a final purification by column chromatography using MeOH/DCM $5: 95$ as mobile phase to obtain the titled compound in pure form. Starting from (E)-(2-(thiophen-2yl)vinyl)boronic acid (50g) (169 mg, $1.10 \mathrm{mmol})$ and 1-acetoxy-1,2-benziodoxol-3-(1H)-one (71) $(477$ $\mathrm{mg}, 1.56 \mathrm{mmol})$, afforded (E)-1-( non-1-en-3-yn-1-yl)-1 $\lambda^{3}$-benzo[d][1,2]iodaoxol-3(1H)-one (1g) as a beige solid (145 mg, $0.407 \mathrm{mmol}, 37 \%$ ). M.p. (dec.) 201-205 ${ }^{\circ} \mathrm{C} ; \mathrm{R}_{\mathrm{f}}=0.13$ (MeOH/DCM 5:95); ${ }^{1} \mathrm{H}$ NMR (400 MHz, MeOD/CD ${ }_{2} \mathrm{Cl}_{2}$ 9:1) $\delta 8.32-8.25(\mathrm{~m}, 1 \mathrm{H}, \mathrm{ArH}), 8.04(\mathrm{~d}, J=15.3 \mathrm{~Hz}, 1 \mathrm{H}, \mathrm{ICHCH}), 7.74-7.65(\mathrm{~m}$, $3 \mathrm{H}, \operatorname{ArH}), 7.62(\mathrm{dt}, J=5.0,0.9 \mathrm{~Hz}, 1 \mathrm{H}, \mathrm{ArH}), 7.43(\mathrm{dd}, J=3.7,1.1 \mathrm{~Hz}, 1 \mathrm{H}, \operatorname{ArH}), 7.29(\mathrm{~d}, J=15.3 \mathrm{~Hz}, 1 \mathrm{H}$, $\mathrm{ICHCH}), 7.18$ (dd, $J=5.1,3.7 \mathrm{~Hz}, 1 \mathrm{H}, \mathrm{ArH}) ;{ }^{13} \mathrm{C} N M R\left(101 \mathrm{MHz}, \mathrm{MeOD} / \mathrm{CD}_{2} \mathrm{Cl}_{2}\right.$ 9:1) $\delta$ 169.8, 148.0, 140.9, 135.1, 134.2, 133.2, 132.3, 131.7, 130.7, 129.1, 128.5, 115.7, 96.3; IR $\left(v_{\max }, \mathrm{cm}^{-1}\right) 2987(\mathrm{~s}), 2967(\mathrm{~s})$, $2907(\mathrm{~m}), 1750(\mathrm{~m}), 1735(\mathrm{~m}), 1649(\mathrm{~m}), 1573(\mathrm{~m}), 1557(\mathrm{~m}), 1540(\mathrm{~m}), 1512(\mathrm{~m}), 1452(\mathrm{w}), 1393(\mathrm{~m})$, $1251(\mathrm{~m}), 1101(\mathrm{w}), 1068(\mathrm{~s}), 1054(\mathrm{~s}), 869(\mathrm{~m}), 765(\mathrm{~m}), 734(\mathrm{~m}), 687(\mathrm{~m}), 629(\mathrm{~s}), 611(\mathrm{~s})$; HRMS (ESI/QTOF) m/z: [M+H] $]^{+}$calcd for $\mathrm{C}_{13} \mathrm{H}_{10} \mathrm{IO}_{2} \mathrm{~S}^{+} 356.9441$; found 356.9442 .

\section{(E)-5-Methoxy-1-styryl-1 $\lambda^{3}$-benzo[d][1,2]iodaoxol-3(1H)-one (1h)}

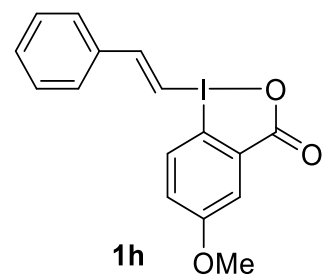

Following general procedure A, starting from (E)-styrylboronic acid (50a) $(221 \mathrm{mg}, 1.50 \mathrm{mmol})$ and 5methoxy-1-hydroxy-1,2-benziodoxol-3-(1H)-one (70b) (382 mg, $1.30 \mathrm{mmol})$, afforded (E)-5-methoxy1-styryl-1 $\lambda^{3}$-benzo[d][1,2]iodaoxol-3(1H)-one (1h) as a white solid (422 mg, $\left.1.11 \mathrm{mmol}, 85 \%\right)$. M.p. 167$168^{\circ} \mathrm{C} ; R_{f}=0.13(\mathrm{MeOH} / \mathrm{DCM} 5: 95) ;{ }^{1} \mathrm{H}$ NMR $(400 \mathrm{MHz}, \mathrm{MeOD}) \delta 7.95(\mathrm{~d}, J=15.4 \mathrm{~Hz}, 1 \mathrm{H}, \mathrm{ICHCHPh}$ ), $7.82(\mathrm{~d}, J=3.0 \mathrm{~Hz}, 1 \mathrm{H}, \mathrm{ArH}), 7.74-7.61(\mathrm{~m}, 3 \mathrm{H}, \mathrm{ArH}$ and ICHCHPh), $7.55(\mathrm{~d}, J=9.0 \mathrm{~Hz}, 1 \mathrm{H}, \mathrm{ArH}), 7.52-$ $7.44(\mathrm{~m}, 3 \mathrm{H}, \mathrm{ArH}), 7.25(\mathrm{dd}, J=9.0,3.1 \mathrm{~Hz}, 1 \mathrm{H}, \mathrm{ArH}), 3.88\left(\mathrm{~s}, 3 \mathrm{H}, \mathrm{OCH}_{3}\right) ;{ }^{13} \mathrm{C}$ NMR (101 MHz, MeOD) $\delta$ $169.9,163.7,155.6,136.7,135.9,132.1,130.2,129.7,129.0,121.7,117.8,103.6,99.6,56.4$; IR $\left(v_{\max }\right.$, $\left.\mathrm{cm}^{-1}\right) 2977(\mathrm{~s}), 2903(\mathrm{~m}), 1617(\mathrm{w}), 1580(\mathrm{w}), 1411(\mathrm{~s}), 1379(\mathrm{~s}), 1259(\mathrm{~m}), 1052(\mathrm{~s}), 811(\mathrm{~m}), 881(\mathrm{~m})$; HRMS (ESI/QTOF) m/z: [M+H] ${ }^{+}$calcd for $\mathrm{C}_{16} \mathrm{H}_{14} \mathrm{IO}_{3}{ }^{+} 380.9982$; found 380.9980 .

(E)-5-Fluoro-1-styryl-1 $\lambda^{3}$-benzo[d][1,2]iodaoxol-3(1H)-one (1i)<smiles>O=C1OI(/C=C/c2ccccc2)c2ccc(F)cc21</smiles>

Following general procedure A, starting from (E)-styrylboronic acid (50a) $(221 \mathrm{mg}, 1.50 \mathrm{mmol})$ and 1hydroxy-5-fluoro-1,2-benziodoxol-3(1H)-one (70c) (367 mg, $1.30 \mathrm{mmol}$ ), afforded (E)-5-fluoro-1-styryl$1 \lambda^{3}$-benzo[d][1,2]iodaoxol-3(1H)-one (1i) as a white solid (278 mg, $\left.0.760 \mathrm{mmol}, 58 \%\right)$. M.p. $174-176{ }^{\circ} \mathrm{C}$; 
$\mathrm{R}_{\mathrm{f}}=0.15(\mathrm{MeOH} / \mathrm{DCM} 5: 95) ;{ }^{1} \mathrm{H}$ NMR (400 MHz, MeOD) $\delta 8.03-7.94(\mathrm{~m}, 2 \mathrm{H}, \mathrm{ArH}$ and ICHCHPh), 7.77 - $7.64\left(\mathrm{~m}, 4 \mathrm{H}, \mathrm{ArH}\right.$ and ICHCHPh), $7.55-7.44(\mathrm{~m}, 4 \mathrm{H}, \mathrm{ArH}) ;{ }^{13} \mathrm{C}$ NMR (101 MHz, MeOD) $\delta$ 168.7, 166.1 (d, $J=250.5 \mathrm{~Hz}$ ), 156.1, 137.3, 136.6, 132.2, 131.0 (d, $J=8.4 \mathrm{~Hz}), 130.2,129.0,122.3(\mathrm{~d}, J=24.0 \mathrm{~Hz}$ ), $119.8(\mathrm{~d}, \mathrm{~J}=23.9 \mathrm{~Hz}), 108.5,99.7 ;{ }^{19} \mathrm{~F}$ NMR $(376 \mathrm{MHz}, \mathrm{MeOD}) \delta$-113.5; IR $\left(v_{\max }, \mathrm{cm}^{-1}\right) 2987(\mathrm{~s}), 2973(\mathrm{~s})$, $2905(\mathrm{~s}), 1748(\mathrm{~m}), 1737(\mathrm{~m}), 1649(\mathrm{~m}), 1559(\mathrm{~m}), 1540(\mathrm{~m}), 1512(\mathrm{~m}), 1395(\mathrm{~m}), 1255(\mathrm{~m}), 1079(\mathrm{~s})$, 1054 (s), 863 (m); HRMS (ESI/QTOF) m/z: [M + Na] ${ }^{+}$calcd for $\mathrm{C}_{15} \mathrm{H}_{10} \mathrm{FINaO}_{2}{ }^{+} 390.9602$; Found 390.9595.

\section{(E)-1-(2-Cyclohexylvinyl)-1 $\lambda^{3}$-benzo[d][1,2]iodaoxol-3(1H)-one (1j)}

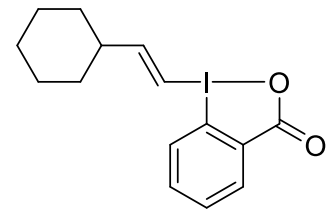

$1 \mathrm{j}$

Following general procedure $B$, starting from trans-2-cyclohexylvinyl)boronic acid (50j) $(200 \mathrm{mg}, 1.30$ $\mathrm{mmol}$ ) and 1-acetoxy-1,2-benziodoxol-3-(1H)-one (71) $(477 \mathrm{mg}, 1.56 \mathrm{mmol})$, afforded (E)-1-(2cyclohexylvinyl)-1 $\lambda^{3}$-benzo[d][1,2]iodaoxol-3(1H)-one (1j) as a white solid (274 $\mathrm{mg}, 0.769 \mathrm{mmol}, 59 \%$ ). M.p. $136-138{ }^{\circ} \mathrm{C} ; \mathrm{R}_{\mathrm{f}}=0.19(\mathrm{MeOH} / \mathrm{DCM} 5: 95) ;{ }^{1} \mathrm{H}$ NMR $(400 \mathrm{MHz}, \mathrm{MeOD}) \delta 8.31-8.24(\mathrm{~m}, 1 \mathrm{H}, \mathrm{ArH})$, $7.75-7.65(\mathrm{~m}, 3 \mathrm{H}, \mathrm{ArH}), 7.13$ (dd, $J=15.1,7.0 \mathrm{~Hz}, 1 \mathrm{H}, \mathrm{ICHCHcy}), 6.84$ (dd, J = 15.1, 1.2 Hz, 1H, ICHCHcy), 2.54 - $2.41(\mathrm{~m}, 1 \mathrm{H}, \mathrm{cy}-H), 1.99$ - $1.90(\mathrm{~m}, 2 \mathrm{H}, \mathrm{cy}-H), 1.89-1.79(\mathrm{~m}, 2 \mathrm{H}, \mathrm{cy}-H), 1.78-1.69(\mathrm{~m}, 1 \mathrm{H}, \mathrm{cy}-\mathrm{H})$, 1.50 - $1.21(\mathrm{~m}, 5 \mathrm{H}, \mathrm{cy}-H) ;{ }^{13} \mathrm{C}$ NMR $(101 \mathrm{MHz}$, MeOD) $\delta 170.4,166.0,135.6,134.9,133.8,132.2,129.2$, $115.2,99.4,46.2,33.2,27.3,27.2$. The values of the NMR spectra are in accordance with reported literature data. ${ }^{48}$

(E)-1-(3-Phenylprop-1-en-1-yl)-1 $\lambda^{3}$-benzo[d][1,2]iodaoxol-3(1H)-one (1k)

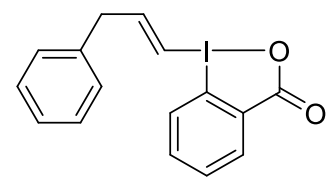

$1 \mathrm{k}$

Following general procedure $B$, starting from trans-3-Phenyl-1-propen-1-ylboronic acid (50k) $(211 \mathrm{mg}$, $1.30 \mathrm{mmol}$ ) and 1-acetoxy-1,2-benziodoxol-3-(1H)-one (71) $(477 \mathrm{mg}, 1.56 \mathrm{mmol})$, afforded (E)-1-(3phenylprop-1-en-1-yl)-1 $\lambda^{3}$-benzo[d][1,2] iodaoxol-3(1H)-one (1) as a white solid (332 mg, $0.912 \mathrm{mmol}$, 70\%). M.p. 144-145 ${ }^{\circ} \mathrm{C} ; \mathrm{R}_{\mathrm{f}}=0.18$ (MeOH/DCM 5:95); ${ }^{1} \mathrm{H}$ NMR (400 MHz, MeOD) $\delta 8.30-8.23(\mathrm{~m}, 1 \mathrm{H}$, $\mathrm{ArH}), 7.72-7.64(\mathrm{~m}, 3 \mathrm{H}, \mathrm{ArH}), 7.41-7.23(\mathrm{~m}, 6 \mathrm{H}, \mathrm{ArH}$ and ICHCHBn), $6.88(\mathrm{dt}, J=14.9,1.5 \mathrm{~Hz}, 1 \mathrm{H}$, ICHCHPh), 3.83 (dd, $J=6.9,1.4 \mathrm{~Hz}, 2 \mathrm{H}, \mathrm{CH}_{2} \mathrm{Ph}$ ); ${ }^{13} \mathrm{CNMR}$ (101 MHz, MeOD) $\delta 170.0,159.0,138.4,135.2$, 134.2, 133.4, 131.8, 130.0, 130.0, 129.0, 128.1, 115.0, 101.2, 42.7; IR $\left(v_{\max }, \mathrm{cm}^{-1}\right) 2987(\mathrm{~s}), 2973(\mathrm{~s})$, $2905(\mathrm{~s}), 1748(\mathrm{~m}), 1737(\mathrm{~m}), 1649(\mathrm{~m}), 1559(\mathrm{~m}), 1540(\mathrm{~m}), 1512(\mathrm{~m}), 1395(\mathrm{~m}), 1255(\mathrm{~m}), 1079(\mathrm{~s})$, $1054(\mathrm{~s}), 863(\mathrm{~m})$; HRMS (ESI) calcd for $\mathrm{C}_{16} \mathrm{H}_{14} \mathrm{IO}_{2}{ }^{+}[\mathrm{M}+\mathrm{H}]^{+}$365.0033; found 365.0033.

\section{(E)-1-(Pent-1-en-1-yl)-1 $\lambda^{3}$-benzo[d][1,2]iodaoxol-3(1H)-one (1l)}

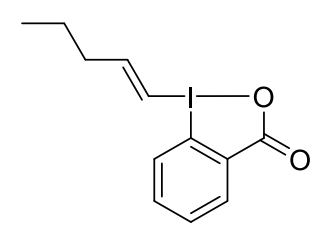

11

Following general procedure $B$, starting from trans-1-penten-1-yboronic acid (50I) (148 $\mathrm{mg}, 1.30 \mathrm{mmol})$ and 1-acetoxy-1,2-benziodoxol-3-(1H)-one (71) $(477 \mathrm{mg}, 1.56 \mathrm{mmol})$, afforded (E)-1-(pent-1-en-1-yl)- 
$1 \lambda^{3}$-benzo[d][1,2]iodaoxol-3(1H)-one (1l) as a white solid (115 mg, $0.364 \mathrm{mmol}, 28 \%$ ). M.p. (dec.) 154$160{ }^{\circ} \mathrm{C} ; R_{f}=0.15(\mathrm{MeOH} / \mathrm{DCM} 5: 95) ;{ }^{1} \mathrm{H}$ NMR (400 MHz, MeOD) $\delta 8.34-8.22(\mathrm{~m}, 1 \mathrm{H}, \mathrm{ArH}), 7.80-7.63$ $(\mathrm{m}, 3 \mathrm{H}, \mathrm{ArH}), 7.16(\mathrm{dt}, J=14.9,7.0 \mathrm{~Hz}, 1 \mathrm{H}, \mathrm{ICHCHCH} 2), 6.87(\mathrm{dt}, J=15.0,1.4 \mathrm{~Hz}, 1 \mathrm{H}, \mathrm{ICHCHCH}$ ) 2.49 (qd, $J=7.2,1.5 \mathrm{~Hz}, 2 \mathrm{H}, \mathrm{CHCH}_{2} \mathrm{CH}_{2}$ ), 1.65 (h, J=7.4 Hz, $2 \mathrm{H}, \mathrm{CH}_{2} \mathrm{CH}_{2} \mathrm{CH}_{3}$ ), 1.05 (t, $J=7.4 \mathrm{~Hz}, 3 \mathrm{H}, \mathrm{CH}_{2} \mathrm{CH}_{3}$ ); ${ }^{13} \mathrm{C}$ NMR (101 MHz, MeOD) $\delta$ 169.7, 160.4, 134.9, 133.1, 131.6, 128.7, 114.7, 100.1, 38.6, 22.2, 13.7; IR $\left(v_{\max }, \mathrm{cm}^{-1}\right) 2987(\mathrm{~s}), 2973(\mathrm{~s}), 2905(\mathrm{~s}), 1748(\mathrm{~m}), 1737(\mathrm{~m}), 1649(\mathrm{~m}), 1559(\mathrm{~m}), 1540(\mathrm{~m}), 1512(\mathrm{~m})$, $1395(\mathrm{~m}), 1255(\mathrm{~m}), 1079(\mathrm{~s}), 1054(\mathrm{~s}), 863(\mathrm{~m})$; HRMS (ESI) calcd for $\mathrm{C}_{12} \mathrm{H}_{14} \mathrm{IO}_{2}{ }^{+}[\mathrm{M}+\mathrm{H}]^{+}$317.0033; found 317.0033.

\section{Methyl (E)-6-(3-oxo-1 $\lambda^{3}$-benzo[d][1,2]iodaoxol-1(3H))-yl)hex-5-enoate (1m)}

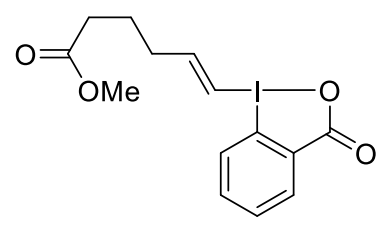

$1 \mathrm{~m}$

Following general procedure $B$, starting from (E)-(6-methoxy-6-oxohex-1-en-1-yl)boronic acid (50m) (224 mg, $1.30 \mathrm{mmol}$ ) and 1-acetoxy-1,2-benziodoxol-3-(1H)-one (71) $(477 \mathrm{mg}, 1.56 \mathrm{mmol})$, afforded methyl (E)-6-(3-oxo-1 $\lambda^{3}$-benzo[d][1,2]iodaoxol-1(3H))-yl)hex-5-enoate $(1 \mathrm{~m})(210 \mathrm{mg}, 0.561 \mathrm{mmol}$, $43 \%$ ) as an off-white solid. M.p. 147-149 ${ }^{\circ} \mathrm{C} ; \mathrm{R}_{\mathrm{f}}=0.07$ (MeOH/DCM 5:95); ${ }^{1} \mathrm{H}$ NMR (400 MHz, MeOD) $\delta$ $8.31-8.23(\mathrm{~m}, 1 \mathrm{H}, \mathrm{ArH}), 7.78-7.64(\mathrm{~m}, 3 \mathrm{H}, \mathrm{ArH}), 7.15(\mathrm{dt}, J=15.0,6.9 \mathrm{~Hz}, 1 \mathrm{H}, \mathrm{ICHCH}), 6.90(\mathrm{dt}, J=$ 14.9, $1.4 \mathrm{~Hz}, 1 \mathrm{H}, \mathrm{ICHCH}), 3.68\left(\mathrm{~s}, 3 \mathrm{H}, \mathrm{OCH}_{3}\right), 2.61-2.50\left(\mathrm{~m}, 2 \mathrm{H}, \mathrm{CH}_{2} \mathrm{CC}\right), 2.46(\mathrm{t}, J=7.3 \mathrm{~Hz}, 2 \mathrm{H}$, $\mathrm{CH}_{2} \mathrm{CO}_{2} \mathrm{Me}$ ), $1.91\left(\mathrm{p}, J=7.4 \mathrm{~Hz}, 2 \mathrm{H}, \mathrm{CH}_{2} \mathrm{CH}_{2} \mathrm{CH}_{2}\right) ;{ }^{13} \mathrm{C} \mathrm{NMR}$ (101 MHz, MeOD) $\delta 175.2,170.0,159.4$, $135.2,134.6,133.3,131.8,129.0,114.9,101.1,52.1,35.9,33.8,24.3 ; \mathrm{IR}\left(v_{\max }, \mathrm{cm}^{-1}\right) 3443(\mathrm{w}), 3047(\mathrm{w})$, $2958(\mathrm{w}), 2922(\mathrm{w}), 1731(\mathrm{~m}), 1606(\mathrm{~s}), 1557(\mathrm{~m}), 1440(\mathrm{~m}), 1363(\mathrm{~m}), 1342(\mathrm{~m}), 1294(\mathrm{w}), 1205(\mathrm{~m})$, $1184(\mathrm{~m}), 1151(\mathrm{~m}), 1005(\mathrm{~m}), 961(\mathrm{~m}), 830(\mathrm{~m})$; HRMS (ESI) calcd for $\mathrm{C}_{14} \mathrm{H}_{16} \mathrm{IO}_{4}{ }^{+}[\mathrm{M}+\mathrm{H}]^{+} 375.0088$; found 375.0091 .

(E)-1-(5-Chloropent-1-en-1-yl)-1 $\lambda^{3}$-benzo[d][1,2]iodaoxol-3(1H)-one (1n)

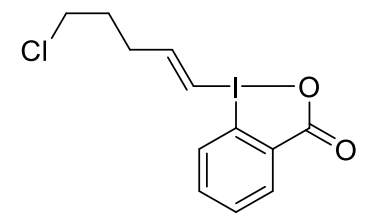

$1 \mathrm{n}$

Following general procedure B, starting from (E)-(5-chloropent-1-en-1-yl)boronic acid (50n) (193 mg, $1.30 \mathrm{mmol})$ and 1-acetoxy-1,2-benziodoxol-3-(1H)-one (71) $(477 \mathrm{mg}, 1.56 \mathrm{mmol})$, afforded $(E)$-1-(5chloropent-1-en-1-yl)-1 $\lambda^{3}$-benzo[d][1,2]iodaoxol-3(1H)-one (1n) as a white solid (201 mg, $0.573 \mathrm{mmol}$, 44\%). M.p. 133-135 ${ }^{\circ} \mathrm{C} ; \mathrm{R}_{\mathrm{f}}=0.19$ (MeOH/DCM 5:95); ${ }^{1} \mathrm{H}$ NMR (400 MHz, MeOD) $\delta 8.34-8.24(\mathrm{~m}, 1 \mathrm{H}$, $\operatorname{ArH}), 7.83-7.66(\mathrm{~m}, 3 \mathrm{H}, \mathrm{ArH}), 7.19\left(\mathrm{dt}, J=15.0,6.9 \mathrm{~Hz}, 1 \mathrm{H}, \mathrm{ICHCHCH}_{2}\right), 6.97(\mathrm{dt}, J=15.0,1.5 \mathrm{~Hz}, 1 \mathrm{H}$, $\left.\mathrm{ICHCHCH}_{2}\right), 3.70\left(\mathrm{t}, J=6.4 \mathrm{~Hz}, 2 \mathrm{H}, \mathrm{CH}_{2} \mathrm{Cl}\right), 2.76-2.62\left(\mathrm{~m}, 2 \mathrm{H}, \mathrm{CH}_{2} \mathrm{CH}_{2} \mathrm{CH}\right), 2.09(\mathrm{p}, J=6.7 \mathrm{~Hz}, 2 \mathrm{H}$, $\left.\mathrm{CH}_{2} \mathrm{CH}_{2} \mathrm{Cl}\right) ;{ }^{13} \mathrm{C}$ NMR $(101 \mathrm{MHz}, \mathrm{MeOD}) \delta 168.6,157.4,133.8,133.1,131.9,130.4,127.6,113.5,100.1$, 43.4, 32.5, 30.4; IR $\left(v_{\max }, \mathrm{cm}^{-1}\right) 2968(\mathrm{~m}), 2897(\mathrm{~m}), 1719(\mathrm{w}), 1596(\mathrm{~m}), 1557(\mathrm{~m}), 1346(\mathrm{~m}), 1276(\mathrm{~m})$, $1261(\mathrm{~m}), 1056(\mathrm{~m}), 961(\mathrm{~m}), 830(\mathrm{~m}), 751(\mathrm{~s}) ; \mathrm{HRMS}(\mathrm{ESI})$ calcd for $\mathrm{C}_{12} \mathrm{H}_{13} \mathrm{ClIO}_{2}{ }^{+}[\mathrm{M}+\mathrm{H}]^{+}$350.9643; found 350.9645 . 
(E)-1-(Cyclohex-1-en-1-yl)-1 $\lambda^{3}$-benzo[d][1,2]iodaoxol-3(1H)-one (10)

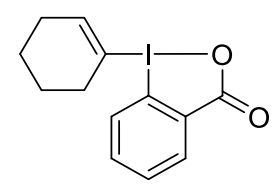

10

Following general procedure $B$, starting from 1-cyclohexenylboronic acid (50o) (164 mg, $1.30 \mathrm{mmol})$ and 1-acetoxy-1,2-benziodoxol-3-(1H)-one (71) $(477 \mathrm{mg}, 1.56 \mathrm{mmol})$, afforded (E)-1-(cyclohex-1-en-1yl)-1 $\lambda^{3}$-benzo[d][1,2]iodaoxol-3(1H)-one (10) as a white solid (213 mg, $\left.0.649 \mathrm{mmol}, 50 \%\right)$. M.p. 116$118{ }^{\circ} \mathrm{C} ; \mathrm{R}_{\mathrm{f}}=0.15(\mathrm{MeOH} / \mathrm{DCM} 5: 95) ;{ }^{1} \mathrm{H}$ NMR $(400 \mathrm{MHz}$, MeOD) $\delta 8.28(\mathrm{dt}, J=7.2,1.3 \mathrm{~Hz}, 1 \mathrm{H}, \operatorname{Ar} H)$, $7.78-7.66(\mathrm{~m}, 3 \mathrm{H}, \mathrm{ArH}), 7.07(\mathrm{tt}, J=3.9,1.8 \mathrm{~Hz}, 1 \mathrm{H}, \mathrm{ICCH}), 2.73-2.68(\mathrm{~m}, 2 \mathrm{H}, \mathrm{cy}-\mathrm{H}), 2.53(\mathrm{tq}, J=6.0,3.0$ $\mathrm{Hz}, 2 \mathrm{H}, \mathrm{cy}-H), 1.94$ (pd, $J=6.0,3.6 \mathrm{~Hz}, 2 \mathrm{H}, \mathrm{cy}-H), 1.88-1.80$ (m, 2H, cy-H); ${ }^{13} \mathrm{C}$ NMR (101 MHz, MeOD) $\delta 170.0,152.3,135.8,133.8,132.0,129.0,118.6,113.5,35.2,30.1,25.7,21.5 ; \mathrm{IR}\left(\mathrm{v}_{\max }, \mathrm{cm}^{-1}\right) 2976(\mathrm{w})$, $2934(\mathrm{w}), 2906(\mathrm{w}), 1651(\mathrm{~m}), 1600(\mathrm{~s}), 1558(\mathrm{~m}), 1435(\mathrm{~m}), 1377(\mathrm{~m}), 1346(\mathrm{~m}), 1332(\mathrm{~m}), 1107(\mathrm{~s})$, $905(\mathrm{~s}), 853(\mathrm{~m}), 826(\mathrm{~m}), 748(\mathrm{~s})$; HRMS (ESI) calcd for $\mathrm{C}_{13} \mathrm{H}_{14} \mathrm{IO}_{2}{ }^{+}[\mathrm{M}+\mathrm{H}]^{+} 329.0033$; found 329.0031 . One carbone was not resolved at $101 \mathrm{MHz}$.

(E)-2-(3-(3-Oxo-1 $\lambda^{3}$-benzo[d][1,2]iodaoxol-1(3H)-yl)allyl)isoindoline-1,3-dione (1p)<smiles>O=C1OI(/C=C/CN2C(=O)c3ccccc3C2=O)c2ccccc21</smiles>

Following general procedure $B$, with the addition of 2,2,2-trifluoroethanol $(1.3 \mathrm{~mL})$ after $3 \mathrm{~h}$ of reaction to dissolve the insoluble material. Starting from (E)-(3-(1,3-dioxoisoindolin-2-yl)prop-1-en-1-yl)boronic acid (50p) (300 mg, $1.30 \mathrm{mmol}$ ) and 1-acetoxy-1,2-benziodoxol-3-(1H)-one (71) (477 mg, $1.56 \mathrm{mmol}$ ), afforded (E)-2-(3-(3-oxo-1 $\lambda^{3}$-benzo[d][1,2]iodaoxol-1(3H)-yl)allyl)isoindoline-1,3-dione (1p) as a white solid (417 mg, $0.963 \mathrm{mmol}, 74 \%$ ). M.p. (dec.) $163-167{ }^{\circ} \mathrm{C} ; \mathrm{R}_{\mathrm{f}}=0.12$ (MeOH/DCM 5:95); ${ }^{1} \mathrm{H}$ NMR (400 $\mathrm{MHz}, \mathrm{MeOD}) \delta 8.40-8.34(\mathrm{~m}, 1 \mathrm{H}, \mathrm{ArH}), 7.98-7.77(\mathrm{~m}, 7 \mathrm{H}, \mathrm{ArH}), 7.35(\mathrm{dt}, J=14.8,4.8 \mathrm{~Hz}, 1 \mathrm{H}, \mathrm{ICHCH})$, $7.21(\mathrm{dt}, J=14.8,1.6 \mathrm{~Hz}, 1 \mathrm{H}, \mathrm{ICHCH}), 4.75\left(\mathrm{dd}, J=4.8,1.6 \mathrm{~Hz}, 2 \mathrm{H}, \mathrm{CH}_{2} \mathrm{~N}\right) ;{ }^{13} \mathrm{C}$ NMR $(101 \mathrm{MHz}, \mathrm{MeOD}) \delta$ 171.0, 169.2, 154.8, 137.6, 135.7, 134.1, 133.4, 132.5, 131.1, 129.1, 124.5, 114.8, 100.4, 42.0; IR ( $v_{\text {max }}$, $\left.\mathrm{cm}^{-1}\right) 2977(\mathrm{~s}), 2917(\mathrm{~s}), 1722(\mathrm{~m}), 1483(\mathrm{~m}), 1407(\mathrm{~s}), 1374(\mathrm{~m}), 1261(\mathrm{~m}), 1329(\mathrm{~m}), 1056(\mathrm{~s}), 875(\mathrm{w})$; HRMS (ESI) calcd for $\mathrm{C}_{18} \mathrm{H}_{12} \mathrm{INNaO}_{4}{ }^{+}[\mathrm{M}+\mathrm{Na}]^{+}$455.9703; found 455.9702 .

(E)-1-(3-((Triisopropylsilyl)oxy)prop-1-en-1-yl)-1 $\lambda^{3}$-benzo[d][1,2]iodaoxol-3(1H)-one (1q)

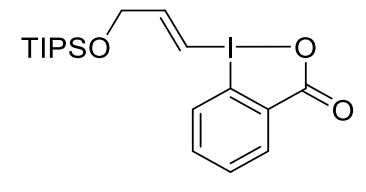

$1 \mathrm{q}$

Following general procedure $B$, starting from (E)-(3-((triisopropylsilyl)oxy)prop-1-en-1-yl)boronic acid (50q) $(336 \mathrm{mg}, 1.30 \mathrm{mmol})$ and 1-acetoxy-1,2-benziodoxol-3-(1H)-one (71) (477 mg, $1.56 \mathrm{mmol})$, afforded (E)-1-(3-((triisopropylsilyl)oxy)prop-1-en-1-yl)-1 $\lambda^{3}$-benzo[d][1,2]iodaoxol-3(1H)-one (1q) (370 $\mathrm{mg}, 0.804 \mathrm{mmol}, 62 \%)$ as a white solid. M.p. $157-159{ }^{\circ} \mathrm{C} ; \mathrm{R}_{\mathrm{f}}=0.20$ (MeOH/DCM 5:95); ${ }^{1} \mathrm{H}$ NMR (400 $\mathrm{MHz}, \mathrm{MeOD}) \delta 8.36-8.26(\mathrm{~m}, 1 \mathrm{H}, \mathrm{ArH}), 7.73(\mathrm{~m}, 3 \mathrm{H}, \mathrm{ArH}), 7.34(\mathrm{dt}, J=14.7,3.2 \mathrm{~Hz}, 1 \mathrm{H}, \mathrm{ICHCH}), 7.08$ (dt, $J=14.7,2.2 \mathrm{~Hz}, 1 \mathrm{H}, \mathrm{ICHCH}), 4.71\left(\mathrm{dd}, J=3.2,2.1 \mathrm{~Hz}, 2 \mathrm{H}, \mathrm{CH}_{2} \mathrm{O}\right), 1.31-1.10(\mathrm{~m}, 21 \mathrm{H}, \mathrm{TIPS}) ;{ }^{13} \mathrm{C}$ NMR 
(101 MHz, MeOD) $\delta$ 170.3, 159.7, 135.7, 133.6, 132.9, 132.0, 129.3, 114.9, 98.7, 66.2, 18.5, 13.2; IR $\left(v_{\max }, \mathrm{cm}^{-1}\right) 3057(w), 2944(w), 2863(w), 1644(w), 1607(w), 1264(m), 1129(w), 1014(w), 943(w)$, 914 (w), 734 (s), 701 (s); HRMS (ESI) calcd for $\mathrm{C}_{19} \mathrm{H}_{30} \mathrm{OO}_{3} \mathrm{Si}^{+}[\mathrm{M}+\mathrm{H}]^{+}$461.1003; found 461.1015.

\section{(E)-1-(3-Chloroprop-1-en-1-yl)-1 $\lambda^{3}$-benzo[d][1,2]iodaoxol-3(1H)-one (1r)}<smiles>O=C1OI(/C=C/CCl)c2ccccc21</smiles>

Following general procedure $B$, with the addition of 2,2,2-trifluoroethanol ( $1.3 \mathrm{~mL}$ ) after $3 \mathrm{~h}$ of reaction to dissolve the insoluble material. Starting from trans-2-chloromethylvinylboronic acid (50r) $(156 \mathrm{mg}$, $1.30 \mathrm{mmol}$ ) and 1-acetoxy-1,2-benziodoxol-3-(1H)-one (71) $(477 \mathrm{mg}, 1.56 \mathrm{mmol})$, afforded $(E)$-1-(3chloroprop-1-en-1-yl)-1 $\lambda^{3}$-benzo[d][1,2]iodaoxol-3(1H)-one (1r) as a white solid (137 mg, $0.425 \mathrm{mmol}$, 46\%). M.p. (dec.) 166-170 ${ }^{\circ} \mathrm{C} ; \mathrm{R}_{\mathrm{f}}=0.10$ (MeOH/DCM 5:95); ${ }^{1} \mathrm{H}$ NMR (400 MHz, MeOD) $\delta 8.37-8.27$ (m, $1 \mathrm{H}, \mathrm{ArH}), 7.84-7.70\left(\mathrm{~m}, 3 \mathrm{H}, \mathrm{ArH}\right.$ and $\left.\mathrm{ICHCHCH}_{2}\right), 7.33-7.28(\mathrm{~m}, 2 \mathrm{H}, \mathrm{ArH}), 4.53-4.46\left(\mathrm{~m}, 2 \mathrm{H}, \mathrm{CH}_{2} \mathrm{Cl}\right)$; ${ }^{13} \mathrm{C}$ NMR (101 MHz, MeOD) $\delta$ 170.3, 153.6, 136.0, 133.6, 132.9, 132.1, 129.6, 115.0, 104.3, 45.2; IR $\left(v_{\max }, \mathrm{cm}^{-1}\right) 2987(\mathrm{~s}), 2973(\mathrm{~s}), 2905(\mathrm{~s}), 1748(\mathrm{~m}), 1737(\mathrm{~m}), 1649(\mathrm{~m}), 1559(\mathrm{~m}), 1540(\mathrm{~m}), 1512(\mathrm{~m})$, $1395(\mathrm{~m}), 1255(\mathrm{~m}), 1079(\mathrm{~s}), 1054(\mathrm{~s}), 863(\mathrm{~m})$; HRMS (ESI) calcd for $\mathrm{C}_{10} \mathrm{H}_{9} \mathrm{ClIO}_{2}{ }^{+}[\mathrm{M}+\mathrm{H}]^{+}$322.9330; found 322.9332 .

(E)-1-(3-Methylbuta-1,3-dien-1-yl)-1 $\lambda^{3}$-benzo[d][1,2]iodaoxol-3(1H)-one (1s)<smiles>C=C(C)C=CI1OC(=O)c2ccccc21</smiles>

$1 \mathrm{~s}$

Following general procedure $B$, starting from (E)-(3-methylbuta-1,3-dien-1-yl)boronic acid (50s) (146 $\mathrm{mg}, 1.30 \mathrm{mmol}$ ) and 1-acetoxy-1,2-benziodoxol-3-(1H)-one (71) $(477 \mathrm{mg}, 1.56 \mathrm{mmol})$, afforded $(E)-1$ (3-methylbuta-1,3-dien-1-yl)-1 $\lambda^{3}$-benzo[d][1,2]iodaoxol-3(1H)-one (1s) as a beige solid (225 $\mathrm{mg}, 0.716$ mmol, 55\%). M.p. (dec.) 70-72 ${ }^{\circ} \mathrm{C} ; \mathrm{R}_{\mathrm{f}}=0.11$ (MeOH/DCM 5:95); ${ }^{1} \mathrm{H}$ NMR (400 MHz, MeOD) $\delta 8.31-8.26$ $(\mathrm{m}, 1 \mathrm{H}, \mathrm{ArH}), 7.78-7.61(\mathrm{~m}, 4 \mathrm{H}, \mathrm{ArH}$ and ICHCHC), $7.09(\mathrm{~d}, \mathrm{~J}=15.2 \mathrm{~Hz}, 1 \mathrm{H}, \mathrm{ICHCHC}), 5.53-5.42(\mathrm{~m}, 2 \mathrm{H}$, $\left.\mathrm{CCH}_{2}\right), 2.05\left(\mathrm{t}, J=1.1 \mathrm{~Hz}, 3 \mathrm{H}, \mathrm{CH}_{3}\right) ;{ }^{13} \mathrm{C}$ NMR $(101 \mathrm{MHz}, \mathrm{MeOD}) \delta 170.6,158.7,143.6,135.9,134.3$, 133.8, 132.3, 129.5, 126.2, 115.5, 100.5, 18.3; IR $\left(v_{\max }, \mathrm{cm}^{-1}\right) 2987(\mathrm{~s}), 2896(\mathrm{~m}), 1632(\mathrm{w}), 1584(\mathrm{~m})$, $1570(\mathrm{~m}), 1407(\mathrm{~m}), 1381(\mathrm{~m}), 1261(\mathrm{~m}), 1230(\mathrm{~m}), 1054(\mathrm{~s}), 873(\mathrm{~m}), 813(\mathrm{~m})$; HRMS (ESI) calcd for $\mathrm{C}_{12} \mathrm{H}_{11} \mathrm{INaO}{ }_{2}^{+}[\mathrm{M}+\mathrm{Na}]^{+} 336.9696$; found 336.9695 .

(E)-1-((1E,3E)-4-Phenylbuta-1,3-dien-1-yl)-1 $\lambda^{3}$-benzo[d][1,2]iodaoxol-3(1H)-one (1t)

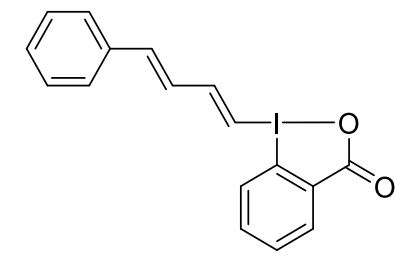

$1 \mathrm{t}$

Following general procedure $B$, starting from ((1E,3E)-4-phenylbuta-1,3-dien-1-yl)boronic acid (50t) (226 mg, $1.30 \mathrm{mmol}$ ) and 1-acetoxy-1,2-benziodoxol-3-(1H)-one (71) $(477 \mathrm{mg}, 1.56 \mathrm{mmol})$, afforded 
(E)-1-((1E,3E)-4-phenylbuta-1,3-dien-1-yl)-1 $\lambda^{3}$-benzo[d][1,2]iodaoxol-3(1H)-one (1t) as a beige solid (196 mg, $0.520 \mathrm{mmol}, 40 \%$ ). M.p. (dec.) $169-173{ }^{\circ} \mathrm{C}$; $\mathrm{R}_{\mathrm{f}}=0.17$ (MeOH/DCM 5:95); ${ }^{1} \mathrm{H} \mathrm{NMR} \mathrm{(400} \mathrm{MHz,}$ MeOD) $\delta 8.35$ - $8.27(\mathrm{~m}, 1 \mathrm{H}, \mathrm{ArH}), 7.82-7.68(\mathrm{~m}, 4 \mathrm{H}, \mathrm{ArH}$ and ICHCH), 7.62 - $7.56(\mathrm{~m}, 2 \mathrm{H}, \mathrm{ArH}), 7.45-$ $7.32(\mathrm{~m}, 3 \mathrm{H}, \mathrm{ArH}), 7.22$ (dd, $J=15.6,10.6 \mathrm{~Hz}, 1 \mathrm{H}, \mathrm{CHCHPh}), 7.13(\mathrm{~d}, J=14.7 \mathrm{~Hz}, 1 \mathrm{H}, \mathrm{ICHCH}), 7.05$ (d, $J=$ $15.6 \mathrm{~Hz}, 1 \mathrm{H}, \mathrm{CHCHPh}) ;{ }^{13} \mathrm{C}$ NMR (101 MHz, MeOD) $\delta$ 170.4, 156.9, 143.1, 137.2, 136.0, 133.7, 133.5, 132.2, 131.0, 130.2, 129.5, 128.9, 127.8, 115.7, 100.0; IR $\left(v_{\max }, \mathrm{cm}^{-1}\right) 2975(\mathrm{~s}), 2911(\mathrm{~m}), 1720(\mathrm{~m}), 1448$ $(\mathrm{m}), 1409(\mathrm{~s}), 1381(\mathrm{~m}), 1259(\mathrm{~m}), 1056(\mathrm{~s}), 873(\mathrm{~m}), 809(\mathrm{~m}), 782(\mathrm{~m})$; HRMS (ESI) calcd for $\mathrm{C}_{17} \mathrm{H}_{13} \mathrm{INaO}{ }^{+}$ $[\mathrm{M}+\mathrm{Na}]^{+} 398.9852$; found 398.9852 .

\section{(E)-1-(Non-1-en-3-yn-1-yl)-1 $\lambda^{3}$-benzo[d][1,2]iodaoxol-3(1H)-one (1u)}

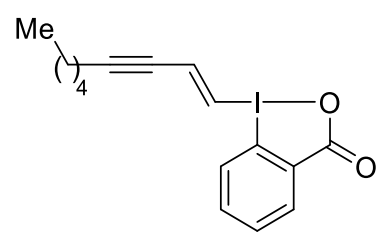

$1 \mathrm{u}$

Following general procedure B, starting from (E)-non-1-en-3-yn-1-ylboronic acid (50u) (216 mg, 1.30 $\mathrm{mmol}$ ) and 1-acetoxy-1,2-benziodoxol-3-(1H)-one (71) (477 mg, $1.56 \mathrm{mmol})$, afforded (E)-1-( non-1-en3-yn-1-yl)-1 $\lambda^{3}$-benzo[d][1,2]iodaoxol-3(1H)-one (1u) as a white solid (376 mg, $\left.1.02 \mathrm{mmol}, 79 \%\right)$. M.p. 139-141 ${ }^{\circ} \mathrm{C} ; \mathrm{R}_{\mathrm{f}}=0.26(\mathrm{MeOH} / \mathrm{DCM} 5: 95) ;{ }^{1} \mathrm{H}$ NMR (400 MHz, MeOD) $\delta 8.30-8.22(\mathrm{~m}, 1 \mathrm{H}, \mathrm{ArH}), 7.77-$ $7.62(\mathrm{~m}, 3 \mathrm{H}, \mathrm{ArH}), 7.33(\mathrm{~d}, J=15.5 \mathrm{~Hz}, 1 \mathrm{H}, \mathrm{ICHCH}), 7.06(\mathrm{dt}, J=15.5,2.3 \mathrm{~Hz}, 1 \mathrm{H}, \mathrm{ICHCH}), 2.47$ (td, $J=$ $\left.7.0,2.2 \mathrm{~Hz}, 2 \mathrm{H}, \mathrm{CCH}_{2} \mathrm{CH}_{2}\right), 1.66-1.56\left(\mathrm{~m}, 2 \mathrm{H}, \mathrm{CCH}_{2} \mathrm{CH}_{2}\right), 1.51-1.31\left(\mathrm{~m}, 4 \mathrm{H}, 2 \times \mathrm{CH}_{2}\right), 0.94(\mathrm{t}, J=7.1 \mathrm{~Hz}$, $\left.3 \mathrm{H}, \mathrm{CH}_{2} \mathrm{CH}_{3}\right) ;{ }^{13} \mathrm{C}$ NMR $(101 \mathrm{MHz}$, MeOD) $\delta 170.0,136.3,135.4,134.3,133.3,131.9,129.1,115.5,111.8$, 101.4, 79.2, 32.2, 29.1, 23.2, 20.2, 14.3; IR $\left(v_{\max }, \mathrm{cm}^{-1}\right) 2975(\mathrm{~s}), 2911(\mathrm{~m}), 1720(\mathrm{~m}), 1448(\mathrm{~m}), 1409(\mathrm{~s})$, $1381(\mathrm{~m}), 1259(\mathrm{~m}), 1056(\mathrm{~s}), 873(\mathrm{~m}), 809(\mathrm{~m}), 782(\mathrm{~m})$; HRMS (ESI) calcd for $\mathrm{C}_{16} \mathrm{H}_{18} \mathrm{IO}_{2}{ }^{+}[\mathrm{M}+\mathrm{H}]^{+}$ 369.0346; found 369.0340 .

\section{(E)-1-Styryl-3,3-bis(trifluoromethyl)-1,3-dihydro-1 $\lambda^{3}$-benzo[d][1,2]iodaoxole (1'a)}

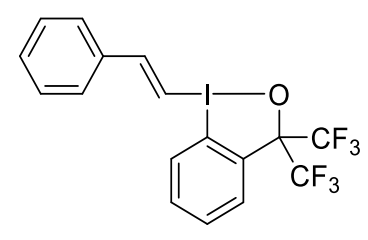

1 'a

Following general procedure $C$, starting from trans-2-phenylvinylboronic acid (50a) (148 mg, 1.00 $\mathrm{mmol}$ ) and 3,3-bis(trifluoromethyl)-1 $\lambda^{3}$-benzo[d][1,2]iodaoxol-1(3H)-yl acetate (71') (514 mg, 1.20 $\mathrm{mmol}$ ), afforded (E)-1-styryl-3,3-bis(trifluoromethyl)-1,3-dihydro-1 $\lambda^{3}$-benzo[d][1,2]iodaoxole (1'a) as a white solid (450 mg, $0.950 \mathrm{mmol}, 95 \%$ ). M.p. 167-168 ${ }^{\circ} \mathrm{C} ; \mathrm{R}_{\mathrm{f}}=0.57$ (EtOAc/pentane 50:50); ${ }^{1} \mathrm{H}$ NMR $\left(400 \mathrm{MHz}, \mathrm{CDCl}_{3}\right) \delta 7.91-7.84(\mathrm{~m}, 1 \mathrm{H}, \mathrm{ArH}), 7.66-7.57(\mathrm{~m}, 2 \mathrm{H}, \mathrm{ArH}$ and ICHCHPh), $7.57-7.42(\mathrm{~m}, 7 \mathrm{H}$, $\operatorname{ArH}), 7.22(\mathrm{~d}, J=16.1 \mathrm{~Hz}, 1 \mathrm{H}, \mathrm{ICHCHPh}) ;{ }^{13} \mathrm{C}$ NMR $\left(101 \mathrm{MHz}, \mathrm{CDCl}_{3}\right) \delta 152.1,135.5,132.2,131.1,130.8$, $130.6,130.6,129.3,127.5,127.4,124.2(\mathrm{q}, J=291.4 \mathrm{~Hz}), 111.3,104.8,81.4(\mathrm{p}, J=29.9 \mathrm{~Hz}) ;{ }^{19} \mathrm{~F} \mathrm{NMR}$

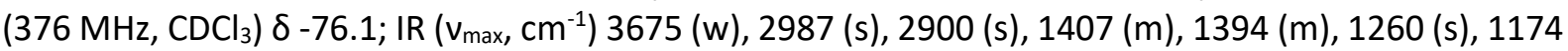
(s), 1147 (s), 1050 (s), 959 (m), 939 (s), 741 (s), 729 (s), 691 (s); HRMS (APPI/LTQ-Orbitrap) m/z: [M+H] ${ }^{+}$ Calcd for $\mathrm{C}_{17} \mathrm{H}_{12} \mathrm{~F}_{6} \mathrm{lO} \mathrm{O}^{+}$472.9832; Found 472.9827; The structure of 1'a was confirmed by X-ray analysis. Crystals were grown by dissolving $10 \mathrm{mg}$ of pure 1 'a in $\mathrm{CDCl}_{3}(500 \mu \mathrm{L})$ at room temperature. Slow evaporation over one week provided suitable crystals. Supplementary crystallographic data for this compound have been deposited at Cambridge Crystallographic Data Centre (CCDC 1993681) and can be obtained free of charge via https://www.ccdc.cam.ac.uk/structures/ 
The reaction was scaled up to trans-2-phenylvinylboronic acid (50a) $(0.740 \mathrm{~g}, 5.00 \mathrm{mmol})$ and 3,3bis(trifluoromethyl)-1 $\lambda^{3}$-benzo[d] [1,2] iodaoxol-1(3H)-yl acetate (71') $(2.57 \mathrm{~g}, 6.00 \mathrm{mmol})$, affording $(E)$ 1-styryl-3,3-bis(trifluoromethyl)-1,3-dihydro-1 $\lambda^{3}$-benzo[d][1,2]iodaoxole (1'a) (2.20 g, $4.65 \mathrm{mmol}$, 93\%).

(E)-3,3-Bis(trifluoromethyl)-1-(4-(trifluoromethyl)styryl)-1,3-dihydro-benzo[d][1,2]iodaoxole (1'd)<smiles>FC(F)(F)c1ccc(/C=C/I2OC(c3ccccc3)(C(F)(F)F)c3ccccc32)cc1</smiles>

1 'd

Following general procedure $\mathrm{C}$, starting from trans-2-[4-(trifluoromethyl)phenylvinylboronic acid (50d) (216 mg, $1.00 \mathrm{mmol}$ ) and 3,3-bis(trifluoromethyl)-1 $\lambda^{3}$-benzo[d][1,2]iodaoxol-1(3H)-yl acetate (71') (514 mg, $1.20 \mathrm{mmol}$ ), afforded (E)-3,3-bis(trifluoromethyl)-1-(4-(trifluoromethyl)styryl)-1,3-dihydrobenzo[d][1,2]iodaoxole (1'd) as a white solid (455 mg, $0.840 \mathrm{mmol}, 84 \%)$. M.p. $188-187^{\circ} \mathrm{C} ; \mathrm{R}_{\mathrm{f}}=0.73$ (EtOAc/pentane 50:50); ${ }^{1} \mathrm{H} \mathrm{NMR}\left(400 \mathrm{MHz}, \mathrm{CDCl}_{3}\right) \delta 7.95-7.84(\mathrm{~m}, 1 \mathrm{H}, \mathrm{ArH}), 7.76-7.59(\mathrm{~m}, 6 \mathrm{H}, \mathrm{ArH}$ and ICHCHPh), $7.59-7.51(\mathrm{~m}, 1 \mathrm{H}, \mathrm{ArH}), 7.51-7.45(\mathrm{~m}, 1 \mathrm{H}, \mathrm{ArH}), 7.38(\mathrm{~d}, J=16.2 \mathrm{~Hz}, 1 \mathrm{H}, \mathrm{ICHCHPh})$; ${ }^{13} \mathrm{C} \mathrm{NMR}\left(101 \mathrm{MHz}, \mathrm{CDCl}_{3}\right) \delta 149.9,138.7,132.3,132.3(\mathrm{q}, J=32.8 \mathrm{~Hz}), 131.0,130.8,130.9-130.6(\mathrm{~m})$, 127.7, 127.4, 126.3 (q, $J=3.8 \mathrm{~Hz}), 124.1$ (q, $J=291.6 \mathrm{~Hz}), 123.8(\mathrm{q}, J=272.2 \mathrm{~Hz}), 111.2,108.7,81.4(\mathrm{p}$, $J=28.9 \mathrm{~Hz}) ;{ }^{19} \mathrm{~F}$ NMR $\left(376 \mathrm{MHz}, \mathrm{CDCl}_{3}\right) \delta-62.9,-76.1$; IR $\left(\mathrm{v}_{\max }, \mathrm{cm}^{-1}\right) 2987(\mathrm{~m}), 2900(\mathrm{~m}), 1323(\mathrm{~m}), 1261$ (s), 1183 (s), 1152 (s), 1119 (s), 1065 (s), 945 (s), 763 (s), 731 (s), 692 (m); HRMS (ESI/QTOF) m/z: [M+H] Calcd for $\mathrm{C}_{18} \mathrm{H}_{11} \mathrm{~F}_{9} \mathrm{OO}^{+}$540.9705; Found 540.9708 .

(E)-1-(2-Cyclohexylvinyl)-3,3-bis(trifluoromethyl)-1,3-dihydro-1 $\lambda^{3}$-benzobenzo[d][1,2]iodaoxole $(1 ' j)$

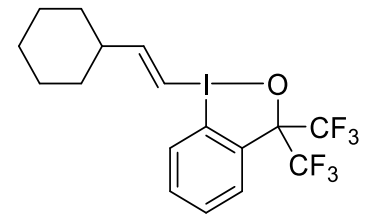

$1 ' j$

Following general procedure $C$, starting from trans-2-cyclohexylvinyl)boronic acid (50j) (154 mg, 1.00 $\mathrm{mmol}$ ) and 3,3-bis(trifluoromethyl)-1 $\lambda^{3}$-benzo[d][1,2]iodaoxol-1(3H)-yl acetate (71') (514 mg, 1.20 $\mathrm{mmol}), \quad$ afforded (E)-1-(2-cyclohexylvinyl)-3,3-bis(trifluoromethyl)-1,3-dihydro-1 $\lambda^{3}$ benzobenzo[d][1,2]iodaoxole (1'j) as a white solid (263 mg, $0.550 \mathrm{mmol}, 55 \%)$. M.p. $170{ }^{\circ} \mathrm{C} ; \mathrm{R}_{\mathrm{f}}=0.55$ (EtOAc/pentane 50:50); ${ }^{1} \mathrm{H}$ NMR $\left(400 \mathrm{MHz}, \mathrm{CDCl}_{3}\right) \delta 7.85(\mathrm{dq}, J=7.7,1.5 \mathrm{~Hz}, 1 \mathrm{H}, \mathrm{ArH}), 7.65-7.44(\mathrm{~m}$, $3 \mathrm{H}, \mathrm{ArH}), 6.80(\mathrm{dd}, J=15.7,6.7 \mathrm{~Hz}, 1 \mathrm{H}, \mathrm{CH}=\mathrm{CHCH}), 6.44(\mathrm{dd}, J=15.7,1.3 \mathrm{~Hz}, 1 \mathrm{H}, \mathrm{ICH}=\mathrm{CH}), 2.36-2.22$ (m, $\left.1 \mathrm{H}, \mathrm{CH}_{\text {-cyclohexyl) }}\right), 1.92-1.76\left(\mathrm{~m}, 4 \mathrm{H}, \mathrm{CH}_{\text {-cyclohexyl }}\right), 1.76-1.64\left(\mathrm{~m}, 1 \mathrm{H}, \mathrm{CH}_{\text {-cyclohexyl }}\right), 1.45-1.13(\mathrm{~m}, 5 \mathrm{H}$, $\mathrm{CH}_{\text {-cyclohexyl) }}{ }^{13} \mathrm{C} \mathrm{NMR}\left(101 \mathrm{MHz}, \mathrm{CDCl}_{3}\right) \delta 161.6,131.9,131.2,130.6-130.5(\mathrm{~m}), 130.4,127.1,124.3$ (q, $J=292.1 \mathrm{~Hz}), 110.9,103.1,81.4(\mathrm{p}, J=28.7 \mathrm{~Hz}), 44.4,32.0,25.9,25.8 ;{ }^{19} \mathrm{~F} \mathrm{NMR}\left(376 \mathrm{MHz}, \mathrm{CDCl}_{3}\right) \delta-$ 76.14; IR ( $\left.v_{\max }, \mathrm{cm}^{-1}\right) 2925(\mathrm{w}), 1256(\mathrm{~m}), 1178(\mathrm{~s}), 1149(\mathrm{~s}), 1126(\mathrm{~m}), 960(\mathrm{~m}), 943(\mathrm{~s}), 761(\mathrm{~s}), 730(\mathrm{~s})$, 692 (m); HRMS (ESI/QTOF) m/z: [M+H] $]^{+}$Calcd for $\mathrm{C}_{17} \mathrm{H}_{18} \mathrm{~F}_{6} \mathrm{OO}^{+}$479.0301; Found 479.0309.

(E)-1-(3-Phenylprop-1-en-1-yl)-3,3-bis(trifluoromethyl)-1,3-dihydro-1 $\lambda^{3}$ benzobenzo[d][1,2]iodaoxole (1'k) 


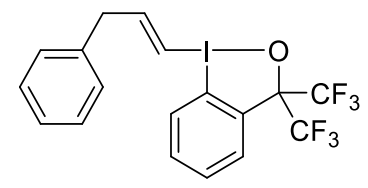

1 'k

Following general procedure $\mathrm{C}$, starting from trans-3-Phenyl-1-propen-1-ylboronic acid (50k) (162 mg, $1.00 \mathrm{mmol}$ ) and 3,3-bis(trifluoromethyl)- $1 \lambda^{3}$-benzo[d][1,2]iodaoxol-1(3H)-yl acetate (71') (514 mg, $1.20 \mathrm{mmol})$, afforded (E)-1-(3-phenylprop-1-en-1-yl)-3,3-bis(trifluoromethyl)-1,3-dihydro-1 $\lambda^{3}$ benzobenzo[d][1,2]iodaoxole (1'k) as a white solid (416 mg, $0.860 \mathrm{mmol}, 86 \%)$. M.p. $125-126{ }^{\circ} \mathrm{C} ; \mathrm{R}_{\mathrm{f}}=$ 0.36 (EtOAc/pentane 50:50); ${ }^{1} \mathrm{H} \mathrm{NMR}\left(400 \mathrm{MHz}, \mathrm{CDCl}_{3}\right) \delta 7.88-7.80(\mathrm{~m}, 1 \mathrm{H}, \mathrm{ArH}), 7.58(\mathrm{td}, J=7.4,1.3$ $\mathrm{Hz}, 1 \mathrm{H}, \mathrm{ArH}), 7.52$ (ddd, J = 8.6, 7.0, 1.6 Hz, 1H, ArH), $7.44(\mathrm{dd}, J=8.2,1.2 \mathrm{~Hz}, 1 \mathrm{H}, \mathrm{ArH}), 7.41-7.34(\mathrm{~m}$, $2 \mathrm{H}, \mathrm{ArH}), 7.33-7.27(\mathrm{~m}, 1 \mathrm{H}, \mathrm{ArH}), 7.25-7.20(\mathrm{~m}, 2 \mathrm{H}, \mathrm{ArH}), 7.01\left(\mathrm{dt}, J=15.6,6.5 \mathrm{~Hz}, 1 \mathrm{H}, \mathrm{CH}_{2} \mathrm{CH}=\mathrm{CH}\right)$, $6.50(\mathrm{dt}, J=15.6,1.5 \mathrm{~Hz}, 1 \mathrm{H}, \mathrm{ICH}=\mathrm{CH}), 3.69$ (dd, $\left.J=6.5,1.5 \mathrm{~Hz}, 2 \mathrm{H}, \mathrm{CH}_{2} \mathrm{Ph}\right) ;{ }^{13} \mathrm{C} \mathrm{NMR}\left(101 \mathrm{MHz}, \mathrm{CDCl}_{3}\right)$ $\delta$ 154.2, 136.9, 132.0, 131.1, $130.6-130.4(\mathrm{~m}), 130.5,129.2,128.8,127.3,127.28,124.2$ (q, $J=291.9$ $\mathrm{Hz}), 111.0,106.8,81.3(\mathrm{p}, J=28.9 \mathrm{~Hz}), 42.3 ;{ }^{19} \mathrm{~F} \mathrm{NMR}\left(376 \mathrm{MHz}, \mathrm{CDCl}_{3}\right) \delta-76.1 ; \mathrm{IR}\left(\mathrm{v}_{\max }, \mathrm{cm}^{-1}\right) 3674(\mathrm{~m})$, $2972(\mathrm{~s}), 2901(\mathrm{~s}), 1394(\mathrm{~m}), 1258(\mathrm{~s}), 1212(\mathrm{~m}), 1173(\mathrm{~s}), 1144(\mathrm{~s}), 1121(\mathrm{~m}), 1049(\mathrm{~s}), 961(\mathrm{~m}), 942(\mathrm{~s})$, 767 (s), 750 (s), 707 (s), 693 (s), 679 (m); HRMS (ESI/QTOF) m/z: [M+H] ${ }^{+}$Calcd for $\mathrm{C}_{18} \mathrm{H}_{14} \mathrm{~F}_{6} \mathrm{OO}^{+}$486.9988; Found 486.9994 .

(E)-1-(Pent-1-en-1-yl)-3,3-bis(trifluoromethyl)-1,3-dihydro-1 $\lambda^{3}$-benzobenzo[d][1,2]iodaoxole (1'I)

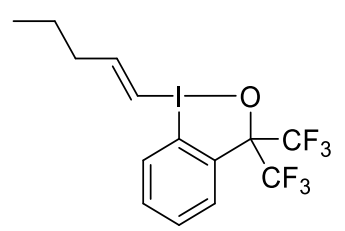

1'।

Following general procedure $C$, starting from trans-1-penten-1-yboronic acid (50I) (114 mg, $1.00 \mathrm{mmol}$ ) and 3,3-bis(trifluoromethyl)- $1 \lambda^{3}$-benzo[d][1,2]iodaoxol-1(3H)-yl acetate (71) $(514 \mathrm{mg}, 1.20 \mathrm{mmol}$ ), afforded (E)-1-(pent-1-en-1-yl)-3,3-bis(trifluoromethyl)-1,3-dihydro-1 $\lambda^{3}$-benzobenzo[d][1,2]iodaoxole (1'I) as a white solid (350 mg, $0.800 \mathrm{mmol}, 80 \%)$. M.p. 150-151 ${ }^{\circ} \mathrm{C} ; \mathrm{R}_{\mathrm{f}}=0.39$ (EtOAc/pentane 50:50); ${ }^{1} \mathrm{H}$ NMR $\left(400 \mathrm{MHz}, \mathrm{CDCl}_{3}\right) \delta 7.86(\mathrm{~d}, J=7.6 \mathrm{~Hz}, 1 \mathrm{H}, \mathrm{ArH}), 7.64-7.49(\mathrm{~m}, 3 \mathrm{H}, \mathrm{ArH}), 6.87(\mathrm{dt}, J=15.4,6.7$ $\left.\mathrm{Hz}, 1 \mathrm{H}, \mathrm{CH}=\mathrm{CHCH}_{2}\right), 6.52(\mathrm{~d}, J=15.4 \mathrm{~Hz}, 1 \mathrm{H}, \mathrm{ICH}=\mathrm{CH}), 2.37\left(\mathrm{q}, J=7.1 \mathrm{~Hz}, 2 \mathrm{H}, \mathrm{CHCH}_{2}\right), 1.59(\mathrm{~h}, J=7.4 \mathrm{~Hz}$, $\left.2 \mathrm{H}, \mathrm{CH}_{2} \mathrm{CH}_{2} \mathrm{CH}_{3}\right), 1.02\left(\mathrm{t}, J=7.3 \mathrm{~Hz}, 3 \mathrm{H}, \mathrm{CH}_{2} \mathrm{CH}_{3}\right) ;{ }^{13} \mathrm{C} \mathrm{NMR}\left(101 \mathrm{MHz}, \mathrm{CDCl}_{3}\right) \delta 156.4,132.0,131.3,130.6$, $130.5,127.3,124.3(\mathrm{q}, J=291.9 \mathrm{~Hz}), 111.0,105.1,82.5-80.7(\mathrm{~m}), 38.1,21.6,13.8 ;{ }^{19} \mathrm{~F} \mathrm{NMR}(376 \mathrm{MHz}$, $\left.\mathrm{CDCl}_{3}\right)$ \& -76.1; IR ( $\left.\mathrm{v}_{\max }, \mathrm{cm}^{-1}\right) 3669(\mathrm{w}), 2987(\mathrm{~s}), 2972(\mathrm{~s}), 2908(\mathrm{~s}), 2851(\mathrm{~m}), 1755(\mathrm{~m}), 1734(\mathrm{~m}), 1450$ $(\mathrm{m}), 1250(\mathrm{~m}), 1153(\mathrm{~m}), 1104(\mathrm{~m}), 1078(\mathrm{~s}), 1057$ (s), $966(\mathrm{~m}), 739(\mathrm{~m})$; HRMS (APPI/LTQ-Orbitrap) $\mathrm{m} / \mathrm{z}:[\mathrm{M}+\mathrm{H}]^{+}$Calcd for $\mathrm{C}_{14} \mathrm{H}_{14} \mathrm{~F}_{6} \mathrm{IO}^{+}$438.9988; Found 438.9992 .

\section{(E)-2-(3-(3,3-Bis(trifluoromethyl)-1 $\lambda^{3}$-benzo[d][1,2]iodaoxol-1(3H)-yl)allyl)isoindoline-1,3-dione} (1'p)<smiles>O=C1c2ccccc2C(=O)N1C/C=C\I(OC(F)(F)F)C(F)(F)F</smiles>

Following general procedure $C$, starting from (E)-(3-(1,3-dioxoisoindolin-2-yl)prop-1-en-1-yl)boronic acid (50p) (231 mg, $1.00 \mathrm{mmol}$ ) and 3,3-bis(trifluoromethyl)-1 $\lambda^{3}$-benzo[d][1,2]iodaoxol-1(3H)-yl acetate (71') (514 mg, $1.20 \mathrm{mmol})$, afforded (E)-2-(3-(3,3-bis(trifluoromethyl)-1 $\lambda^{3}-$ 
benzo[d][1,2]iodaoxol-1(3H)-yl)allyl)isoindoline-1,3-dione (1'p) as a white solid (422 $\mathrm{mg}, 0.760 \mathrm{mmol}$, 76\%). M.p. $179-180^{\circ} \mathrm{C} ; \mathrm{R}_{\mathrm{f}}=0.18$ (EtOAc/pentane 50:50); $\left.{ }^{1} \mathrm{H} \mathrm{NMR} \mathrm{(400} \mathrm{MHz,} \mathrm{CDCl}_{3}\right) \delta 7.90$ (dd, $J=5.5$, $3.0 \mathrm{~Hz}, 2 \mathrm{H}, \mathrm{ArH}), 7.86-7.74(\mathrm{~m}, 3 \mathrm{H}, \mathrm{ArH}), 7.64-7.56(\mathrm{~m}, 2 \mathrm{H}, \mathrm{ArH}), 7.56-7.48(\mathrm{~m}, 1 \mathrm{H}, \mathrm{ArH}), 6.83$ (dt, $\left.J=15.8,5.0 \mathrm{~Hz}, 1 \mathrm{H}, \mathrm{CH}_{2} \mathrm{CH}=\mathrm{CH}\right), 6.72(\mathrm{dt}, J=15.8,1.4 \mathrm{~Hz}, 1 \mathrm{H}, \mathrm{CH}=\mathrm{CHI}), 4.56(\mathrm{dd}, J=5.0,1.4 \mathrm{~Hz}, 2 \mathrm{H}$, $\left.\mathrm{NCH}_{2}\right) ;{ }^{13} \mathrm{C} \mathrm{NMR}\left(101 \mathrm{MHz}, \mathrm{CDCl}_{3}\right) \delta 167.8,146.9,134.7,132.5,131.9,130.8,130.6,130.6-130.4(\mathrm{~m})$, $127.9,124.1(\mathrm{q}, J=291.5 \mathrm{~Hz}), 123.9,111.1,109.3,81.2(p, J=29.2 \mathrm{~Hz}), 41.4 ;{ }^{19} \mathrm{~F} \mathrm{NMR}\left(376 \mathrm{MHz}, \mathrm{CDCl}_{3}\right)$ $\delta$-76.1; IR ( $\left.v_{\text {max }} \mathrm{cm}^{-1}\right) 3674(\mathrm{~m}), 2973(\mathrm{~s}), 2900(\mathrm{~s}), 1771(\mathrm{~m}), 1720(\mathrm{~s}), 1421(\mathrm{~m}), 1392(\mathrm{~s}), 1260(\mathrm{~s}), 1211$ $(\mathrm{m}), 1173(\mathrm{~s}), 1156(\mathrm{~s}), 1048(\mathrm{~s}), 978(\mathrm{w}), 962(\mathrm{~m}), 944(\mathrm{~s}), 930(\mathrm{~s}), 761(\mathrm{~m}), 718(\mathrm{~s}), 693(\mathrm{~m})$; HRMS (ESI/QTOF) m/z: $[\mathrm{M}+\mathrm{H}]^{+}$Calcd for $\mathrm{C}_{20} \mathrm{H}_{13} \mathrm{~F}_{6} \mathrm{NNO}_{3}{ }^{+}$555.9839; Found 555.9839. 


\section{Optimization of the reaction}

\section{a) Table S1 - Intramolecular reaction}

Under inert atmosphere, a solution of catalyst was prepared by mixing $\mathrm{Cu}\left(\mathrm{CH}_{3} \mathrm{CN}\right)_{4} \mathrm{BF}_{4}(12.6 \mathrm{mg}, 40.0$ $\mu \mathrm{mol})$ and ligand (3a-f) $(50.0 \mu \mathrm{mol})$ in DCE $(5.0 \mathrm{~mL})$ at $25^{\circ} \mathrm{C}$ for $1 \mathrm{~h}$. Then, $0.5 \mathrm{~mL}$ of the catalytic solution was then added to a stirring suspension of VBX $(0.10 \mathrm{mmol}, 1.00$ equiv) and diazo compound $(0.200 \mathrm{mmol}, 1.00$ equiv) in DCE $(2.0 \mathrm{~mL})$. After completion of the reaction, the solvent was removed under reduced pressure and the resulting crude oil was purified by column chromatography (EtOAc/pentane) directly without further work-up to afford the corresponding product.

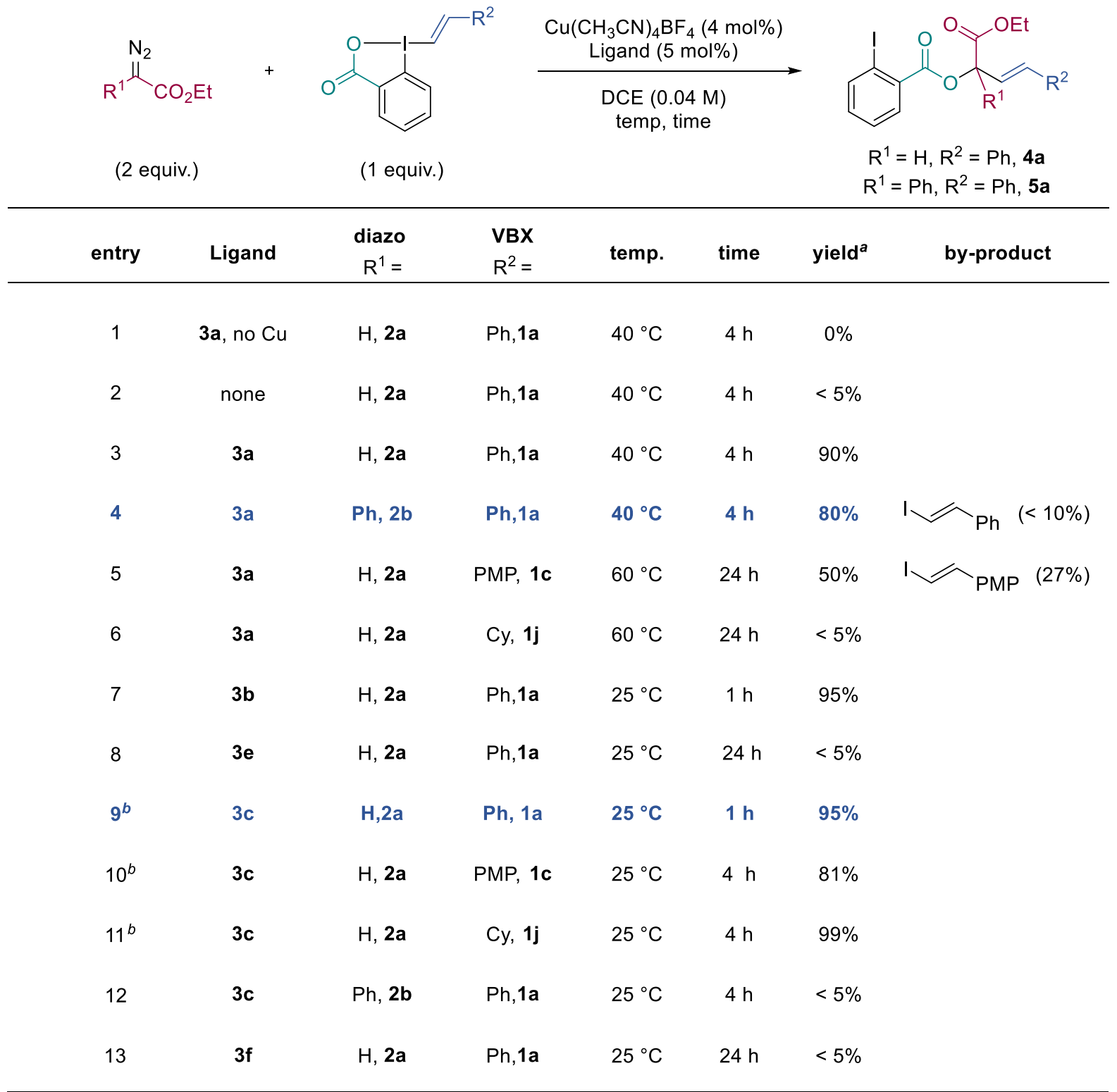

[a] Isolated yield. [b] On $0.20 \mathrm{mmol}$ scale. $\mathrm{Ph}=$ phenyl, $\mathrm{Cy}=$ cyclohexyl, PMP = para-methoxyphenyl.<smiles>Fc1c(Cl)cccc1Cl</smiles><smiles>CC(C)[C@H]1COC(C(C)(C)C2=N[C@H](C(C)(C)C)CO2)=N1</smiles><smiles>CC1(C)COC(C(C)(C)C2=NC(C)(C)CO2)=N1</smiles>

(3c)<smiles>C1COC(CC2=NCCO2)=N1</smiles>

(3e)<smiles>C1=CC(c2ccccn2)=NCC1</smiles>

(3f)

(3a) 
Two sets of reactions conditions were identified:

- For non-substituted diazo $\left(\mathrm{R}^{1}=\mathrm{H}\right): \mathrm{Cu}\left(\mathrm{CH}_{3} \mathrm{CN}\right)_{4} \mathrm{BF}_{4}(4 \mathrm{~mol} \%)+3 \mathrm{c}(5 \mathrm{~mol} \%)$ in DCE at $25^{\circ} \mathrm{C}$.

- For substituted diazo $(\mathrm{R} 1 \neq \mathrm{H}): \mathrm{Cu}\left(\mathrm{CH}_{3} \mathrm{CN}\right)_{4} \mathrm{BF}_{4}(4 \mathrm{~mol} \%)+3 \mathrm{a}(5 \mathrm{~mol} \%)$ in DCE at $40{ }^{\circ} \mathrm{C}$.

\section{b) Table S2 - Intermolecular/3-component reaction}

Under inert atmosphere, ethyl diazoacetate (2a) $(19.0 \mu \mathrm{L}, 0.16 \mathrm{mmol}, 2.00$ equiv., $87 \% \mathrm{wt}$ in DCM) was added to a stirred solution of Ph-VBX (1'a) ( $38 \mathrm{mg}, 80 \mu \mathrm{mol}, 1.00$ equiv.), EtOH (7a) (x equiv.) and $\mathrm{Cu}$ cat. (y mol\%) in $\mathrm{CD}_{2} \mathrm{Cl}_{2}(0.8 \mathrm{~mL})$. The resulting reaction mixture was stirred at $25^{\circ} \mathrm{C}$ for $1 \mathrm{~h}$. After this time, $\mathrm{CH}_{2} \mathrm{Br}_{2}\left(100 \mu \mathrm{L}, 0.8 \mathrm{M}\right.$ in $\mathrm{CD}_{2} \mathrm{Cl}_{2}, 0.08 \mathrm{mmol}, 1.00$ equiv.) was added as internal standard and the ${ }^{1} \mathrm{H}$ NMR spectrum of the reaction mixture was recorded.

When a ligand was used, the corresponding catalytic solution ( $\mathrm{Cu}$ cat. + Ligand) was premixed for $1 \mathrm{~h}$ in $\mathrm{CD}_{2} \mathrm{Cl}_{2}$ before addition of $\mathrm{Ph}-\mathrm{VBX}(\mathbf{1}$ 'a), $\mathrm{EtOH}(\mathbf{7 a})$ and ethyl diazoacetate (2a). 


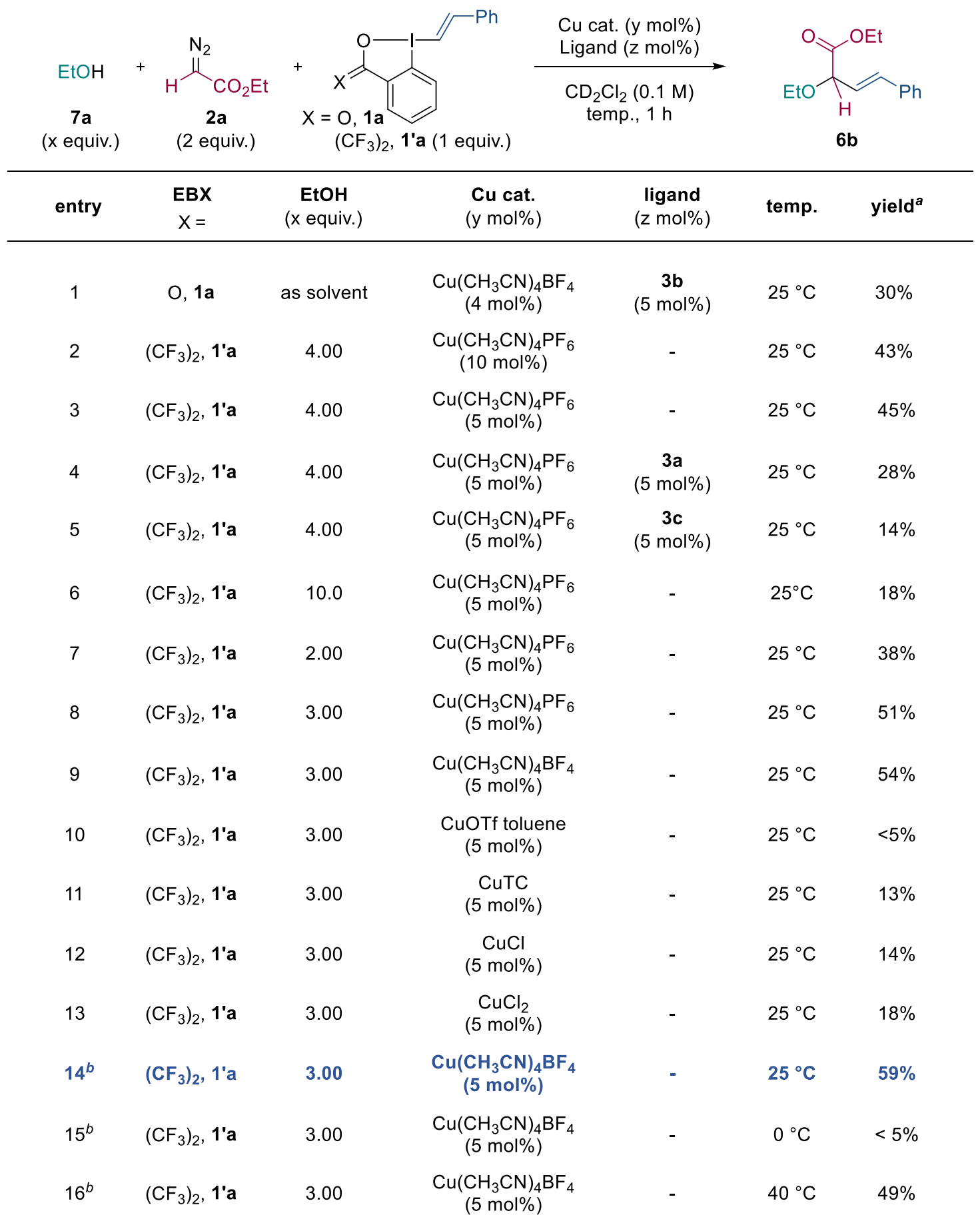

[a] Determined by ${ }^{1} \mathrm{H}$ NMR analysis. [b] 2a was slowly added in $1 \mathrm{~h}$ as a $0.6 \mathrm{M}$ solution in $\mathrm{CD}_{2} \mathrm{Cl}_{2}$ using a sering $\epsilon$ pump.

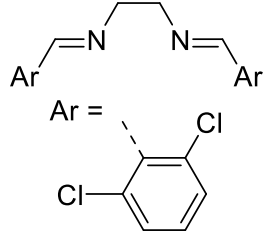

(3a)

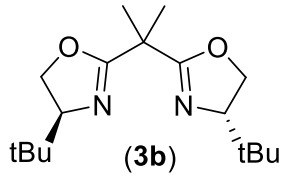

(3b)<smiles>CC1(C)COC(C(C)(C)C2=NC(C)(C)CO2)=N1</smiles>

(3c)

In line with our previous work, ${ }^{49}$ no competitive intramolecular reaction was observed with nonnucleophilic Ph-VBX 1'a. The reaction perfomed better without additional ligand. $\mathrm{Cu}\left(\mathrm{CH}_{3} \mathrm{CN}\right)_{4} \mathrm{BF}_{4}(5$ mol\%) was the optimal catalyst found.

${ }^{49}$ G. Pisella, A. Gagnebin, and J. Waser, Chem. Eur. J. 2020, DOI: 10.1002/chem.202001317. 


\section{Reaction mechanism}

\section{Scheme S1 - Proposed reaction mechanism}
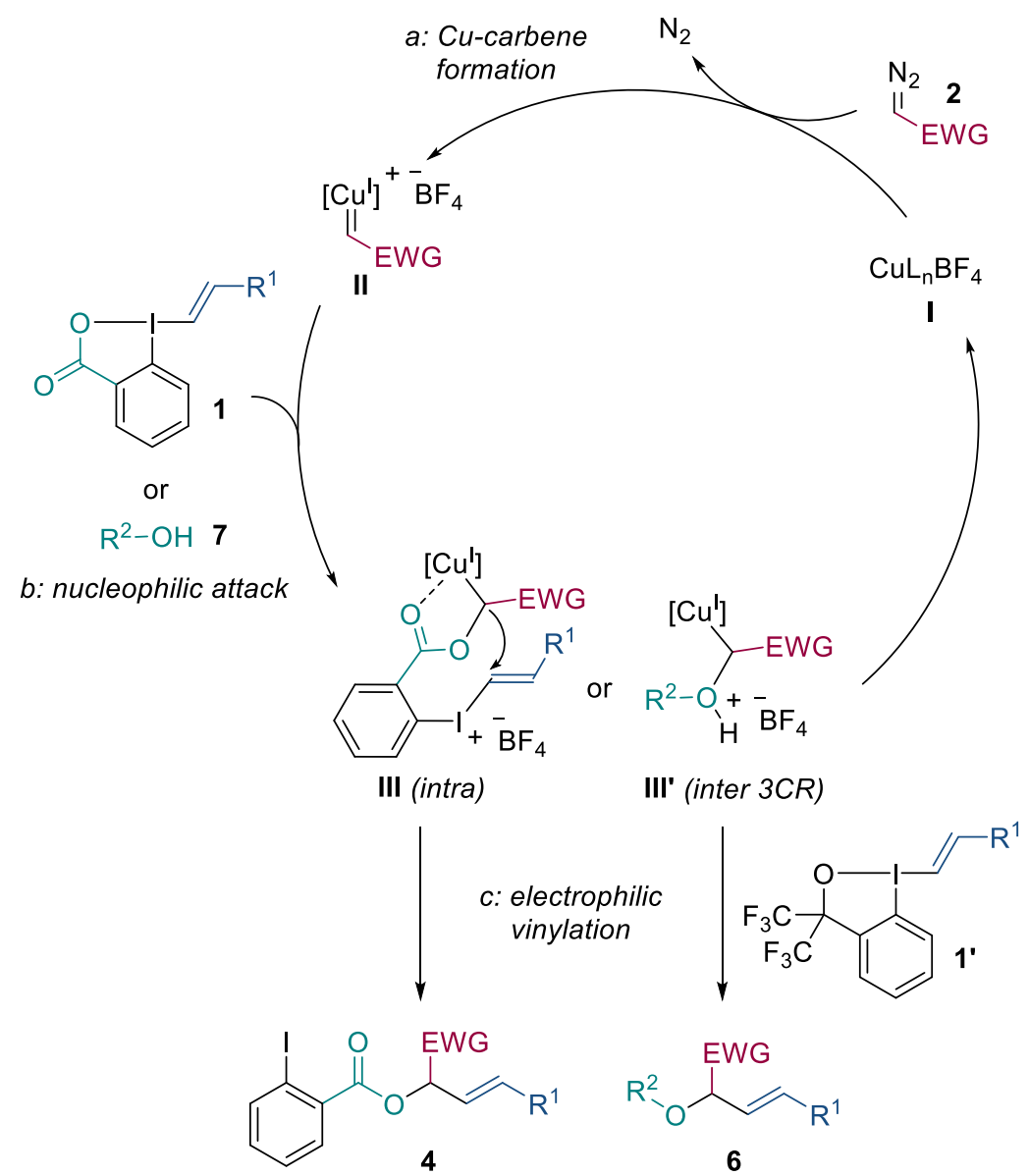

Starting with $\mathrm{Cu}(\mathrm{I})$ catalyst I, decomposition of diazo compound $\mathbf{2}$ would generate electrophilic coppercarbene II. At this stage, nucleophilic attack of the carboxylate part of the VBX reagent $\mathbf{1}$ forms copperiodonium intermediate III. Direct intramolecular electrophilic vinylation leads to product $\mathbf{4}$ and regenerates catalyst I; With bis-trifluoromethyl reagents $\mathbf{1}$ ', the oxygen atom of the benziodoxole is not nucleophilic enough, and attack of the external alcohol $\mathbf{7}$ forms oxonium-ylide intermediate III'. Intermolecular alkenylation by VBX reagent 1 ' with simultaneous deprotonation then generates the 3-component product 6 and release the copper catalyst $\mathbf{I}$. 


\section{Oxy-vinylation reaction with VBX reagents}

General procedure D: Oxy-vinylation of unsubstituted diazo compound:

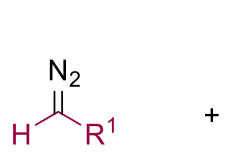

2a-k<smiles>[R]C=CI1OC(=O)c2ccccc21</smiles>

1a-u

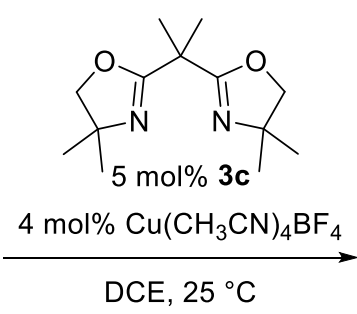

DCE, $25^{\circ} \mathrm{C}$<smiles>[R]C=CC([R])OC(=O)c1ccccc1I</smiles>

$4 a-u$

Under inert atmosphere, a catalytic solution was prepared by mixing $\mathrm{Cu}\left(\mathrm{CH}_{3} \mathrm{CN}\right)_{4} \mathrm{BF}_{4}(12.6 \mathrm{mg}, 40.0$ $\mu \mathrm{mol})$ and 2,2'-(propane-2,2-diyl)bis(4,4-dimethyl-4,5-dihydrooxazole) (3c) $(11.9 \mathrm{mg}, 50.0 \mu \mathrm{mol})$ in DCE $(5.0 \mathrm{~mL})$ at $25^{\circ} \mathrm{C}$ for $1 \mathrm{~h}$.

$1.0 \mathrm{~mL}$ of the catalytic solution was then added to a suspension of $\mathrm{VBX}(\mathbf{1} \mathrm{a}-\mathbf{u})(0.200 \mathrm{mmol}, 1.00$ equiv) and diazo compound (2a-k) $(0.400 \mathrm{mmol}, 2.00$ equiv) in DCE $(4.0 \mathrm{~mL})$.

The reaction mixture was stirred at $25{ }^{\circ} \mathrm{C}$. After the reaction was completed (monitored by TLC, EtOAc/pentane 5:95 and $\mathrm{MeOH} / \mathrm{DCM} 5: 95)$, the solvent was removed under reduced pressure and the resulting crude oil was purified by column chromatography (EtOAc/pentane) directly without further work-up to afford the corresponding product (4a-u; $\mathbf{5 b}-\mathbf{j})$.

\section{General procedure E: Oxy-vinylation of substituted diazo compound:}

2b-o

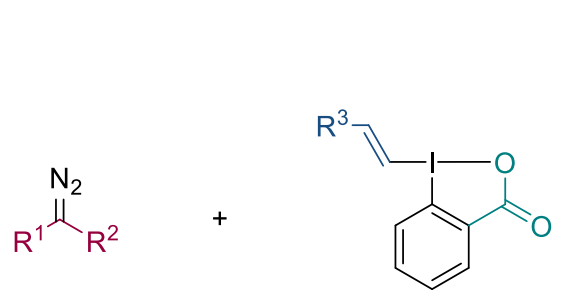

$1 \mathbf{a}$
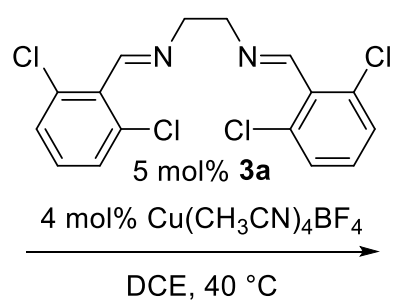

DCE, $40^{\circ} \mathrm{C}$<smiles>[R]C=CC([R])([R])OC(=O)c1ccccc1I</smiles>

5a-p

Under inert atmosphere, a catalytic solution was prepared by mixing $\mathrm{Cu}\left(\mathrm{CH}_{3} \mathrm{CN}_{4}\right)_{4} \mathrm{BF}_{4}(12.6 \mathrm{mg}, 40.0$ $\mu \mathrm{mol})$ and $\left(1 E, 1^{\prime} E\right)-N, N^{\prime}$-(ethane-1,2-diyl)bis(1-(2,6-dichlorophenyl)methanimine) (3a) (18.7 mg, 50.0 $\mu \mathrm{mol})$ in DCE $(5.0 \mathrm{~mL})$ at $25^{\circ} \mathrm{C}$ for $1 \mathrm{~h}$.

$1.0 \mathrm{~mL}$ of the catalytic solution was then added to a suspension of Ph-VBX (1a) $(0.200 \mathrm{mmol}, 1.00$ equiv) and diazo compound (2b-o) $(0.400 \mathrm{mmol}, 2.00$ equiv) in DCE $(4.0 \mathrm{~mL})$.

The reaction mixture was stirred at $40{ }^{\circ} \mathrm{C}$. After the reaction was completed (monitored by TLC, EtOAc/pentane 5:95 and $\mathrm{MeOH} / \mathrm{DCM} 5: 95$ ), the solvent was removed under reduced pressure and the resulting crude oil was purified by column chromatography (EtOAc/pentane, ratio indicated in the $R_{f}$ measurement) directly without further work-up to afford the corresponding product (5a-p).

\section{General procedure F: Oxy-vinylation of diazo compound, three-component reaction:}

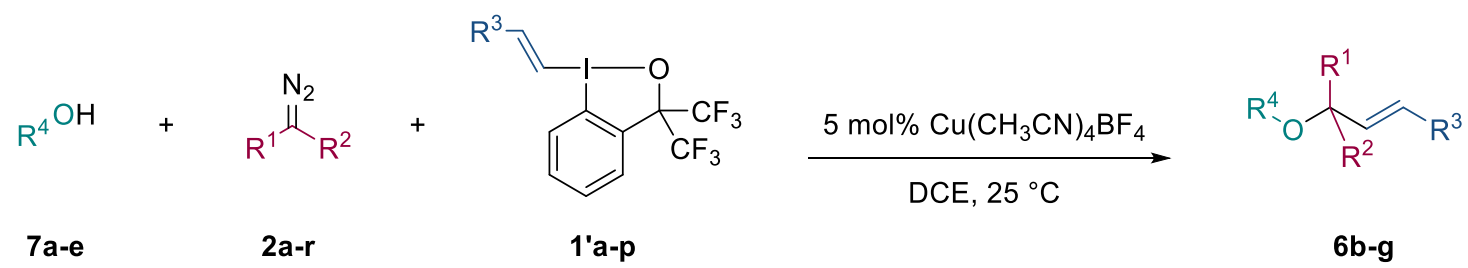

An oven-dried $10 \mathrm{~mL}$ microwave vial was charged with $\mathrm{Cu}\left(\mathrm{CH}_{3} \mathrm{CN}\right)_{4} \mathrm{BF}_{4}(4.72 \mathrm{mg}, 15.0 \mu \mathrm{mol}, 0.05$ equiv.), VBX reagent (1'a-p) ( $0.30 \mathrm{mmol}, 1.00$ equiv.) and alcohol (7a-e) $(0.90 \mathrm{mmol}, 3.00$ equiv.), if 
solid. The vial was capped, removed from the glovebox and dry DCM $(3.0 \mathrm{~mL})$ was added. The alcohol was added at this point if liquid. To the resulting solution was added a $0.6 \mathrm{M}$ solution of diazo compound (2a-r) $\left(0.60 \mathrm{mmol}, 2.00\right.$ equiv.) in dry DCM $(1.0 \mathrm{~mL})$ in $1 \mathrm{~h}$ via seringe pump at $25^{\circ} \mathrm{C}$. At the end of the addition, the reaction was continued for $1 \mathrm{~h}$ at the same temperature. The solvent was removed under reduced pressure and the resulting crude product was purified by column chromatography using EtOAc/pentane as eluent (the solvent ratio indicated in the $\mathrm{Rf}$ measurement was used), directly without further work-up to afford the corresponding product (6b-g).

(E)-1-Ethoxy-1-oxo-4-phenylbut-3-en-2-yl 2-iodobenzoate (4a)<smiles>CCOC(=O)C(/C=C/c1ccccc1)OC(=O)c1ccccc1I</smiles>

Following general procedure $\mathrm{D}$, starting from $(E)$-1-styryl-1 $\lambda^{3}$-benzo[d][1,2]iodaoxol-3(1H)-one (1a) (70.0 mg, $0.200 \mathrm{mmol}$ ) and ethyl 2-diazoacetate (2a) $(48.0 \mu \mathrm{L}, 87 \% \mathrm{wt}$ in DCM, $0.400 \mathrm{mmol})$, afforded (E)-1-ethoxy-1-oxo-4-phenylbut-3-en-2-yl 2-iodobenzoate (4a) as a colorless oil $(83 \mathrm{mg}, 0.19 \mathrm{mmol}$, 95\%). $\mathrm{R}_{\mathrm{f}}=0.24$ (EtOAc/pentane 5:95); ${ }^{1} \mathrm{H} \mathrm{NMR}\left(400 \mathrm{MHz}, \mathrm{CDCl}_{3}\right) \delta 8.01$ (ddd, $J=10.8,7.9,1.4 \mathrm{~Hz}, 2 \mathrm{H}$, $\operatorname{ArH}), 7.49-7.41(\mathrm{~m}, 3 \mathrm{H}, \mathrm{ArH}), 7.38-7.27(\mathrm{~m}, 3 \mathrm{H}, \mathrm{ArH}), 7.19(\mathrm{ddd}, J=7.9,7.4,1.7 \mathrm{~Hz}, 1 \mathrm{H}, \mathrm{ArH}), 6.93$ (dd, $J=15.9,1.2 \mathrm{~Hz}, 1 \mathrm{H}, \mathrm{CHCHPh}), 6.38$ (dd, $J=15.9,7.1 \mathrm{~Hz}, 1 \mathrm{H}, \mathrm{CHCHPh}), 5.87$ (dd, $J=7.1,1.3 \mathrm{~Hz}, 1 \mathrm{H}$, OCHCC), 4.29 (qd, $\left.J=7.1,2.4 \mathrm{~Hz}, 2 \mathrm{H}, \mathrm{OCH}_{2} \mathrm{CH}_{3}\right), 1.32\left(\mathrm{t}, J=7.1 \mathrm{~Hz}, 3 \mathrm{H}, \mathrm{OCH}_{2} \mathrm{CH}_{3}\right) ;{ }^{13} \mathrm{C} \mathrm{NMR}(101 \mathrm{MHz}$, $\left.\mathrm{CDCl}_{3}\right) \delta 168.5,165.6,141.6,135.8,135.7,134.2,133.2,131.7,128.8,128.8,128.1,127.0,120.7,94.6$, 74.3, 62.2, 14.3; IR ( $\left.v_{\max } \mathrm{cm}^{-1}\right) 2978(\mathrm{~m}), 2902(\mathrm{~m}), 1735(\mathrm{~s}), 1582(\mathrm{w}), 1451(\mathrm{~m}), 1395(\mathrm{~m}), 1369(\mathrm{~m})$, $1278(\mathrm{~s}), 1258(\mathrm{~s}), 1199(\mathrm{~m}), 1129(\mathrm{~m}), 1098(\mathrm{~s}), 1044(\mathrm{~s}), 1016(\mathrm{~s}), 966(\mathrm{~m}), 863(\mathrm{~m}), 764(\mathrm{~s}), 750(\mathrm{~s})$; HRMS (ESI) calcd for $\mathrm{C}_{19} \mathrm{H}_{17} / \mathrm{NaO}_{4}{ }^{+}[\mathrm{M}+\mathrm{Na}]^{+}$459.0064; found 459.0070 .

(E)-1-Ethoxy-4-(4-methoxyphenyl)-1-oxobut-3-en-2-yl 2-iodobenzoate (4b)<smiles>CCOC(=O)C(/C=C/c1ccc(OC)cc1)OC(=O)c1ccccc1I</smiles>

Following general procedure $D$, starting from $(E)$-1-(4-methoxystyryl)-1 $\lambda^{3}$-benzo[d] $[1,2]$ iodaoxol$3(1 \mathrm{H})$-one (1b) $(76.0 \mathrm{mg}, 0.200 \mathrm{mmol})$ and ethyl 2-diazoacetate (2a) $(48.0 \mu \mathrm{L}, 87 \% \mathrm{wt}$ in DCM, 0.400 mmol), afforded (E)-1-ethoxy-4-(4-methoxyphenyl)-1-oxobut-3-en-2-yl 2-iodobenzoate (4b) as a colorless oil (76 mg, $0.16 \mathrm{mmol}, 81 \%) . \mathrm{R}_{\mathrm{f}}=0.12$ (EtOAc/pentane 5:95); $\left.{ }^{1} \mathrm{H} \mathrm{NMR} \mathrm{(400} \mathrm{MHz,} \mathrm{CDCl}_{3}\right) \delta 8.05$ - $7.95(\mathrm{~m}, 2 \mathrm{H}, \mathrm{ArH}), 7.44(\mathrm{td}, J=7.6,1.2 \mathrm{~Hz}, 1 \mathrm{H}, \mathrm{ArH}), 7.40-7.34(\mathrm{~m}, 2 \mathrm{H}, \mathrm{ArH}), 7.18$ (ddd, J = 7.9, 7.4, $1.7 \mathrm{~Hz}, 1 \mathrm{H}, \mathrm{ArH}), 6.90-6.82(\mathrm{~m}, 3 \mathrm{H}, \mathrm{ArH}$ and $\mathrm{CHCHPh}), 6.23(\mathrm{dd}, J=15.9,7.4 \mathrm{~Hz}, 1 \mathrm{H}, \mathrm{CHCHPh}), 5.83$ (dd, $J=7.4,1.2 \mathrm{~Hz}, 1 \mathrm{H}, \mathrm{OCHCC}$ ), 4.28 (qd, $\left.J=7.1,3.0 \mathrm{~Hz}, 2 \mathrm{H}, \mathrm{OCH}_{2} \mathrm{CH}_{3}\right), 3.81\left(\mathrm{~s}, 3 \mathrm{H}, \mathrm{ArOCH}_{3}\right), 1.31$ (t, $J$ $\left.=7.1 \mathrm{~Hz}, 3 \mathrm{H}, \mathrm{OCH}_{2} \mathrm{CH}_{3}\right) ;{ }^{13} \mathrm{C} \mathrm{NMR}\left(101 \mathrm{MHz}, \mathrm{CDCl}_{3}\right) \delta 168.7,165.7,160.1,141.6,135.6,134.2,133.2$, 131.7, 128.4, 128.3, 128.1, 118.3, 114.2, 94.5, 74.6, 62.1, 55.5, 14.3; IR $\left(v_{\max }, \mathrm{cm}^{-1}\right) 2933(\mathrm{~m}), 2862(\mathrm{w})$, $2091(\mathrm{w}), 1731(\mathrm{~s}), 1607(\mathrm{~m}), 1582(\mathrm{w}), 1511(\mathrm{~s}), 1465(\mathrm{~m}), 1288(\mathrm{~m}), 1248(\mathrm{~s}), 1194(\mathrm{~m}), 1175(\mathrm{~s}), 1128$ $(\mathrm{m}), 1096(\mathrm{~s}), 1015(\mathrm{~s}), 969(\mathrm{~m}), 824(\mathrm{~m})$; HRMS (ESI) calcd for $\mathrm{C}_{20} \mathrm{H}_{19} \mathrm{NNaO}_{5}{ }^{+}[\mathrm{M}+\mathrm{Na}]^{+}$489.0169; found 489.0169 . 
<smiles>CCOC(=O)C(/C=C/c1ccc([N+](=O)[O-])cc1)OC(=O)c1ccccc1I</smiles>

Following general procedure $D$, starting from $(E)$-1-(4-methylstyryl)-1 $\lambda^{3}$-benzo[ $[d][1,2]$ iodaoxol-3(1H)one (1c) $(72.8 \mathrm{mg}, 0.200 \mathrm{mmol})$ and ethyl 2-diazoacetate (2a) $(48.0 \mu \mathrm{L}, 87 \% \mathrm{wt}$ in DCM, $0.400 \mathrm{mmol})$, afforded (E)-1-ethoxy-1-oxo-4-( $p$-tolyl)but-3-en-2-yl 2-iodobenzoate (4c) as a colorless oil (83 mg, 0.18 mmol, 92\%). $\mathrm{R}_{\mathrm{f}}=0.26$ (EtOAc/pentane 5:95); ${ }^{1} \mathrm{H} \mathrm{NMR}\left(400 \mathrm{MHz}, \mathrm{CDCl}_{3}\right) \delta 8.01$ (ddd, $J=9.7,7.9,1.4 \mathrm{~Hz}$, $2 \mathrm{H}, \mathrm{ArH}), 7.44(\mathrm{td}, J=7.6,1.2 \mathrm{~Hz}, 1 \mathrm{H}, \mathrm{ArH}), 7.37-7.29(\mathrm{~m}, 2 \mathrm{H}, \mathrm{ArH}), 7.23-7.12(\mathrm{~m}, 3 \mathrm{H}, \mathrm{ArH}), 6.93-6.85$ (m, 1H, CHCHPh), 6.32 (dd, J = 15.9, 7.2 Hz, 1H, CHCHPh), 5.85 (dd, J = 7.2, 1.3 Hz, 1H, OCHCC), 4.28 (qd, $\left.J=7.1,2.2 \mathrm{~Hz}, 2 \mathrm{H}, \mathrm{OCH}_{2} \mathrm{CH}_{3}\right), 2.35\left(\mathrm{~s}, 3 \mathrm{H}, \mathrm{ArCH}_{3}\right), 1.31\left(\mathrm{t}, J=7.1 \mathrm{~Hz}, 3 \mathrm{H}, \mathrm{OCH}_{2} \mathrm{CH}_{3}\right) ;{ }^{13} \mathrm{C}$ NMR (101 $\left.\mathrm{MHz}, \mathrm{CDCl}_{3}\right) \delta 168.6,165.6,141.6,138.8,135.8,134.2,133.2,132.9,131.7,129.5,128.1,126.9,119.6$, 94.5, 74.5, 62.1, 21.4, 14.3; IR ( $\left.\mathrm{v}_{\max }, \mathrm{cm}^{-1}\right) 2979(\mathrm{~m}), 2906(\mathrm{~m}), 1732(\mathrm{~s}), 1462(\mathrm{~m}), 1429(\mathrm{~m}), 1372(\mathrm{~m})$, 1294 (s), 1239 (s), 1198 (s), 1127 (s), 1098 (s), 1041 (s), 1014 (s), 965 (s), 855 (m), 810 (m), 740 (s); HRMS (ESI) calcd for $\mathrm{C}_{20} \mathrm{H}_{19} \mathrm{INaO}_{4}{ }^{+}[\mathrm{M}+\mathrm{Na}]^{+}$473.0220; found 473.0220 .

\section{(E)-1-Ethoxy-1-oxo-4-(4-(trifluoromethyl)phenyl)but-3-en-2-yl 2-iodobenzoate (4d)}<smiles>CCOC(=O)C(/C=C/c1ccc(C(F)(F)F)cc1)OC(=O)c1ccccc1I</smiles>

Following general procedure $D$, starting from $(E)-1$-(4-(trifluoromethyl)-1 $\lambda^{3}$-benzo[d] $[1,2]$ iodaoxol$3(1 \mathrm{H})$-one (1d) $(84.0 \mathrm{mg}, 0.200 \mathrm{mmol})$ and ethyl 2-diazoacetate (2a) $(48.0 \mu \mathrm{L}, 87 \% \mathrm{wt}$ in DCM, 0.400 $\mathrm{mmol})$, afforded (E)-1-ethoxy-1-oxo-4-(4-(trifluoromethyl)phenyl)but-3-en-2-yl 2-iodobenzoate (4d) as a colorless oil $(73 \mathrm{mg}, 0.15 \mathrm{mmol}, 72 \%) . \mathrm{R}_{\mathrm{f}}=0.22$ (EtOAc/pentane $\left.5: 95\right) ;{ }^{1} \mathrm{H} \mathrm{NMR}\left(400 \mathrm{MHz}, \mathrm{CDCl}_{3}\right) \delta$ $8.02(\mathrm{ddd}, J=15.1,7.9,1.4 \mathrm{~Hz}, 2 \mathrm{H}, \operatorname{ArH}), 7.60(\mathrm{~d}, J=8.2 \mathrm{~Hz}, 2 \mathrm{H}, \operatorname{ArH}), 7.53(\mathrm{~d}, J=8.2 \mathrm{~Hz}, 2 \mathrm{H}, \operatorname{ArH}), 7.46$ $(\mathrm{td}, J=7.6,1.2 \mathrm{~Hz}, 1 \mathrm{H}, \mathrm{ArH}), 7.24-7.17(\mathrm{~m}, 1 \mathrm{H}, \mathrm{ArH}), 6.96$ (dd, $J=16.0,1.4 \mathrm{~Hz}, 1 \mathrm{H}, \mathrm{CHCHPh}), 6.48$ (dd, $J=16.0,6.6 \mathrm{~Hz}, 1 \mathrm{H}, \mathrm{CHCHPh}$ ), 5.91 (dd, $J=6.7,1.4 \mathrm{~Hz}, 1 \mathrm{H}, \mathrm{OCHCC}), 4.30$ (qd, $J=7.1,2.3 \mathrm{~Hz}, 2 \mathrm{H}$, $\left.\mathrm{OCH}_{2} \mathrm{CH}_{3}\right), 1.33\left(\mathrm{t}, J=7.1 \mathrm{~Hz}, 3 \mathrm{H}, \mathrm{OCH}_{2} \mathrm{CH}_{3}\right) ;{ }^{13} \mathrm{C} \mathrm{NMR}\left(101 \mathrm{MHz}, \mathrm{CDCl}_{3}\right) \delta 168.1,165.5,141.7,139.2$, 134.0, 133.9, 133.4, 131.7, 130.5 (q, $J=32.6 \mathrm{~Hz}), 128.2,127.2,125.8$ (q, $J=3.9 \mathrm{~Hz}), 124.1$ (q, $J=272.0$ $\mathrm{Hz}), 123.5,94.6,73.8,62.4,14.3 ;{ }^{19} \mathrm{~F}$ NMR $\left(376 \mathrm{MHz}, \mathrm{CDCl}_{3}\right) \delta-62.7 ; \mathrm{IR}\left(\mathrm{v}_{\max }, \mathrm{cm}^{-1}\right) 2979(\mathrm{~m}), 2914(\mathrm{~m})$, $1732(\mathrm{~m}), 1466(\mathrm{w}), 1415(\mathrm{~m}), 1374(\mathrm{w}), 1325(\mathrm{~s}), 1243(\mathrm{~s}), 1196(\mathrm{~m}), 1166(\mathrm{~m}), 1108(\mathrm{~s}), 1067(\mathrm{~s}), 1047$ (s), $1014(\mathrm{~s}), 969(\mathrm{~m}), 857(\mathrm{~m}), 822(\mathrm{~m}), 742(\mathrm{~s}) ; \mathrm{HRMS}(\mathrm{ESI})$ calcd for $\mathrm{C}_{20} \mathrm{H}_{16} \mathrm{~F}_{3} \mathrm{INaO}_{4}{ }^{+}[\mathrm{M}+\mathrm{Na}]^{+} 526.9938$; found 526.9951 .

\section{(E)-1-Ethoxy-4-(4-fluorophenyl)-1-oxobut-3-en-2-yl 2-iodobenzoate (4e)}<smiles>CCOC(=O)C(/C=C/c1ccc(F)cc1)OC(=O)c1ccccc1I</smiles>

Following general procedure $D$, starting from $(E)$-1-(4-fluorostyryl)-1 $\lambda^{3}$-benzo[ $[d][1,2]$ iodaoxol-3(1H)one (1e) $(73.6 \mathrm{mg}, 0.200 \mathrm{mmol})$ and ethyl 2-diazoacetate (2a) $(48.0 \mu \mathrm{L}, 87 \% \mathrm{wt}$ in DCM, $0.400 \mathrm{mmol})$, afforded (E)-1-ethoxy-4-(4-fluorophenyl)-1-oxobut-3-en-2-yl 2-iodobenzoate (4e) as a colorless oil (60 $\mathrm{mg}, 0.13 \mathrm{mmol}, 66 \%) . \mathrm{R}_{\mathrm{f}}=0.22\left(\mathrm{EtOAc} /\right.$ pentane 5:95); ${ }^{1} \mathrm{H} \mathrm{NMR}\left(400 \mathrm{MHz}, \mathrm{CDCl}_{3}\right) \delta 8.02$ (dd, $J=7.9,1.2$ $\mathrm{Hz}, 1 \mathrm{H}, \mathrm{ArH}), 7.99(\mathrm{dd}, J=7.8,1.8 \mathrm{~Hz}, 1 \mathrm{H}, \mathrm{ArH}), 7.50-7.36(\mathrm{~m}, 3 \mathrm{H}, \mathrm{ArH}), 7.19(\mathrm{td}, J=7.7,1.7 \mathrm{~Hz}, 1 \mathrm{H}$, ArH), 7.08 - $6.99(\mathrm{~m}, 2 \mathrm{H}, \mathrm{ArH}), 6.93-6.84(\mathrm{~m}, 1 \mathrm{H}, \mathrm{CHCHPh}), 6.30(\mathrm{dd}, J=15.9,7.1 \mathrm{~Hz}, 1 \mathrm{H}, \mathrm{CHCHPh})$, 
$5.85(\mathrm{dd}, J=7.1,1.3 \mathrm{~Hz}, 1 \mathrm{H}, \mathrm{OCHCC}), 4.28\left(\mathrm{qd}, J=7.1,3.2 \mathrm{~Hz}, 2 \mathrm{H}, \mathrm{OCH}_{2} \mathrm{CH}_{3}\right), 1.32(\mathrm{t}, J=7.1 \mathrm{~Hz}, 3 \mathrm{H}$, $\left.\mathrm{OCH}_{2} \mathrm{CH}_{3}\right) ;{ }^{13} \mathrm{C}$ NMR $\left(101 \mathrm{MHz}, \mathrm{CDCl}_{3}\right) \delta 168.5,165.6,163.0(\mathrm{~d}, J=248.5 \mathrm{~Hz}), 141.6,134.6,134.1,133.3$, $131.9(\mathrm{~d}, J=3.3 \mathrm{~Hz}), 131.7,128.7(\mathrm{~d}, J=8.2 \mathrm{~Hz}), 128.2,120.5(\mathrm{~d}, J=2.2 \mathrm{~Hz}), 115.8(\mathrm{~d}, J=21.7 \mathrm{~Hz}), 94.5$, 74.2, 62.2, 14.3; $\left.{ }^{19} \mathrm{~F} \mathrm{NMR} \mathrm{(376} \mathrm{MHz,} \mathrm{CDCl}\right)$ ) -112.7; IR ( $\left.\mathrm{v}_{\max }, \mathrm{cm}^{-1}\right) 2981(\mathrm{~m}), 2932(\mathrm{w}), 1734(\mathrm{~s}), 1601$ $(\mathrm{m}), 1585(\mathrm{~m}), 1509(\mathrm{~s}), 1466(\mathrm{~m}), 1423(\mathrm{~m}), 1376(\mathrm{~m}), 1290(\mathrm{~s}), 1211(\mathrm{~s}), 1131(\mathrm{~s}), 1104(\mathrm{~s}), 1016(\mathrm{~s})$, $967(\mathrm{~m}), 859(\mathrm{~m}), 826(\mathrm{~m}), 740(\mathrm{~s}), 716(\mathrm{~m})$; HRMS (ESI) calcd for $\mathrm{C}_{19} \mathrm{H}_{16} \mathrm{FINaO}_{4}{ }^{+}[\mathrm{M}+\mathrm{Na}]^{+}$476.9970; found 476.9971 .

(E)-1-Ethoxy-4-(naphthalen-1-yl)-1-oxobut-3-en-2-yl 2-iodobenzoate (4f)<smiles>CCOC(=O)C(/C=C/c1cccc2ccccc12)OC(=O)c1ccccc1I</smiles>

Following general procedure $D$, starting from $(E)-1-\left(2-\left(\right.\right.$ naphthalen-1-yl)-1 $1 \lambda^{3}$-benzo[d] $[1,2]$ iodaoxol$3(1 \mathrm{H})$-one (1f) $(80.0 \mathrm{mg}, 0.200 \mathrm{mmol})$ and ethyl 2-diazoacetate (2a) $(48.0 \mu \mathrm{L}, 87 \% \mathrm{wt}$ in DCM, 0.400 $\mathrm{mmol})$, afforded (E)-1-ethoxy-4-(naphthalen-1-yl)-1-oxobut-3-en-2-yl 2-iodobenzoate (4f) as a white solid (79 mg, $0.16 \mathrm{mmol}, 81 \%)$. M.p. 59-61 ${ }^{\circ} \mathrm{C} ; \mathrm{R}_{\mathrm{f}}=0.18$ (EtOAc/pentane 5:95); ${ }^{1} \mathrm{H} \mathrm{NMR} \mathrm{(400} \mathrm{MHz,}$ $\left.\mathrm{CDCl}_{3}\right) \delta 8.15$ - $8.09(\mathrm{~m}, 1 \mathrm{H}, \mathrm{ArH}), 8.04(\mathrm{dt}, J=7.8,1.4 \mathrm{~Hz}, 2 \mathrm{H}, \mathrm{ArH}), 7.91-7.78(\mathrm{~m}, 2 \mathrm{H}, \operatorname{ArH}), 7.71(\mathrm{~d}, J$ $=15.7 \mathrm{~Hz}, 1 \mathrm{H}, \mathrm{CHCHPh}), 7.64(\mathrm{dt}, J=7.2,1.0 \mathrm{~Hz}, 1 \mathrm{H}, \mathrm{ArH}), 7.58-7.42(\mathrm{~m}, 4 \mathrm{H}, \mathrm{ArH}), 7.20$ (ddd, J = 7.9, 7.4, 1.7 Hz, 1H, ArH), 6.44 (dd, J = 15.7, $6.9 \mathrm{~Hz}, 1 \mathrm{H}, \mathrm{CHCHPh}), 6.01$ (dd, $J=6.9,1.4 \mathrm{~Hz}, 1 \mathrm{H}, \mathrm{OCHCC}), 4.33$ (q, $\left.J=7.1 \mathrm{~Hz}, 2 \mathrm{H}, \mathrm{OCH}_{2} \mathrm{CH}_{3}\right), 1.35\left(\mathrm{t}, J=7.1 \mathrm{~Hz}, 3 \mathrm{H}, \mathrm{OCH}_{2} \mathrm{CH}_{3}\right) ;{ }^{13} \mathrm{C} \mathrm{NMR}\left(101 \mathrm{MHz}, \mathrm{CDCl}_{3}\right) \delta 168.4,165.7$, 141.6, 134.2, 133.7, 133.5, 133.3, 133.1, 131.7, 131.2, 129.0, 128.7, 128.2, 126.5, 126.1, 125.7, 124.5, 123.9, 123.8, 94.5, 74.4, 62.2, 14.3; IR $\left(v_{\max } \mathrm{cm}^{-1}\right) 3057(\mathrm{w}), 2985(\mathrm{~m}), 2904(\mathrm{~m}), 1732(\mathrm{~s}), 1583(\mathrm{~m})$, $1464(\mathrm{~m}), 1429(\mathrm{~m}), 1395(\mathrm{~m}), 1370(\mathrm{~m}), 1335(\mathrm{~m}), 1284(\mathrm{~s}), 1241(\mathrm{~s}), 1192(\mathrm{~s}), 1131(\mathrm{~s}), 1094(\mathrm{~s}), 1016$ (s), 967 (s), $859(\mathrm{~m}), 775$ (s), 736 (s); HRMS (ESI) calcd for $\mathrm{C}_{23} \mathrm{H}_{19} \mathrm{NaOO}_{4}{ }^{+}[\mathrm{M}+\mathrm{Na}]^{+}$509.0220; found 509.0233 .

\section{(E)-1-Ethoxy-1-oxo-4-(thiophen-2-yl)but-3-en-2-yl 2-iodobenzoate (4g)}<smiles>CCOC(=O)C(/C=C/c1cccs1)OC(=O)c1ccccc1I</smiles>

Following general procedure $D$, starting from $(E)-1$-(2-(thiophen-2-yl)vinyl)-1 $1 \lambda^{3}$-benzo $[d][1,2]$ iodaoxol$3(1 \mathrm{H})$-one $(\mathbf{1 g})(71.2 \mathrm{mg}, 0.200 \mathrm{mmol})$ and ethyl 2-diazoacetate $(\mathbf{2 a})(48.0 \mathrm{~mL}, 87 \%$ wt in DCM, 0.400 $\mathrm{mmol})$, afforded $(E)$-1-ethoxy-1-oxo-4-(thiophen-2-yl)but-3-en-2-yl 2-iodobenzoate $(\mathbf{4 g})$ as a clear yellow oil (67 mg, $0.15 \mathrm{mmol}, 76 \%) . \mathrm{R}_{\mathrm{f}}=0.24$ (EtOAc/pentane 5:95); $\left.{ }^{1} \mathrm{H} \mathrm{NMR} \mathrm{(400} \mathrm{MHz,} \mathrm{CDCl}_{3}\right) \delta 8.06$ - $7.95(\mathrm{~m}, 2 \mathrm{H}, \mathrm{ArH}), 7.45$ (td, $J=7.6,1.2 \mathrm{~Hz}, 1 \mathrm{H}, \mathrm{ArH}), 7.24$ (dt, $J=5.0,0.9 \mathrm{~Hz}, 1 \mathrm{H}, \operatorname{ArH}), 7.19$ (ddd, $J=$ 7.9, 7.4, 1.7 Hz, 1H, ArH), $7.08-7.00(\mathrm{~m}, 2 \mathrm{H}, \mathrm{ArH}$ and CHCHPh), 6.99 (dd, $J=5.1,3.6 \mathrm{~Hz}, 1 \mathrm{H}, \mathrm{ArH}), 6.20$ (dd, $J=15.7,7.2 \mathrm{~Hz}, 1 \mathrm{H}, \mathrm{CHCHPh}$ ), 5.82 (dd, $J=7.2,1.3 \mathrm{~Hz}, 1 \mathrm{H}, \mathrm{OCHCC}$ ), 4.28 (qq, $J=7.1,3.6 \mathrm{~Hz}, 2 \mathrm{H}$, $\left.\mathrm{OCH}_{2} \mathrm{CH}_{3}\right), 1.32\left(\mathrm{t}, J=7.1 \mathrm{~Hz}, 3 \mathrm{H}, \mathrm{OCH}_{2} \mathrm{CH}_{3}\right) ;{ }^{13} \mathrm{C} \mathrm{NMR}\left(101 \mathrm{MHz}, \mathrm{CDCl}_{3}\right) \delta 168.4,165.6,141.6,140.6$, 134.1, 133.3, 131.7, 128.9, 128.2, 127.7, 127.6, 125.8, 119.9, 94.6, 74.1, 62.2, 14.3; IR $\left(v_{\max }, \mathrm{cm}^{-1}\right) 3057$ (w), $2985(\mathrm{~m}), 2904(\mathrm{~m}), 1732(\mathrm{~s}), 1583(\mathrm{~m}), 1464(\mathrm{~m}), 1429(\mathrm{~m}), 1395(\mathrm{~m}), 1370(\mathrm{~m}), 1335(\mathrm{~m}), 1284$ (s), $1241(\mathrm{~s}), 1192(\mathrm{~s}), 1131$ (s), $1094(\mathrm{~s}), 1016$ (s), 967 (s), 859 (m), 775 (s), 736 (s); HRMS (ESI) calcd for $\mathrm{C}_{17} \mathrm{H}_{15} \mathrm{IO}_{4} \mathrm{~S}\left[\mathrm{M}^{+}\right]$441.9730; found 441.9733 . 
<smiles>CCOC(=O)C(/C=C/c1ccccc1)OC(=O)c1cc(OC)ccc1I</smiles>

Following general procedure $D$, starting from $(E)$-5-methoxy-1-styryl- $1 \lambda^{3}$-benzo[ $[d][1,2]$ iodaoxol-3(1H)one (1h) $(76.0 \mathrm{mg}, 0.200 \mathrm{mmol})$ and ethyl 2-diazoacetate (2a) $(48.0 \mu \mathrm{L}, 87 \% \mathrm{wt}$ in DCM, $0.400 \mathrm{mmol})$, afforded (E)-1-ethoxy-1-oxo-4-phenylbut-3-en-2-yl 2-iodo-5-methoxybenzoate (4h) as a colorless oil (78 mg, $0.17 \mathrm{mmol}, 84 \%) . \mathrm{R}_{\mathrm{f}}=0.14$ (EtOAc/pentane 5:95); ${ }^{1} \mathrm{H} \mathrm{NMR}\left(400 \mathrm{MHz}, \mathrm{CDCl}_{3}\right) \delta 7.86$ (d, $J=8.7$ $\mathrm{Hz}, 1 \mathrm{H}, \operatorname{ArH}), 7.52(\mathrm{~d}, J=3.1 \mathrm{~Hz}, 1 \mathrm{H}, \operatorname{ArH}), 7.48-7.41(\mathrm{~m}, 2 \mathrm{H}, \operatorname{ArH}), 7.39-7.27(\mathrm{~m}, 3 \mathrm{H}, \operatorname{ArH}), 6.93(\mathrm{dd}, J$ $=16.0,1.2 \mathrm{~Hz}, 1 \mathrm{H}, \mathrm{CHCHPh}), 6.79(\mathrm{dd}, J=8.7,3.1 \mathrm{~Hz}, 1 \mathrm{H}, \mathrm{ArH}), 6.38(\mathrm{dd}, J=15.9,7.1 \mathrm{~Hz}, 1 \mathrm{H}, \mathrm{CHCHPh}$ ), 5.85 (dd, $J=7.1,1.3 \mathrm{~Hz}, 1 \mathrm{H}, \mathrm{OCHCC}$ ), 4.29 (qd, $\left.J=7.1,2.8 \mathrm{~Hz}, 2 \mathrm{H}, \mathrm{OCH}_{2} \mathrm{CH}_{3}\right), 3.84\left(\mathrm{~s}, 3 \mathrm{H}, \mathrm{ArOCH}_{3}\right), 1.32$ (t, J = 7.1 Hz, 3H, OCH $\left.\mathrm{CH}_{3}\right) ;{ }^{13} \mathrm{C} \mathrm{NMR}\left(101 \mathrm{MHz}, \mathrm{CDCl}_{3}\right) \delta 168.5,165.5,159.7,142.1,135.8,135.7,135.0$, 128.8, 128.8, 127.0, 120.7, 119.8, 117.2, 82.8, 74.4, 62.1, 55.7, 14.3; IR $\left(v_{\max }, \mathrm{cm}^{-1}\right) 2986(\mathrm{w}), 2937(\mathrm{w})$, $1736(\mathrm{~s}), 1590(\mathrm{~m}), 1565(\mathrm{~m}), 1469(\mathrm{~m}), 1449(\mathrm{~m}), 1394(\mathrm{~m}), 1368(\mathrm{~m}), 1313(\mathrm{~m}), 1284(\mathrm{~s}), 1241(\mathrm{~s})$, $1213(\mathrm{~s}), 1184(\mathrm{~s}), 1092(\mathrm{~s}), 1046(\mathrm{~s}), 1029(\mathrm{~s}), 1009(\mathrm{~s}), 966(\mathrm{~s}), 911(\mathrm{~m}), 811(\mathrm{~m}), 777(\mathrm{~m}), 732(\mathrm{~s}), 693$ (s); HRMS (ESI) calcd for $\mathrm{C}_{20} \mathrm{H}_{19} \mathrm{IO}_{5}\left[\mathrm{M}^{+}\right]$466.0272; found 466.0276 .

\section{(E)-1-Ethoxy-1-oxo-4-phenylbut-3-en-2-yl 5-fluoro-2-iodobenzoate (4i)}<smiles>CCOC(=O)/C(=C/c1ccccc1)OC(=O)c1cc(F)ccc1I</smiles>

Following general procedure $\mathrm{D}$, starting from $(E)$-5-fluoro-1-styryl-1 $\lambda^{3}$-benzo[ $\left.d\right][1,2]$ iodaoxol-3(1H)one (1i) $(73.6 \mathrm{mg}, 0.200 \mathrm{mmol})$ and ethyl 2-diazoacetate (2a) $(48.0 \mu \mathrm{L}, 87 \% \mathrm{wt}$ in DCM, $0.400 \mathrm{mmol})$, afforded (E)-1-ethoxy-1-oxo-4-phenylbut-3-en-2-yl 5-fluoro-2-iodobenzoate (4i) as a colorless oil (77 $\mathrm{mg}, 0.17 \mathrm{mmol}, 85 \%) . \mathrm{R}_{\mathrm{f}}=0.34$ (EtOAc/pentane 5:95); ${ }^{1} \mathrm{H} \mathrm{NMR}\left(400 \mathrm{MHz}, \mathrm{CDCl}_{3}\right) \delta 7.97$ (dd, $J=8.7,5.3$ $\mathrm{Hz}, 1 \mathrm{H}, \mathrm{ArH}), 7.73(\mathrm{dd}, J=8.9,3.1 \mathrm{~Hz}, 1 \mathrm{H}, \mathrm{ArH}), 7.48-7.41(\mathrm{~m}, 2 \mathrm{H}, \mathrm{ArH}), 7.39-7.28(\mathrm{~m}, 3 \mathrm{H}, \mathrm{ArH}), 7.01$ - $6.88(\mathrm{~m}, 2 \mathrm{H}, \mathrm{ArH}$ and CHCHPh), $6.37(\mathrm{dd}, J=15.9,7.2 \mathrm{~Hz}, 1 \mathrm{H}, \mathrm{CHCHPh}), 5.85(\mathrm{dd}, J=7.2,1.3 \mathrm{~Hz}, 1 \mathrm{H}$, OCHCC), 4.29 (qd, $\left.J=7.1,3.3 \mathrm{~Hz}, 2 \mathrm{H}, \mathrm{OCH}_{2} \mathrm{CH}_{3}\right), 1.32\left(\mathrm{t}, J=7.1 \mathrm{~Hz}, 3 \mathrm{H}, \mathrm{OCH}_{2} \mathrm{CH}_{3}\right) ;{ }^{13} \mathrm{C} \mathrm{NMR}(101 \mathrm{MHz}$, $\left.\mathrm{CDCl}_{3}\right) \delta 168.3,164.5(\mathrm{~d}, J=2.6 \mathrm{~Hz}), 162.5(\mathrm{~d}, J=249.7 \mathrm{~Hz}), 143.0(\mathrm{~d}, J=7.3 \mathrm{~Hz}), 136.1,135.6(\mathrm{~d}, J=7.3$ $\mathrm{Hz}), 135.6,128.9,127.0,120.9(\mathrm{~d}, J=21.4 \mathrm{~Hz}), 120.4,119.2(\mathrm{~d}, J=24.2 \mathrm{~Hz}), 87.6(\mathrm{~d}, J=3.6 \mathrm{~Hz}), 74.6$, 62.3, 14.3; ${ }^{19} \mathrm{~F}$ NMR (376 MHz, CDCl3) $\delta$-113.0; IR $\left(v_{\max }, \mathrm{cm}^{-1}\right) 1736(\mathrm{~s}), 1575(\mathrm{~m}), 1465(\mathrm{~m}), 1449(\mathrm{~m})$, $1394(\mathrm{~m}), 1370(\mathrm{~m}), 1296(\mathrm{~m}), 1264(\mathrm{~s}), 1241(\mathrm{~s}), 1188(\mathrm{~s}), 1127(\mathrm{~m}), 1084(\mathrm{~m}), 1017(\mathrm{~s}), 964(\mathrm{~m}), 819$ (m), $777(\mathrm{~m}), 734(\mathrm{~s}), 691(\mathrm{~m})$; HRMS (ESI) calcd for $\mathrm{C}_{19} \mathrm{H}_{16} \mathrm{FIO}_{4}\left[\mathrm{M}^{+}\right]$454.0072; found 454.0074. One carbon was not resolved at $101 \mathrm{MHz}$.

(E)-4-Cyclohexyl-1-ethoxy-1-oxobut-3-en-2-yl 2-iodobenzoate (4j)<smiles>CCOC(=O)C(/C=C/C1CCCCC1)OC(=O)c1ccccc1I</smiles>

$4 \mathbf{j}$

Following general procedure $D$, starting from $(E)-1-\left(2\right.$-cyclohexylvinyl)-1 $1 \lambda^{3}$-benzo[d] $[1,2]$ iodaoxol$3(1 \mathrm{H})$-one (1j) $(71.2 \mathrm{mg}, 0.200 \mathrm{mmol})$ and ethyl 2-diazoacetate (2a) $(48.0 \mu \mathrm{L}, 87 \% \mathrm{wt}$ in DCM, 0.400 $\mathrm{mmol}$ ), afforded (E)-1-ethoxy-1-oxo-5-phenylpent-3-en-2-yl 2-iodobenzoate (4j) as a colorless oil (88 $\mathrm{mg}, 0.20 \mathrm{mmol}, 99 \%) . \mathrm{R}_{\mathrm{f}}=0.37$ (EtOAc/pentane 5:95); ${ }^{1} \mathrm{H} \mathrm{NMR}\left(400 \mathrm{MHz}, \mathrm{CDCl}_{3}\right) \delta 8.00$ (dd, $J=7.9,1.2$ 
$\mathrm{Hz}, 1 \mathrm{H}, \mathrm{ArH}), 7.94$ (dd, J = 7.8, 1.7 Hz, 1H, ArH), 7.42 (td, J= 7.6, 1.2 Hz, 1H, ArH), 7.17 (ddd, J = 7.9, 7.4, $1.7 \mathrm{~Hz}, 1 \mathrm{H}, \mathrm{ArH}), 6.04-5.94(\mathrm{~m}, 1 \mathrm{H}, \mathrm{CHCHcy}), 5.66-5.57(\mathrm{~m}, 2 \mathrm{H}, \mathrm{CHCHy}$ and $\mathrm{OCHCC}), 4.24$ (qd, $J=7.1$, $\left.2.7 \mathrm{~Hz}, 2 \mathrm{H}, \mathrm{OCH}_{2} \mathrm{CH}_{3}\right), 2.98(\mathrm{~m}, 1 \mathrm{H}, \mathrm{cy}-\mathrm{H}), 1.80-1.69(\mathrm{~m}, 4 \mathrm{H}, \mathrm{cy}-\mathrm{H}), 1.69-1.61(\mathrm{~m}, 1 \mathrm{H}, \mathrm{cy}-\mathrm{H}), 1.34-1.03$ (m, 8H, cy- $\mathrm{H}$ and $\left.\mathrm{OCH}_{2} \mathrm{CH}_{3}\right) ;{ }^{13} \mathrm{CNMR}\left(101 \mathrm{MHz}, \mathrm{CDCl}_{3}\right) \delta$ 169.0, 165.7, 143.9, 141.5, 134.3, 133.1, 131.7, $128.1,119.4,94.5,74.6,61.8,40.6,32.5-32.3$ (2 s, rotamer), 32.5, 32.4, 26.2, 26.0, 14.3; IR ( $v_{\max }, \mathrm{cm}^{-}$ 1) $2977(\mathrm{~m}), 2920(\mathrm{~m}), 2848(\mathrm{~m}), 1736(\mathrm{~s}), 1579(\mathrm{~m}), 1450(\mathrm{~m}), 1286(\mathrm{~s}), 1239(\mathrm{~s}), 1190(\mathrm{~s}), 1133(\mathrm{~s})$, 1100 (s), 1014 (s), 965 (s), 740 (s); HRMS (ESI) calcd for $\mathrm{C}_{19} \mathrm{H}_{23} \mathrm{INaO}_{4}{ }^{+}[\mathrm{M}+\mathrm{Na}]^{+}$465.0533; found 465.0542 .

(E)-1-Ethoxy-1-oxo-5-phenylpent-3-en-2-yl 2-iodobenzoate (4k)<smiles>CCOC(=O)C(/C=C/Cc1ccccc1)OC(=O)c1ccccc1I</smiles>

Following general procedure $D$, starting from (E)-1-(3-phenylprop-1-en-1-yl)-1 $\lambda^{3}$ benzo[d][1,2]iodaoxol-3(1H)-one (1k) $(72.8 \mathrm{mg}, 0.200 \mathrm{mmol})$ and ethyl 2-diazoacetate (2a) $(48.0 \mu \mathrm{L}$, $87 \%$ wt in DCM, $0.400 \mathrm{mmol}$ ), afforded (E)-1-ethoxy-1-oxo-5-phenylpent-3-en-2-yl 2-iodobenzoate (4k) as a colorless oil $(81 \mathrm{mg}, 0.18 \mathrm{mmol}, 90 \%) . \mathrm{R}_{\mathrm{f}}=0.26$ (EtOAc/pentane 5:95); ${ }^{1} \mathrm{H} \mathrm{NMR}(400 \mathrm{MHz}$, $\left.\mathrm{CDCl}_{3}\right) \delta 8.00(\mathrm{dd}, J=8.0,1.1 \mathrm{~Hz}, 1 \mathrm{H}, \mathrm{ArH}), 7.94(\mathrm{dd}, J=7.8,1.7 \mathrm{~Hz}, 1 \mathrm{H}, \mathrm{ArH}), 7.42(\mathrm{td}, J=7.6,1.2 \mathrm{~Hz}$, $1 \mathrm{H}, \mathrm{ArH}), 7.35-7.27(\mathrm{~m}, 2 \mathrm{H}, \mathrm{ArH}), 7.25-7.13(\mathrm{~m}, 4 \mathrm{H}, \mathrm{ArH}), 6.22(\mathrm{dtd}, J=14.7,6.8,0.8 \mathrm{~Hz}, 1 \mathrm{H}, \mathrm{CHCHBn})$, $5.80-5.66(\mathrm{~m}, 2 \mathrm{H}, \mathrm{CHCHBn}$ and $\mathrm{OCHCC}), 4.26\left(\mathrm{qd}, J=7.1,2.4 \mathrm{~Hz}, 2 \mathrm{H}, \mathrm{OCH}_{2} \mathrm{CH}_{3}\right), 3.50-3.43(\mathrm{~m}, 2 \mathrm{H}$, $\left.\mathrm{CHCH}_{2} \mathrm{Ph}\right), 1.29\left(\mathrm{t}, J=7.1 \mathrm{~Hz}, 3 \mathrm{H}, \mathrm{OCH}_{2} \mathrm{CH}_{3}\right) ;{ }^{13} \mathrm{C} \mathrm{NMR}\left(101 \mathrm{MHz}, \mathrm{CDCl}_{3}\right) \delta 168.6,165.5,141.4,138.9$, $136.3,134.1,133.0,131.5,128.6,128.6,128.0,126.4,123.1,94.4,74.0,61.8,38.6,14.2 ; \mathrm{IR}\left(\mathrm{v}_{\max }, \mathrm{cm}^{-1}\right)$ $2981(\mathrm{w}), 2918(\mathrm{~m}), 1732(\mathrm{~s}), 1456(\mathrm{~m}), 1429(\mathrm{~m}), 1288(\mathrm{~s}), 1237(\mathrm{~s}), 1200(\mathrm{~s}), 1129(\mathrm{~s}), 1098(\mathrm{~s}), 1016$ (s), 973 (s), $742(\mathrm{~s}), 699$ (s); HRMS (ESI) calcd for $\mathrm{C}_{20} \mathrm{H}_{19} \mathrm{INaO}_{4}{ }^{+}[\mathrm{M}+\mathrm{Na}]^{+} 473.0220$; found 473.0223 .

(E)-1-Ethoxy-1-oxohept-3-en-2-yl 2-iodobenzoate (4I)<smiles>CCC/C=C/C(OC(=O)c1ccccc1I)C(=O)OCC</smiles>

Following general procedure $D$, starting from $(E)-1$-(1-(pent-1-en-1-yl)-1 $\lambda^{3}$-benzo[d][1,2]iodaoxol$3(1 \mathrm{H})$-one (1) $(63.2 \mathrm{mg}, 0.200 \mathrm{mmol})$ and ethyl 2-diazoacetate (2a) $(48.0 \mu \mathrm{L}, 87 \% \mathrm{wt}$ in DCM, 0.400 $\mathrm{mmol}$ ), afforded (E)-1-ethoxy-1-oxohept-3-en-2-yl 2-iodobenzoate (4I) as a colorless oil (76 mg, 0.19 mmol, 94\%). $\mathrm{R}_{\mathrm{f}}=0.37$ (EtOAc/pentane 5:95); ${ }^{1} \mathrm{H} \mathrm{NMR}\left(400 \mathrm{MHz}, \mathrm{CDCl}_{3}\right) \delta 8.00$ (dd, J=8.0, $1.2 \mathrm{~Hz}, 1 \mathrm{H}$, $\operatorname{ArH}), 7.95(\mathrm{dd}, J=7.8,1.7 \mathrm{~Hz}, 1 \mathrm{H}, \operatorname{ArH}), 7.42(\mathrm{td}, J=7.6,1.2 \mathrm{~Hz}, 1 \mathrm{H}, \operatorname{ArH}), 7.21-7.12(\mathrm{~m}, 1 \mathrm{H}, \operatorname{ArH}), 6.10$ - $5.99\left(\mathrm{~m}, 1 \mathrm{H}, \mathrm{CHCHCH}_{2}\right), 5.72-5.60\left(\mathrm{~m}, 2 \mathrm{H}, \mathrm{CHCHCH}_{2}\right.$ and $\left.\mathrm{OCHCC}\right), 4.25(\mathrm{td}, J=7.2,6.7 \mathrm{~Hz}, 2 \mathrm{H}$, $\left.\mathrm{OCH}_{2} \mathrm{CH}_{3}\right), 2.15-2.05\left(\mathrm{~m}, 2 \mathrm{H}, \mathrm{CHCH}_{2} \mathrm{CH}_{2}\right), 1.45\left(\mathrm{~h}, J=7.3 \mathrm{~Hz}, 2 \mathrm{H}, \mathrm{CH}_{2} \mathrm{CH}_{2} \mathrm{CH}_{3}\right), 1.29(\mathrm{t}, J=7.1 \mathrm{~Hz}, 3 \mathrm{H}$, $\left.\mathrm{OCH}_{2} \mathrm{CH}_{3}\right), 0.91\left(\mathrm{t}, J=7.4 \mathrm{~Hz}, 3 \mathrm{H}, \mathrm{CH}_{2} \mathrm{CH}_{2} \mathrm{CH}_{3}\right) ;{ }^{13} \mathrm{C} \mathrm{NMR}\left(101 \mathrm{MHz}, \mathrm{CDCl}_{3}\right) \delta 169.0,165.7,141.6,138.4$, 134.3, 133.1, 131.7, 128.1, 121.9, 94.5, 74.5, 61.8, 34.5, 21.9, 14.3, 13.7; IR $\left(v_{\max }, \mathrm{cm}^{-1}\right) 2959(\mathrm{~m}), 2928$ $(\mathrm{m}), 2867(\mathrm{~m}), 1732(\mathrm{~s}), 1591(\mathrm{~m}), 1464(\mathrm{~m}), 1431(\mathrm{~m}), 1368(\mathrm{~m}), 1284(\mathrm{~s}), 1239(\mathrm{~s}), 1192(\mathrm{~s}), 1131(\mathrm{~s})$, 1096 (s), 1014 (s), 965 (s), 740 (s); HRMS (ESI) calcd for $\mathrm{C}_{16} \mathrm{H}_{19} \mathrm{INaO}_{4}{ }^{+}[\mathrm{M}+\mathrm{Na}]^{+}$425.0220; found 425.0232 . 
<smiles>CCOC(=O)C(/C=C/CCCC(=O)OC)OC(=O)c1ccccc1I</smiles>

Following general procedure $D$, starting from methyl $(E)-6$-(3-oxo- $1 \lambda^{3}$-benzo $[d][1,2]$ iodaoxol- $1(3 H)$ one $(1 \mathrm{~m})(74.8 \mathrm{mg}, 0.200 \mathrm{mmol})$ and ethyl 2-diazoacetate (2a) $(48.0 \mu \mathrm{L}, 87 \% \mathrm{wt}$ in DCM, $0.400 \mathrm{mmol})$, afforded (E)-1-ethyl 8-methyl 2-((2-iodobenzoyl)oxy)oct-3-enedioate $(4 \mathrm{~m})$ as a colorless oil $(77 \mathrm{mg}$, $0.17 \mathrm{mmol}, 84 \%) . \mathrm{R}_{\mathrm{f}}=0.13$ (EtOAc/pentane 5:95); ${ }^{1} \mathrm{H} \mathrm{NMR}\left(400 \mathrm{MHz}, \mathrm{CDCl}_{3}\right) \delta 8.00$ (dd, J = 8.0, $1.1 \mathrm{~Hz}$, $1 \mathrm{H}, \operatorname{ArH}), 7.94(\mathrm{dd}, J=7.8,1.7 \mathrm{~Hz}, 1 \mathrm{H}, \operatorname{ArH}), 7.42(\mathrm{td}, J=7.6,1.2 \mathrm{~Hz}, 1 \mathrm{H}, \operatorname{ArH}), 7.21-7.14(\mathrm{~m}, 1 \mathrm{H}, \operatorname{ArH})$, $6.01\left(\mathrm{dtd}, J=14.8,6.8,0.8 \mathrm{~Hz}, 1 \mathrm{H}, \mathrm{CHCHCH}_{2}\right), 5.75-5.60\left(\mathrm{~m}, 2 \mathrm{H}, \mathrm{OCHCC}\right.$ and $\left.\mathrm{CHCHCH}_{2}\right), 4.24$ (q, $J=7.1$ $\left.\mathrm{Hz}, 2 \mathrm{H}, \mathrm{OCH}_{2} \mathrm{CH}_{3}\right), 3.66\left(\mathrm{~s}, 3 \mathrm{H}, \mathrm{OCH}_{3}\right), 2.32\left(\mathrm{t}, J=7.5 \mathrm{~Hz}, 2 \mathrm{H}, \mathrm{CH}_{2} \mathrm{CO}_{2} \mathrm{Me}\right), 2.21-2.12\left(\mathrm{~m}, 2 \mathrm{H}, \mathrm{CHCH}_{2} \mathrm{CH}_{2}\right)$, $1.76\left(\mathrm{p}, J=7.3 \mathrm{~Hz}, 2 \mathrm{H}, \mathrm{CH}_{2} \mathrm{CH}_{2} \mathrm{CH}_{2}\right), 1.29\left(\mathrm{t}, J=7.1 \mathrm{~Hz}, 3 \mathrm{H}, \mathrm{OCH}_{2} \mathrm{CH}_{3}\right) ;{ }^{13} \mathrm{C} \mathrm{NMR}\left(101 \mathrm{MHz}, \mathrm{CDCl}_{3}\right) \delta 173.9$, 168.7, 165.6, 141.5, 136.9, 134.2, 133.1, 131.6, 128.1, 122.8, 94.5, 74.2, 61.9, 51.7, 33.3, 31.7, 23.9, 14.3; IR ( $\left.v_{\max }, \mathrm{cm}^{-1}\right) 2956(\mathrm{w}), 1735(\mathrm{~s}), 1606(\mathrm{~s}), 1436(\mathrm{~m}), 1367(\mathrm{w}), 1344(\mathrm{~m}), 1292(\mathrm{~m}), 1238(\mathrm{~m}), 1209$ $(\mathrm{m}), 1157(\mathrm{~m}), 1096(\mathrm{~m}), 1017(\mathrm{~s}), 965(\mathrm{~m}), 834(\mathrm{~m})$; HRMS (ESI) calcd for $\mathrm{C}_{18} \mathrm{H}_{21} \mathrm{INaO}_{6}{ }^{+}[\mathrm{M}+\mathrm{Na}]^{+}$ 483.0275; found 483.0280 .

\section{(E)-7-Chloro-1-ethoxy-1-oxohept-3-en-2-yl 2-iodobenzoate (4n)}<smiles>CCOC(=O)C(/C=C/CCCCl)OC(=O)c1ccccc1I</smiles>

Following general procedure $D$, starting from $(E)$-1-(5-chloropent-1-en-1-yl)- $1 \lambda^{3}$ benzo[d][1,2]iodaoxol-3(1H)-one (1n) $(70.1 \mathrm{mg}, 0.200 \mathrm{mmol})$ and ethyl 2-diazoacetate (2a) $(48.0 \mu \mathrm{L}$, $87 \% \mathrm{wt}$ in DCM, $0.400 \mathrm{mmol}$ ), afforded (E)-7-chloro-1-ethoxy-1-oxohept-3-en-2-yl 2-iodobenzoate (4n) as a colorless oil $(82 \mathrm{mg}, 0.19 \mathrm{mmol}, 94 \%) . \mathrm{R}_{\mathrm{f}}=0.20$ (EtOAc/pentane $\left.5: 95\right) ;{ }^{1} \mathrm{H}$ NMR $\left(400 \mathrm{MHz}, \mathrm{CDCl}_{3}\right)$ $\delta 8.01(\mathrm{dd}, J=7.9,1.1 \mathrm{~Hz}, 1 \mathrm{H}, \mathrm{ArH}), 7.94(\mathrm{dd}, J=7.8,1.7 \mathrm{~Hz}, 1 \mathrm{H}, \mathrm{ArH}), 7.43(\mathrm{td}, J=7.6,1.2 \mathrm{~Hz}, 1 \mathrm{H}, \operatorname{ArH})$, $7.18(\mathrm{td}, J=7.7,1.7 \mathrm{~Hz}, 1 \mathrm{H}, \mathrm{ArH}), 6.02\left(\mathrm{dtd}, J=15.1,6.9,1.1 \mathrm{~Hz}, 1 \mathrm{H}, \mathrm{CHCHCH}_{2}\right), 5.75$ (ddt, $J=15.3,7.1$, $\left.1.4 \mathrm{~Hz}, 1 \mathrm{H}, \mathrm{CHCHCH}_{2}\right), 5.66$ (dd, J = 7.1, $\left.1.0 \mathrm{~Hz}, 1 \mathrm{H}, \mathrm{OCHCC}\right), 4.25$ (q, J = 7.1 Hz, $\left.2 \mathrm{H}, \mathrm{OCH}_{2} \mathrm{CH}_{3}\right), 3.54$ (t, J $\left.=6.5 \mathrm{~Hz}, 2 \mathrm{H}, \mathrm{CH}_{2} \mathrm{CH}_{2} \mathrm{Cl}\right), 2.35-2.24\left(\mathrm{~m}, 2 \mathrm{H}, \mathrm{CHCH}_{2} \mathrm{CH}_{2}\right), 1.96-1.85\left(\mathrm{~m}, 2 \mathrm{H}, \mathrm{CH}_{2} \mathrm{CH}_{2} \mathrm{CH}_{2} \mathrm{Cl}\right), 1.30$ (t, J = $\left.7.1 \mathrm{~Hz}, 3 \mathrm{H}, \mathrm{OCH}_{2} \mathrm{CH}_{3}\right) ;{ }^{13} \mathrm{C} \mathrm{NMR}\left(101 \mathrm{MHz}, \mathrm{CDCl}_{3}\right) \delta 168.7,165.6,141.6,136.1,134.2,133.2,131.6$, 128.1, 123.3, 94.5, 74.1, 62.0, 44.2, 31.4, 29.5, 14.3; IR $\left(v_{\max }, \mathrm{cm}^{-1}\right) 2977(\mathrm{~m}), 2920(\mathrm{~m}), 2848(\mathrm{~m}), 1736$ (s), $1579(\mathrm{~m}), 1450(\mathrm{~m}), 1286$ (s), 1239 (s), 1190 (s), 1133 (s), 1100 (s), 1014 (s), 965 (s), 740 (s); HRMS (ESI) calcd for $\mathrm{C}_{16} \mathrm{H}_{18} \mathrm{ClINaO}_{4}{ }^{+}[\mathrm{M}+\mathrm{Na}]^{+}$458.9831; found 458.9835 .

\section{1-(Cyclohex-1-en-1-yl)-2-ethoxy-2-oxoethyl 2-iodobenzoate (40)}<smiles>CCOC(=O)C(OC(=O)c1ccccc1I)C1=CCCCC1</smiles>

Following general procedure $D$, starting from $(E)$-1-(cyclohex-1-en-1-yl)-1 $1 \lambda^{3}$-benzo $[d][1,2]$ iodaoxol$3(1 \mathrm{H})$-one (10) $(65.6 \mathrm{mg}, 0.200 \mathrm{mmol})$ and ethyl 2-diazoacetate (2a) $(48.0 \mu \mathrm{L}, 87 \% \mathrm{wt}$ in DCM, 0.400 $\mathrm{mmol}$ ), afforded 1-(cyclohex-1-en-1-yl)-2-ethoxy-2-oxoethyl 2-iodobenzoate (40) as a colorless oil (80 $\mathrm{mg}, 0.19 \mathrm{mmol}, 97 \%) . \mathrm{R}_{\mathrm{f}}=0.36$ (EtOAc/pentane 5:95); ${ }^{1} \mathrm{H} \mathrm{NMR}\left(400 \mathrm{MHz}, \mathrm{CDCl}_{3}\right) \delta 8.00$ (dd, $J=8.0,1.1$ $\mathrm{Hz}, 1 \mathrm{H}, \mathrm{ArH}), 7.94(\mathrm{dd}, J=7.8,1.7 \mathrm{~Hz}, 1 \mathrm{H}, \mathrm{ArH}), 7.42(\mathrm{td}, J=7.6,1.2 \mathrm{~Hz}, 1 \mathrm{H}, \mathrm{ArH}), 7.20-7.14(\mathrm{~m}, 1 \mathrm{H}$, $\operatorname{ArH}), 6.04-5.99\left(\mathrm{~m}, 1 \mathrm{H}, \mathrm{CCHCH}_{2}\right), 5.55(\mathrm{~d}, J=1.0 \mathrm{~Hz}, 1 \mathrm{H}, \mathrm{OCHCC}), 4.25$ (q, J = $\left.7.1 \mathrm{~Hz}, 2 \mathrm{H}, \mathrm{OCH}_{2} \mathrm{CH}_{3}\right)$, 
$2.30-1.18(\mathrm{~m}, 1 \mathrm{H}, \mathrm{cy}-\mathrm{H}), 2.16-1.96(\mathrm{~m}, 3 \mathrm{H}, \mathrm{cy}-H), 1.74-1.58(\mathrm{~m}, 4 \mathrm{H}, \mathrm{cy}-H), 1.29(\mathrm{t}, J=7.1 \mathrm{~Hz}, 3 \mathrm{H}$, $\left.\mathrm{OCH}_{2} \mathrm{CH}_{3}\right) ;{ }^{13} \mathrm{C} \mathrm{NMR}\left(101 \mathrm{MHz}, \mathrm{CDCl}_{3}\right) \delta 168.7,165.9,141.6,134.4,133.1,131.7,131.1,130.5,128.1$, 94.5, 78.1, 61.7, 25.4, 24.9, 22.4, 22.0, 14.3; IR $\left(v_{\max }, \mathrm{cm}^{-1}\right) 2959(\mathrm{~m}), 2928(\mathrm{~m}), 2867(\mathrm{~m}), 1732(\mathrm{~s}), 1591$ (m), $1464(\mathrm{~m}), 1431(\mathrm{~m}), 1368(\mathrm{~m}), 1284(\mathrm{~s}), 1239(\mathrm{~s}), 1192(\mathrm{~s}), 1131$ (s), 1096 (s), 1014 (s), 965 (s), 740 (s); HRMS (ESI) calcd for $\mathrm{C}_{17} \mathrm{H}_{19} \mathrm{INaO}_{4}{ }^{+}[\mathrm{M}+\mathrm{Na}]^{+}$437.0220; found 437.0225 .

\section{(E)-5-(1,3-Dioxoisoindolin-2-yl)-1-ethoxy-1-oxopent-3-en-2-yl 2-iodobenzoate (4p)}<smiles>CCOC(=O)C(/C=C/CN1C(=O)c2ccccc2C1=O)OC(=O)c1ccccc1I</smiles>

Following general procedure $D$, starting from $(E)-2-\left(3-\left(3-o x o-1 \lambda^{3}\right.\right.$-benzo $[d][1,2]$ iodaoxol- $1(3 H)$ yl)allyl)isoindoline-1,3-dione (1p) $(87.0 \mathrm{mg}, 0.200 \mathrm{mmol})$ and ethyl 2-diazoacetate (2a) $(48.0 \mu \mathrm{L}, 87 \%$ wt in DCM, $0.400 \mathrm{mmol}$ ), afforded (E)-5-(1,3-dioxoisoindolin-2-yl)-1-ethoxy-1-oxopent-3-en-2-yl 2iodobenzoate (4p) as a white sticky solid $(31.0 \mathrm{mg}, 0.06 \mathrm{mmol}, 30 \%)$. M.p. $77-78{ }^{\circ} \mathrm{C} ; \mathrm{R}_{\mathrm{f}}=0.31$ (EtOAc/pentane 25:75); ${ }^{1} \mathrm{H} \mathrm{NMR}\left(400 \mathrm{MHz}, \mathrm{CDCl}_{3}\right) \delta 7.99$ (dd, J = 8.0, $\left.1.1 \mathrm{~Hz}, 1 \mathrm{H}, \mathrm{ArH}\right), 7.93$ (dd, J = 7.8, $1.7 \mathrm{~Hz}, 1 \mathrm{H}, \mathrm{ArH}), 7.89-7.81(\mathrm{~m}, 2 \mathrm{H}, \mathrm{ArH}), 7.77-7.69(\mathrm{~m}, 2 \mathrm{H}, \mathrm{ArH}), 7.42(\mathrm{td}, J=7.6,1.2 \mathrm{~Hz}, 1 \mathrm{H}, \operatorname{ArH})$, 7.17 (td, $J=7.7,1.7 \mathrm{~Hz}, 1 \mathrm{H}, \mathrm{ArH}), 6.12\left(\mathrm{dtd}, J=15.5,5.9,1.4 \mathrm{~Hz}, 1 \mathrm{H}, \mathrm{CHCHCH}_{2} \mathrm{~N}\right), 5.96$ (ddt, $J=15.5$, 6.0, 1.4 Hz, $1 \mathrm{H}, \mathrm{CHCHCH}_{2} \mathrm{~N}$ ), 5.71 (dd, J =6.0, $1.3 \mathrm{~Hz}, 1 \mathrm{H}, \mathrm{OCHCC}$ ), 4.36 (dt, J=5.9, $1.2 \mathrm{~Hz}, 2 \mathrm{H}, \mathrm{CH}_{2} \mathrm{NPhth}$ ), 4.24 (qd, $\left.J=7.1,0.9 \mathrm{~Hz}, 2 \mathrm{H}, \mathrm{OCH}_{2} \mathrm{CH}_{3}\right), 1.28\left(\mathrm{t}, J=7.1 \mathrm{~Hz}, 3 \mathrm{H}, \mathrm{OCH}_{2} \mathrm{CH}_{3}\right) ;{ }^{13} \mathrm{C} \mathrm{NMR}\left(101 \mathrm{MHz}, \mathrm{CDCl}_{3}\right) \delta$ 168.0, 167.9, 165.4, 141.6, 134.3, 133.9, 133.2, 132.2, 131.7, 129.3, 128.1, 125.7, 123.6, 94.5, 73.1, 62.2, 38.9, 14.2; IR ( $\left.v_{\max }, \mathrm{cm}^{-1}\right) 3463(\mathrm{w}), 3053(\mathrm{w}), 2985(\mathrm{w}), 2922(\mathrm{~m}), 2854(\mathrm{w}), 1733(\mathrm{~m}), 1709(\mathrm{~s})$, $1582(\mathrm{w}), 1467(\mathrm{~m}), 1430(\mathrm{~m}), 1392(\mathrm{~s}), 1288(\mathrm{~m}), 1244(\mathrm{~m}), 1200(\mathrm{~m}), 1130(\mathrm{~m}), 1101(\mathrm{~m}), 1046(\mathrm{~m})$, 1017 (s), $944(\mathrm{~m})$; HRMS (ESI) calcd for $\mathrm{C}_{22} \mathrm{H}_{18} \mathrm{INNaO}_{6}{ }^{+}[\mathrm{M}+\mathrm{Na}]^{+} 542.0071$; found 542.0082.

(E)-1-Ethoxy-1-oxo-5-((triisopropylsilyl)oxy)pent-3-en-2-yl 2-iodobenzoate (4q)<smiles>CCOC(=O)C(/C=C/CO[Na])OC(=O)c1ccccc1I</smiles>

Following general procedure D, starting from $(E)$-1-(3-((triisopropylsilyl)oxy)prop-1-en-1-yl)-1 $\lambda^{3}$ benzo[d][1,2]iodaoxol-3(1H)-one (1q) $(92.0 \mathrm{mg}, 0.200 \mathrm{mmol})$ and ethyl 2-diazoacetate (2a) $(48.0 \mu \mathrm{L}$, $87 \%$ wt in DCM, $0.400 \mathrm{mmol})$, afforded (E)-1-ethoxy-1-oxo-5-((triisopropylsilyl)oxy)pent-3-en-2-yl 2iodobenzoate $(\mathbf{4 q})$ as a colorless oil $(94 \mathrm{mg}, 0.17 \mathrm{mmol}, 86 \%) . \mathrm{R}_{\mathrm{f}}=0.54$ (EtOAc/pentane 5:95); ${ }^{1} \mathrm{H}$ NMR $\left(400 \mathrm{MHz}, \mathrm{CDCl}_{3}\right) \delta 8.01(\mathrm{dd}, J=8.0,1.1 \mathrm{~Hz}, 1 \mathrm{H}, \mathrm{ArH}), 7.96(\mathrm{dd}, J=7.8,1.7 \mathrm{~Hz}, 1 \mathrm{H}, \mathrm{ArH}), 7.42$ (td, $J=$ 7.6, $1.2 \mathrm{~Hz}, 1 \mathrm{H}, \mathrm{ArH}), 7.17(\mathrm{td}, J=7.7,1.7 \mathrm{~Hz}, 1 \mathrm{H}, \mathrm{ArH}), 6.14$ (dtd, $J=15.4,3.7,1.2 \mathrm{~Hz}, 1 \mathrm{H}, \mathrm{CHCHCH}_{2} \mathrm{O}$ ), 6.02 (ddt, $\left.J=15.4,6.5,2.0 \mathrm{~Hz}, 1 \mathrm{H}, \mathrm{CHCHCH}_{2} \mathrm{O}\right), 5.74(\mathrm{dq}, J=6.5,1.3 \mathrm{~Hz}, 1 \mathrm{H}, \mathrm{OCHCC}), 4.33(\mathrm{dt}, J=3.6$, $1.7 \mathrm{~Hz}, 2 \mathrm{H}, \mathrm{CH}_{2} \mathrm{OTIPS}$ ), 4.25 (qd, $J=7.1,1.2 \mathrm{~Hz}, 2 \mathrm{H}, \mathrm{OCH}_{2} \mathrm{CH}_{3}$ ), 1.29 (t, $J=7.1 \mathrm{~Hz}, 3 \mathrm{H}, \mathrm{OCH}_{2} \mathrm{CH}_{3}$ ), $1.17-$ $1.02(\mathrm{~m}, 21 \mathrm{H}, \mathrm{TIPS}) ;{ }^{13} \mathrm{C}$ NMR $\left(101 \mathrm{MHz}, \mathrm{CDCl}_{3}\right) \delta$ 168.6, 165.6, 141.6, 136.0, 134.2, 133.2, 131.7, 128.1, 120.8, 94.5, 73.8, 62.8, 61.9, 18.1, 14.3, 12.1; IR $\left(v_{\max }, \mathrm{cm}^{-1}\right) 2960(\mathrm{~m}), 2941(\mathrm{~s}), 2866(\mathrm{~s}), 2727(\mathrm{w}), 1736$ $(\mathrm{s}), 1463(\mathrm{~m}), 1378(\mathrm{w}), 1284(\mathrm{~m}), 1248(\mathrm{~s}), 1200(\mathrm{~m}), 1124(\mathrm{~s}), 1044(\mathrm{~s}), 1017(\mathrm{~s}), 967(\mathrm{~m}), 880(\mathrm{~s})$; HRMS (ESI) calcd for $\mathrm{C}_{23} \mathrm{H}_{35} \mathrm{INaO}_{5} \mathrm{Si}^{+}[\mathrm{M}+\mathrm{Na}]^{+} 569.1191$; found 569.1197 . 
<smiles>CCOC(=O)C(/C=C/CCl)OC(=O)c1ccccc1I</smiles>

Following general procedure $D$, starting from (E)-1-(3-chloroprop-1-en-1-yl)-1 $\lambda^{3}$ benzo[d][1,2]iodaoxol-3(1H)-one (1r) $(64.5 \mathrm{mg}, 0.200 \mathrm{mmol})$ and ethyl 2-diazoacetate (2a) $(48.0 \mu \mathrm{L}$, $87 \%$ wt in DCM, $0.400 \mathrm{mmol}$ ), afforded (E)-5-chloro-1-ethoxy-1-oxopent-3-en-2-yl 2-iodobenzoate (4r) as a colorless oil ( $26.0 \mathrm{mg}, 0.06 \mathrm{mmol}, 32 \%) . \mathrm{R}_{\mathrm{f}}=0.19$ (EtOAc/pentane 5:95); ${ }^{1} \mathrm{H} \mathrm{NMR}\left(400 \mathrm{MHz}, \mathrm{CDCl}_{3}\right)$ $\delta 8.02(\mathrm{dd}, J=8.0,1.1 \mathrm{~Hz}, 1 \mathrm{H}, \operatorname{ArH}), 7.96(\mathrm{dd}, J=7.8,1.7 \mathrm{~Hz}, 1 \mathrm{H}, \operatorname{ArH}), 7.44(\mathrm{td}, J=7.6,1.2 \mathrm{~Hz}, 1 \mathrm{H}, \operatorname{ArH})$, 7.20 (ddd, $J=8.0,7.4,1.7 \mathrm{~Hz}, 1 \mathrm{H}, \mathrm{ArH}), 6.20$ (dtd, $J=15.3,6.4,1.4 \mathrm{~Hz}, 1 \mathrm{H}, \mathrm{CHCHCH}_{2} \mathrm{Cl}$ ), 6.04 (ddt $J=$ $15.3,6.0,1.3 \mathrm{~Hz}, 1 \mathrm{H}, \mathrm{CHCHCH}_{2} \mathrm{Cl}$ ), $5.76(\mathrm{dq}, J=5.9,1.1 \mathrm{~Hz}, 1 \mathrm{H}, \mathrm{OCHCC}), 4.27$ (q, $J=7.1 \mathrm{~Hz}, 2 \mathrm{H}, \mathrm{OCH}_{2} \mathrm{CH}_{3}$ ), $4.11\left(\mathrm{dt}, J=6.4,1.1 \mathrm{~Hz}, 2 \mathrm{H}, \mathrm{CH}_{2} \mathrm{Cl}\right), 1.31\left(\mathrm{t}, J=7.2 \mathrm{~Hz}, 3 \mathrm{H}, \mathrm{OCH}_{2} \mathrm{CH}_{3}\right) ;{ }^{13} \mathrm{C} \mathrm{NMR}\left(101 \mathrm{MHz}, \mathrm{CDCl}_{3}\right) \delta 167.9$, 165.4, 141.7, 133.9, 133.3, 131.7, 131.3, 128.2, 126.0, 94.6, 72.9, 62.3, 43.6, 14.3; IR $\left(v_{\max }, \mathrm{cm}^{-1}\right) 2959$ $(\mathrm{m}), 2928(\mathrm{~m}), 2867(\mathrm{~m}), 1732(\mathrm{~s}), 1591(\mathrm{~m}), 1464(\mathrm{~m}), 1431(\mathrm{~m}), 1368(\mathrm{~m}), 1284(\mathrm{~s}), 1239(\mathrm{~s}), 1192(\mathrm{~s})$, 1131 (s), 1096 (s), 1014 (s), 965 (s), 740 (s); HRMS (ESI) calcd for $\mathrm{C}_{14} \mathrm{H}_{14} \mathrm{ClINaO}_{4}{ }^{+}[\mathrm{M}+\mathrm{Na}]^{+} 430.9518$; found 430.9521 .

(E)-1-Ethoxy-5-methyl-1-oxohexa-3,5-dien-2-yl 2-iodobenzoate (4s)<smiles>C=C(C)C=CC(OC(=O)c1ccccc1I)C(=O)OCC</smiles>

Following general procedure $D$, starting from (E)-1-(3-methylbuta-1,3-dien-1-yl)-1 $\lambda^{3}$ benzo[d][1,2]iodaoxol-3(1H)-one (1s) $(62.8 \mathrm{mg}, 0.200 \mathrm{mmol})$ and ethyl 2-diazoacetate (2a) $(48.0 \mu \mathrm{L}$, $87 \% \mathrm{wt}$ in DCM, $0.400 \mathrm{mmol}$ ), afforded (E)-1-ethoxy-5-methyl-1-oxohexa-3,5-dien-2-yl 2-iodobenzoate (4s) as a colorless oil $(66 \mathrm{mg}, 0.17 \mathrm{mmol}, 82 \%) . \mathrm{R}_{\mathrm{f}}=0.33$ (EtOAc/pentane 5:95); ${ }^{1} \mathrm{H} \mathrm{NMR}(400 \mathrm{MHz}$, $\left.\mathrm{CDCl}_{3}\right) \delta 8.01(\mathrm{dd}, J=7.9,1.2 \mathrm{~Hz}, 1 \mathrm{H}, \mathrm{ArH}), 7.97(\mathrm{dd}, J=7.8,1.7 \mathrm{~Hz}, 1 \mathrm{H}, \mathrm{ArH}), 7.43(\mathrm{td}, J=7.6,1.2 \mathrm{~Hz}$, $1 \mathrm{H}, \operatorname{ArH}), 7.18(\mathrm{ddd}, J=8.0,7.5,1.7 \mathrm{~Hz}, 1 \mathrm{H}, \mathrm{ArH}), 6.63(\mathrm{~d}, J=15.3 \mathrm{~Hz}, 1 \mathrm{H}, \mathrm{CHCHC}), 5.85-5.73(\mathrm{~m}, 2 \mathrm{H}$, $\mathrm{CHCHC}$ and $\mathrm{OCHCC}), 5.14-5.09\left(\mathrm{~m}, 2 \mathrm{H}, \mathrm{CCH}_{2}\right), 4.27\left(\mathrm{qd}, J=7.1,1.7 \mathrm{~Hz}, 2 \mathrm{H}, \mathrm{OCH}_{2} \mathrm{CH}_{3}\right), 1.88(\mathrm{t}, J=1.0$ $\left.\mathrm{Hz}, 3 \mathrm{H}, \mathrm{CCH}_{3}\right), 1.31\left(\mathrm{t}, J=7.1 \mathrm{~Hz}, 3 \mathrm{H}, \mathrm{OCH}_{2} \mathrm{CH}_{3}\right) ;{ }^{13} \mathrm{C} \mathrm{NMR}\left(101 \mathrm{MHz}, \mathrm{CDCl}_{3}\right) \delta 168.6,165.6,141.6,140.8$, $138.5,134.2,133.2,131.7,128.1,120.7,119.6,94.5,74.3,62.1,18.5,14.3 ; \mathrm{IR}\left(v_{\max }, \mathrm{cm}^{-1}\right) 2959(\mathrm{~m})$, $2928(\mathrm{~m}), 2867(\mathrm{~m}), 1732(\mathrm{~s}), 1591(\mathrm{~m}), 1464(\mathrm{~m}), 1431(\mathrm{~m}), 1368(\mathrm{~m}), 1284(\mathrm{~s}), 1239(\mathrm{~s}), 1192(\mathrm{~s}), 1131$ (s), 1096 (s), 1014 (s), 965 (s), 740 (s); HRMS (ESI) calcd for $\mathrm{C}_{16} \mathrm{H}_{17} \mathrm{INaO}_{4}{ }^{+}[\mathrm{M}+\mathrm{Na}]^{+}$423.0064; found 423.0065 .

(3E,5E)-1-Ethoxy-1-oxo-6-phenylhexa-3,5-dien-2-yl 2-iodobenzoate (4t)<smiles>CCOC(=O)C(/C=C/C=C/c1ccccc1)OC(=O)c1ccccc1I</smiles>

Following general procedure $D$, starting from $(E)-1-\left((1 E, 3 E)-4\right.$-phenylbuta-1,3-dien-1-yl)-1 $\lambda^{3}$ benzo[d][1,2]iodaoxol-3(1H)-one (1t) $(75.0 \mathrm{mg}, 0.200 \mathrm{mmol})$ and ethyl 2-diazoacetate (2a) $(48.0 \mu \mathrm{L}$, $87 \% \mathrm{wt}$ in DCM, $0.400 \mathrm{mmol}$ ), afforded (3E,5E)-1-ethoxy-1-oxo-6-phenylhexa-3,5-dien-2-yl 2iodobenzoate (4t) as a colorless oil $(84 \mathrm{mg}, 0.18 \mathrm{mmol}, 91 \%)$. $\mathrm{R}_{\mathrm{f}}=0.23$ (EtOAc/pentane 5:95); ${ }^{1} \mathrm{H} \mathrm{NMR}$ $\left(400 \mathrm{MHz}, \mathrm{CDCl}_{3}\right) \delta 8.02(\mathrm{dd}, J=7.9,1.1 \mathrm{~Hz}, 1 \mathrm{H}, \mathrm{ArH}), 7.98(\mathrm{dd}, J=7.8,1.7 \mathrm{~Hz}, 1 \mathrm{H}, \mathrm{ArH}), 7.49-7.38(\mathrm{~m}$, 
3H, ArH), 7.37 - 7.30 (m, 2H, ArH), 7.29 - 7.22 (m, 1H, ArH), $7.19(\mathrm{td}, J=7.7,1.8 \mathrm{~Hz}, 1 \mathrm{H}, \operatorname{ArH}), 6.80(\mathrm{dd}$, $J=15.4,10.3 \mathrm{~Hz}, 1 \mathrm{H}, \mathrm{CHCHCHCHPh}), 6.75-6.64(\mathrm{~m}, 2 \mathrm{H}, \mathrm{CHCHCHCHPh}), 6.01-5.93(\mathrm{~m}, 1 \mathrm{H}$, $\mathrm{CHCHCHCHPh}$ ), 5.79 (dd, $J=7.0,1.1 \mathrm{~Hz}, 1 \mathrm{H}, \mathrm{OCHCC}$ ), 4.28 (qd, $\left.J=7.1,0.9 \mathrm{~Hz}, 2 \mathrm{H}, \mathrm{OCH}_{2} \mathrm{CH}_{3}\right), 1.32$ (t, $J$ $\left.=7.1 \mathrm{~Hz}, 3 \mathrm{H}, \mathrm{OCH}_{2} \mathrm{CH}_{3}\right) ;{ }^{13} \mathrm{C} \mathrm{NMR}\left(101 \mathrm{MHz}, \mathrm{CDCl}_{3}\right) \delta 168.5,165.6,141.6,136.8,136.0,135.5,134.1$, 133.2, 131.7, 128.8, 128.3, 128.1, 127.2, 126.8, 124.0, 94.6, 74.1, 62.1, 14.3; IR $\left(v_{\max }, \mathrm{cm}^{-1}\right) 2985(\mathrm{w})$, $2918(\mathrm{w}), 1732(\mathrm{~s}), 1583(\mathrm{w}), 1466(\mathrm{w}), 1284(\mathrm{~m}), 1243(\mathrm{~s}), 1129(\mathrm{~m}), 1100(\mathrm{~m}), 1014(\mathrm{~s}), 988(\mathrm{~m}), 738$ (s), 689 (s); HRMS (ESI) calcd for $\mathrm{C}_{21} \mathrm{H}_{19} \mathrm{INaO}_{4}^{+}[\mathrm{M}+\mathrm{Na}]^{+}$485.0220; found 485.0216.

(E)-1-Ethoxy-1-oxoundec-3-en-5-yn-2-yl 2-iodobenzoate (4u)<smiles>CCCCCC#C/C=C/C(OC(=O)c1ccccc1I)C(=O)OCC</smiles>

Following general procedure $D$, starting from $(E)$-1-(non-1-en-3-yn-1-yl)-1 $\lambda^{3}$-benzo[d][1,2]iodaoxol$3(1 \mathrm{H})$-one (1u) $(73.6 \mathrm{mg}, 0.200 \mathrm{mmol})$ and ethyl 2-diazoacetate $(2 \mathrm{a})(48.0 \mu \mathrm{L}, 87 \% \mathrm{wt}$ in DCM, 0.400 $\mathrm{mmol}$ ), afforded (E)-1-ethoxy-1-oxoundec-3-en-5-yn-2-yl 2-iodobenzoate (4u) as a colorless oil ( $88 \mathrm{mg}$, $0.19 \mathrm{mmol}, 97 \%) . \mathrm{R}_{\mathrm{f}}=0.40$ (EtOAc/pentane 5:95); ${ }^{1} \mathrm{H} \mathrm{NMR}\left(400 \mathrm{MHz}, \mathrm{CDCl}_{3}\right) \delta 8.01$ (dd, J = 7.9, $1.1 \mathrm{~Hz}$, $1 \mathrm{H}, \operatorname{ArH}), 7.95(\mathrm{dd}, J=7.8,1.7 \mathrm{~Hz}, 1 \mathrm{H}, \mathrm{ArH}), 7.42(\mathrm{td}, J=7.6,1.2 \mathrm{~Hz}, 1 \mathrm{H}, \mathrm{ArH}), 7.18$ (ddd, $J=7.9,7.4,1.7$ $\mathrm{Hz}, 1 \mathrm{H}, \mathrm{ArH}), 6.17$ (ddt, $J=15.8,6.5,0.7 \mathrm{~Hz}, 1 \mathrm{H}, \mathrm{CHCHCC}), 6.02$ (dtd, $J=15.8,2.1,1.4 \mathrm{~Hz}, 1 \mathrm{H}, \mathrm{CHCHCC}$ ), $5.72(\mathrm{dd}, J=6.6,1.4 \mathrm{~Hz}, 1 \mathrm{H}, \mathrm{OCHCC}), 4.25$ (qd, $\left.J=7.1,2.2 \mathrm{~Hz}, 2 \mathrm{H}, \mathrm{OCH}_{2} \mathrm{CH}_{3}\right), 2.31$ (td, $J=7.1,2.2 \mathrm{~Hz}$, $\left.2 \mathrm{H}, \mathrm{CCH}_{2} \mathrm{CH}_{2}\right), 1.57-1.48\left(\mathrm{~m}, 2 \mathrm{H}, \mathrm{CCH}_{2} \mathrm{CH}_{2}\right), 1.42-1.21\left(\mathrm{~m}, 7 \mathrm{H}\right.$, pentyl- $\mathrm{H}$ and $\left.\mathrm{OCH}_{2} \mathrm{CH}_{3}\right), 0.90(\mathrm{t}, J=7.1$ $\left.\mathrm{Hz}, 3 \mathrm{H}, \mathrm{CH}_{2} \mathrm{CH}_{3}\right) ;{ }^{13} \mathrm{C}$ NMR $\left(101 \mathrm{MHz}, \mathrm{CDCl}_{3}\right) \delta 167.7,165.2,141.5,133.7,133.2,131.8,131.6,128.0$ 116.1, 94.5, 94.2, 77.5, 73.4, 62.1, 31.1, 28.2, 22.2, 19.4, 14.1, 14.0; IR $\left(v_{\max }, \mathrm{cm}^{-1}\right) 2957(\mathrm{~m}), 2935(\mathrm{~m})$, $2859(\mathrm{w}), 2219(\mathrm{w}), 1738(\mathrm{~s}), 1584(\mathrm{~m}), 1465(\mathrm{~m}), 1429(\mathrm{~m}), 1370(\mathrm{~m}), 1284(\mathrm{~m}), 1241(\mathrm{~s}), 1196(\mathrm{~s}), 1131$ (s), 1096 (s), 1043 (m), 1027 (s), 1017 (s), 954 (s), 738 (s); HRMS (ESI) calcd for $\mathrm{C}_{20} \mathrm{H}_{24} \mathrm{OO}_{4}{ }^{+}[\mathrm{M}+\mathrm{H}]^{+}$ 455.0714; found 455.0720 .

(E)-1-Ethoxy-1-oxo-2,4-diphenylbut-3-en-2-yl 2-iodobenzoate (5a)<smiles>CCOC(=O)C(C=Cc1ccccc1)(C(=O)OC(=O)c1ccccc1I)c1ccccc1</smiles>

Following general procedure $E$, starting from $(E)$-1-styryl-1 $\lambda^{3}$-benzo[d][1,2]iodaoxol-3(1H)-one (1a) (70.0 $\mathrm{mg}, 0.200 \mathrm{mmol}$ ) and ethyl 2-diazo-2-phenylacetate $(2 \mathrm{~b})(76.0 \mathrm{mg}, 0.400 \mathrm{mmol})$, afforded $(E)-1$ ethoxy-1-oxo-2,4-diphenylbut-3-en-2-yl 2-iodobenzoate (5a) as a colorless oil $(73 \mathrm{mg}, 0.14 \mathrm{mmol}$, $71 \%) . R_{\mathrm{f}}=0.40$ (EtOAc/pentane 5:95); ${ }^{1} \mathrm{H}$ NMR (400 MHz, $\left.\mathrm{CDCl}_{3}\right) \delta 8.02$ (d, J = 8.0 Hz, 1H, ArH), 7.95 (dd, J = 7.7, 1.7 Hz, 1H, ArH), 7.76- $7.64(\mathrm{~m}, 2 \mathrm{H}, \mathrm{ArH}), 7.52-7.14(\mathrm{~m}, 11 \mathrm{H}, \mathrm{ArH}$ and $\mathrm{CHCHPh}), 6.53(\mathrm{~d}, J$ $=16.3 \mathrm{~Hz}, 1 \mathrm{H}, \mathrm{CHCHPh}), 4.41-4.15\left(\mathrm{~m}, 2 \mathrm{H}, \mathrm{OCH}_{2} \mathrm{CH}_{3}\right), 1.26\left(\mathrm{t}, J=7.2 \mathrm{~Hz}, 3 \mathrm{H}, \mathrm{OCH}_{2} \mathrm{CH}_{3}\right) ;{ }^{13} \mathrm{C}$ NMR (101 $\left.\mathrm{MHz}, \mathrm{CDCl}_{3}\right) \delta 169.8,165.2,141.5,138.2,136.2,135.2,133.9,133.0,131.2,128.7,128.6,128.6,128.4$, 128.2, 127.1, 126.6, 94.1, 84.2, 62.4, 14.2; IR $\left(v_{\max }, \mathrm{cm}^{-1}\right) 2974(\mathrm{~m}), 2900(\mathrm{~m}), 1735(\mathrm{~s}), 1495(\mathrm{~m}), 1449$ (m), $1431(\mathrm{~m}), 1276$ (s), 1256 (s), 1092 (s), 1042 (s), 1016 (s), 974 (m), 764 (s), 750 (s); HRMS (ESI) calcd for $\mathrm{C}_{24} \mathrm{H}_{19} \mathrm{INaO}_{4}{ }^{+}[\mathrm{M}+\mathrm{Na}]^{+} 521.0220$; found 521.0227 . One carbon was not resolved at $101 \mathrm{MHz}$. 
<smiles>CCCCCCCCOC(=O)c1ccccc1I</smiles>

Following general procedure $D$, starting from $(E)$-1-styryl-1 $\lambda^{3}$-benzo[d] $[1,2]$ iodaoxol-3(1H)-one (1a) (70.0 $\mathrm{mg}, 0.200 \mathrm{mmol}$ ) and tert-butyl 2-diazoacetate (2c) $(65.0 \mu \mathrm{L}, 85 \% \mathrm{wt}$ in DCM, $0.400 \mathrm{mmol}$ ), afforded (E)-1-(tert-butoxy)-1-oxo-4-phenylbut-3-en-2-yl 2-iodobenzoate (5b) as a white solid (90 mg, $0.19 \mathrm{mmol}, 97 \%)$. M.p. $62-64{ }^{\circ} \mathrm{C} ; \mathrm{R}_{\mathrm{f}}=0.36$ (EtOAc/pentane 5:95); ${ }^{1} \mathrm{H} \mathrm{NMR}\left(400 \mathrm{MHz}, \mathrm{CDCl}_{3}\right) \delta 8.01$ (td, $J=7.9,1.4 \mathrm{~Hz}, 2 \mathrm{H}, \mathrm{ArH}), 7.47-7.40(\mathrm{~m}, 3 \mathrm{H}, \mathrm{ArH}), 7.38-7.32(\mathrm{~m}, 2 \mathrm{H}, \mathrm{ArH}), 7.32-7.27(\mathrm{~m}, 1 \mathrm{H}, \mathrm{ArH}), 7.19$ (ddd, $J=7.9,7.4,1.8 \mathrm{~Hz}, 1 \mathrm{H}, \mathrm{ArH}), 6.90$ (dd, $J=15.9,1.4 \mathrm{~Hz}, 1 \mathrm{H}, \mathrm{CHCHPh}), 6.37$ (dd, $J=16.0,6.9 \mathrm{~Hz}$, $1 \mathrm{H}, \mathrm{CHCHPh}), 5.75(\mathrm{dd}, J=6.9,1.4 \mathrm{~Hz}, 1 \mathrm{H}, \mathrm{OCHCC}), 1.51\left(\mathrm{~s}, 9 \mathrm{H}, \mathrm{C}\left(\mathrm{CH}_{3}\right)_{3}\right) ;{ }^{13} \mathrm{C} \mathrm{NMR}\left(101 \mathrm{MHz}, \mathrm{CDCl}_{3}\right) \delta$ 167.5, 165.7, 141.6, 135.9, 135.2, 134.4, 133.1, 131.7, 128.8, 128.6, 128.1, 127.0, 121.2, 94.5, 83.1, 74.8, 28.2; IR ( $\left.v_{\max }, \mathrm{cm}^{-1}\right) 2978(\mathrm{~m}), 2902(\mathrm{~m}), 1735(\mathrm{~s}), 1582(\mathrm{w}), 1451(\mathrm{~m}), 1395(\mathrm{~m}), 1369(\mathrm{~m}), 1278$ (s), $1258(\mathrm{~s}), 1199(\mathrm{~m}), 1129(\mathrm{~m}), 1098(\mathrm{~s}), 1044(\mathrm{~s}), 1016(\mathrm{~s}), 966$ (m), $863(\mathrm{~m}), 764(\mathrm{~s}), 750$ (s); HRMS (ESI) calcd for $\mathrm{C}_{21} \mathrm{H}_{21} \mathrm{INaO}_{4}{ }^{+}[\mathrm{M}+\mathrm{Na}]^{+} 487.0377$; found 487.0382 .

(E)-1-(2,6-di-tert-Butyl-4-methylphenoxy)-1-oxo-4-phenylbut-3-en-2-yl 2-iodobenzoate (5c)<smiles>CC(C)(C)c1cc(C(=O)Oc2c(I)cc(I)cc2C(=O)OC(C=Cc2ccccc2)C(=O)OCc2ccccc2)cc(C(C)(C)C)c1</smiles>

Following general procedure $D$, starting from $(E)$-1-styryl-1 $\lambda^{3}$-benzo[d][1,2]iodaoxol-3(1H)-one (1a) (70.0 $\mathrm{mg}, 0.200 \mathrm{mmol}$ ) and 2,6-di-tert-butyl-4-methylphenyl 2-diazoacetate (2d) $(115 \mathrm{mg}, 0.400$ $\mathrm{mmol})$, afforded (E)-1-(2,6-di-tert-butyl-4-methylphenoxy)-1-oxo-4-phenylbut-3-en-2-yl 2iodobenzoate (5c) as a white solid (123 mg, $0.200 \mathrm{mmol}, 100 \%) . \mathrm{R}_{\mathrm{f}}=0.45$ (EtOAc/pentane 5:95); M.p. 151-153 ${ }^{\circ} \mathrm{C}$; ${ }^{1} \mathrm{H}$ NMR $\left(400 \mathrm{MHz}, \mathrm{CDCl}_{3}\right) \delta 8.02$ (ddd, $\left.J=7.8,4.5,1.4 \mathrm{~Hz}, 2 \mathrm{H}, \mathrm{ArH}\right), 7.51-7.45(\mathrm{~m}, 2 \mathrm{H}$, $\operatorname{ArH}), 7.43(\mathrm{td}, J=7.6,1.2 \mathrm{~Hz}, 1 \mathrm{H}, \operatorname{ArH}), 7.40-7.29(\mathrm{~m}, 3 \mathrm{H}, \operatorname{ArH}), 7.23-7.16(\mathrm{~m}, 1 \mathrm{H}, \mathrm{ArH}), 7.16-7.10$ $(\mathrm{m}, 2 \mathrm{H}, \mathrm{ArH}), 7.02(\mathrm{~d}, J=14.9 \mathrm{~Hz}, 1 \mathrm{H}, \mathrm{CHCHPh}), 6.62-6.52(\mathrm{~m}, 2 \mathrm{H}, \mathrm{CHCHPh}$ and OCHCC), $2.32(\mathrm{~s}, 3 \mathrm{H}$, $\left.\mathrm{ArCH}_{3}\right), 1.38\left(\mathrm{~s}, 9 \mathrm{H}, \mathrm{C}\left(\mathrm{CH}_{3}\right)_{3}\right), 1.31\left(\mathrm{~s}, 9 \mathrm{H}, \mathrm{C}\left(\mathrm{CH}_{3}\right)_{3}\right) ;{ }^{13} \mathrm{C} \mathrm{NMR}\left(101 \mathrm{MHz}, \mathrm{CDCl}_{3}\right) \delta 168.5,165.0,145.8$, 142.2, 142.1, 141.6, 136.2, 135.7, 135.2, 134.4, 133.2, 131.6, 128.9, 128.8, 128.1, 127.5, 127.2, 127.0, 120.7, 94.6, 74.1, 35.5, 35.5, 31.8, 31.4, 21.6; IR $\left(v_{\max }, \mathrm{cm}^{-1}\right) 2961(\mathrm{~m}), 2922(\mathrm{~m}), 1769(\mathrm{~s}), 1742(\mathrm{~s}), 1468$ $(\mathrm{m}), 1425(\mathrm{~m}), 1270(\mathrm{~s}), 1247(\mathrm{~s}), 1196(\mathrm{~s}), 1180(\mathrm{~s}), 1129(\mathrm{~s}), 1100(\mathrm{~s}), 1016(\mathrm{~s}), 969(\mathrm{~m}), 742(\mathrm{~s})$; HRMS (ESI) calcd for $\mathrm{C}_{32} \mathrm{H}_{35} \mathrm{INaO}_{4}{ }^{+}[\mathrm{M}+\mathrm{Na}]^{+} 633.1472$; found 633.1474 ; The structure of $5 \mathrm{c}$ was confirmed by $\mathrm{X}$-ray analysis. Crystals were grown by dissolving $10 \mathrm{mg}$ of pure $\mathbf{5 c}$ in a minimum amount of benzene $(100 \mu \mathrm{L})$ at room temperature. Slow evaporation over one week provided suitable crystals. Supplementary crystallographic data for this compound have been deposited at Cambridge Crystallographic Data Centre (CCDC 1897009) and can be obtained free of charge via https://www.ccdc.cam.ac.uk/structures/ 
<smiles>O=C(OC(/C=C/c1ccccc1)C(=O)OCc1ccccc1)c1ccccc1I</smiles>

Following general procedure $D$, starting from $(E)$-1-styryl-1 $\lambda^{3}$-benzo[d][1,2]iodaoxol-3(1H)-one (1a) $(70.0 \mathrm{mg}, 0.200 \mathrm{mmol})$ and benzyl 2-diazoacetate (2e) $(88.0 \mu \mathrm{L}, 90 \% \mathrm{wt}$ in DCM, $0.400 \mathrm{mmol})$, afforded (E)-1-(Benzyloxy)-1-oxo-4-phenylbut-3-en-2-yl 2-iodobenzoate (5d) as a colorless oil (92.0 $\mathrm{mg}, 0.19$ $\mathrm{mmol}, 92 \%) . \mathrm{R}_{\mathrm{f}}=0.26$ (EtOAc/pentane 5:95); ${ }^{1} \mathrm{H} \mathrm{NMR}\left(400 \mathrm{MHz}, \mathrm{CDCl}_{3}\right) \delta 8.02$ (dd, J = 8.0, $1.1 \mathrm{~Hz}, 1 \mathrm{H}$, $\operatorname{ArH}), 7.96(\mathrm{dd}, J=7.8,1.7 \mathrm{~Hz}, 1 \mathrm{H}, \operatorname{ArH}), 7.46-7.27(\mathrm{~m}, 11 \mathrm{H}, \mathrm{ArH}), 7.19(\mathrm{td}, J=7.7,1.7 \mathrm{~Hz}, 1 \mathrm{H}, \operatorname{ArH})$, 6.90 (dd, $J=16.0,1.3 \mathrm{~Hz}, 1 \mathrm{H}, \mathrm{CHCHPh}$ ), 6.37 (dd, $J=15.9,7.1 \mathrm{~Hz}, 1 \mathrm{H}, \mathrm{CHCHPh}$ ), 5.93 (dd, $J=7.1,1.3 \mathrm{~Hz}$, $1 \mathrm{H}, \mathrm{OCHCC}), 5.26\left(\mathrm{~s}, 2 \mathrm{H}, \mathrm{OCH}_{2} \mathrm{Ph}\right) ;{ }^{13} \mathrm{C} \mathrm{NMR}\left(101 \mathrm{MHz}, \mathrm{CDCl}_{3}\right) \delta 168.4,165.6,141.6,136.0,135.7,135.3$, $134.1,133.3,131.7,128.8,128.8,128.8,128.6,128.4,128.1,127.0,120.5,94.5,74.3,67.7$; IR ( $v_{\max }$ $\left.\mathrm{cm}^{-1}\right) 2978(\mathrm{~m}), 2902(\mathrm{~m}), 1735(\mathrm{~s}), 1582(\mathrm{w}), 1451(\mathrm{~m}), 1395(\mathrm{~m}), 1369(\mathrm{~m}), 1278(\mathrm{~s}), 1258(\mathrm{~s}), 1199$ $(\mathrm{m}), 1129(\mathrm{~m}), 1098(\mathrm{~s}), 1044$ (s), $1016(\mathrm{~s}), 966(\mathrm{~m}), 863(\mathrm{~m}), 764$ (s), 750 (s); HRMS (ESI) calcd for $\mathrm{C}_{24} \mathrm{H}_{19} \mathrm{NaOO}_{4}^{+}[\mathrm{M}+\mathrm{Na}]^{+}$521.0220; found 521.0235.

\section{(E)-1-(Allyloxy)-1-oxo-4-phenylbut-3-en-2-yl 2-iodobenzoate (5e)}<smiles>C=CCOC(=O)C(/C=C/c1ccccc1)OC(=O)c1ccccc1I</smiles>

Following general procedure $D$, starting from $(E)$-1-styryl-1 $\lambda^{3}$-benzo[d][1,2]iodaoxol-3(1H)-one (1a) $(70.0 \mathrm{mg}, 0.200 \mathrm{mmol})$ and allyl 2-diazoacetate $(2 \mathrm{f})(50.4 \mathrm{mg}, 0.400 \mathrm{mmol})$, afforded (E)-1-(allyloxy)-1oxo-4-phenylbut-3-en-2-yl 2-iodobenzoate (5e) as a colorless oil $(82 \mathrm{mg}, 0.18 \mathrm{mmol}, 91 \%) . R_{\mathrm{f}}=0.24$ (EtOAc/pentane 5:95); $\left.{ }^{1} \mathrm{H} \mathrm{NMR} \mathrm{(400} \mathrm{MHz,} \mathrm{CDCl}_{3}\right) \delta 8.01$ (ddd, J = 10.7, 7.9, $\left.1.4 \mathrm{~Hz}, 2 \mathrm{H}, \mathrm{ArH}\right), 7.45$ (td, J $=7.6,1.2 \mathrm{~Hz}, 3 \mathrm{H}, \mathrm{ArH}), 7.39-7.27(\mathrm{~m}, 3 \mathrm{H}, \mathrm{ArH}), 7.19(\mathrm{td}, J=7.7,1.7 \mathrm{~Hz}, 1 \mathrm{H}, \mathrm{ArH}), 6.94(\mathrm{dd}, J=16.0,1.2$ $\mathrm{Hz}, 1 \mathrm{H}, \mathrm{CHCHPh}$ ), 6.39 (dd, J = 15.9, 7.1 Hz, $1 \mathrm{H}, \mathrm{CHCHPh}), 6.00-5.87\left(\mathrm{~m}, 2 \mathrm{H}, \mathrm{OCHCC}\right.$ and $\mathrm{OCH}_{2} \mathrm{CHCH}_{2}$ ), $5.36\left(\mathrm{dq}, J=17.2,1.5 \mathrm{~Hz}, 1 \mathrm{H}, \mathrm{CHCH}_{2}\right), 5.26\left(\mathrm{dq}, J=10.5,1.3 \mathrm{~Hz}, 1 \mathrm{H}, \mathrm{CHCH}_{2}\right), 4.72(\mathrm{dt}, J=5.8,1.4 \mathrm{~Hz}, 2 \mathrm{H}$, $\left.\mathrm{OCH}_{2} \mathrm{CHCH}_{2}\right) ;{ }^{13} \mathrm{C} \mathrm{NMR}\left(101 \mathrm{MHz}, \mathrm{CDCl}_{3}\right) \delta 168.2,165.6,141.6,136.0,135.7,134.1,133.3,131.7,131.5$, 128.9, 128.8, 128.1, 127.0, 120.6, 119.1, 94.6, 74.3, 66.5; IR ( $\left.v_{\max }, \mathrm{cm}^{-1}\right) 3063(\mathrm{w}), 3026(\mathrm{w}), 2946(\mathrm{w})$, 1736 (s), 1585 (m), 1427 (w), $1290(\mathrm{~m}), 1239$ (s), 1188 (s), 1133 (s), 1096 (s), 1043 (m), 1014 (s), 963 (s), $937(\mathrm{~m}), 742(\mathrm{~s}), 689(\mathrm{~s})$; HRMS (ESI) calcd for $\mathrm{C}_{20} \mathrm{H}_{17} \mathrm{INaO}_{4}{ }^{+}[\mathrm{M}+\mathrm{Na}]^{+}$471.0064; found 471.0063.

\section{(E)-1-(Diethylamino)-1-oxo-4-phenylbut-3-en-2-yl 2-iodobenzoate (5f)}<smiles>CCNC(=O)C(/C=C/c1ccccc1)OC(=O)c1ccccc1I</smiles>

Following general procedure $D$, starting from $(E)$-1-styryl-1 $\lambda^{3}$-benzo[d][1,2]iodaoxol-3(1H)-one (1a) (70.0 $\mathrm{mg}, 0.200 \mathrm{mmol}$ ) and 2-diazo- $\mathrm{N}, \mathrm{N}$-diethylacetamide $(2 \mathrm{~g})(56.5 \mathrm{mg}, 0.400 \mathrm{mmol})$, afforded $(E)-1$ (diethylamino)-1-oxo-4-phenylbut-3-en-2-yl 2-iodobenzoate (5f) as a white solid (87 mg, $0.19 \mathrm{mmol}$, 
94\%). $R_{f}=0.24$ (EtOAc/pentane 20:80); M.p. $113-115^{\circ} \mathrm{C} ;{ }^{1} \mathrm{H}$ NMR (400 MHz, $\left.\mathrm{CDCl}_{3}\right) \delta 8.06$ (dd, $J=7.8$, $1.7 \mathrm{~Hz}, 1 \mathrm{H}, \mathrm{ArH}), 7.98(\mathrm{dd}, J=7.9,1.1 \mathrm{~Hz}, 1 \mathrm{H}, \mathrm{ArH}), 7.46-7.38(\mathrm{~m}, 3 \mathrm{H}, \mathrm{ArH}), 7.38-7.27(\mathrm{~m}, 3 \mathrm{H}, \operatorname{ArH})$, $7.15(\mathrm{td}, J=7.7,1.7 \mathrm{~Hz}, 1 \mathrm{H}, \mathrm{ArH}), 6.88(\mathrm{~d}, J=16.0 \mathrm{~Hz}, 1 \mathrm{H}, \mathrm{CHCHPh}), 6.43(\mathrm{dd}, J=16.0,7.9 \mathrm{~Hz}, 1 \mathrm{H}$, CHCHPh), 6.12 (dd, $J=7.9,0.9 \mathrm{~Hz}, 1 \mathrm{H}, \mathrm{OCHCC}), 3.59-3.30\left(\mathrm{~m}, 4 \mathrm{H}, \mathrm{N}\left(\mathrm{CH}_{2} \mathrm{CH}_{3}\right)_{2}\right), 1.31(\mathrm{t}, J=7.2 \mathrm{~Hz}, 3 \mathrm{H}$, $\left.\mathrm{N}\left(\mathrm{CH}_{2} \mathrm{CH}_{3}\right)_{2}\right), 1.17\left(\mathrm{t}, \mathrm{J}=7.1 \mathrm{~Hz}, 3 \mathrm{H}, \mathrm{N}\left(\mathrm{CH}_{2} \mathrm{CH}_{3}\right)_{2}\right) ;{ }^{13} \mathrm{C} \mathrm{NMR}\left(101 \mathrm{MHz}, \mathrm{CDCl}_{3}\right) \delta 166.9,166.1,141.3,136.9$, 135.7, 134.5, 133.0, 132.1, 128.9 (2 C), 128.1, 127.1, 122.0, 94.4, 72.9, 41.9, 41.0, 14.5, 13.0; IR ( $v_{\max }$, $\left.\mathrm{cm}^{-1}\right) 3063(\mathrm{w}), 3026(\mathrm{w}), 2946(\mathrm{w}), 1736(\mathrm{~s}), 1585(\mathrm{~m}), 1427(\mathrm{w}), 1290(\mathrm{~m}), 1239(\mathrm{~s}), 1188(\mathrm{~s}), 1133(\mathrm{~s})$, $1096(\mathrm{~s}), 1043(\mathrm{~m}), 1014(\mathrm{~s}), 963(\mathrm{~s}), 937(\mathrm{~m}), 742(\mathrm{~s}), 689$ (s); HRMS (ESI) calcd for $\mathrm{C}_{21} \mathrm{H}_{22} \mathrm{INNaO}_{3}{ }^{+}$ $[\mathrm{M}+\mathrm{Na}]^{+}$486.0537; found 486.0535 .

\section{(E)-1-(Methoxy(methyl)amino)-1-oxo-4-phenylbut-3-en-2-yl 2-iodobenzoate (5g)}<smiles>CON(C)C(=O)C(/C=C/c1ccccc1)OC(=O)c1ccccc1I</smiles>

Following general procedure $D$, starting from $(E)$-1-styryl-1 $\lambda^{3}$-benzo[d][1,2]iodaoxol-3(1H)-one (1a) (70.0 $\mathrm{mg}, 0.200 \mathrm{mmol}$ ) and 2-diazo- $\mathrm{N}$-methoxy- $\mathrm{N}$-methylacetamide $(2 \mathrm{~h})(51.6 \mathrm{mg}, 0.400 \mathrm{mmol})$, afforded (E)-1-(methoxy(methyl)amino)-1-oxo-4-phenylbut-3-en-2-yl 2-iodobenzoate (5g) as a white solid (89 mg, $0.20 \mathrm{mmol}, 99 \%$ ). $\mathrm{R}_{\mathrm{f}}=0.27$ (EtOAc/pentane 20:80); M.p. 90-92 ${ }^{\circ} \mathrm{C}$; ${ }^{1} \mathrm{H} \mathrm{NMR}(400 \mathrm{MHz}$, $\left.\mathrm{CDCl}_{3}\right) \delta 8.05(\mathrm{dd}, J=7.8,1.7 \mathrm{~Hz}, 1 \mathrm{H}, \mathrm{ArH}), 8.00(\mathrm{dd}, J=7.9,1.1 \mathrm{~Hz}, 1 \mathrm{H}, \operatorname{ArH}), 7.45-7.40(\mathrm{~m}, 3 \mathrm{H}, \operatorname{Ar} H)$, $7.37-7.26(\mathrm{~m}, 3 \mathrm{H}, \mathrm{ArH}), 7.17(\mathrm{td}, J=7.7,1.7 \mathrm{~Hz}, 1 \mathrm{H}, \mathrm{ArH}), 6.93(\mathrm{~d}, J=15.9 \mathrm{~Hz}, 1 \mathrm{H}, \mathrm{CHCHPh}), 6.41$ (dd, $J=15.9,7.5 \mathrm{~Hz}, 1 \mathrm{H}, \mathrm{CHCHPh}), 6.27(\mathrm{~d}, J=7.5 \mathrm{~Hz}, 1 \mathrm{H}, \mathrm{OCHCC}), 3.87\left(\mathrm{~s}, 3 \mathrm{H}, \mathrm{OCH}_{3}\right), 3.27\left(\mathrm{~s}, 3 \mathrm{H}, \mathrm{NCH}_{3}\right) ;{ }^{13} \mathrm{C}$ $\operatorname{NMR}\left(101 \mathrm{MHz}, \mathrm{CDCl}_{3}\right) \delta 168.4,166.0,141.4,136.0,136.0,134.4,133.1,132.0,128.8,128.7,128.1$, 127.0, 121.0, 94.4, 72.9, 61.7, 32.5; IR ( $\left.v_{\max }, \mathrm{cm}^{-1}\right) 3055(\mathrm{w}), 3020(\mathrm{w}), 2973(\mathrm{w}), 2942(\mathrm{w}), 1728(\mathrm{~s})$, $1681(\mathrm{~s}), 1466(\mathrm{~m}), 1431(\mathrm{~m}), 1284(\mathrm{~m}), 1251$ (s), 1133 (s), 1102 (s), $1016(\mathrm{~m}), 969$ (s), 738 (s); HRMS (ESI) calcd for $\mathrm{C}_{19} \mathrm{H}_{18} \mathrm{INNaO}_{4}{ }^{+}[\mathrm{M}+\mathrm{Na}]^{+}$474.0173; found 474.0175 .

\section{(E)-1-(Ethoxysulfonyl)-3-phenylallyl 2-iodobenzoate (5h)}<smiles>CCOS(=O)(=O)C(/C=C/c1ccccc1)OC(=O)c1ccccc1I</smiles>

Following general procedure $D$, starting from $(E)$-1-styryl- $1 \lambda^{3}$-benzo[d] $[1,2]$ iodaoxol-3(1H)-one (1a) $(70.0 \mathrm{mg}, 0.200 \mathrm{mmol})$ and ethyl diazomethanesulfonate (2i) $(60.1 \mathrm{mg}, 0.400 \mathrm{mmol})$, afforded $(E)-1-$ (ethoxysulfonyl)-3-phenylallyl 2-iodobenzoate $\left(5 \mathrm{~h}\right.$ ) as a colorless oil $(96 \mathrm{mg}, 0.20 \mathrm{mmol}, 100 \%)$. $\mathrm{R}_{\mathrm{f}}=$ 0.12 (EtOAc/pentane 5:95); ${ }^{1} \mathrm{H} \mathrm{NMR}\left(400 \mathrm{MHz}, \mathrm{CDCl}_{3}\right) \delta 8.07$ (dd, $\left.J=8.0,1.2 \mathrm{~Hz}, 1 \mathrm{H}, \mathrm{ArH}\right), 8.01$ (dd, $J=$ 7.8, $1.7 \mathrm{~Hz}, 1 \mathrm{H}, \mathrm{ArH}), 7.51$ - $7.44(\mathrm{~m}, 3 \mathrm{H}, \mathrm{ArH}), 7.40$ - $7.30(\mathrm{~m}, 3 \mathrm{H}, \mathrm{ArH}), 7.27$ - $7.21(\mathrm{~m}, 1 \mathrm{H}, \mathrm{ArH}), 7.12$ $7.03(\mathrm{~m}, 1 \mathrm{H}, \mathrm{CHCHPh}), 6.70$ (dd, $J=7.5,1.1 \mathrm{~Hz}, 1 \mathrm{H}, \mathrm{OCHCC}), 6.40$ (dd, $J=15.9,7.5 \mathrm{~Hz}, 1 \mathrm{H}, \mathrm{CHCHPh}$ ), $4.43\left(\mathrm{q}, J=7.1 \mathrm{~Hz}, 2 \mathrm{H}, \mathrm{OCH}_{2} \mathrm{CH}_{3}\right), 1.40\left(\mathrm{t}, J=7.1 \mathrm{~Hz}, 3 \mathrm{H}, \mathrm{OCH}_{2} \mathrm{CH}_{3}\right) ;{ }^{13} \mathrm{C} \mathrm{NMR}\left(101 \mathrm{MHz}, \mathrm{CDCl}_{3}\right) \delta 163.6$, $142.1,140.0,134.8,134.0,132.6,132.0,129.6,129.0,128.4,127.4,116.0,95.1,84.169 .8,15.5$; IR $\left(v_{\max }, \mathrm{cm}^{-1}\right) 2975(\mathrm{w}), 2924(\mathrm{w}), 1742(\mathrm{~m}), 1675(\mathrm{~s}), 1624(\mathrm{~m}), 1581(\mathrm{~m}), 1364(\mathrm{~m}), 1291(\mathrm{~m}), 1237(\mathrm{~s})$, 1174 (s), 1129 (s), 1088 (s), 1015 (s), 968 (s), 919 (s), 739 (s), 688 (s); HRMS (ESI) calcd for $\mathrm{C}_{18} \mathrm{H}_{17} \mathrm{NaOO}_{5} \mathrm{~S}^{+}$ $[\mathrm{M}+\mathrm{Na}]^{+}$494.9734; found 494.9730 . 
<smiles>CCOP(=O)(OCC)C(/C=C/c1ccccc1)OC(=O)c1ccccc1I</smiles>

Following general procedure $\mathrm{D}$, starting from $(E)$-1-styryl-1 $\lambda^{3}$-benzo[d] $[1,2]$ iodaoxol-3(1H)-one (1a) $(70.0 \mathrm{mg}, 0.200 \mathrm{mmol}$ ) and diethyl (diazomethyl)phosphonate $(\mathbf{2 j})(71.3 \mathrm{mg}, 0.400 \mathrm{mmol})$, afforded (E)-1-(diethoxyphosphoryl)-3-phenylallyl 2-iodobenzoate (5i) as a colorless oil $(97 \mathrm{mg}, 0.19 \mathrm{mmol}$, 97\%). $R_{f}=0.28$ (EtOAc/pentane 50:50); ${ }^{1} \mathrm{H} \mathrm{NMR}\left(400 \mathrm{MHz}, \mathrm{CDCl}_{3}\right) \delta 8.03$ (dd, J = 7.9, $\left.1.2 \mathrm{~Hz}, 1 \mathrm{H}, \mathrm{ArH}\right)$, $7.93(\mathrm{dd}, J=7.8,1.7 \mathrm{~Hz}, 1 \mathrm{H}, \mathrm{ArH}), 7.47-7.40(\mathrm{~m}, 3 \mathrm{H}, \mathrm{ArH}), 7.36-7.27(\mathrm{~m}, 3 \mathrm{H}, \mathrm{ArH}), 7.22-7.16(\mathrm{~m}, 1 \mathrm{H}$, $\operatorname{ArH}), 6.91-6.83(\mathrm{~m}, 1 \mathrm{H}, \mathrm{CHCHPh}), 6.37$ (ddd, $J=15.9,7.6,5.8 \mathrm{~Hz}, 1 \mathrm{H}, \mathrm{CHCHPh}), 6.09$ (ddd, $J=13.5$, 7.6, $1.3 \mathrm{~Hz}, 1 \mathrm{H}, \mathrm{OCHCC}), 4.27$ - $4.16\left(\mathrm{~m}, 4 \mathrm{H},(\mathrm{O}) \mathrm{P}\left(\mathrm{OCH}_{2} \mathrm{CH}_{3}\right)_{2}\right), 1.33\left(\mathrm{t}, J=7.1 \mathrm{~Hz}, 6 \mathrm{H},(\mathrm{O}) \mathrm{P}\left(\mathrm{OCH}_{2} \mathrm{CH}_{3}\right)_{2}\right)$; ${ }^{13} \mathrm{C} \mathrm{NMR}\left(101 \mathrm{MHz}, \mathrm{CDCl}_{3}\right) \delta 164.9(\mathrm{~d}, J=7.9 \mathrm{~Hz}), 141.7,136.0,135.9(\mathrm{~d}, J=3.1 \mathrm{~Hz}), 134.1,133.3,131.5$, 128.8, 128.6, 128.2, 127.0, 120.0 (d, $J=4.5 \mathrm{~Hz}), 94.7,70.6$ (d, $J=170.7 \mathrm{~Hz}), 63.6$ (dd, $J=9.0,6.8 \mathrm{~Hz})$, $16.7(\mathrm{t}, J=5.8 \mathrm{~Hz}) ;{ }^{31} \mathrm{P}$ NMR $\left(162 \mathrm{MHz}, \mathrm{CDCl}_{3}\right) \delta$ 17.4; IR ( $\left.\mathrm{v}_{\max }, \mathrm{cm}^{-1}\right) 3057(\mathrm{w}), 2981(\mathrm{w}), 2930(\mathrm{w}), 2901$ $(\mathrm{w}), 1734(\mathrm{~m}), 1288(\mathrm{~m}), 1241(\mathrm{~s}), 1131(\mathrm{~m}), 1096(\mathrm{~m}), 1014(\mathrm{~s}), 967(\mathrm{~s}), 793(\mathrm{~m}), 738(\mathrm{~s}), 691(\mathrm{~m})$; HRMS (ESI) calcd for $\mathrm{C}_{20} \mathrm{H}_{22} \mathrm{INaO}_{5} \mathrm{P}^{+}[\mathrm{M}+\mathrm{Na}]^{+}$523.0142; found 523.0154 .

\section{(E)-1,1,1-Trifluoro-4-phenylbut-3-en-2-yl 2-iodobenzoate (5I)}<smiles>O=C(OC(/C=C/c1ccccc1)C(F)(F)F)c1ccccc1I</smiles>

Following general procedure $D$, starting from $(E)$-1-styryl-1 $\lambda^{3}$-benzo[d] $[1,2]$ iodaoxol-3(1H)-one (1a) (70.0 mg, $0.200 \mathrm{mmol}$ ) and 2-diazo-1,1,1-trifluoroethane (2k) (1.08 mL, $0.37 \mathrm{M}$ in DCM, $0.400 \mathrm{mmol}$ ), afforded (E)-1,1,1-trifluoro-4-phenylbut-3-en-2-yl 2-iodobenzoate (5I) as a colorless oil (88 $\mathrm{mg}, 0.20$ $\mathrm{mmol}, 100 \%) . \mathrm{R}_{\mathrm{f}}=0.52$ (EtOAc/pentane 5:95); ${ }^{1} \mathrm{H} \mathrm{NMR}\left(400 \mathrm{MHz}, \mathrm{CDCl}_{3}\right) \delta 8.05$ (dd, $J=8.0,1.2 \mathrm{~Hz}, 1 \mathrm{H}$, $\operatorname{ArH}), 7.93(\mathrm{dd}, J=7.8,1.7 \mathrm{~Hz}, 1 \mathrm{H}, \mathrm{ArH}), 7.45(\mathrm{dtd}, J=7.7,4.1,1.9 \mathrm{~Hz}, 3 \mathrm{H}, \mathrm{ArH}), 7.40-7.29(\mathrm{~m}, 3 \mathrm{H}, \operatorname{ArH})$, $7.21(\mathrm{td}, J=7.7,1.7 \mathrm{~Hz}, 1 \mathrm{H}, \mathrm{ArH}), 7.00(\mathrm{~d}, J=15.9 \mathrm{~Hz}, 1 \mathrm{H}, \mathrm{CHCHPh}), 6.24(\mathrm{dd}, J=15.9,7.9 \mathrm{~Hz}, 1 \mathrm{H}$, CHCHPh), 6.12 - $6.02(\mathrm{~m}, 1 \mathrm{H}, \mathrm{OCHCC}) ;{ }^{13} \mathrm{C} \mathrm{NMR}\left(101 \mathrm{MHz}, \mathrm{CDCl}_{3}\right) \delta 164.2,141.9,139.6,135.1,133.6$, 133.3, 131.6, 129.3, 128.9, 128.2, 127.2, 123.3 (q, $J=280.6 \mathrm{~Hz}$ ), 117.0 (d, $J=1.7 \mathrm{~Hz}$ ), 94.8, 72.4 (q, $J=$ $33.8 \mathrm{~Hz}) ;{ }^{19} \mathrm{~F} \mathrm{NMR}\left(376 \mathrm{MHz}, \mathrm{CDCl}_{3}\right) \delta$-75.9; HRMS (ESI) calcd for $\mathrm{C}_{17} \mathrm{H}_{12} \mathrm{~F}_{3} \mathrm{IO}_{2}\left[\mathrm{M}^{+}\right]$431.9829; found 431.9846 .

(E)-1-Ethoxy-2-methyl-1-oxo-4-phenylbut-3-en-2-yl 2-iodobenzoate (5m)<smiles>CCOC(=O)C(C)(C=Cc1ccccc1)OC(=O)c1ccccc1I</smiles>

Following general procedure $E$, starting from $(E)$-1-styryl-1 $\lambda^{3}$-benzo[d][1,2]iodaoxol-3(1H)-one (1a) (70.0 mg, $0.200 \mathrm{mmol}$ ) and ethyl 2-diazopropanoate (2I) $(51.3 \mathrm{mg}, 0.400 \mathrm{mmol})$, afforded (E)-1-ethoxy2-methyl-1-oxo-4-phenylbut-3-en-2-yl 2-iodobenzoate $(5 \mathrm{~m})$ as a colorless oil ( $80 \mathrm{mg}, 0.18 \mathrm{mmol}, 89 \%)$. $\mathrm{R}_{\mathrm{f}}=0.26$ (EtOAc/pentane 5:95); ${ }^{1} \mathrm{H}$ NMR $\left(400 \mathrm{MHz}, \mathrm{CDCl}_{3}\right) \delta 7.99$ (dd, J = 8.0, $\left.1.2 \mathrm{~Hz}, 1 \mathrm{H}, \mathrm{ArH}\right), 7.85$ (dd, $J=7.8,1.7 \mathrm{~Hz}, 1 \mathrm{H}, \mathrm{ArH}), 7.45-7.39(\mathrm{~m}, 3 \mathrm{H}, \mathrm{ArH}), 7.35-7.29(\mathrm{~m}, 2 \mathrm{H}, \mathrm{ArH}), 7.28-7.23(\mathrm{~m}, 1 \mathrm{H}, \mathrm{ArH}), 7.16$ (ddd, $J=8.0,7.4,1.7 \mathrm{~Hz}, 1 \mathrm{H}, \mathrm{ArH}), 6.80(\mathrm{~d}, J=16.3 \mathrm{~Hz}, 1 \mathrm{H}, \mathrm{CHCHPh}), 6.62(\mathrm{~d}, J=16.2 \mathrm{~Hz}, 1 \mathrm{H}, \mathrm{CHCHPh}$ ), $4.27\left(\mathrm{qd}, J=7.1,2.6 \mathrm{~Hz}, 2 \mathrm{H}, \mathrm{OCH}_{2} \mathrm{CH}_{3}\right), 1.92\left(\mathrm{~s}, 3 \mathrm{H}, \mathrm{CCH}_{3}\right), 1.29\left(\mathrm{t}, J=7.1 \mathrm{~Hz}, 3 \mathrm{H}, \mathrm{OCH}_{2} \mathrm{CH}_{3}\right) ;{ }^{13} \mathrm{C} \mathrm{NMR}$ $\left(101 \mathrm{MHz}, \mathrm{CDCl}_{3}\right) \delta 170.7,165.4,141.4,136.1,135.3,132.9,131.4,131.2,128.8,128.4,128.1,127.8$, 
126.9, 94.0, 81.4, 62.1, 23.2, 14.2; IR $\left(v_{\max }, \mathrm{cm}^{-1}\right) 2963(\mathrm{w}), 2920(\mathrm{~m}), 2856(\mathrm{w}), 1744(\mathrm{~m}), 1345(\mathrm{w})$, $1274(\mathrm{~m}), 1241(\mathrm{~s}), 1180(\mathrm{~s}), 1131(\mathrm{~s}), 1092(\mathrm{~s}), 1043(\mathrm{~m}), 1016(\mathrm{~s}), 965(\mathrm{~m}), 914(\mathrm{~m}), 736(\mathrm{~s}), 691(\mathrm{~s})$; HRMS (ESI) calcd for $\mathrm{C}_{20} \mathrm{H}_{19} \mathrm{INaO}_{4}{ }^{+}[\mathrm{M}+\mathrm{Na}]^{+}$473.0220; found 473.0213 .

\section{(E)-2-0xo-3-styryltetrahydrofuran-3-yl 2-iodobenzoate (50)}

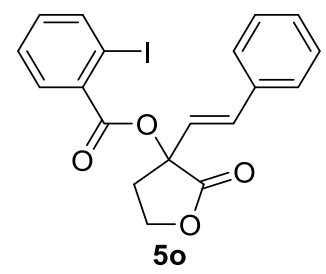

Following general procedure $E$, starting from $(E)$-1-styryl-1 $\lambda^{3}$-benzo[d][1,2]iodaoxol-3(1H)-one (1a) $(70.0 \mathrm{mg}, 0.200 \mathrm{mmol})$ and 3-diazodihydrofuran-2(3H)-one $(2 \mathrm{~m})(44.8 \mathrm{mg}, 0.400 \mathrm{mmol})$, afforded $(E)$ 2-oxo-3-styryltetrahydrofuran-3-yl 2-iodobenzoate (5o) as a thick colorless oil $(78 \mathrm{mg}, 0.18 \mathrm{mmol}$, 90\%). $R_{\mathrm{f}}=0.31$ (EtOAc/pentane 20:80); ${ }^{1} \mathrm{H} \mathrm{NMR}\left(400 \mathrm{MHz}, \mathrm{CDCl}_{3}\right) \delta 8.00(\mathrm{dd}, J=7.9,1.1 \mathrm{~Hz}, 1 \mathrm{H}, \operatorname{Ar} H)$, $7.91(\mathrm{dd}, J=7.8,1.7 \mathrm{~Hz}, 1 \mathrm{H}, \mathrm{ArH}), 7.50-7.39(\mathrm{~m}, 3 \mathrm{H}, \mathrm{ArH}), 7.39-7.28(\mathrm{~m}, 3 \mathrm{H}, \mathrm{ArH}), 7.18(\mathrm{td}, J=7.7$, $1.7 \mathrm{~Hz}, 1 \mathrm{H}, \mathrm{ArH}), 6.95(\mathrm{~d}, J=16.2 \mathrm{~Hz}, 1 \mathrm{H}, \mathrm{CHCHPh}), 6.48(\mathrm{~d}, J=16.2 \mathrm{~Hz}, 1 \mathrm{H}, \mathrm{CHCHPh}), 4.65$ (td, $J=9.2$, $2.4 \mathrm{~Hz}, 1 \mathrm{H}, \mathrm{OCH}_{2}{ }^{1}$ ), $4.36\left(\mathrm{td}, J=9.4,7.0 \mathrm{~Hz}, 1 \mathrm{H}, \mathrm{OCH}_{2}{ }^{2}\right.$ ), $3.10\left(\mathrm{dt}, J=13.4,9.4 \mathrm{~Hz}, 1 \mathrm{H}, \mathrm{CCH}_{2}{ }^{1}\right.$ ), 2.90 (ddd, $\left.J=13.4,7.0,2.5 \mathrm{~Hz}, 1 \mathrm{H}, \mathrm{CCH}_{2}{ }^{2}\right) ;{ }^{13} \mathrm{C}$ NMR $\left(101 \mathrm{MHz}, \mathrm{CDCl}_{3}\right) \delta 172.5,165.2,141.6,135.1,134.6,133.9$, 133.4, 131.6, 129.1, 128.9, 128.2, 127.2, 123.1, 94.3, 80.4, 65.0, 33.4; IR $\left(v_{\max }, \mathrm{cm}^{-1}\right) 2974(\mathrm{~m}), 2900$ $(\mathrm{m}), 1735(\mathrm{~s}), 1495(\mathrm{~m}), 1449(\mathrm{~m}), 1431(\mathrm{~m}), 1276(\mathrm{~s}), 1256(\mathrm{~s}), 1092(\mathrm{~s}), 1127(\mathrm{~m}), 1042(\mathrm{~s}), 1016(\mathrm{~s})$, $974(\mathrm{~m}), 764$ (s), 750 (s); HRMS (ESI) calcd for $\mathrm{C}_{19} \mathrm{H}_{15} \mathrm{INaO}_{4}{ }^{+}[\mathrm{M}+\mathrm{Na}]^{+}$456.9907; found 456.9906.

\section{(3E,5E)-4-(Methoxycarbonyl)-6-phenylhexa-3,5-dien-2-yl 2-iodobenzoate (5p)}<smiles>CC(=O)/C=C/c1ccccc1/C=C/C(C)OC(=O)c1ccccc1I</smiles>

Following general procedure $E$, starting from $(E)$-1-styryl-1 $\lambda^{3}$-benzo[d][1,2]iodaoxol-3(1H)-one (1a) $(70.0 \mathrm{mg}, 0.200 \mathrm{mmol})$ and $(E)$-methyl 2-diazopent-3-enoate $(2 \mathrm{n})(0.400 \mathrm{~mL}, 1.0 \mathrm{M}$ in pentane, 0.400 $\mathrm{mmol})$, afforded (3E,5E)-4-(methoxycarbonyl)-6-phenylhexa-3,5-dien-2-yl 2-iodobenzoate (5p) as a colorless oil ( $58 \mathrm{mg}, 0.13 \mathrm{mmol}, 63 \%) . \mathrm{R}_{\mathrm{f}}=0.22$ (EtOAc/pentane $\left.5: 95\right) ;{ }^{1} \mathrm{H} \mathrm{NMR}\left(400 \mathrm{MHz}, \mathrm{CDCl}_{3}\right) \delta 7.99$ (dd, $J=8.0,1.2 \mathrm{~Hz}, 1 \mathrm{H}, \mathrm{ArH}), 7.79(\mathrm{dd}, J=7.8,1.7 \mathrm{~Hz}, 1 \mathrm{H}, \mathrm{ArH}), 7.53-7.46(\mathrm{~m}, 2 \mathrm{H}, \mathrm{ArH}), 7.43-7.31(\mathrm{~m}$, $3 \mathrm{H}, \operatorname{ArH}), 7.31-7.27(\mathrm{~m}, 1 \mathrm{H}, \mathrm{ArH}), 7.15(\mathrm{td}, J=7.7,1.7 \mathrm{~Hz}, 1 \mathrm{H}, \mathrm{ArH}), 7.09(\mathrm{~d}, J=16.3 \mathrm{~Hz}, 1 \mathrm{H}, \mathrm{CHCHPh})$, $6.97(\mathrm{~d}, J=16.0 \mathrm{~Hz}, 1 \mathrm{H}, \mathrm{CHCHPh}), 6.71\left(\mathrm{~d}, J=8.7 \mathrm{~Hz}, 1 \mathrm{H}, \mathrm{CH}_{3} \mathrm{CHCH}\right), 6.15(\mathrm{dq}, J=8.3,6.5 \mathrm{~Hz}, 1 \mathrm{H}$, $\left.\mathrm{OCHCH}_{3}\right), 3.83\left(\mathrm{~s}, 3 \mathrm{H}, \mathrm{OCH}_{3}\right), 1.59\left(\mathrm{~d}, J=6.5 \mathrm{~Hz}, 3 \mathrm{H}, \mathrm{OCHCH}_{3}\right) ;{ }^{13} \mathrm{C} \mathrm{NMR}\left(101 \mathrm{MHz}, \mathrm{CDCl}_{3}\right) \delta 167.3,165.9$, $141.5,139.3,136.9,135.7,135.2,132.8,131.7,131.1,128.8,128.5,128.1,127.1,120.2,94.2,68.9$, 52.4, 20.5; IR ( $\left(\mathrm{v}_{\max }, \mathrm{cm}^{-1}\right) 2948(\mathrm{w}), 2995(\mathrm{w}), 2844(\mathrm{w}), 1789(\mathrm{w}), 1718(\mathrm{~s}), 1583(\mathrm{~m}), 1436(\mathrm{~m}), 1282$ (m), 1241 (s), 1156 (m), 1129 (s), 1098 (s), 1039 (s), 1015 (s), 968 (m), 739 (s), 694 (s); HRMS (ESI) calcd for $\mathrm{C}_{21} \mathrm{H}_{19} \mathrm{INaO}_{4}{ }^{+}[\mathrm{M}+\mathrm{Na}]^{+}$485.0220; found 485.0219. 


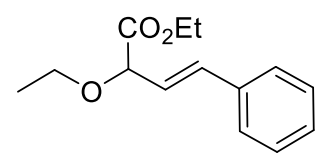

6b

Following general procedure $F$, starting from ethanol $(7 \mathrm{a})(52.5 \mu \mathrm{L}, 0.900 \mathrm{mmol}),(E)-1$-styryl-3,3bis(trifluoromethyl)-1,3-dihydro-1 $\lambda^{3}$-benzo[d][1,2]iodaoxole (1'a) (142 $\mathrm{mg}, 0.300 \mathrm{mmol}$ ) and ethyl 2diazoacetate (2a) $(1.0 \mathrm{~mL}, 0.60 \mathrm{mmol}, 0.6 \mathrm{M}$ in $D C M)$, afforded $(E)$-ethyl 2-ethoxy-4-phenylbut-3enoate (6b) as a colorless oil $(28 \mathrm{mg}, 0.12 \mathrm{mmol}, 40 \%) . \mathrm{R}_{\mathrm{f}}=0.26$ (EtOAc/pentane 3:97), $p$-anisaldehyde; ${ }^{1} \mathrm{H} \mathrm{NMR}\left(400 \mathrm{MHz}, \mathrm{CDCl}_{3}\right) \delta 7.43-7.37(\mathrm{~m}, 2 \mathrm{H}, \mathrm{ArH}), 7.35-7.29(\mathrm{~m}, 2 \mathrm{H}, \mathrm{ArH}), 7.29-7.23(\mathrm{~m}, 1 \mathrm{H}, \mathrm{Ar} H)$, $6.77(\mathrm{dd}, J=16.0,1.3 \mathrm{~Hz}, 1 \mathrm{H}, \mathrm{HC}=\mathrm{CHPh}), 6.23(\mathrm{dd}, J=15.9,6.8 \mathrm{~Hz}, 1 \mathrm{H}, H \mathrm{HC}=\mathrm{CHPh}), 4.51(\mathrm{dd}, J=6.8,1.4$ $\mathrm{Hz}, 1 \mathrm{H}, \mathrm{OCHC}), 4.31-4.18\left(\mathrm{~m}, 2 \mathrm{H}, \mathrm{C}(\mathrm{O}) \mathrm{OCH}_{2} \mathrm{CH}_{3}\right), 3.61$ (qq, J = 9.1, 7.0 Hz, $\left.2 \mathrm{H}, \mathrm{OCH}_{2} \mathrm{CH}_{3}\right), 1.30(\mathrm{t}, J=$ $\left.7.1 \mathrm{~Hz}, 6 \mathrm{H}, 2 \times \mathrm{OCH}_{2} \mathrm{CH}_{3}\right) ;{ }^{13} \mathrm{C} \mathrm{NMR}\left(101 \mathrm{MHz}, \mathrm{CDCl}_{3}\right) \delta 171.1,136.2,134.0,128.7,128.3,126.9,124.3$, 79.9, 65.5, 61.4, 15.3, 14.4; IR $\left(v_{\max }, \mathrm{cm}^{-1}\right) 2980(\mathrm{~m}), 2937(\mathrm{w}), 1738(\mathrm{~s}), 1636(\mathrm{~m}), 1451(\mathrm{~m}), 1371(\mathrm{~m})$, 1313 (s), 1268 (s), 1189 (s), 1159 (s), 1091 (s), 1023 (s), 699 (s); HRMS (ESI) calcd for $\mathrm{C}_{14} \mathrm{H}_{18} \mathrm{NaO}_{3}{ }^{+}$ $[\mathrm{M}+\mathrm{Na}]^{+}$257.1148; found 257.1146 .

\section{(E)-Furan-2-ylmethyl 2-adamantan-1-yloxy)-4-cyclohexylbut-3-enoate (6c)}

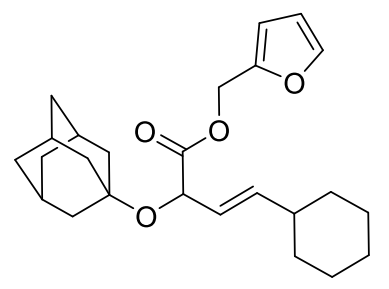

$6 c$

Following general procedure $\mathrm{F}$, starting from 1-adamantanol (7b) $(161 \mathrm{mg}, 0.90 \mathrm{mmol}),(E)-1-(2-$ cyclohexylvinyl)-3,3-bis(trifluoromethyl)-1,3-dihydro-1 $\lambda^{3}$-benzobenzo[d][1,2]iodaoxole (1'j) (143 mg, $0.300 \mathrm{mmol}$ ) and furan-2-ylmethyl 2-diazoacetate (2o) $(1.0 \mathrm{~mL}, 0.60 \mathrm{mmol}, 0.6 \mathrm{M}$ in DCM), afforded (E)-furan-2-ylmethyl 2-adamantan-1-yloxy)-4-cyclohexylbut-3-enoate (6c) as a colorless oil $(47 \mathrm{mg}$, $0.12 \mathrm{mmol}, 39 \%) . \mathrm{R}_{\mathrm{f}}=0.21$ (EtOAc/pentane 2:98), $p$-anisaldehyde; ${ }^{1} \mathrm{H} \mathrm{NMR}\left(400 \mathrm{MHz}, \mathrm{CDCl}_{3}\right) \delta 7.41-$ $7.38(\mathrm{~m}, 1 \mathrm{H}, \mathrm{ArH}), 6.40(\mathrm{~d}, J=3.2 \mathrm{~Hz}, 1 \mathrm{H}, \operatorname{ArH}), 6.34$ (dd, $J=3.3,1.8 \mathrm{~Hz}, 1 \mathrm{H}, \operatorname{ArH}), 5.72$ (ddd, $J=15.6$, 6.6, 1.4 Hz, $1 \mathrm{H}, \mathrm{HC}=\mathrm{CH}-\mathrm{cHex}$ ), 5.43 (ddd, $J=15.6,5.9,1.4 \mathrm{~Hz}, 1 \mathrm{H}, \mathrm{HC}=\mathrm{CH}-\mathrm{cHex}), 5.12$ (q, J=13.1 Hz, $2 \mathrm{H}$, $\mathrm{CH}_{2} \mathrm{Ar}$ ), 4.65 (dt, $\left.J=5.9,1.1 \mathrm{~Hz}, 1 \mathrm{H}, \mathrm{OCHC}\right), 2.10$ (p, $J=3.3 \mathrm{~Hz}, 3 \mathrm{H}, \mathrm{CH}$-aliphatic), 1.93 (dtd, $J=11.1,7.4,3.2$ $\mathrm{Hz}, 1 \mathrm{H}, \mathrm{CH}$-aliphatic), $1.80-1.50\left(\mathrm{~m}, 17 \mathrm{H}, \mathrm{CH}\right.$-aliphatic), $1.33-0.95\left(\mathrm{~m}, 5 \mathrm{H}, \mathrm{CH}\right.$-aliphatic); ${ }^{13} \mathrm{C} \mathrm{NMR}(101 \mathrm{MHz}$, $\left.\mathrm{CDCl}_{3}\right)$ $\delta 173.0,149.5,143.2,139.8,124.1,111.0,110.7,74.7,70.8,58.3,41.8,40.4,36.4,32.6,32.5$, 30.7, 26.3, 26.1; IR ( $\left.v_{\max } \mathrm{cm}^{-1}\right) 3669(\mathrm{w}), 2972(\mathrm{~s}), 2908(\mathrm{~s}), 2851(\mathrm{~m}), 1755(\mathrm{~m}), 1734(\mathrm{~m}), 1450(\mathrm{~m})$, $1250(\mathrm{~m}), 1153(\mathrm{~m}), 1104(\mathrm{~m}), 1078(\mathrm{~s}), 966(\mathrm{~m}), 739(\mathrm{~m})$; HRMS (ESI/QTOF) m/z: [M+H] ${ }^{+}$Calcd for $\mathrm{C}_{25} \mathrm{H}_{35} \mathrm{O}_{4}{ }^{+}$399.2530; Found 399.2536.

(E)-Diethyl (1-ethoxyhex-2-en-1-yl)phosphonate (6d)<smiles>CCC/C=C/C(OCC)P(=O)(OCC)OCC</smiles>

Following general procedure $F$, starting from ethanol (7a) $(52.5 \mu \mathrm{L}, 0.900 \mathrm{mmol}),(E)-1$-(pent-1-en-1yl)-3,3-bis(trifluoromethyl)-1,3-dihydro-1 $\lambda^{3}$-benzobenzo[d][1,2]iodaoxole (1'I) (131 mg, $\left.0.300 \mathrm{mmol}\right)$ and diethyl (diazomethyl)phosphonate $(2 \mathrm{j})(1.0 \mathrm{~mL}, 0.60 \mathrm{mmol}, 0.6 \mathrm{M}$ in DCM), afforded (E)-diethyl (1- 
ethoxyhex-2-en-1-yl)phosphonate $(\mathbf{6 d})$ as a colorless oil (18 $\mathrm{mg}, 70 \mu \mathrm{mol}, 23 \%) . R_{f}=0.22$ (EtOAc/pentane 50:50), $p$-anisaldehyde; ${ }^{1} \mathrm{H}$ NMR $\left(400 \mathrm{MHz}, \mathrm{CDCl}_{3}\right) \delta 5.87-5.75(\mathrm{~m}, 1 \mathrm{H}, \mathrm{HC}=\mathrm{CH}-n \mathrm{Pr})$, 5.49 (dddt, $J=15.5,7.8,4.8,1.5 \mathrm{~Hz}, 1 \mathrm{H}, \mathrm{HC}=\mathrm{CH}-n \mathrm{Pr}$ ), $4.22-4.11\left(\mathrm{~m}, 4 \mathrm{H}, 2 \times \mathrm{P}(\mathrm{O}) \mathrm{OCH}_{2} \mathrm{CH}_{3}\right), 4.05$ (ddd, $J=14.7,7.8,1.0 \mathrm{~Hz}, 1 \mathrm{H}, \mathrm{OCHC}), 3.66\left(\mathrm{dq}, J=9.3,7.0 \mathrm{~Hz}, 1 \mathrm{H}, \mathrm{OCH}_{2} \mathrm{CH}_{3}\right), 3.49$ (dq $J=9.3,6.9 \mathrm{~Hz}, 1 \mathrm{H}$, $\left.\mathrm{OCH}_{2} \mathrm{CH}_{3}\right), 2.13-2.02\left(\mathrm{~m}, 2 \mathrm{H}, \mathrm{CH}_{2} \mathrm{CH}_{2} \mathrm{CH}_{3}\right), 1.43\left(\mathrm{~h}, J=7.3 \mathrm{~Hz}, 2 \mathrm{H}, \mathrm{CH}_{2} \mathrm{CH}_{2} \mathrm{CH}_{3}\right), 1.32$ (td, J = 7.1, $1.2 \mathrm{~Hz}$, $\left.6 \mathrm{H}, 2 \times \mathrm{P}(\mathrm{O}) \mathrm{OCH}_{2} \mathrm{CH}_{3}\right), 1.21\left(\mathrm{t}, J=7.0 \mathrm{~Hz}, 3 \mathrm{H}, \mathrm{OCH}_{2} \mathrm{CH}_{3}\right), 0.91\left(\mathrm{t}, J=7.4 \mathrm{~Hz}, 3 \mathrm{H}, \mathrm{CH}_{2} \mathrm{CH}_{2} \mathrm{CH}_{3}\right) ;{ }^{13} \mathrm{C} \mathrm{NMR}$ $\left(101 \mathrm{MHz}, \mathrm{CDCl}_{3}\right) \delta 137.0(\mathrm{~d}, J=13.5 \mathrm{~Hz}), 123.6(\mathrm{~d}, J=3.6 \mathrm{~Hz}), 77.3(\mathrm{~d}, J=169.8 \mathrm{~Hz}), 66.0(\mathrm{~d}, J=12.6$ $\mathrm{Hz}), 62.9(\mathrm{dd}, J=25.4,6.9 \mathrm{~Hz}), 34.6,22.3(\mathrm{~d}, J=2.9 \mathrm{~Hz}), 16.7(\mathrm{t}, J=5.0 \mathrm{~Hz}), 15.3,13.8 ;{ }^{31} \mathrm{P}$ NMR $(162$ $\left.\mathrm{MHz}, \mathrm{CDCl}_{3}\right) \delta$ 20.49; IR $\left(\mathrm{v}_{\max }, \mathrm{cm}^{-1}\right) 2968(\mathrm{~m}), 2930(\mathrm{~m}), 2872(\mathrm{w}), 1393(\mathrm{w}), 1251(\mathrm{~m}), 1099(\mathrm{~m}), 1051$ (s), 1024 (s), 967 (s), 790 (m); HRMS (ESI/QTOF) m/z: [M+Na] ${ }^{+}$Calcd for $\mathrm{C}_{12} \mathrm{H}_{25} \mathrm{NaO}_{4} \mathrm{P}^{+}$287.1383; Found 287.1391.

\section{(E)-Ethyl 2-((2,3-dihydro-1H-inden-2-yl)oxy)-4-(4-(trifluoromethyl)phenyl)but-3-enoate (6e)}

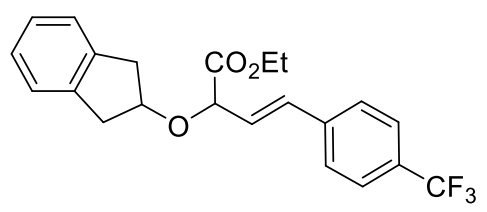

6 e

Following general procedure $F$, starting from 2-indanol (7c) (161 $\mathrm{mg}, 0.900 \mathrm{mmol}),(E)-3,3-$ bis(trifluoromethyl)-1-(4-(trifluoromethyl)styryl)-1,3-dihydro-benzo[d][1,2]iodaoxole (1'd) (162 mg, $0.300 \mathrm{mmol}$ ) and ethyl 2-diazoacetate $(2 \mathrm{a})(1.0 \mathrm{~mL}, 0.60 \mathrm{mmol}, 0.6 \mathrm{M}$ in DCM), afforded (E)-ethyl 2((2,3-dihydro-1H-inden-2-yl)oxy)-4-(4-(trifluoromethyl)phenyl)but-3-enoate (6e) as a colorless oil (52 $\mathrm{mg}, 0.13 \mathrm{mmol}, 44 \%) . \mathrm{R}_{\mathrm{f}}=0.12$ (EtOAc/pentane 3:97), $p$-anisaldehyde; ${ }^{1} \mathrm{H} \mathrm{NMR}\left(400 \mathrm{MHz}, \mathrm{CDCl}_{3}\right) \delta 7.57$ $(\mathrm{d}, J=8.2 \mathrm{~Hz}, 2 \mathrm{H}, \operatorname{ArH}), 7.46(\mathrm{~d}, J=8.2 \mathrm{~Hz}, 2 \mathrm{H}, \mathrm{ArH}), 7.25-7.12(\mathrm{~m}, 4 \mathrm{H}, \operatorname{ArH}), 6.78(\mathrm{dd}, J=16.0,1.5 \mathrm{~Hz}$, $1 \mathrm{H}, \mathrm{HC}=\mathrm{CHAr}$ ), 6.37 (dd, $J=15.9,6.0 \mathrm{~Hz}, 1 \mathrm{H}, \mathrm{HC}=\mathrm{CHAr}$ ), 4.70 (dd, $J=6.1,1.5 \mathrm{~Hz}, 1 \mathrm{H}, \mathrm{OCHC}), 4.54(\mathrm{tt}, J$ $\left.=6.6,5.1 \mathrm{~Hz}, 1 \mathrm{H}, \mathrm{OCH}\left(\mathrm{CH}_{2}\right)_{2}\right), 4.27\left(\mathrm{q}, J=7.1 \mathrm{~Hz}, 2 \mathrm{H}, \mathrm{OCH}_{2} \mathrm{CH}_{3}\right), 3.29-3.03\left(\mathrm{~m}, 4 \mathrm{H}, 2 \times \mathrm{CH}_{2} \mathrm{Ar}\right), 1.32(\mathrm{t}$, $\left.J=7.1 \mathrm{~Hz}, 3 \mathrm{H}, \mathrm{OCH}_{2} \mathrm{CH}_{3}\right) ;{ }^{13} \mathrm{C} \mathrm{NMR}\left(101 \mathrm{MHz}, \mathrm{CDCl}_{3}\right) \delta 170.8,140.7,140.4,139.7,132.0,130.0$ (q, $J=$ $32.6 \mathrm{~Hz}$ ), 127.2, 127.0, 126.9, 126.8, 125.7 (q, $J=3.8 \mathrm{~Hz}), 124.8,124.2$ (q, $J=272.1 \mathrm{~Hz}$ ), 80.3, 78.3, 61.7, 39.7, 39.3, 14.4; ${ }^{19} \mathrm{~F}$ NMR (376 MHz, CDCl $) \delta$-62.6; IR $\left(v_{\max }, \mathrm{cm}^{-1}\right) 2932(\mathrm{w}), 2359(\mathrm{w}), 1743(\mathrm{~m}), 1614$ (w), $1324(\mathrm{~s}), 1261(\mathrm{~m}), 1168(\mathrm{~s}), 1116(\mathrm{~s}), 1067(\mathrm{~s}), 1024(\mathrm{~m}), 972(\mathrm{~m}), 831(\mathrm{~m}), 742(\mathrm{~m})$; HRMS (ESI/QTOF) m/z: [M+Na] ${ }^{+}$Calcd for $\mathrm{C}_{22} \mathrm{H}_{21} \mathrm{~F}_{3} \mathrm{NaO}_{3}{ }^{+}$413.1335; Found 413.1342 .

(E)-4-(2-(3-Chloropropoxy)-1,1,1-trifluoro-5-phenylpent-3-en-2-yl)-1,1'-biphenyl (6f)

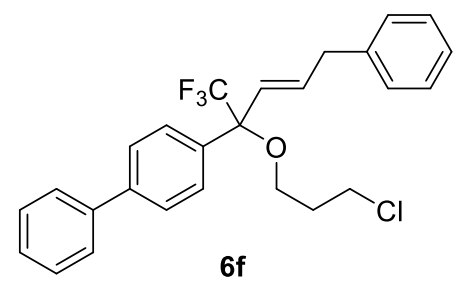

Following general procedure $\mathrm{F}$, starting from 3-chloro-1-propanol, (7d) $(75 \mu \mathrm{L}, 0.90 \mathrm{mmol}),(E)-1-(3-$ phenylprop-1-en-1-yl)-3,3-bis(trifluoromethyl)-1,3-dihydro-1 $\lambda^{3}$-benzobenzo[d][1,2]iodaoxole (146 mg, $0.300 \mathrm{mmol}$ ) and 4-(1-diazo-2,2,2-trifluoroethyl)-1,1'-biphenyl $(2 \mathrm{p})(1.0 \mathrm{~mL}, 0.60 \mathrm{mmol}, 0.60$ $M$ in DCM), afforded (E)-4-(2-(3-chloropropoxy)-1,1,1-trifluoro-5-phenylpent-3-en-2-yl)-1,1'-biphenyl (6f) as a colorless oil $(96 \mathrm{mg}, 0.22 \mathrm{mmol}, 72 \%) . \mathrm{R}_{\mathrm{f}}=0.45$ (EtOAc/pentane 2:98); ${ }^{1} \mathrm{H} \mathrm{NMR}(400 \mathrm{MHz}$, $\left.\mathrm{CDCl}_{3}\right) \delta^{1} \mathrm{H}$ NMR $\left(400 \mathrm{MHz}, \mathrm{CDCl}_{3}\right) \delta 7.69-7.58(\mathrm{~m}, 6 \mathrm{H}, \mathrm{ArH}), 7.53-7.43(\mathrm{~m}, 2 \mathrm{H}, \mathrm{ArH}), 7.43-7.31(\mathrm{~m}$, $3 \mathrm{H}, \mathrm{ArH}), 7.30-7.20(\mathrm{~m}, 3 \mathrm{H}, \mathrm{ArH}), 6.21\left(\mathrm{dt}, J=15.9,6.8 \mathrm{~Hz}, 1 \mathrm{H}, \mathrm{HC}=\mathrm{CH}-\mathrm{CH}_{2} \mathrm{Ph}\right), 5.95-5.82(\mathrm{~m}, 1 \mathrm{H}$, $\left.H \mathrm{C}=\mathrm{CH}-\mathrm{CH}_{2} \mathrm{Ph}\right), 3.72\left(\mathrm{t}, J=6.4 \mathrm{~Hz}, 2 \mathrm{H}, \mathrm{CH}_{2} \mathrm{Cl}\right), 3.66\left(\mathrm{t}, J=5.9 \mathrm{~Hz}, 2 \mathrm{H}, \mathrm{CH}_{2} \mathrm{O}\right), 3.59(\mathrm{dd}, J=6.9,1.5 \mathrm{~Hz}, 2 \mathrm{H}$, $\left.\mathrm{CH}_{2} \mathrm{Ph}\right), 2.10\left(\mathrm{p}, J=6.1 \mathrm{~Hz}, 2 \mathrm{H}, \mathrm{CH}_{2} \mathrm{CH}_{2} \mathrm{Cl}\right) ;{ }^{13} \mathrm{CNMR}\left(101 \mathrm{MHz}, \mathrm{CDCl}_{3}\right) \delta 141.7,140.5,139.1,137.6,134.5$, $129.0,129.0,128.8,128.7,127.7,127.3,127.0,126.6,125.9,125.0$ (q, $J=287.5 \mathrm{~Hz}), 81.9$ (q, $J=27.4$ 
$\mathrm{Hz}), 61.2,41.8,39.3,33.1 ;{ }^{19} \mathrm{~F} \mathrm{NMR}\left(376 \mathrm{MHz}, \mathrm{CDCl}_{3}\right) \delta$-74.9; IR $\left(\mathrm{v}_{\max }, \mathrm{cm}^{-1}\right) 3668(\mathrm{w}), 2987(\mathrm{~m}), 2971$ $(\mathrm{m}), 2910(\mathrm{~m}), 1487(\mathrm{w}), 1262(\mathrm{~m}), 1163(\mathrm{~s}), 1075(\mathrm{~s}), 840(\mathrm{~m}), 766(\mathrm{~m}), 737(\mathrm{~s}), 696(\mathrm{~s})$; HRMS (ESI/QTOF) $\mathrm{m} / \mathrm{z}$ : [M+Na] ${ }^{+}$Calcd for $\mathrm{C}_{26} \mathrm{H}_{24} \mathrm{ClF}_{3} \mathrm{NaO}^{+}$467.1360; Found 467.1366.

\section{2-((E)-4-(((3S,8S,9S,10R,13R,14S,17R)-10,13-Dimethyl-17-((R)-6-methylheptan-2-yl)-}

2,3,4,7,8,9,10,11,12,13,14,15,16,17-tetradecahydro-1H-cyclopenta[a]phenanthren-3-yl)oxy)-5,5,5trifluoropent-2-en-1-yl)isoindoline-1,3-dione (6g)

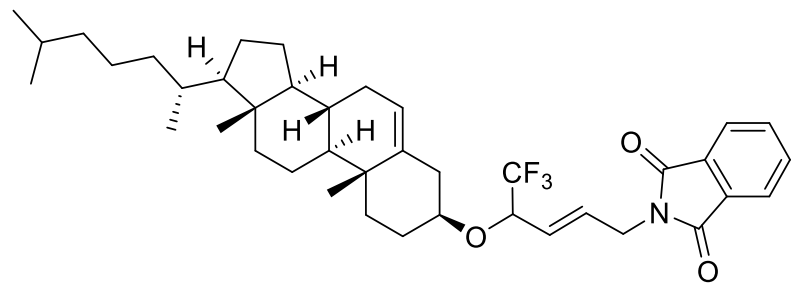

$6 \mathrm{~g}$

Following general procedure $\mathrm{F}$, starting from cholesterol (7e) $(348 \mathrm{mg}, 0.900 \mathrm{mmol}),(E)-2-(3-(3,3-$ bis(trifluoromethyl)-1 $\lambda^{3}$-benzo[d][1,2]iodaoxol-1(3H)-yl)allyl)isoindoline-1,3-dione $\quad\left(1^{\prime} \mathbf{p}\right) \quad(167 \mathrm{mg}$, $0.300 \mathrm{mmol})$ and 2-diazo-1,1,1-trifluoroethane $(\mathbf{2 k})(1.67 \mathrm{~mL}, 0.600 \mathrm{mmol}, 0.36 \mathrm{M}$ in DCM), afforded 2-((E)-4-(((3S,8S,9S,10R,13R,14S,17R)-10,13-dimethyl-17-((R)-6-methylheptan-2-yl)-

2,3,4,7,8,9,10,11,12,13,14,15,16,17-tetradecahydro-1H-cyclopenta[a]phenanthren-3-yl)oxy)-5,5,5trifluoropent-2-en-1-yl)isoindoline-1,3-dione $(6 \mathrm{~g})\left(55: 45 \mathrm{dr}\right.$ in the crude ${ }^{19} \mathrm{~F}$ NMR) as a white solid (120 $\mathrm{mg}, 0.180 \mathrm{mmol}, 61 \%)$. M.p. $158{ }^{\circ} \mathrm{C} ; \mathrm{R}_{\mathrm{f}}=0.23$ (EtOAc/pentane 5:95), $p$-anisaldehyde; ${ }^{1} \mathrm{H}$ NMR (400 $\left.\mathrm{MHz}, \mathrm{CDCl}_{3}\right) \delta 7.89-7.82(\mathrm{~m}, 2 \mathrm{H}, \mathrm{ArH}), 7.73(\mathrm{dd}, J=5.5,3.0 \mathrm{~Hz}, 2 \mathrm{H}, \mathrm{ArH}), 6.08-5.96(\mathrm{~m}, 1 \mathrm{H}, \mathrm{HC}=\mathrm{CH}-$ $\left.\mathrm{CH}_{2} \mathrm{~N}\right), 5.75-5.63\left(\mathrm{~m}, 1 \mathrm{H}, H \mathrm{C}=\mathrm{CH}-\mathrm{CH}_{2} \mathrm{~N}\right), 5.34-5.26\left(\mathrm{~m}, 1 \mathrm{H}, \mathrm{HC}=\mathrm{C}(\mathrm{C})_{2}\right), 4.34(\mathrm{dt}, J=6.0,1.8 \mathrm{~Hz}, 2 \mathrm{H}$, $\left.\mathrm{CH}_{2} \mathrm{~N}\right), 4.24-4.15\left(\mathrm{~m}, 1 \mathrm{H}, \mathrm{CHCF}_{3}\right), 3.36-3.23(\mathrm{~m}, 1 \mathrm{H}, \mathrm{CHO}), 2.36-2.19(\mathrm{~m}, 2 \mathrm{H}, \mathrm{CH}$-aliphatic $), 2.03-1.73$ (m, $5 \mathrm{H}, \mathrm{CH}$-aliphatic), $1.62-0.79$ (m, 33H, $\mathrm{CH}$-aliphatic), $0.66\left(\mathrm{~s}, 3 \mathrm{H}, \mathrm{CH}\right.$-aliphatic); ${ }^{13} \mathrm{C} \mathrm{NMR}\left(101 \mathrm{MHz}, \mathrm{CDCl}_{3}\right) \delta$ $167.8,140.4,140.3,134.2,132.2,130.5,130.5,126.0,125.9,124.0$ (q, $J=281.9 \mathrm{~Hz}$ ), 124.0 (q, $J=281.9$ $\mathrm{Hz}), 123.6,122.3,122.3,80.0,79.9,75.5(q, J=31.1 \mathrm{~Hz}), 75.5(\mathrm{q}, J=31.1 \mathrm{~Hz}), 56.9,56.3,50.2,42.4$, 39.9, 39.7, 39.5, 38.9, 38.8, 37.2, 37.1, 36.8, 36.8, 36.3, 35.9, 32.0, 32.0, 29.0, 28.4, 28.2, 24.4, 24.0, 23.0, 22.7, 21.2, 19.5, 18.9, 12.0; ${ }^{50}{ }^{19} \mathrm{~F} N M R\left(376 \mathrm{MHz}, \mathrm{CDCl}_{3}\right) \delta-77.26,-77.28 ; \mathrm{IR}\left(\mathrm{v}_{\max }, \mathrm{cm}^{-1}\right) 2949(\mathrm{~m})$, $1775(\mathrm{w}), 1711(\mathrm{~s}), 1468(\mathrm{w}), 1429(\mathrm{~m}), 1399(\mathrm{~m}), 1275(\mathrm{~m}), 1181(\mathrm{~m}), 1150(\mathrm{~m}), 1121(\mathrm{~s}), 1078(\mathrm{~m})$, $944(\mathrm{~m}), 727(\mathrm{~s}), 714(\mathrm{~m})$; HRMS (ESI/QTOF) m/z: [M+Na] ${ }^{+}$Calcd for $\mathrm{C}_{40} \mathrm{H}_{54} \mathrm{~F}_{3} \mathrm{NNaO}_{3}{ }^{+}$676.3948; Found 676.3954 .

${ }^{50} \mathrm{All}{ }^{13} \mathrm{C}$ signals of the diastereoisomeric mixture were not resolved. 


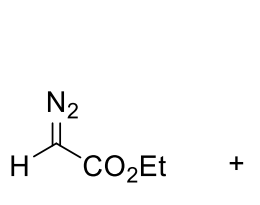

$2 a$

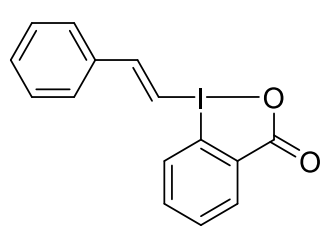

1a

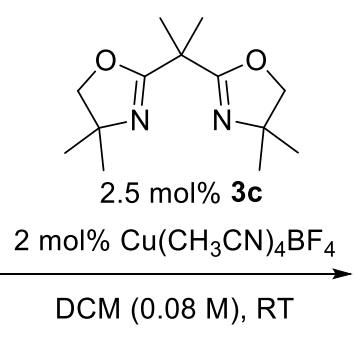

DCM (0.08 M), RT<smiles>CCOC(=O)C(/C=C/c1ccccc1)OC(=O)c1ccccc1I</smiles>

$4 a$

A catalytic solution was prepared by mixing $\mathrm{Cu}\left(\mathrm{CH}_{3} \mathrm{CN}_{4}\right)_{4} \mathrm{BF}_{4}(12.6 \mathrm{mg}, 40.0 \mu \mathrm{mol})$ and 2,2'-(propane2,2-diyl)bis(4,4-dimethyl-4,5-dihydrooxazole) (3c) $(11.9 \mathrm{mg}, 50.0 \mu \mathrm{mol})$ in $\mathrm{DCM}(5.0 \mathrm{~mL})$ at $25^{\circ} \mathrm{C}$ for 1 h.

The catalyst solution was then added to a stirring suspension of Ph-VBX (1a) $(700 \mathrm{mg}, 2.00 \mathrm{mmol}, 1.00$ equiv) and ethyl 2-diazoacetate (2a) $(0.484 \mathrm{~mL}, 4.00 \mathrm{mmol}, 2.00$ equiv) in DCM ( $20.0 \mathrm{~mL})$.

The reaction mixture was stirred at $25^{\circ} \mathrm{C}$ for $2 \mathrm{~h}$, then the solvent was removed under reduced pressure and the resulting crude oil was purified by column chromatography using EtOAc/pentane 5:95 as mobile phase to afford (E)-1-ethoxy-1-oxo-4-phenylbut-3-en-2-yl 2-iodobenzoate (4a) as a colorless oil (562 mg, $1.29 \mathrm{mmol}, 64 \%$ ). 
(E)-4-Phenylbut-3-ene-1,2-diol (8)<smiles>CCOC(=O)C(/C=C/c1ccccc1)OC(=O)c1ccccc1I</smiles>

$4 a$

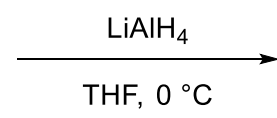<smiles>OCC(O)C=Cc1ccccc1</smiles>

Following a reported procedure, ${ }^{8}(E)$-1-ethoxy-1-oxo-4-phenylbut-3-en-2-yl 2-iodobenzoate (4a) (87.2 $\mathrm{mg}, 0.200 \mathrm{mmol}, 1.00$ equiv) was dissolved in anhydrous THF (2.00 mL) under $\mathrm{N}_{2}$ in a $5 \mathrm{~mL}$ microwave vial. Then $\mathrm{LiAlH}_{4}\left(2.4 \mathrm{M}\right.$ in THF, $0.300 \mathrm{~mL}, 0.600 \mathrm{mmol}, 3.00$ equiv) was added at $0{ }^{\circ} \mathrm{C}$ and stirred for 1 $\mathrm{h}$. The resulting solution was quenched by the addition of saturated aqueous potassium sodium tartrate $(2.00 \mathrm{~mL})$ and the biphasic mixture was stirred for $1 \mathrm{~h}$ at room temperature. Then the reaction mixture was diluted with water $(2.0 \mathrm{~mL})$ and extracted with EtOAc $(3 \times 10 \mathrm{~mL})$. The combined organic layers were dried over $\mathrm{MgSO}_{4}$, filtered and the solvent removed under reduced pressure. The crude product was purified by column chromatography using EtOAc/pentane 50:50 as mobile phase affording (E)-4-phenylbut-3-ene-1,2-diol (8) as a white solid (30.0 mg, $0.183 \mathrm{mmol}, 91 \%) .{ }^{1} \mathrm{H}$ NMR (400 $\mathrm{MHz}, \mathrm{CDCl}_{3}$ ) $\delta 7.42$ - $7.18(\mathrm{~m}, 5 \mathrm{H}, \mathrm{ArH}), 6.70$ (dd, $\left.J=16.0,1.3 \mathrm{~Hz}, 1 \mathrm{H}, \mathrm{CHCHPh}\right), 6.21$ (dd, $J=16.0,6.3$ $\mathrm{Hz}, 1 \mathrm{H}, \mathrm{CHCHPh}), 4.44(\mathrm{~m}, 1 \mathrm{H}, \mathrm{HOCHCC}), 3.76\left(\mathrm{dd}, J=11.2,3.6 \mathrm{~Hz}, 1 \mathrm{H}, \mathrm{CH}_{2} \mathrm{OH}\right), 3.61(\mathrm{dd}, J=11.2,7.3$ $\left.\mathrm{Hz}, 1 \mathrm{H}, \mathrm{CH}_{2} \mathrm{OH}\right), 2.09$ (br s, $\left.2 \mathrm{H}, 2 \times \mathrm{OH}\right) ;{ }^{13} \mathrm{C} \mathrm{NMR}\left(101 \mathrm{MHz}, \mathrm{CDCl}_{3}\right) \delta 136.4,132.4,128.8,128.1,127.8$, $126.7,73.3,66.6$. The values of the NMR spectra are in accordance with reported literature data. ${ }^{51}$

\section{Ethyl 3-benzyl-4-hydroxy-5-oxo-2-phenethyl-2,5-dihydrofuran-2-carboxylate (9)}<smiles>CCOC(=O)C(/C=C/c1ccccc1)OC(=O)c1ccccc1I</smiles>

4a<smiles>CCOC(=O)C1(CCc2ccccc2)OC(=O)C(O)=C1Cc1ccccc1</smiles>

9

DBU (0.151 mL, $1.00 \mathrm{mmol}, 10.0$ equiv) was added to a solution of (E)-1-ethoxy-1-oxo-4-phenylbut-3en-2-yl 2-iodobenzoate (4a) $(43.6 \mathrm{mg}, 0.100 \mathrm{mmol}, 1.00$ equiv) in ethanol $(1 \mathrm{~mL})$. The resulting solution was stirred $6 \mathrm{~h}$ at $50{ }^{\circ} \mathrm{C}$. The solvent was removed under reduced pressure and the resulting crude product was purified by column chromatography using $\mathrm{MeOH/DCM} \mathrm{2:98} \mathrm{as} \mathrm{mobile} \mathrm{phase} \mathrm{affording}$ ethyl 3-benzyl-4-hydroxy-5-oxo-2-phenethyl-2,5-dihydrofuran-2-carboxylate (9) as a white solid (17 $\mathrm{mg}, 0.046 \mathrm{mmol}, 93 \%)$. M.p. $111-113^{\circ} \mathrm{C} ; \mathrm{R}_{\mathrm{f}}=0.55(\mathrm{MeOH} / \mathrm{DCM} 3: 97) ;{ }^{1} \mathrm{H} \mathrm{NMR}\left(400 \mathrm{MHz}, \mathrm{CDCl}_{3}\right) \delta 7.33$ - $7.27(\mathrm{~m}, 2 \mathrm{H}, \mathrm{ArH}), 7.27$ - $7.21(\mathrm{~m}, 5 \mathrm{H}, \mathrm{ArH}), 7.20$ - $7.14(\mathrm{~m}, 1 \mathrm{H}, \mathrm{ArH}), 7.01$ - $6.94(\mathrm{~m}, 2 \mathrm{H}, \mathrm{ArH}), 5.78(\mathrm{br}$ $\mathrm{s}, 1 \mathrm{H}, \mathrm{OH}), 3.95\left(\mathrm{q}, J=7.1 \mathrm{~Hz}, 2 \mathrm{H}, \mathrm{OCH}_{2} \mathrm{CH}_{3}\right), 3.67\left(\mathrm{~s}, 2 \mathrm{H}, \mathrm{CCH}_{2} \mathrm{Ph}\right), 2.55-2.32\left(\mathrm{~m}, 3 \mathrm{H}, \mathrm{CH}_{2}\right), 2.19-2.05$ $\left(\mathrm{m}, 1 \mathrm{H}, \mathrm{CH}_{2}\right), 1.15\left(\mathrm{t}, J=7.1 \mathrm{~Hz}, 3 \mathrm{H}, \mathrm{OCH}_{2} \mathrm{CH}_{3}\right) ;{ }^{13} \mathrm{C} \mathrm{NMR}\left(101 \mathrm{MHz}, \mathrm{CDCl}_{3}\right) \delta 169.1,168.0,140.4,139.1$, $136.2,130.9,129.1,128.9,128.6,128.5,127.2,126.4,87.2,62.6,36.0,30.2,29.3,14.0 ; \mathrm{IR}\left(\mathrm{V}_{\max }, \mathrm{cm}^{-1}\right)$ $2919(\mathrm{w}), 1739(\mathrm{~s}), 1292(\mathrm{~m}), 1249(\mathrm{~m}), 1218(\mathrm{~m}), 1136(\mathrm{~m}), 1105(\mathrm{~m}), 1017(\mathrm{~m}), 748(\mathrm{~s}), 691(\mathrm{~m}), 668$ (s); HRMS (ESI) calcd for $\mathrm{C}_{22} \mathrm{H}_{23} \mathrm{O}_{5}{ }^{+}[\mathrm{M}+\mathrm{H}]^{+} 367.1540$; found $[\mathrm{M}+\mathrm{H}]^{+} 367.1549$.

\footnotetext{
${ }^{51}$ T. Saravanan, R. Selvakumar, M. Doble and A. Chadha, Tetrahedron: Asymmetry, 2012, 23, 1360.
} 
<smiles>CCOC(=O)C(/C=C/c1ccccc1)OC(=O)c1ccccc1I</smiles>

$4 a$<smiles>C=CC[AsH3]</smiles>

73

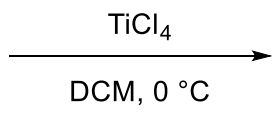

$\mathrm{DCM}, 0^{\circ} \mathrm{C}$<smiles>C=CCC(/C=C/C(=O)OCC)c1ccccc1</smiles>

10

To a solution of (E)-1-ethoxy-1-oxo-4-phenylbut-3-en-2-yl 2-iodobenzoate (4a) $(87.2 \mathrm{mg}, 0.200 \mathrm{mmol}$, 1.00 equiv) and allyltrimethylsilane (73) $(48.0 \mu \mathrm{L}, 0.300 \mathrm{mmol}, 1.50$ equiv) in dry DCM $(2.0 \mathrm{~mL})$ was added $\mathrm{TiCl}_{4}\left(23.0 \mu \mathrm{L}, 0.210 \mathrm{mmol}, 1.05\right.$ equiv) dropwise at $0{ }^{\circ} \mathrm{C}$ under $\mathrm{N}_{2}$. The reaction was stirred 15 minutes at $0{ }^{\circ} \mathrm{C}$ and then quenched with a saturated solution of $\mathrm{NaHCO}_{3}(2.0 \mathrm{~mL})$. The layers were separated and the aqueous layer was extracted with DCM $(3 \times 5 \mathrm{~mL})$. The combined organic layers were washed with brine $(10 \mathrm{~mL})$, dried over $\mathrm{MgSO}_{4}$, filtered and the solvent was removed under reduced pressure. The crude product was purified by column chromatography using DCM/pentane 10:90 as mobile phase affording (E)-ethyl 4-phenylhepta-2,6-dienoate (10) as a colorless oil $(38.0 \mathrm{mg}$, $0.165 \mathrm{mmol}, 83 \%) . \mathrm{R}_{\mathrm{f}}=0.50$ (DCM/pentane 50:50); ${ }^{1} \mathrm{H}$ NMR $\left(400 \mathrm{MHz}, \mathrm{CDCl}_{3}\right) \delta 7.36-7.28(\mathrm{~m}, 2 \mathrm{H}$, $\mathrm{ArH}), 7.27$ - $7.15(\mathrm{~m}, 3 \mathrm{H}, \mathrm{ArH}), 7.09\left(\mathrm{dd}, J=15.7,7.5 \mathrm{~Hz}, 1 \mathrm{H}, \mathrm{CHCHCO}_{2} \mathrm{Et}\right), 5.78(\mathrm{dd}, J=15.7,1.4 \mathrm{~Hz}, 1 \mathrm{H}$, $\mathrm{CHCHCO}_{2} \mathrm{Et}$ ), 5.69 (ddt, $\left.J=17.1,10.1,6.9 \mathrm{~Hz}, 1 \mathrm{H}, \mathrm{CHCH}_{2}\right), 5.10-4.96\left(\mathrm{~m}, 2 \mathrm{H}, \mathrm{CHCH}_{2}\right), 4.17$ (q, J = 7.2 $\mathrm{Hz}, 2 \mathrm{H}, \mathrm{OCH}_{2} \mathrm{CH}_{3}$ ), 3.50 (qd, J = 7.5, $1.3 \mathrm{~Hz}, 1 \mathrm{H}, \mathrm{PhCHCH}_{2}$ ), 2.56 (tt, $J=7.1,1.3 \mathrm{~Hz}, 2 \mathrm{H}, \mathrm{PhCHCH}_{2}$ ), 1.27 $\left(\mathrm{t}, J=7.1 \mathrm{~Hz}, 3 \mathrm{H}, \mathrm{OCH}_{2} \mathrm{CH}_{3}\right) ;{ }^{13} \mathrm{C} \mathrm{NMR}\left(101 \mathrm{MHz}, \mathrm{CDCl}_{3}\right) \delta 166.7,151.0,141.7,135.7,128.8,128.0,127.0$, 121.3, 117.2, 60.5, 48.4, 39.3, 14.4; IR ( $\left.v_{\max }, \mathrm{cm}^{-1}\right) 2975(\mathrm{~m}), 2924(\mathrm{~m}), 1718(\mathrm{~s}), 1650(\mathrm{~m}), 1456(\mathrm{w})$, $1368(\mathrm{~m}), 1311(\mathrm{~m}), 1270(\mathrm{~m}), 1233(\mathrm{~m}), 1168(\mathrm{~s}), 1045(\mathrm{~m}), 981(\mathrm{~m}), 916(\mathrm{~m}), 759(\mathrm{~m}), 699(\mathrm{~s})$; HRMS (ESI) calcd for $\mathrm{C}_{15} \mathrm{H}_{19} \mathrm{O}_{2}{ }^{+}[\mathrm{M}+\mathrm{H}]^{+}$231.1380; found 231.1377.

\section{(E)-Ethyl 4-phenylhepta-2,5,6-trienoate (11)}<smiles>CCOC(=O)C(/C=C/c1ccccc1)OC(=O)c1ccccc1I</smiles>

$4 a$<smiles>C#CC[AsH3]</smiles>

74

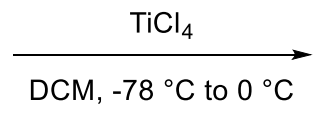

DCM, $-78^{\circ} \mathrm{C}$ to $0^{\circ} \mathrm{C}$

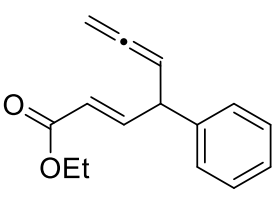

11

To a solution of (E)-1-ethoxy-1-oxo-4-phenylbut-3-en-2-yl 2-iodobenzoate (4a) $(87.2 \mathrm{mg}, 0.200 \mathrm{mmol}$, 1.00 equiv) and propargyltrimethylsilane (74) $(60.0 \mu \mathrm{L}, 0.400 \mathrm{mmol}, 2.00$ equiv) in dry DCM $(2.0 \mathrm{~mL})$ was added $\mathrm{TiCl}_{4}\left(23.0 \mu \mathrm{L}, 0.210 \mathrm{mmol}, 1.05\right.$ equiv) dropwise at $-78{ }^{\circ} \mathrm{C}$ under $\mathrm{N}_{2}$. The reaction was allowed to warm slowly to $0{ }^{\circ} \mathrm{C}$ and then quenched with a saturated solution of $\mathrm{NaHCO}_{3}(2.0 \mathrm{~mL})$. The layers were separated and the aqueous layer was extracted with DCM $(3 \times 5 \mathrm{~mL})$. The combined organic layers were washed with brine $(10 \mathrm{~mL})$, dried over $\mathrm{MgSO}_{4}$, filtered and the solvent was removed under reduced pressure. The crude product was purified by column chromatography using EtOAc/pentane 2:98 as mobile phase affording afford $(E)$-ethyl 4-phenylhepta-2,5,6-trienoate (11) as a colorless oil (27.0 mg, $0.118 \mathrm{mmol}, 59 \%) . \mathrm{R}_{\mathrm{f}}=0.54$ (DCM/pentane 50:50); ${ }^{1} \mathrm{H} \mathrm{NMR}\left(400 \mathrm{MHz}, \mathrm{CDCl}_{3}\right) \delta 7.38-7.31$ $(\mathrm{m}, 2 \mathrm{H}, \mathrm{ArH}), 7.29-7.20(\mathrm{~m}, 3 \mathrm{H}, \mathrm{ArH}), 7.13$ (dd, $\left.J=15.6,7.0 \mathrm{~Hz}, 1 \mathrm{H}, \mathrm{CHCHCO}_{2} \mathrm{Et}\right), 5.84$ (dd, $J=15.6,1.5$ $\mathrm{Hz}, 1 \mathrm{H}, \mathrm{CHCHCO}_{2} \mathrm{Et}$ ), 5.37 (q, $\left.J=6.8 \mathrm{~Hz}, 1 \mathrm{H}, \mathrm{CHCCH}_{2}\right), 4.82$ (dd, $J=6.6,2.7 \mathrm{~Hz}, 2 \mathrm{H}, \mathrm{CHCCH}_{2}$ ), 4.18 (q, $J=$ $7.1 \mathrm{~Hz}, 3 \mathrm{H}, \mathrm{PhCH}$ and $\left.\mathrm{OCH}_{2} \mathrm{CH}_{3}\right), 1.28\left(\mathrm{t}, J=7.1 \mathrm{~Hz}, 3 \mathrm{H}, \mathrm{OCH}_{2} \mathrm{CH}_{3}\right) ;{ }^{13} \mathrm{C} \mathrm{NMR}\left(101 \mathrm{MHz}, \mathrm{CDCl}_{3}\right) \delta 208.6$, 166.6, 149.4, 140.9, 128.9, 128.1, 127.3, 121.9, 91.9, 77.2, 60.5, 47.4, 14.4; IR $\left(v_{\max }, \mathrm{cm}^{-1}\right) 2982(\mathrm{~m})$, $2924(\mathrm{~m}), 2853(\mathrm{w}), 1958(\mathrm{w}), 1715(\mathrm{~s}), 1650(\mathrm{~m}), 1454(\mathrm{~m}), 1367(\mathrm{~m}), 1307(\mathrm{~m}), 1269(\mathrm{~m}), 1232(\mathrm{~m})$, $1169(\mathrm{~s}), 1071(\mathrm{~m}), 1040(\mathrm{~s}), 982(\mathrm{~m}), 853(\mathrm{~m})$; HRMS (ESI) calcd for $\mathrm{C}_{15} \mathrm{H}_{17} \mathrm{O}_{2}{ }^{+}[\mathrm{M}+\mathrm{H}]^{+}$229.1223; found 229.1220. 
(E)-Ethyl 4-azido-4-phenylbut-2-enoate (12) and (E)-Ethyl 2-azido-4-phenylbut-3-enoate (12')<smiles>CCOC(=O)C(/C=C/c1ccccc1)OC(=O)c1ccccc1I</smiles>

4a

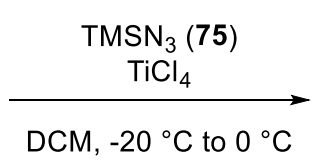

DCM, $-20^{\circ} \mathrm{C}$ to $0^{\circ} \mathrm{C}$<smiles>CCOC(=O)/C=C/C(N=[N+]=[N-])c1ccccc1</smiles>

12<smiles>CCOC(=O)C(/C=C/c1ccccc1)N=[N+]=[N-]</smiles>

12

To a solution of (E)-1-ethoxy-1-oxo-4-phenylbut-3-en-2-yl 2-iodobenzoate (4a) $(87.2 \mathrm{mg}, 0.200 \mathrm{mmol}$, 1.00 equiv) and azidotrimethylsilane (75) $(40.0 \mu \mathrm{L}, 0.300 \mathrm{mmol}, 1.50$ equiv) in dry DCM $(2.0 \mathrm{~mL})$ was added $\mathrm{TiCl}_{4}\left(23.0 \mu \mathrm{L}, 0.210 \mathrm{mmol}, 1.05\right.$ equiv) dropwise at $-20{ }^{\circ} \mathrm{C}$ under $\mathrm{N}_{2}$. The reaction was allowed to warm to room temperature and then quenched with a saturated solution of $\mathrm{NaHCO}_{3}(2.0 \mathrm{~mL})$. The layers were separated and the aqueous layer was extracted with DCM $(3 \times 5 \mathrm{~mL})$. The combined organic layers were washed with brine $(10 \mathrm{~mL})$, dried over $\mathrm{MgSO}_{4}$, filtered and the solvent was removed under reduced pressure. The crude product was purified by column chromatography using DCM/pentane 10:90 as mobile phase affording an isomeric mixture of $(E)$-ethyl 4-azido-4-phenylbut-2-enoate (12) and (E)-ethyl 2-azido-4-phenylbut-3-enoate (12') as a colorless oil, 70:30 mixture of 12 and 12' (40 mg, $0.17 \mathrm{mmol}, 86 \%) .{ }^{1} \mathrm{H}$ NMR $\left(400 \mathrm{MHz}, \mathrm{CDCl}_{3}\right) \delta 7.45-7.28(\mathrm{~m}, 5 \mathrm{H}, \mathrm{ArH}), 6.94(\mathrm{dd}, J=15.5,5.7 \mathrm{~Hz}, 1 \mathrm{H}$, $\mathrm{CHCHCO}_{2} \mathrm{Et}$ ), 6.14 (dd, J=15.5, $1.6 \mathrm{~Hz}, 1 \mathrm{H}, \mathrm{CHCHCO}_{2} \mathrm{Et}$ ), 5.18 (dd, $J=5.7,1.6 \mathrm{~Hz}, 1 \mathrm{H}, \mathrm{N}_{3} \mathrm{CHCC}$ ), $4.33-$ $4.18\left(\mathrm{~m}, 2 \mathrm{H}, \mathrm{OCH}_{2} \mathrm{CH}_{3}\right), 1.34-1.28\left(\mathrm{~m}, 3 \mathrm{H}, \mathrm{OCH}_{2} \mathrm{CH}_{3}\right) ;{ }^{13} \mathrm{C} \mathrm{NMR}\left(101 \mathrm{MHz}, \mathrm{CDCl}_{3}\right) \delta 165.9,144.0,129.3$, 129.1, 127.6, 127.0, 123.0, 65.6, 60.9, 14.4 for $\gamma$-azidated ester $(12) ;{ }^{1} \mathrm{H}$ NMR $\left(400 \mathrm{MHz}, \mathrm{CDCl}_{3}\right) \delta 7.45$ - $7.28(\mathrm{~m}, 5 \mathrm{H}, \mathrm{ArH}), 6.77$ (dd, $J=15.8 \mathrm{~Hz}, 1.2 \mathrm{~Hz}, 1 \mathrm{H}, \mathrm{PhCHCH}), 6.27$ (dd, $J=15.8,7.5 \mathrm{~Hz}, 1 \mathrm{H}, \mathrm{PhCHCH}$ ), $4.54\left(\mathrm{dd}, J=7.5,1.3 \mathrm{~Hz}, 1 \mathrm{H}, \mathrm{N}_{3} \mathrm{CHCO}_{2} \mathrm{Et}\right), 4.33-4.18\left(\mathrm{~m}, 2 \mathrm{H}, \mathrm{OCH}_{2} \mathrm{CH}_{3}\right), 1.34-1.28\left(\mathrm{~m}, 3 \mathrm{H}, \mathrm{OCH}_{2} \mathrm{CH}_{3}\right)$; ${ }^{13} \mathrm{C}$ NMR $\left(101 \mathrm{MHz}, \mathrm{CDCl}_{3}\right) \delta 169.1,136.6,136.0,135.5,128.9,128.9,120.8,63.9,62.4,14.3$ for $\alpha-$ azidated ester (12'). The values of the NMR spectra are in accordance with reported literature data. ${ }^{52}$

(E)-1-Ethoxy-2-methyl-1-oxo-4-phenylbut-3-en-2-yl 2-((E)-3-methoxy-3-oxoprop-1-en-1-yl)benzoate (13)

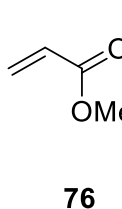

76

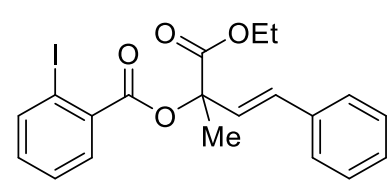

$5 \mathrm{~m}$

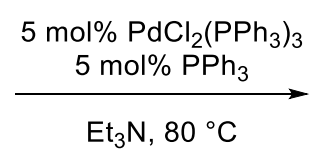

$\mathrm{Et}_{3} \mathrm{~N}, 80^{\circ} \mathrm{C}$

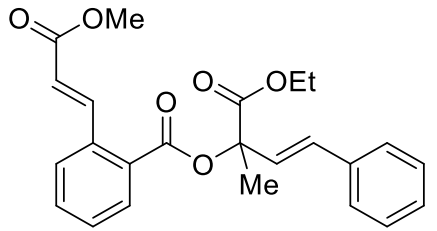

13

A flame dried $8 \mathrm{~mL}$ microwave vial was charged with $(E)$-1-ethoxy-2-methyl-1-oxo-4-phenylbut-3-en2-yl 2-iodobenzoate $(5 \mathrm{~m})(45.0 \mathrm{mg}, 0.100 \mathrm{mmol}, 1.00$ equiv), bis(triphenylphosphine)palladium (II) chloride ( $3.51 \mathrm{mg}, 5.00 \mu \mathrm{mol}, 0.05$ equiv), triphenylphosphine $(1.31 \mathrm{mg}, 5.00 \mu \mathrm{mol}, 0.05$ equiv) and trimethylamine $(0.5 \mathrm{~mL})$. The resulting reaction mixture was degassed by "pump-freeze-thaw" cycles (3 times) via a syringe needle and then methyl acrylate (76) $(45.0 \mu \mathrm{L}, 0.500 \mathrm{mmol}, 5.00$ equiv) was added by syringe and the reaction mixture was stirred at $80^{\circ} \mathrm{C}$ for $24 \mathrm{~h}$. The solvent was removed under reduced pressure and the product was purified by column chromatography using EtOAc/pentane 15:85 as mobile phase affording (E)-1-ethoxy-2-methyl-1-oxo-4-phenylbut-3-en-2-yl 2((E)-3-methoxy-3-oxoprop-1-en-1-yl)benzoate (13) as a thick colorless oil (27.0 mg, $66.1 \mu \mathrm{mol}, 66 \%)$. $\mathrm{R}_{\mathrm{f}}=0.32$ (EtOAc/pentane 15:85); ${ }^{1} \mathrm{H}$ NMR $\left(400 \mathrm{MHz}, \mathrm{CDCl}_{3}\right) \delta 8.45$ (d, J=15.9 Hz, $\left.1 \mathrm{H}, \mathrm{ArCHCHCO}_{2} \mathrm{Me}\right)$, $7.99(\mathrm{dd}, J=7.8,1.4 \mathrm{~Hz}, 1 \mathrm{H}, \operatorname{ArH}), 7.66-7.59(\mathrm{~m}, 1 \mathrm{H}, \operatorname{ArH}), 7.59-7.54(\mathrm{~m}, 1 \mathrm{H}, \operatorname{ArH}), 7.47(\mathrm{td}, J=7.5$, $1.5 \mathrm{~Hz}, 1 \mathrm{H}, \mathrm{ArH}), 7.44-7.39(\mathrm{~m}, 2 \mathrm{H}, \mathrm{ArH}), 7.37-7.30(\mathrm{~m}, 2 \mathrm{H}, \mathrm{ArH}), 7.29-7.22(\mathrm{~m}, 1 \mathrm{H}, \operatorname{ArH}), 6.77(\mathrm{~d}, J$ $=16.2 \mathrm{~Hz}, 1 \mathrm{H}, \mathrm{CHCHPh}), 6.65(\mathrm{~d}, J=16.2 \mathrm{~Hz}, 1 \mathrm{H}, \mathrm{CHCHPh}), 6.34$ (d, J = $15.9 \mathrm{~Hz}, 1 \mathrm{H}, \mathrm{ArCHCHCO}_{2} \mathrm{Me}$ ), $4.28\left(\mathrm{qd}, J=7.1,1.9 \mathrm{~Hz}, 2 \mathrm{H}, \mathrm{OCH}_{2} \mathrm{CH}_{3}\right), 3.74\left(\mathrm{~s}, 3 \mathrm{H}, \mathrm{OCH}_{3}\right), 1.93\left(\mathrm{~s}, 3 \mathrm{H}, \mathrm{CCH}_{3}\right), 1.29(\mathrm{t}, J=7.1 \mathrm{~Hz}, 3 \mathrm{H}$,

\footnotetext{
${ }^{52}$ Y. Sawama, S. Nagata, Y. Yabe, K. Morita, Y. Monguchi and H. Sajiki, Chem. Eur. J., 2012, 18, 16608.
} 
$\left.\mathrm{OCH}_{2} \mathrm{CH}_{3}\right) ;{ }^{13} \mathrm{C}$ NMR $\left(101 \mathrm{MHz}, \mathrm{CDCl}_{3}\right) \delta 170.8,167.0,165.8,144.0,136.3,136.1,132.7,131.4,131.0$, 130.3, 129.6, 128.8, 128.4, 128.0, 127.9, 127.0, 120.8, 81.3, 62.1, 51.9, 23.2, 14.2; IR $\left(v_{\max }, \mathrm{cm}^{-1}\right) 2991$ $(\mathrm{m}), 2956(\mathrm{~m}), 2926(\mathrm{~m}), 1715(\mathrm{~s}), 1636(\mathrm{w}), 1479(\mathrm{w}), 1448(\mathrm{~m}), 1377(\mathrm{w}), 1315(\mathrm{~m}), 1269(\mathrm{~s}), 1196$ $(\mathrm{m}), 1173(\mathrm{~m}), 1121(\mathrm{~m}), 1071(\mathrm{~s}), 1044(\mathrm{~m}), 1021(\mathrm{~m}), 972(\mathrm{~m}), 865(\mathrm{~m})$; HRMS (ESI) calcd for $\mathrm{C}_{24} \mathrm{H}_{24} \mathrm{NaO}_{6}{ }^{+}[\mathrm{M}+\mathrm{Na}]^{+}$431.1465; found 431.1472.

\section{(E)-1-Ethoxy-1-oxo-4-phenylbut-3-en-2-yl benzoate (14)}<smiles>CCOC(=O)C(/C=C/c1ccccc1)OC(=O)c1ccccc1I</smiles>

$4 a$

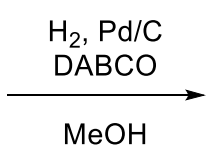

$\mathrm{MeOH}$<smiles>CCOC(=O)C(/C=C/c1ccccc1)OC(=O)c1ccccc1</smiles>

14

Following a reported procedure, ${ }^{53}$ in a $20 \mathrm{~mL}$ Schlenk flask, $(E)$-1-ethoxy-1-oxo-4-phenylbut-3-en-2-yl 2-iodobenzoate (4a) $(43.6 \mathrm{mg}, 0.100 \mathrm{mmol}, 1.00$ equiv), DABCO (112 mg, $1.00 \mathrm{mmol}, 10.0$ equiv) and $\mathrm{Pd} / \mathrm{C}(5.0 \mathrm{mg}$ ) were suspended in $\mathrm{MeOH}(10 \mathrm{~mL})$. The reaction flask was evacuated and backfilled with argon (3 times) before being evacuated and backfilled with $\mathrm{H}_{2}(1 \mathrm{~atm})$. The reaction was stirred $10 \mathrm{~min}$ at room temperature, then the hydrogen was evacuated and replaced with argon. The reaction mixture was filtered through a pad of celite and the filtrate was evaporated under reduced pressure. The crude product was purified by column chromatography using EtOAc/pentane 95:5 as mobile phase affording (E)-1-ethoxy-1-oxo-4-phenylbut-3-en-2-yl benzoate (14) as a colorless oil (24.0 mg, 77.0 $\mu \mathrm{mol}, 77 \%) . \mathrm{R}_{\mathrm{f}}=0.29$ (EtOAc/pentane 5:95); ${ }^{1} \mathrm{H}$ NMR $\left(400 \mathrm{MHz}, \mathrm{CDCl}_{3}\right) \delta 8.19-8.10(\mathrm{~m}, 2 \mathrm{H}, \mathrm{ArH}), 7.65$ - $7.55(\mathrm{~m}, 1 \mathrm{H}, \mathrm{ArH}), 7.53$ - $7.41(\mathrm{~m}, 4 \mathrm{H}, \mathrm{ArH}), 7.40$ - $7.27(\mathrm{~m}, 3 \mathrm{H}, \mathrm{ArH}), 6.92(\mathrm{dd}, J=16.0,1.3 \mathrm{~Hz}, 1 \mathrm{H}$, CHCHPh), 6.41 (dd, $J=15.9,7.0 \mathrm{~Hz}, 1 \mathrm{H}, \mathrm{CHCHPh}), 5.85$ (dd, $J=7.0,1.3 \mathrm{~Hz}, 1 \mathrm{H}, \mathrm{OCHCC}$ ), 4.27 (qd, $J=$ 7.1, $\left.5.1 \mathrm{~Hz}, 2 \mathrm{H}, \mathrm{OCH}_{2} \mathrm{CH}_{3}\right), 1.30\left(\mathrm{t}, J=7.1 \mathrm{~Hz}, 3 \mathrm{H}, \mathrm{OCH}_{2} \mathrm{CH}_{3}\right) ;{ }^{13} \mathrm{C} \mathrm{NMR}\left(101 \mathrm{MHz}, \mathrm{CDCl}_{3}\right) \delta 168.8,165.9$, $135.8,135.4,133.6,130.1,129.5,128.8,128.7,128.6,127.0,121.2,73.8,62.0,14.3 ; \mathrm{IR}\left(\mathrm{v}_{\max }, \mathrm{cm}^{-1}\right) 3057$ $(\mathrm{w}), 3030(\mathrm{w}), 1748(\mathrm{~m}), 1724(\mathrm{~s}), 1452(\mathrm{~m}), 1315(\mathrm{w}), 1272(\mathrm{~s}), 1251(\mathrm{~m}), 1196(\mathrm{~m}), 1106(\mathrm{~s}), 1069(\mathrm{~m})$, $1024(\mathrm{~m}), 965(\mathrm{~m}), 738(\mathrm{~m}), 712(\mathrm{~s}), 689(\mathrm{~s})$; $\mathrm{HRMS}(\mathrm{ESI})$ calcd for $\mathrm{C}_{19} \mathrm{H}_{18} \mathrm{NaO}_{4}{ }^{+}[\mathrm{M}+\mathrm{Na}]^{+}$333.1097; found 333.1099.

\section{(Z)-1-Ethoxy-1-oxo-4-phenylbut-3-en-2-yl benzoate (15)}<smiles>CCOC(=O)C(/C=C/c1ccccc1)OC(=O)c1ccccc1I</smiles>

4a

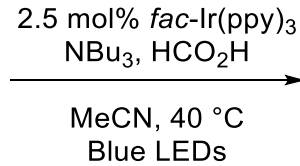

Blue LEDs<smiles>CCOC(=O)C(/C=C\c1ccccc1)OC(=O)c1ccccc1</smiles>

15

Following a reported procedure, ${ }^{54}$ a flame dried $8 \mathrm{~mL}$ microwave vial with a rubber septum and magnetic stirring bar was charged with (E)-1-ethoxy-1-oxo-4-phenylbut-3-en-2-yl 2-iodobenzoate (4a) (43.6 mg, $0.100 \mathrm{mmol}, 1.00$ equiv), MeCN (1.0 mL), tributylamine ( $240 \mu \mathrm{L}, 1.00 \mathrm{mmol}, 10.0$ equiv), formic acid (38 $\mu \mathrm{L}, 1.00 \mathrm{mmol}, 10.0$ equiv) and fac- $\operatorname{lr}(\mathrm{ppy})_{3}(1.64 \mathrm{mg}, 2.50 \mu \mathrm{mol}, 0.025$ equiv). The resulting reaction mixture was degassed by "pump-freeze-thaw" cycles ( 3 times) via a syringe needle and placed in a $250 \mathrm{~mL}$ beaker with blue LEDs wrapped inside. The reaction mixture was stirred at 40 ${ }^{\circ} \mathrm{C}$ for $18 \mathrm{~h}$. The solvent was removed under reduced pressure and the product was purified by column chromatography using DCM/pentane $50: 50$ as mobile phase affording (Z)-1-ethoxy-1-oxo-4phenylbut-3-en-2-yl benzoate (15) as a white solid $(25.2 \mathrm{mg}, 82.0 \mu \mathrm{mol}, 82 \%)$. M.p. $76-78{ }^{\circ} \mathrm{C} ; \mathrm{R}_{\mathrm{f}}=$ (DCM/pentane 50:50); $\left.{ }^{1} \mathrm{H} \mathrm{NMR} \mathrm{(400} \mathrm{MHz,} \mathrm{CDCl}_{3}\right) \delta 8.11$ - $8.03(\mathrm{~m}, 2 \mathrm{H}, \mathrm{ArH}), 8.60-7.54(\mathrm{~m}, 1 \mathrm{H}, \mathrm{ArH})$,

\footnotetext{
${ }^{53}$ N. Faucher, Y. Ambroise, J.-C. Cintrat, E. Doris, F. Pillon and B. Rousseau, J. Org. Chem., 2002, 67, 932.

54 J. D. Nguyen, E. M. D’Amato, J. M. R. Narayanam and C. R. J. Stephenson, Nat. Chem., 2012, 4, 854.
} 
$7.51-7.28(\mathrm{~m}, 7 \mathrm{H}, \mathrm{ArH}), 6.94(\mathrm{~d}, J=11.4 \mathrm{~Hz}, 1 \mathrm{H}, \mathrm{CHCHPh}), 6.05$ (dd, $J=9.8,0.9 \mathrm{~Hz}, 1 \mathrm{H}, \mathrm{OCHCC}), 5.91$ (dd, $J=11.4,9.9 \mathrm{~Hz}, 1 \mathrm{H}, \mathrm{CHCHPh}$ ), $4.28\left(\mathrm{q}, J=7.1 \mathrm{~Hz}, 2 \mathrm{H}, \mathrm{OCH}_{2} \mathrm{CH}_{3}\right), 1.30$ (t, $J=7.1 \mathrm{~Hz}, 3 \mathrm{H}, \mathrm{OCH}_{2} \mathrm{CH}_{3}$ ); ${ }^{13} \mathrm{C} \mathrm{NMR}\left(101 \mathrm{MHz}, \mathrm{CDCl}_{3}\right) \delta$ 169.2, 165.8, 136.8, 135.4, 133.5, 130.1, 129.5, 129.0, 128.7, 128.5, 128.3, 123.0, 70.3, 62.0, 14.2; IR ( $\left.v_{\max }, \mathrm{cm}^{-1}\right) 3065(\mathrm{w}), 3024(\mathrm{w}), 2981(\mathrm{w}), 1750(\mathrm{~s}), 1722(\mathrm{~s}), 1452(\mathrm{~m}), 1370$ (w), $1333(\mathrm{w}), 1315(\mathrm{~m}), 1278(\mathrm{~s}), 1258(\mathrm{~s}), 1194(\mathrm{~m}), 1100(\mathrm{~s}), 1069$ (s), $1026(\mathrm{~s}), 814(\mathrm{~m}), 773(\mathrm{~m}), 710$ (s); HRMS (ESI) calcd for $\mathrm{C}_{19} \mathrm{H}_{18} \mathrm{NaO}_{4}{ }^{+}[\mathrm{M}+\mathrm{Na}]^{+} 333.1097$; found 333.1106 . 


\section{Enantioselective transformation}

\section{Table S3: Preliminary results for the enantioselective transformation}

Under inert atmosphere, a catalytic solution was prepared by mixing $\mathrm{Cu}$ cat. ( $4.00 \mu \mathrm{mol}, 0.08$ equiv), and BOX ligand (3b-d) $\left(5.00 \mu \mathrm{mol}, 0.10\right.$ equiv) in DCE $(0.500 \mathrm{~mL})$ at $25^{\circ} \mathrm{C}$ for $1 \mathrm{~h}$.

$0.250 \mathrm{~mL}$ of the catalytic solution was then added to a stirring suspension of VBX $(0.05 \mathrm{mmol}, 1.00$ equiv) and diazo compound $(0.10 \mathrm{mmol}, 2.00$ equiv) in DCE $(1.0 \mathrm{~mL})$.

The reaction mixture was stirred at the indicated temperature and time (monitored by TLC (EtOAc/pentane 5:95 and MeOH/DCM 5:95)) and the solvent was removed under reduced pressure. The resulting crude oil was purified by PTLC (EtOAc/pentane) directly without further work-up to afford the corresponding allylic ester product.

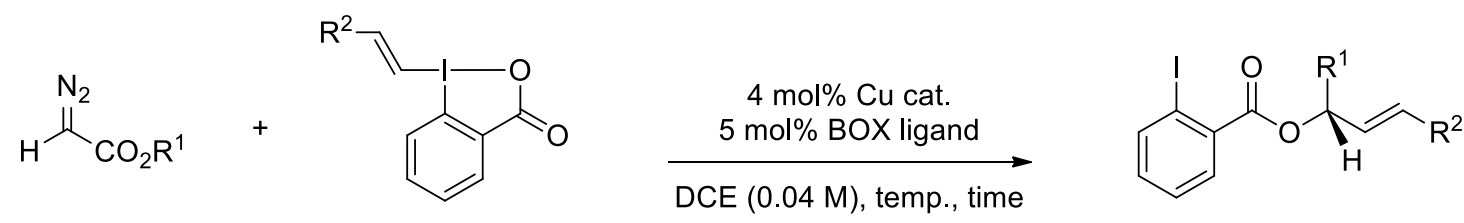

\begin{tabular}{|c|c|c|c|c|c|c|c|c|}
\hline entry & $\begin{array}{c}\text { diazo } \\
\mathrm{R}^{1}=\end{array}$ & $\begin{array}{l}\text { VBX } \\
R^{2}=\end{array}$ & Cu cat. & ligand & temp. & time & yield $^{a}$ & $e^{b}$ \\
\hline 1 & $\mathrm{Et}$ & $\mathrm{Ph}$ & $\mathrm{Cu}\left(\mathrm{CH}_{3} \mathrm{CN}\right)_{4} \mathrm{BF}_{4}$ & $3 \mathbf{b}$ & $25^{\circ} \mathrm{C}$ & $2 \mathrm{~h}$ & $>90 \%$ & $14 \%$ \\
\hline 2 & $\mathrm{Et}$ & $\mathrm{Ph}$ & $\mathrm{Cu}(\mathrm{OTf})_{2}$ & $3 \mathbf{b}$ & $25{ }^{\circ} \mathrm{C}$ & $2 \mathrm{~h}$ & $>90 \%$ & $13 \%$ \\
\hline 3 & $\mathrm{Et}$ & $\mathrm{Ph}$ & $\mathrm{Cu}\left(\mathrm{CH}_{3} \mathrm{CN}\right)_{4} \mathrm{BF}_{4}$ & 3d & $25^{\circ} \mathrm{C}$ & $2 \mathrm{~h}$ & $>90 \%$ & $33 \%$ \\
\hline 4 & Et & $\mathrm{Ph}$ & $\mathrm{Cu}\left(\mathrm{CH}_{3} \mathrm{CN}\right)_{4} \mathrm{BF}_{4}$ & 3d & $0{ }^{\circ} \mathrm{C}$ & $8 \mathrm{~h}$ & $50 \%$ & $20 \%$ \\
\hline $5^{c}$ & Et & $\mathrm{Ph}$ & $\mathrm{Cu}\left(\mathrm{CH}_{3} \mathrm{CN}\right)_{4} \mathrm{BF}_{4}$ & 3d & $25{ }^{\circ} \mathrm{C}$ & $2 \mathrm{~h}$ & $>90 \%$ & $40 \%$ \\
\hline $6^{d}$ & Et & $\mathrm{Ph}$ & $\mathrm{Cu}\left(\mathrm{CH}_{3} \mathrm{CN}\right)_{4} \mathrm{BF}_{4}$ & 3d & $25^{\circ} \mathrm{C}$ & $2 \mathrm{~h}$ & $56 \%$ & $30 \%$ \\
\hline 7 & $\mathrm{Et}$ & $\mathrm{Ph}$ & $\mathrm{Cu}(\mathrm{OTf})_{2}$ & 3d & $25^{\circ} \mathrm{C}$ & $2 \mathrm{~h}$ & $>90 \%$ & $30 \%$ \\
\hline $8^{e}$ & $\mathrm{Et}$ & $\mathrm{Ph}$ & $\mathrm{Cu}\left(\mathrm{CH}_{3} \mathrm{CN}\right)_{4} \mathrm{BF}_{4}$ & $3 d$ & $25^{\circ} \mathrm{C}$ & $2 \mathrm{~h}$ & $>90 \%$ & $23 \%$ \\
\hline 9 & $\mathrm{Et}$ & Cy & $\mathrm{Cu}\left(\mathrm{CH}_{3} \mathrm{CN}\right)_{4} \mathrm{BF}_{4}$ & $3 d$ & $25{ }^{\circ} \mathrm{C}$ & $<1 \mathrm{~h}$ & $>90 \%$ & $30 \%$ \\
\hline 10 & BHT & $\mathrm{Ph}$ & $\mathrm{Cu}\left(\mathrm{CH}_{3} \mathrm{CN}\right)_{4} \mathrm{BF}_{4}$ & 3d & $25^{\circ} \mathrm{C}$ & $<1 \mathrm{~h}$ & $>90 \%$ & $50 \%$ \\
\hline
\end{tabular}

[a] Crude ${ }^{1} \mathrm{H}$ NMR yield using $\mathrm{CH}_{2} \mathrm{Br}_{2}$ as internal standard. [b] Obtained by chiral HPLC. [c] Using DCE/acetone 1:1 as solvent. [d] Using DCE/tAmOH 1:1 as solvent. In this case, the three-component product $\mathbf{6 a}$ was also observed (19\%). [e] Dropwise addition of the diazo in $1 \mathrm{~h}(0.6 \mathrm{M}$ solution in DCE). Et $=$ ethyl, $\mathrm{Ph}=$ phenyl, $\mathrm{Cy}=$ cyclohexyl, $\mathrm{BHT}=2,6$-di-tert-butyl-4-methylphenyl.<smiles>CC(C)C[C@H]1COC(C(C)(C)C2=N[C@H](CC(C)C)CO2)=N1</smiles>

3b<smiles>CC(C)(C)CC1COC(C2(C3=NC(C(C)(C)C)CO3)CC2)=N1</smiles> 
HPLC of compound $4 a$ (entry 3 )
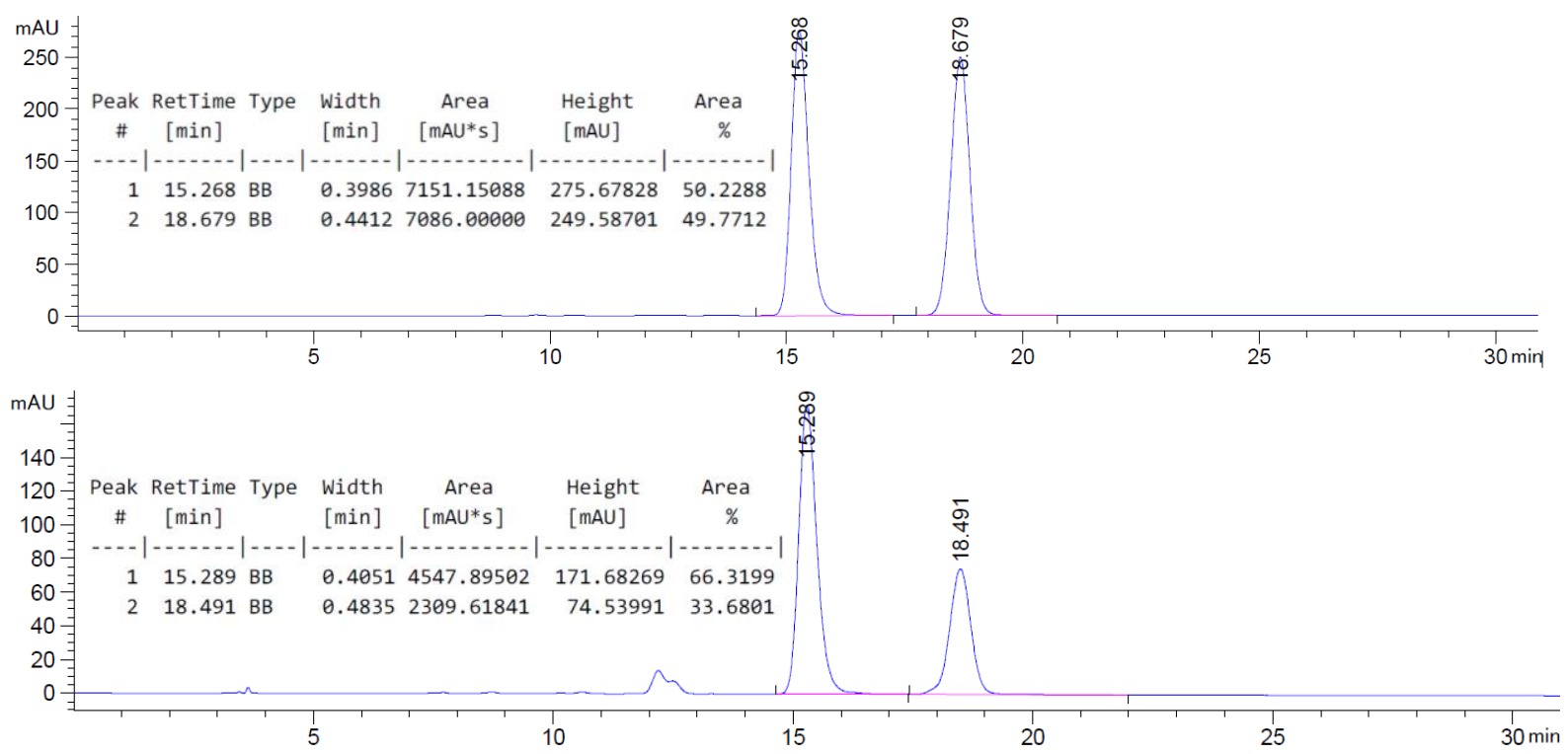

HPLC of compound $\mathbf{4 j}$ (entry 9)
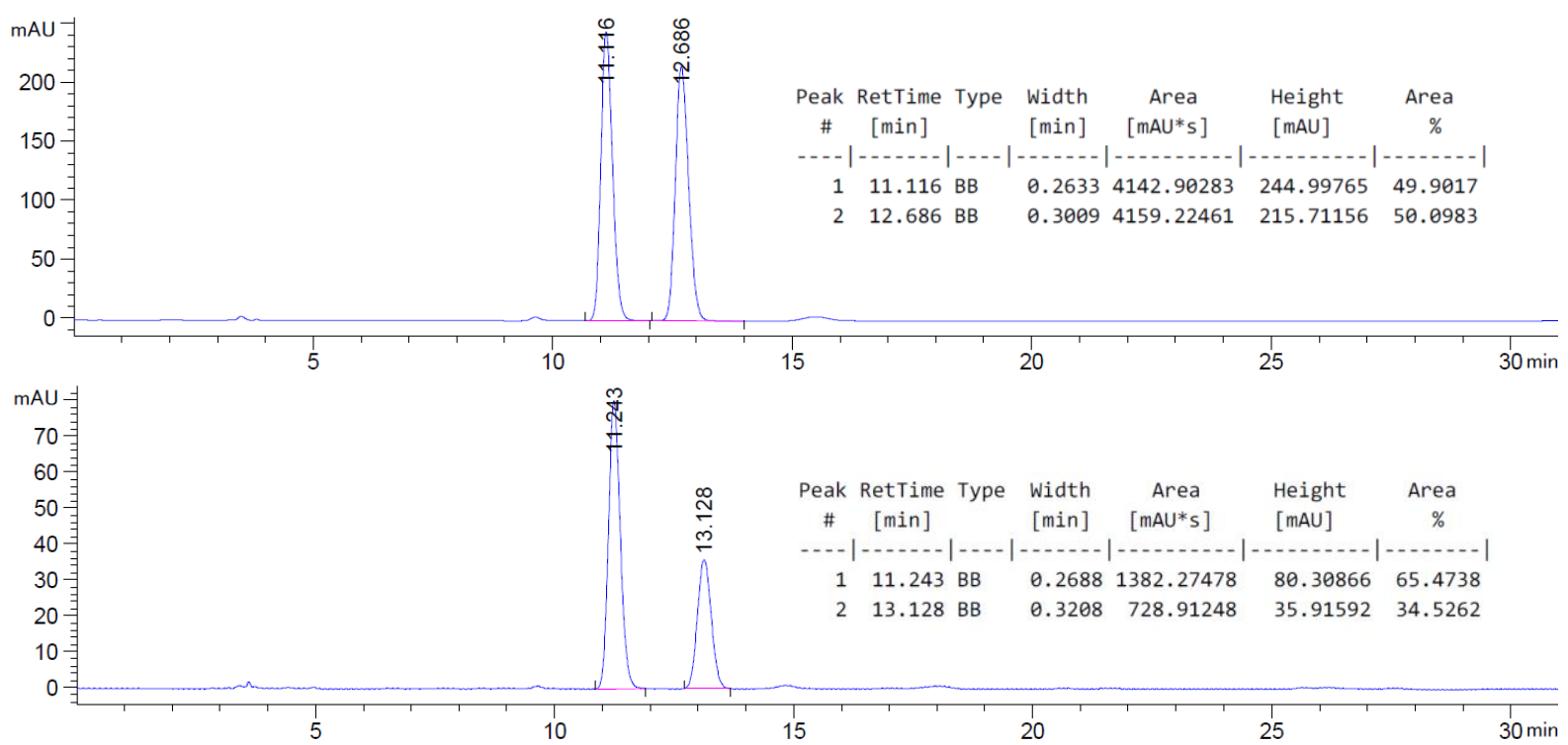
HPLC of compound $5 c$ (entry 10)
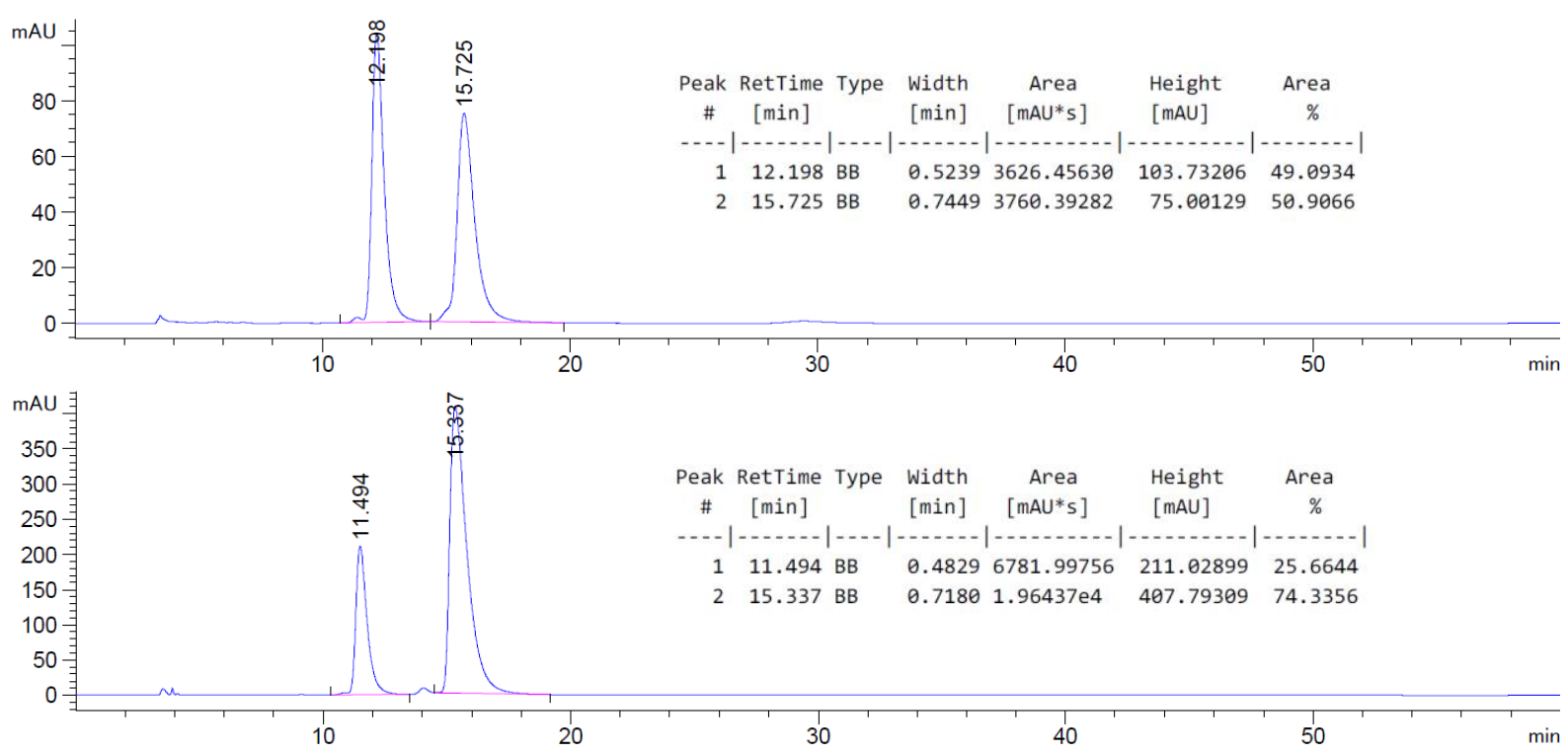
Compound 1'a. CCDC number 1993681.

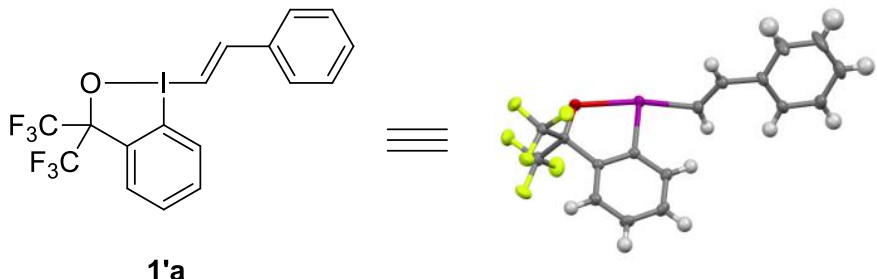

The ORTEP picture has been obtained by using a probability level of $50 \%$ for the ellipsoid display.

Empirical formula

Formula weight

Temperature

Wavelength

Crystal system

Space group

Unit cell dimensions

Volume

Z

Density (calculated)

Absorption coefficient

$\mathrm{F}(000)$

Crystal size

Theta range for data collection

Index ranges

Reflections collected

Independent reflections

Completeness to $q=25.242^{\circ}$

Absorption correction

Max. and min. transmission

Refinement method

Data / restraints / parameters

Goodness-of-fit on $\mathrm{F}^{2}$

Final $\mathrm{R}$ indices $[\mathrm{I}>2 \operatorname{sigma}(\mathrm{I})]$

$\mathrm{R}$ indices (all data)

Largest diff. peak and hole
$\mathrm{C}_{17} \mathrm{H}_{11} \mathrm{~F}_{6} \mathrm{IO}$

472.16

100.00(10) K

$0.71073 \AA$

Monoclinic

$P 2_{1} / c$

$a=11.1353(5) \AA$

$\alpha=90^{\circ}$.

$\mathrm{b}=15.0180(6) \AA$

$\beta=106.691(5)^{\circ}$.

$c=10.6385(5) \AA$

$\gamma=90^{\circ}$.
$1.840 \mathrm{Mg} / \mathrm{m}^{3}$

$1.942 \mathrm{~mm}^{-1}$

912

$0.514 \times 0.114 \times 0.098 \mathrm{~mm}^{3}$

2.415 to $33.022^{\circ}$.

$-16 \leq h \leq 16,-22 \leq k \leq 21,-16 \leq \mathrm{I} \leq 15$

7694

7694

$99.9 \%$

Gaussian

1.000 and 0.696

Full-matrix least-squares on $\mathrm{F}^{2}$

7694 / 0 / 227

0.914

$R_{1}=0.0264, w R_{2}=0.0545$

$R_{1}=0.0419, w R_{2}=0.0568$

1.621 and -0.734 e. $\AA^{-3}$ 
Compound 5c. CCDC number 1897009.
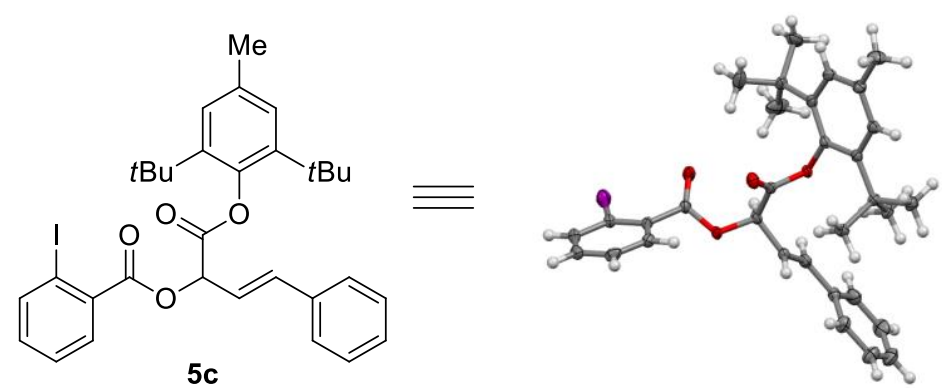

The ORTEP picture has been obtained by using a probability level of $50 \%$ for the ellipsoid display.

Empirical formula

Formula weight

Temperature

Wavelength

Crystal system

Space group

Unit cell dimensions

Volume

Z

Density (calculated)

Absorption coefficient

$\mathrm{F}(000)$

Crystal size

Theta range for data collection

Index ranges

Reflections collected

Independent reflections

Completeness to theta $=67.684^{\circ}$

Absorption correction

Max. and min. transmission

Refinement method

Data / restraints / parameters

Goodness-of-fit on $\mathrm{F}^{2}$

Final $R$ indices [ $\mathrm{I}>2 \operatorname{sigma}(\mathrm{I})]$

$R$ indices (all data)

Largest diff. peak and hole
$\mathrm{C}_{32} \mathrm{H}_{35} \mathrm{IO}_{4}$

610.50

101(1) K

$1.54184 \AA$

Triclinic

$P-1$

$a=10.8114(6) \AA$ $\alpha=81.599(4)^{\circ}$.

$\mathrm{b}=10.9975(5) \AA$ $\beta=82.906(5)^{\circ}$.

$c=12.6115(7) \AA$ $\gamma=78.119(4)^{\circ}$.
2

$1.403 \mathrm{Mg} / \mathrm{m}^{3}$

$8.972 \mathrm{~mm}^{-1}$

624

$0.635 \times 0.181 \times 0.049 \mathrm{~mm}^{3}$

3.559 to $75.162^{\circ}$.

$-13 \leq h \leq 13,-13 \leq k \leq 10,-15 \leq \mathrm{l} \leq 15$

10366

$5771\left[R_{\text {int }}=0.0382\right]$

$99.9 \%$

Analytical

0.675 and 0.116

Full-matrix least-squares on $\mathrm{F}^{2}$

5771 / 0 / 341

1.039

$R_{1}=0.0400, w R_{2}=0.1027$

$R_{1}=0.0464, w R_{2}=0.1072$

0.919 and -1.211 e. $\AA^{-3}$ 
11. Spectra of new compounds

${ }^{1} \mathrm{H}-\mathrm{NMR}\left(400 \mathrm{MHz}\right.$, DMSO-d $\mathrm{d}_{6} / \mathrm{D}_{2} \mathrm{O}$ 9:1) of compound 50n

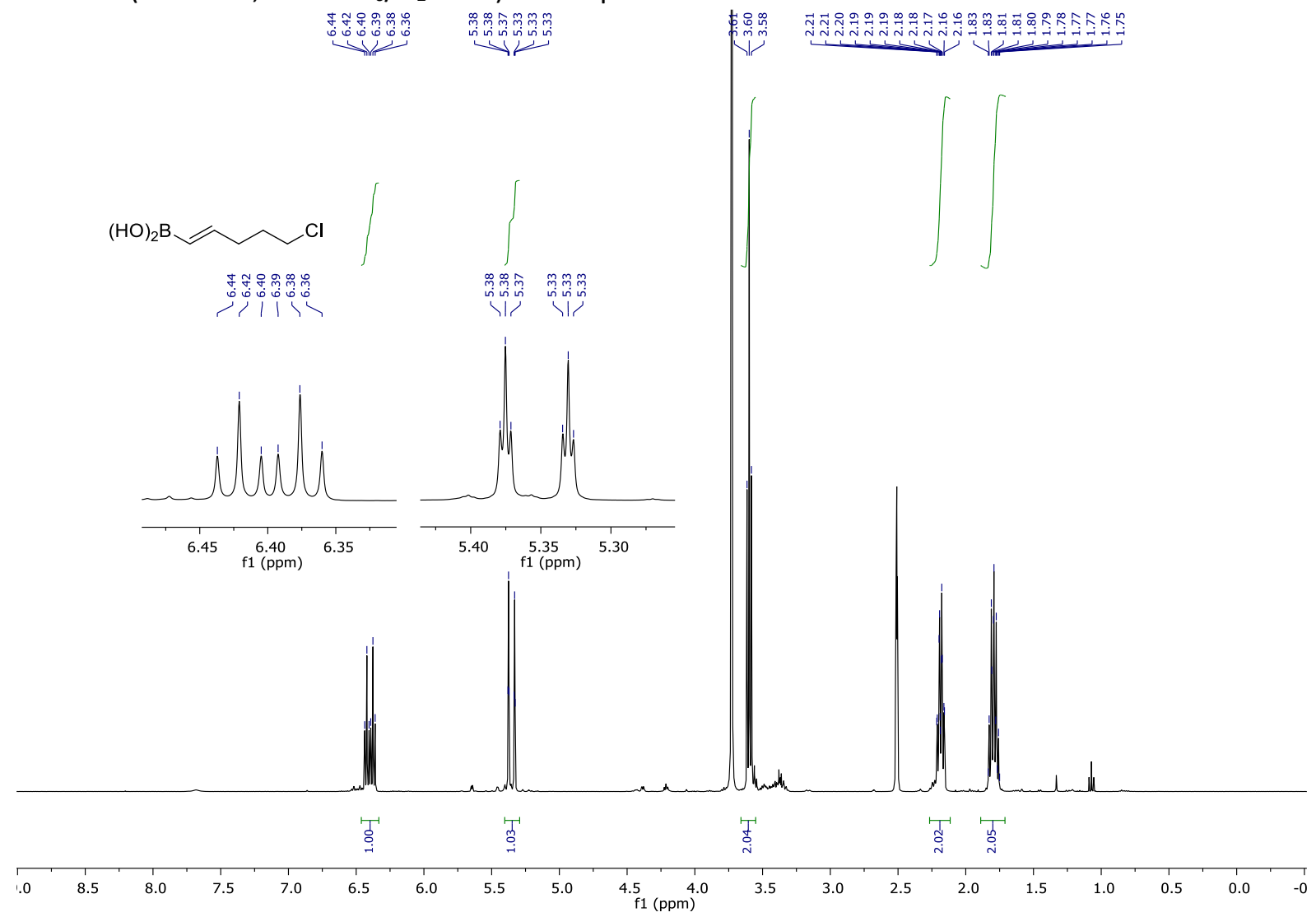

${ }^{13} \mathrm{C}-\mathrm{NMR}\left(101 \mathrm{MHz}\right.$, DMSO- $d_{6} / \mathrm{D}_{2} \mathrm{O}$ 9:1) of compound 50n

$(\mathrm{HO})_{2} \mathrm{~B} \sim \mathrm{Cl}$

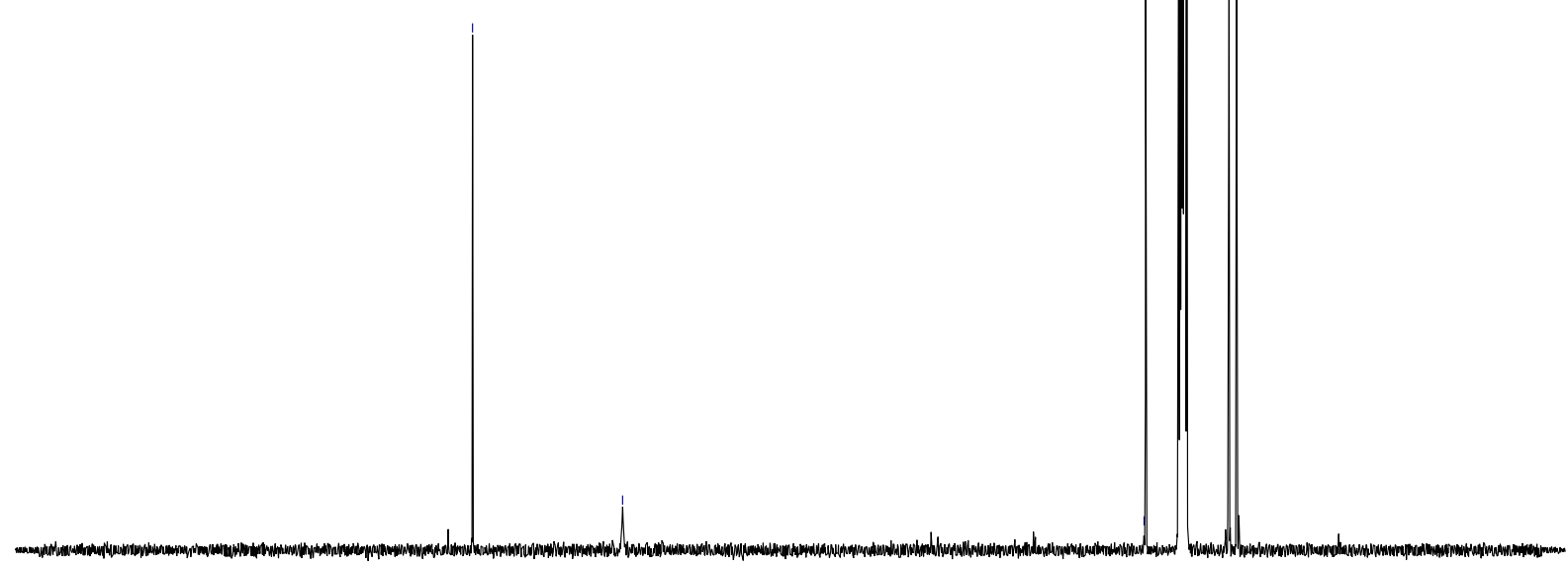

$\begin{array}{lllllllllll}210 & 200 & 190 & 180 & 170 & 160 & 150 & 140 & 130 & 120 & 110 \\ \mathrm{f} 1(\mathrm{ppm}) & 90\end{array}$ 
${ }^{1} \mathrm{H}-\mathrm{NMR}$ (400 MHz, DMSO- $d_{6} / \mathrm{D}_{2} \mathrm{O}$ 9:1) of compound 50p

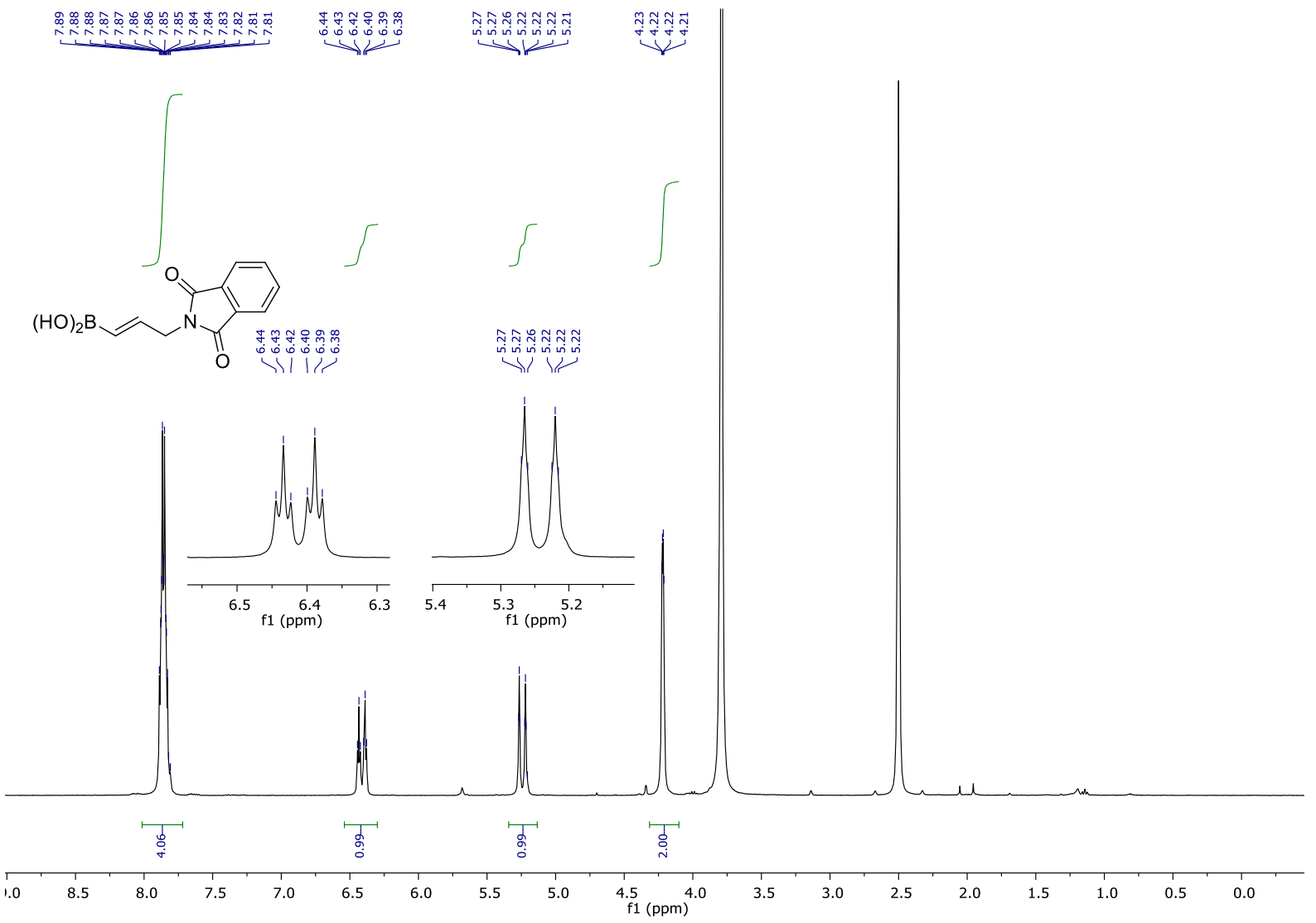

${ }^{13}$ C-NMR (101 MHz, DMSO- $d_{6} / D_{2} \mathrm{O} 9: 1$ ) of compound 50p

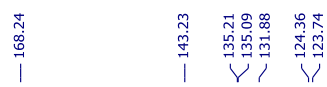<smiles>O=C1c2ccccc2C(=O)N1C/C=C/O</smiles> 
${ }^{1} \mathrm{H}-\mathrm{NMR}\left(400 \mathrm{MHz}\right.$, DMSO- $\left.d_{6} / \mathrm{D}_{2} \mathrm{O} 9: 1\right)$ of compound 50q

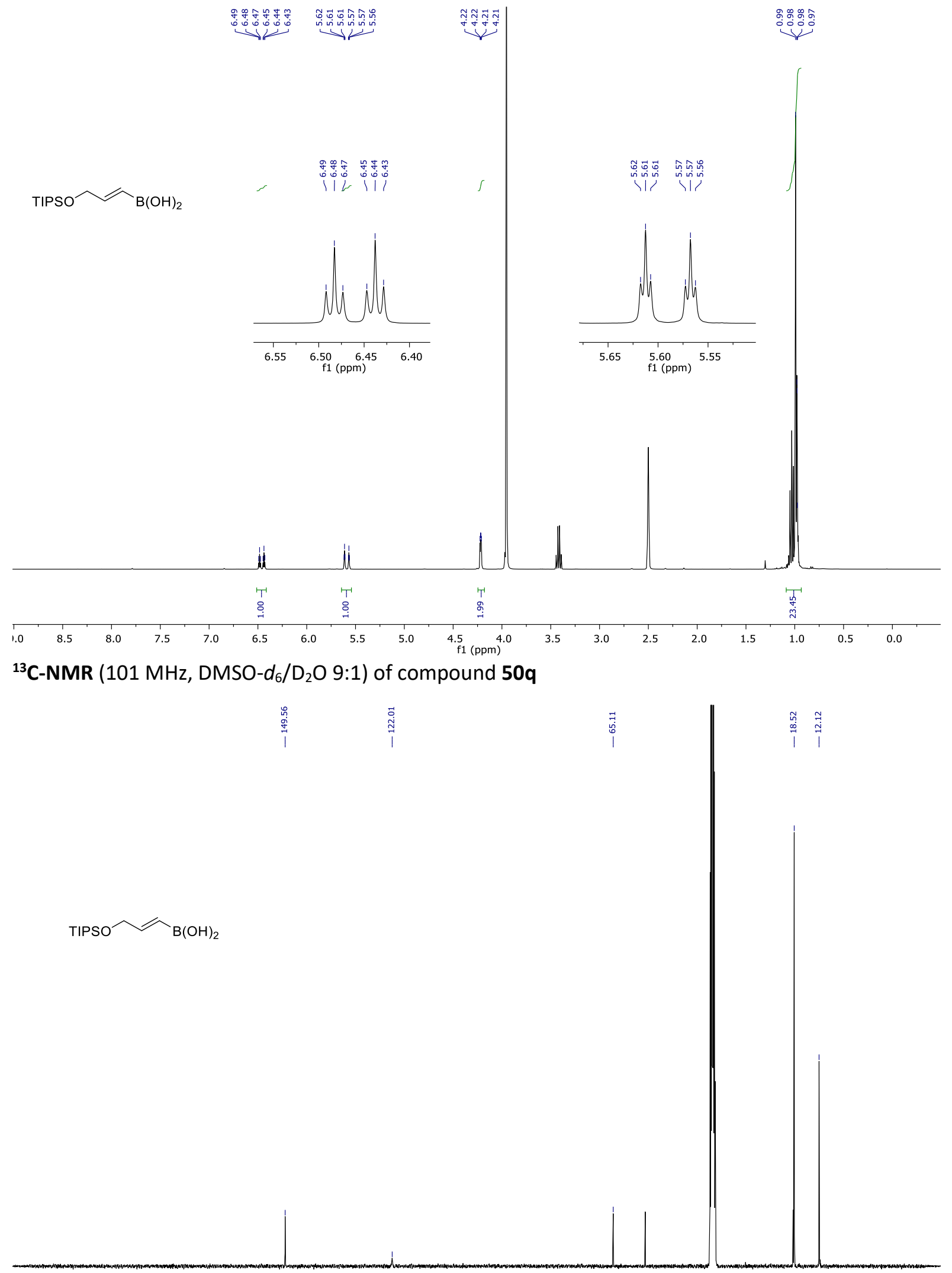

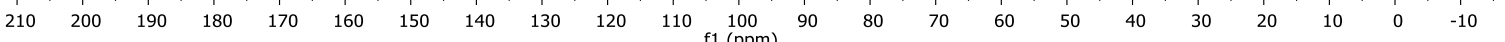


${ }^{1} \mathrm{H}-\mathrm{NMR}\left(400 \mathrm{MHz}\right.$, DMSO- $d_{6} / \mathrm{D}_{2} \mathrm{O} 9: 1$ ) of compound 50t

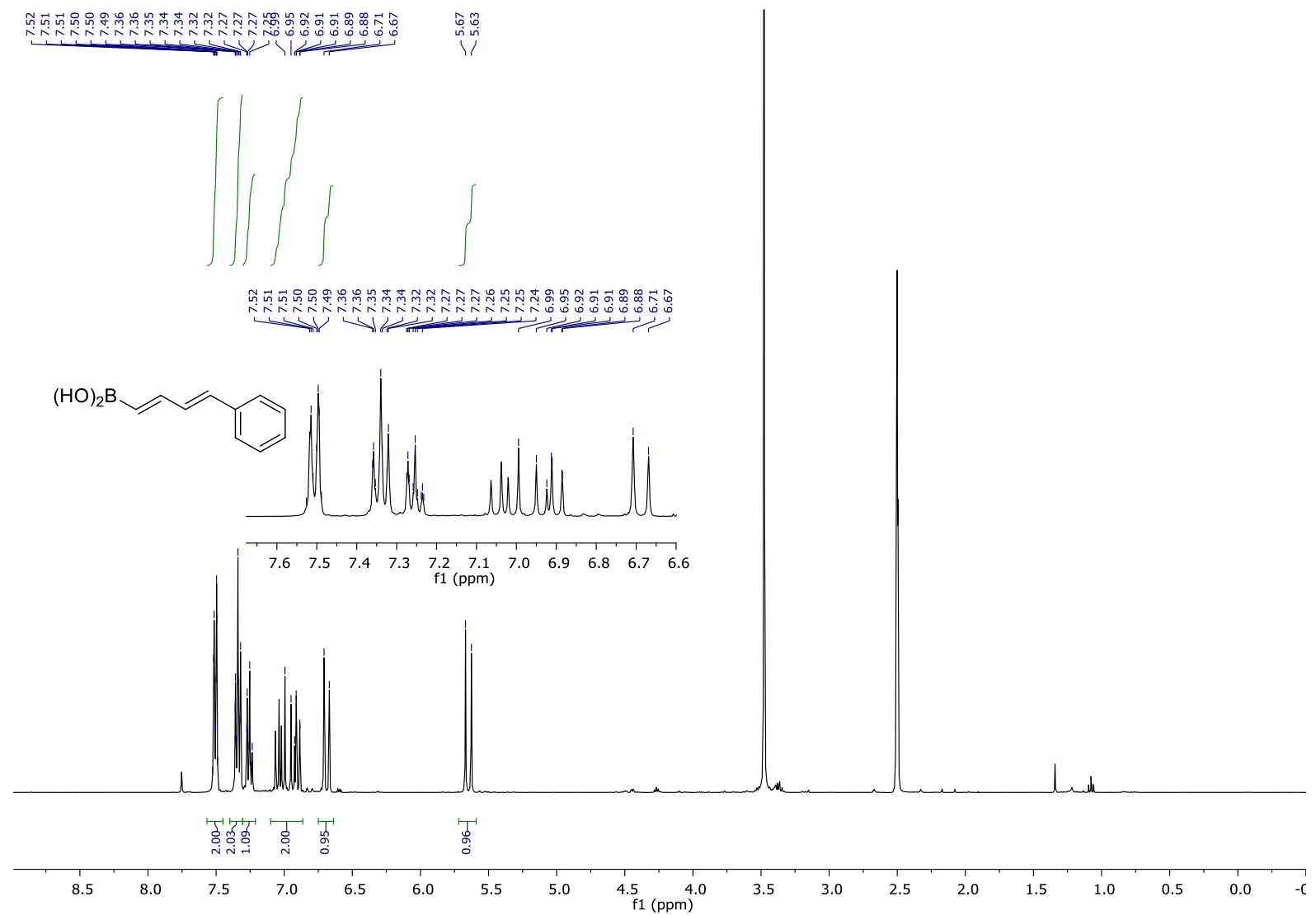

${ }^{13} \mathrm{C}-\mathrm{NMR}\left(101 \mathrm{MHz}\right.$, DMSO- $d_{6} / \mathrm{D}_{2} \mathrm{O}$ 9:1) of compound 50t

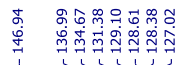

$(\mathrm{HO})_{2} \mathrm{~B}$

舟

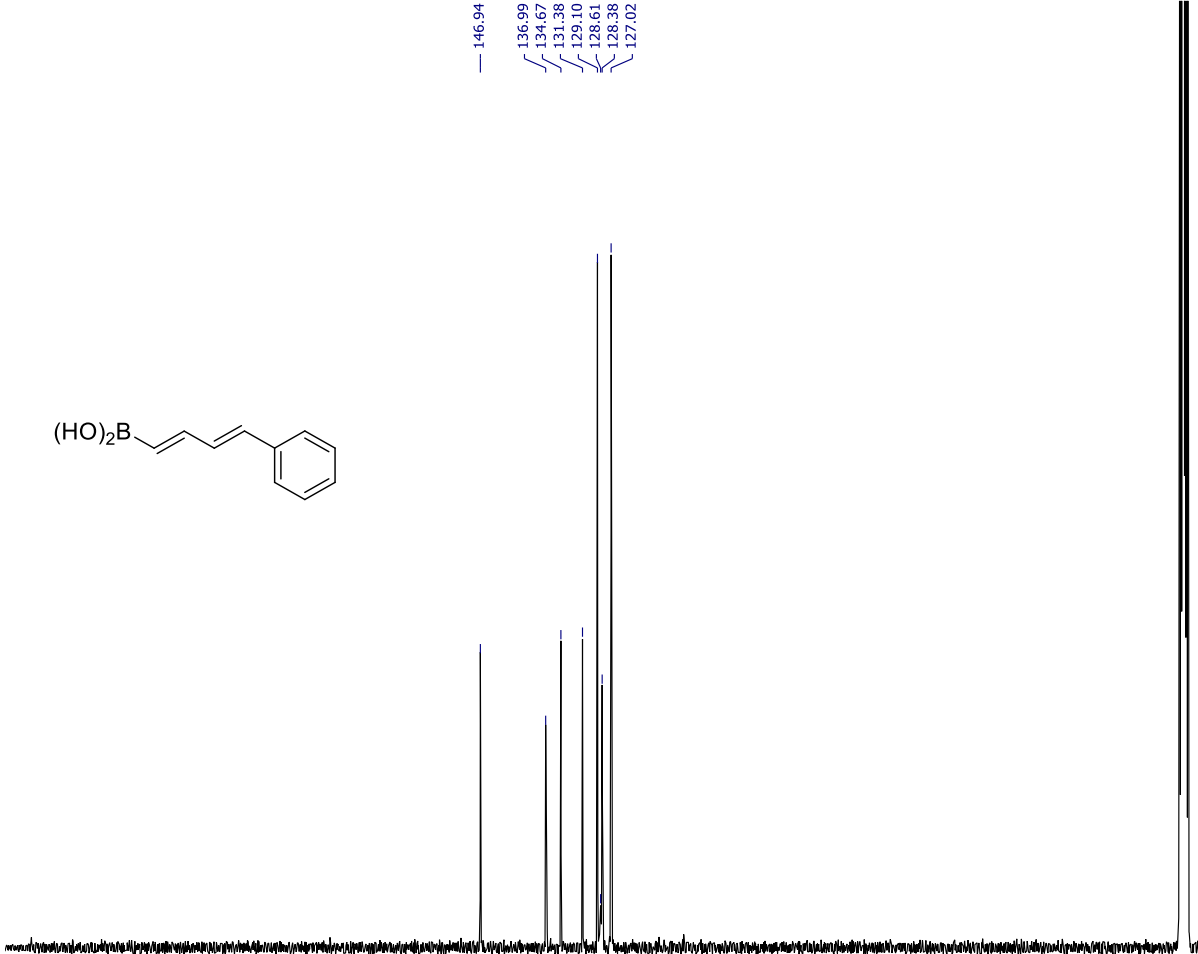

$\begin{array}{llllllllllllllllllllllll}210 & 200 & 190 & 180 & 170 & 160 & 150 & 140 & 130 & 120 & 110 & 100 & 90 & 80 & 70 & 60 & 50 & 40 & 30 & 20 & 10 & 0 & -10\end{array}$ 
${ }^{1} \mathrm{H}-\mathrm{NMR}\left(400 \mathrm{MHz}, \mathrm{DMSO}-d_{6} / \mathrm{D}_{2} \mathrm{O}\right.$ 9:1) of compound $50 \mathrm{u}$

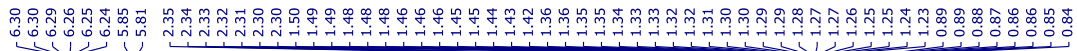

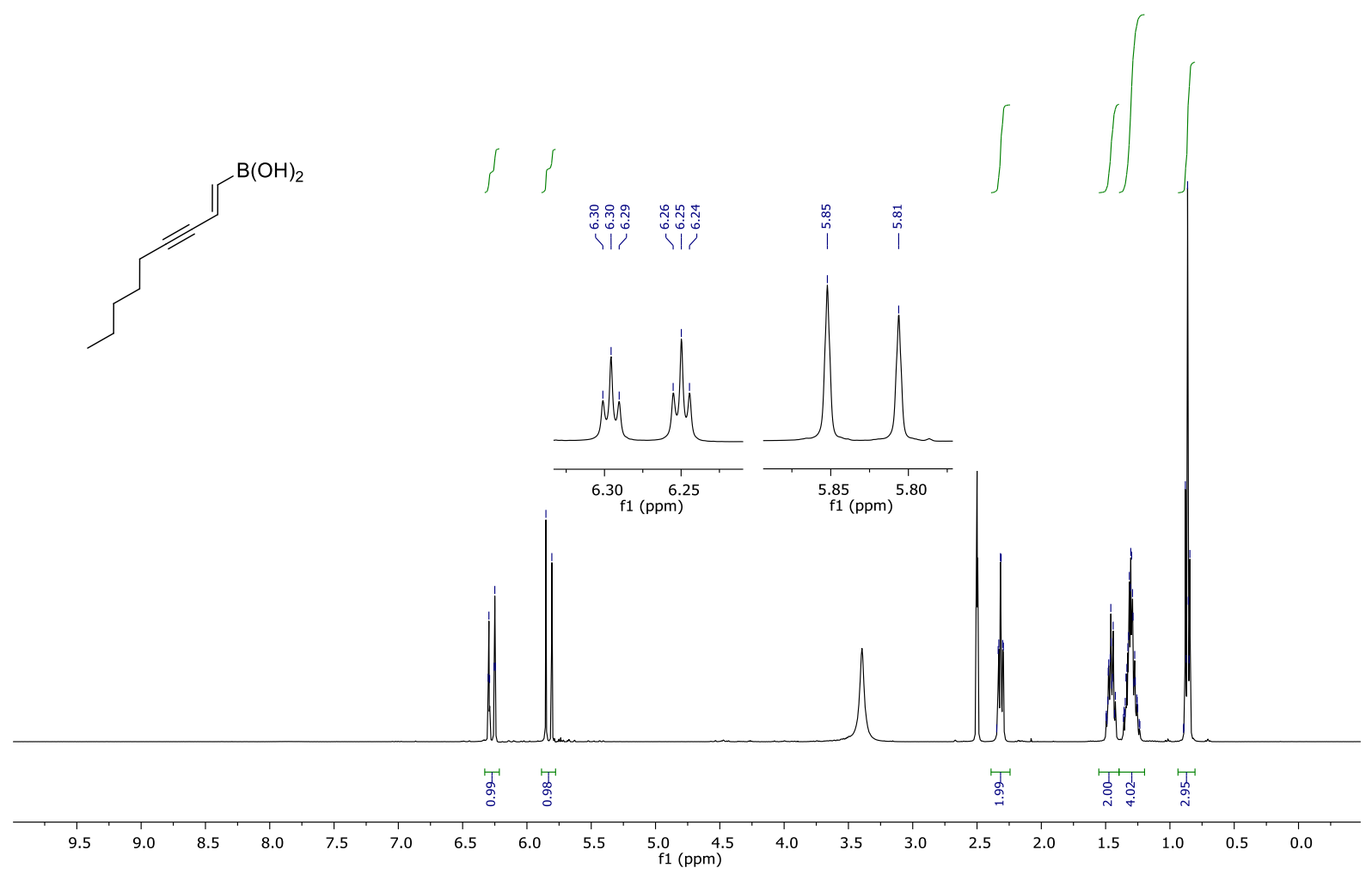

${ }^{13} \mathrm{C}-\mathrm{NMR}\left(101 \mathrm{MHz}\right.$, DMSO- $\left.d_{6} / \mathrm{D}_{2} \mathrm{O} 9: 1\right)$ of compound $50 \mathrm{u}$

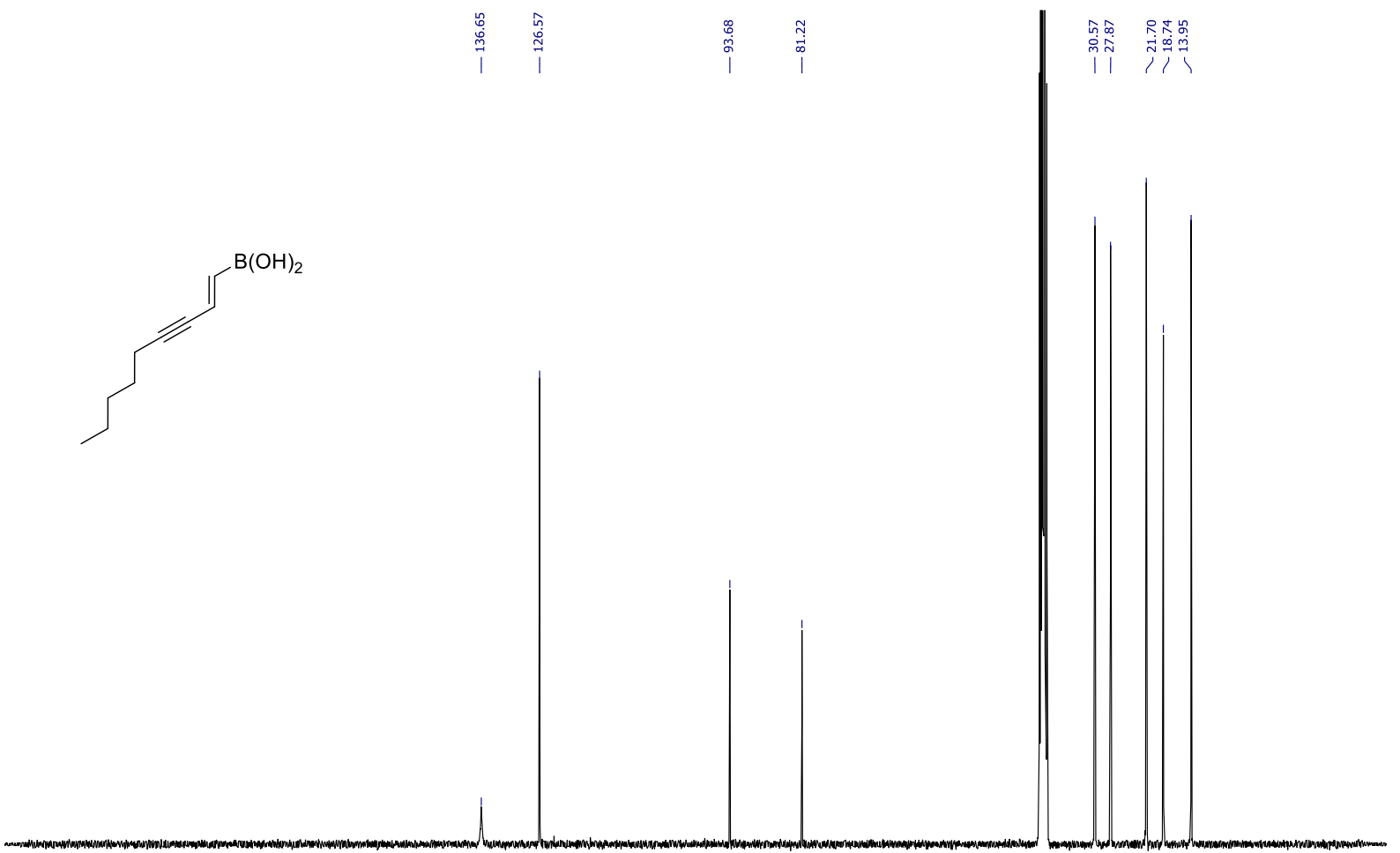

$\begin{array}{lllllllllllllllllllllllll}210 & 200 & 190 & 180 & 170 & 160 & 150 & 140 & 130 & 120 & 110 & 100 & 90 & 80 & 70 & 60 & 50 & 40 & 30 & 20 & 10 & 0 & -10\end{array}$ 
${ }^{1}$ H-NMR (400 MHz, CD 30 O) of compound $1 \mathbf{e}$

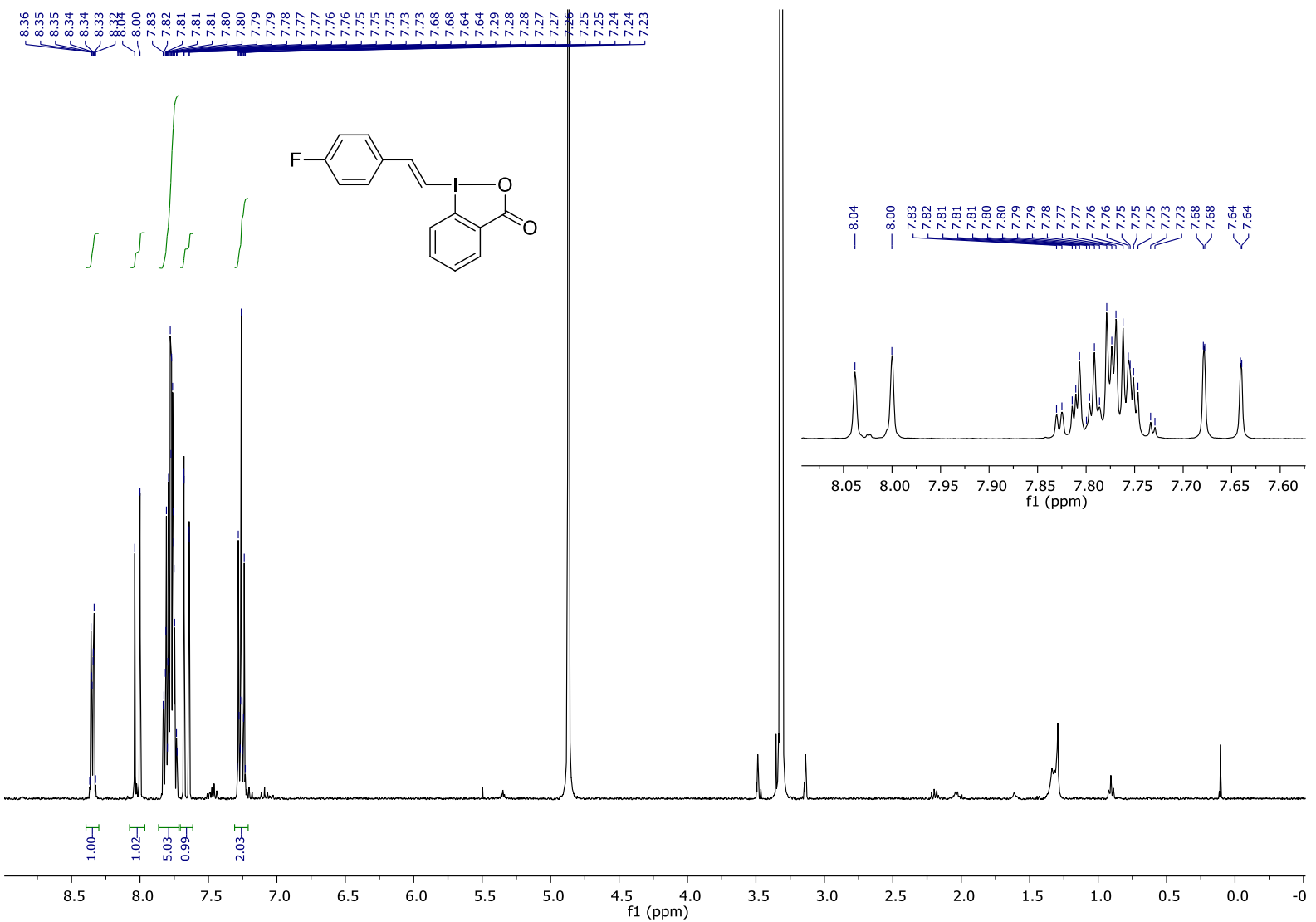

${ }^{13}$ C-NMR (101 MHz, CD ${ }_{3} \mathrm{OD}$ ) of compound 1e

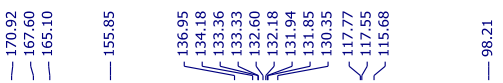

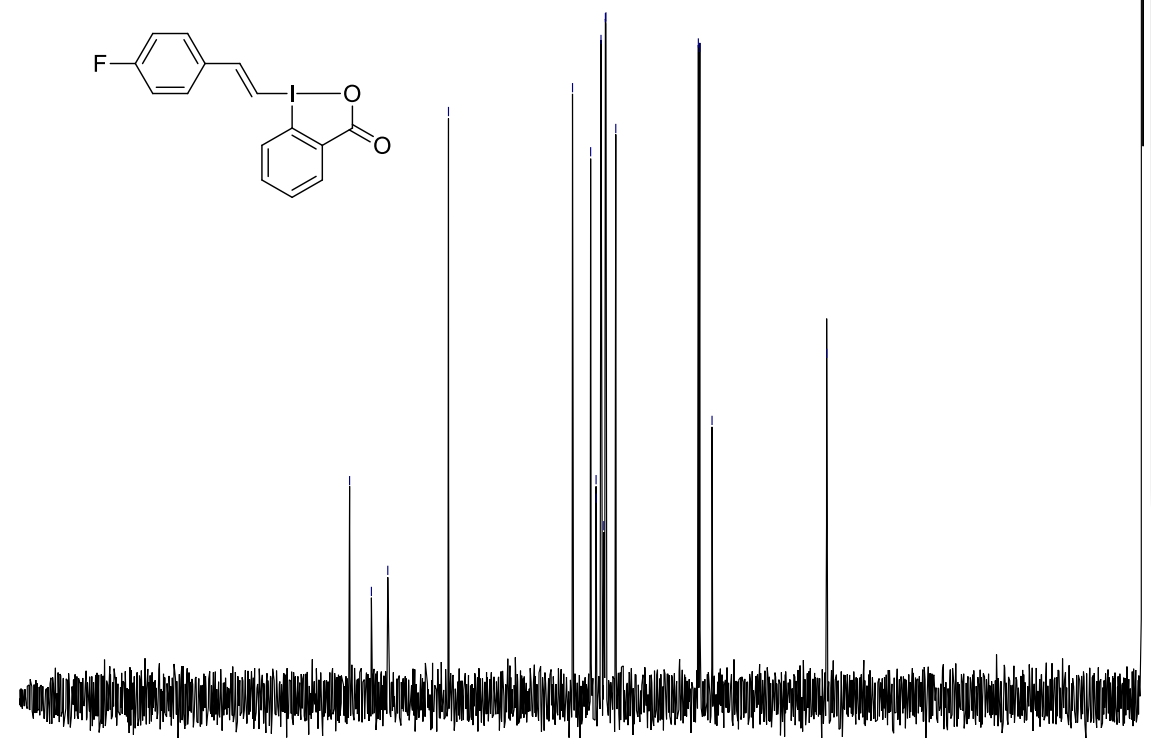

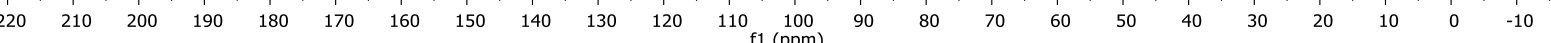


${ }^{19} \mathrm{~F}-\mathrm{NMR}\left(376 \mathrm{MHz}, \mathrm{CD}_{3} \mathrm{OD}\right)$ of compound $1 \mathrm{e}$

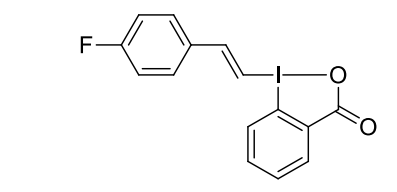

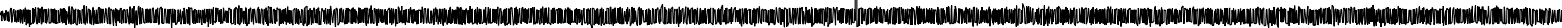

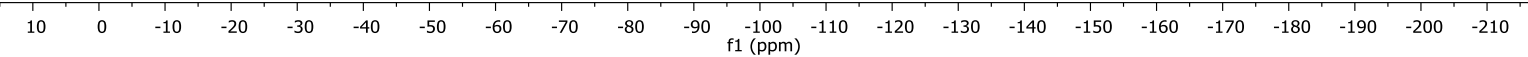


${ }^{1} \mathrm{H}-\mathrm{NMR}\left(400 \mathrm{MHz}, \mathrm{CD}_{3} \mathrm{OD}\right.$ ) of compound $1 \mathrm{f}$

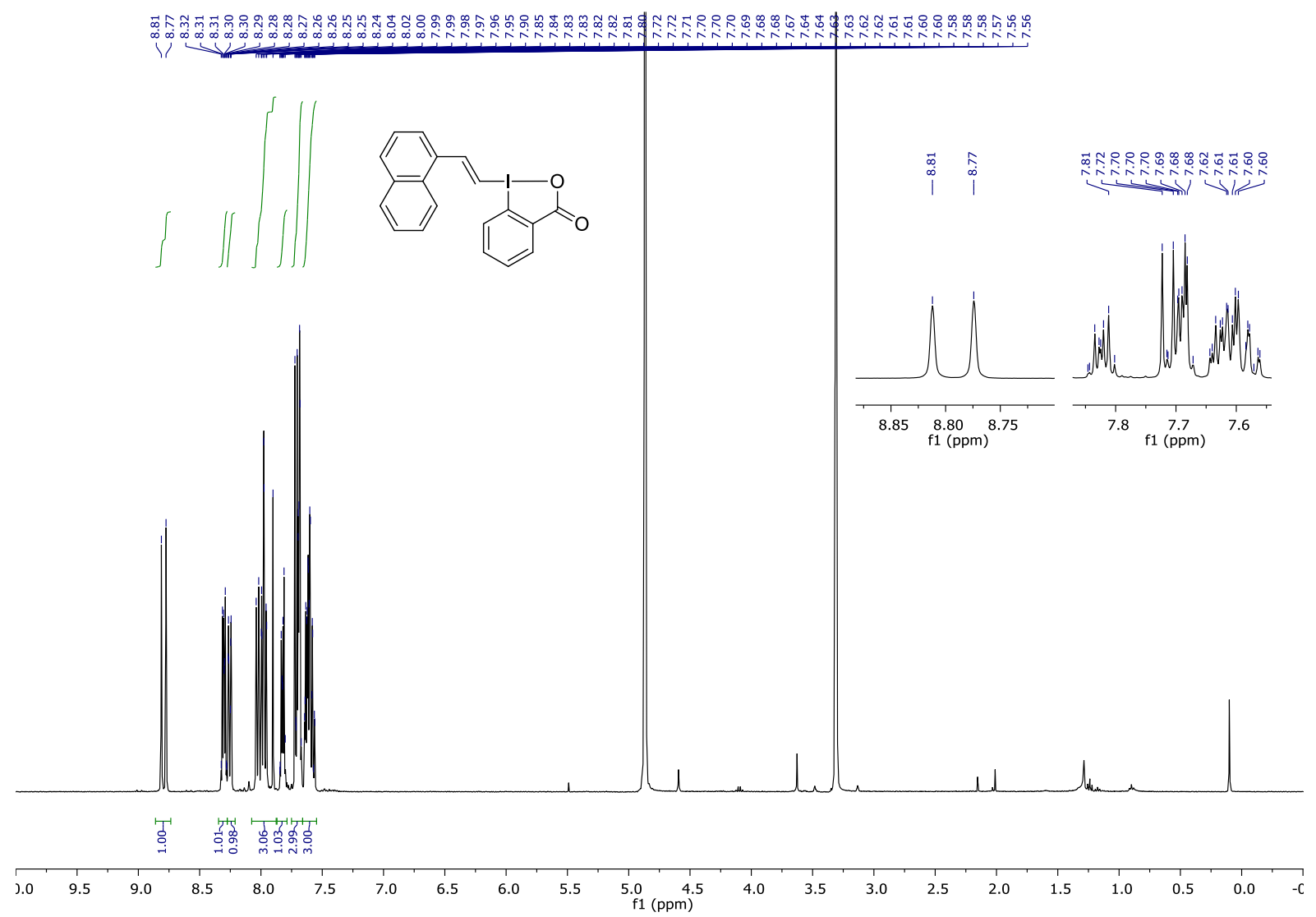

${ }^{13} \mathrm{C}-\mathrm{NMR}\left(101 \mathrm{MHz}, \mathrm{CD}_{3} \mathrm{OD}\right)$ of compound $\mathbf{1 f}$ |
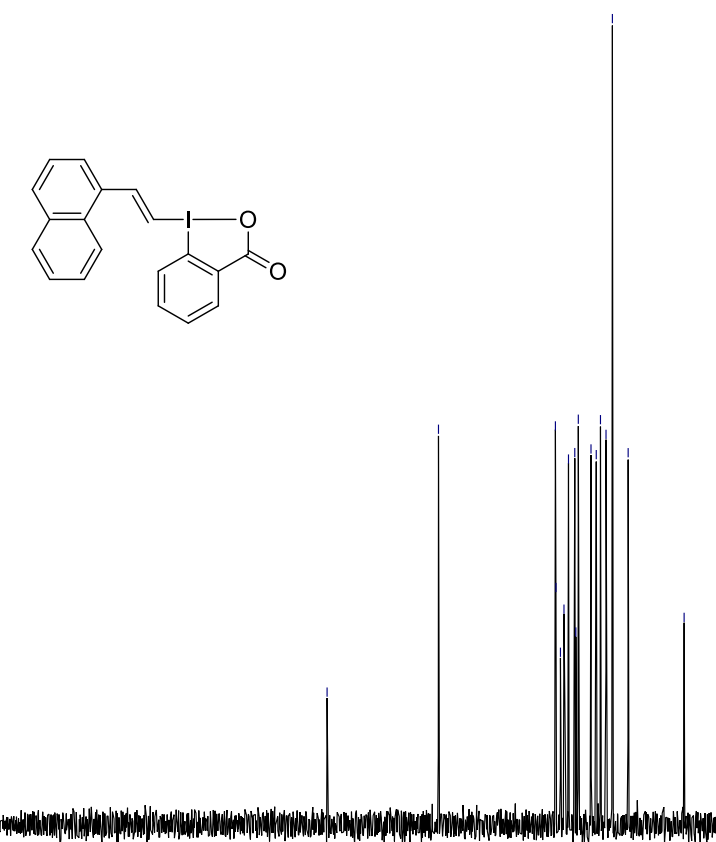

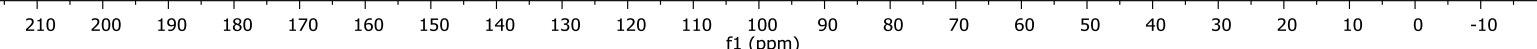


${ }^{1} \mathrm{H}-\mathrm{NMR}\left(400 \mathrm{MHz}, \mathrm{CD}_{3} \mathrm{OD} / \mathrm{CD}_{2} \mathrm{Cl}_{2}\right.$ 9:1) of compound $\mathbf{1 g}$

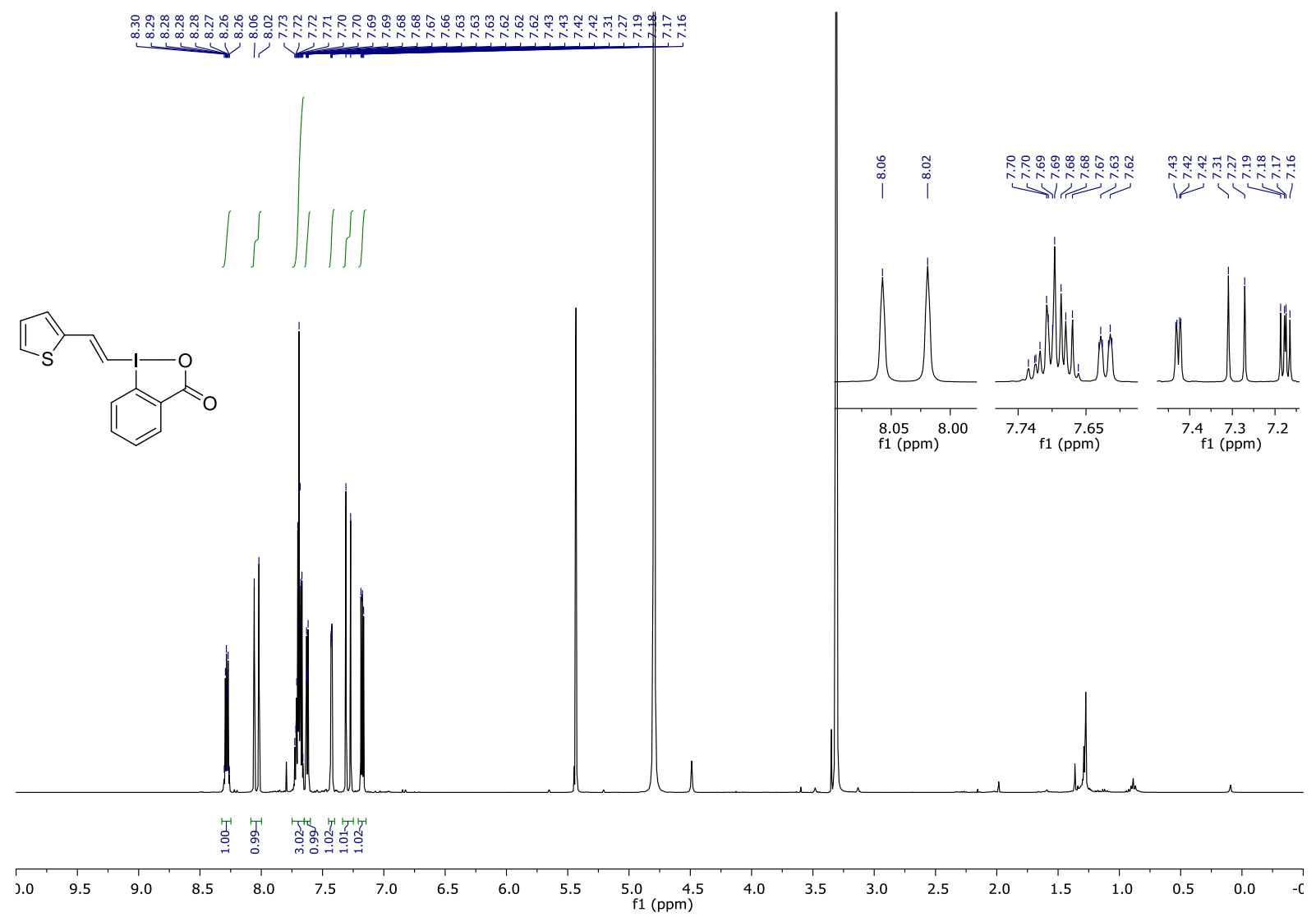

${ }^{13}$ C-NMR (101 MHz, $\mathrm{CD}_{3} \mathrm{OD} / \mathrm{CD}_{2} \mathrm{Cl}_{2}$ 9:1) of compound $\mathbf{1 g}$

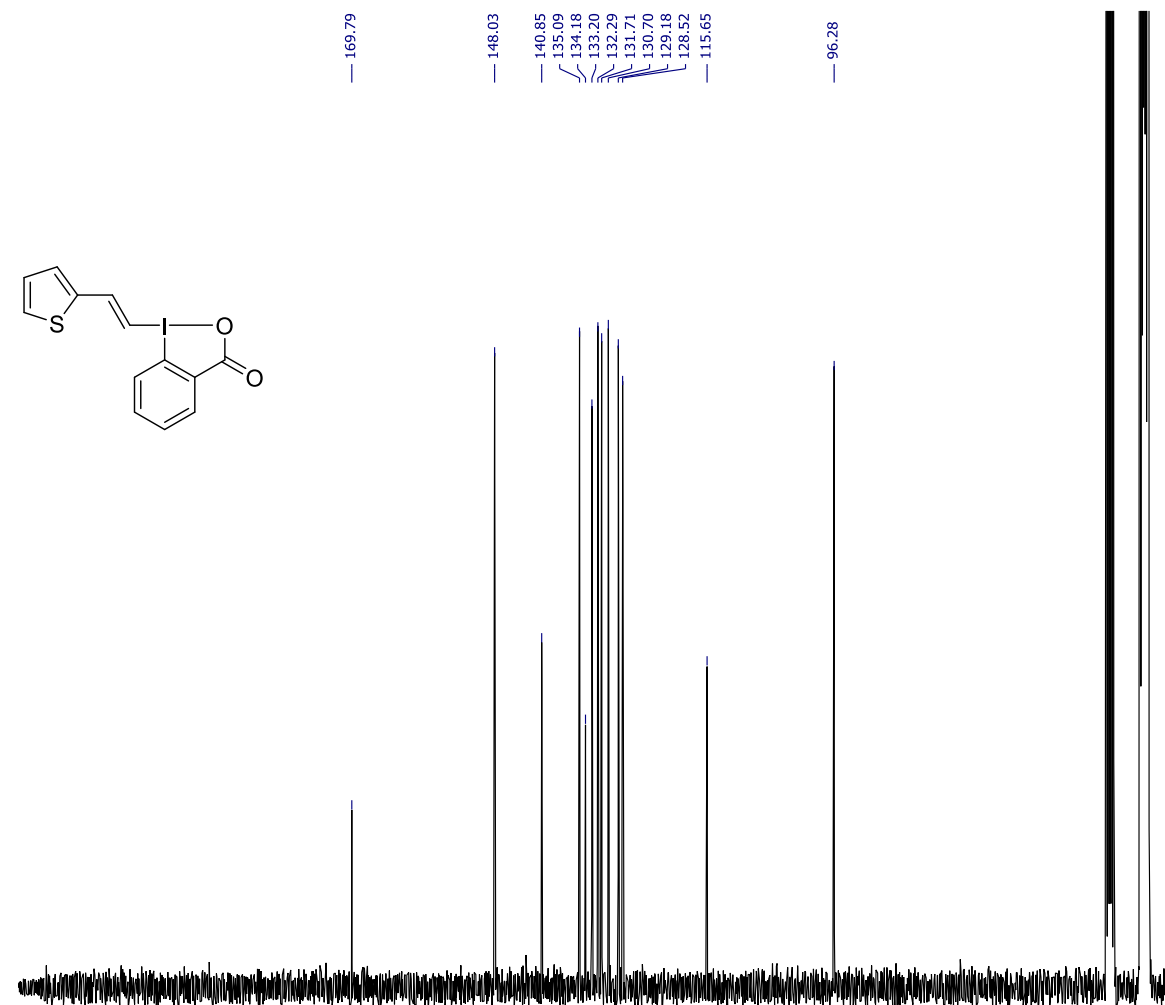

$\begin{array}{lllllllllllllllllllllllll}20 & 210 & 200 & 190 & 180 & 170 & 160 & 150 & 140 & 130 & 120 & 110 & 100 & 90 & 80 & 70 & 60 & 50 & 40 & 30 & 20 & 10 & 0 & -10\end{array}$ 
${ }^{1} \mathbf{H}-\mathrm{NMR}$ (400 MHz, CD ${ }_{3} \mathrm{OD}$ ) of compound $\mathbf{1 h}$

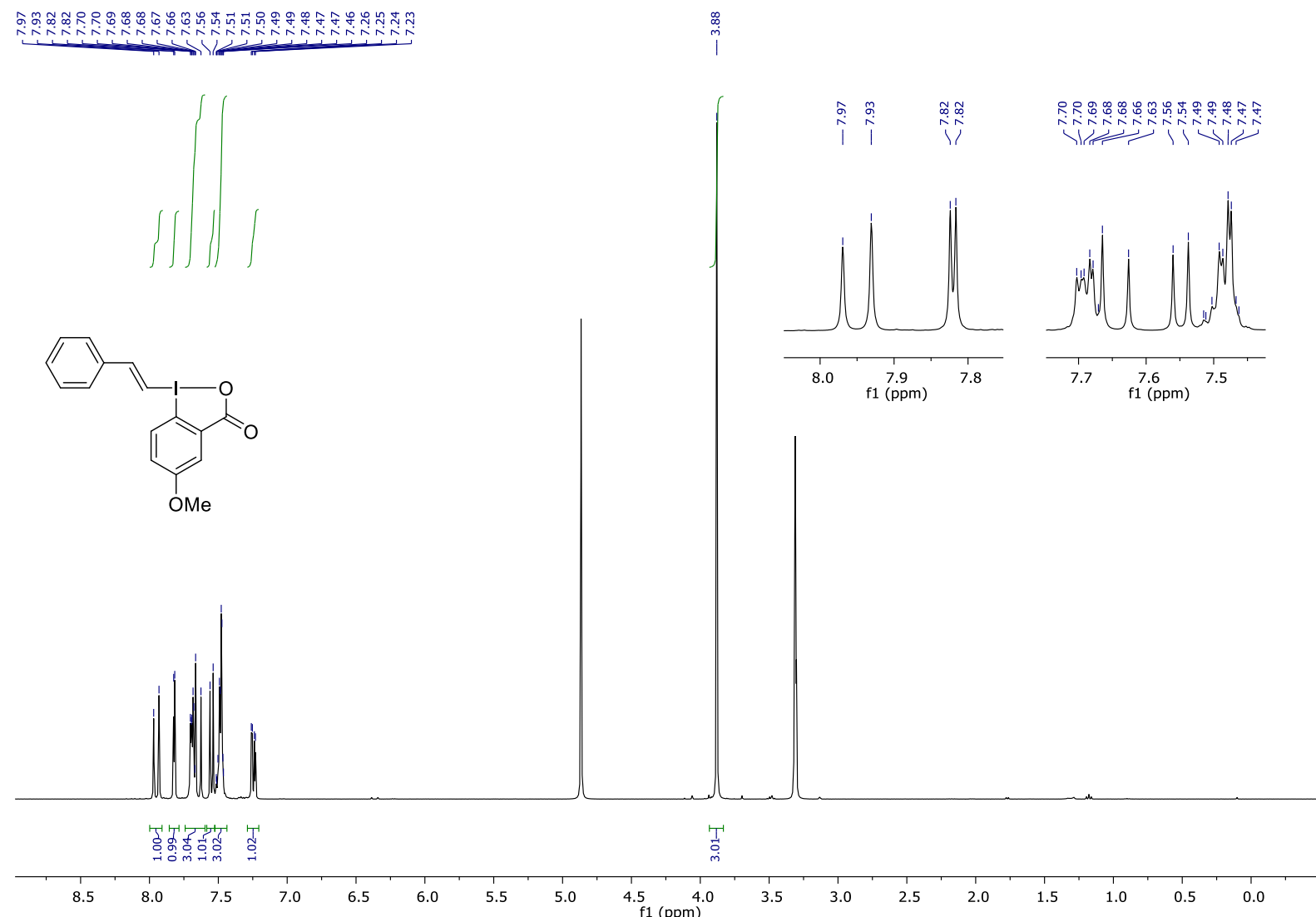

${ }^{13} \mathrm{C}-\mathrm{NMR}\left(101 \mathrm{MHz}, \mathrm{CD}_{3} \mathrm{OD}\right)$ of compound $\mathbf{1 h}$

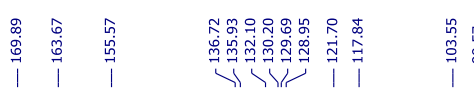
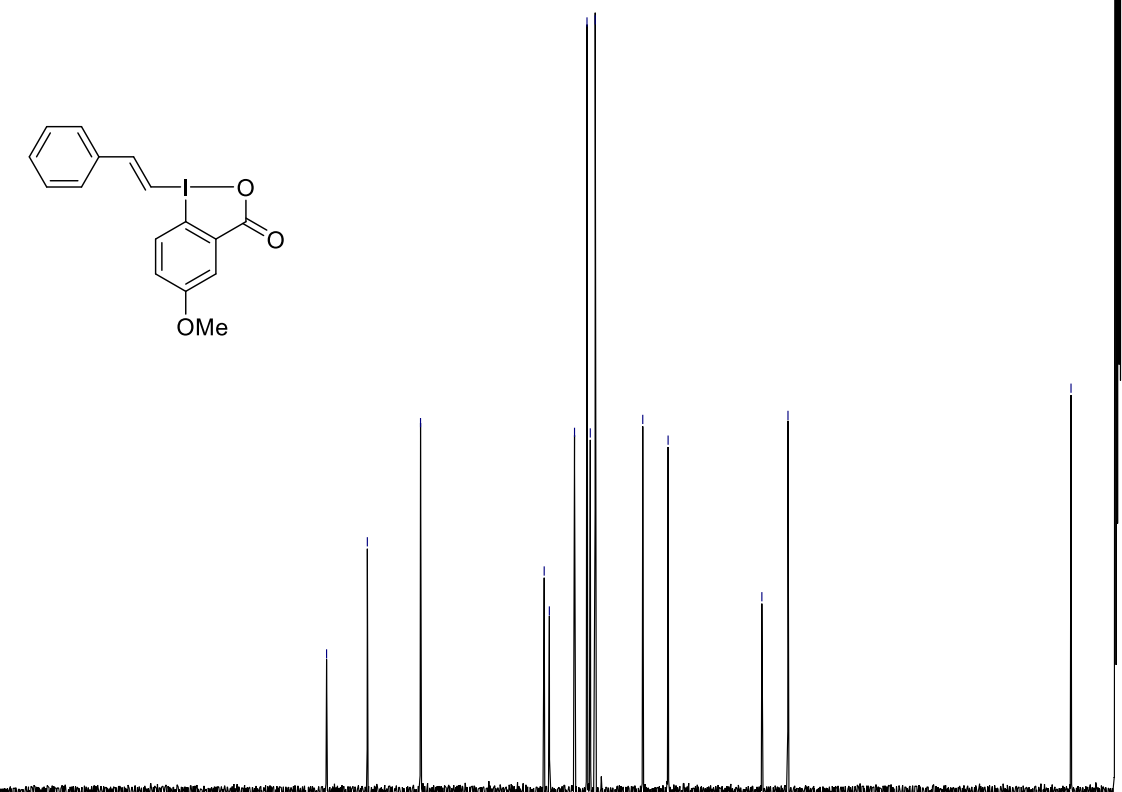

$\begin{array}{llllllllllllllllllllllllllll}120 & 210 & 200 & 190 & 180 & 170 & 160 & 150 & 140 & 130 & 120 & 110 & 100 & 90 & 80 & 70 & 60 & 50 & 40 & 30 & 20 & 10 & 0 & -10 & 10\end{array}$ 
${ }^{1} \mathbf{H}-\mathrm{NMR}$ (400 MHz, CD 3 OD) of compound $\mathbf{1 i}$

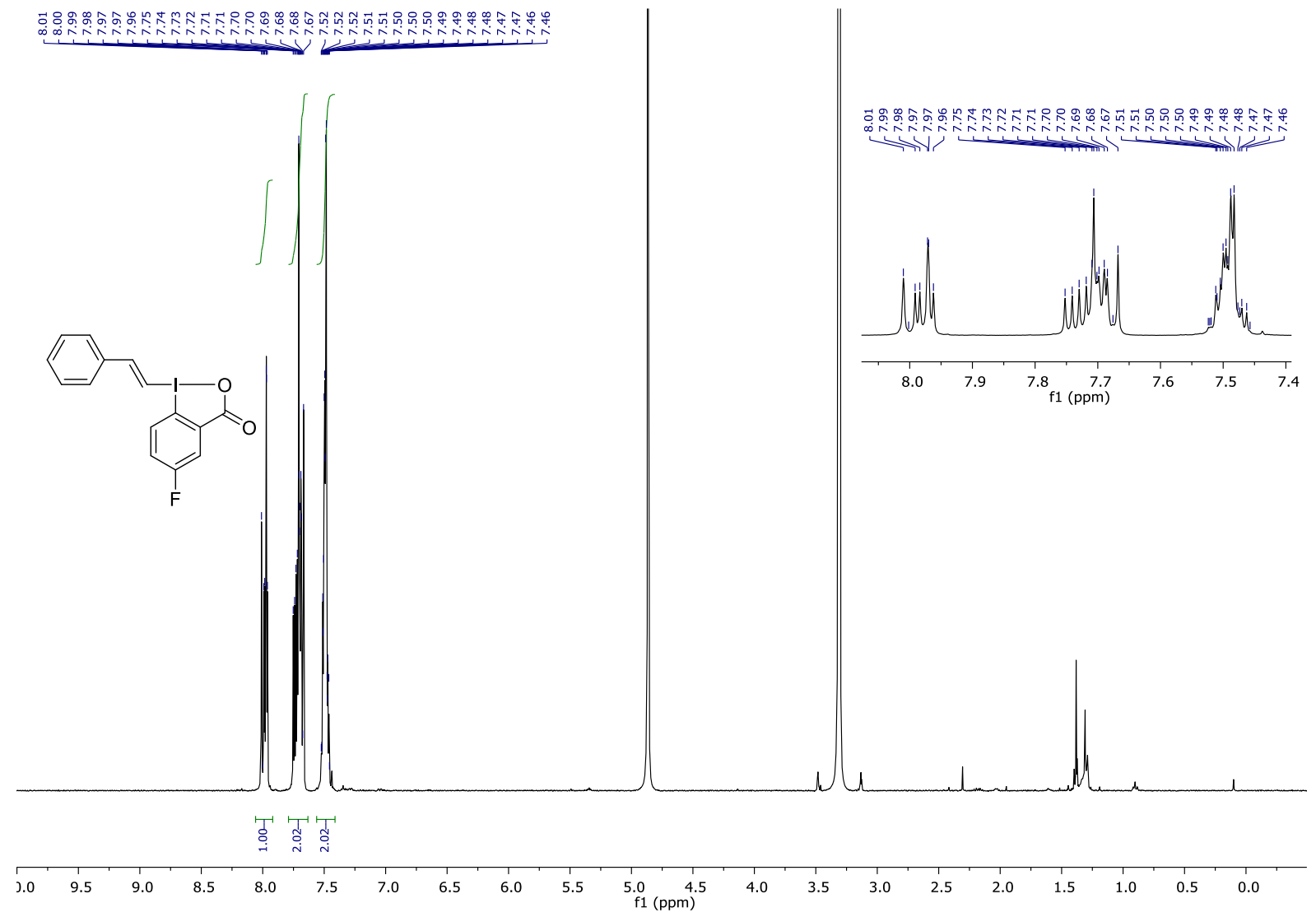

${ }^{13}$ C-NMR (101 MHz, CD ${ }_{3} \mathrm{OD}$ ) of compound $\mathbf{1 i}$

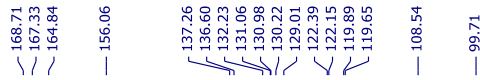

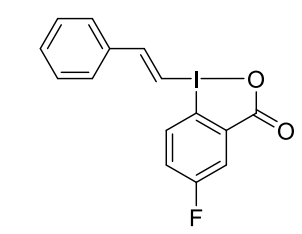

$\begin{array}{llllllllllllllllllllllllllllll}120 & 210 & 200 & 190 & 180 & 170 & 160 & 150 & 140 & 130 & 120 & 110 & 100 & 90 & 80 & 70 & 60 & 50 & 40 & 30 & 20 & 10 & 0 & -10\end{array}$ 
${ }^{19}$ F-NMR (376 MHz, CD $30 D$ ) of compound $\mathbf{1 i}$

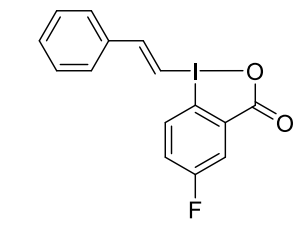

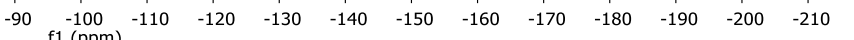


${ }^{1} \mathbf{H}-\mathrm{NMR}\left(400 \mathrm{MHz}, \mathrm{CD}_{3} \mathrm{OD}\right)$ of compound $\mathbf{1} \mathbf{j}$

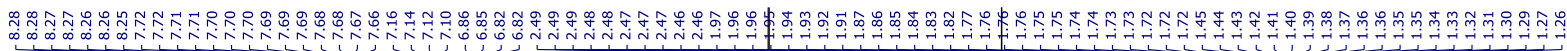

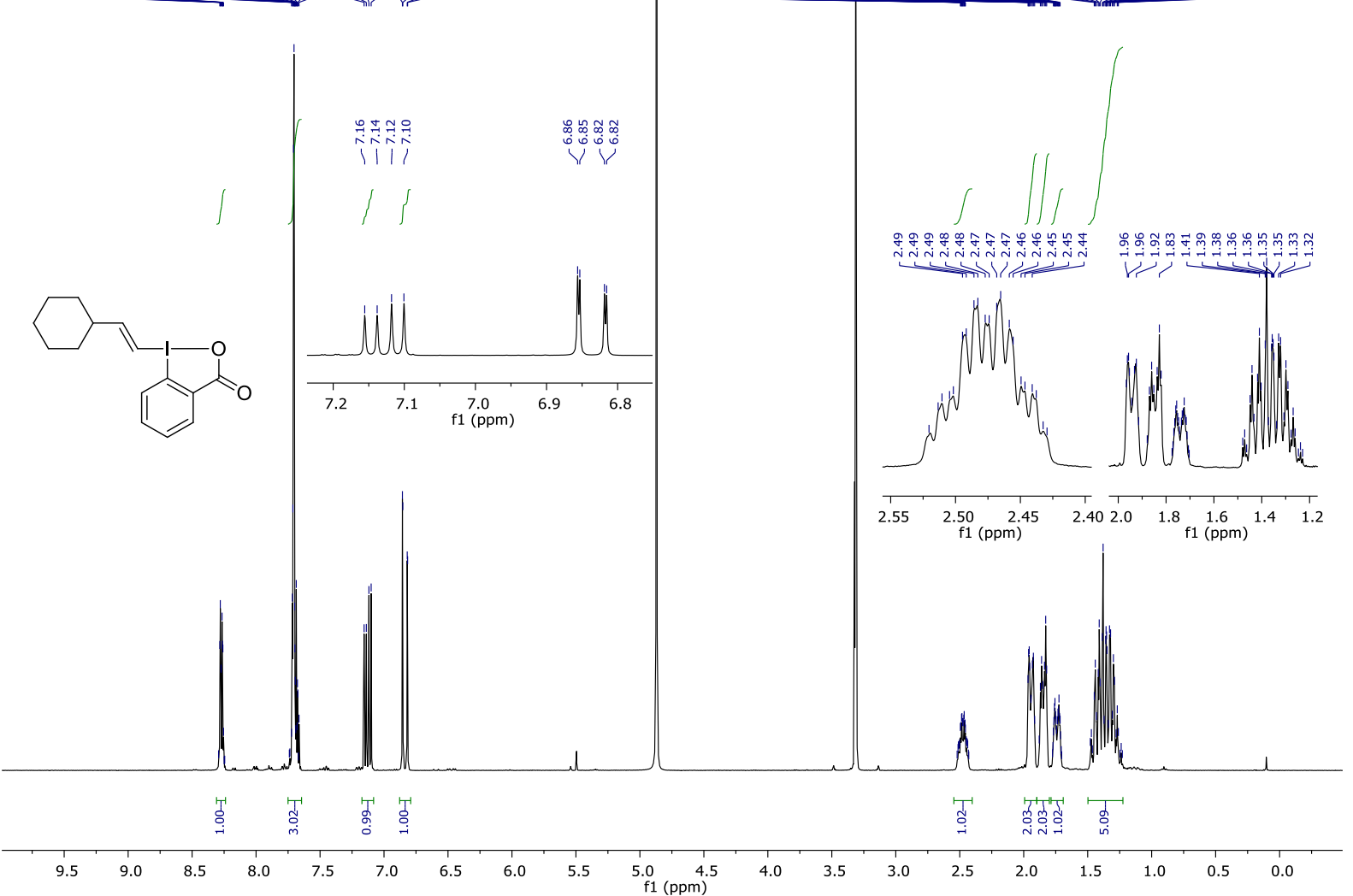

${ }^{13} \mathrm{C}$-NMR (101 MHz, CD $\left.{ }_{3} \mathrm{OD}\right)$ of compound $\mathbf{1 j}$

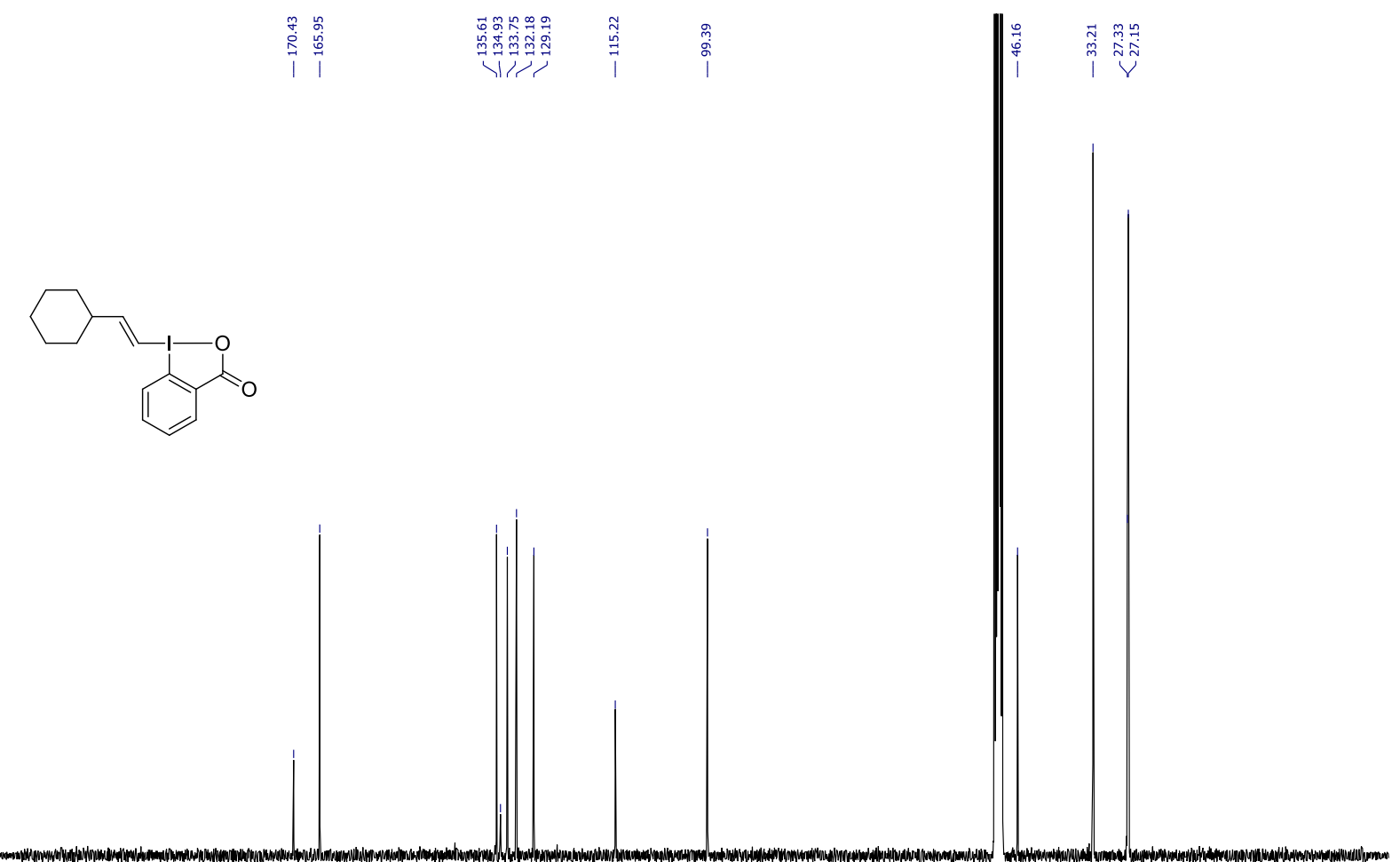

$\begin{array}{llllllllllllllllllllllllll}220 & 210 & 200 & 190 & 180 & 170 & 160 & 150 & 140 & 130 & 120 & 110 & 100 & 90 & 80 & 70 & 60 & 50 & 40 & 30 & 20 & 10 & 0 & -10\end{array}$ 
${ }^{1} \mathbf{H}-\mathrm{NMR}\left(400 \mathrm{MHz}, \mathrm{CD}_{3} \mathrm{OD}\right.$ ) of compound $\mathbf{1 k}$

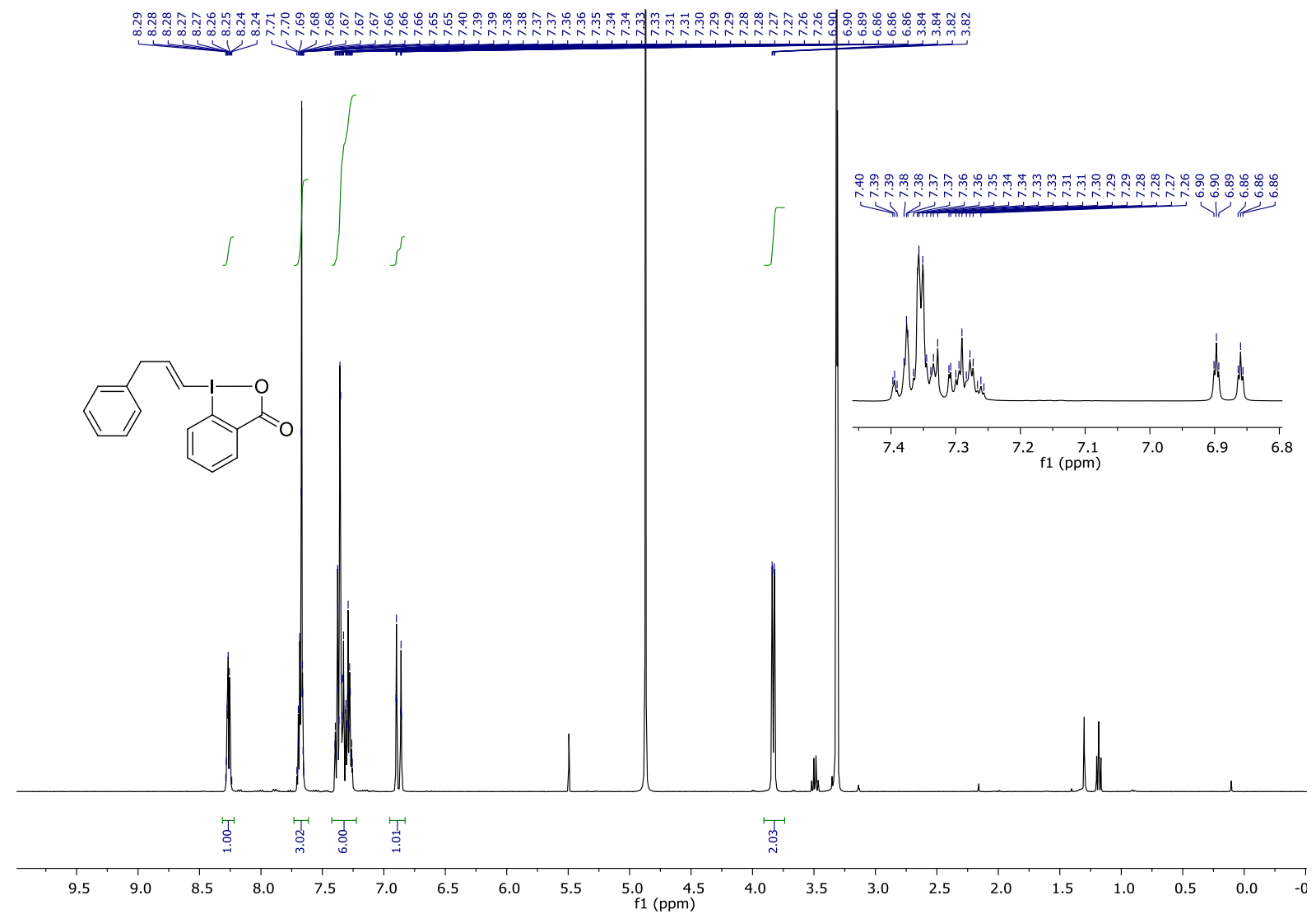

${ }^{13} \mathrm{C}$-NMR (101 MHz, CD 30 OD) of compound $\mathbf{1 k}$
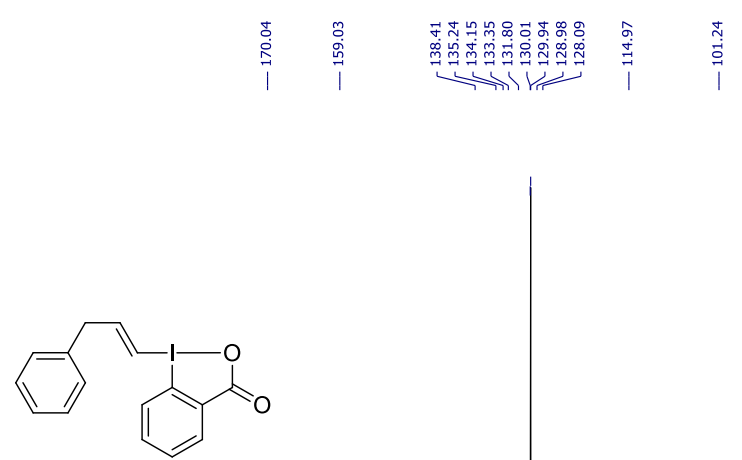

$\begin{array}{llllllllllllllllllllllllll}120 & 210 & 200 & 190 & 180 & 170 & 160 & 150 & 140 & 130 & 120 & 110 & 100 & 90 & 80 & 70 & 60 & 50 & 40 & 30 & 20 & 10 & 0 & -10\end{array}$ 
${ }^{1} \mathrm{H}-\mathrm{NMR}\left(400 \mathrm{MHz}, \mathrm{CD}_{3} \mathrm{OD}\right.$ ) of compound $\mathbf{1}$ )

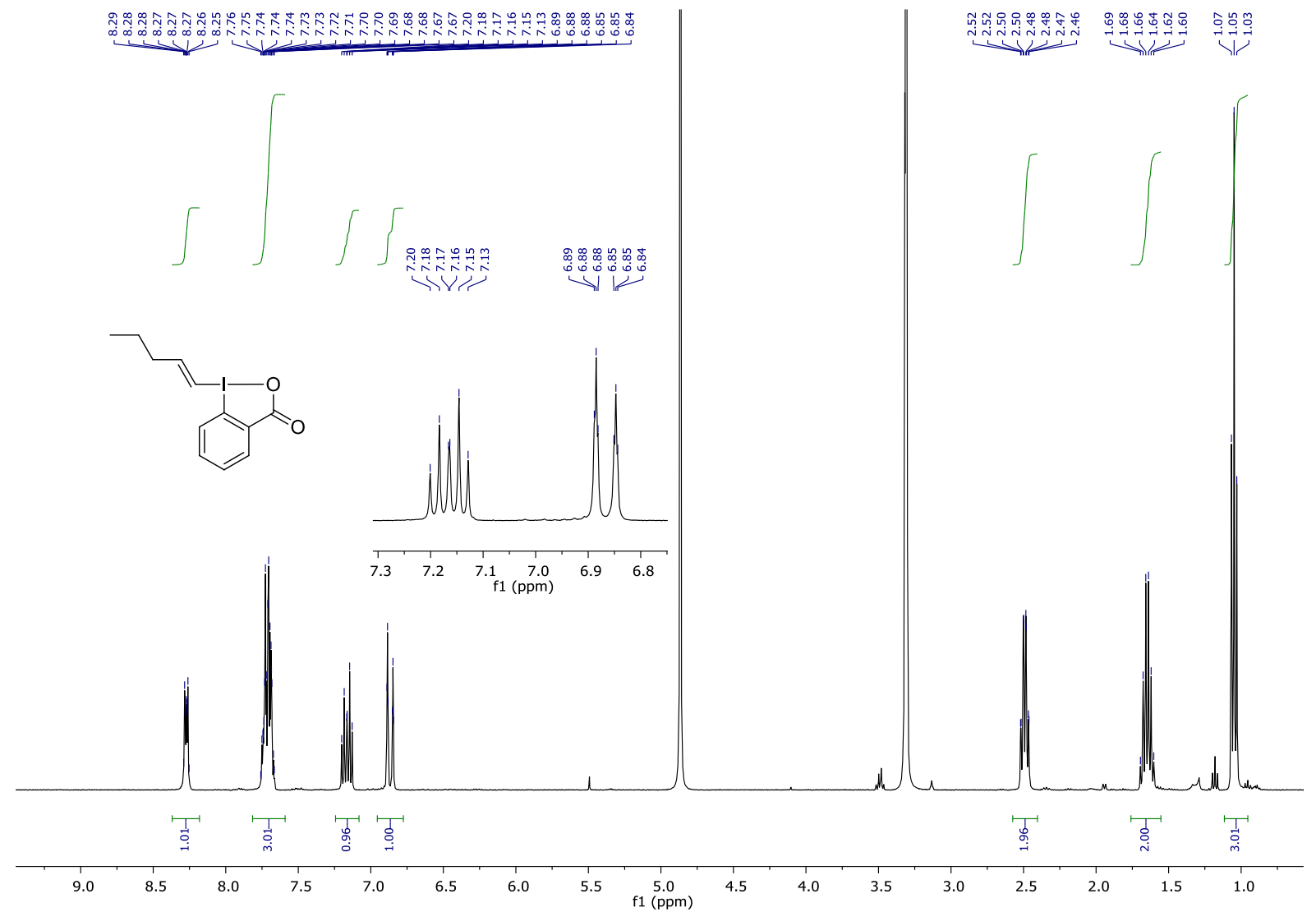

${ }^{13} \mathrm{C}$-NMR (101 MHz, CD ${ }_{3} \mathrm{OD}$ ) of compound 1 I<smiles>CCCC=C1OC(=O)c2ccccc21</smiles>

$\begin{array}{llllllllllll}20 & 210 & 200 & 190 & 180 & 170 & 160 & 150 & 140 & 130 & 120 & 110 \\ \mathrm{f} 1(\mathrm{ppm})\end{array}$ 
${ }^{1} \mathrm{H}-\mathrm{NMR}$ (400 MHz, CD ${ }_{3} \mathrm{OD}$ ) of compound $\mathbf{1 m}$

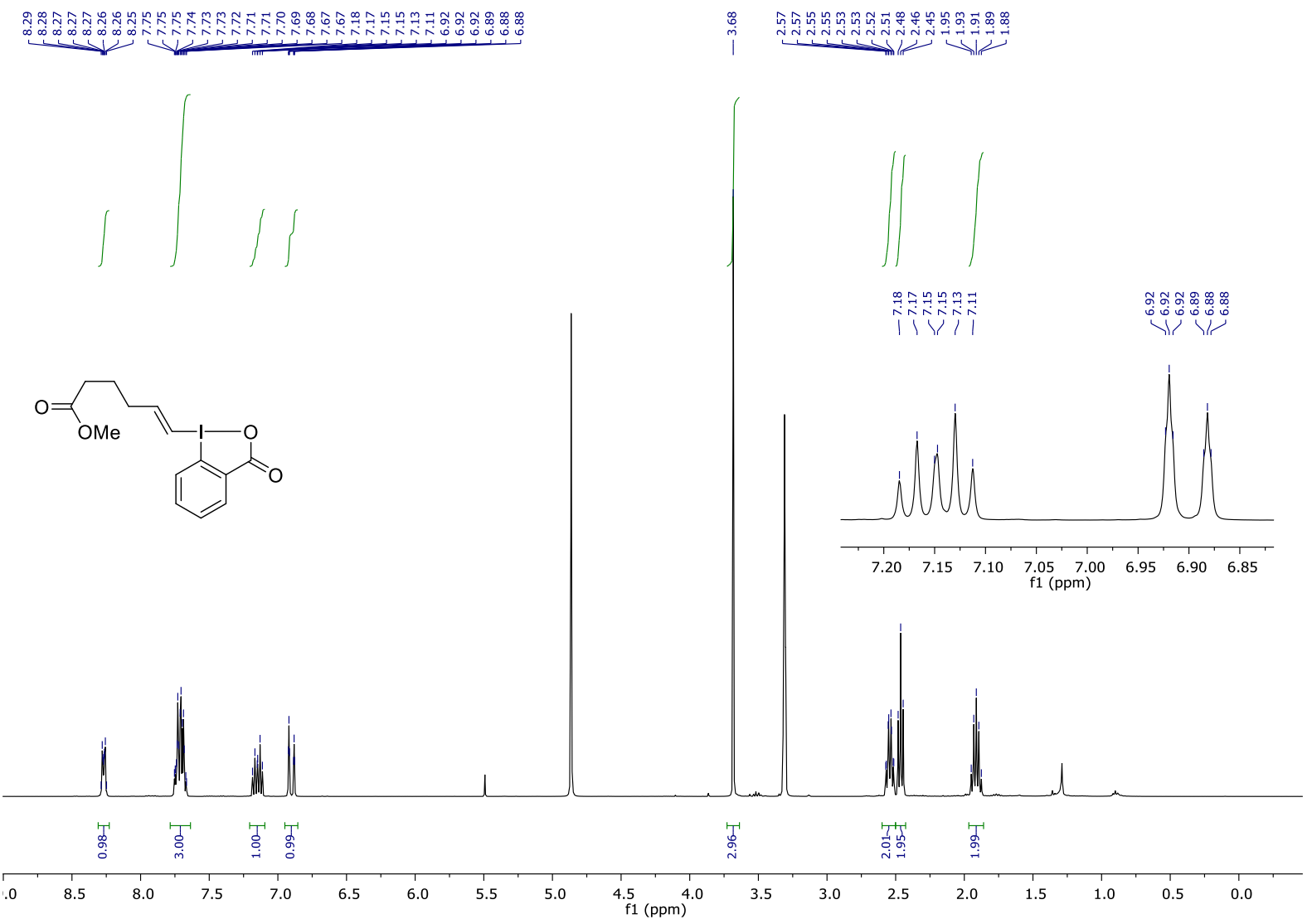

${ }^{13} \mathrm{C}$-NMR (101 MHz, CD ${ }_{3} \mathrm{OD}$ ) of compound $\mathbf{1 m}$

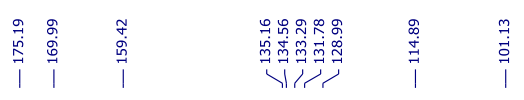

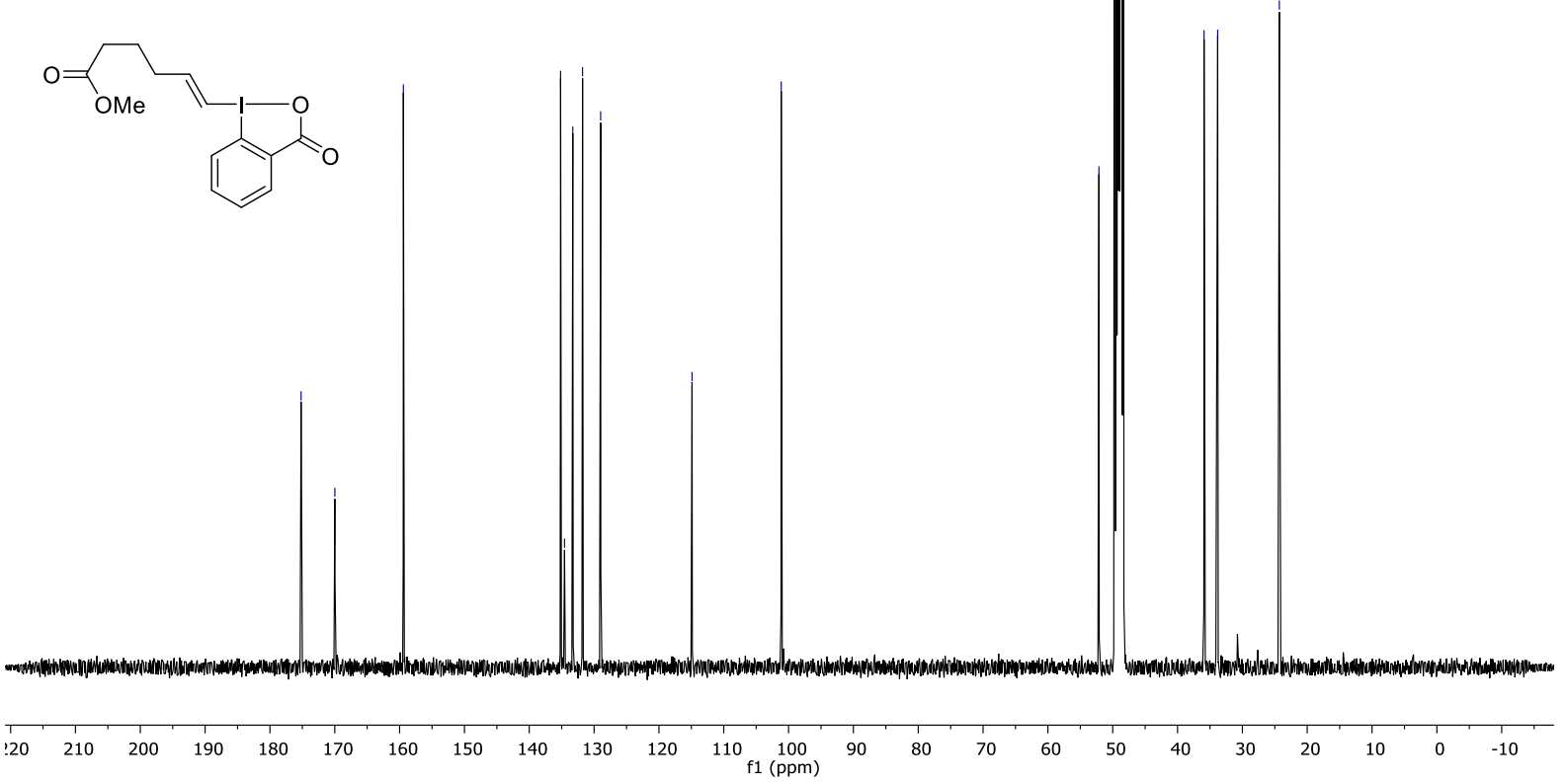


${ }^{1} \mathrm{H}-\mathrm{NMR}\left(400 \mathrm{MHz}, \mathrm{CD}_{3} \mathrm{OD}\right.$ ) of compound $\mathbf{1 n}$

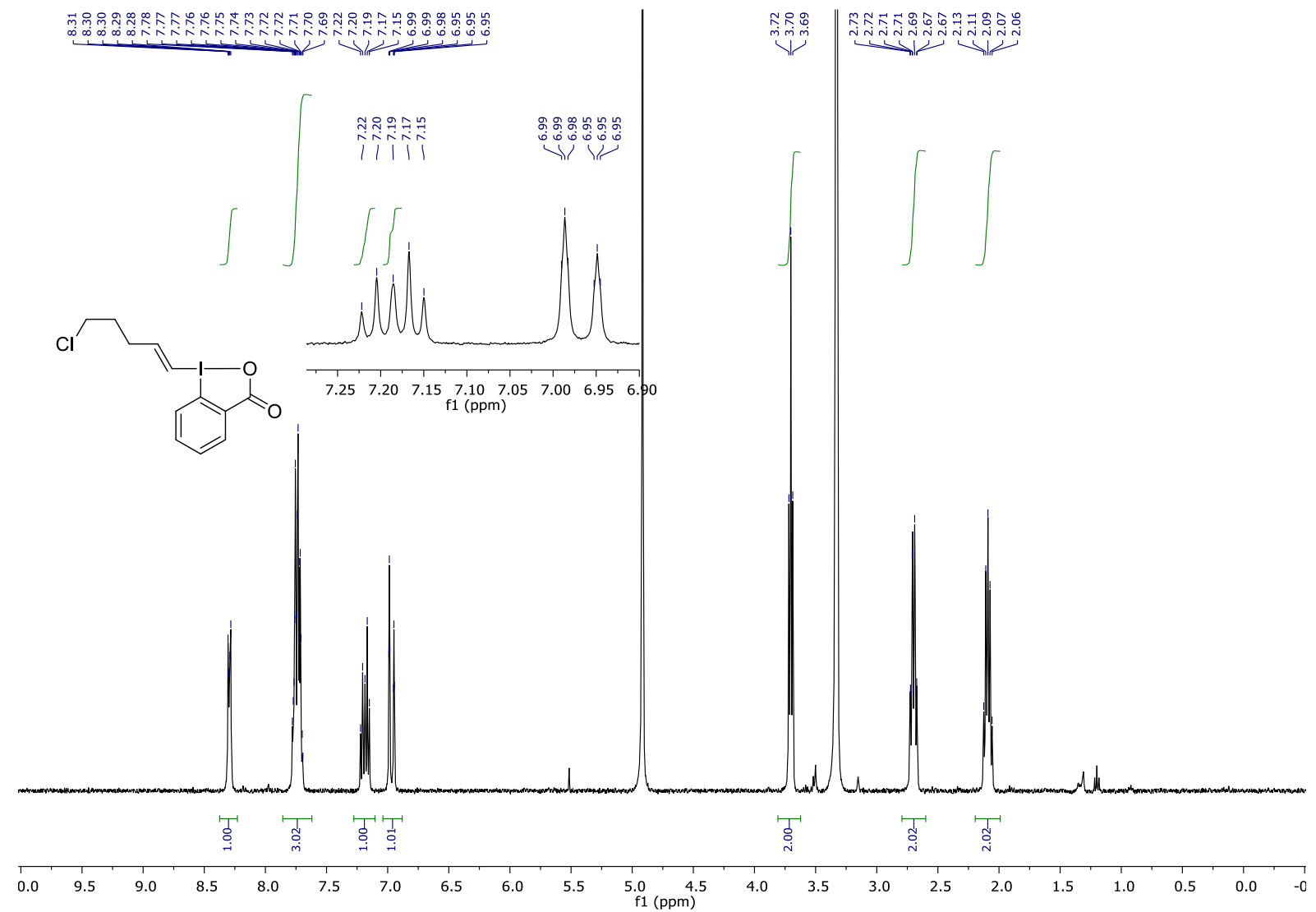

${ }^{13}$ C-NMR (101 MHz, CD ${ }_{3} \mathrm{OD}$ ) of compound $\mathbf{1 n}$

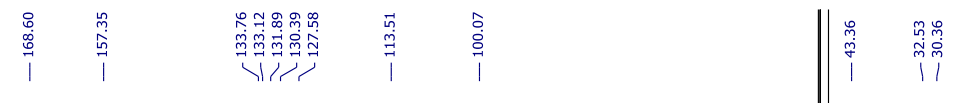

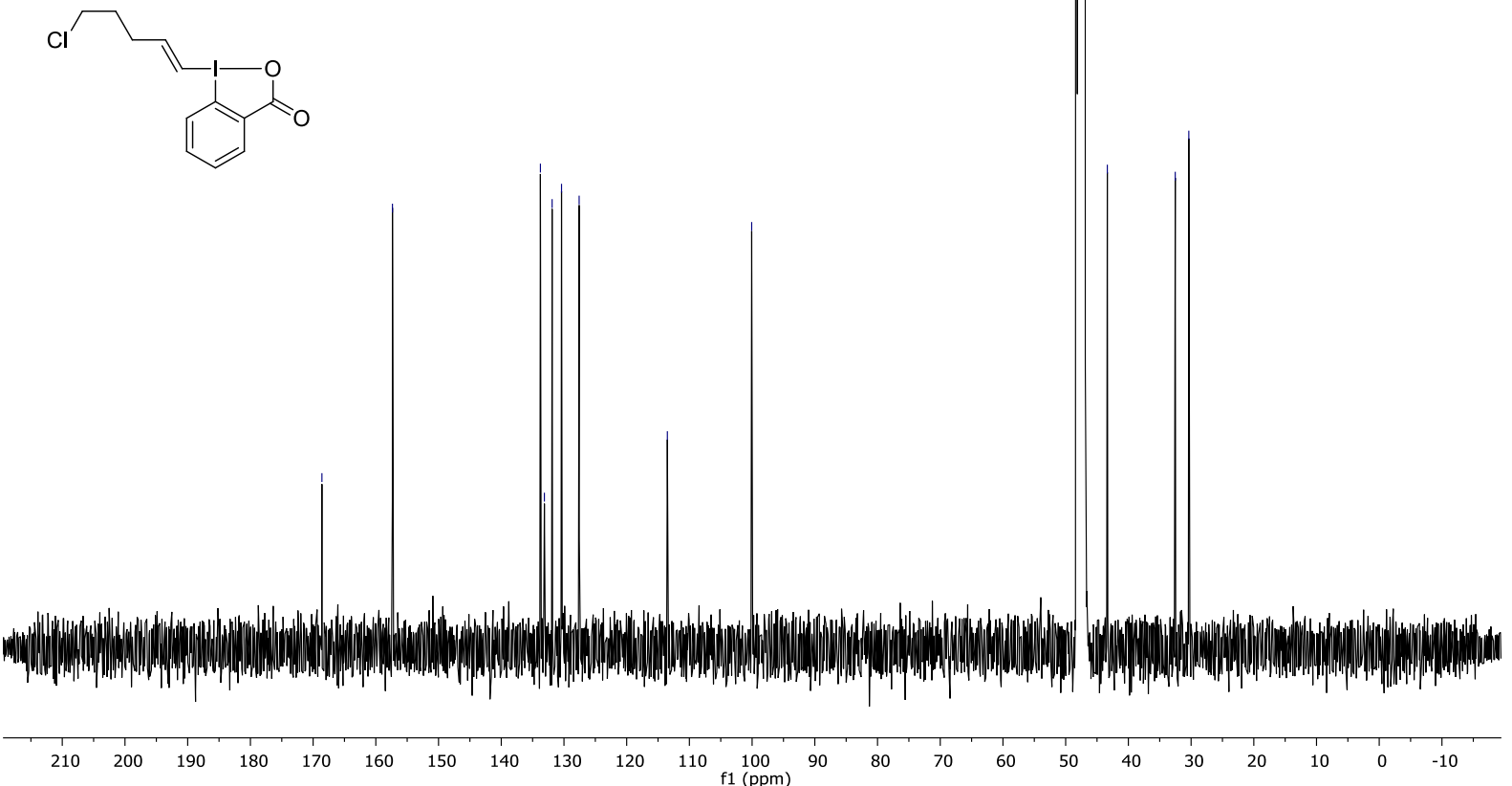


${ }^{1} \mathrm{H}-\mathrm{NMR}\left(400 \mathrm{MHz}, \mathrm{CD}_{3} \mathrm{OD}\right.$ ) of compound 10

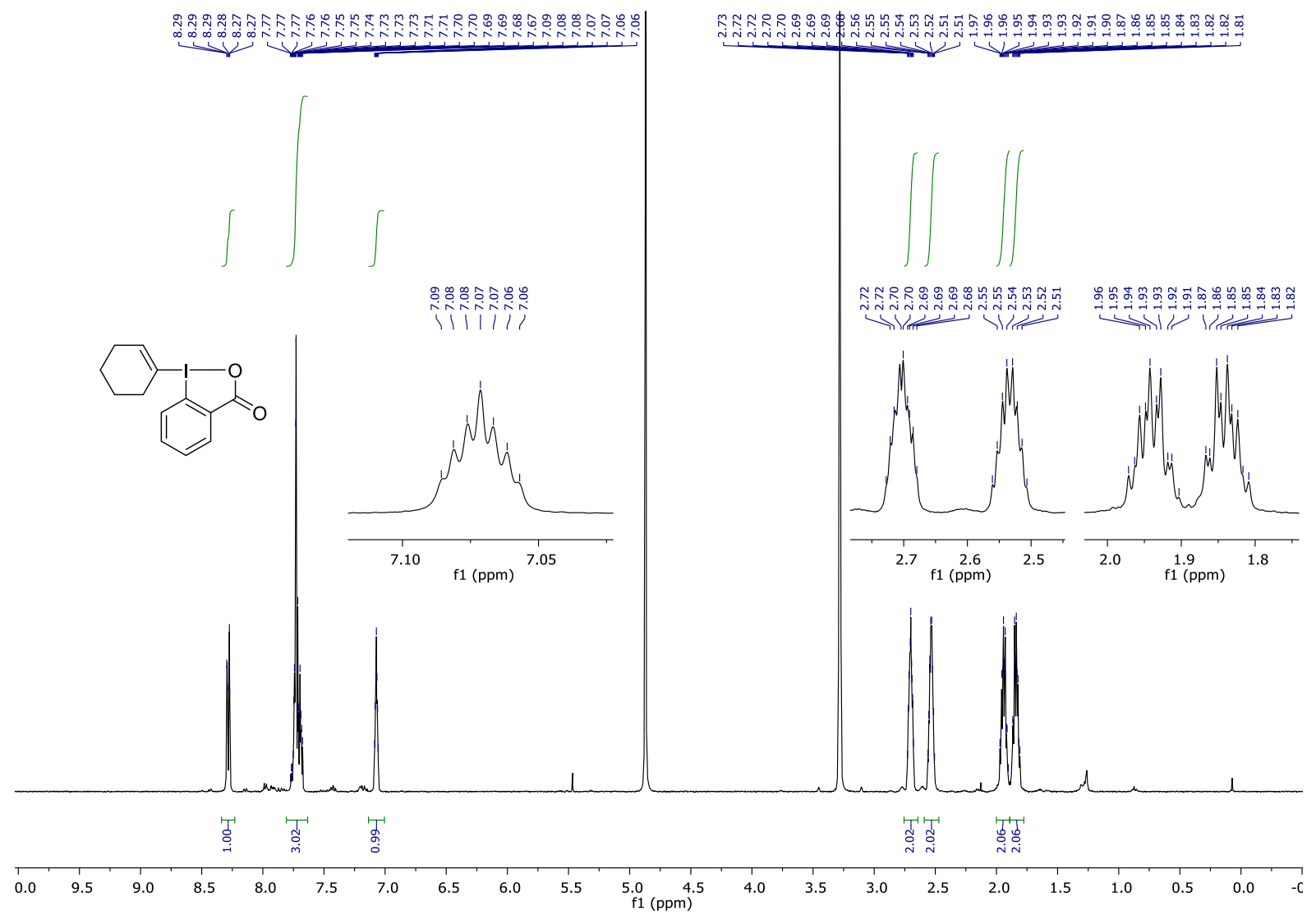

${ }^{13} \mathrm{C}$-NMR (101 MHz, CD 3 OD) of compound 10

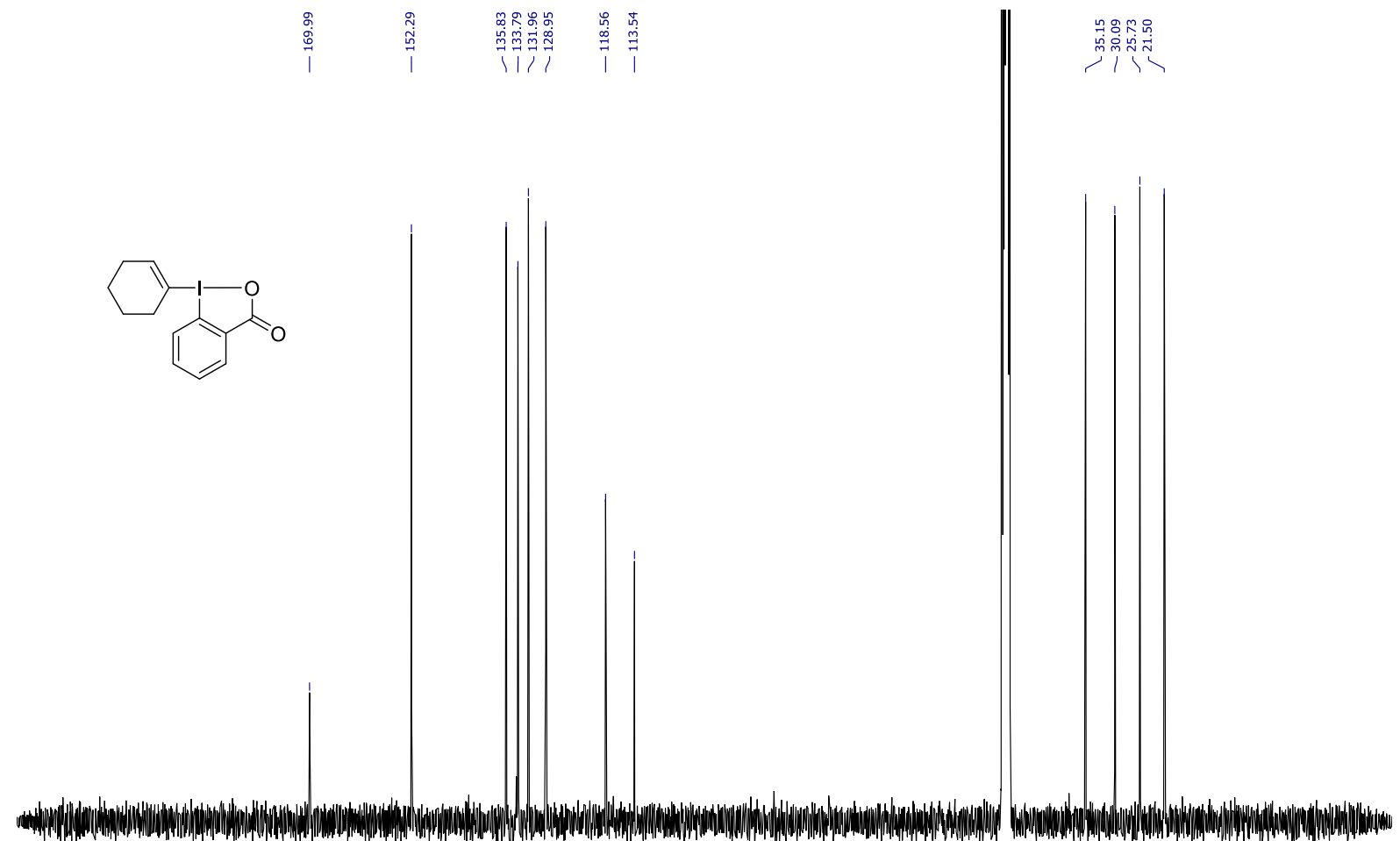

$\begin{array}{llllllllllllllllllllllllllllllllll}20 & 210 & 200 & 190 & 180 & 170 & 160 & 150 & 140 & 130 & 120 & 110 & 100 & 90 & 80 & 70 & 60 & 50 & 40 & 30 & 20 & 10 & 0 & -10\end{array}$ 
${ }^{1} \mathbf{H}-\mathrm{NMR}$ (400 MHz, CD $\mathrm{CD}_{3} \mathrm{OD}$ ) of compound 1p

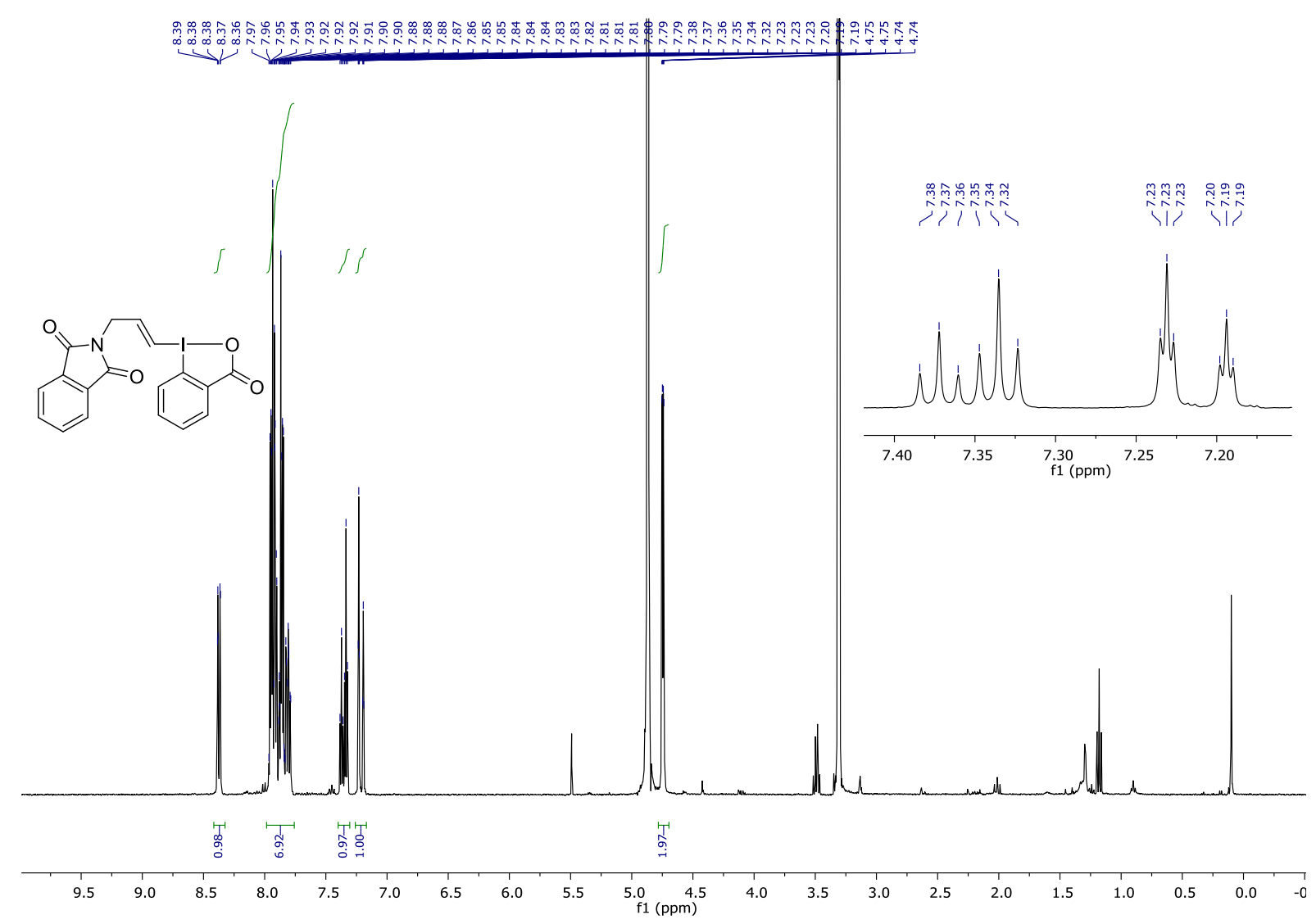

${ }^{13}$ C-NMR (101 MHz, CD ${ }_{3} \mathrm{OD}$ ) of compound 1p

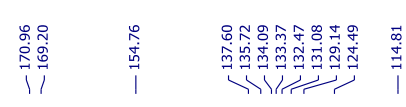
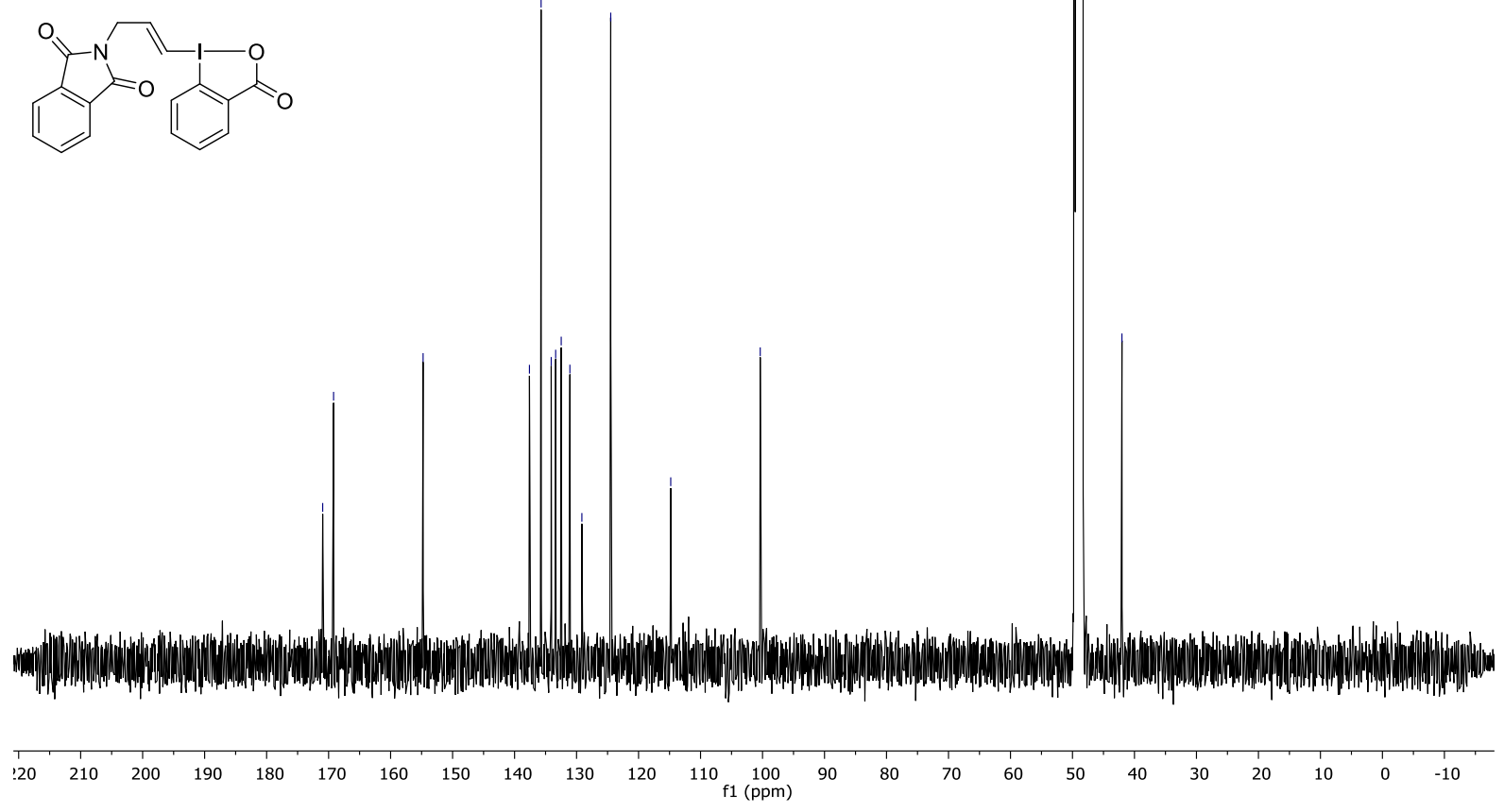

S87 
${ }^{1} \mathrm{H}-\mathrm{NMR}\left(400 \mathrm{MHz}, \mathrm{CD}_{3} \mathrm{OD}\right.$ ) of compound 1q

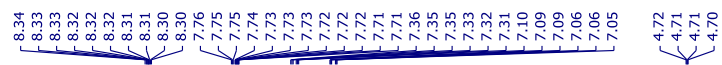

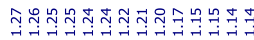

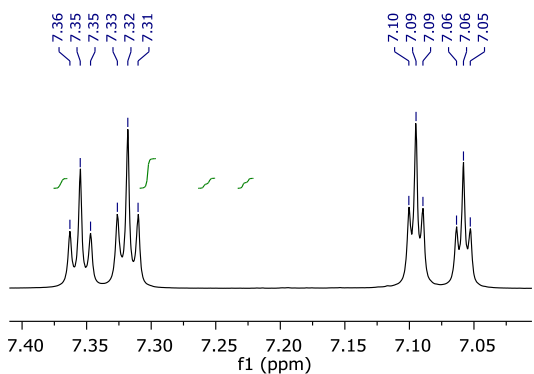

TIPSO
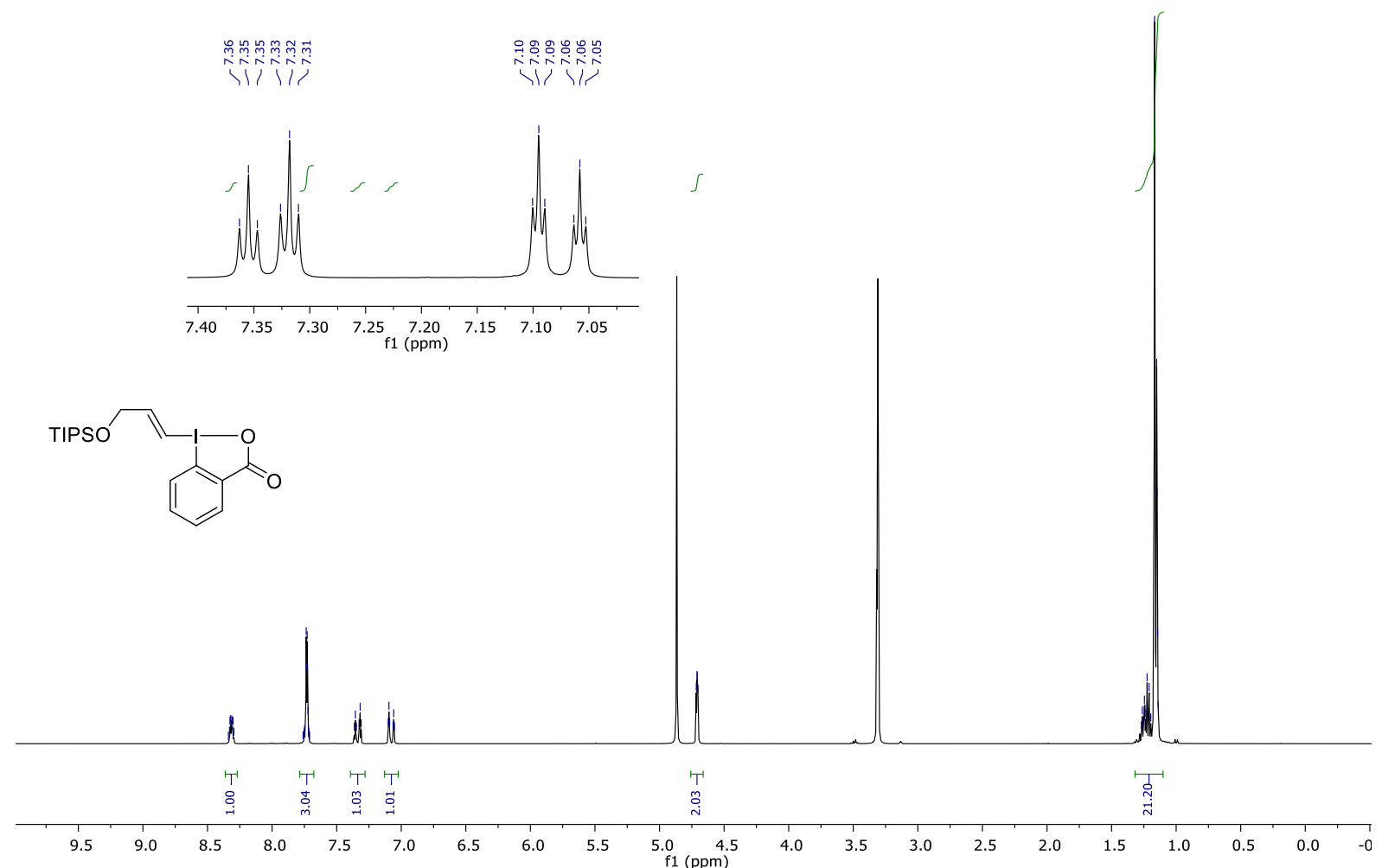

${ }^{13} \mathrm{C}-\mathrm{NMR}\left(101 \mathrm{MHz}, \mathrm{CD}_{3} \mathrm{OD}\right)$ of compound 1q

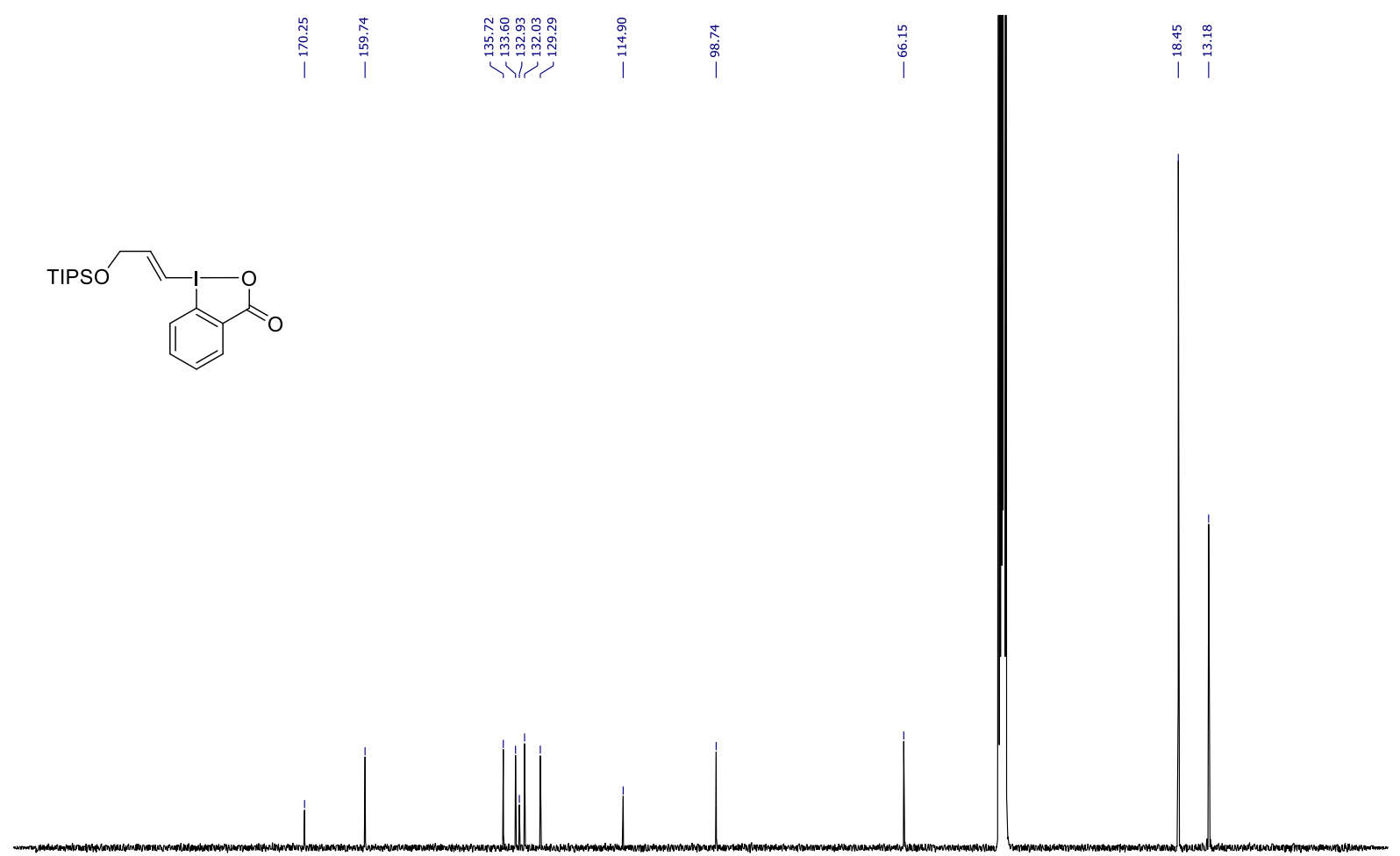

$\begin{array}{lllllllllllllllllllllllllll}120 & 210 & 200 & 190 & 180 & 170 & 160 & 150 & 140 & 130 & 120 & 110 & 100 & 90 & 80 & 70 & 60 & 50 & 40 & 30 & 20 & 10 & 0 & -10 & \end{array}$ 
${ }^{1} \mathbf{H}-\mathrm{NMR}$ (400 MHz, CD $\mathrm{CD}_{3} \mathrm{OD}$ ) of compound $\mathbf{1} \mathbf{r}$

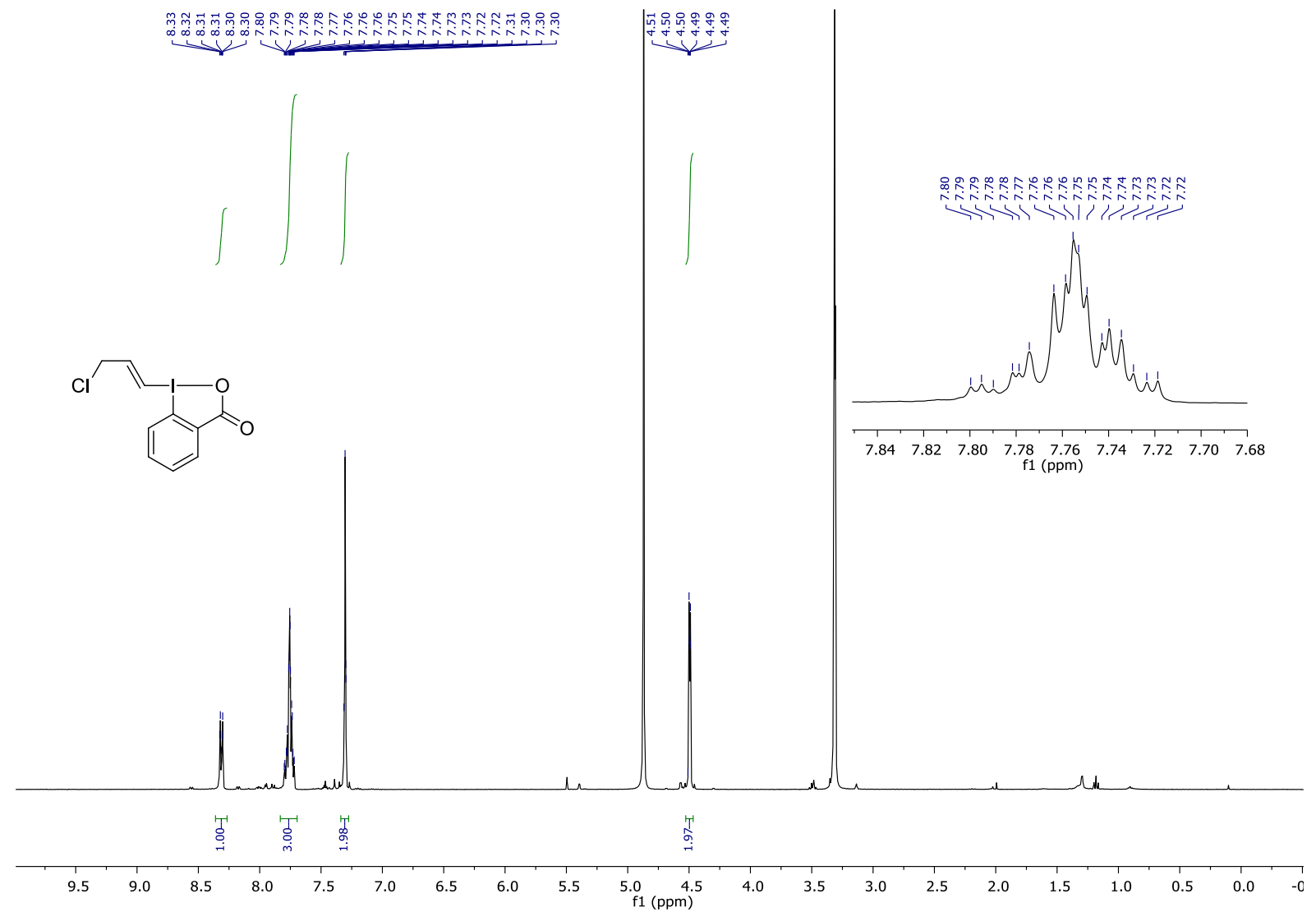

${ }^{13}$ C-NMR (101 MHz, CD ${ }_{3} \mathrm{OD}$ ) of compound $\mathbf{1 r}$
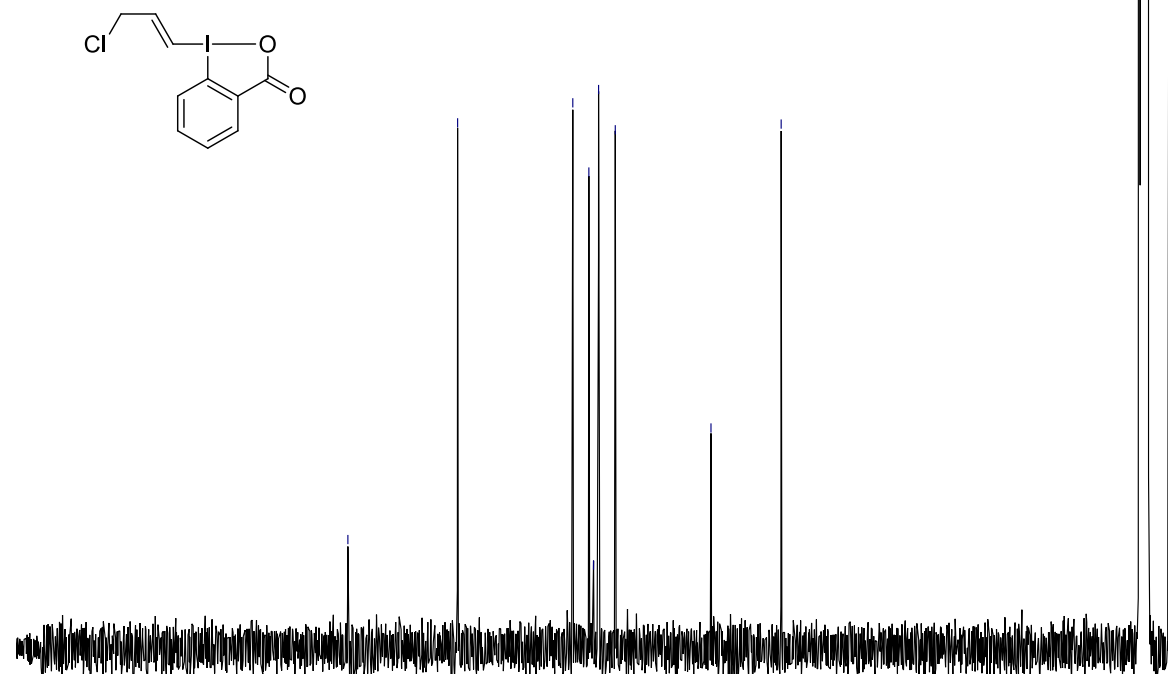

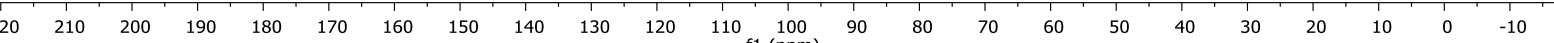


${ }^{1} \mathrm{H}-\mathrm{NMR}\left(400 \mathrm{MHz}, \mathrm{CD}_{3} \mathrm{OD}\right.$ ) of compound 1s

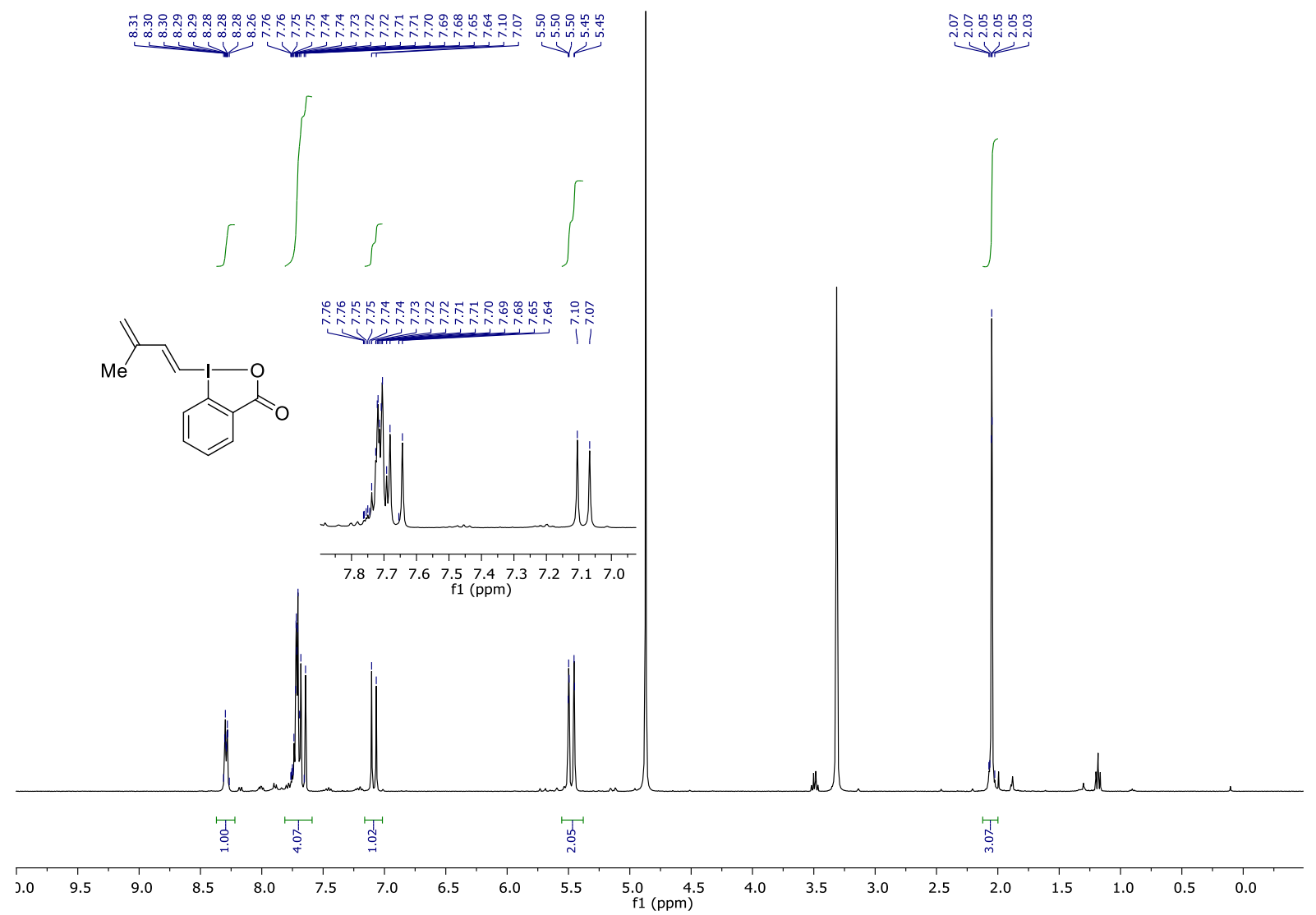

${ }^{13} \mathrm{C}$-NMR (101 MHz, CD ${ }_{3} \mathrm{OD}$ ) of compound 1s

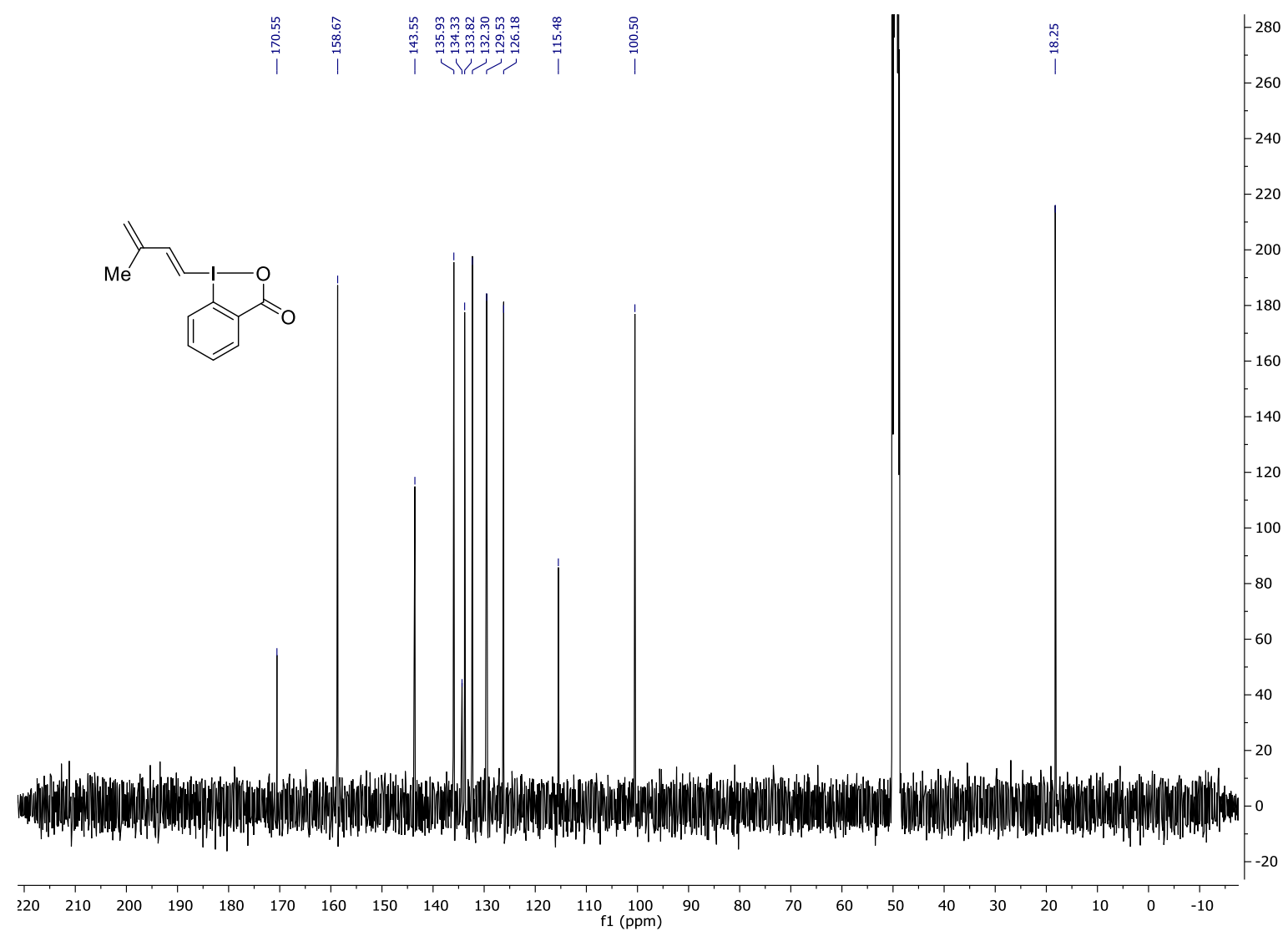


${ }^{1} \mathrm{H}-\mathrm{NMR}\left(400 \mathrm{MHz}, \mathrm{CD}_{3} \mathrm{OD}\right.$ ) of compound $1 \mathrm{t}$

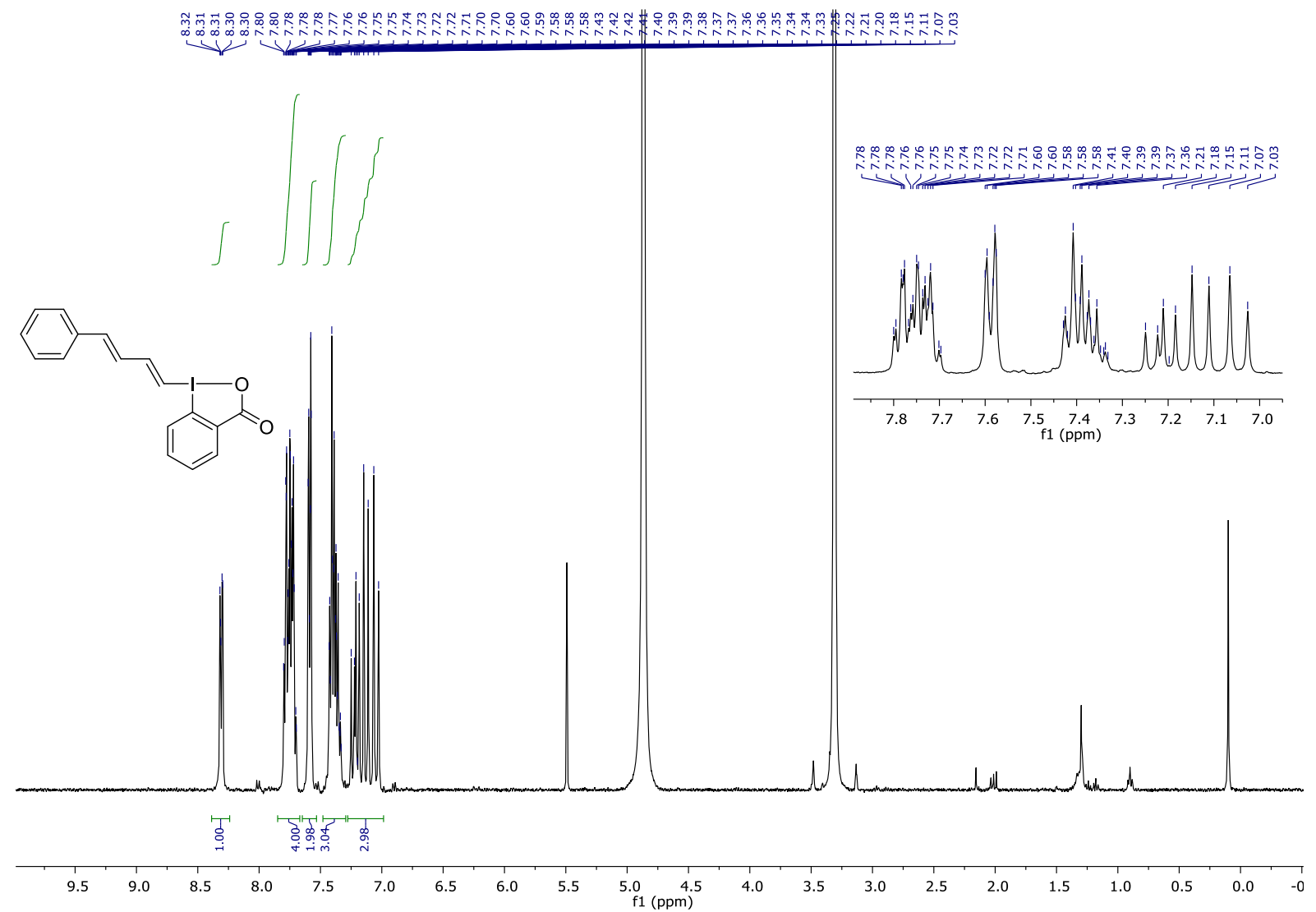

${ }^{13}$ C-NMR (101 MHz, CD 3 OD) of compound $\mathbf{1 t}$

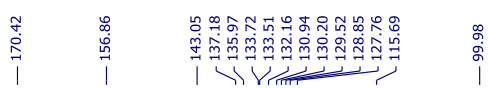
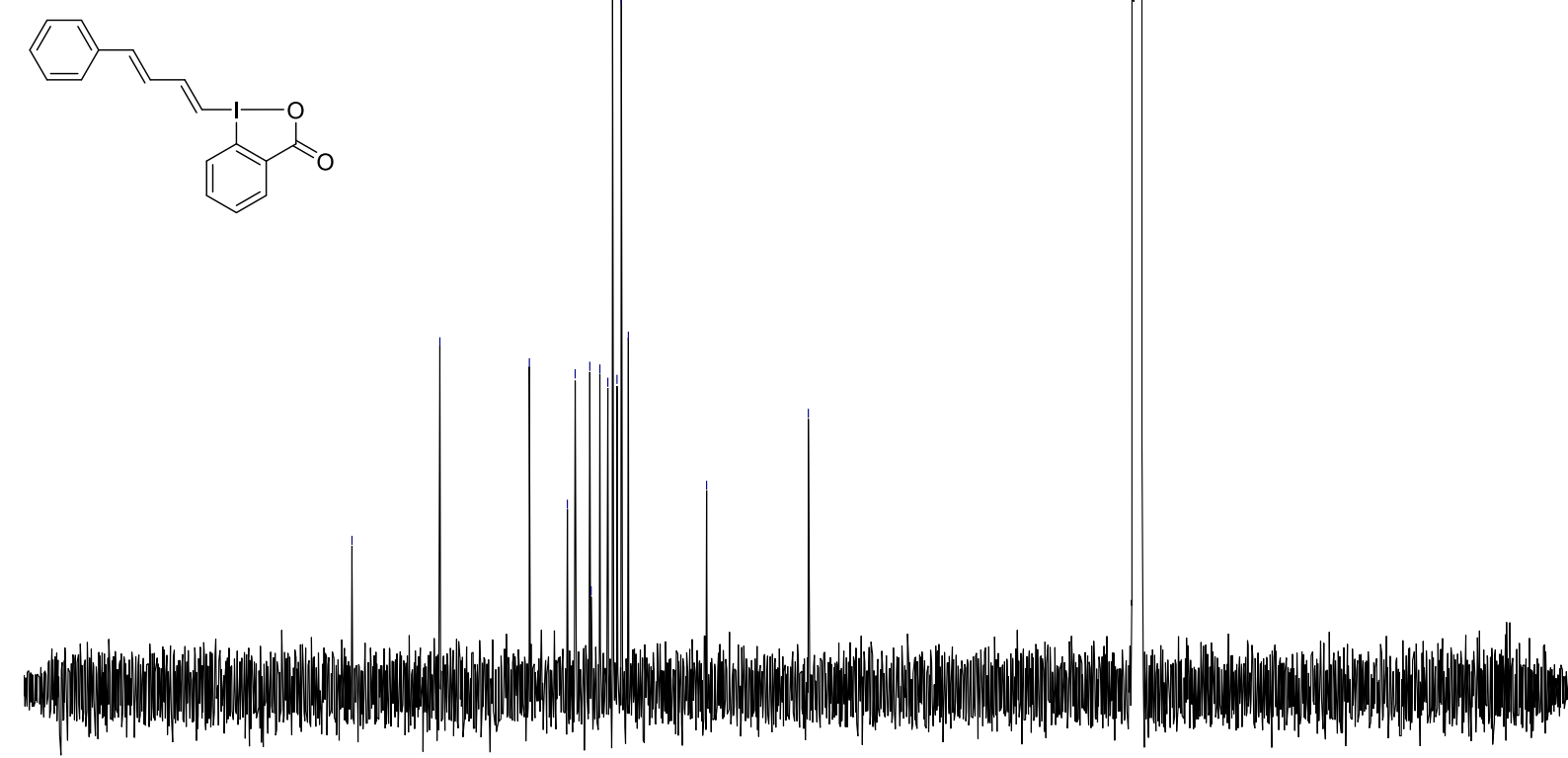

$\begin{array}{llllllllllll}220 & 210 & 200 & 190 & 180 & 170 & 160 & 150 & 140 & 130 & 120 & 110 \\ \mathrm{f} 1(\mathrm{ppm})\end{array}$ 
${ }^{1} \mathrm{H}-\mathrm{NMR}\left(400 \mathrm{MHz}, \mathrm{CD}_{3} \mathrm{OD}\right.$ ) of compound $\mathbf{1 u}$

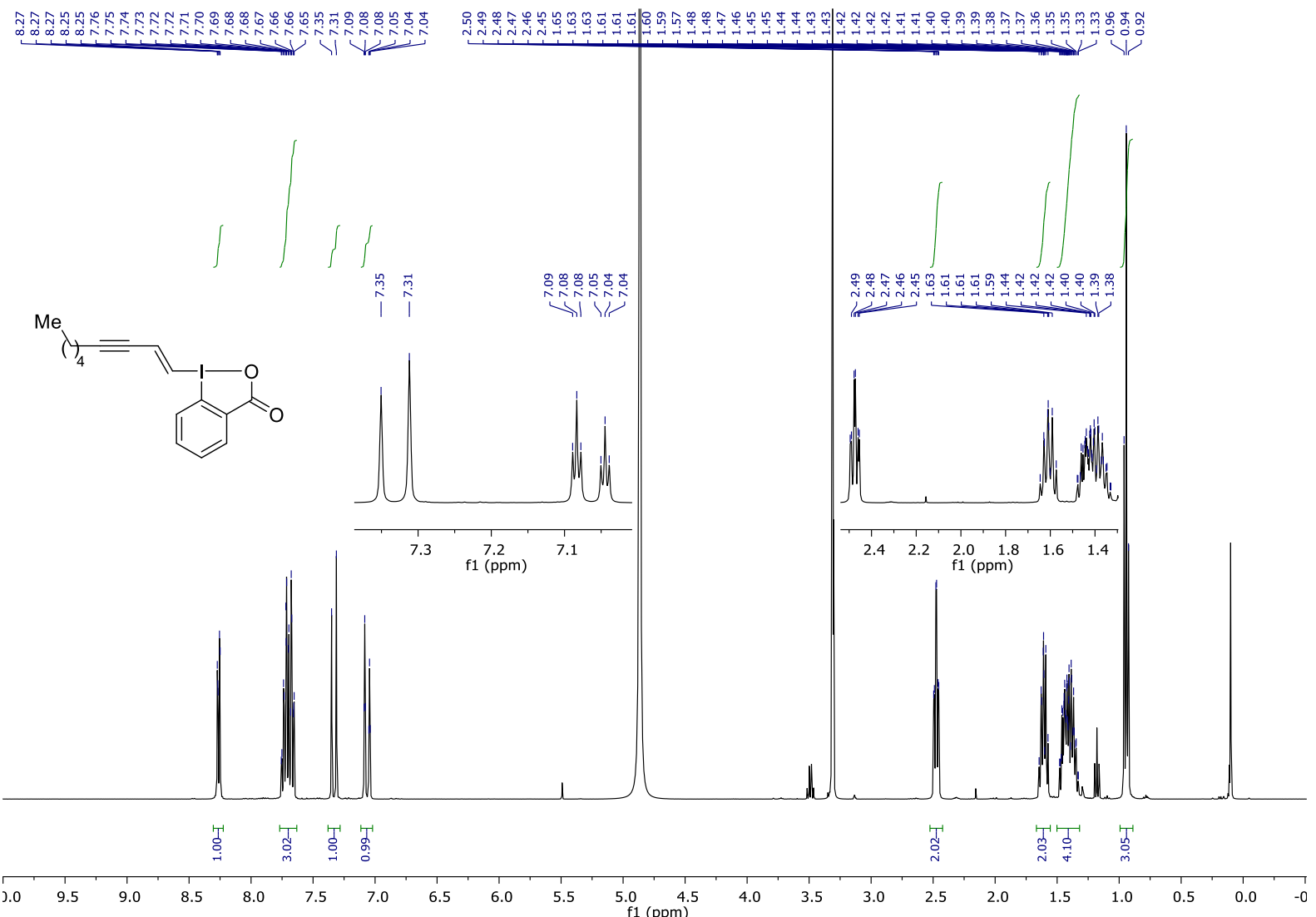

${ }^{13} \mathrm{C}-\mathrm{NMR}$ (101 MHz, $\mathrm{CD}_{3} \mathrm{OD}$ ) of compound $\mathbf{1 u}$

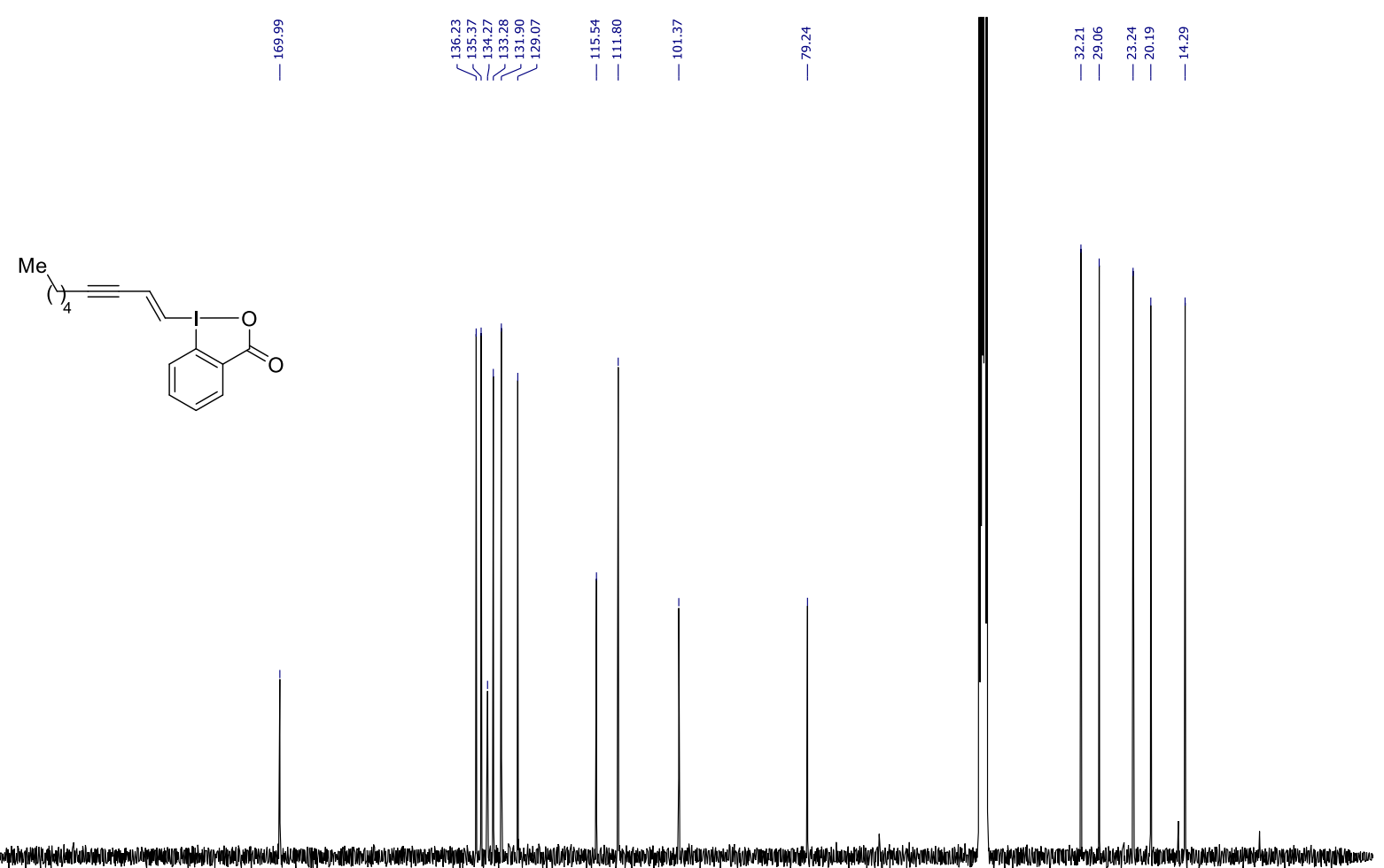

$\begin{array}{lllllllllllllllllllllllllllll}120 & 210 & 200 & 190 & 180 & 170 & 160 & 150 & 140 & 130 & 120 & 110 & 100 & 90 & 80 & 70 & 60 & 50 & 40 & 30 & 20 & 10 & 0 & -10\end{array}$ 
${ }^{1} \mathrm{H}-\mathrm{NMR}\left(400 \mathrm{MHz}, \mathrm{CDCl}_{3}\right.$ ) of compound 1'a

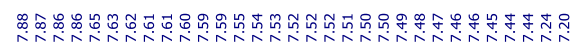

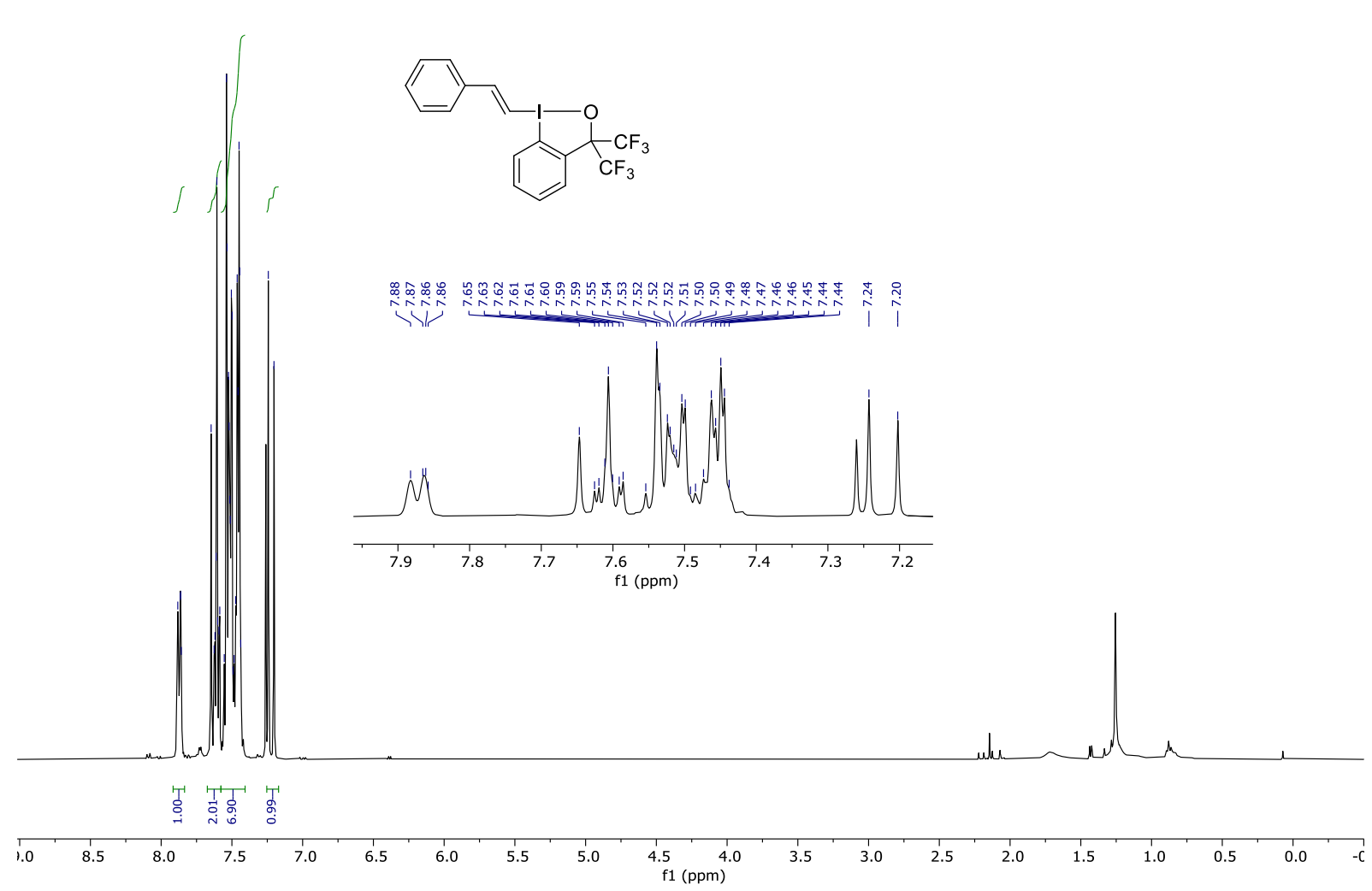

${ }^{13} \mathrm{C}$-NMR (101 MHz, $\left.\mathrm{CDCl}_{3}\right)$ of compound 1'a
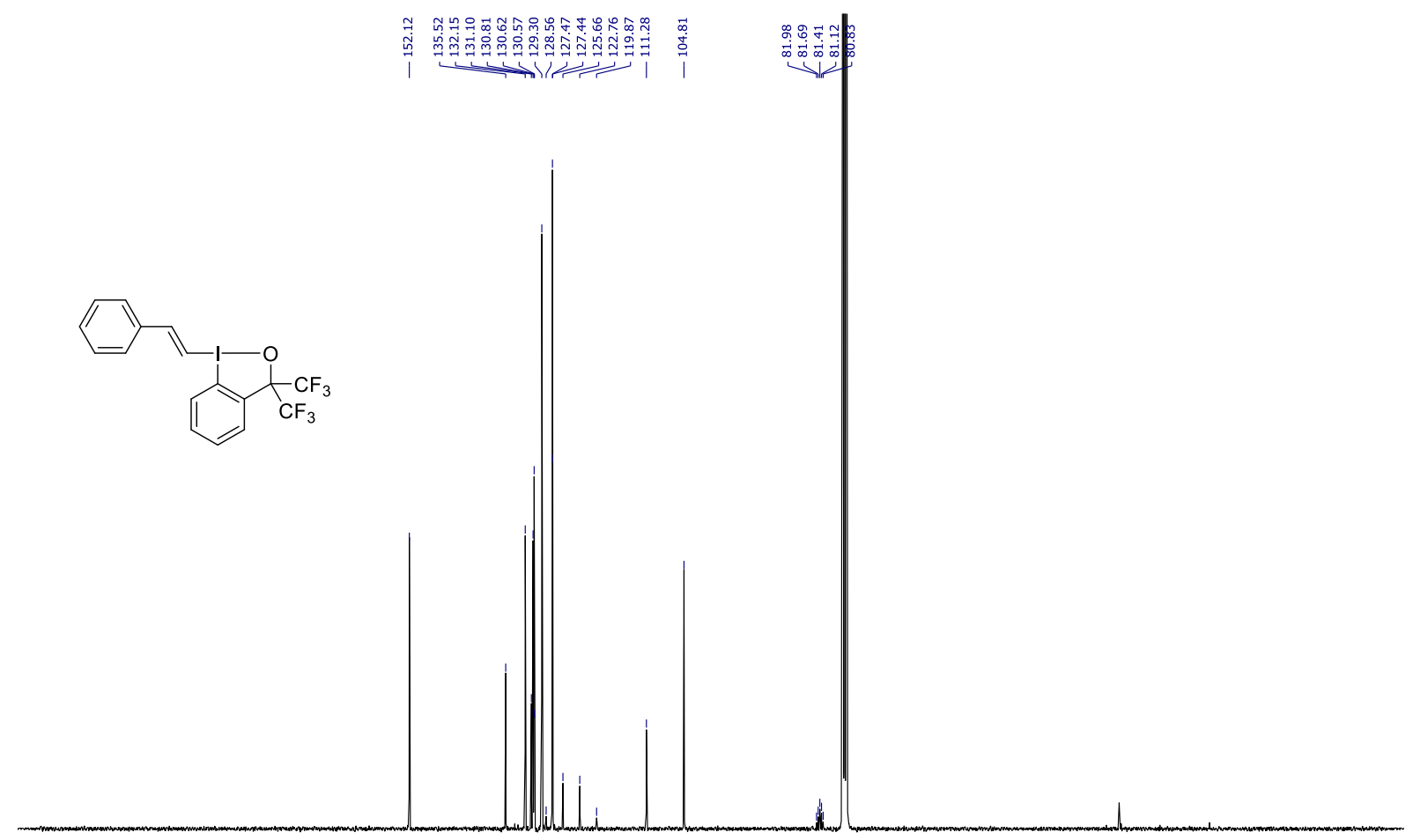

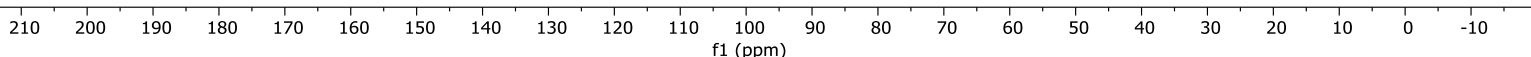


${ }^{19}$ F-NMR (376 MHz, $\mathrm{CDCl}_{3}$ ) of compound 1'a

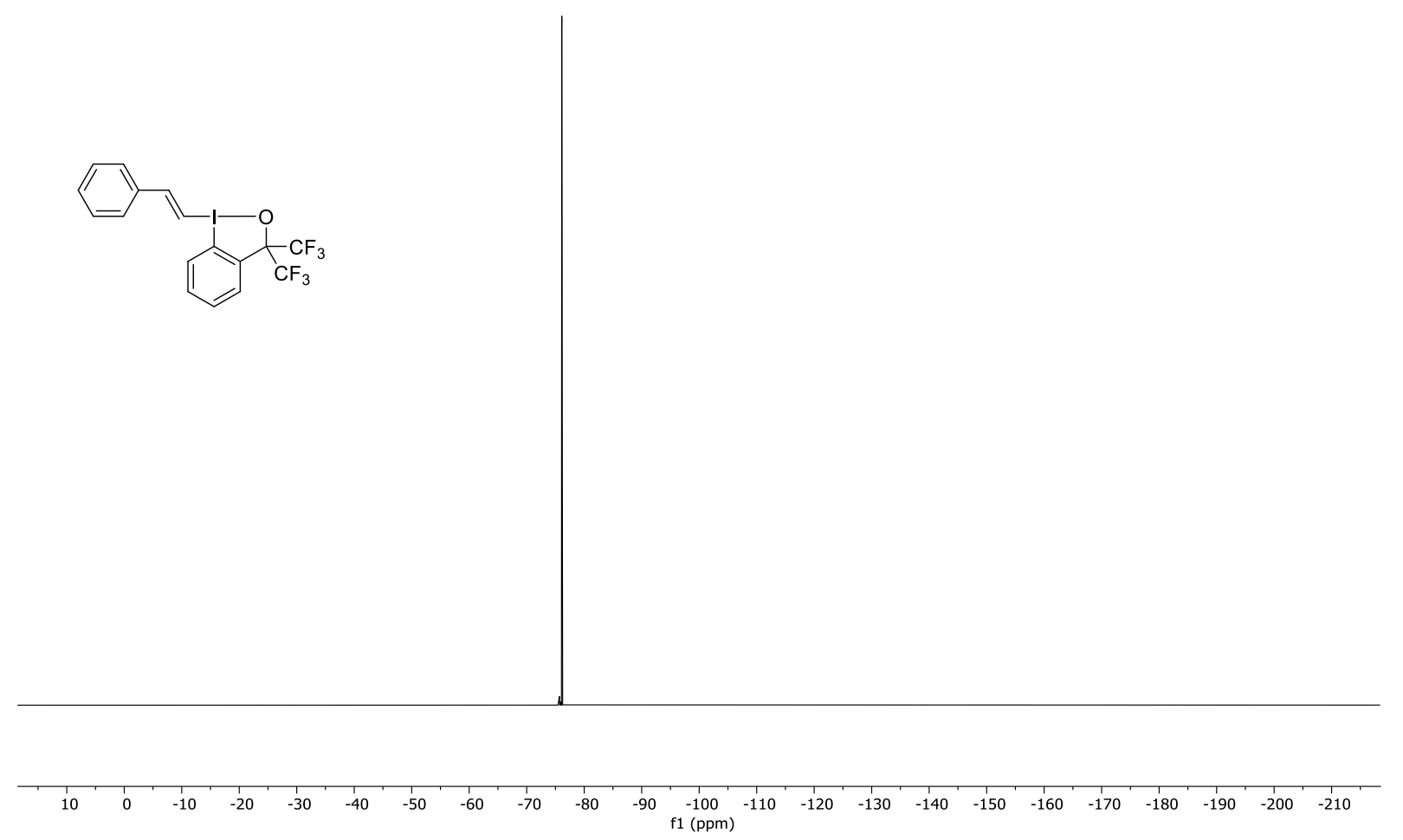


${ }^{1} \mathbf{H}-\mathrm{NMR}\left(400 \mathrm{MHz}, \mathrm{CDCl}_{3}\right.$ ) of compound $\mathbf{1} \mathbf{d}$

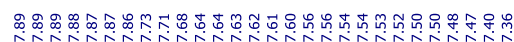

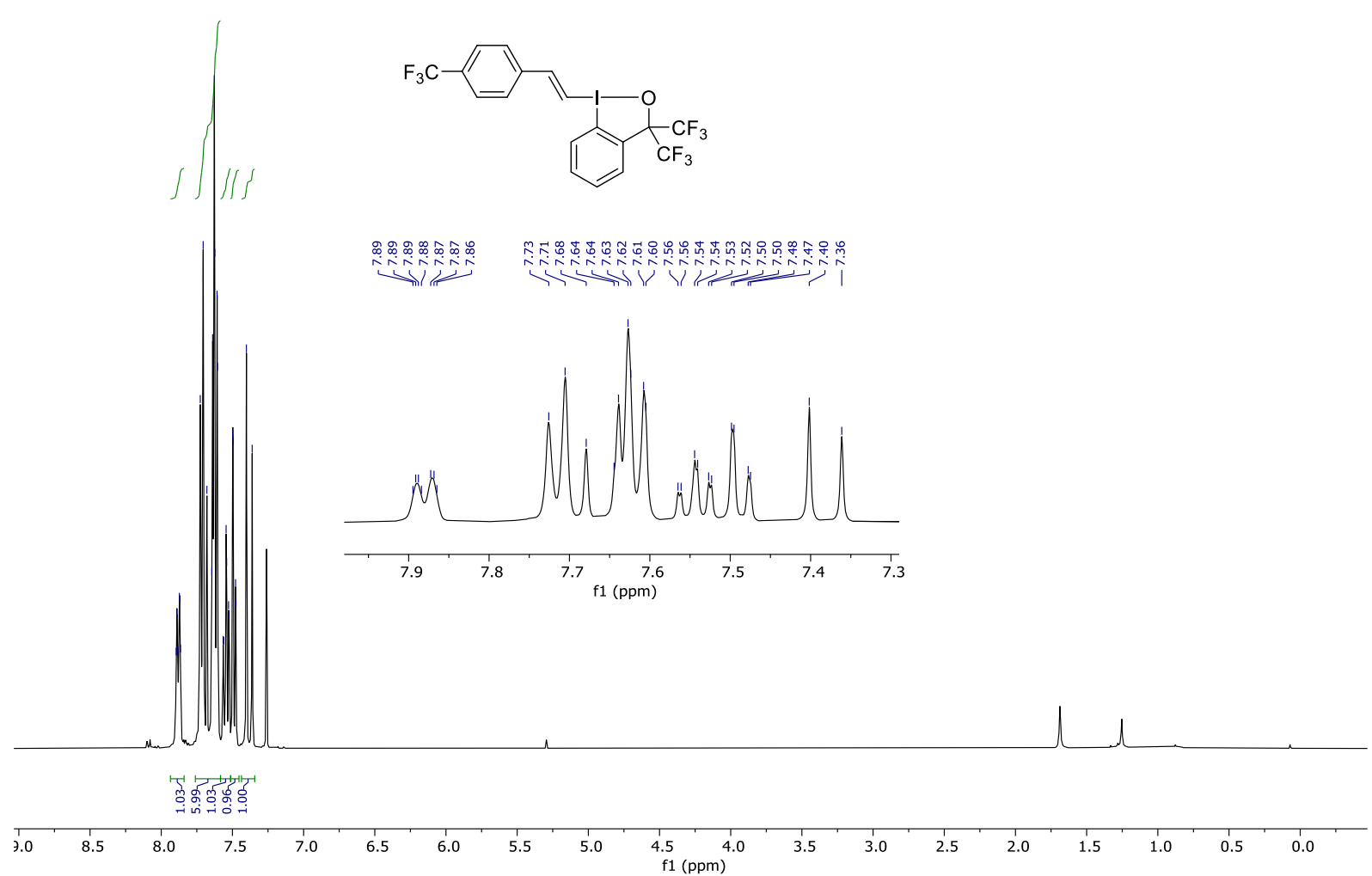

${ }^{13}$ C-NMR (101 MHz, $\mathrm{CDCl}_{3}$ ) of compound 1'd

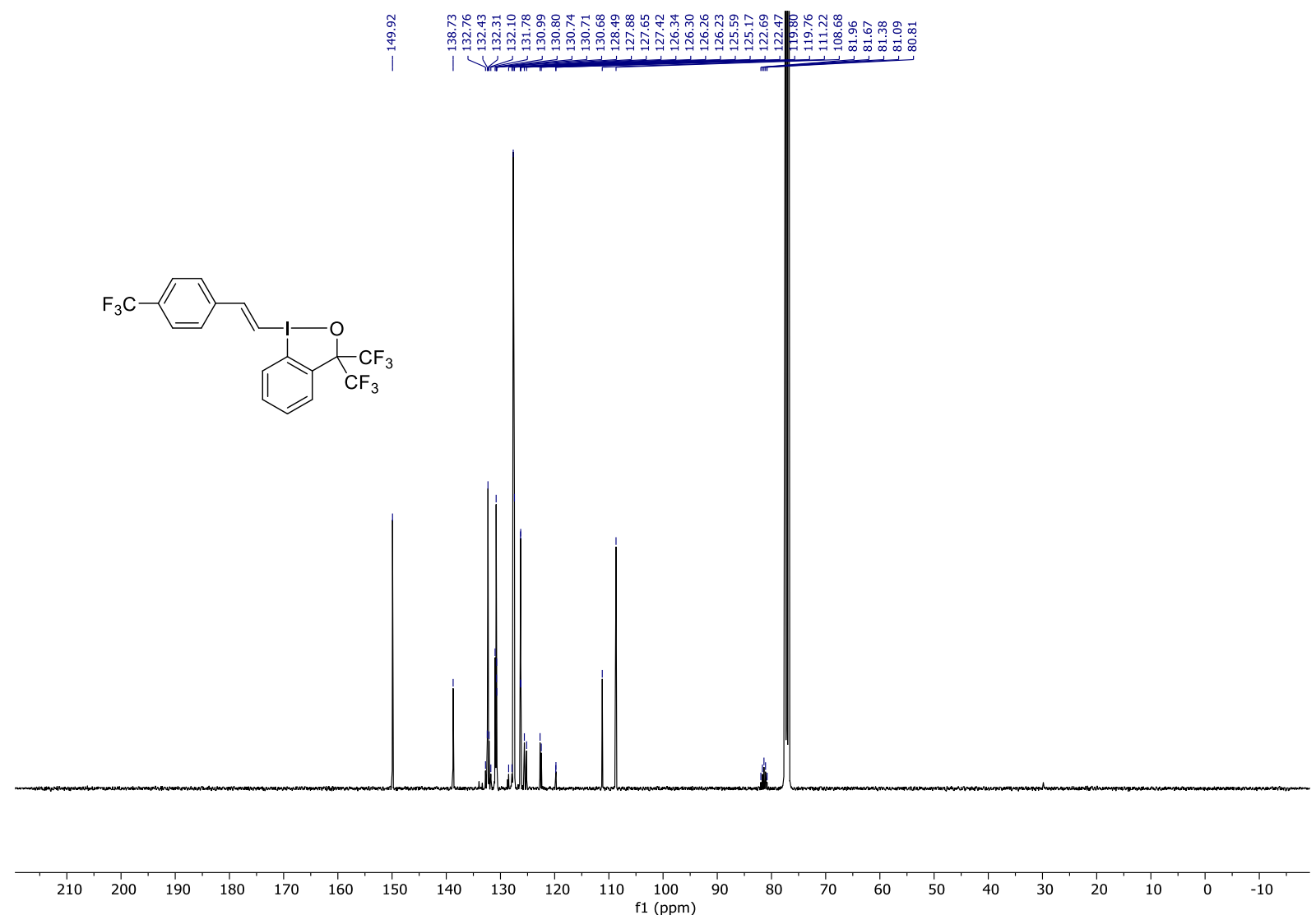


${ }^{19} \mathrm{~F}-\mathrm{NMR}\left(376 \mathrm{MHz}, \mathrm{CDCl}_{3}\right.$ ) of compound $\mathbf{1}$ 'd

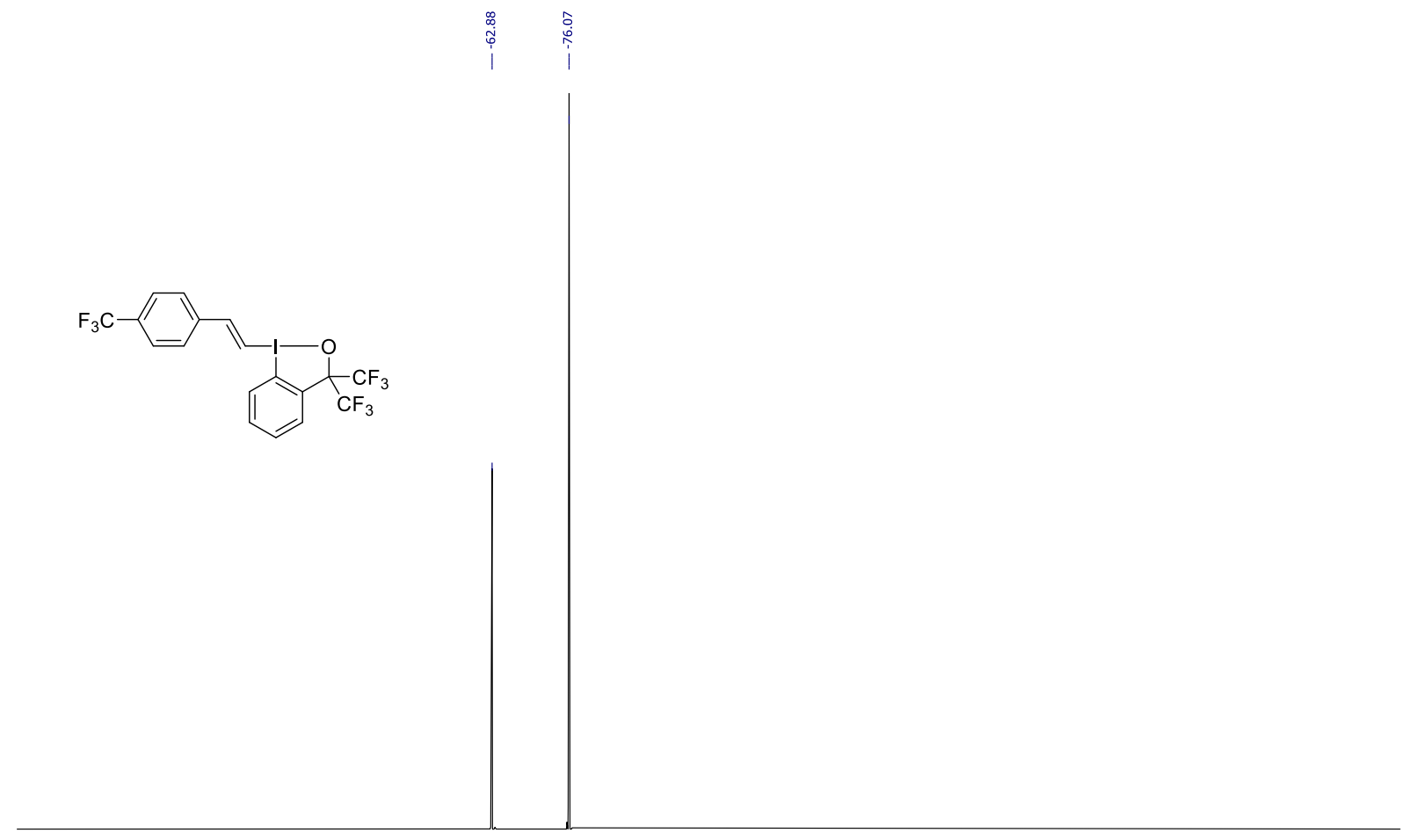


${ }^{1} \mathbf{H}-\mathrm{NMR}\left(400 \mathrm{MHz}, \mathrm{CDCl}_{3}\right.$ ) of compound $\mathbf{1} \mathbf{j}$

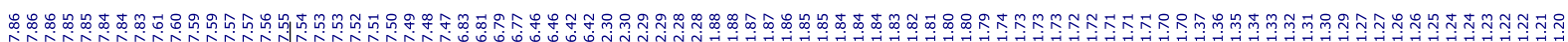

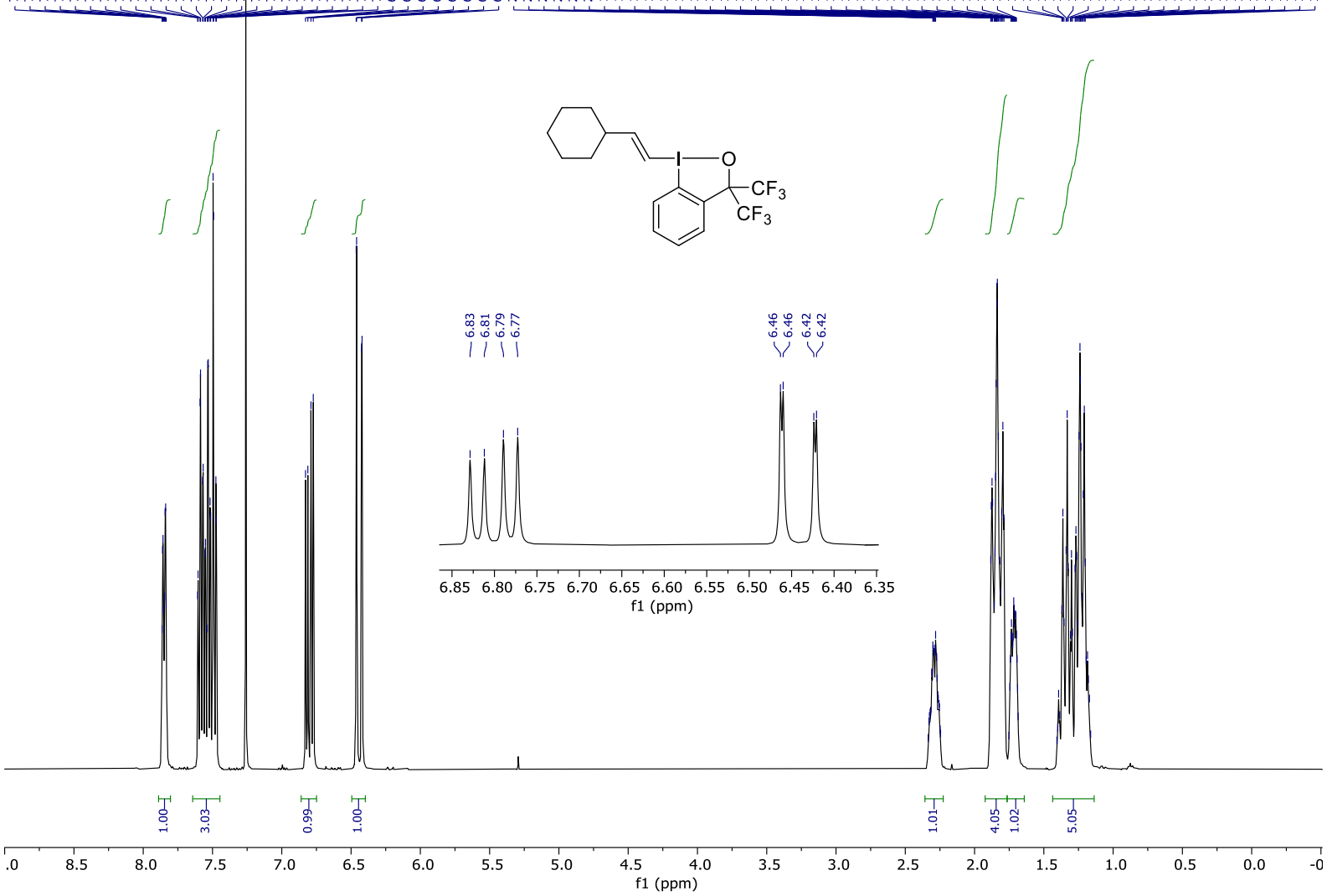

${ }^{13} \mathrm{C}-\mathrm{NMR}\left(101 \mathrm{MHz}, \mathrm{CDCl}_{3}\right.$ ) of compound $\mathbf{1}$ 'j

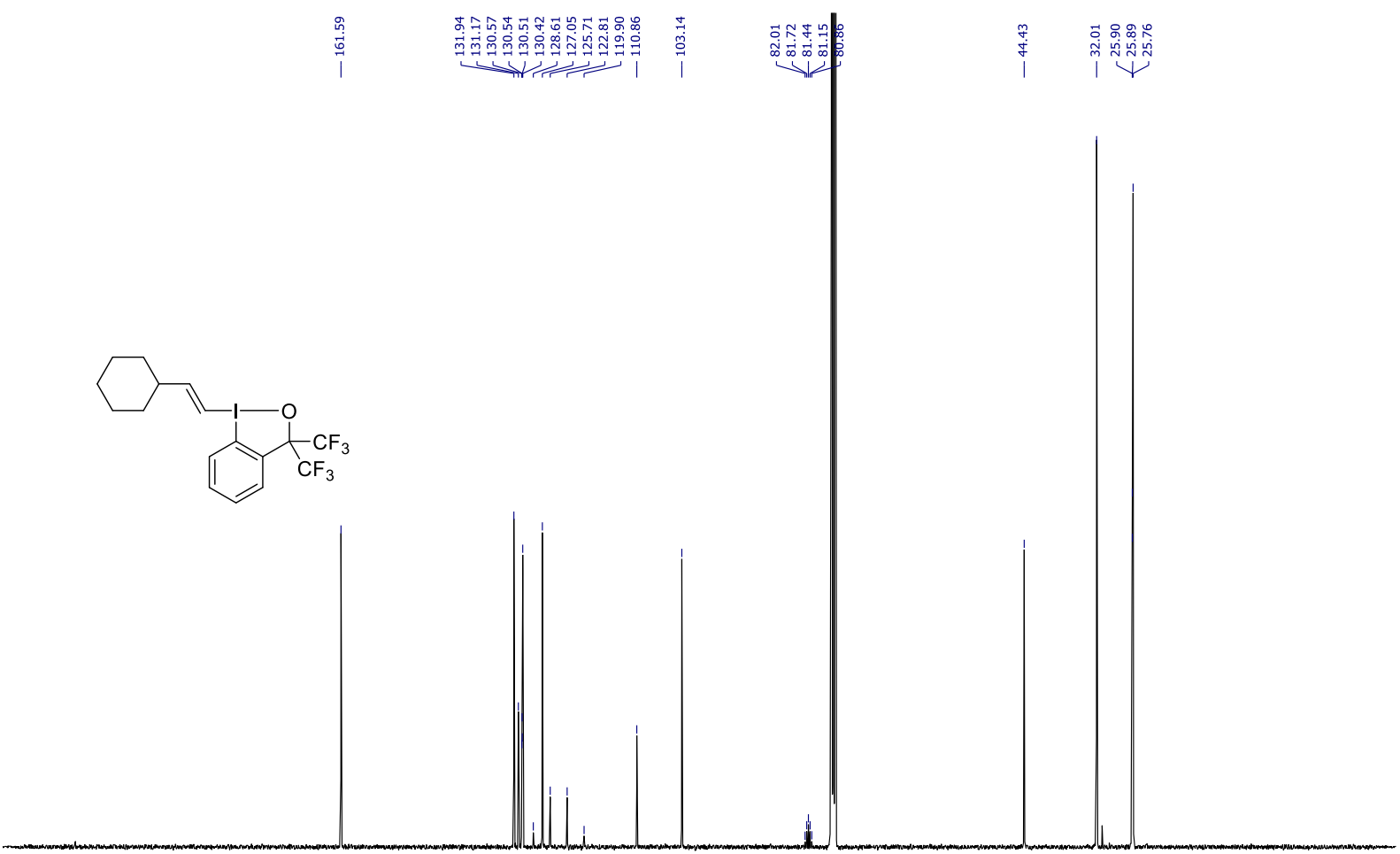

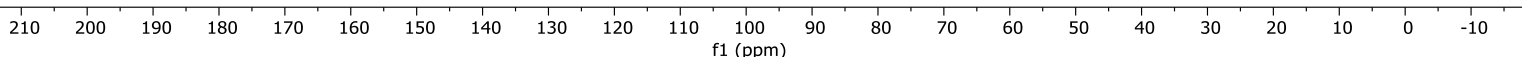


${ }^{19} \mathrm{~F}-\mathrm{NMR}\left(376 \mathrm{MHz}, \mathrm{CDCl}_{3}\right.$ ) of compound $\mathbf{1} \mathbf{j}$

i

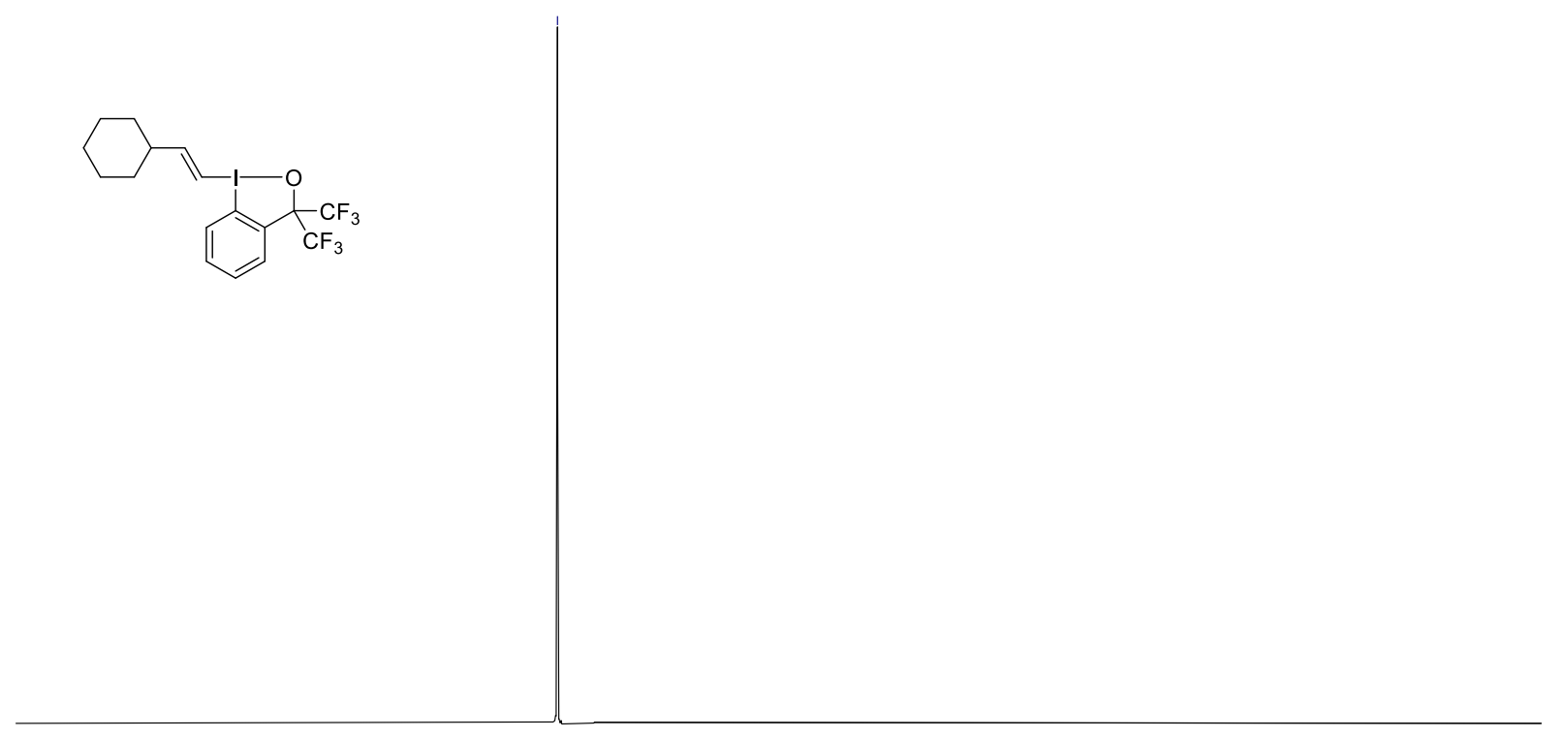

\begin{tabular}{lllllllllllllllllllllll}
\hline & -69 & -70 & -71 & -72 & -73 & -74 & -75 & -76 & -77 & -78 & -79 & -80 & -81 & -82 & -83 & -84 & -85 & -86 & -87 & -88 & -89
\end{tabular} 
${ }^{1} \mathbf{H}-\mathrm{NMR}\left(400 \mathrm{MHz}, \mathrm{CDCl}_{3}\right)$ of compound $\mathbf{1}$ 'k

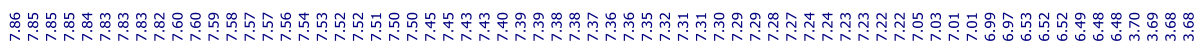

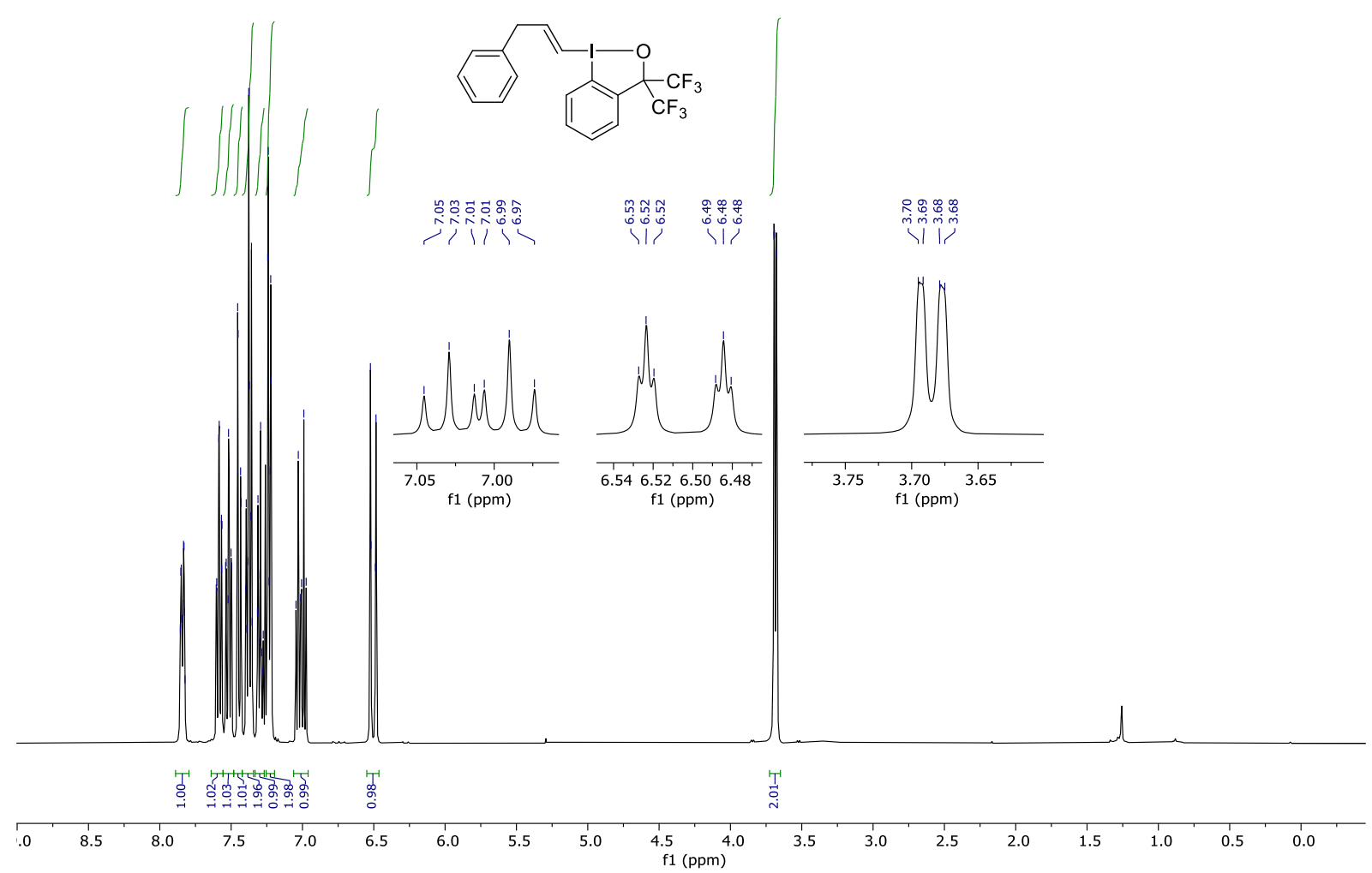

${ }^{13} \mathbf{C}-\mathrm{NMR}\left(101 \mathrm{MHz}, \mathrm{CDCl}_{3}\right)$ of compound 1'k

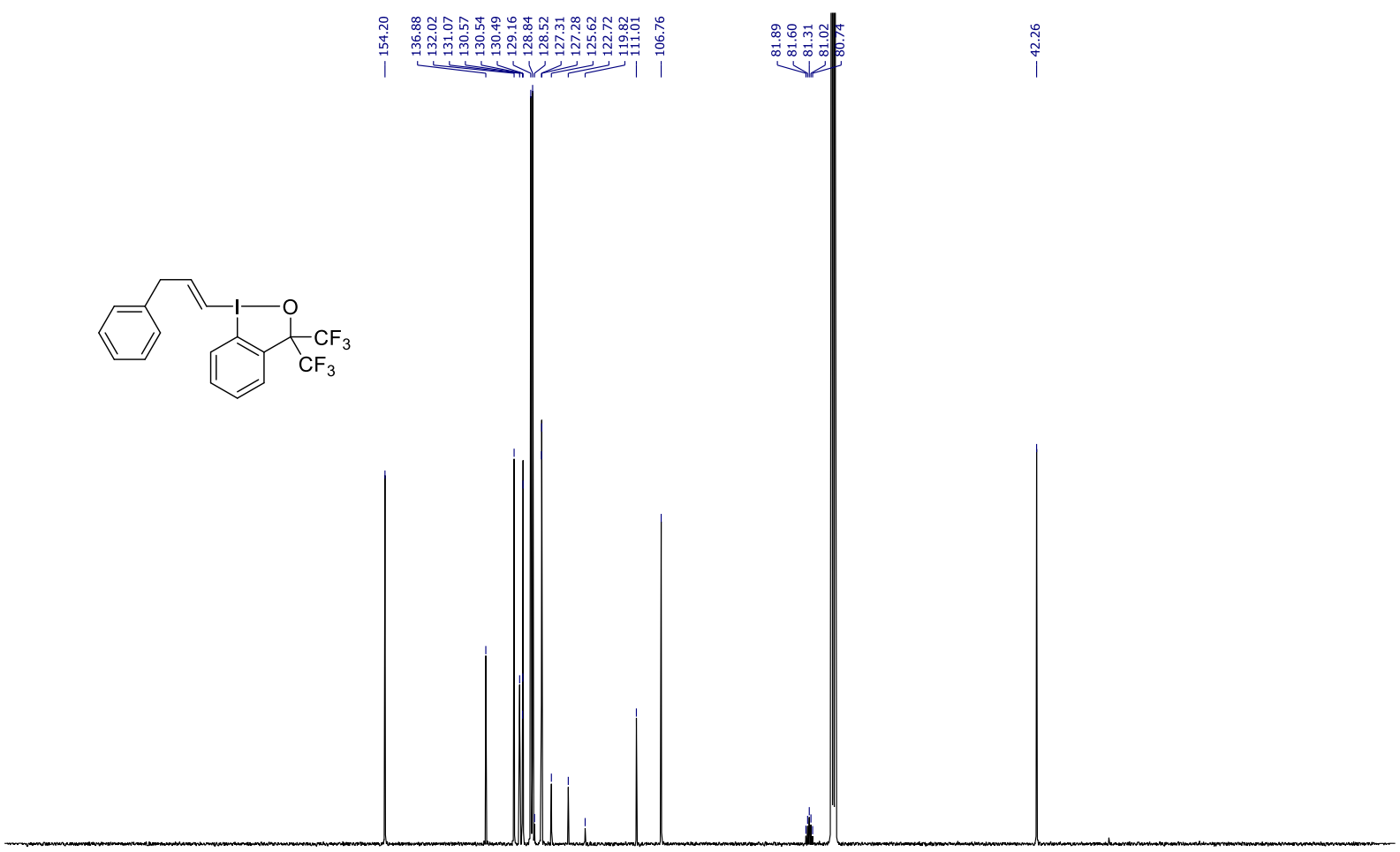

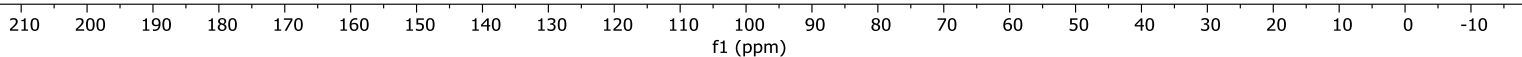


${ }^{19}$ F-NMR (376 MHz, $\mathrm{CDCl}_{3}$ ) of compound 1'k

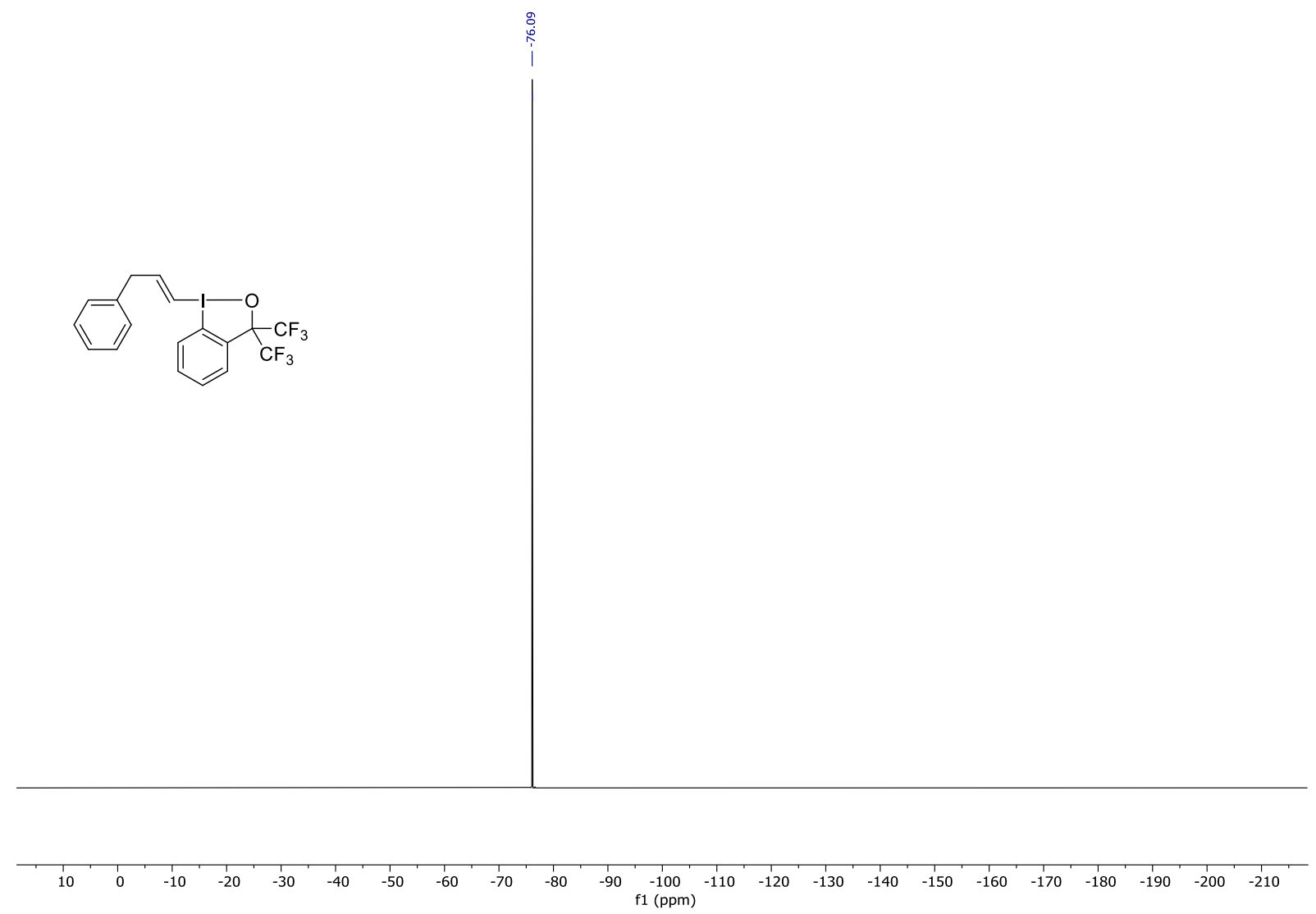


${ }^{1}$ H-NMR $\left(400 \mathrm{MHz}, \mathrm{CDCl}_{3}\right.$ ) of compound 1'I

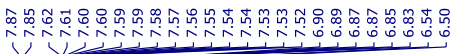

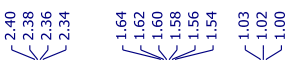

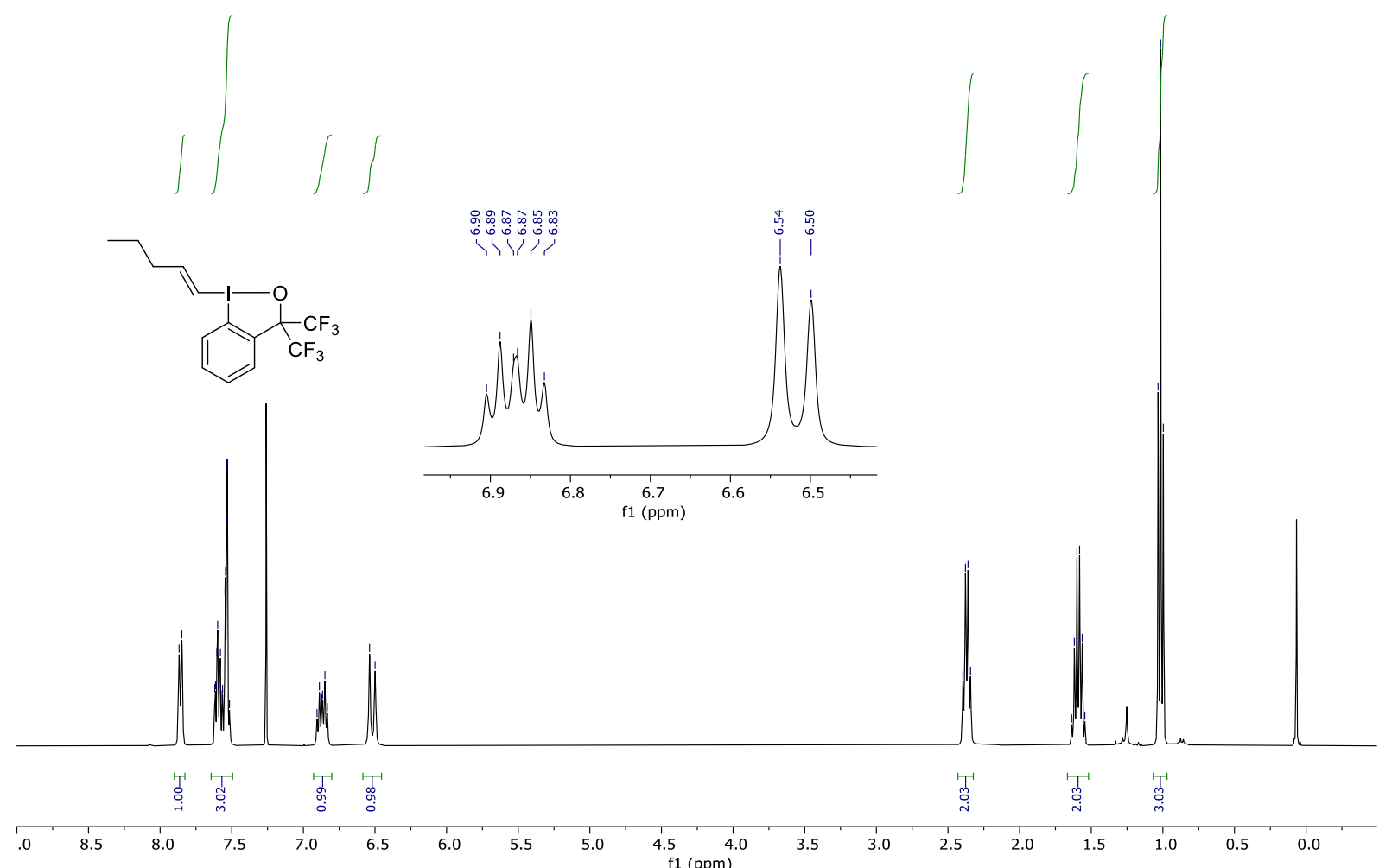

${ }^{13} \mathrm{C}$-NMR (101 MHz, $\mathrm{CDCl}_{3}$ ) of compound 1'I

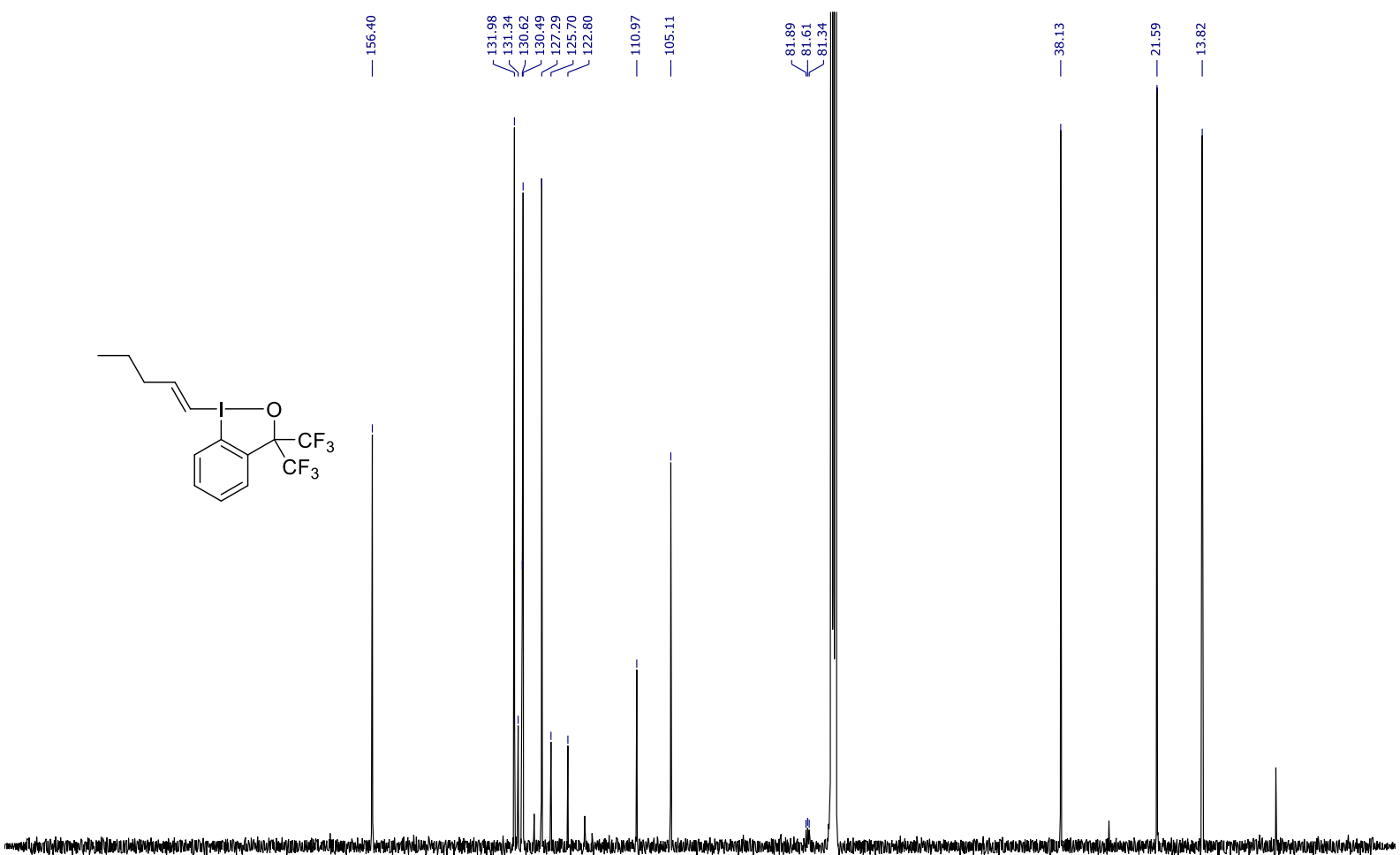

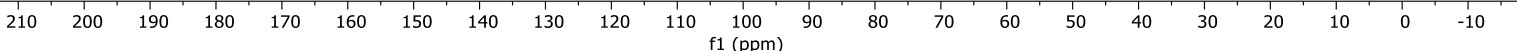


${ }^{19} \mathrm{~F}-\mathrm{NMR}\left(376 \mathrm{MHz}, \mathrm{CDCl}_{3}\right.$ ) of compound 1'I

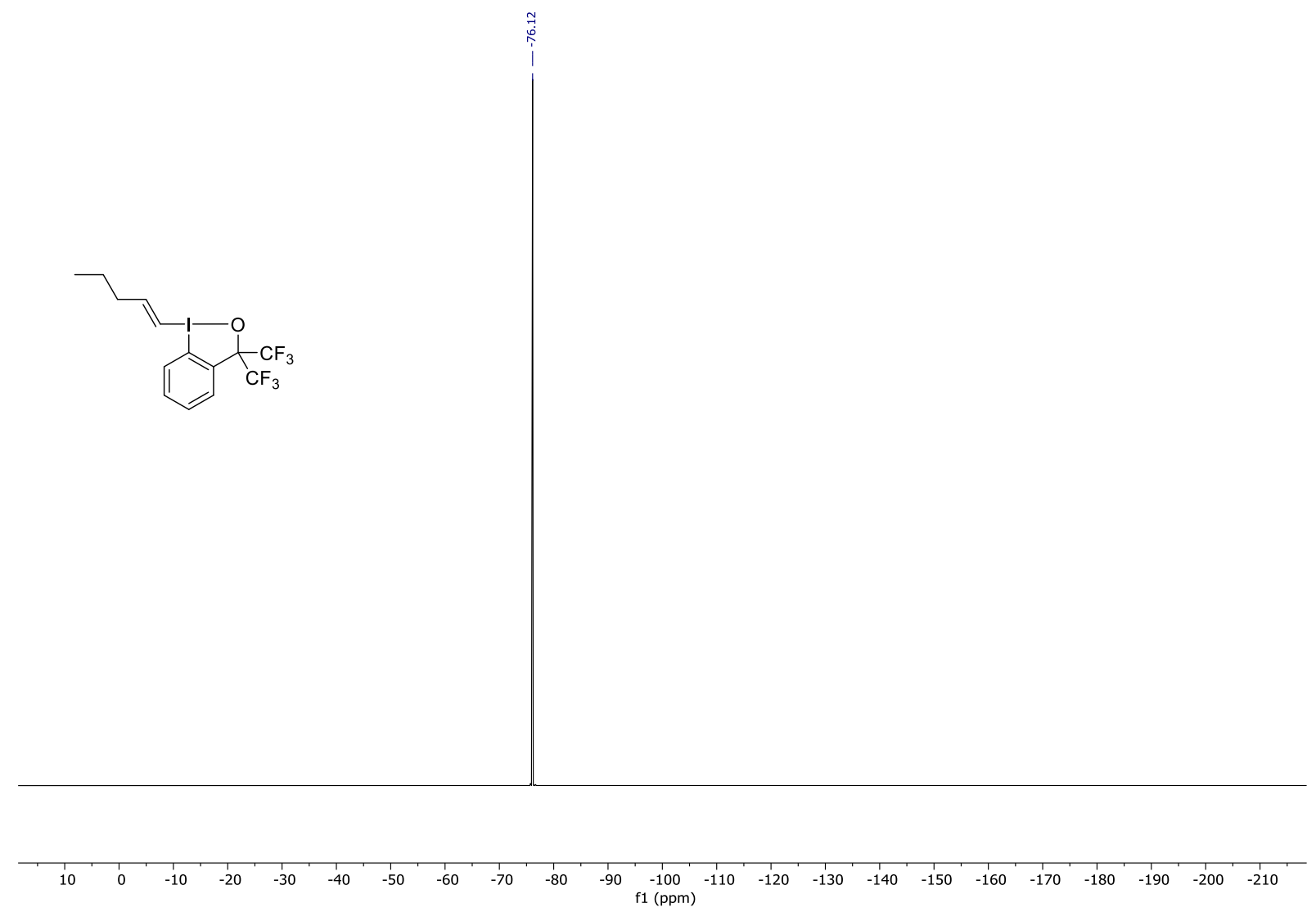


${ }^{1} \mathbf{H}-\mathrm{NMR}\left(400 \mathrm{MHz}, \mathrm{CDCl}_{3}\right.$ ) of compound $\mathbf{1}$ 'p

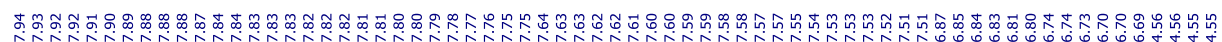

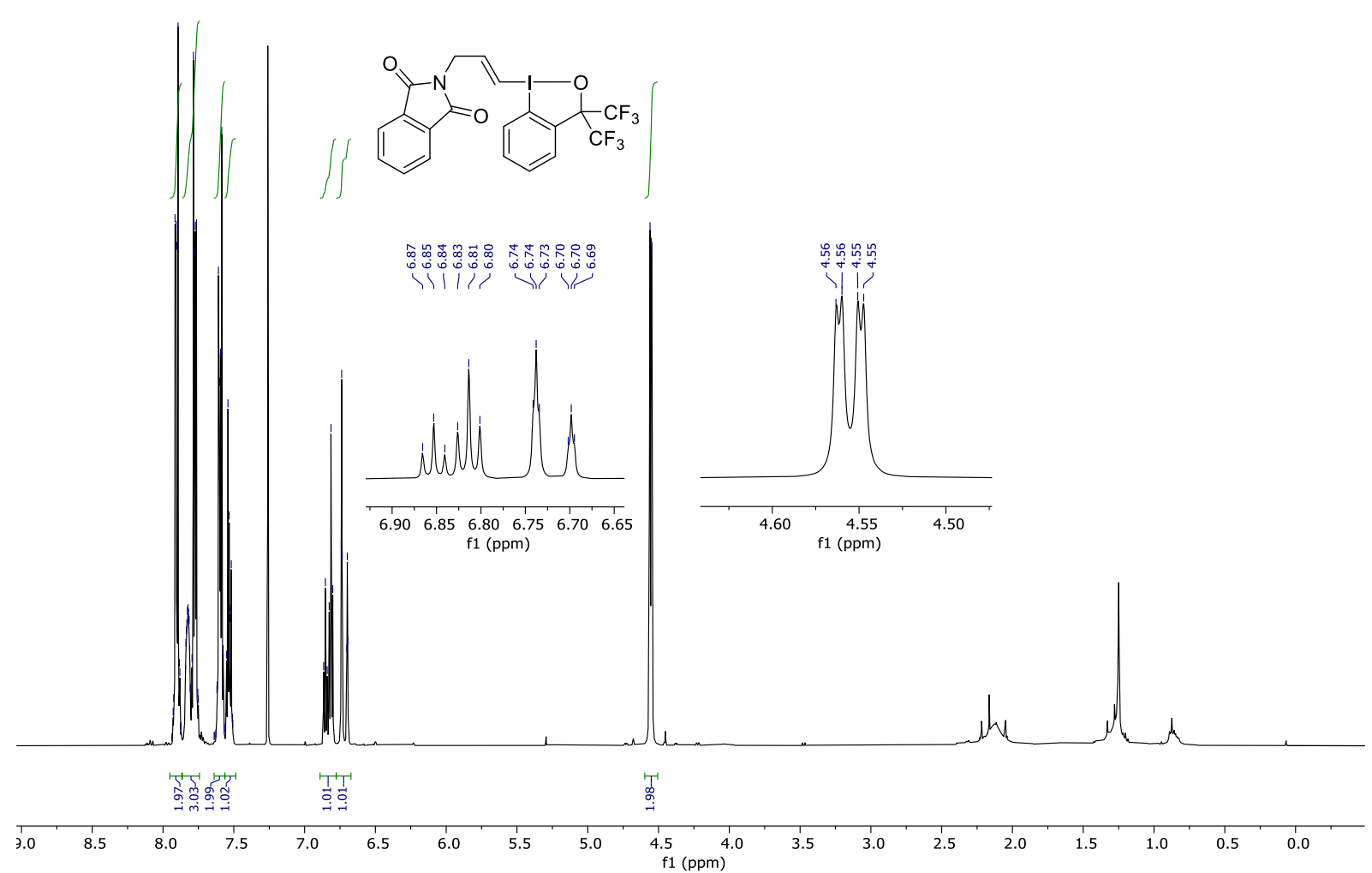

${ }^{13}$ C-NMR (101 MHz, $\mathrm{CDCl}_{3}$ ) of compound 1'p

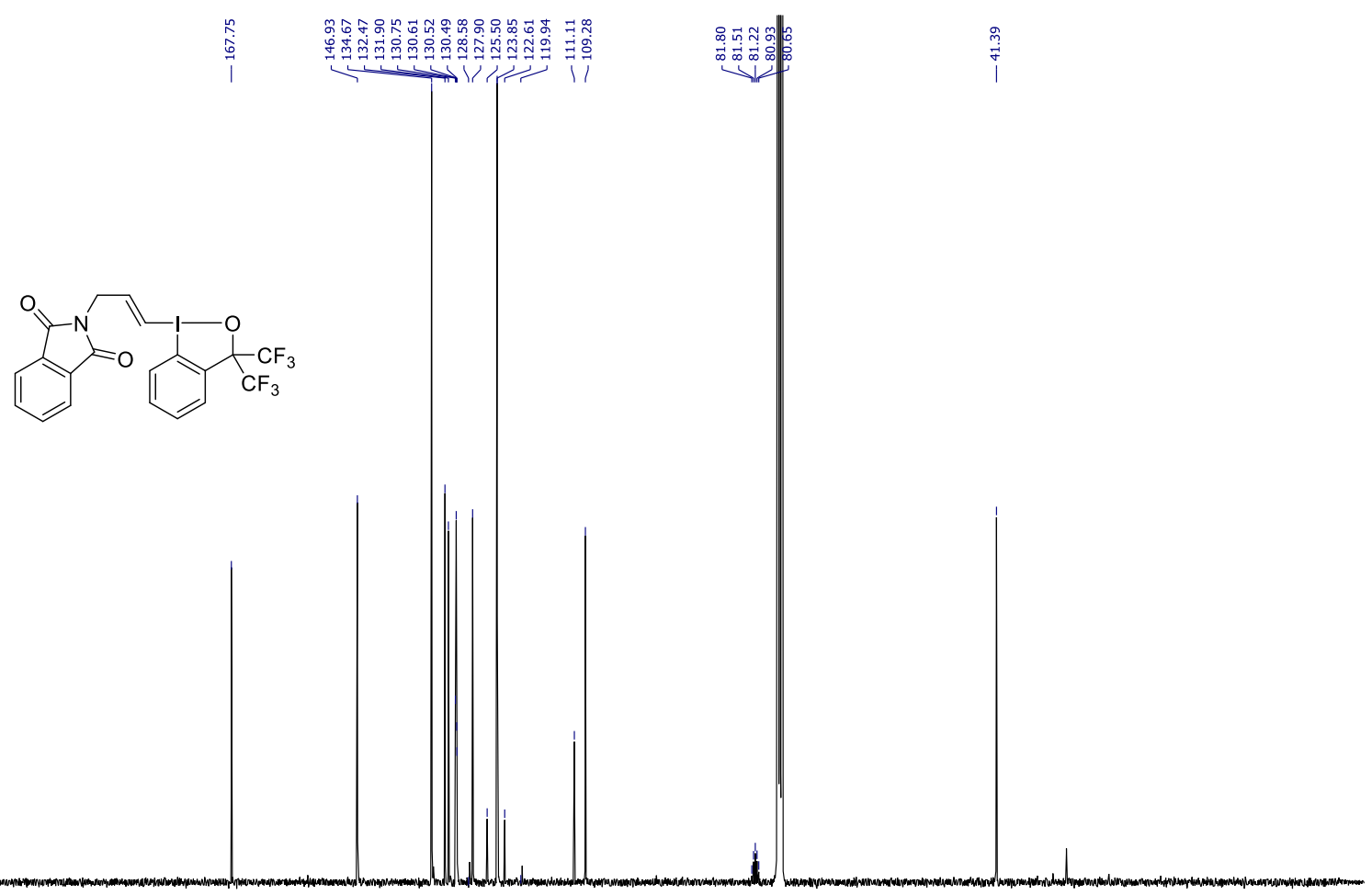

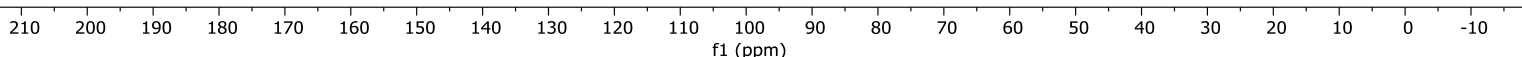


${ }^{19}$ F-NMR (376 MHz, $\mathrm{CDCl}_{3}$ ) of compound 1'p

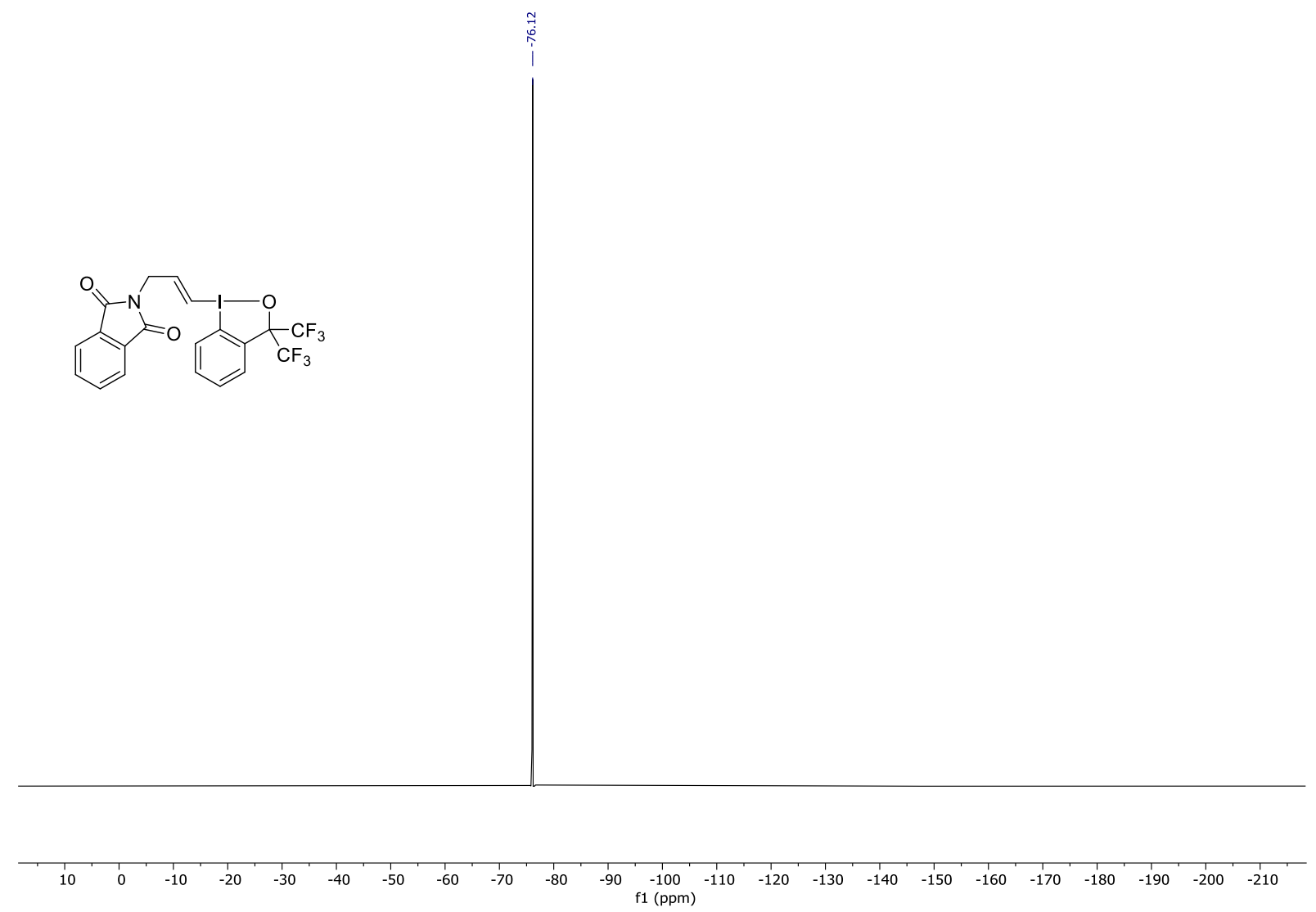


${ }^{1} \mathbf{H}-\mathbf{N M R}\left(400 \mathrm{MHz} \mathrm{CDCl}_{3}\right.$ ) of compound $\mathbf{4 a}$

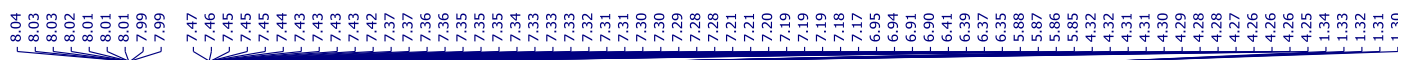
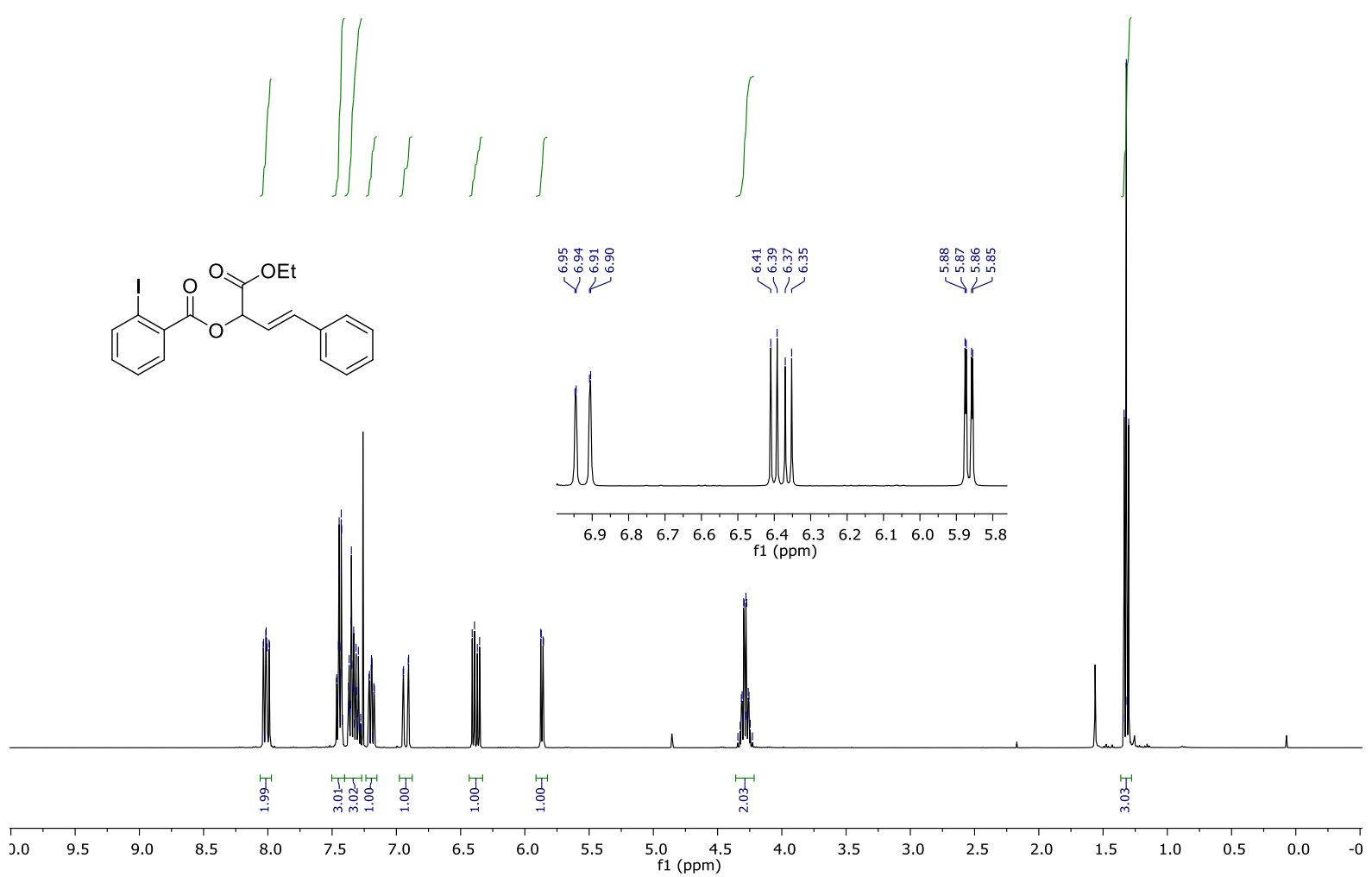

${ }^{13}$ C-NMR (101 MHz, $\mathrm{CDCl}_{3}$ ) of compound 4a

|
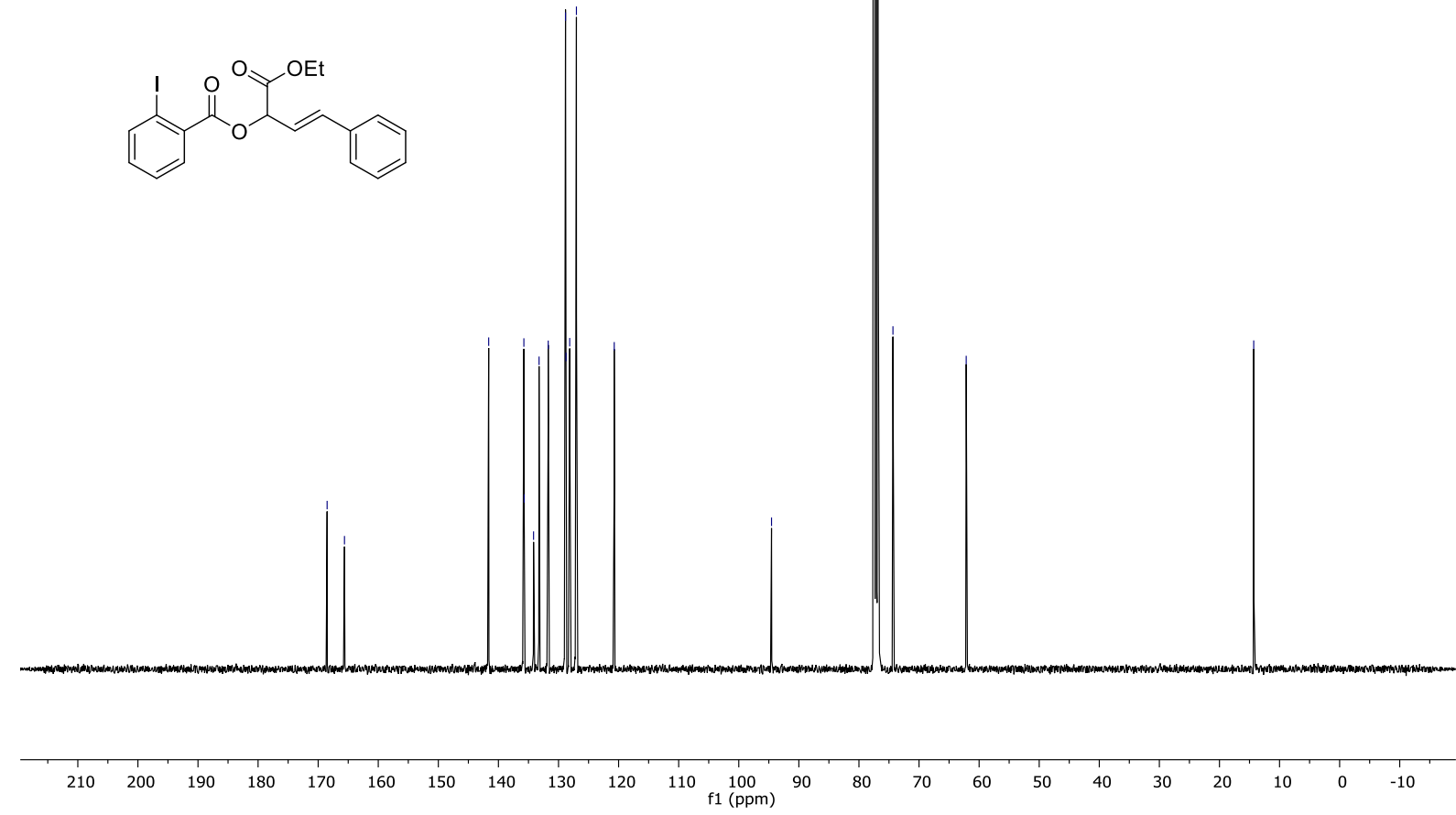

S105 
${ }^{1} \mathbf{H}-\mathrm{NMR}\left(400 \mathrm{MHz}, \mathrm{CDCl}_{3}\right)$ of compound $\mathbf{4 b}$

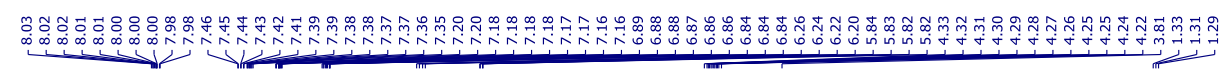
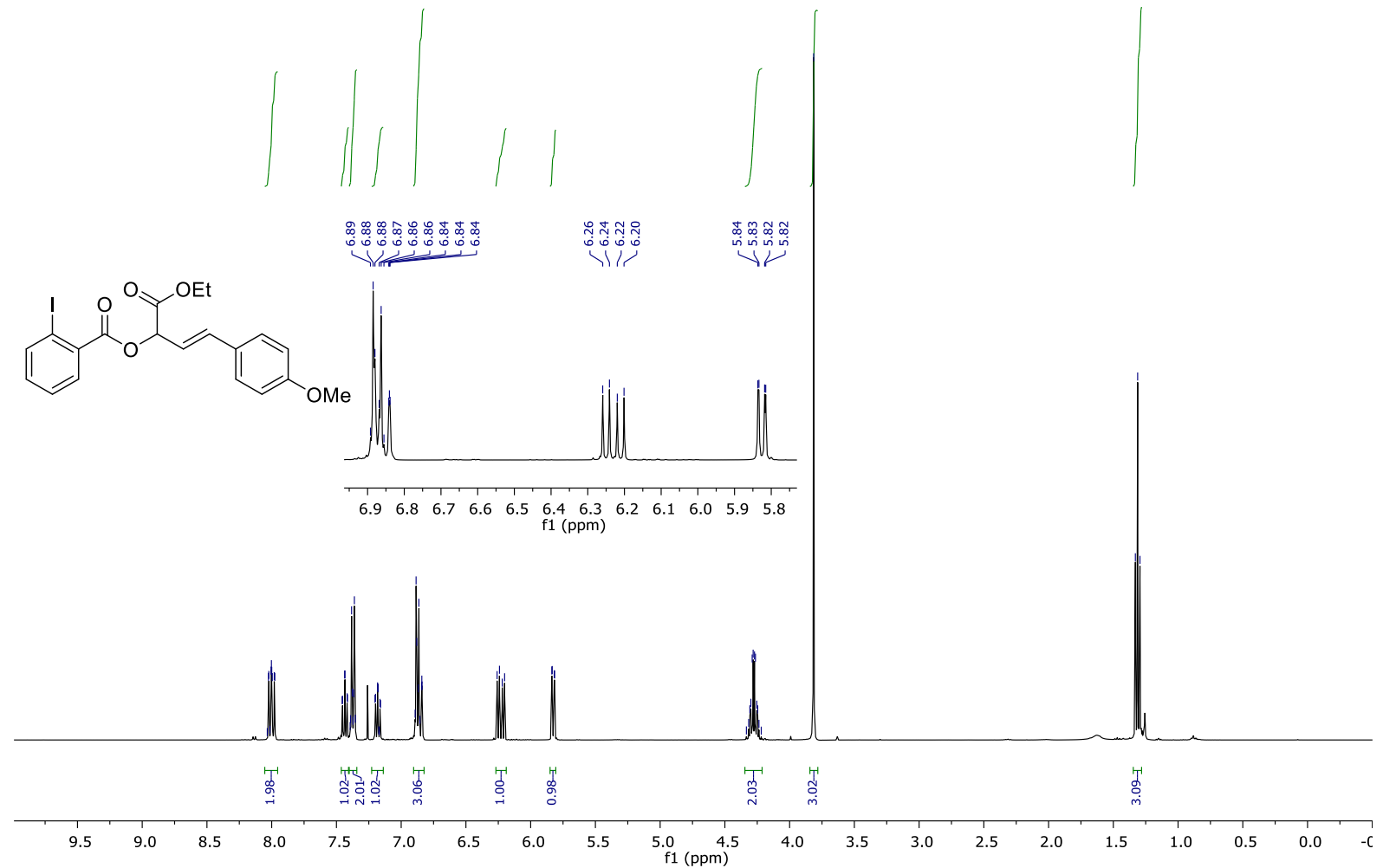

${ }^{13} \mathrm{C}$-NMR (101 MHz, $\mathrm{CDCl}_{3}$ ) of compound 4b

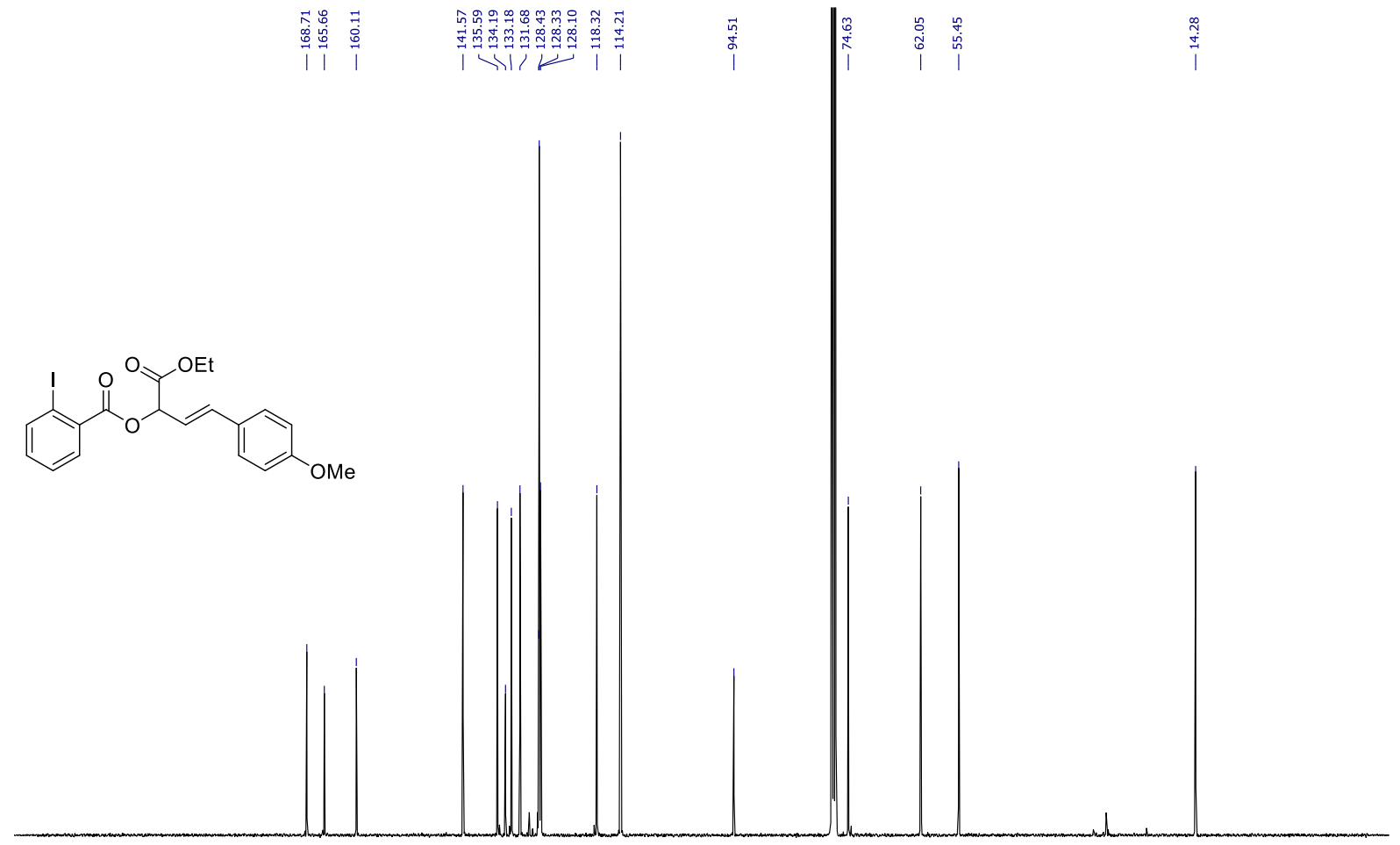

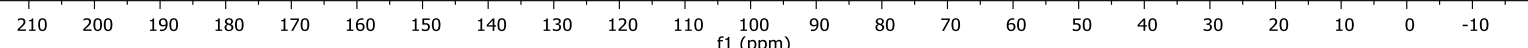


${ }^{1} \mathbf{H}-\mathrm{NMR}\left(400 \mathrm{MHz}, \mathrm{CDCl}_{3}\right.$ ) of compound $\mathbf{4 c}$

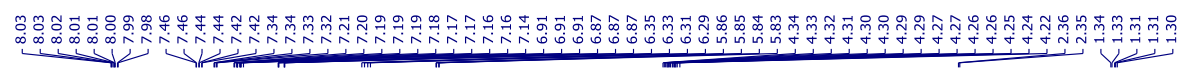<smiles>CCOC(=O)C(=Cc1ccc([N+](=O)[O-])cc1)OC(=O)c1ccccc1C</smiles>
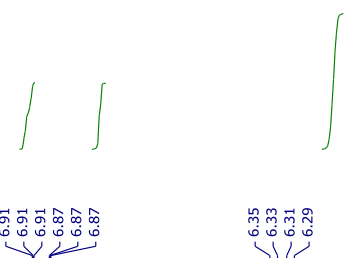

10
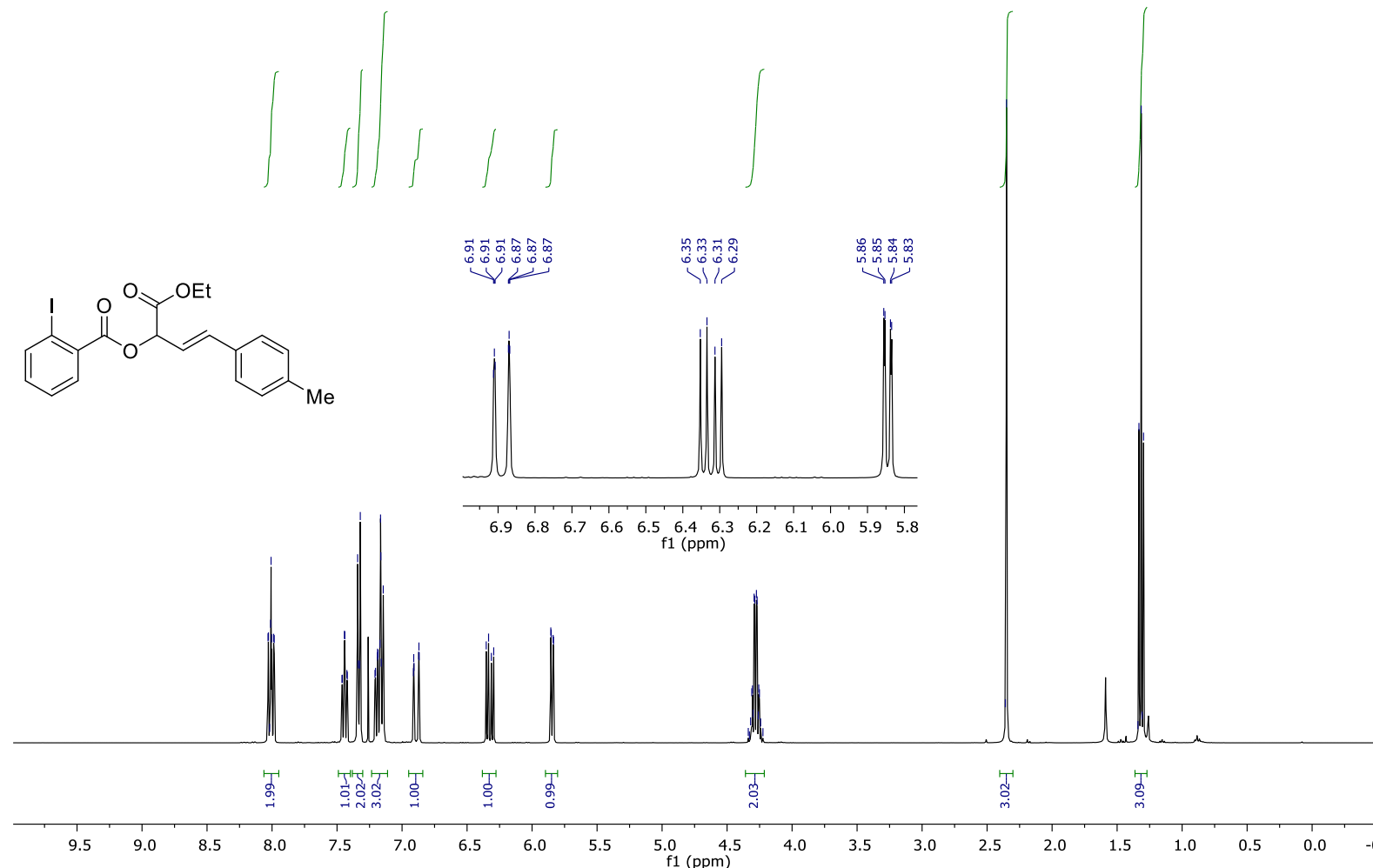

${ }^{13} \mathrm{C}$-NMR (101 MHz, $\mathrm{CDCl}_{3}$ ) of compound 4c

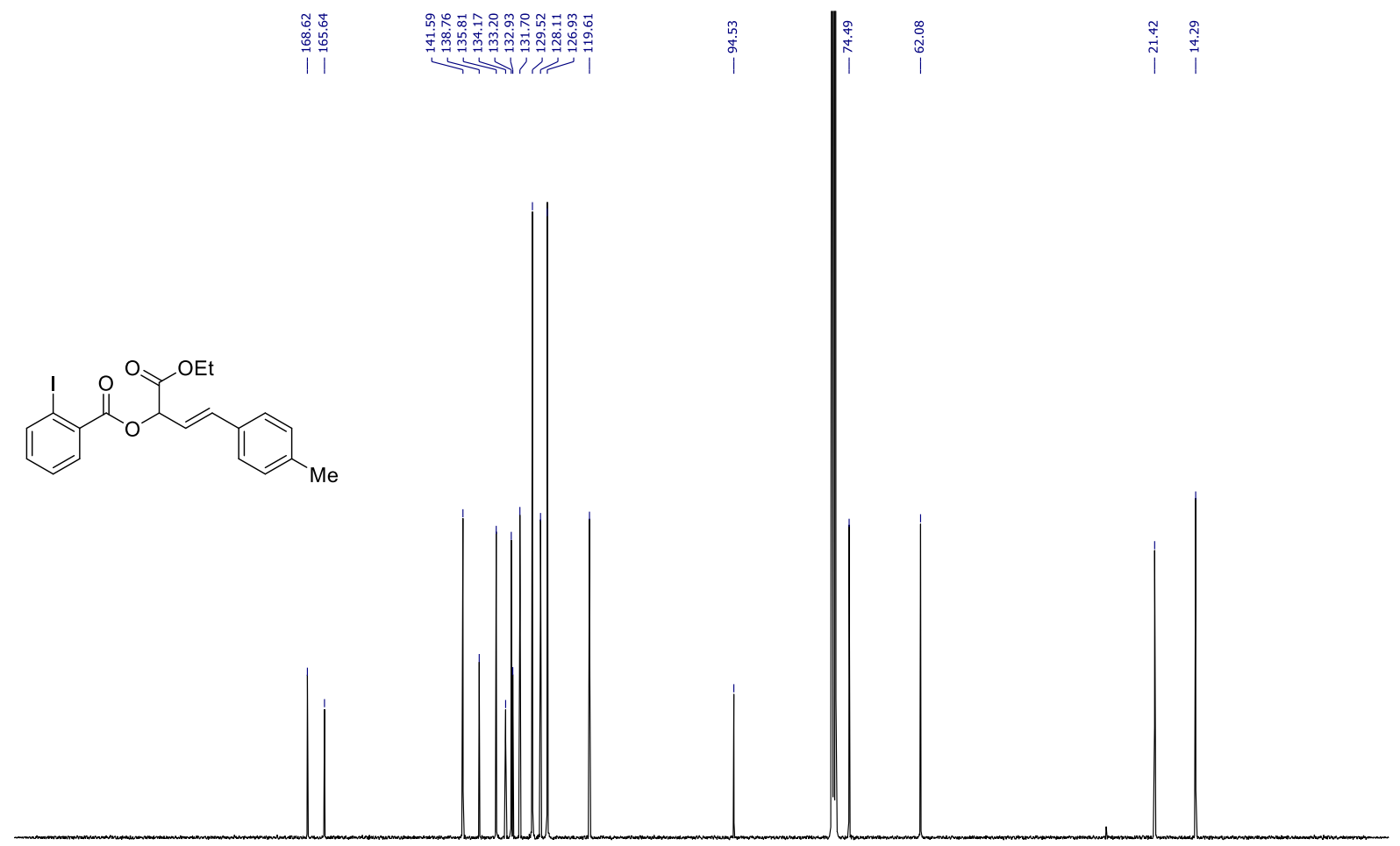

$\begin{array}{lllllllllllllllllllllll}210 & 200 & 190 & 180 & 170 & 160 & 150 & 140 & 130 & 120 & 110 & 100 & 90 & 80 & 70 & 60 & 50 & 40 & 30 & 20 & 10 & 0 & -10\end{array}$ 
${ }^{1} \mathbf{H}-\mathrm{NMR}\left(400 \mathrm{MHz}, \mathrm{CDCl}_{3}\right)$ of compound $\mathbf{4 d}$

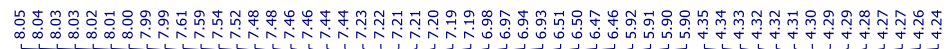
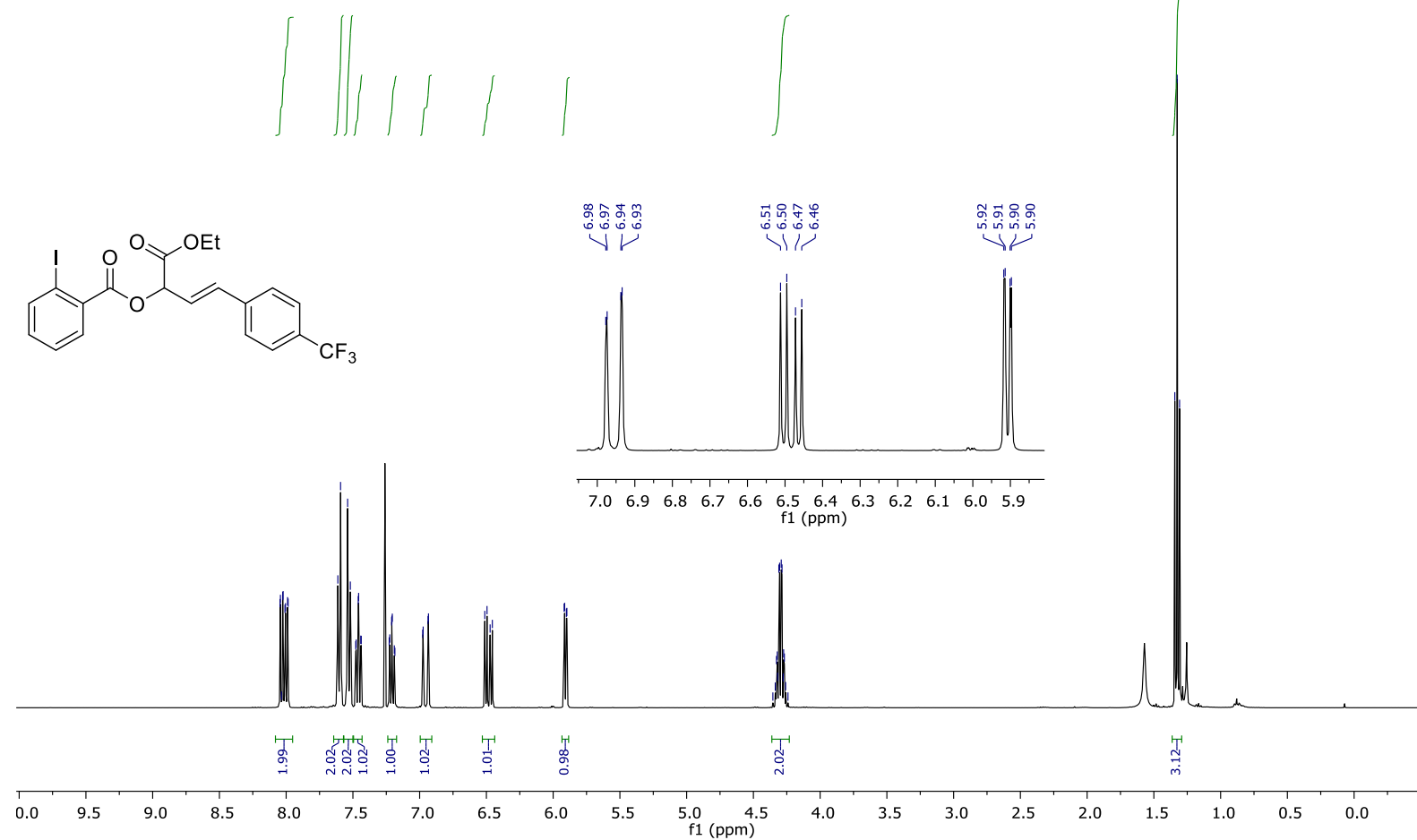

${ }^{13}$ C-NMR (101 MHz, $\mathrm{CDCl}_{3}$ ) of compound 4d

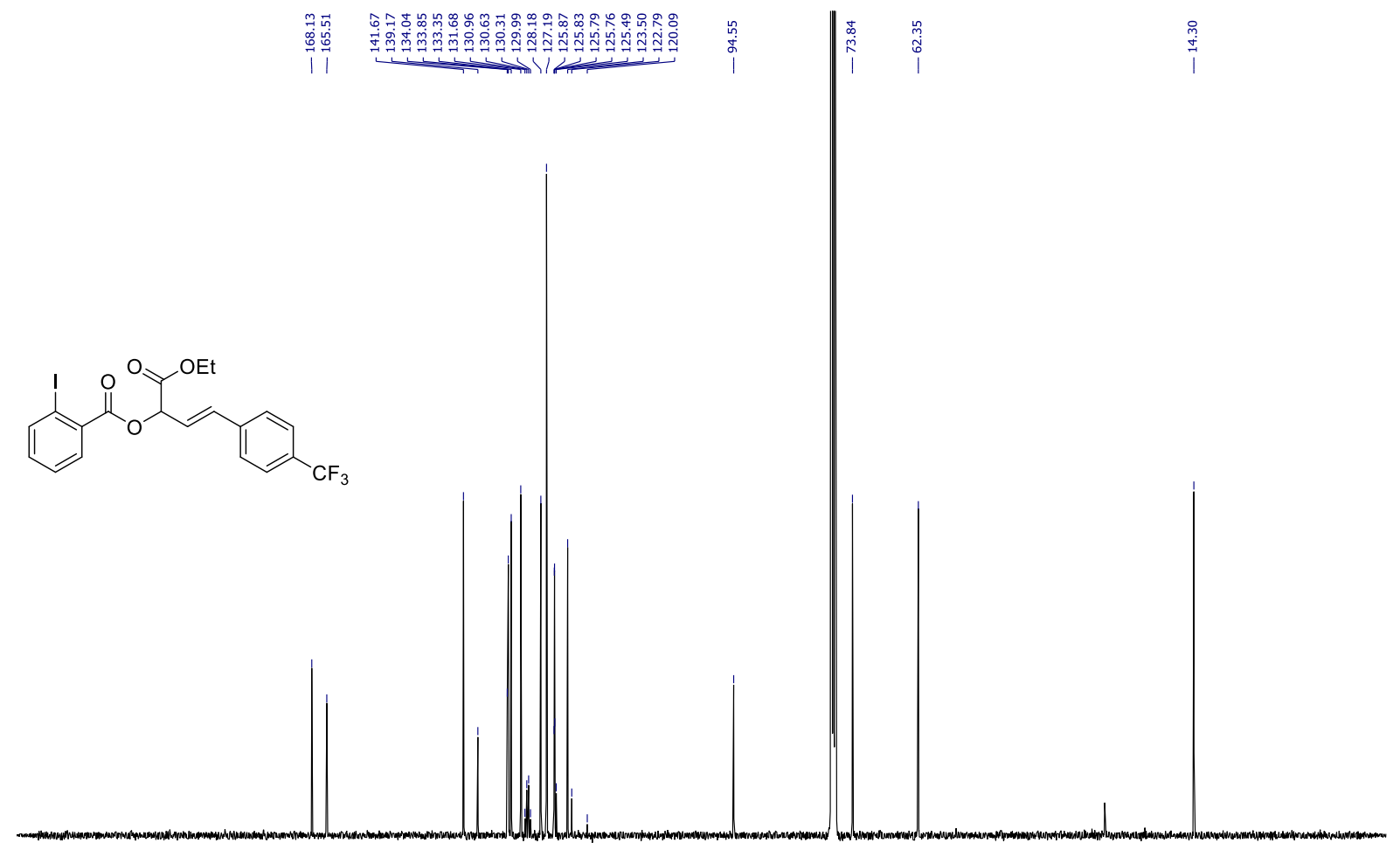

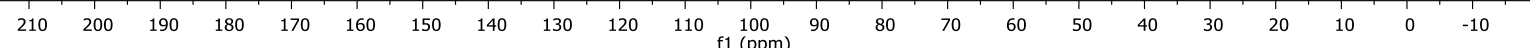


${ }^{19}$ F-NMR (376 MHz, $\mathrm{CDCl}_{3}$ ) of compound $\mathbf{4 d}$

$\underset{\substack{\stackrel{\leftrightarrow}{\leftrightarrow} \\ i}}{\mid}$<smiles>CCOC(=O)C(C=Cc1ccc(C(F)(F)F)cc1)OC(=O)c1ccccc1C</smiles>

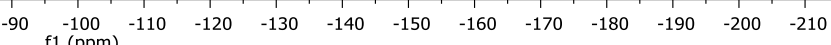


${ }^{1} \mathbf{H}-\mathrm{NMR}\left(400 \mathrm{MHz}, \mathrm{CDCl}_{3}\right.$ ) of compound $4 \mathbf{e}$

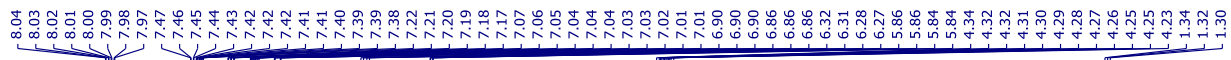

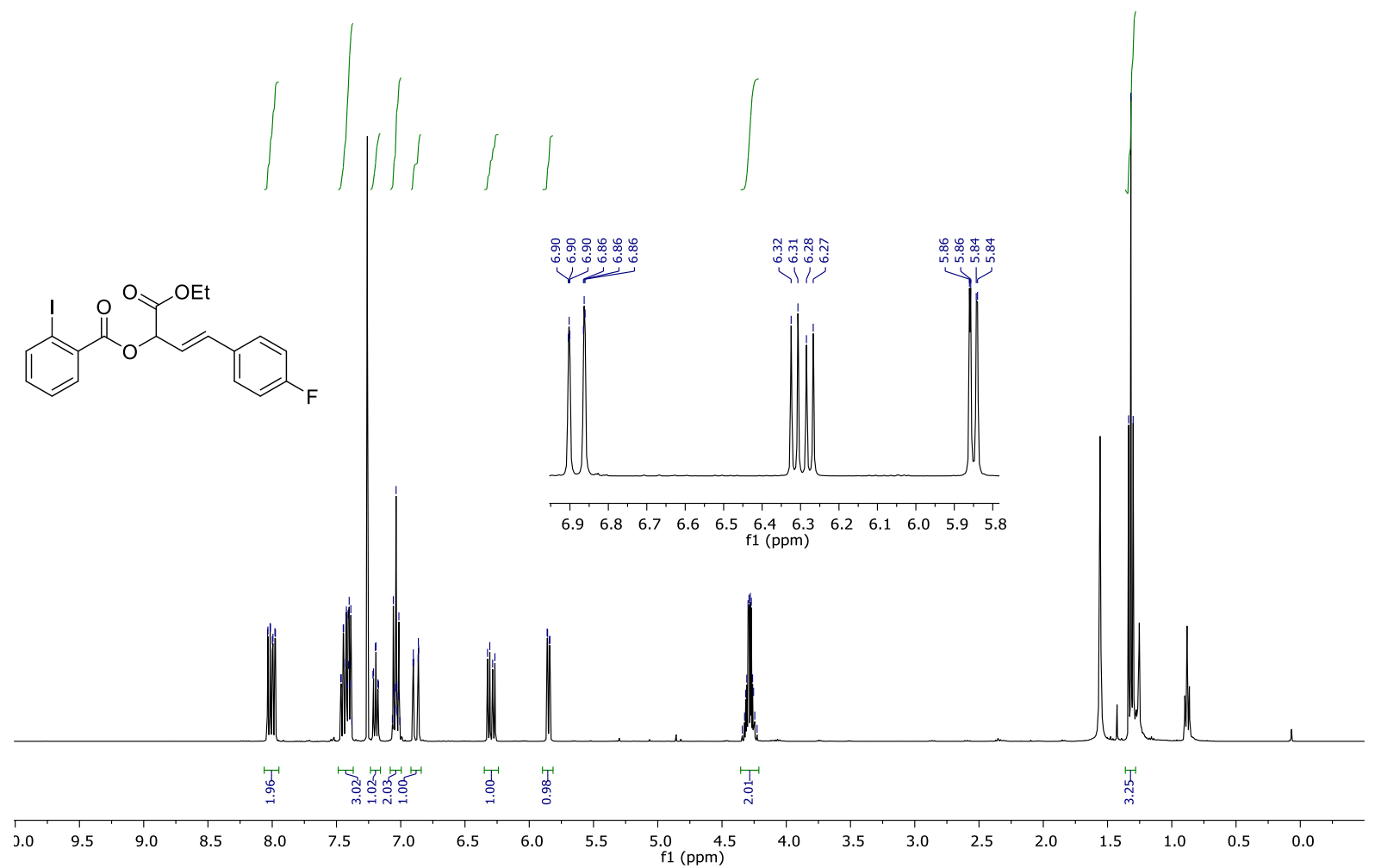

${ }^{13} \mathrm{C}$-NMR (101 MHz, $\mathrm{CDCl}_{3}$ ) of compound $4 \mathrm{e}$

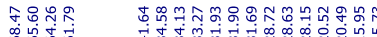

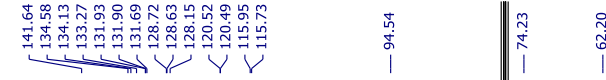

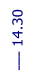<smiles>CCOC(=O)/C(=C\c1ccc(F)cc1)OC(=O)c1ccccc1I</smiles>
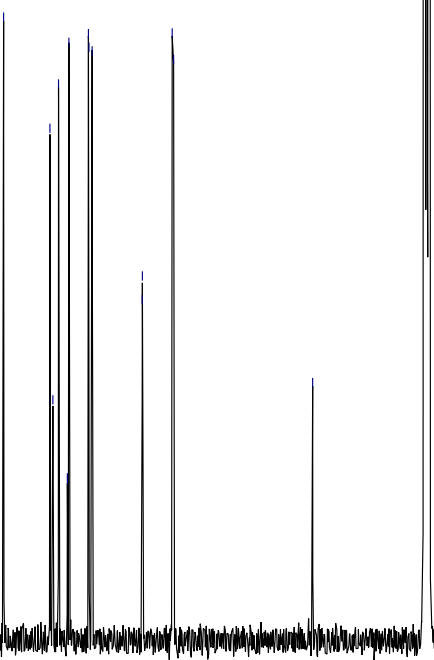

$\begin{array}{llllllllllll}210 & 200 & 190 & 180 & 170 & 160 & 150 & 140 & 130 & 120 & 110 & \begin{array}{c}100 \\ \mathrm{f} 1(\mathrm{ppm})\end{array}\end{array}$

$70 \quad 60$

50

30

10 
${ }^{19}$ F-NMR (376 MHz, $\mathrm{CDCl}_{3}$ ) of compound $4 \mathrm{e}$

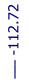<smiles>CCOC(=O)/C(=C\c1ccc(F)cc1)OC(=O)c1ccccc1I</smiles>

$\begin{array}{lllllllllllll}-90 & -100 & -110 & -120 & -130 & -140 & -150 & -160 & -170 & -180 & -190 & -200 & -210\end{array}$ 
${ }^{1} \mathbf{H}-\mathrm{NMR}\left(400 \mathrm{MHz}, \mathrm{CDCl}_{3}\right)$ of compound $\mathbf{4 f}$

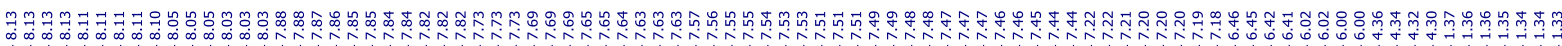

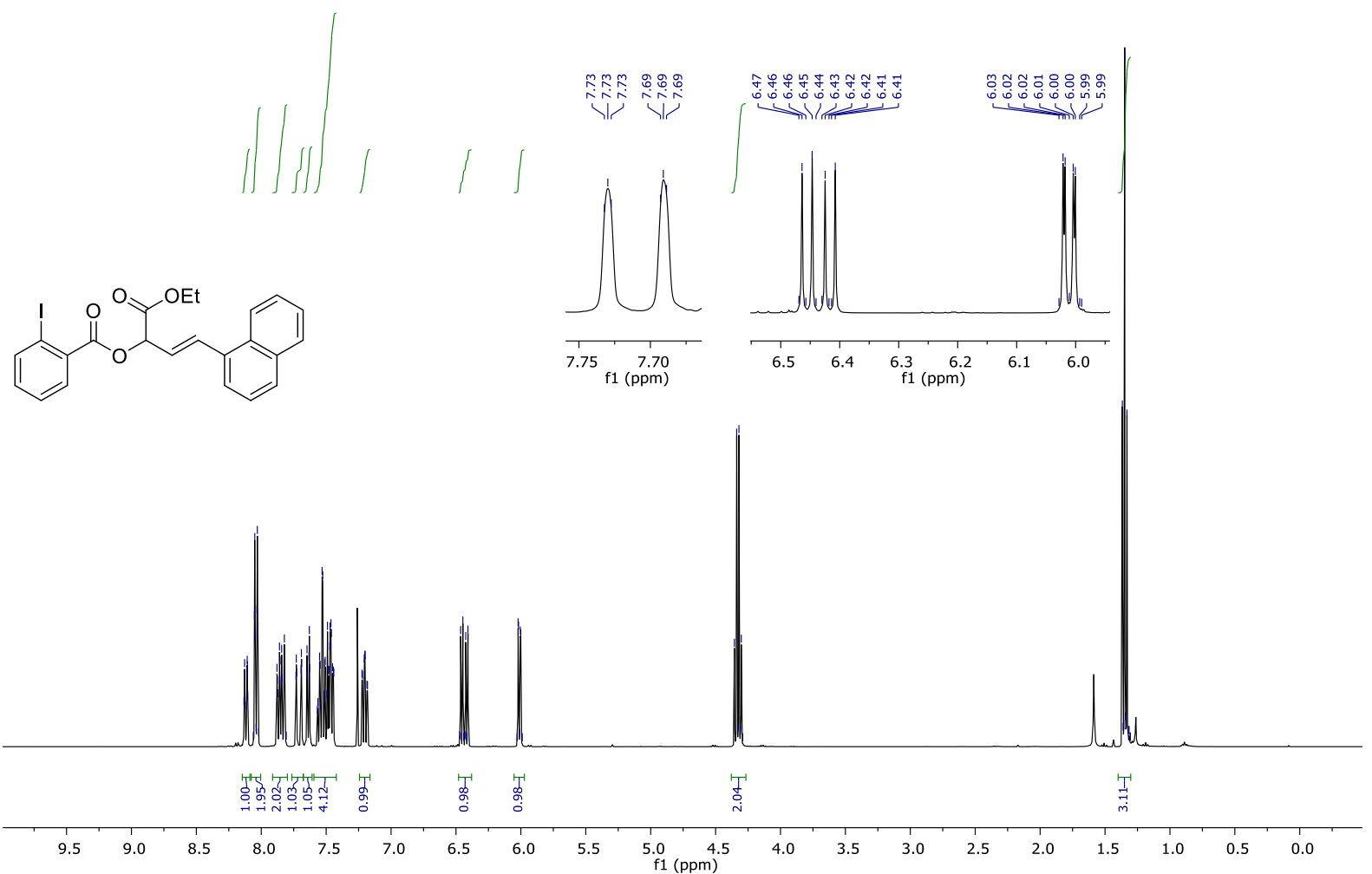

${ }^{13} \mathrm{C}-\mathrm{NMR}\left(101 \mathrm{MHz}, \mathrm{CDCl}_{3}\right)$ of compound $\mathbf{4 f}$

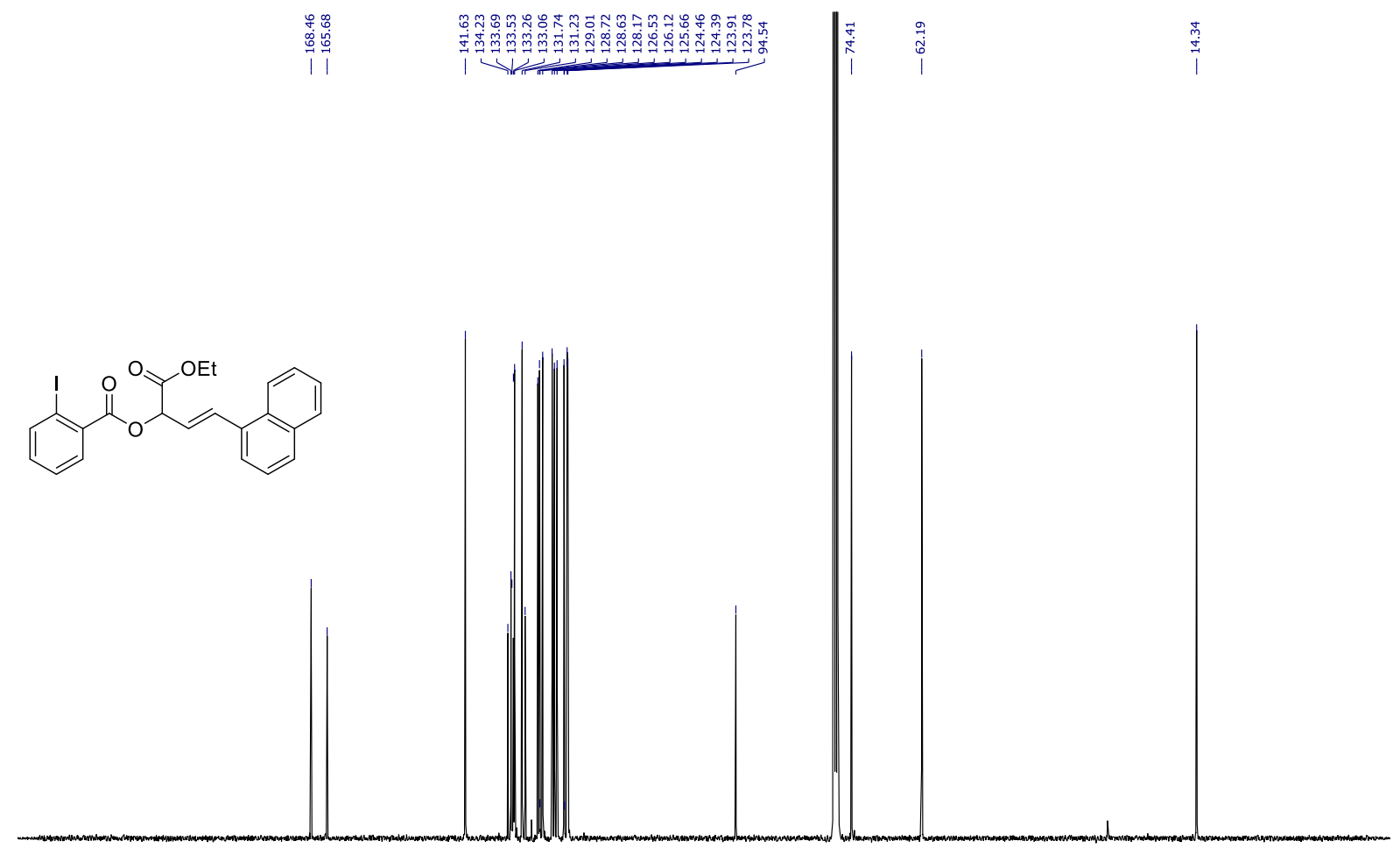

$\begin{array}{lllllllllllllllllllllll}210 & 200 & 190 & 180 & 170 & 160 & 150 & 140 & 130 & 120 & 110 & 100 & 90 & 80 & 70 & 60 & 50 & 40 & 30 & 20 & 10 & 0 & -10\end{array}$ 
${ }^{1} \mathbf{H}-\mathrm{NMR}\left(400 \mathrm{MHz}, \mathrm{CDCl}_{3}\right)$ of compound $\mathbf{4 g}$

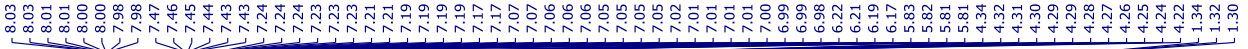

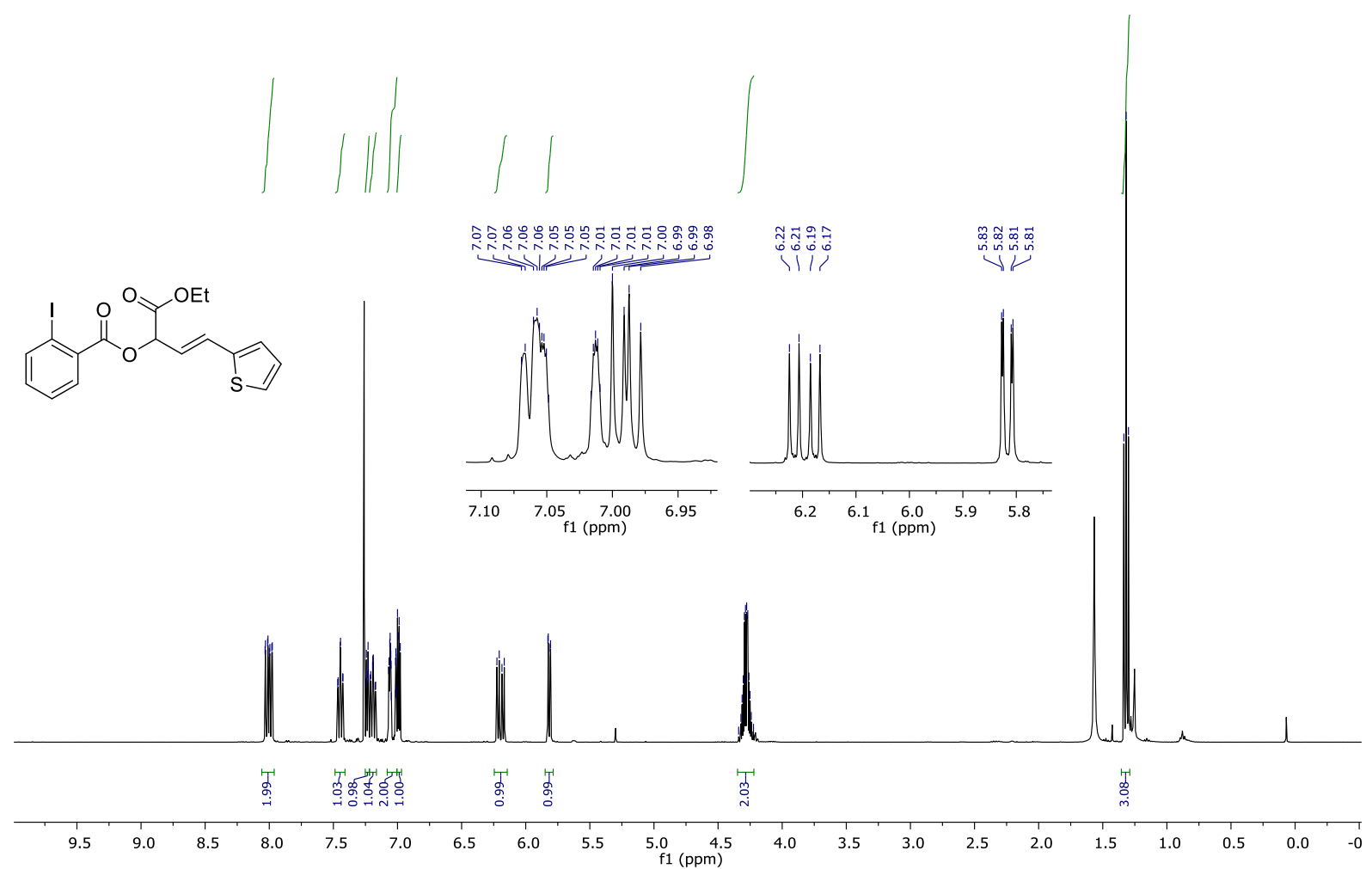

${ }^{13} \mathrm{C}-\mathrm{NMR}\left(101 \mathrm{MHz}, \mathrm{CDCl}_{3}\right)$ of compound $\mathbf{4 g}$

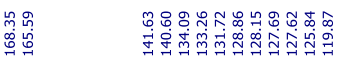

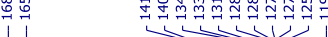

$\underbrace{O O E t}_{2}$
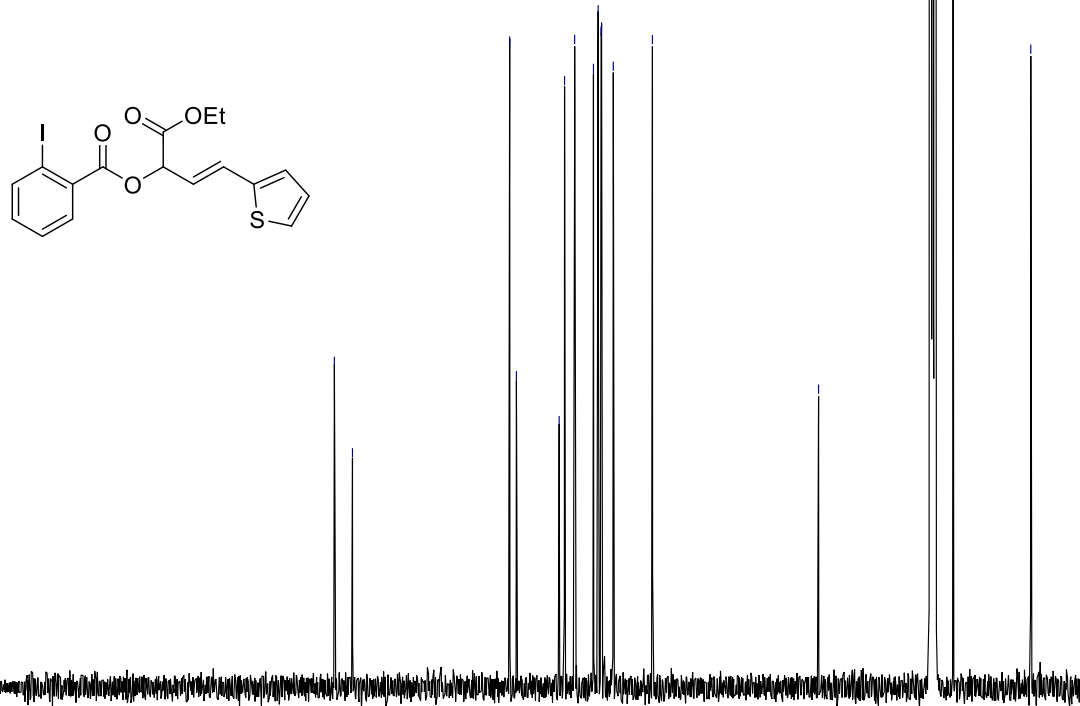

$\begin{array}{lllllllllll}210 & 200 & 190 & 180 & 170 & 160 & 150 & 140 & 130 & 120 & 110 \\ \mathrm{f} 1(\mathrm{ppm})\end{array}$ 
${ }^{1} \mathbf{H}-\mathrm{NMR}\left(400 \mathrm{MHz}, \mathrm{CDCl}_{3}\right)$ of compound $\mathbf{4 h}$

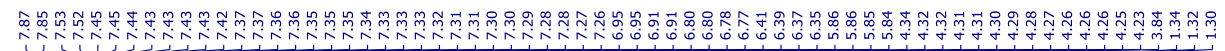
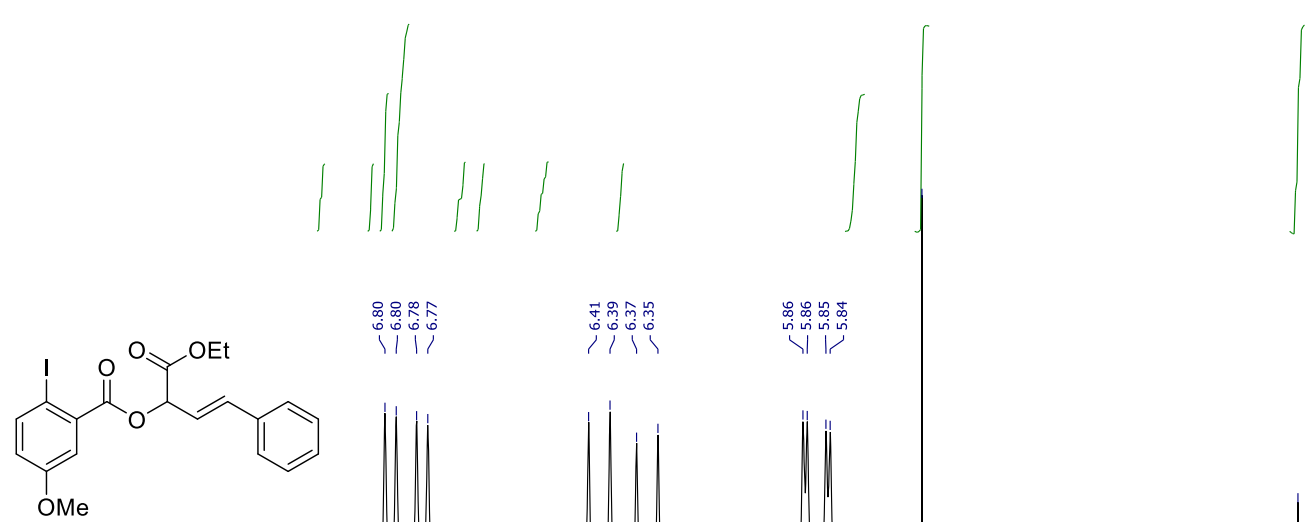

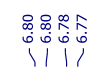
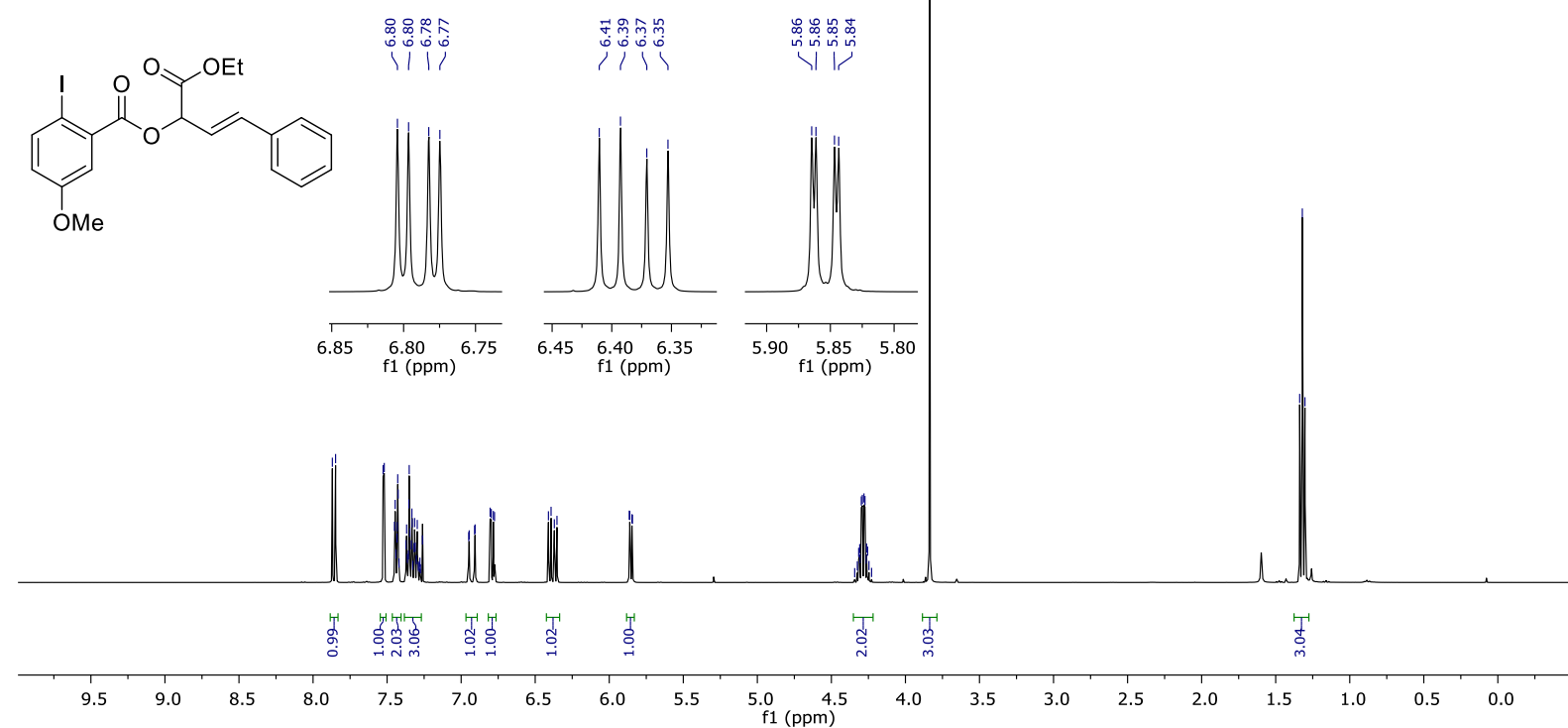

${ }^{13} \mathrm{C}-\mathrm{NMR}\left(101 \mathrm{MHz}, \mathrm{CDCl}_{3}\right)$ of compound $\mathbf{4 h}$

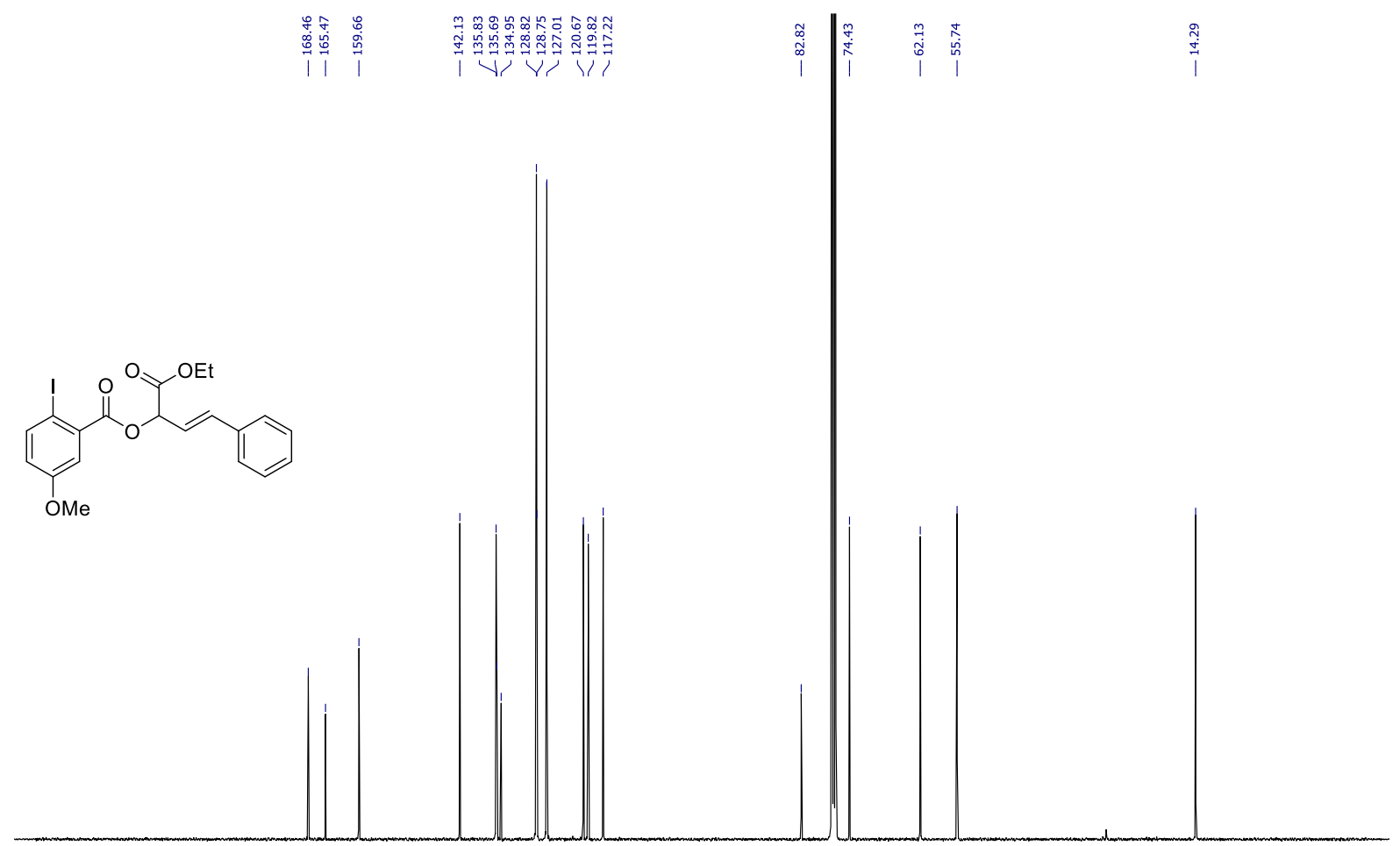

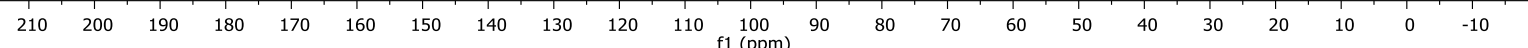


${ }^{1} \mathrm{H}-\mathrm{NMR}\left(400 \mathrm{MHz}, \mathrm{CDCl}_{3}\right.$ ) of compound $\mathbf{4 i}$

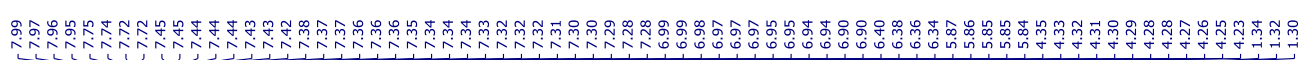

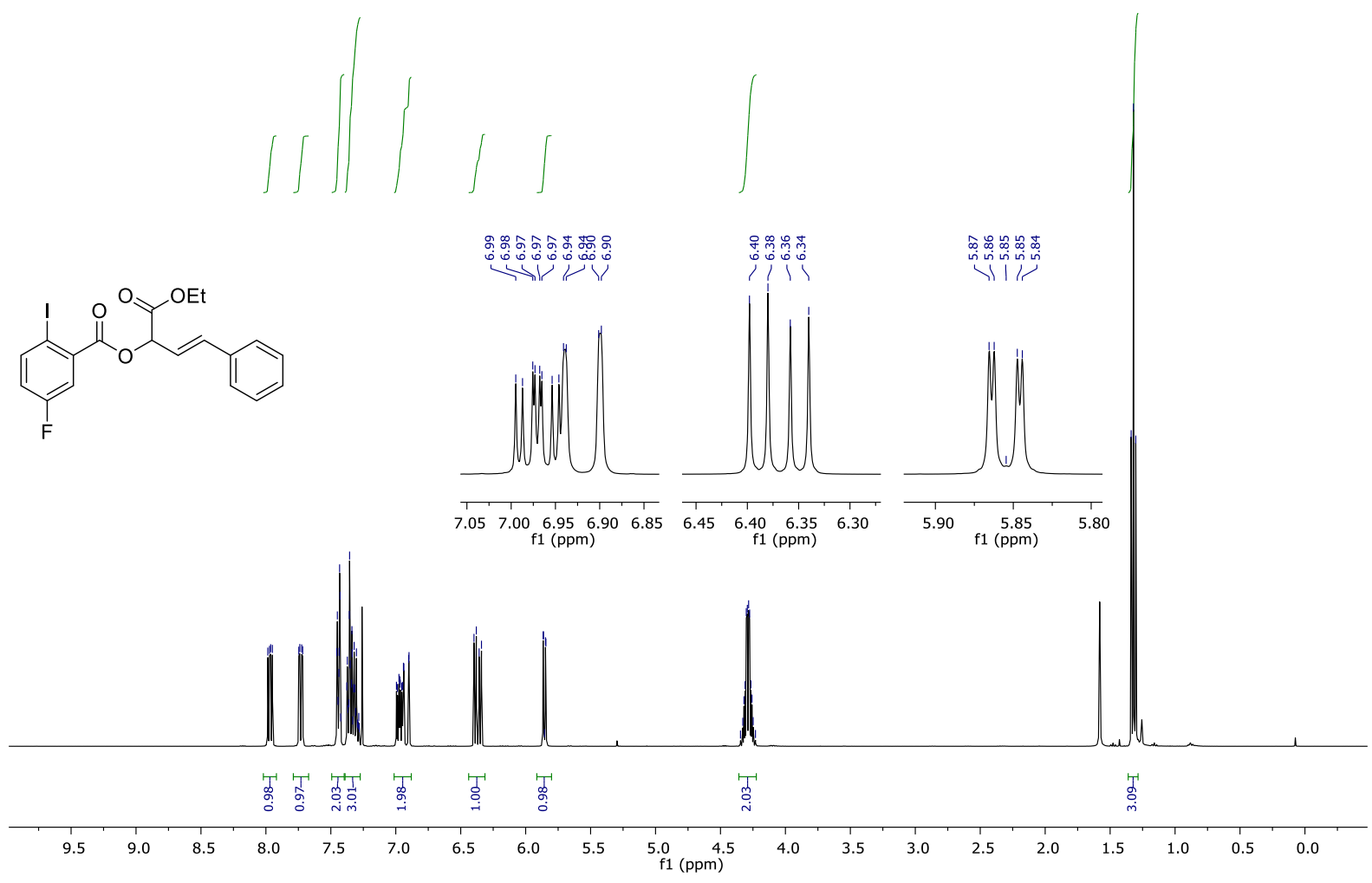

${ }^{13} \mathrm{C}-\mathrm{NMR}\left(101 \mathrm{MHz}, \mathrm{CDCl}_{3}\right)$ of compound $4 \mathbf{i}$

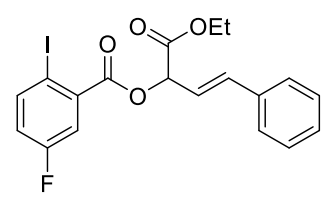

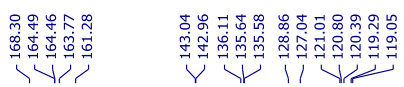

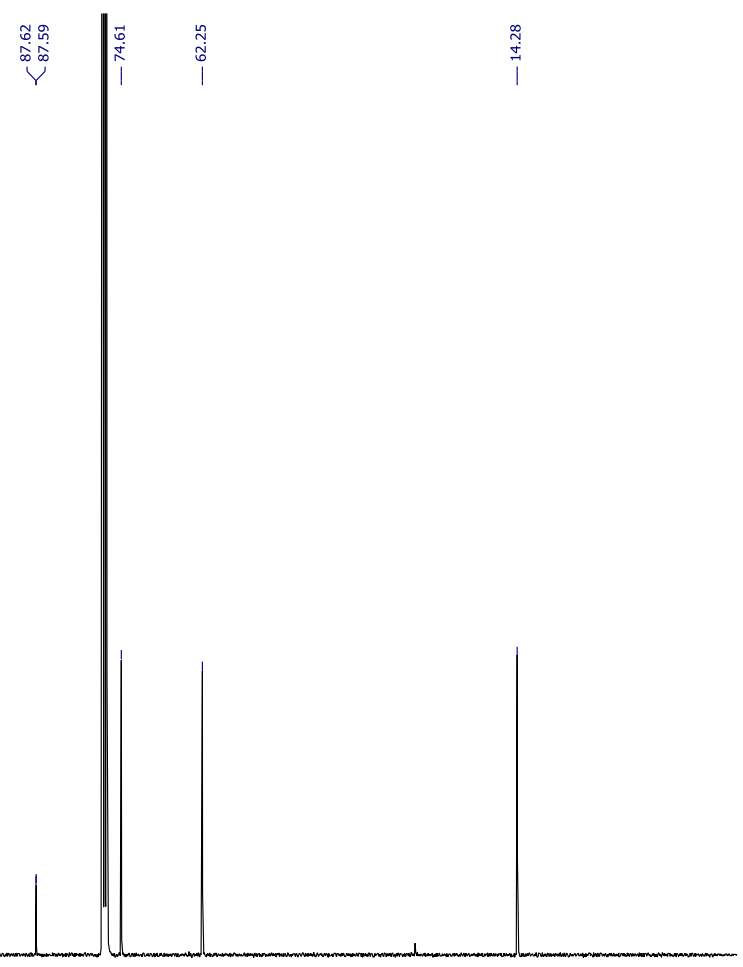

210

$\begin{array}{lllllllllll}200 & 190 & 180 & 170 & 160 & 150 & 140 & 130 & 120 & 110 & \begin{array}{c}100 \\ \mathrm{f} 1(\mathrm{ppm})\end{array}\end{array}$

S115 
${ }^{19}$ F-NMR (376 MHz, $\mathrm{CDCl}_{3}$ ) of compound 4i

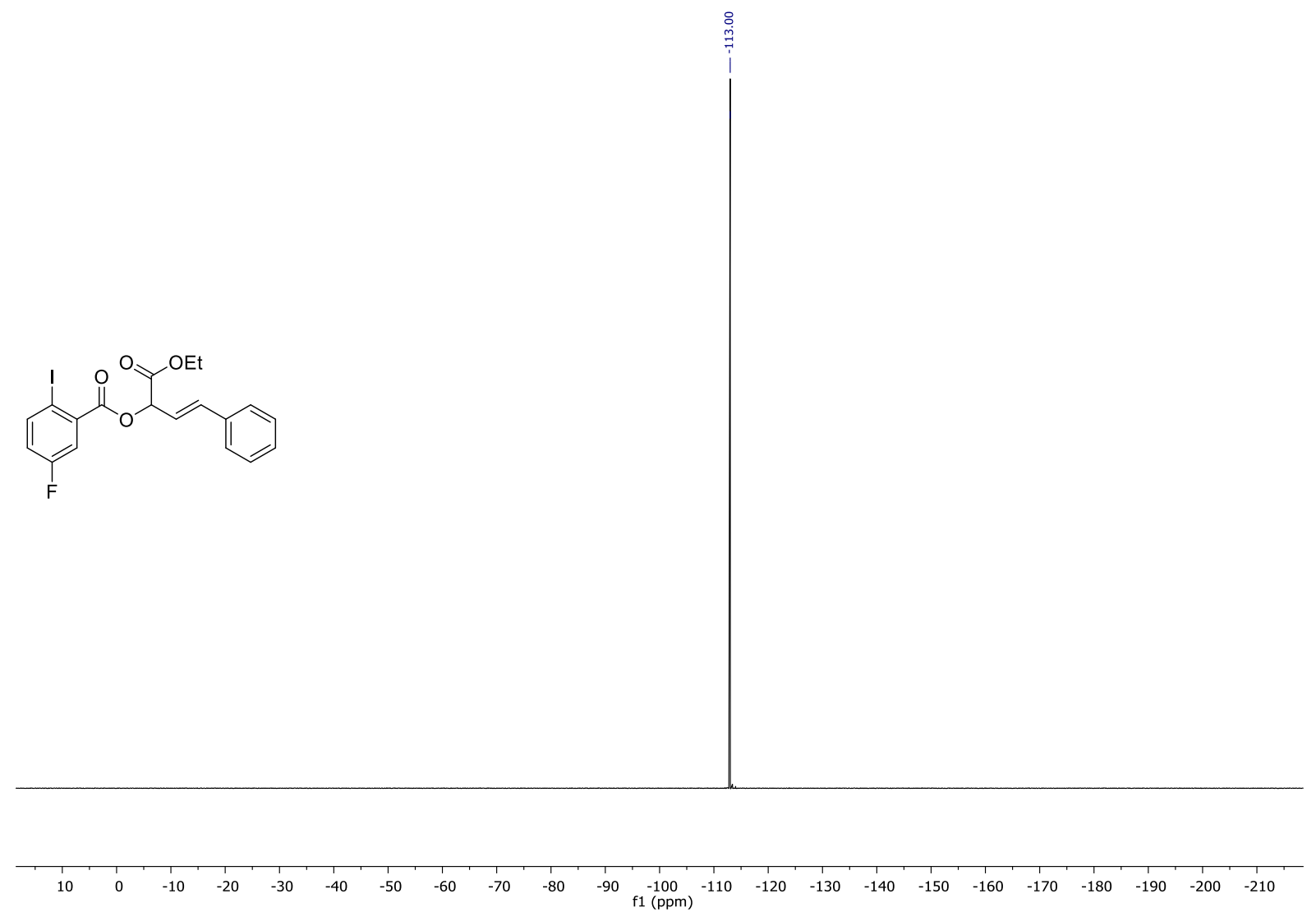


${ }^{1} \mathbf{H}-\mathrm{NMR}\left(400 \mathrm{MHz}, \mathrm{CDCl}_{3}\right)$ of compound $\mathbf{4 j}$

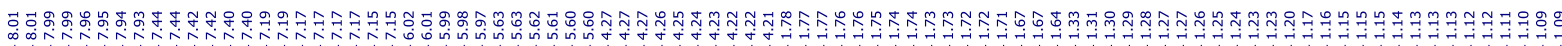

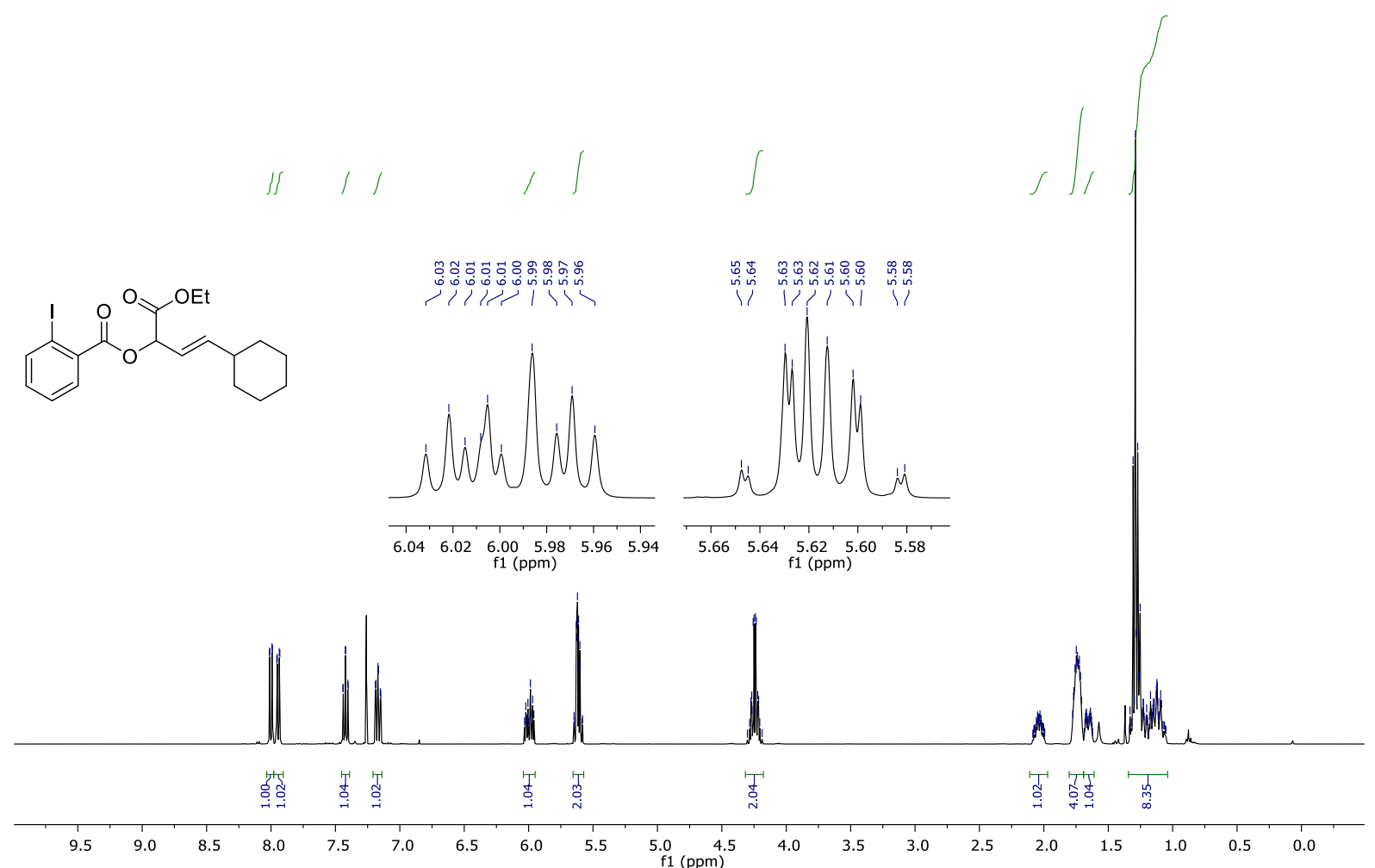

${ }^{13} \mathrm{C}-\mathrm{NMR}\left(101 \mathrm{MHz}, \mathrm{CDCl}_{3}\right)$ of compound $\mathbf{4 j}$

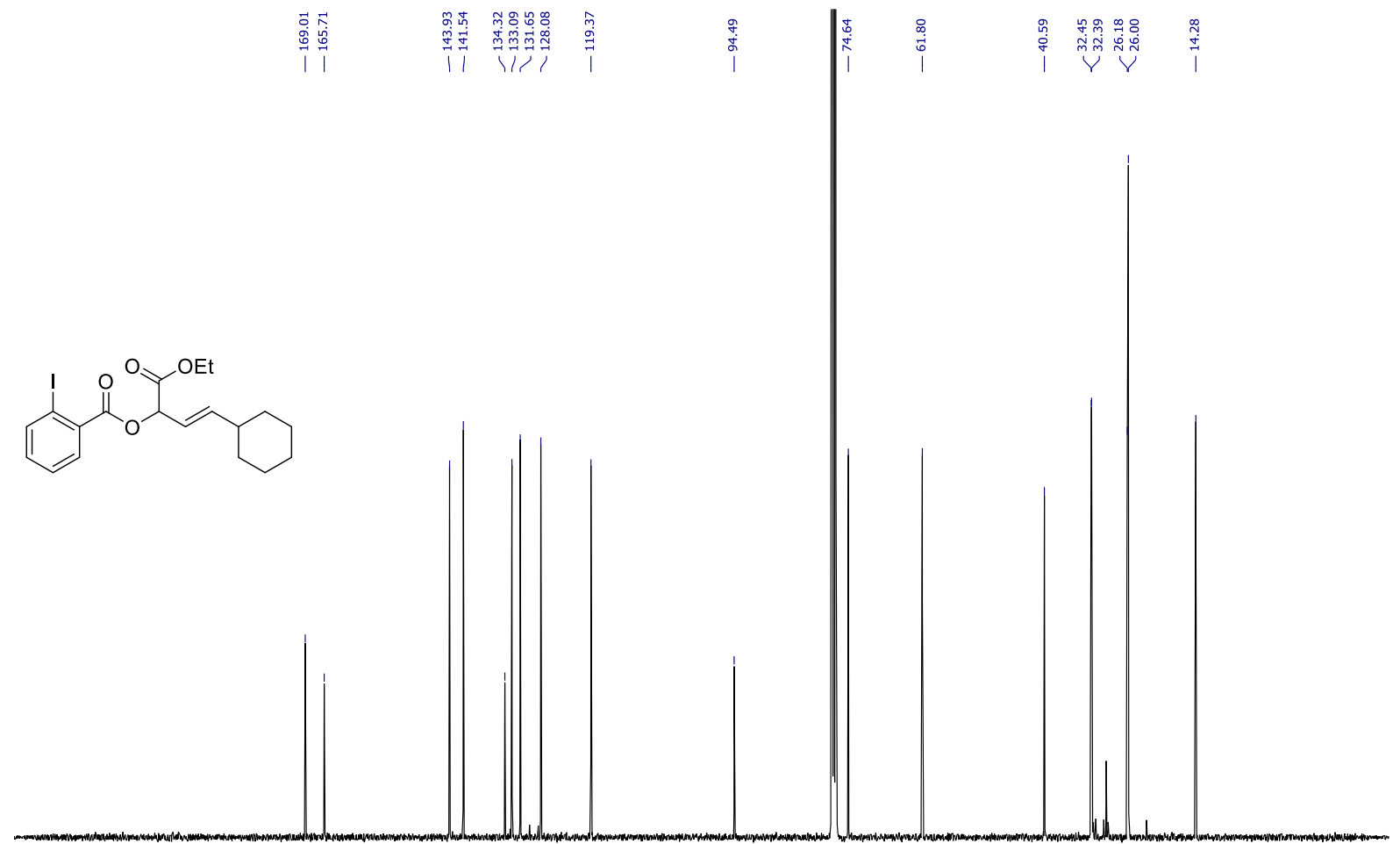

$\begin{array}{lllllllllllllllllllllll}210 & 200 & 190 & 180 & 170 & 160 & 150 & 140 & 130 & 120 & 110 & 100 & 90 & 80 & 70 & 60 & 50 & 40 & 30 & 20 & 10 & 0 & -10\end{array}$ 


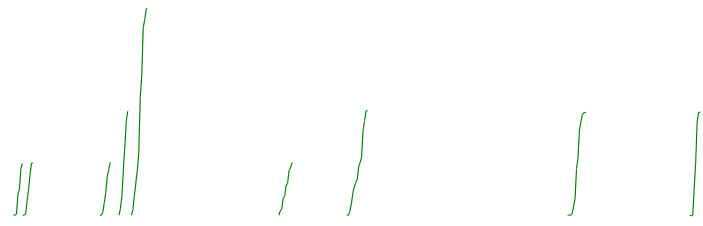

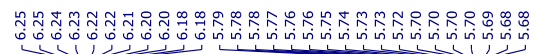<smiles>CCOC(=O)C(=CCc1ccccc1)OC(=O)c1ccccc1I</smiles>
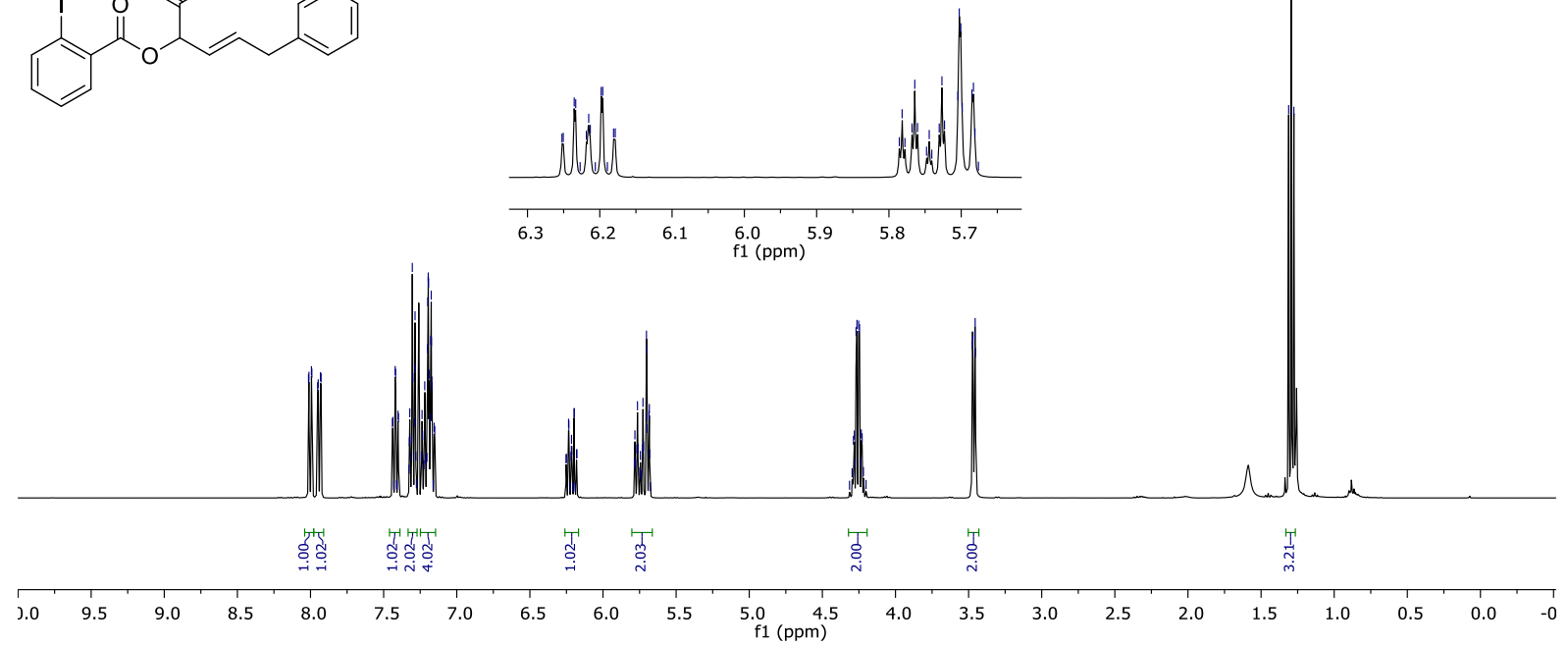

${ }^{13} \mathrm{C}-\mathrm{NMR}\left(101 \mathrm{MHz}, \mathrm{CDCl}_{3}\right)$ of compound $\mathbf{4 k}$

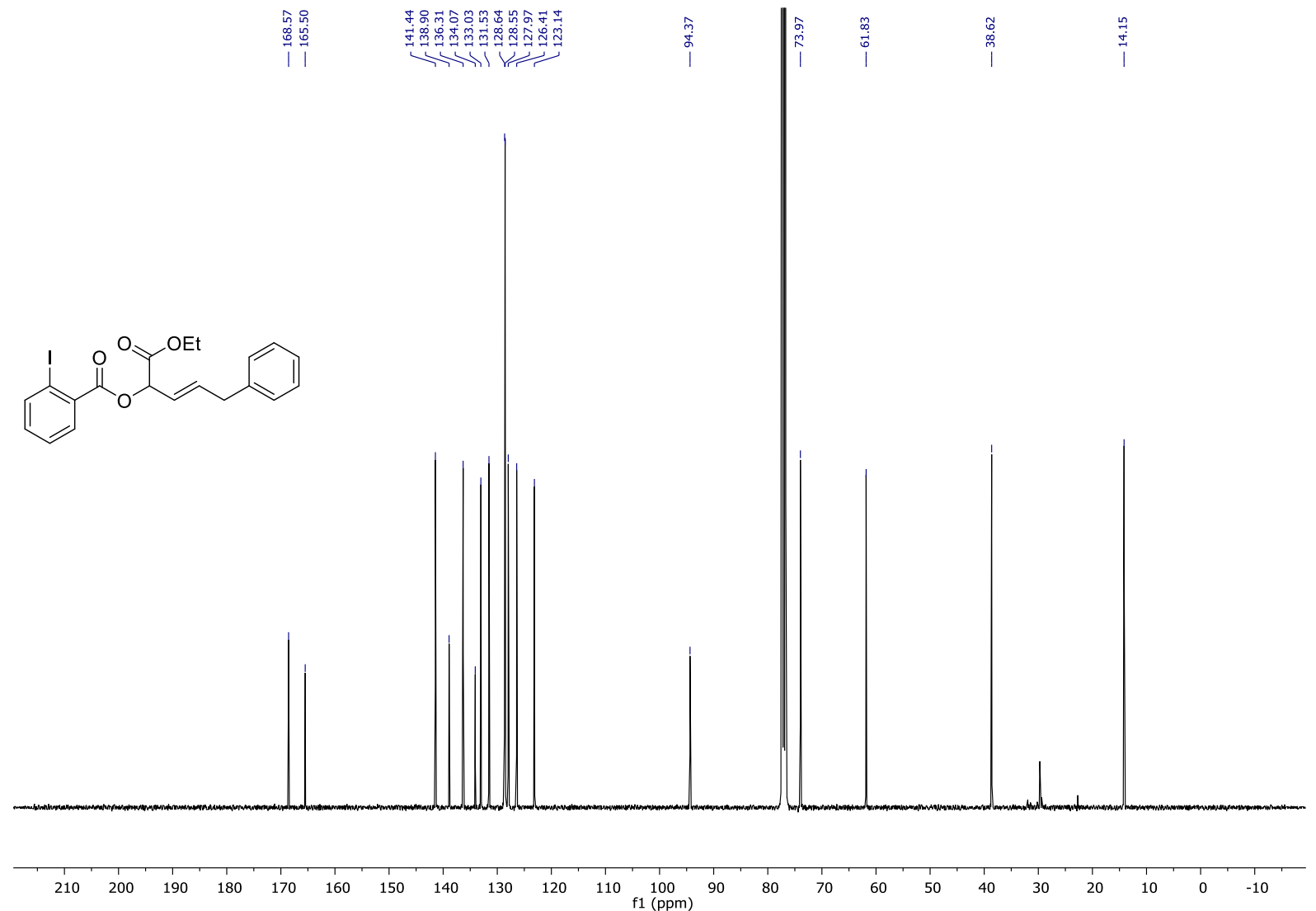


${ }^{1} \mathbf{H}-\mathrm{NMR}\left(400 \mathrm{MHz}, \mathrm{CDCl}_{3}\right)$ of compound $4 \mathbf{I}$

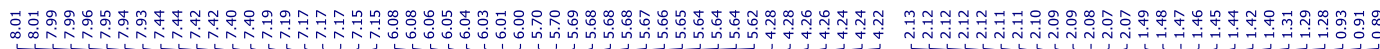

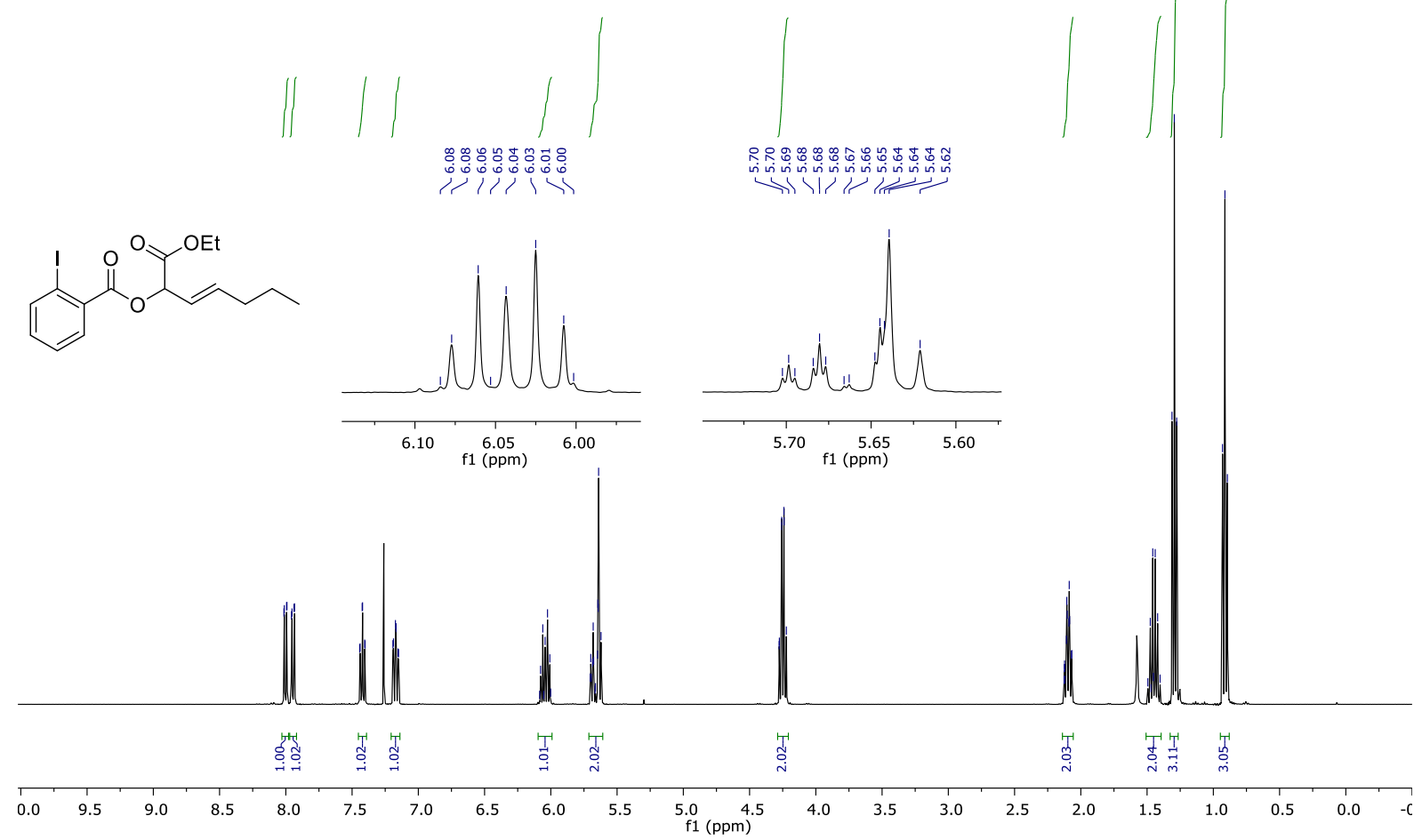

${ }^{13} \mathrm{C}-\mathrm{NMR}\left(101 \mathrm{MHz}, \mathrm{CDCl}_{3}\right)$ of compound $4 \mathrm{I}$

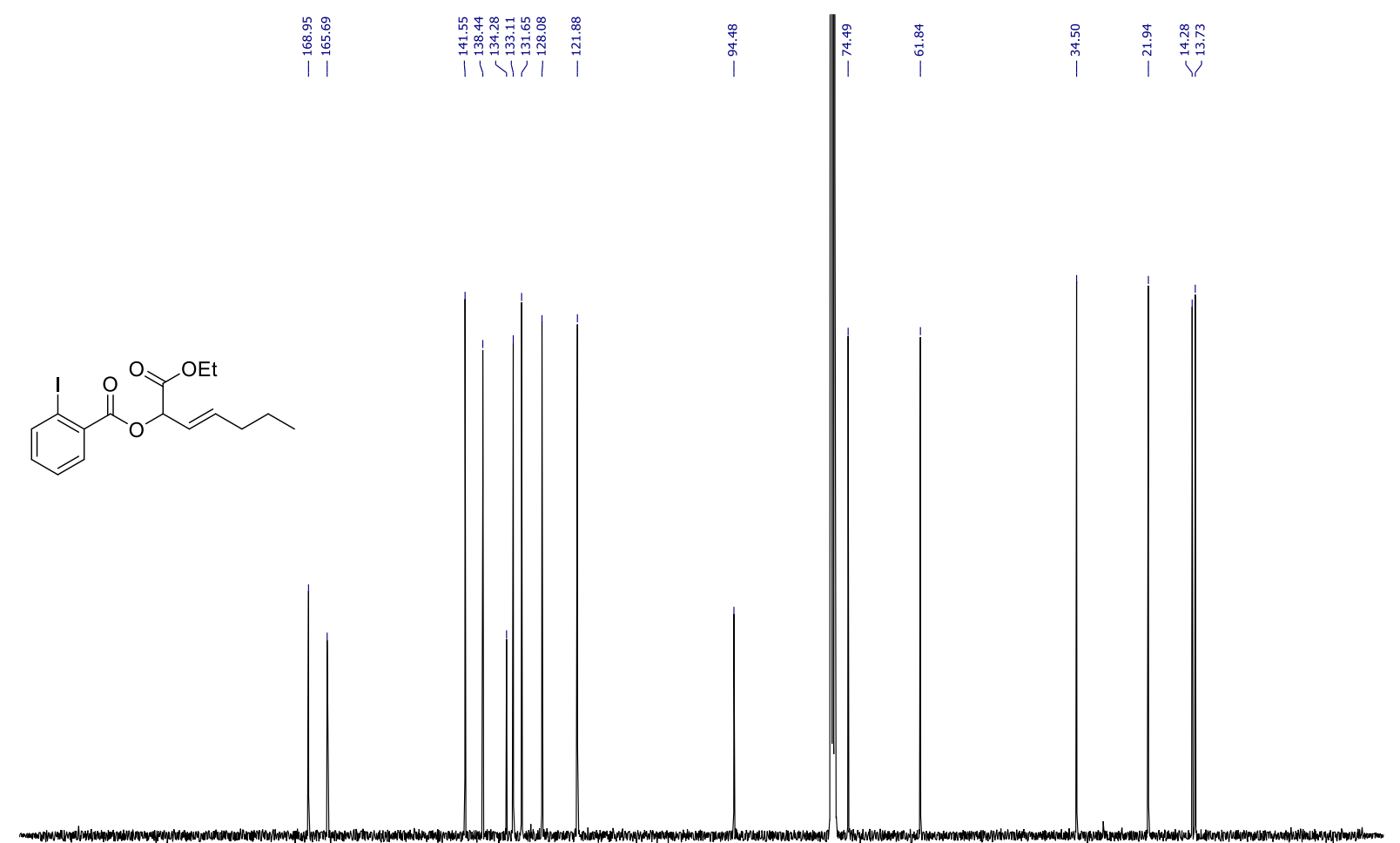

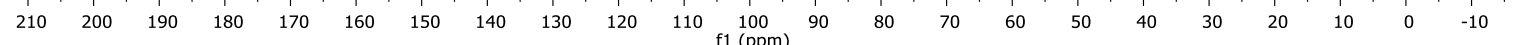


${ }^{1} \mathrm{H}-\mathrm{NMR}\left(400 \mathrm{MHz}, \mathrm{CDCl}_{3}\right)$ of compound $\mathbf{4 m}$

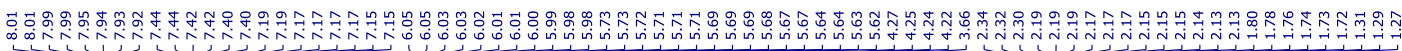
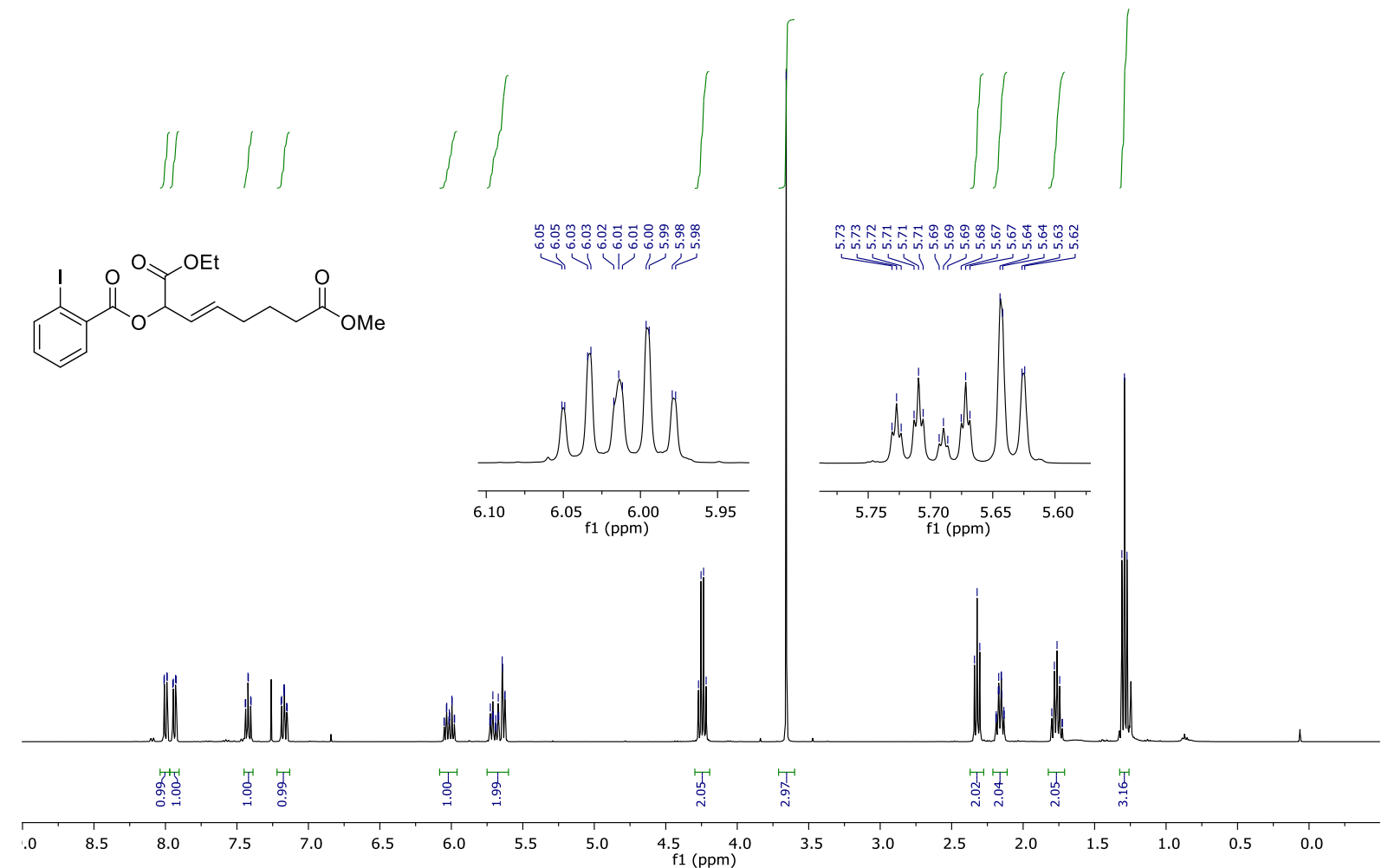

${ }^{13} \mathrm{C}-\mathrm{NMR}\left(101 \mathrm{MHz}, \mathrm{CDCl}_{3}\right)$ of compound $4 \mathrm{~m}$

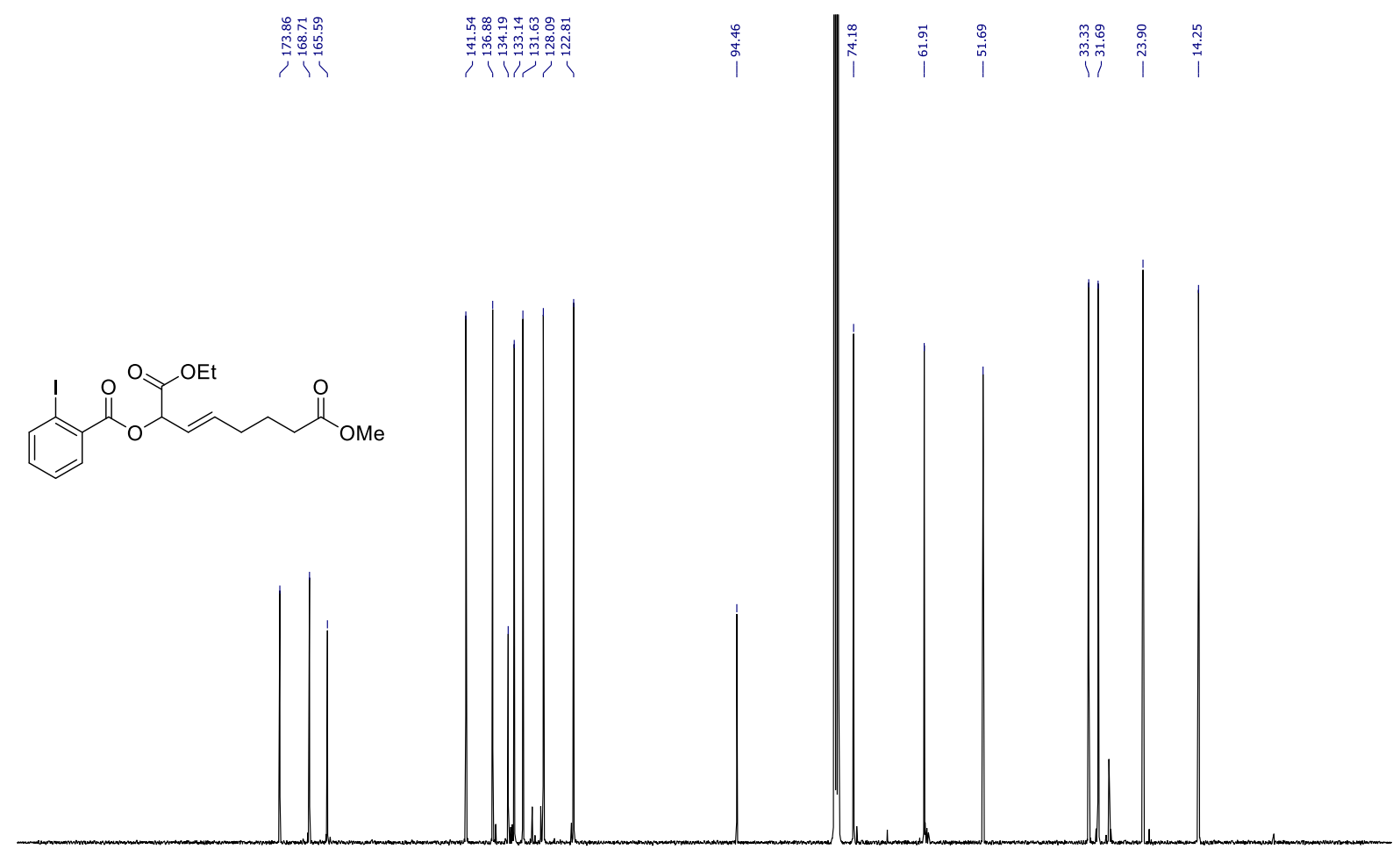

$\begin{array}{lllllllllllllllllllllll}210 & 200 & 190 & 180 & 170 & 160 & 150 & 140 & 130 & 120 & 110 & 100 & 90 & 80 & 70 & 60 & 50 & 40 & 30 & 20 & 10 & 0 & -10\end{array}$ 
${ }^{1} \mathbf{H}-N M R\left(400 \mathrm{MHz}, \mathrm{CDCl}_{3}\right)$ of compound $\mathbf{4 n}$

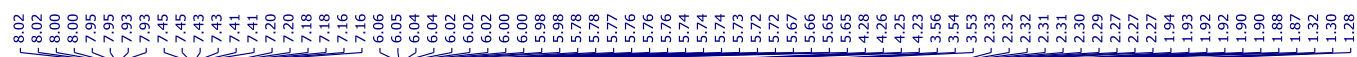
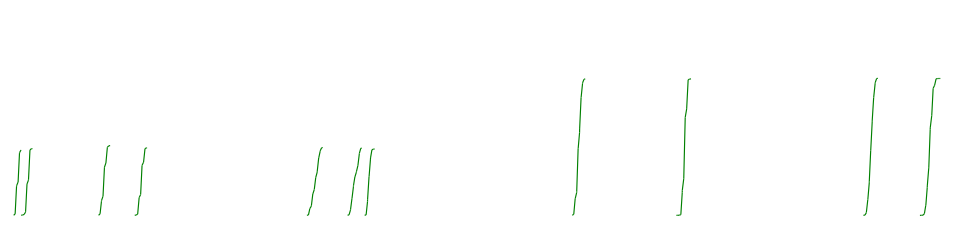

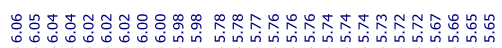<smiles>CCOC(=O)C(C=CCCCCl)OC(=O)c1ccccc1C</smiles>
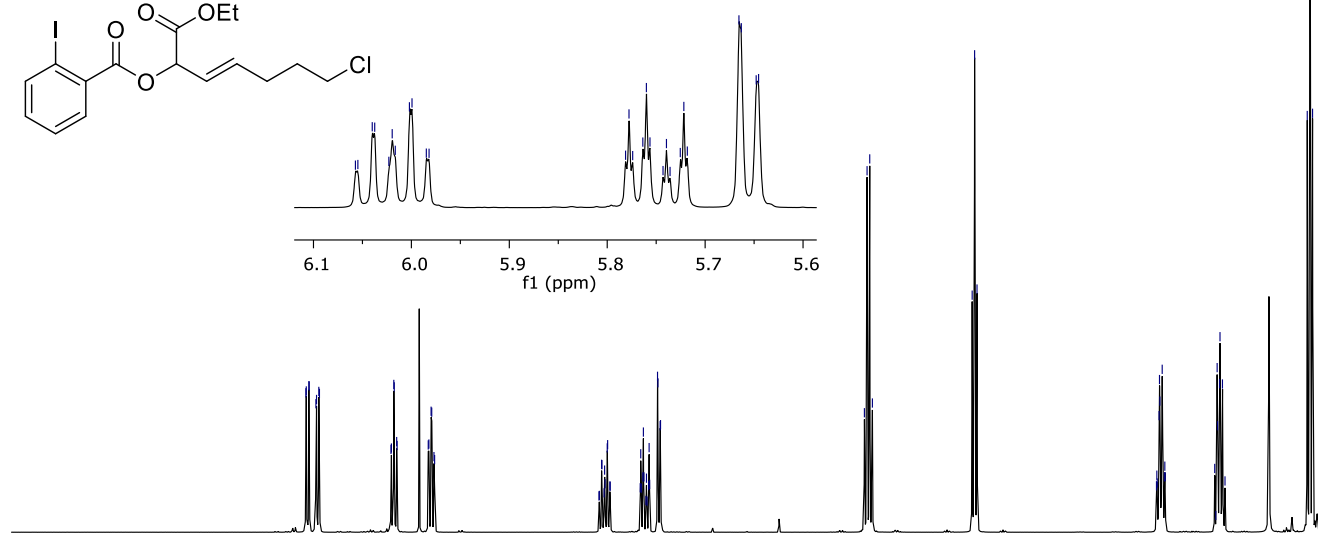

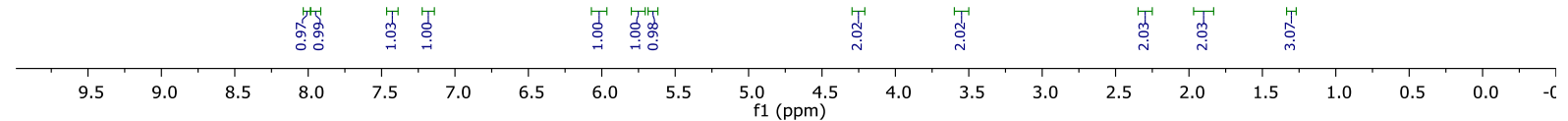

${ }^{13} \mathrm{C}$-NMR (101 MHz, $\mathrm{CDCl}_{3}$ ) of compound 4n

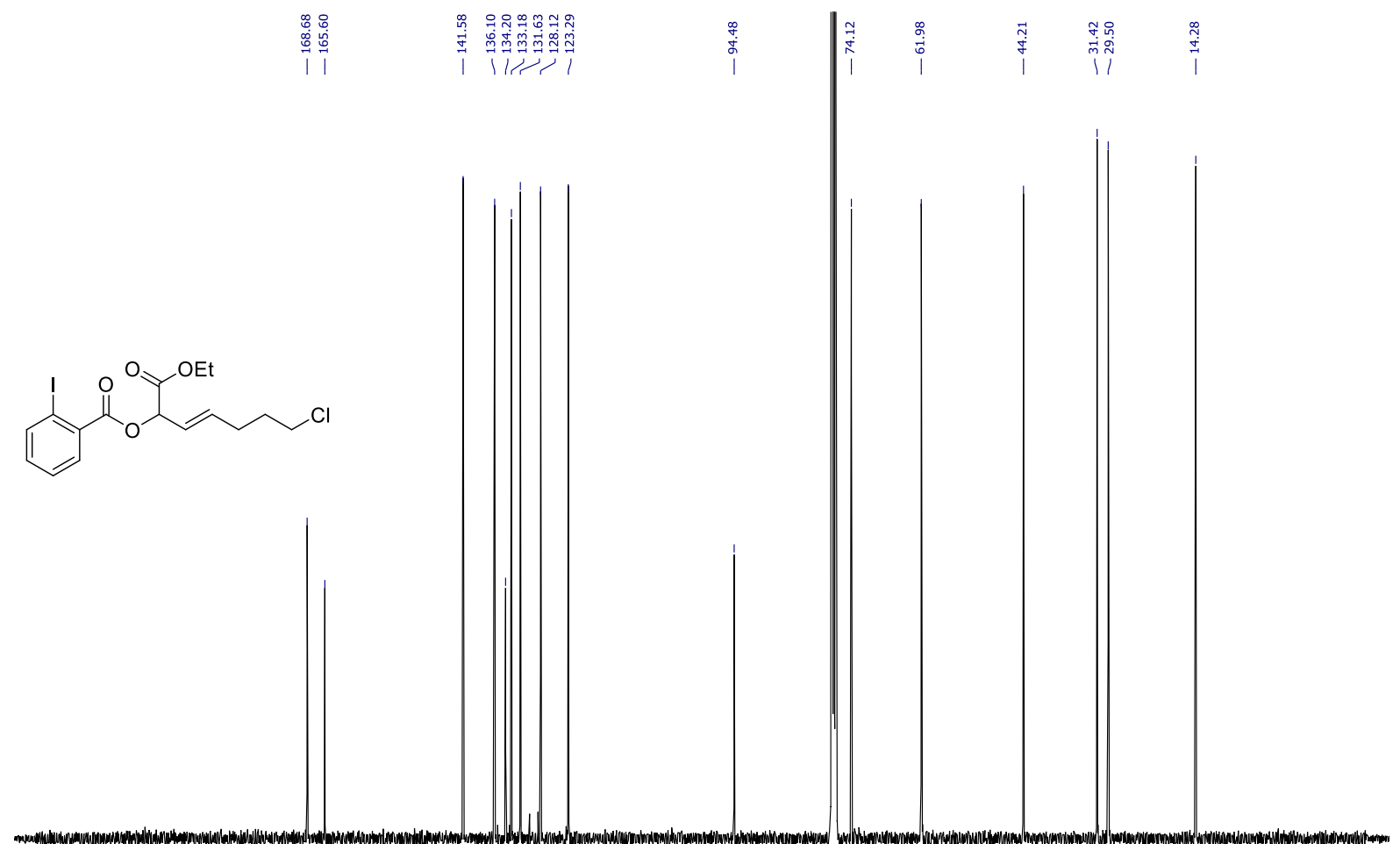

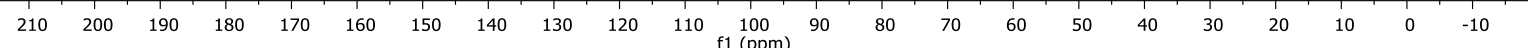


${ }^{1} \mathbf{H}-\mathrm{NMR}\left(400 \mathrm{MHz}, \mathrm{CDCl}_{3}\right)$ of compound 40

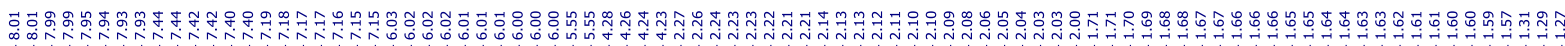

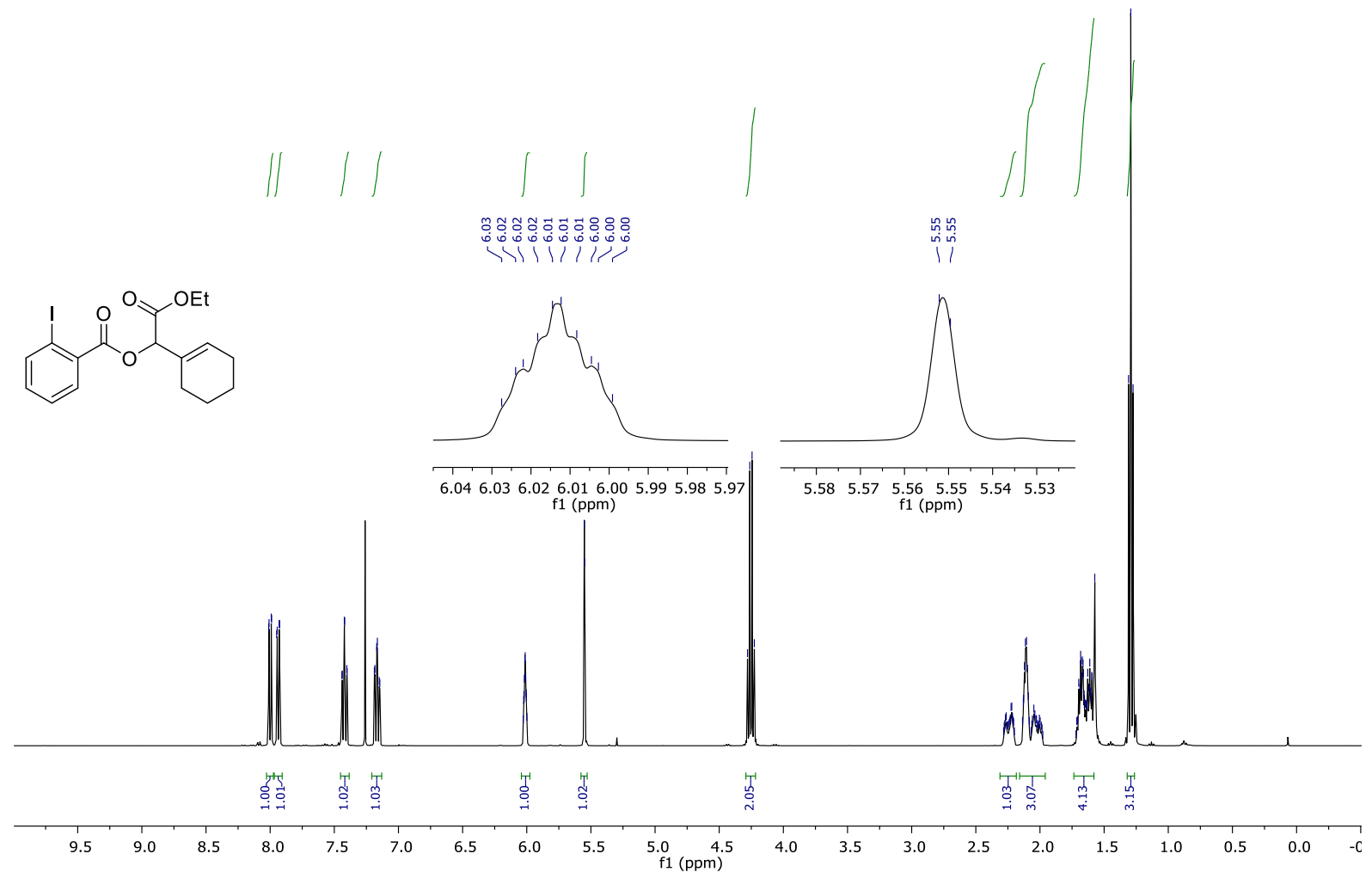

${ }^{13} \mathrm{C}-\mathrm{NMR}\left(101 \mathrm{MHz}, \mathrm{CDCl}_{3}\right)$ of compound 40

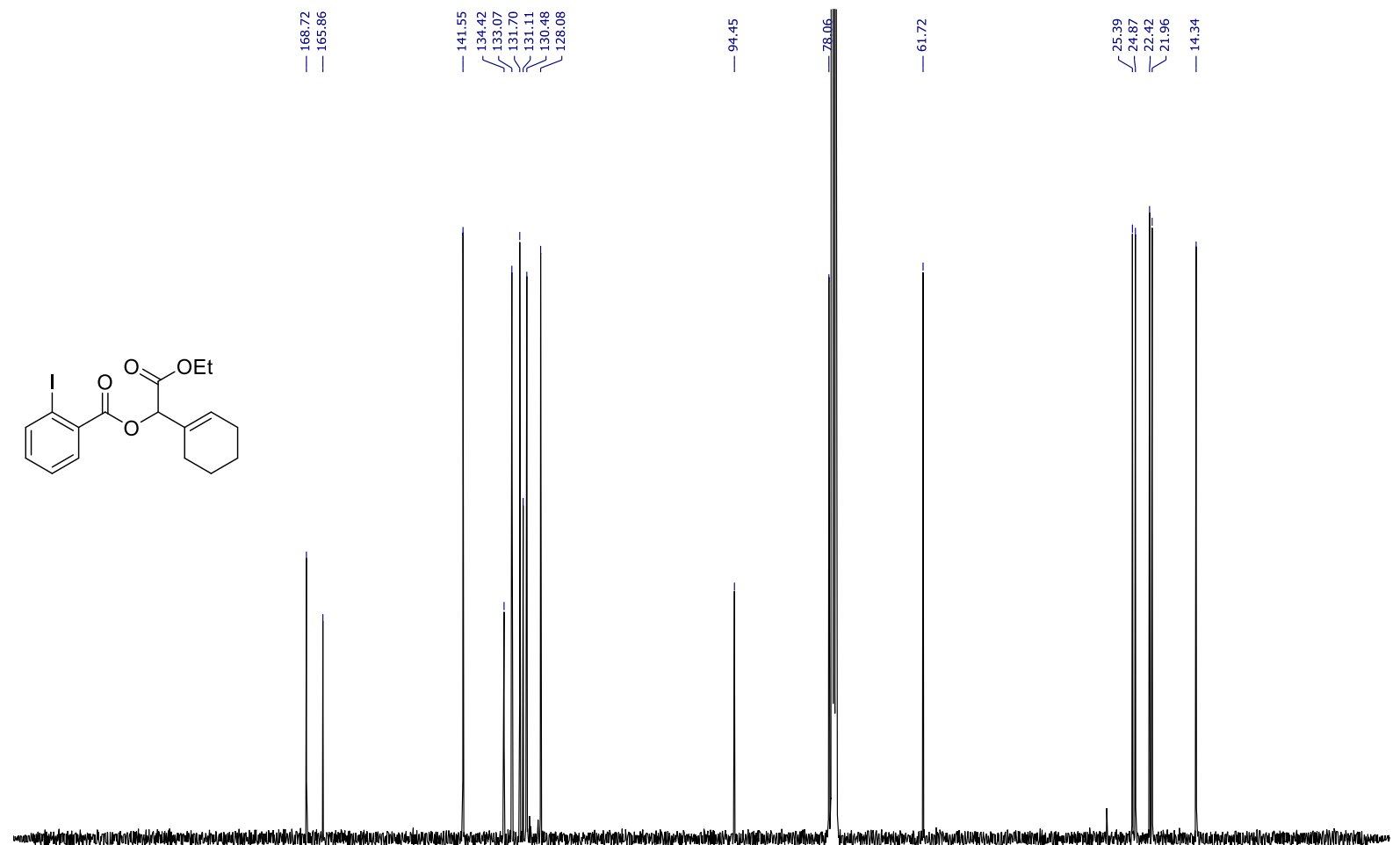

$\begin{array}{lllllllllllllllllllllll}210 & 200 & 190 & 180 & 170 & 160 & 150 & 140 & 130 & 120 & 110 & 100 & 90 & 80 & 70 & 60 & 50 & 40 & 30 & 20 & 10 & 0 & -10\end{array}$ 


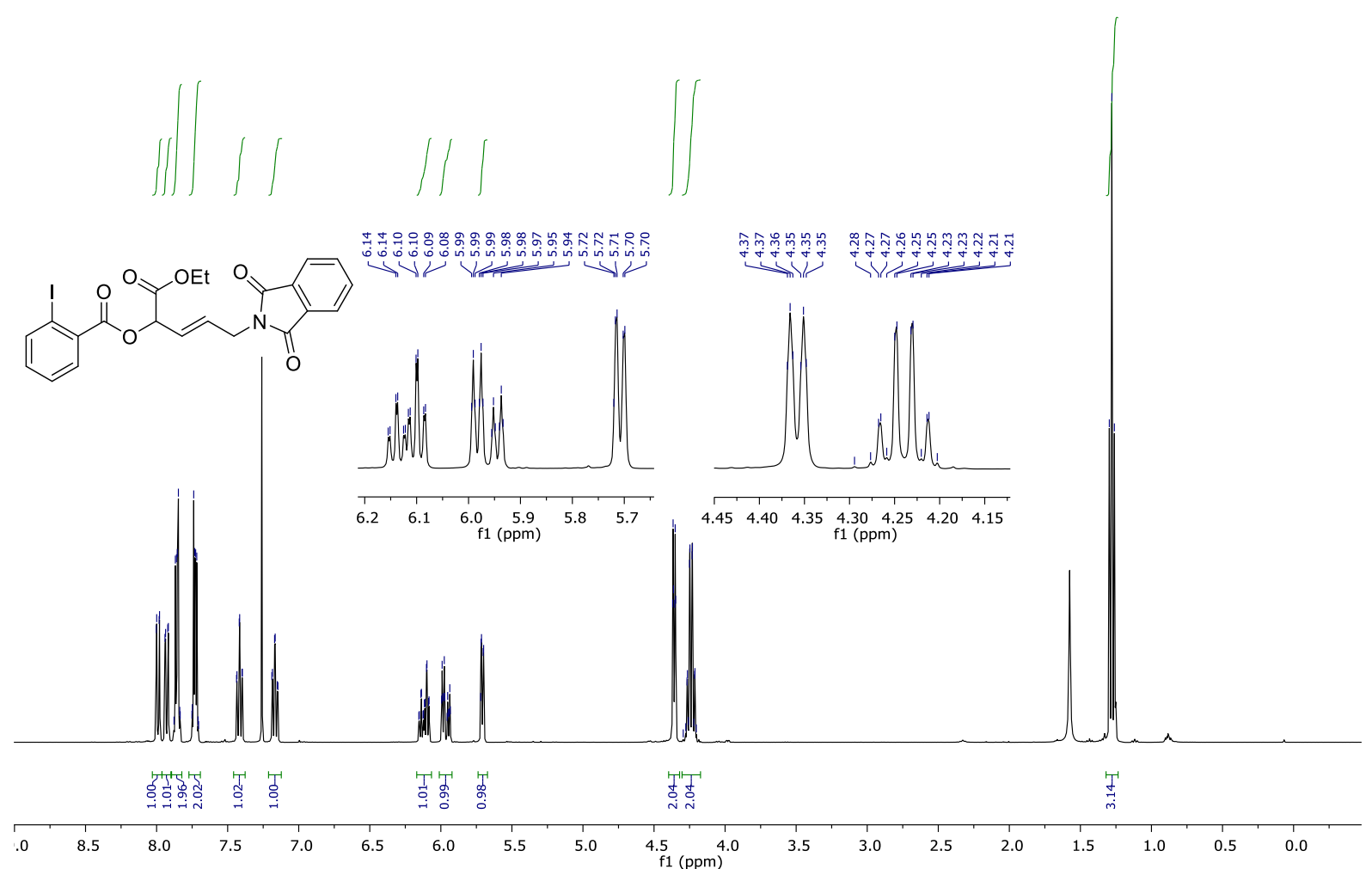

${ }^{13} \mathrm{C}-\mathrm{NMR}\left(101 \mathrm{MHz}, \mathrm{CDCl}_{3}\right)$ of compound $4 \mathrm{p}$

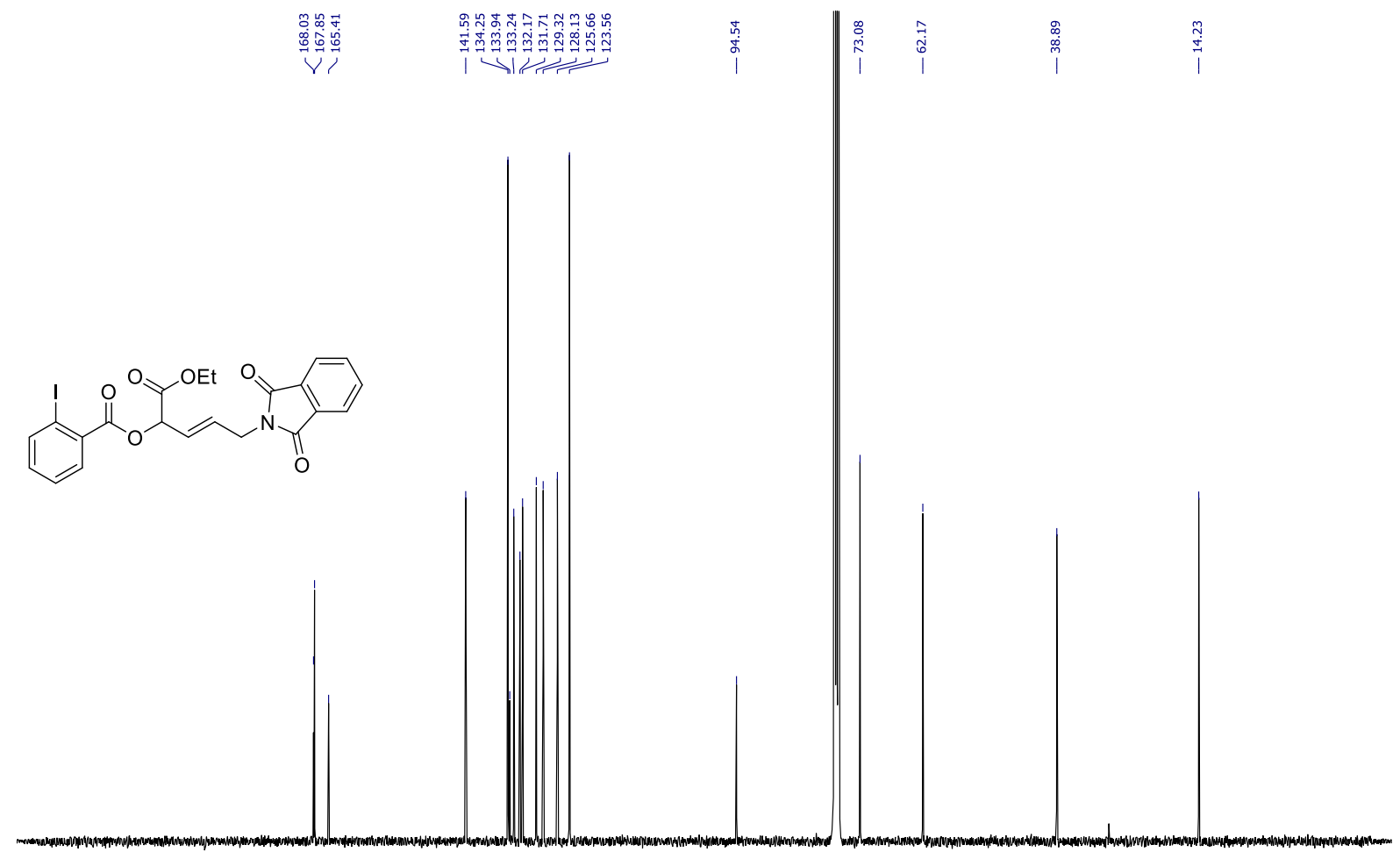

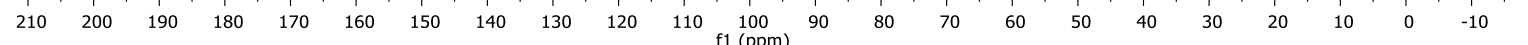


${ }^{1} \mathbf{H}-\mathrm{NMR}\left(400 \mathrm{MHz}, \mathrm{CDCl}_{3}\right)$ of compound $\mathbf{4 q}$

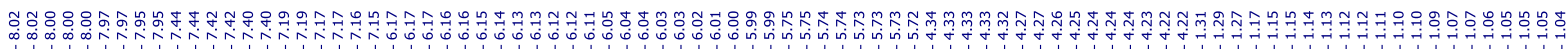

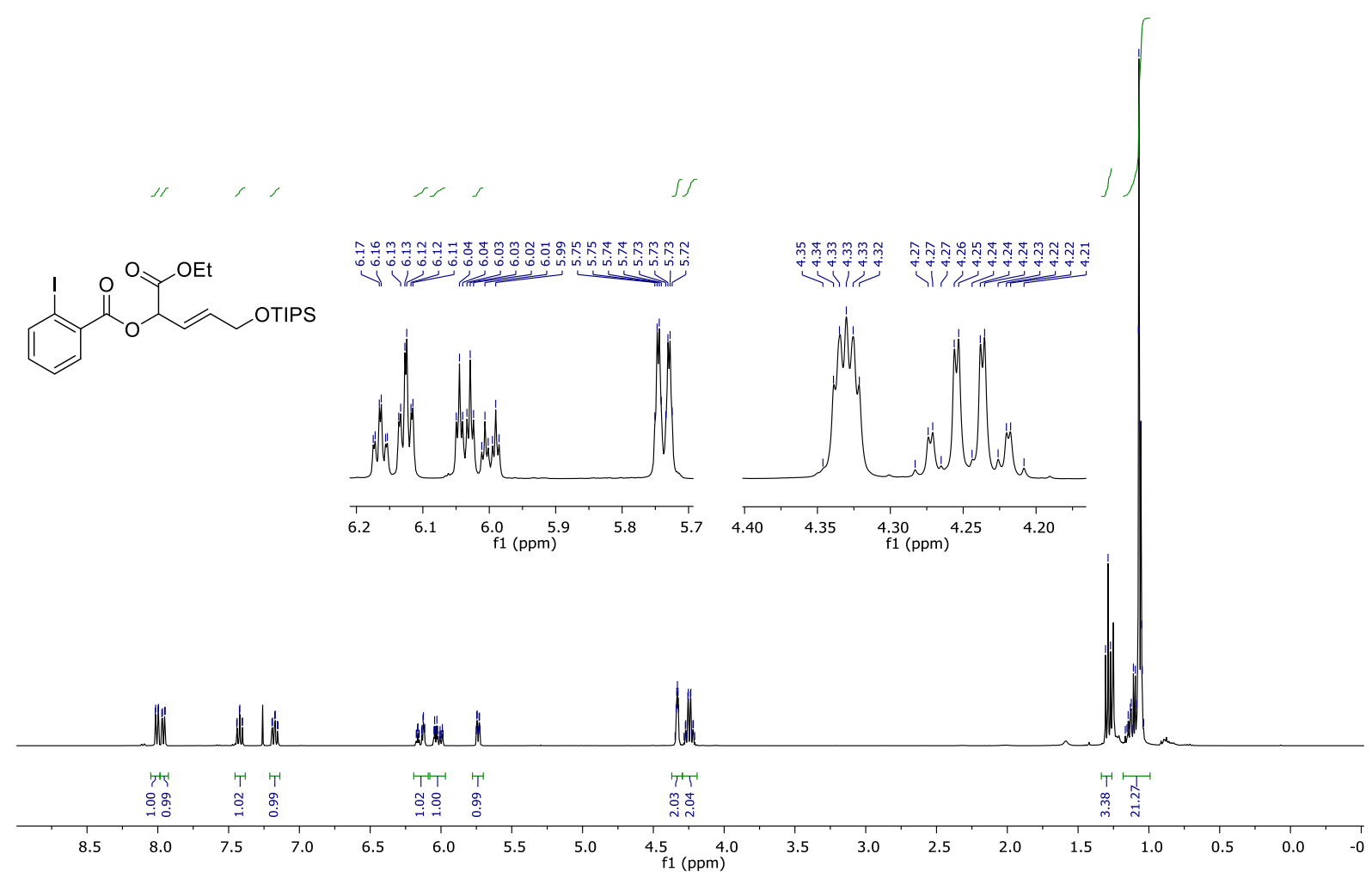

${ }^{13} \mathrm{C}-\mathrm{NMR}\left(101 \mathrm{MHz}, \mathrm{CDCl}_{3}\right)$ of compound $\mathbf{4 q}$

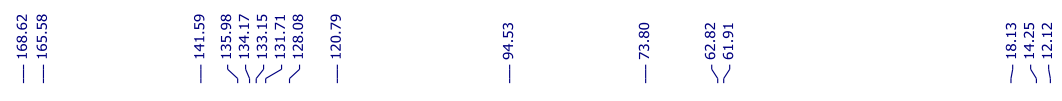

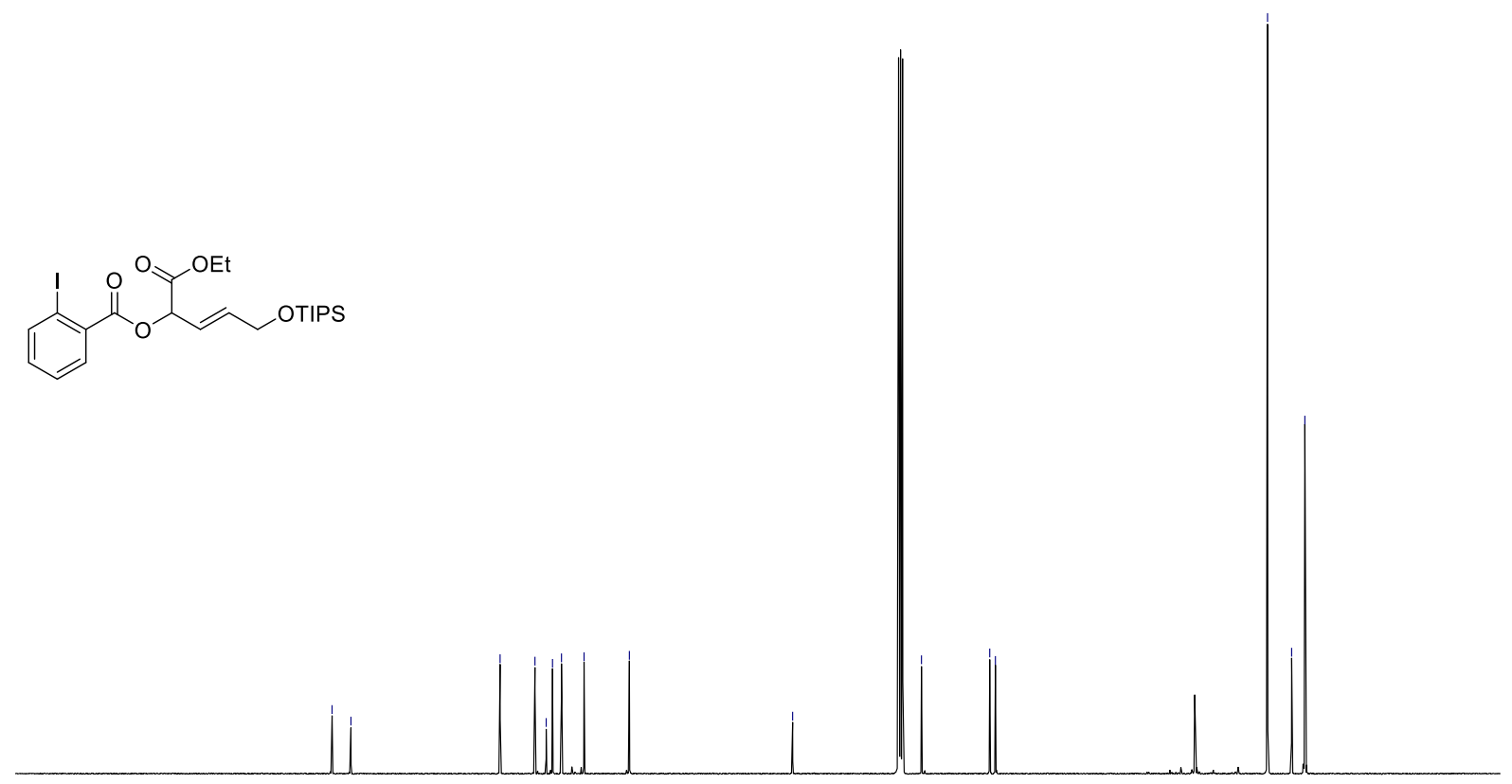

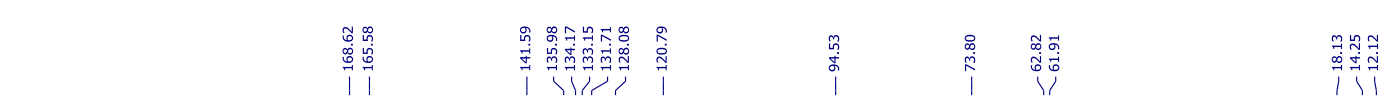

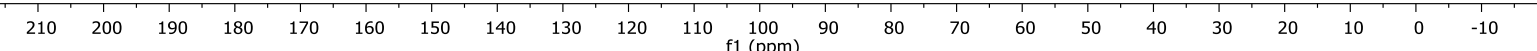


${ }^{1} \mathbf{H}-\mathrm{NMR}\left(400 \mathrm{MHz}, \mathrm{CDCl}_{3}\right)$ of compound $\mathbf{4 r}$

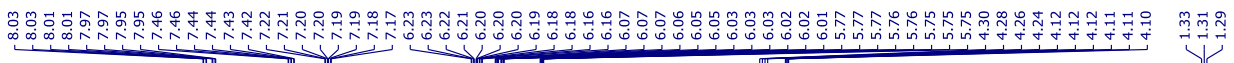

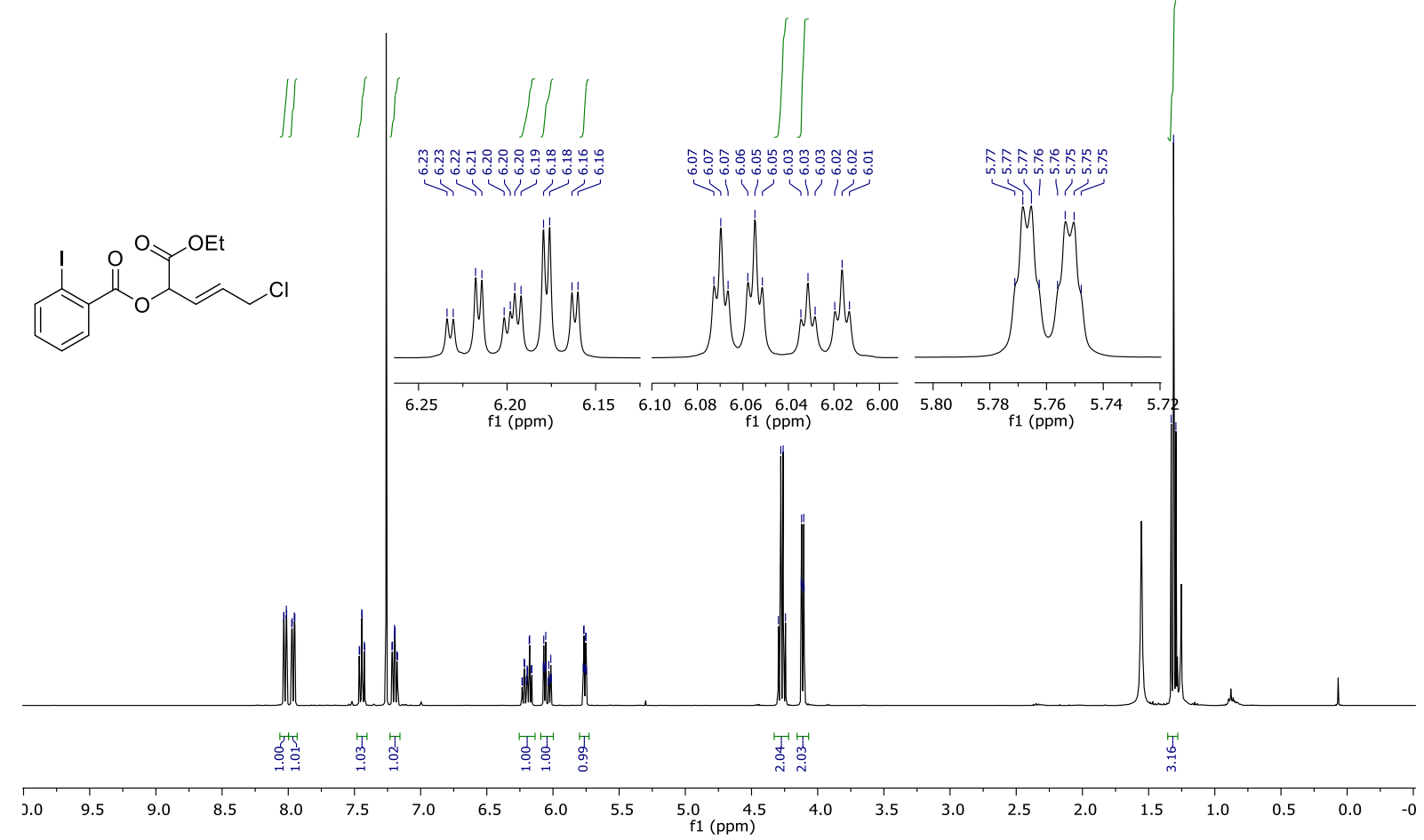

${ }^{13} \mathrm{C}-\mathrm{NMR}\left(101 \mathrm{MHz}, \mathrm{CDCl}_{3}\right)$ of compound $4 \mathrm{r}$

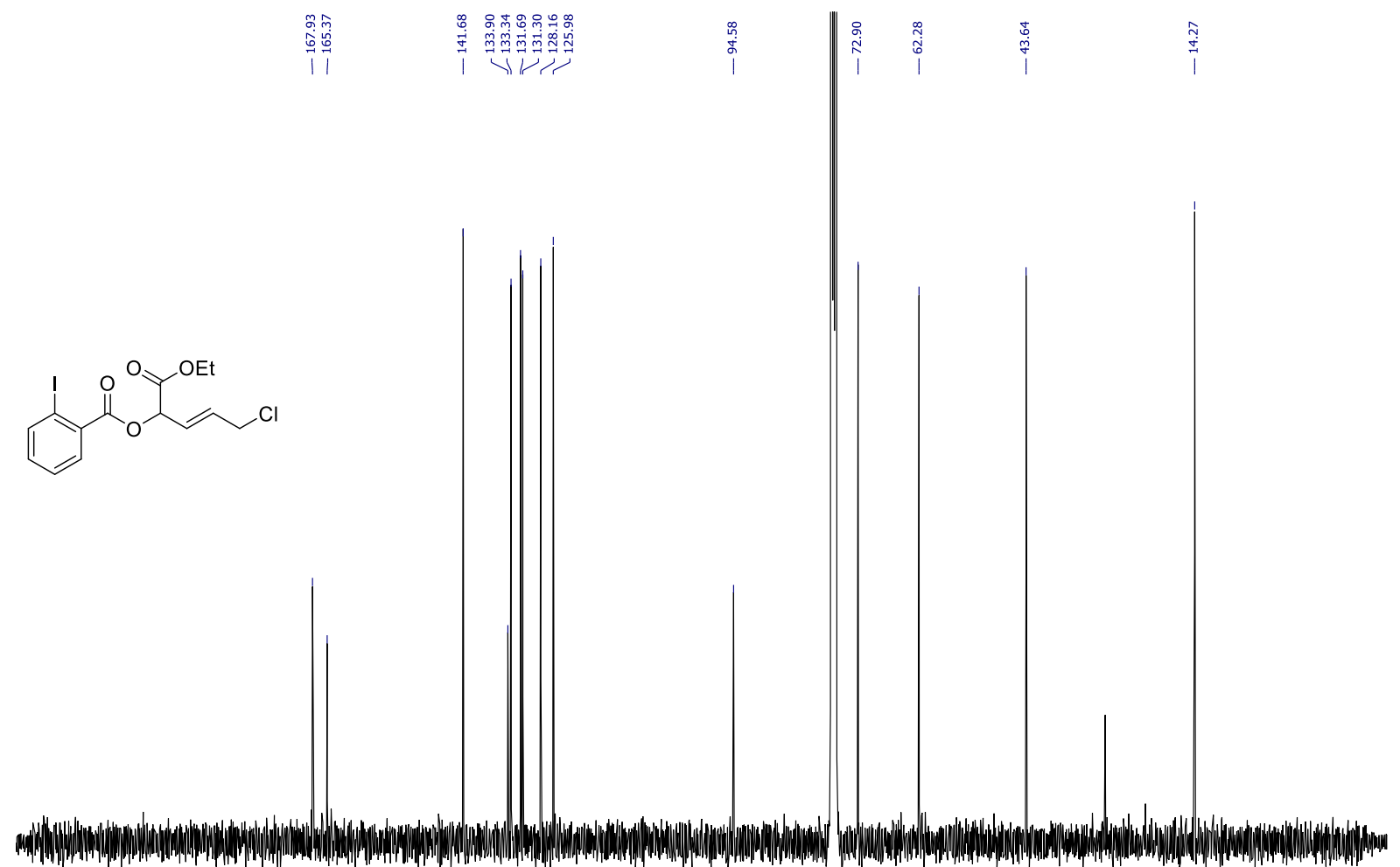

$\begin{array}{lllllllllllllllllllllll}210 & 200 & 190 & 180 & 170 & 160 & 150 & 140 & 130 & 120 & 110 & 100 & 100 & 80 & 70 & 60 & 50 & 40 & 30 & 20 & 10 & 0 & -10\end{array}$ 
${ }^{1} \mathbf{H}-\mathrm{NMR}\left(400 \mathrm{MHz}, \mathrm{CDCl}_{3}\right.$ ) of compound $\mathbf{4 s}$

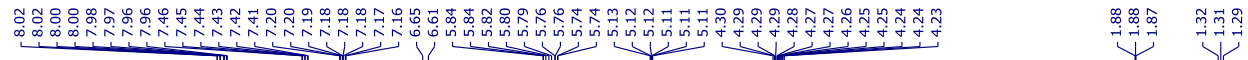

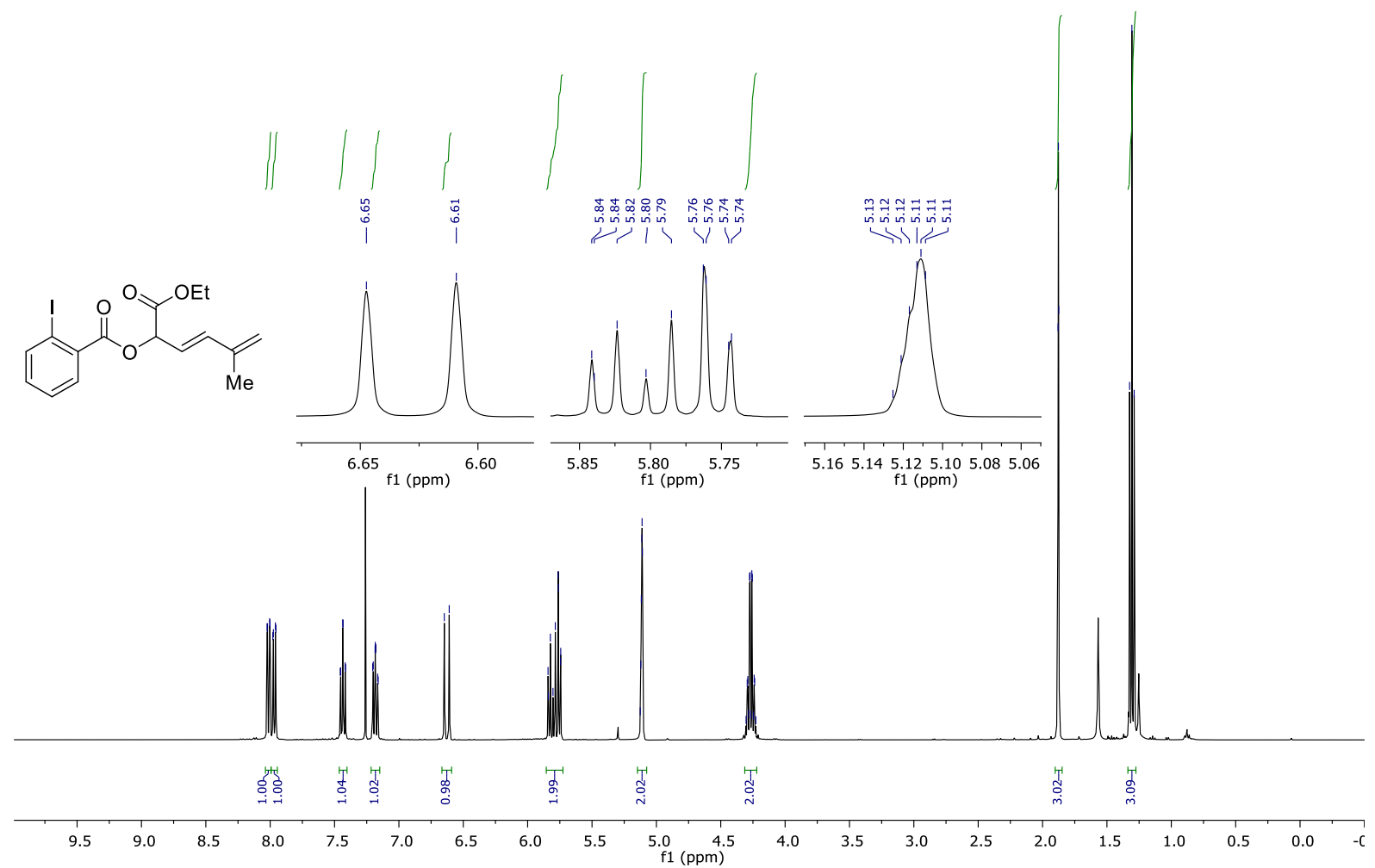

${ }^{13} \mathrm{C}-\mathrm{NMR}\left(101 \mathrm{MHz}, \mathrm{CDCl}_{3}\right)$ of compound $4 \mathrm{~s}$

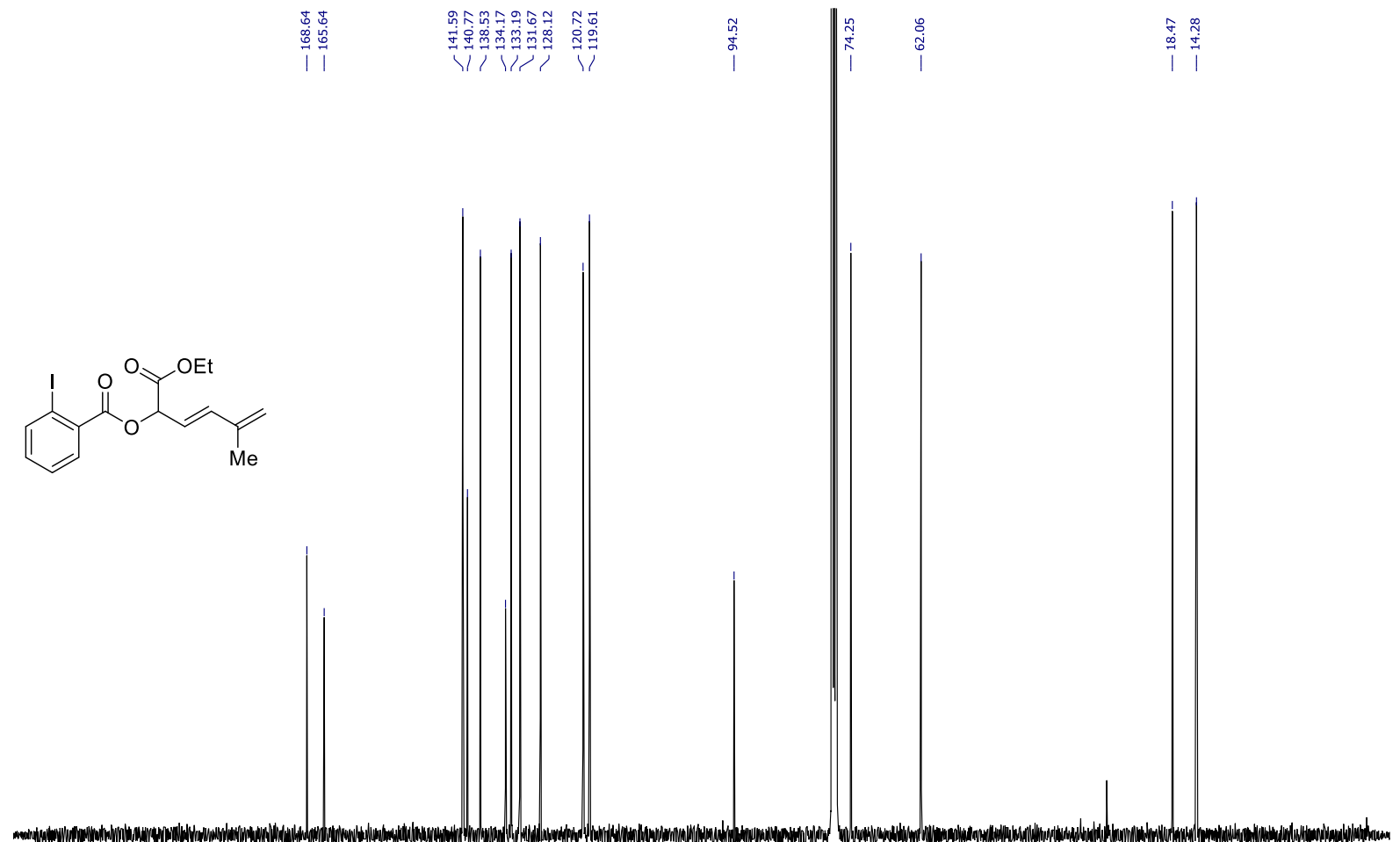

$\begin{array}{lllllllllllllllllllllll}210 & 200 & 190 & 180 & 170 & 160 & 150 & 140 & 130 & 120 & 110 & 100 & 90 & 80 & 70 & 60 & 50 & 40 & 30 & 20 & 10 & 0 & -10\end{array}$ 
${ }^{1} \mathbf{H}-\mathrm{NMR}\left(400 \mathrm{MHz}, \mathrm{CDCl}_{3}\right)$ of compound $\mathbf{4 t}$

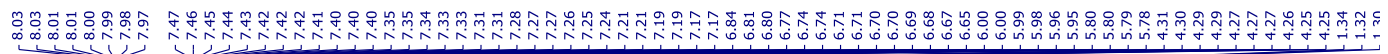

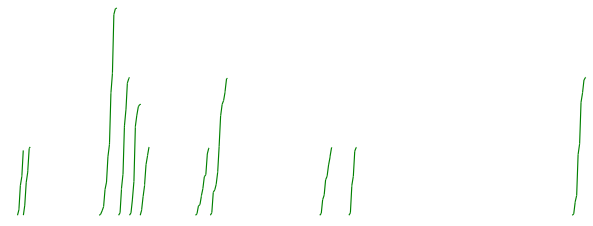

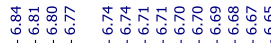

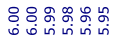

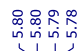

(1)
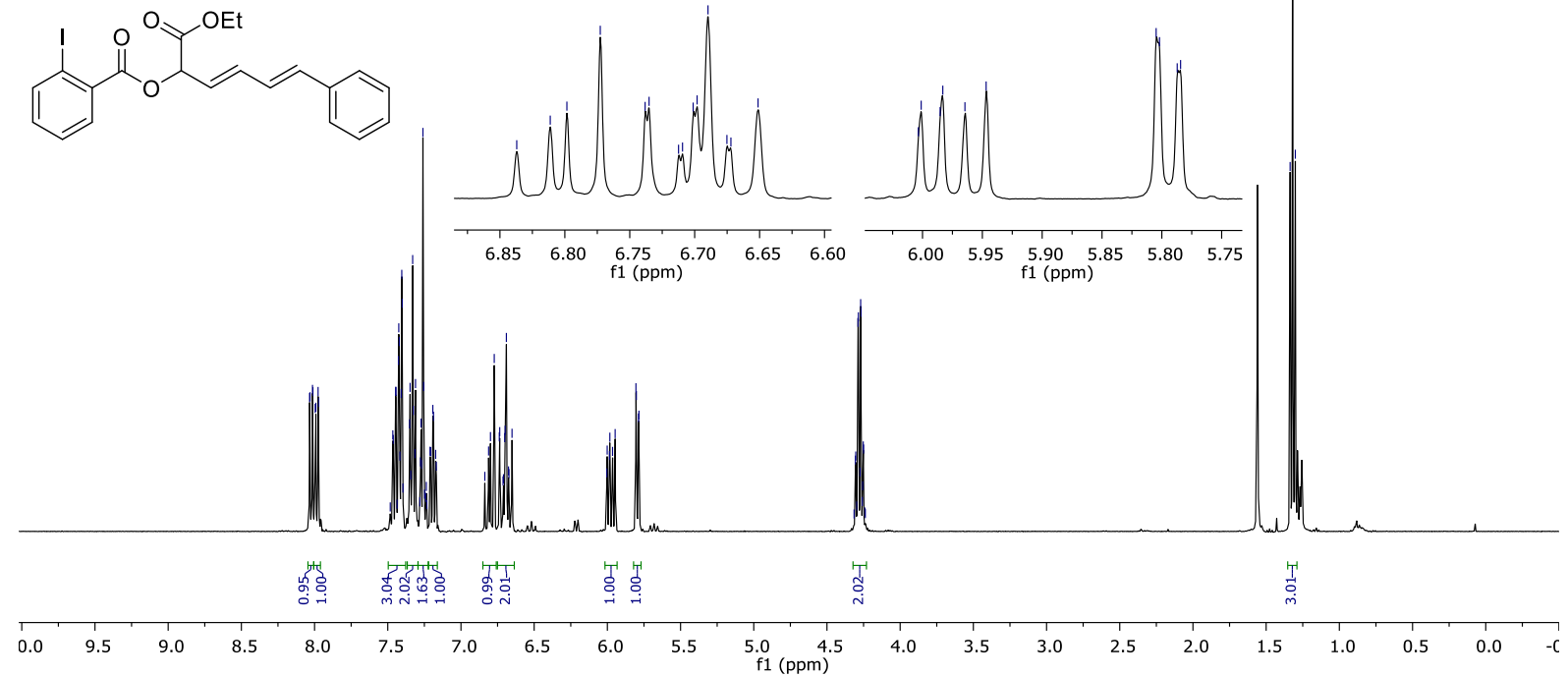

${ }^{13} \mathrm{C}-\mathrm{NMR}\left(101 \mathrm{MHz}, \mathrm{CDCl}_{3}\right)$ of compound $\mathbf{4 t}$

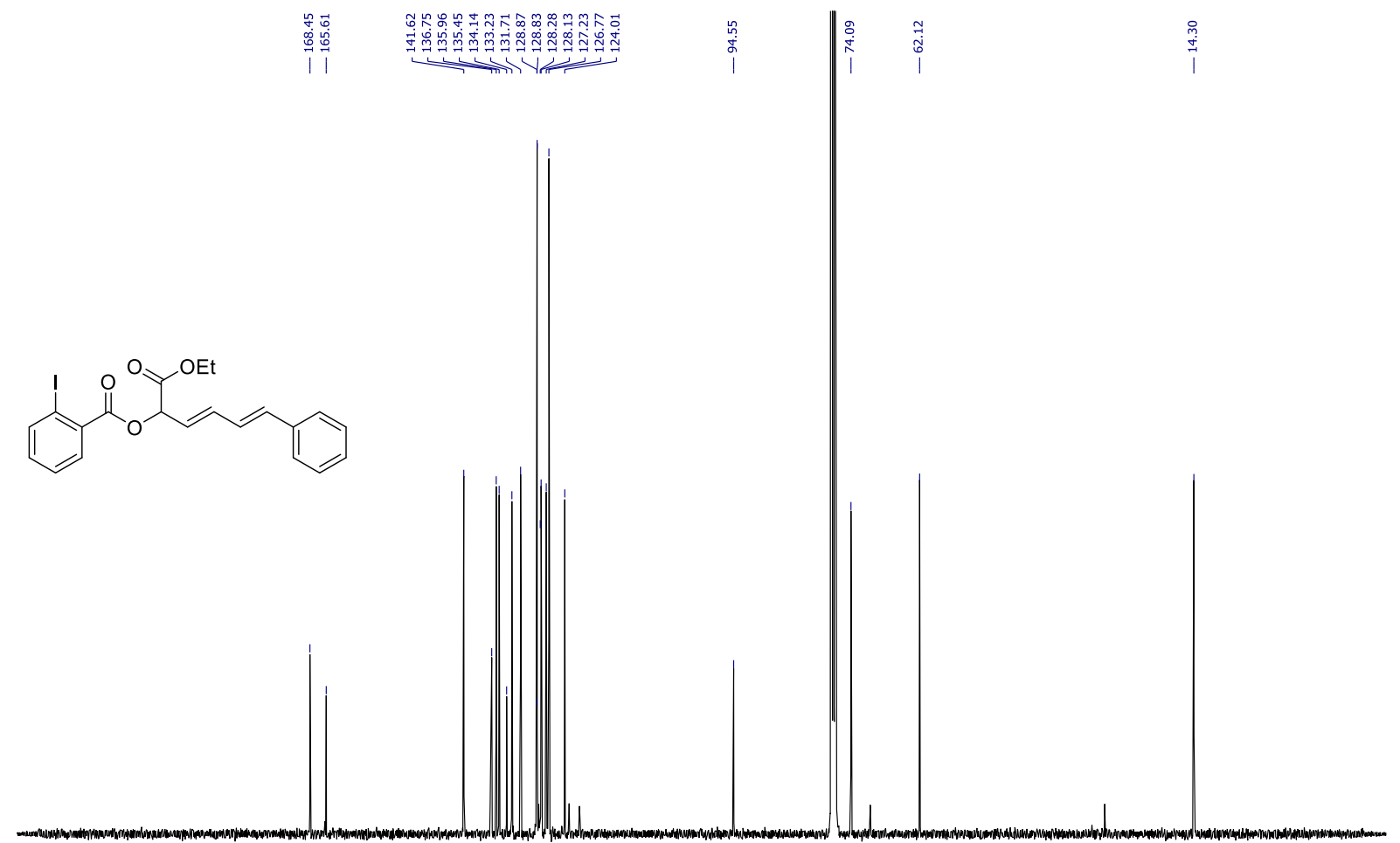

$\begin{array}{lllllllllllllllllllllll}210 & 200 & 190 & 180 & 170 & 160 & 150 & 140 & 130 & 120 & 110 & 100 & 90 & 80 & 70 & 60 & 50 & 40 & 30 & 20 & 10 & 0 & -10\end{array}$ 
${ }^{1} \mathbf{H}-\mathrm{NMR}\left(400 \mathrm{MHz}, \mathrm{CDCl}_{3}\right)$ of compound $4 \mathbf{u}$

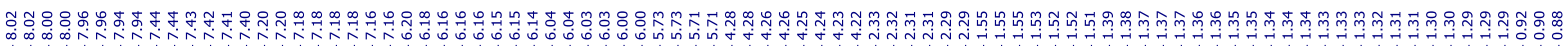

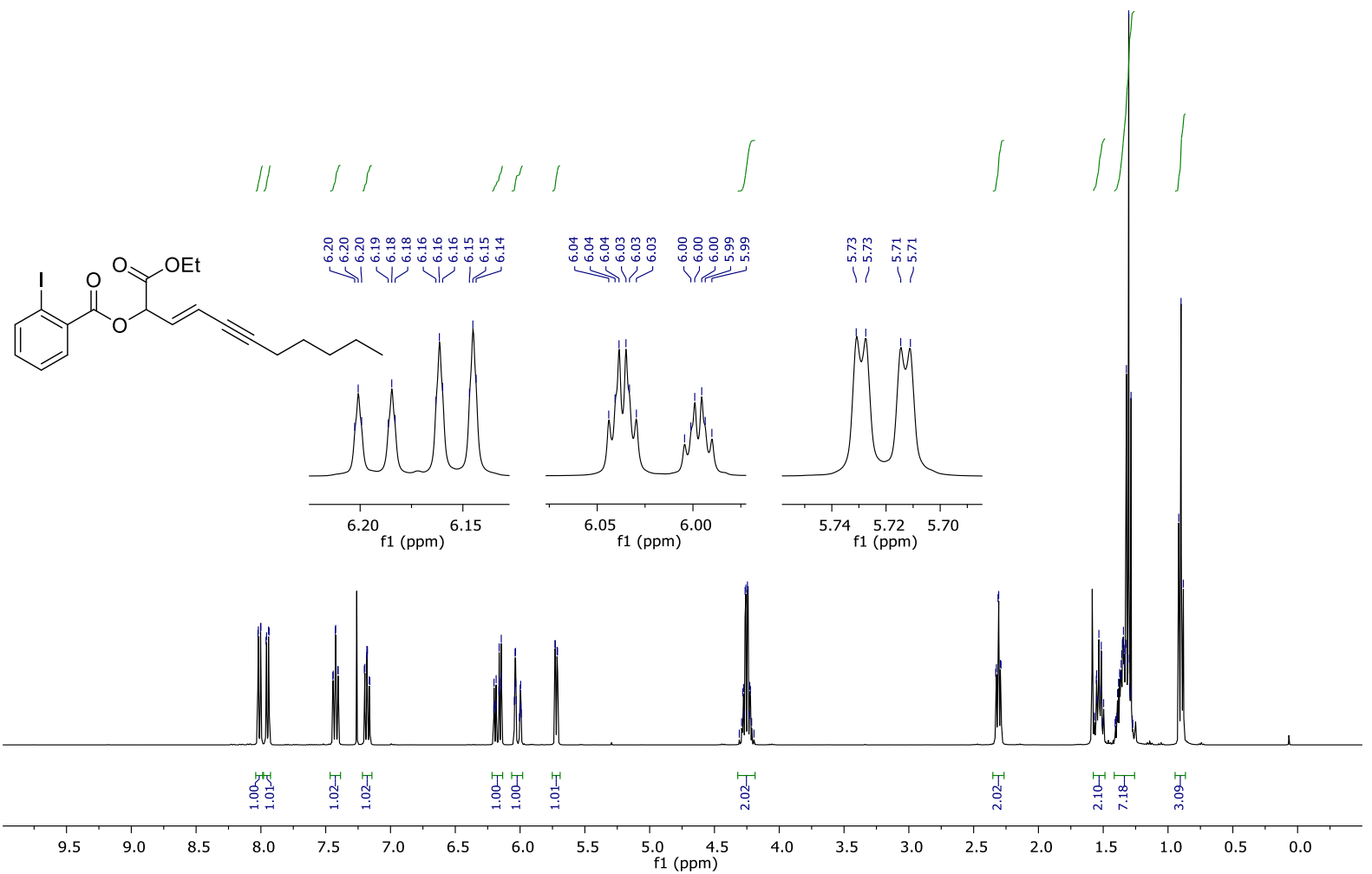

${ }^{13}$ C-NMR (101 MHz, $\mathrm{CDCl}_{3}$ ) of compound $\mathbf{4 u}$

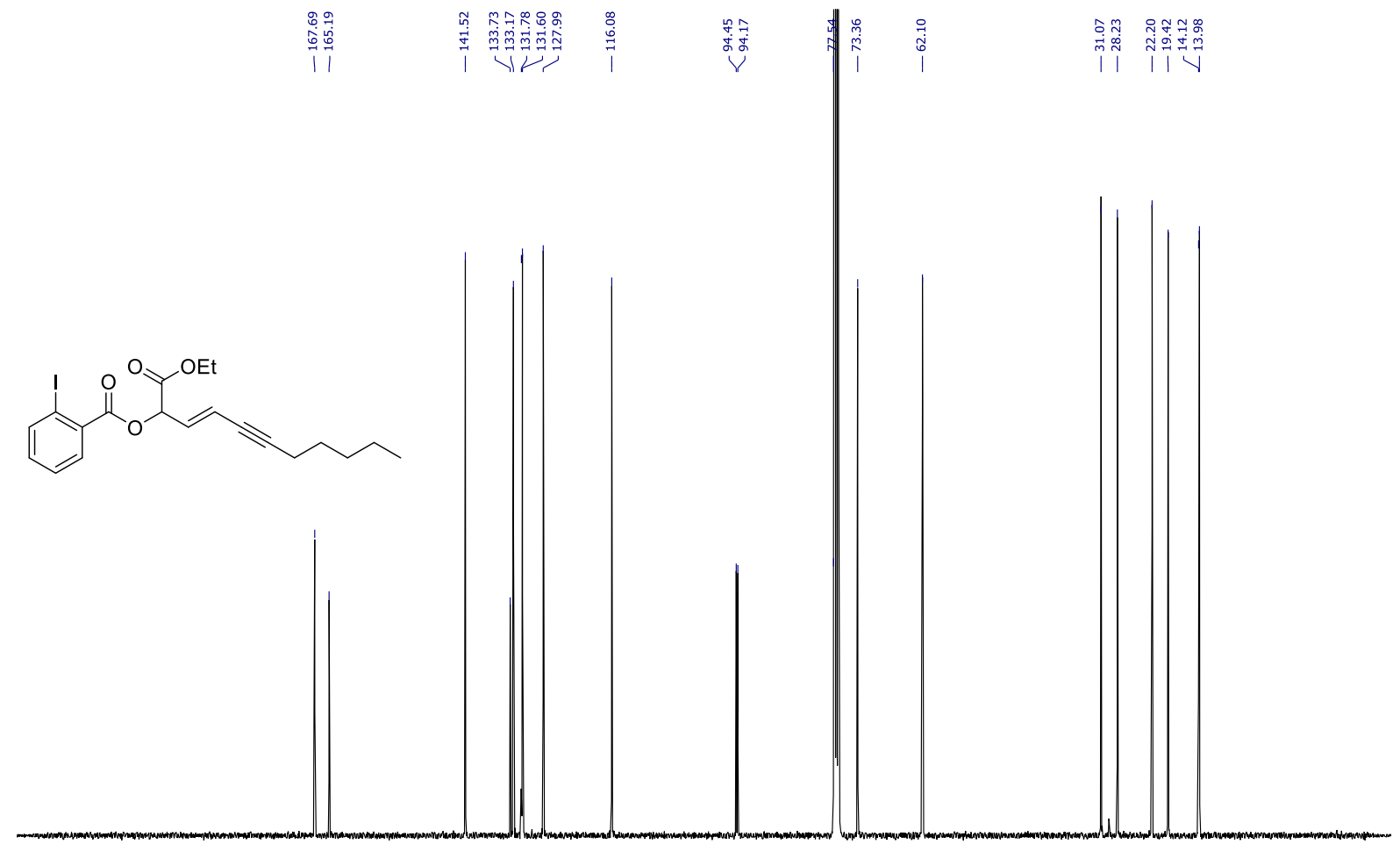

$\begin{array}{lllllllllllllllllllllll}210 & 200 & 190 & 180 & 170 & 160 & 150 & 140 & 130 & 120 & 110 & 100 & 90 & 80 & 70 & 60 & 50 & 40 & 30 & 20 & 10 & 0 & -10\end{array}$ 
${ }^{1} \mathbf{H}-\mathbf{N M R}\left(400 \mathrm{MHz} \mathrm{CDCl}_{3}\right.$ ) of compound $\mathbf{5 a}$

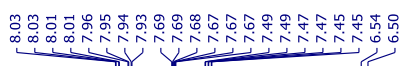
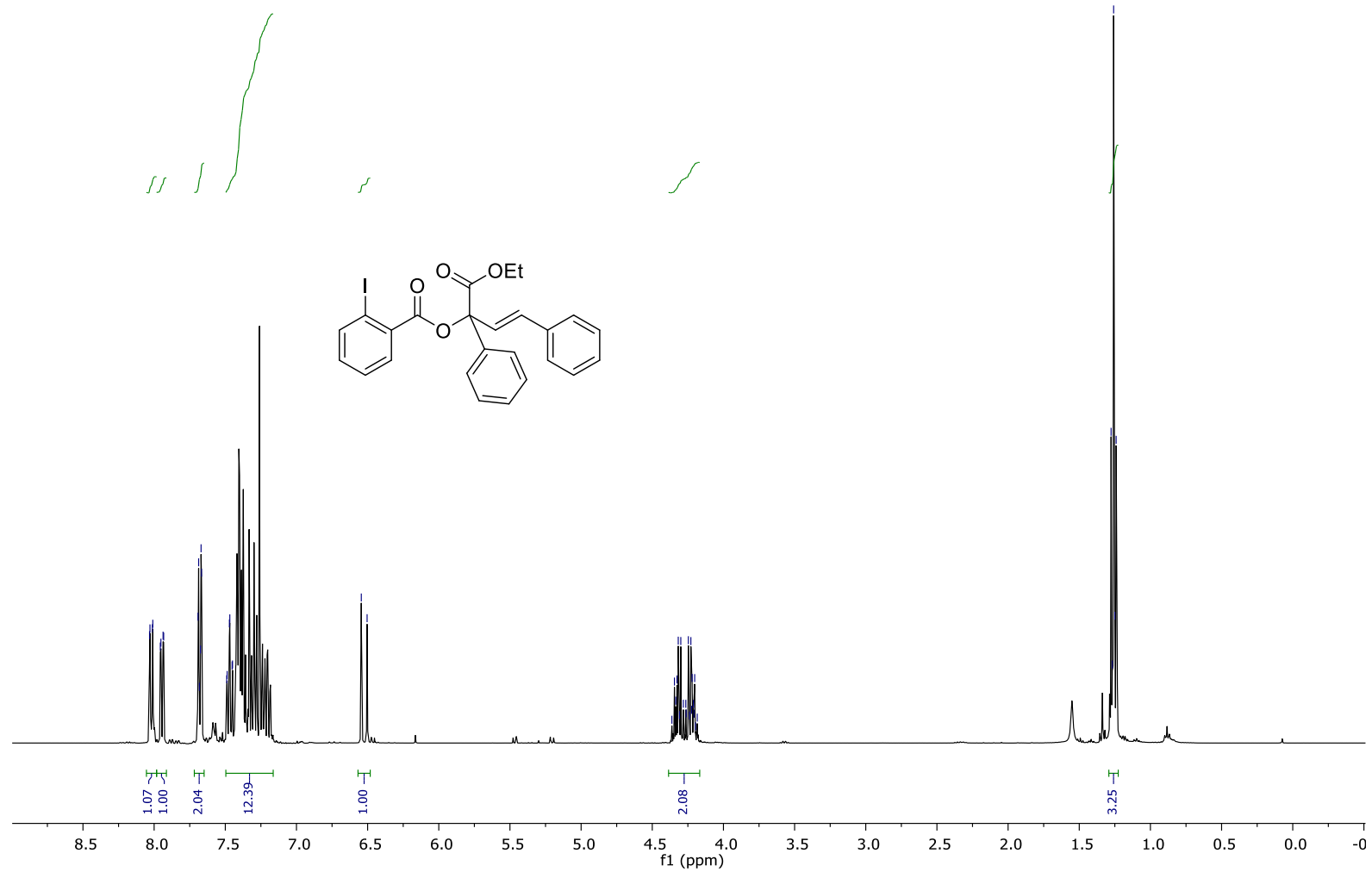

${ }^{13}$ C-NMR (101 MHz, $\mathrm{CDCl}_{3}$ ) of compound 5a

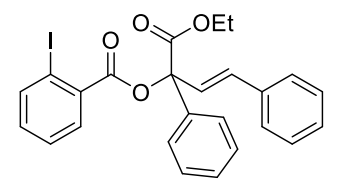

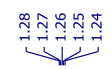

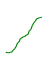

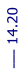
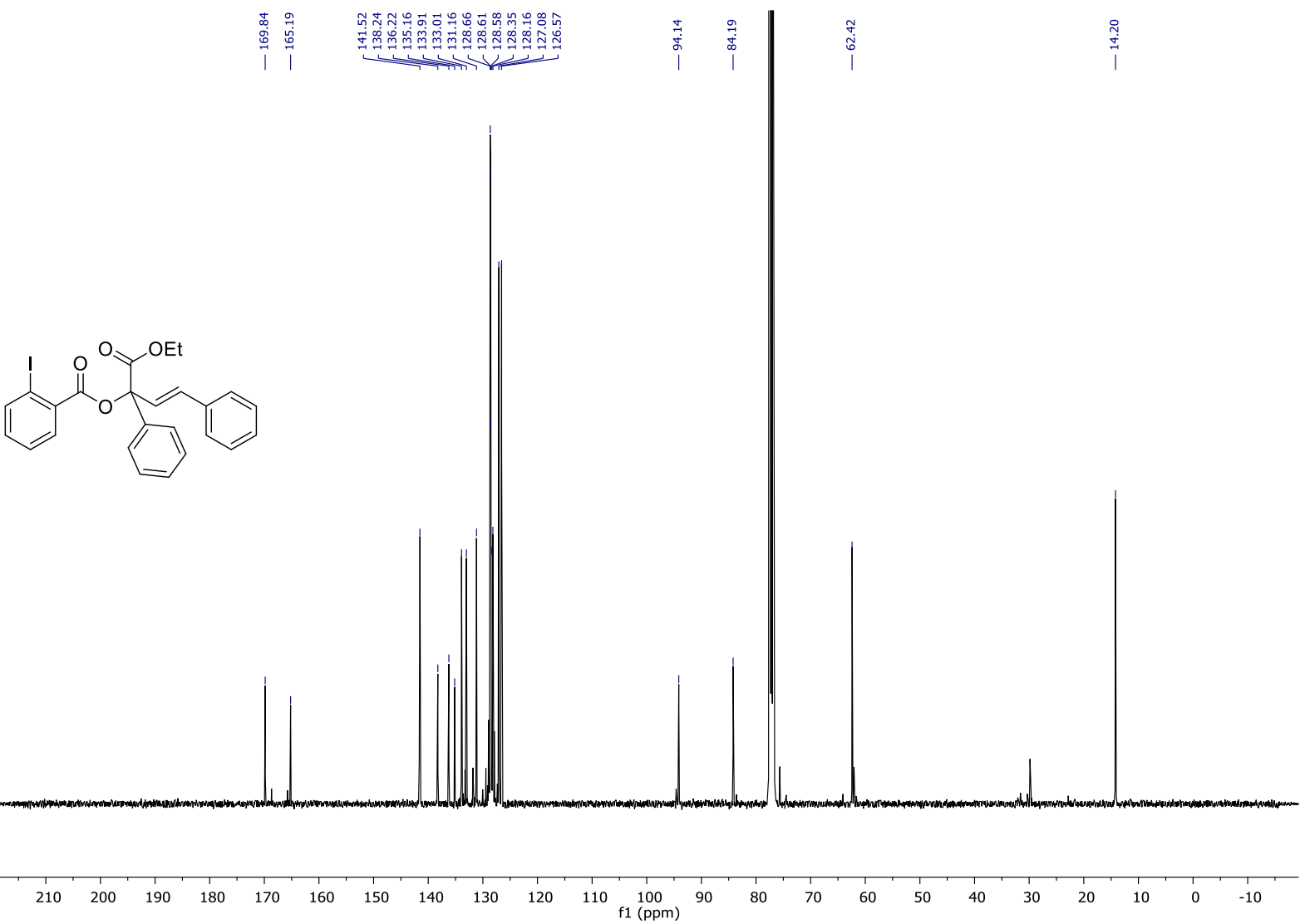

S129 
${ }^{1} \mathbf{H}-\mathrm{NMR}\left(400 \mathrm{MHz}, \mathrm{CDCl}_{3}\right)$ of compound $\mathbf{5 b}$

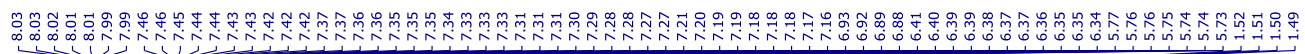

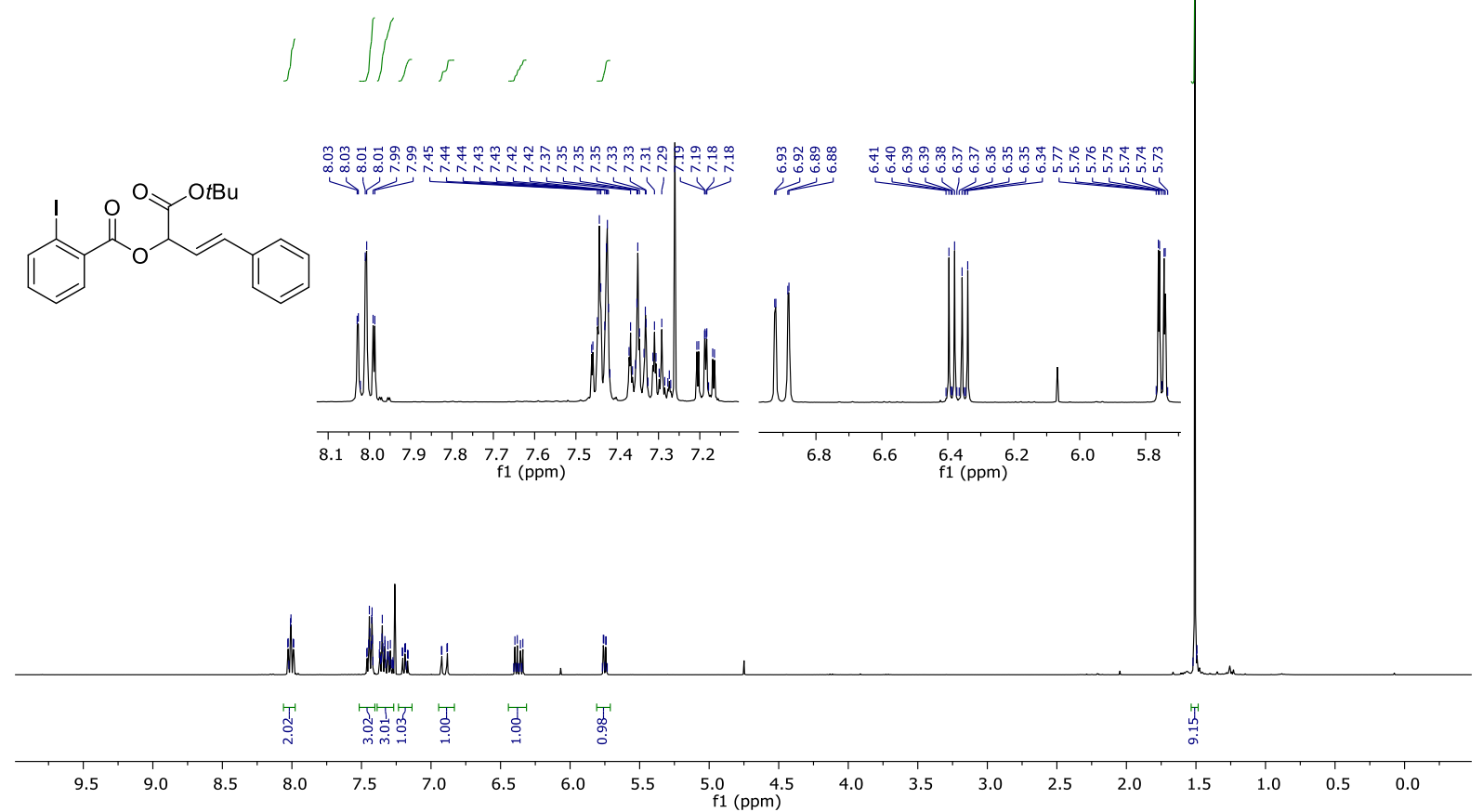

${ }^{13} \mathrm{C}-\mathrm{NMR}\left(101 \mathrm{MHz}, \mathrm{CDCl}_{3}\right)$ of compound $\mathbf{5 b}$

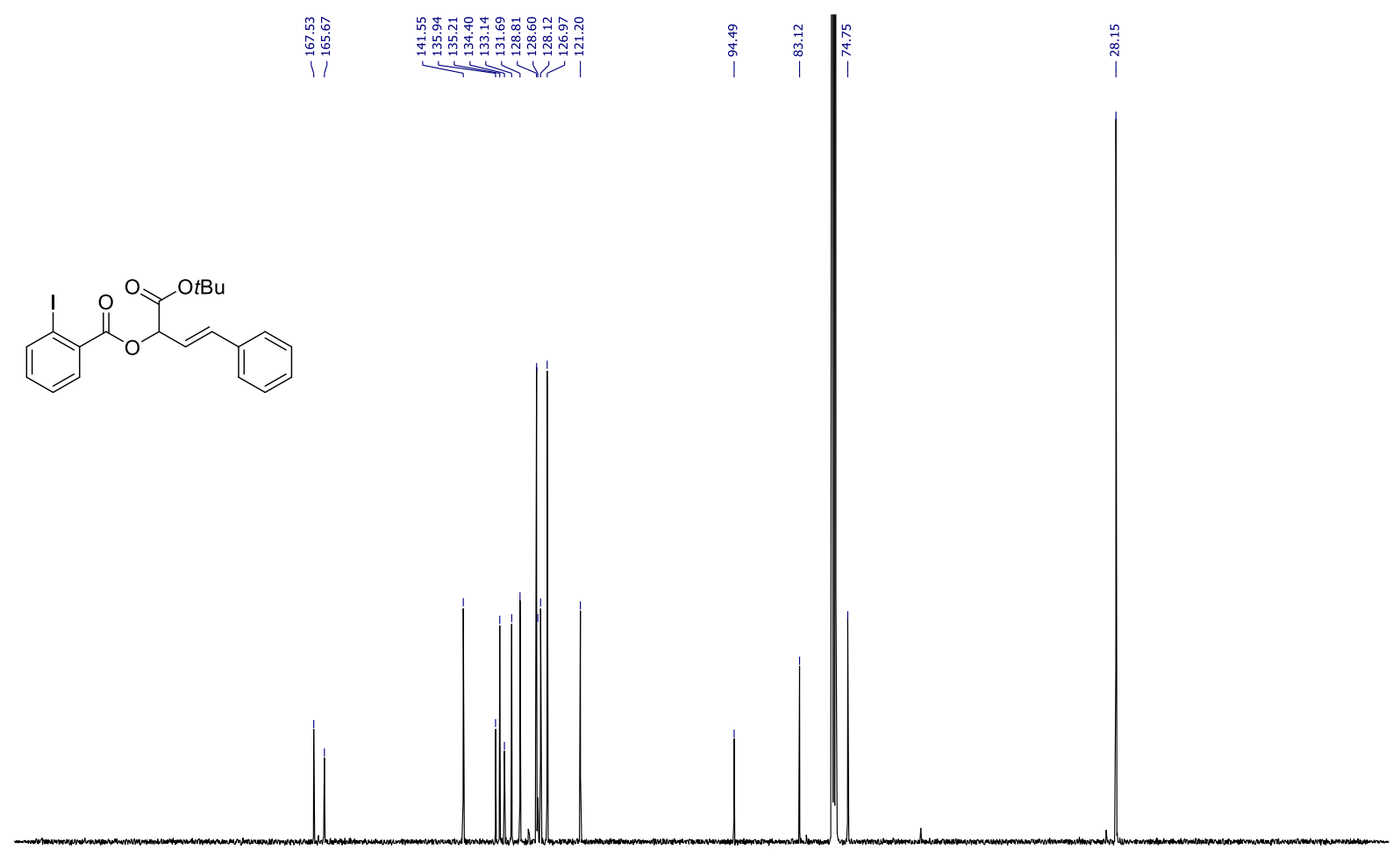

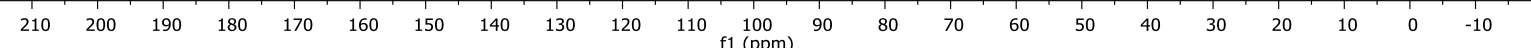


${ }^{1}$ H-NMR (400 MHz, $\mathrm{CDCl}_{3}$ ) of compound $\mathbf{5 c}$

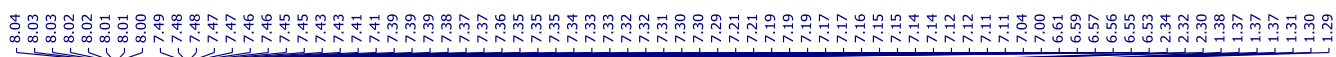
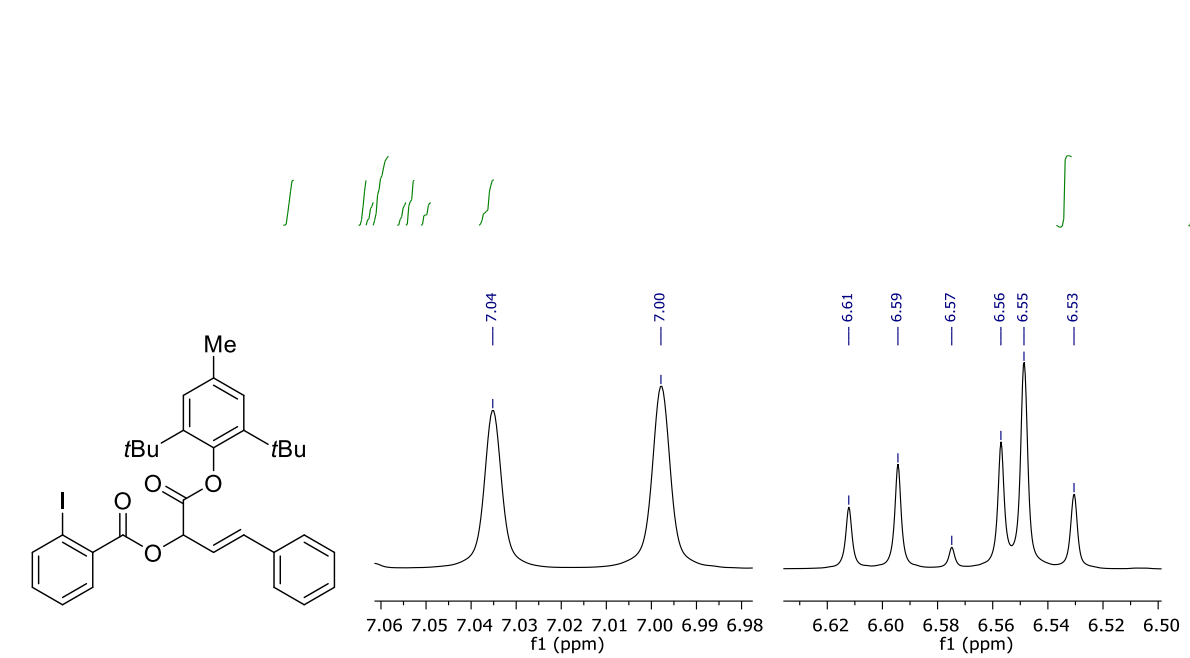

$7.067 .057 .04 \underset{f}{7} 7.037 .027 .017 .006 .996 .98$
(ppm)
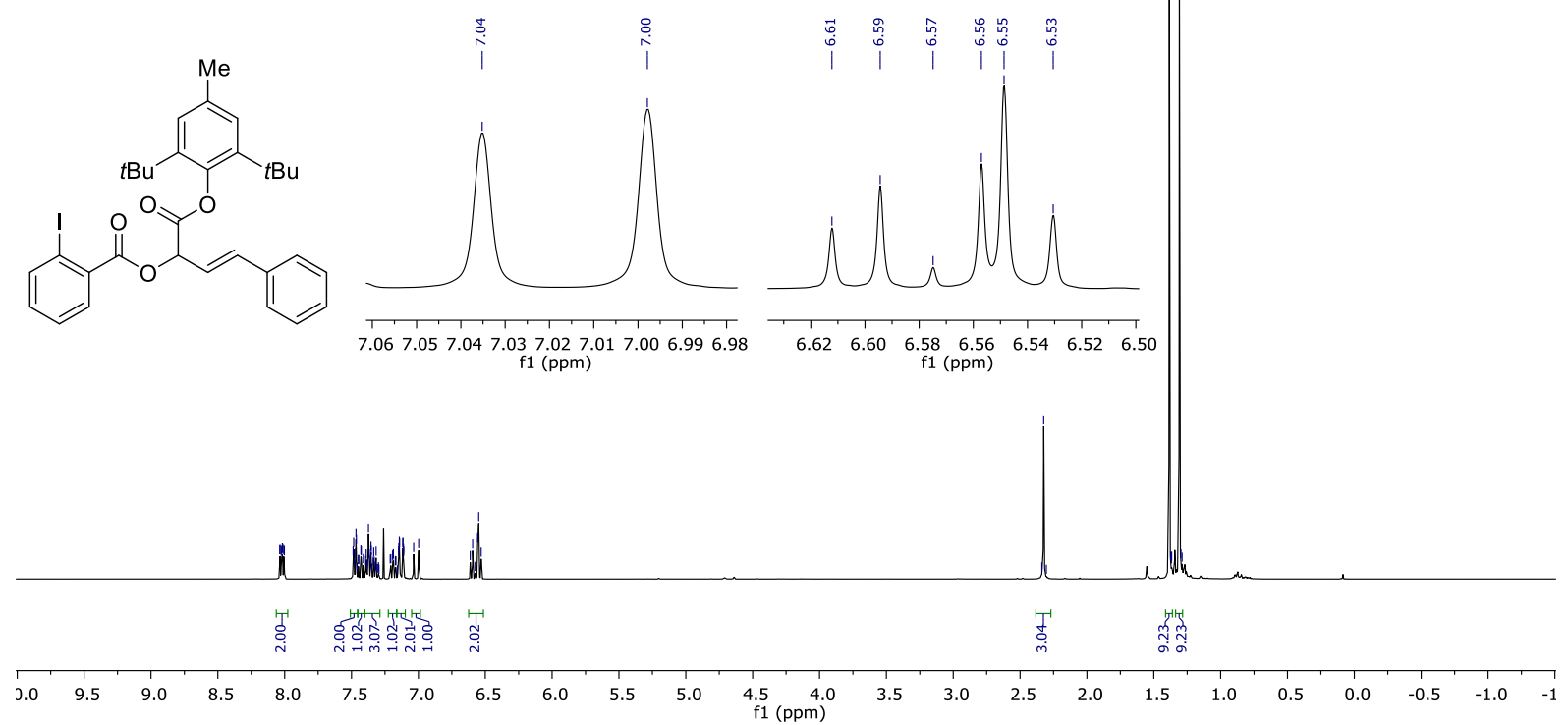

${ }^{13}$ C-NMR (101 MHz, $\mathrm{CDCl}_{3}$ ) of compound 5c

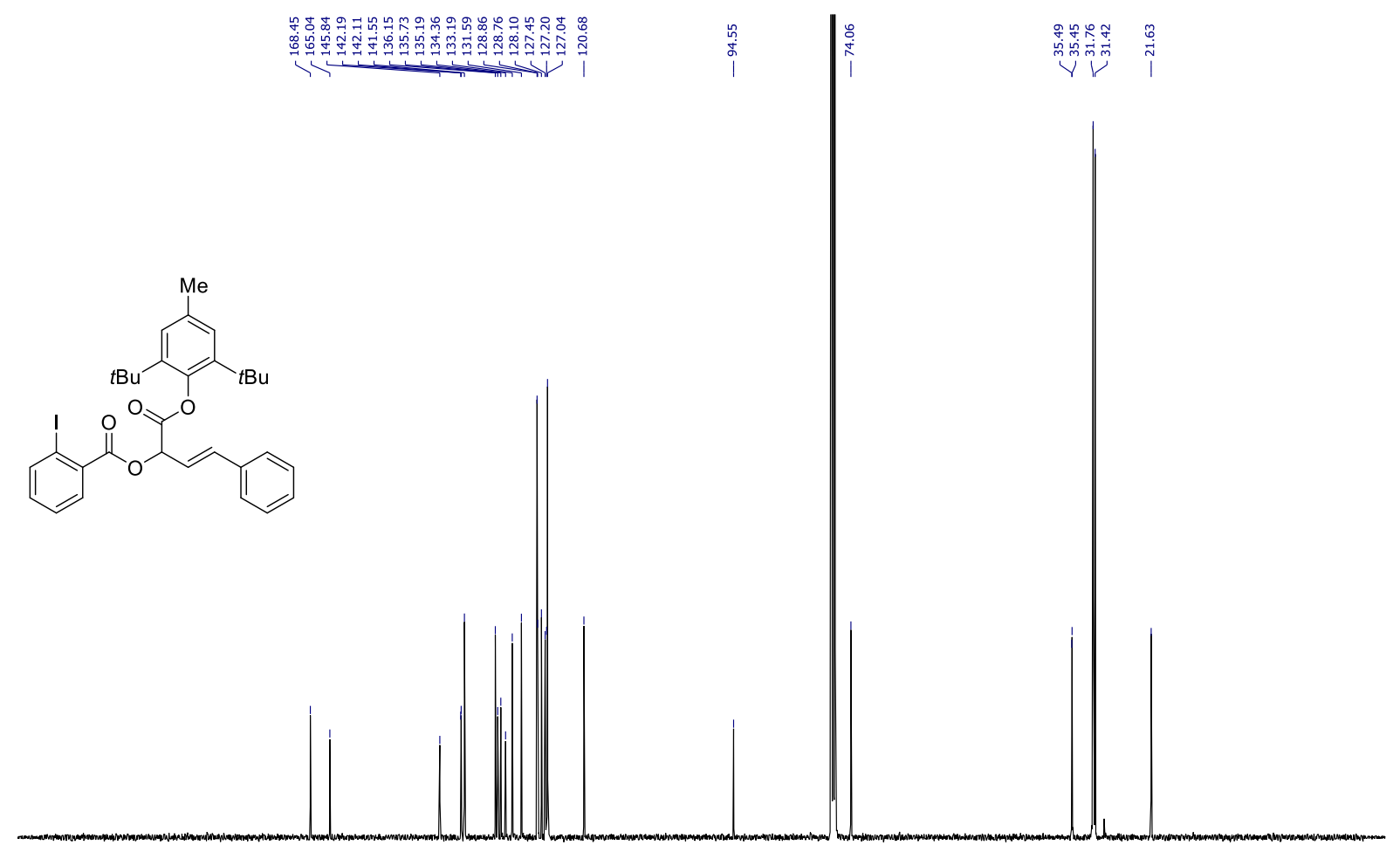

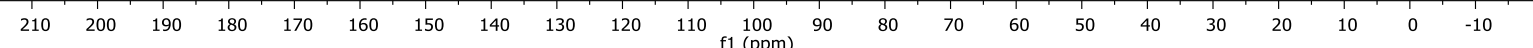


${ }^{1} \mathbf{H}-\mathrm{NMR}$ (400 MHz, $\mathrm{CDCl}_{3}$ ) of compound $\mathbf{5 d}$

$\underbrace{\text { mojo }}$

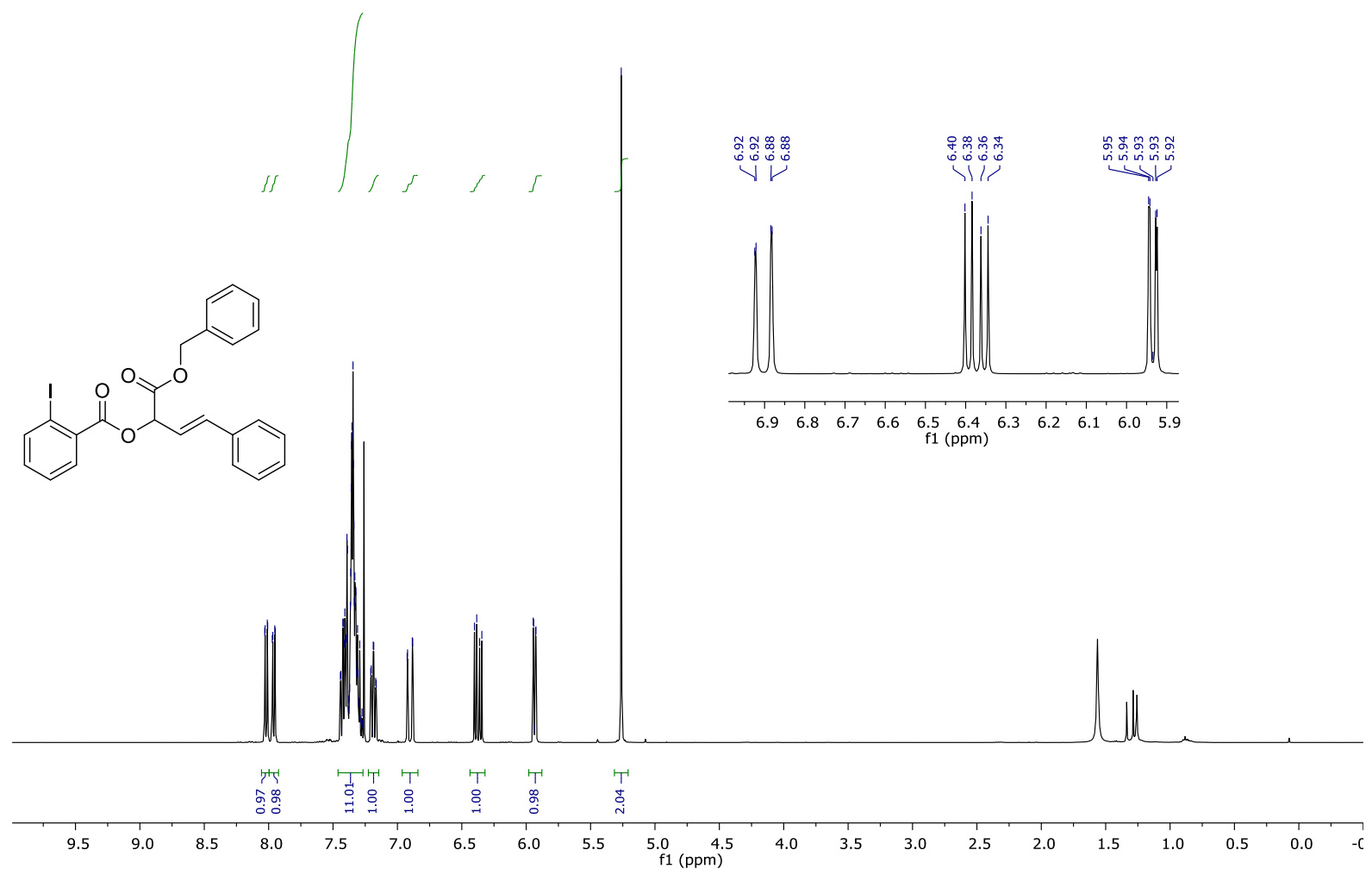

${ }^{13}$ C-NMR (101 MHz, $\mathrm{CDCl}_{3}$ ) of compound $\mathbf{5 d}$
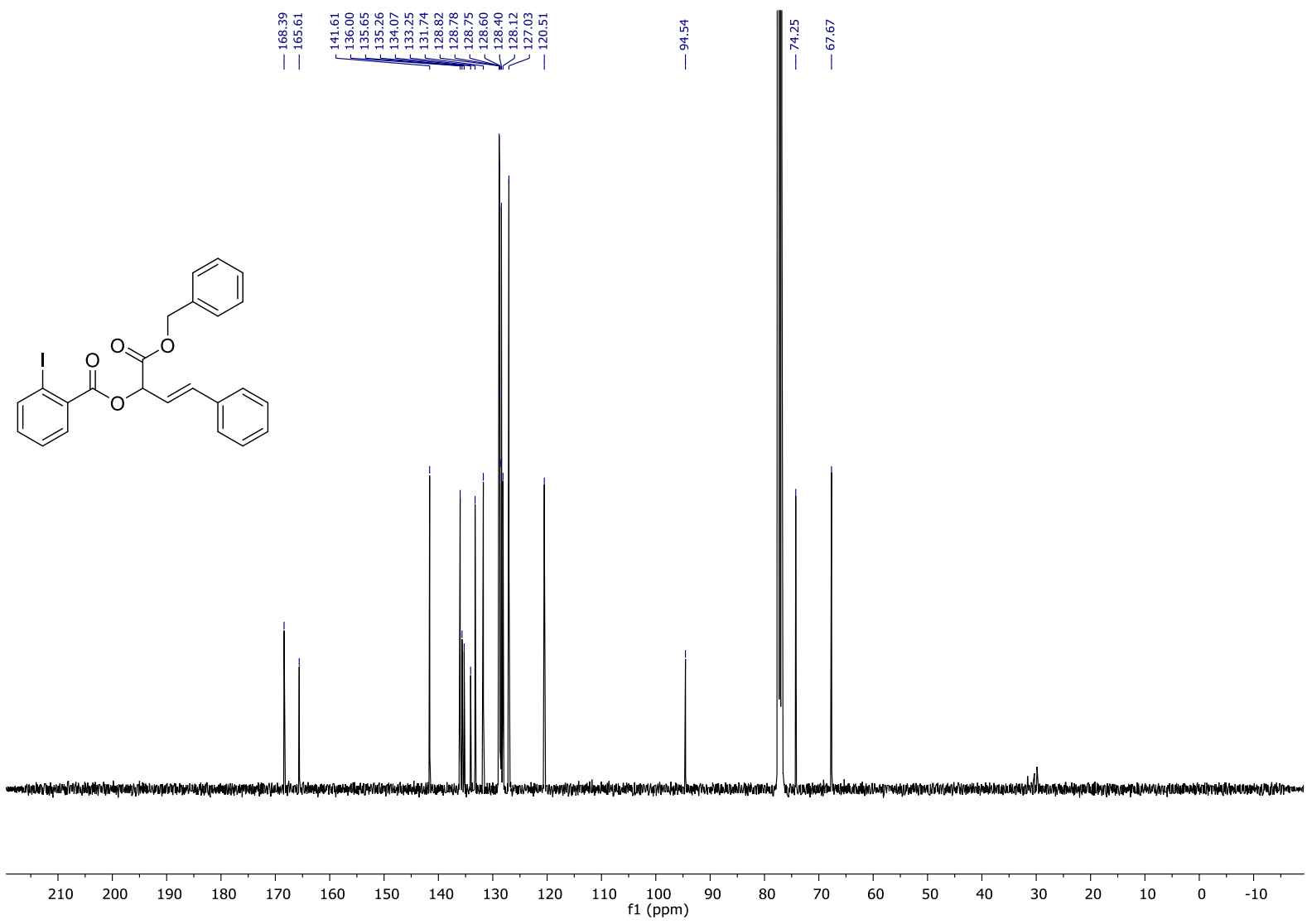

S132 
${ }^{1} \mathbf{H}-\mathrm{NMR}\left(400 \mathrm{MHz}, \mathrm{CDCl}_{3}\right.$ ) of compound $\mathbf{5 e}$

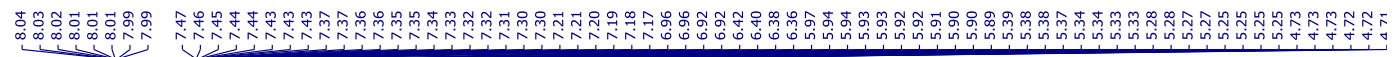
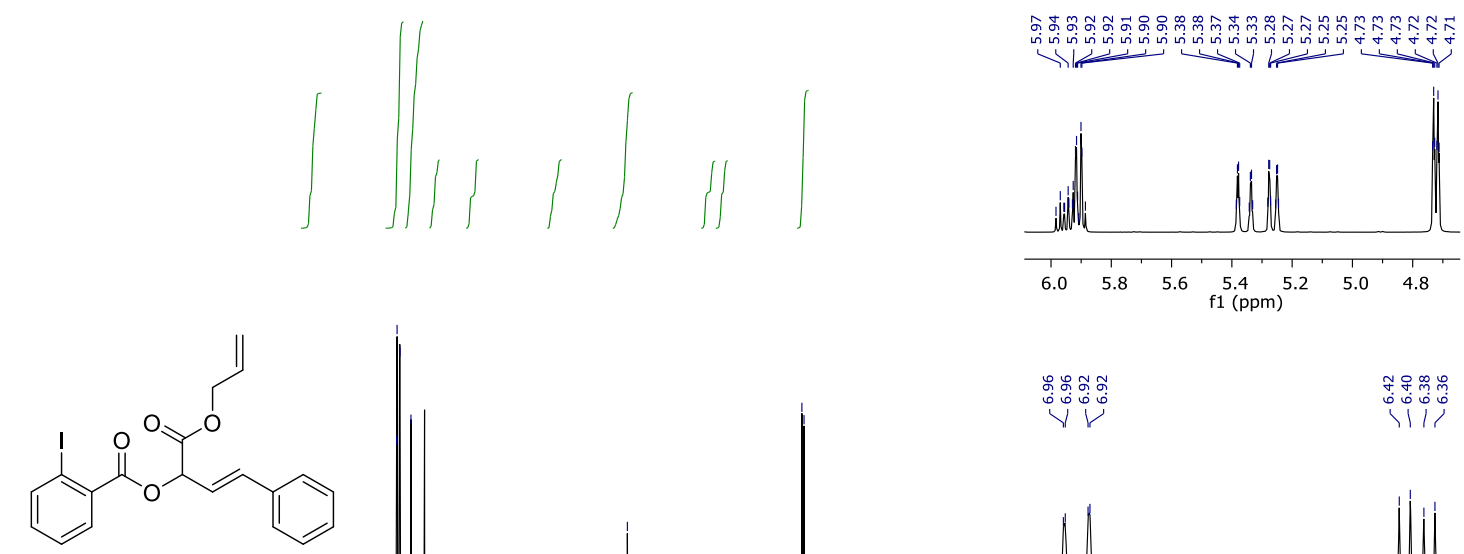

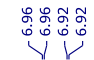

\11
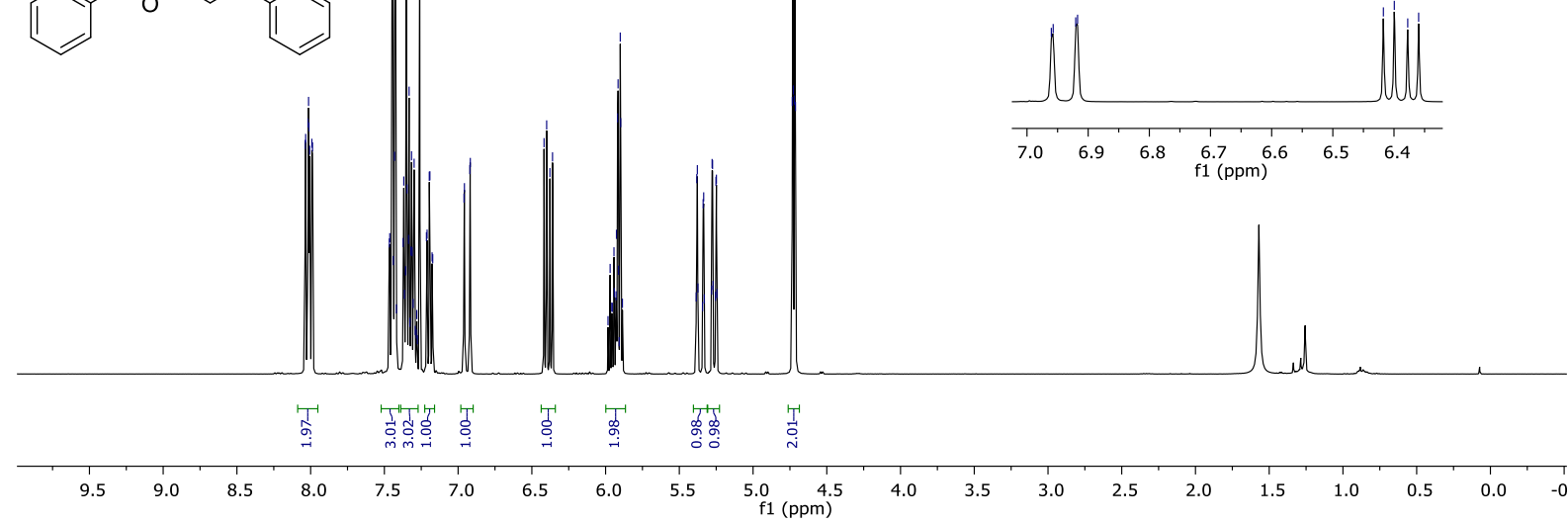

${ }^{13}$ C-NMR (101 MHz, $\mathrm{CDCl}_{3}$ ) of compound $\mathbf{5 e}$

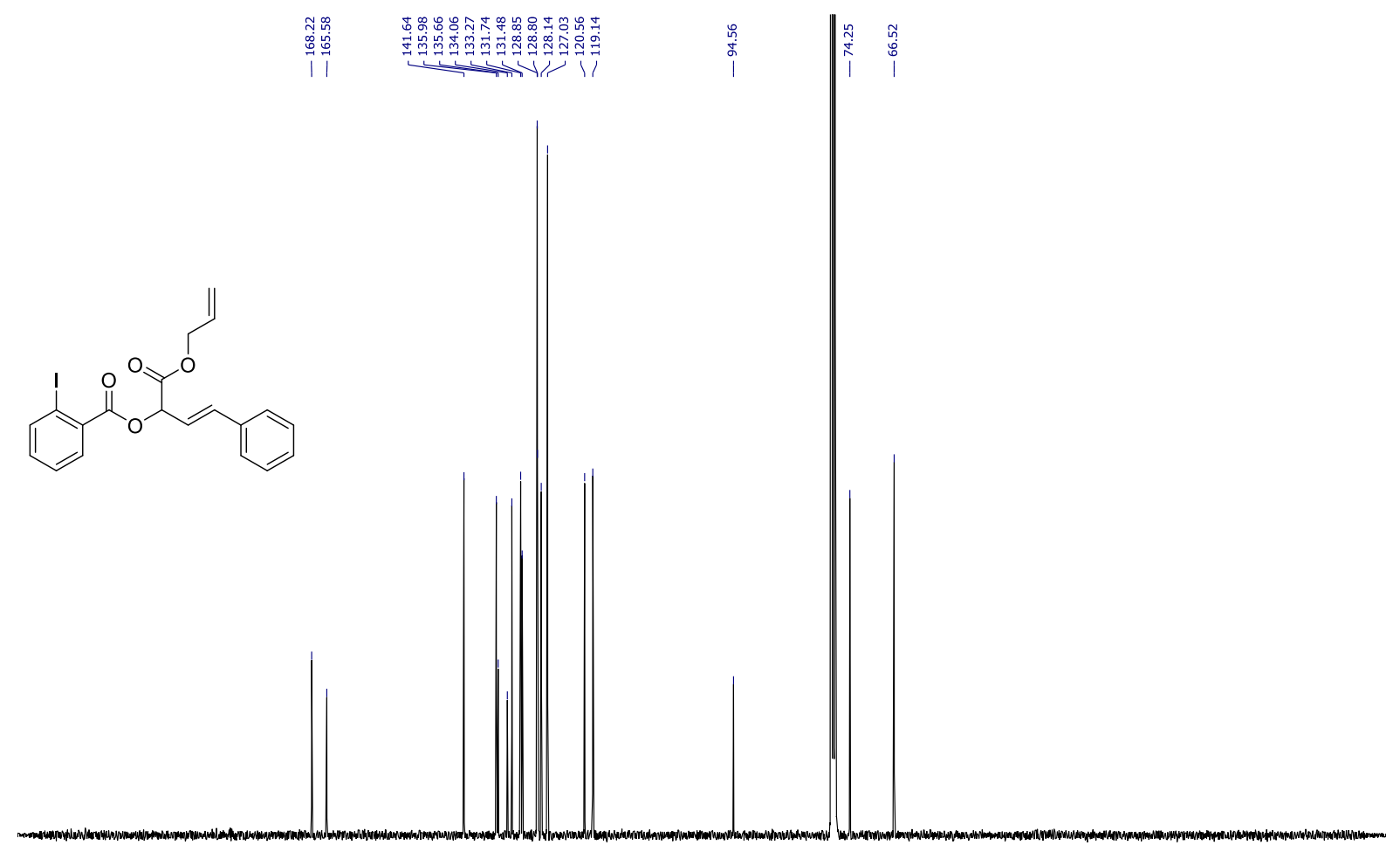

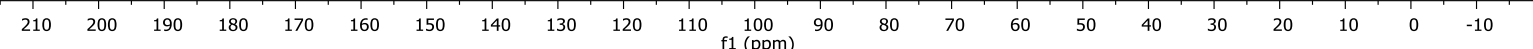


${ }^{1}$ H-NMR (400 MHz, $\mathrm{CDCl}_{3}$ ) of compound $\mathbf{5 f}$

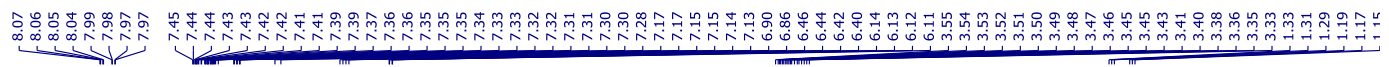
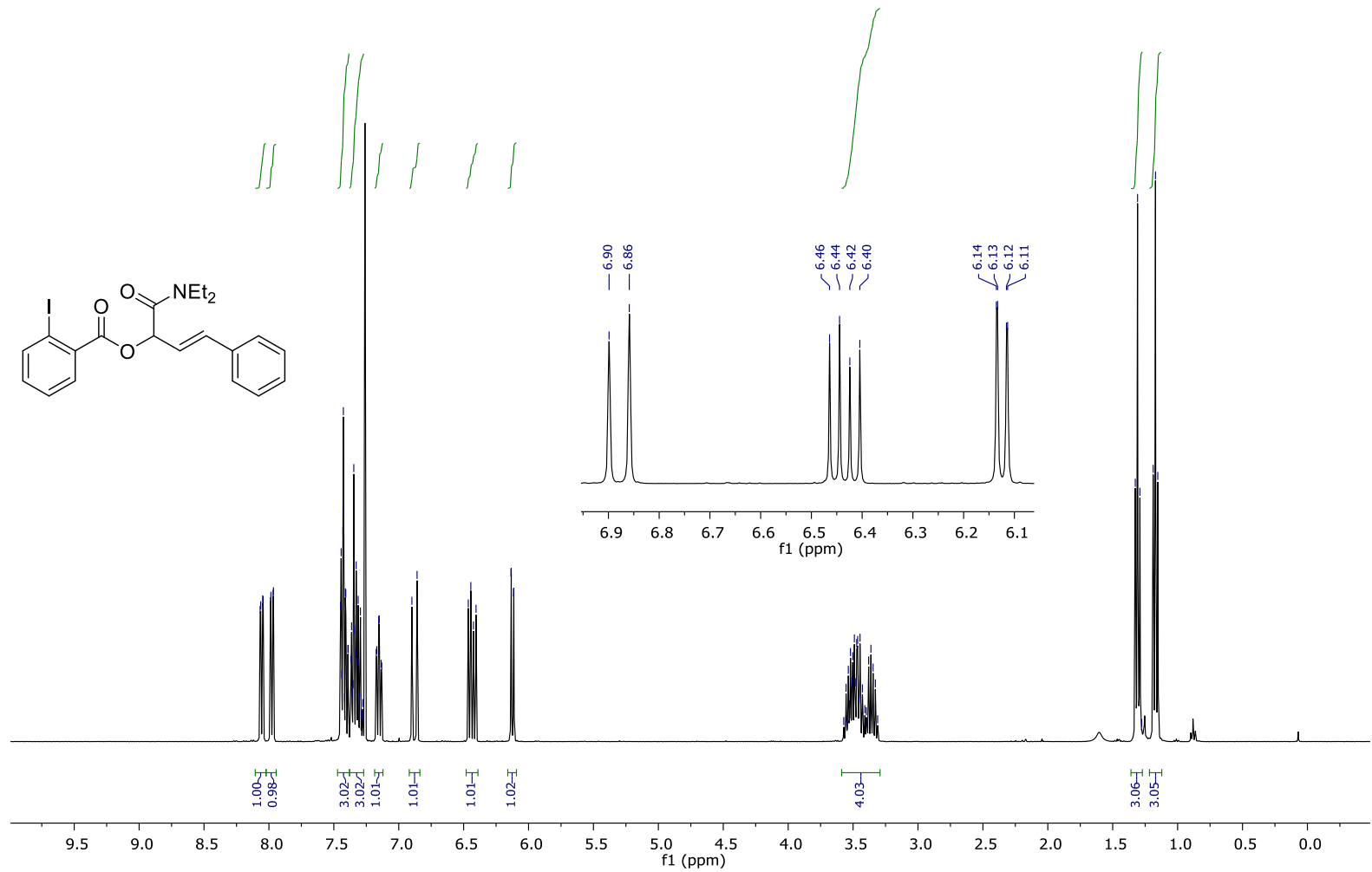

${ }^{13} \mathrm{C}$-NMR (101 MHz, $\mathrm{CDCl}_{3}$ ) of compound $\mathbf{5 f}$

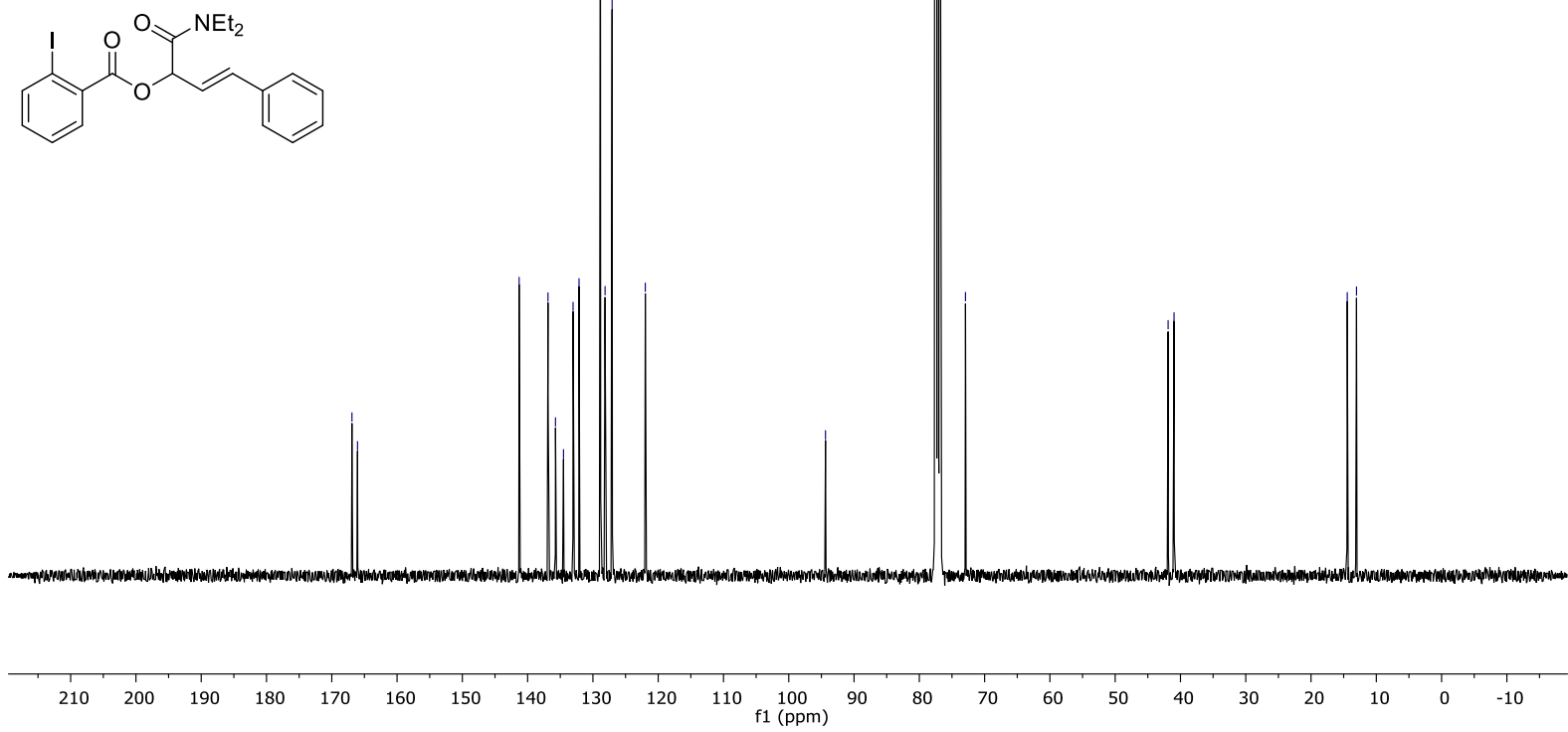

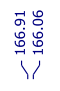

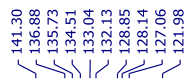

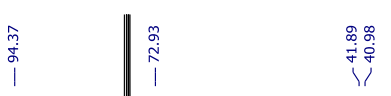

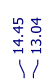

S134 
${ }^{1} \mathbf{H}-\mathrm{NMR}\left(400 \mathrm{MHz}, \mathrm{CDCl}_{3}\right.$ ) of compound $\mathbf{5 g}$

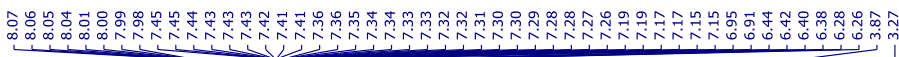

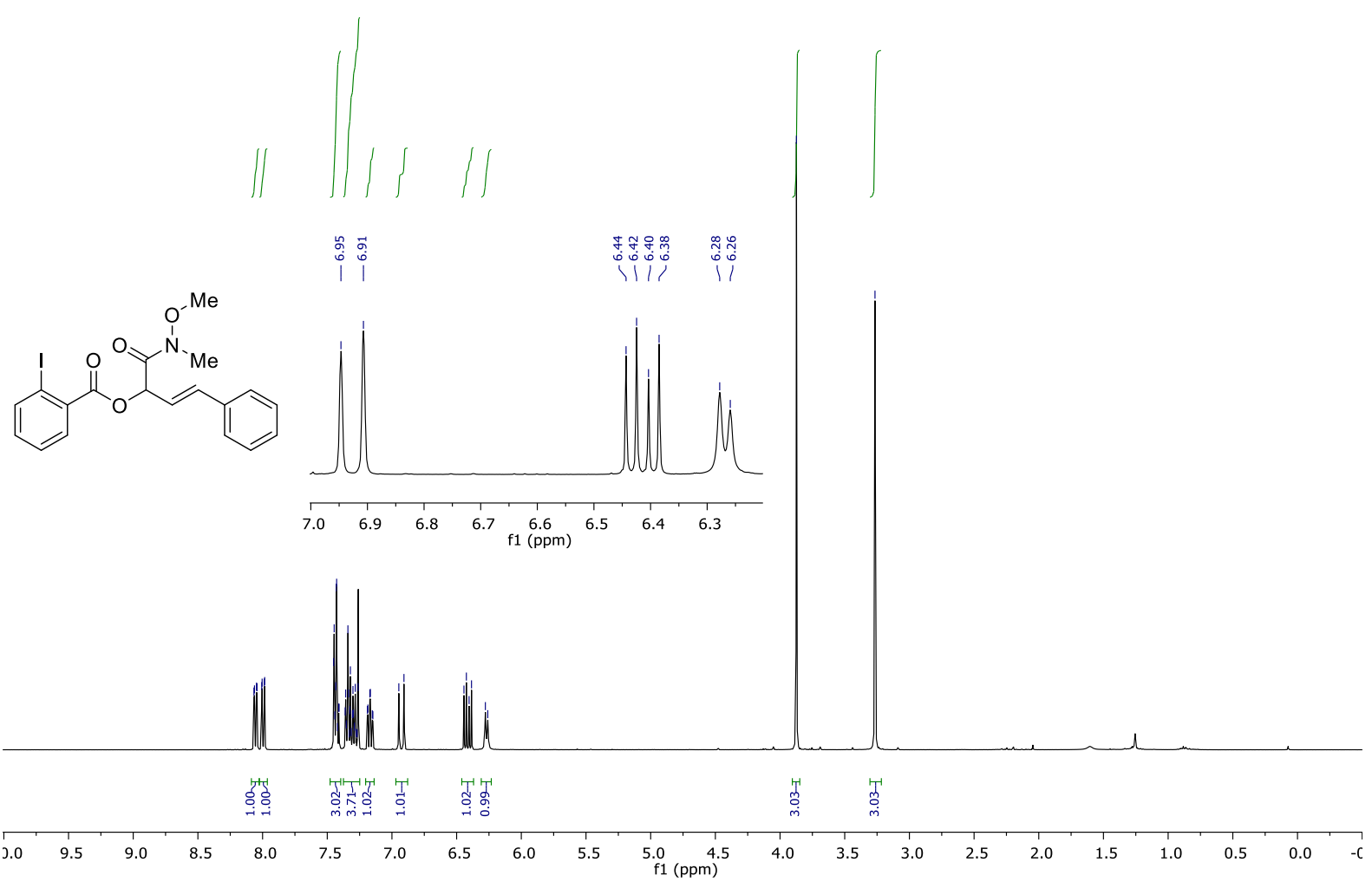

${ }^{13}$ C-NMR (101 MHz, $\mathrm{CDCl}_{3}$ ) of compound $5 \mathrm{~g}$

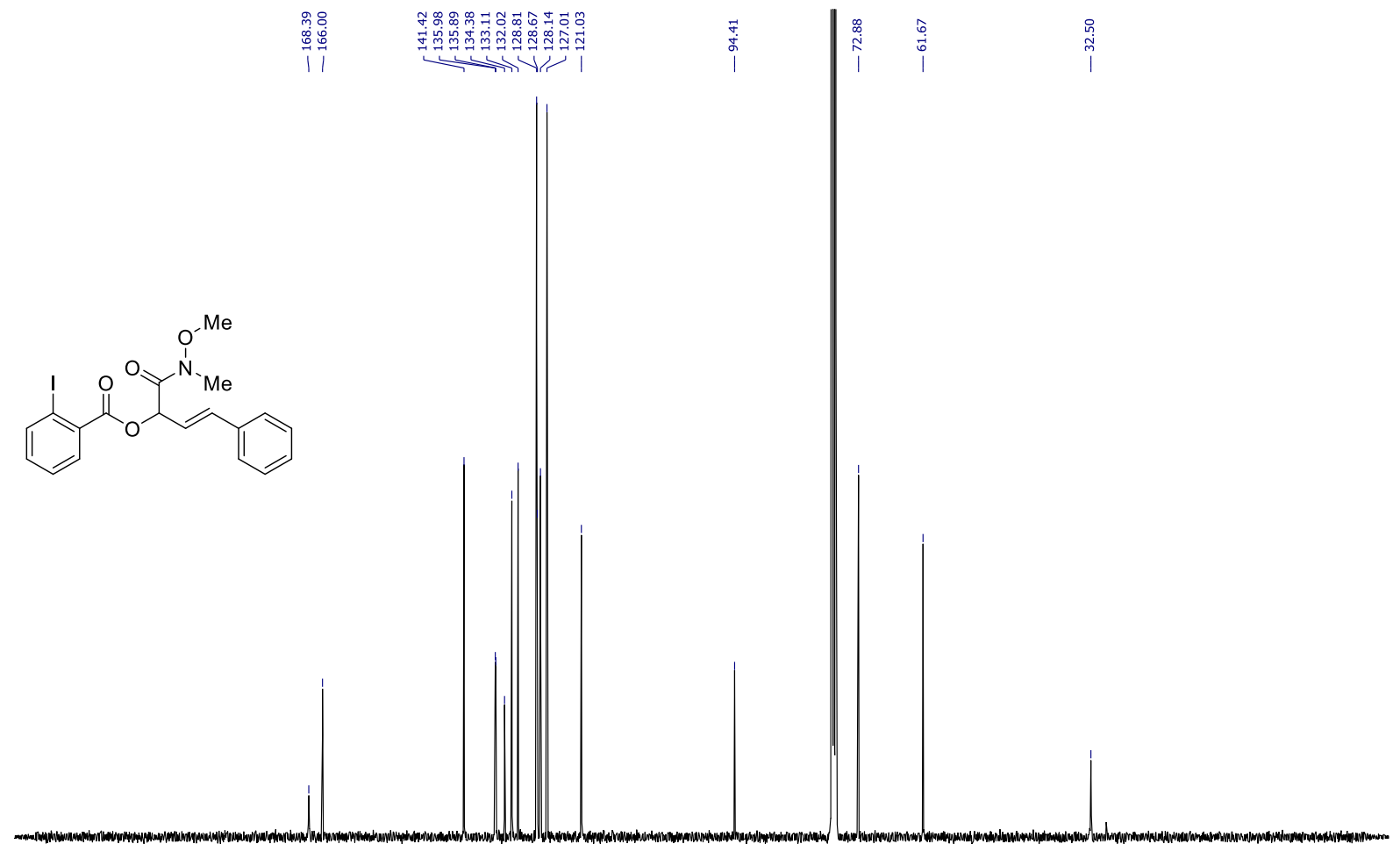

$\begin{array}{lllllllllllllllllllllll}210 & 200 & 190 & 180 & 170 & 160 & 150 & 140 & 130 & 120 & 110 & 100 & 90 & 80 & 70 & 60 & 50 & 40 & 30 & 20 & 10 & 0 & -10\end{array}$ 
${ }^{1} \mathbf{H}-\mathrm{NMR}\left(400 \mathrm{MHz}, \mathrm{CDCl}_{3}\right)$ of compound $\mathbf{5 h}$

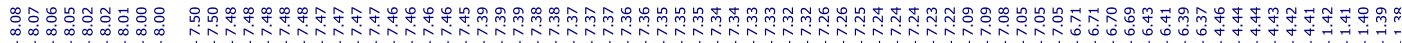

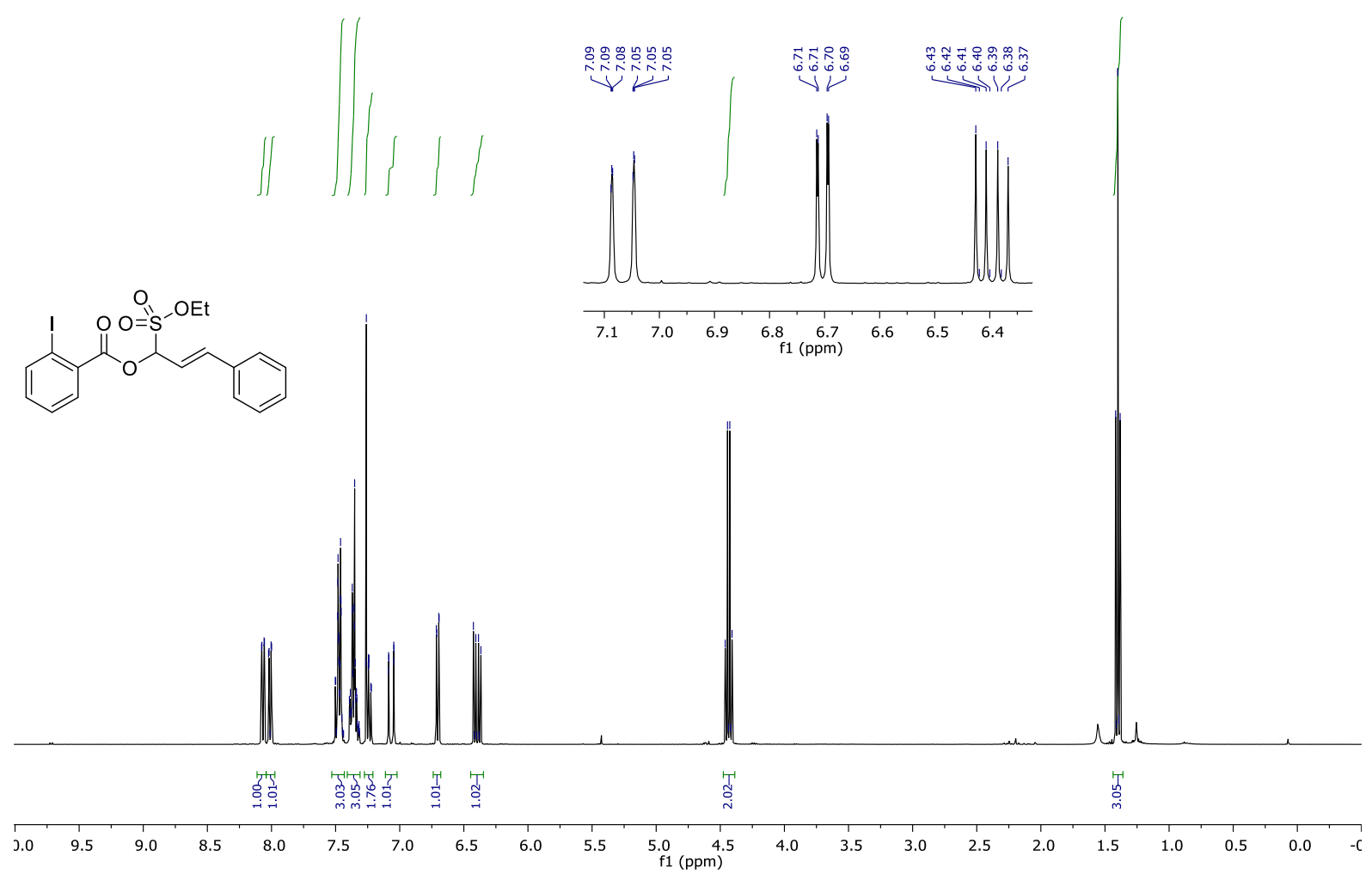

${ }^{13} \mathrm{C}-\mathrm{NMR}\left(101 \mathrm{MHz}, \mathrm{CDCl}_{3}\right)$ of compound $\mathbf{5 h}$

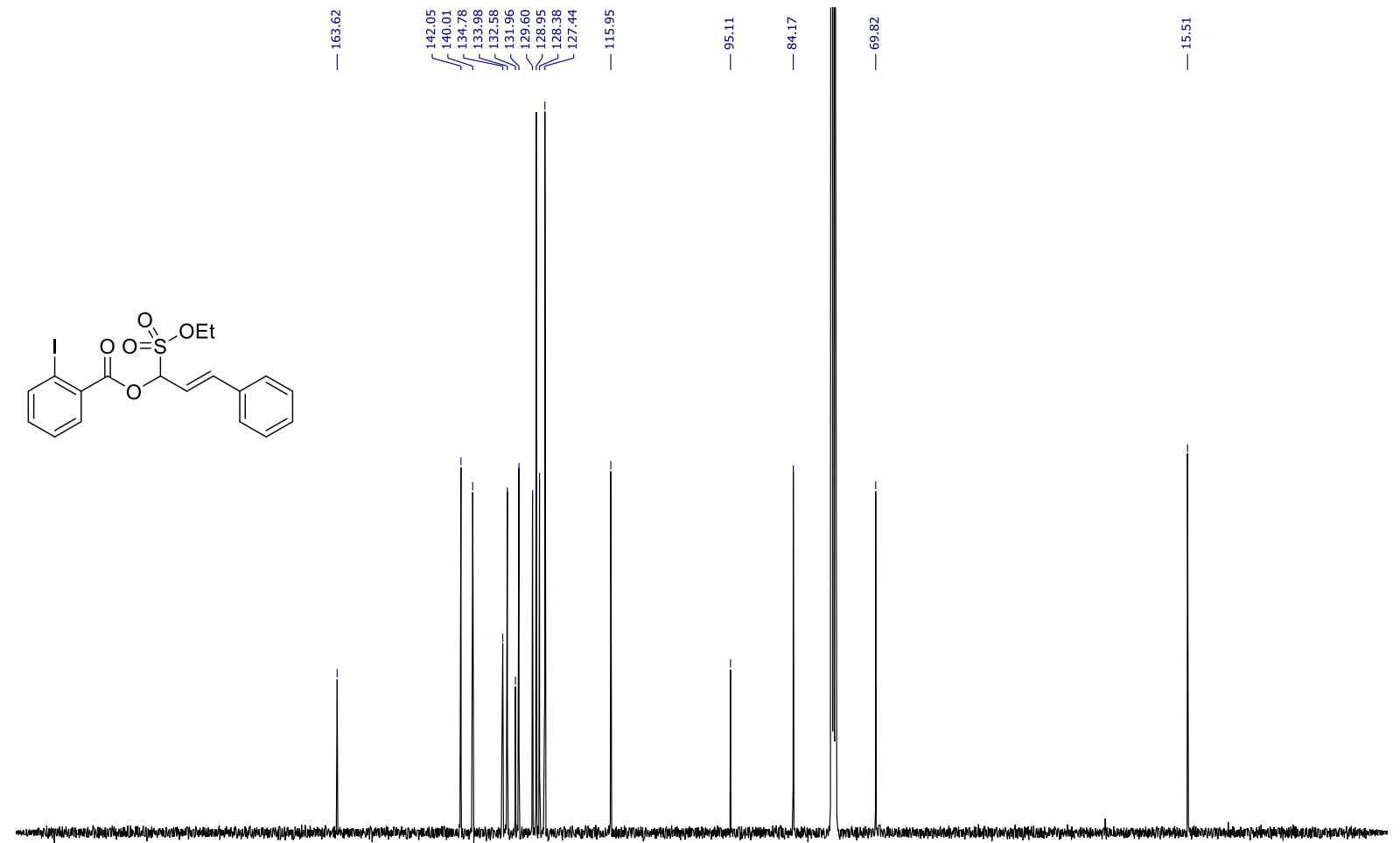

$\begin{array}{lllllllllllllllllllllll}210 & 200 & 190 & 180 & 170 & 160 & 150 & 140 & 130 & 120 & 110 & 100 & 90 & 80 & 70 & 60 & 50 & 40 & 30 & 20 & 10 & 0 & -10\end{array}$ 
${ }^{1} \mathbf{H}-\mathrm{NMR}\left(400 \mathrm{MHz}, \mathrm{CDCl}_{3}\right)$ of compound $\mathbf{5 i}$

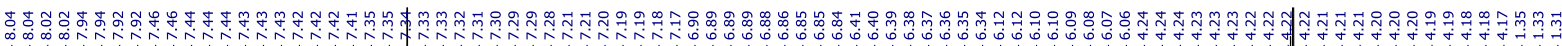

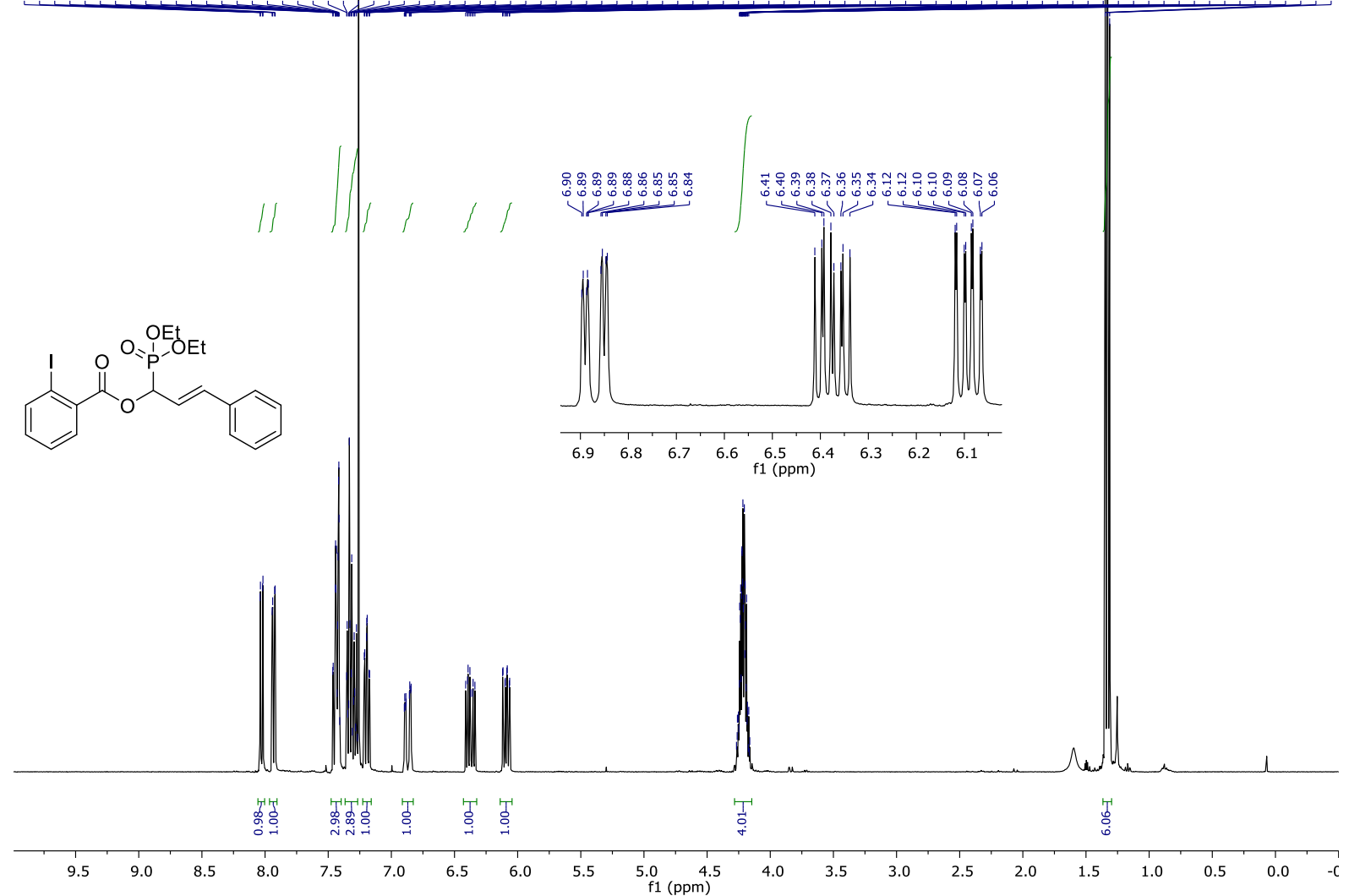

${ }^{13} \mathrm{C}-\mathrm{NMR}\left(101 \mathrm{MHz}, \mathrm{CDCl}_{3}\right)$ of compound $\mathbf{5 i}$

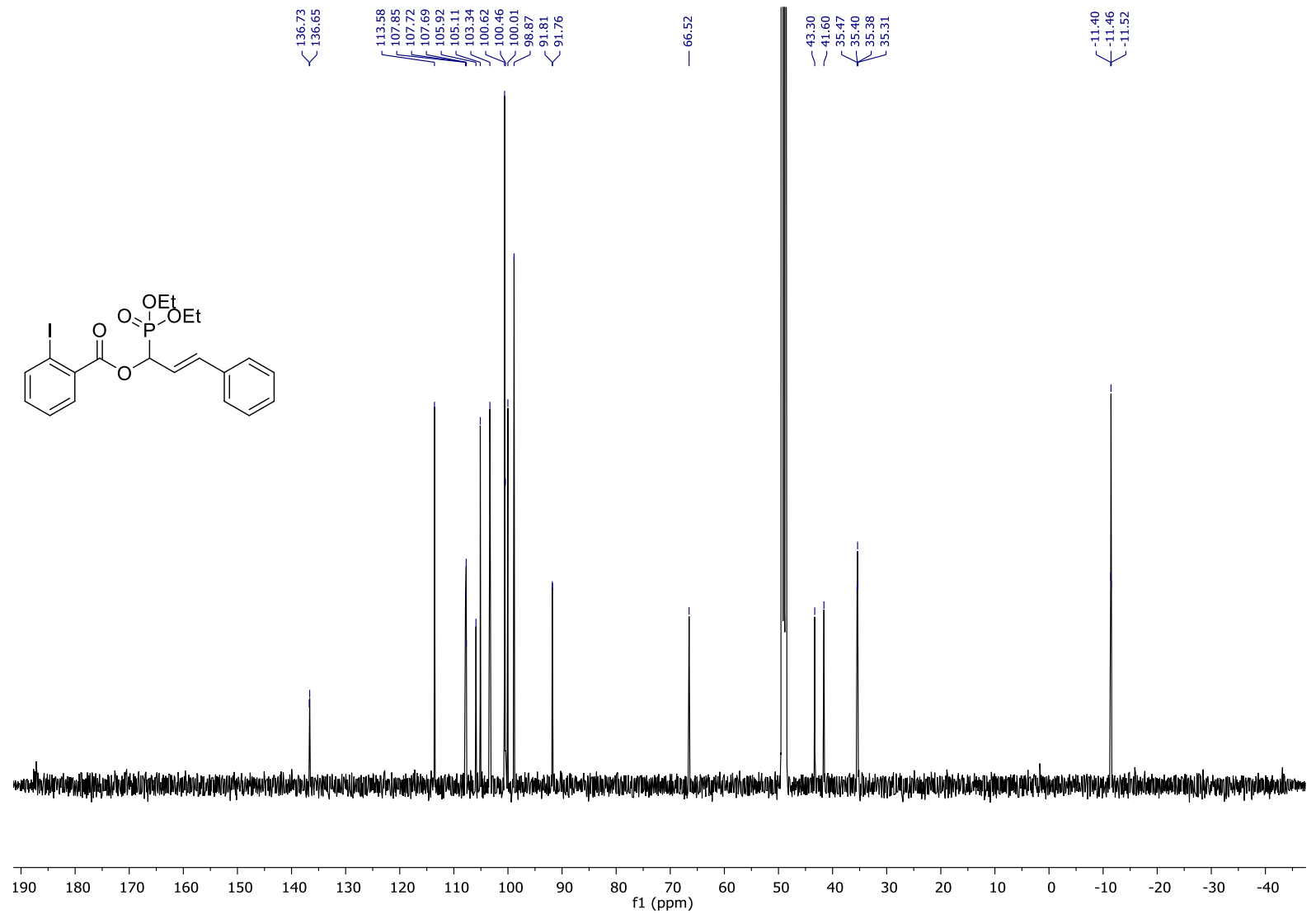


${ }^{31} \mathbf{P}-\mathrm{NMR}\left(126 \mathrm{MHz}, \mathrm{CDCl}_{3}\right)$ of compound $\mathbf{5 i}$

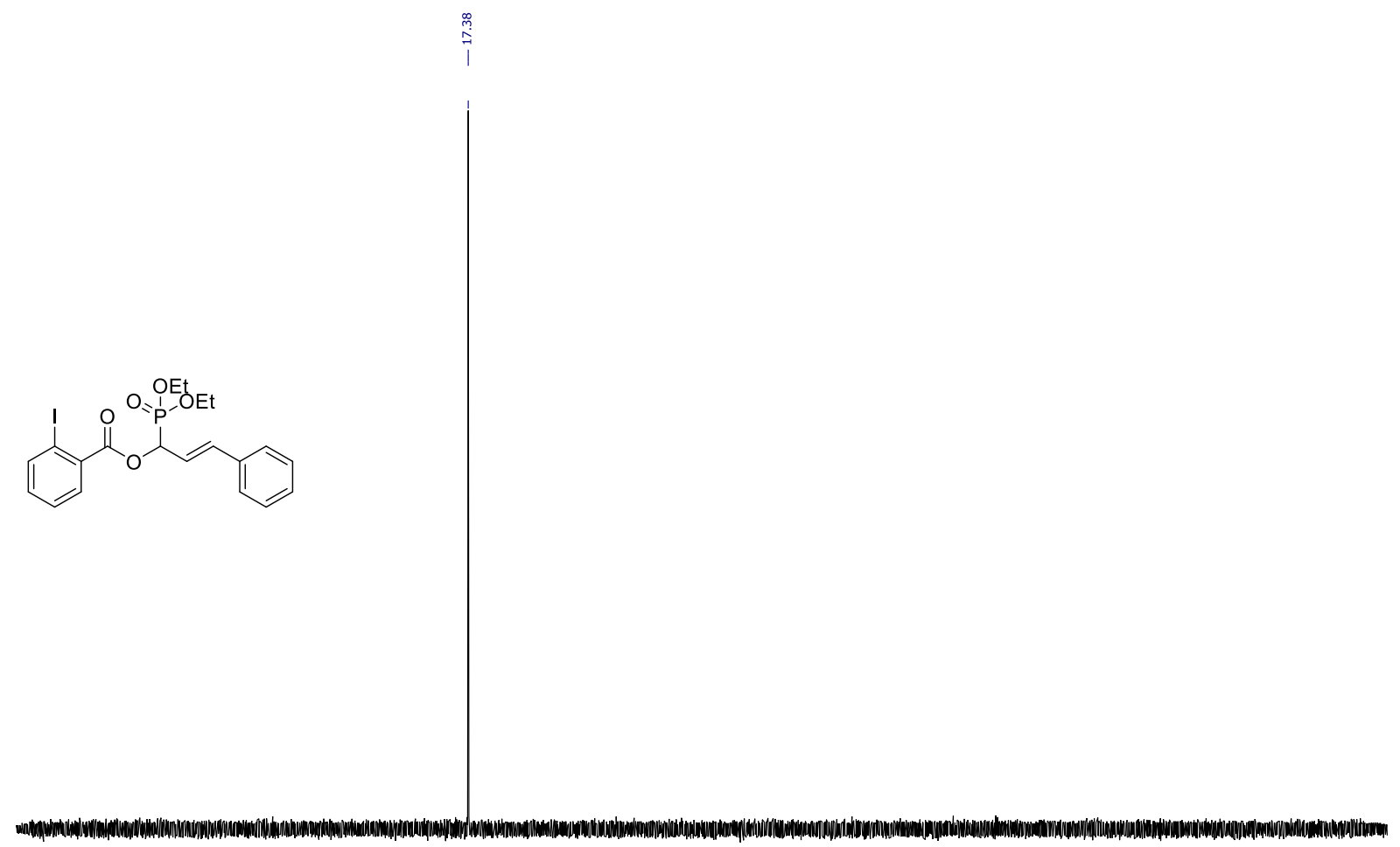

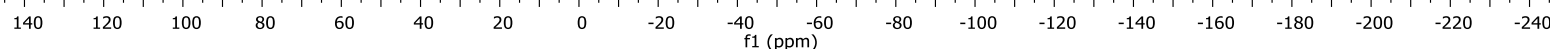


${ }^{1}$ H-NMR (400 MHz, $\mathrm{CDCl}_{3}$ ) of compound 5 I

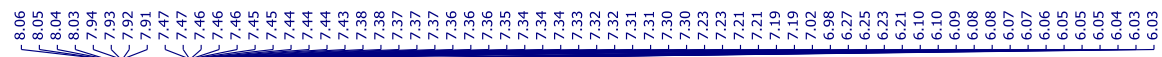

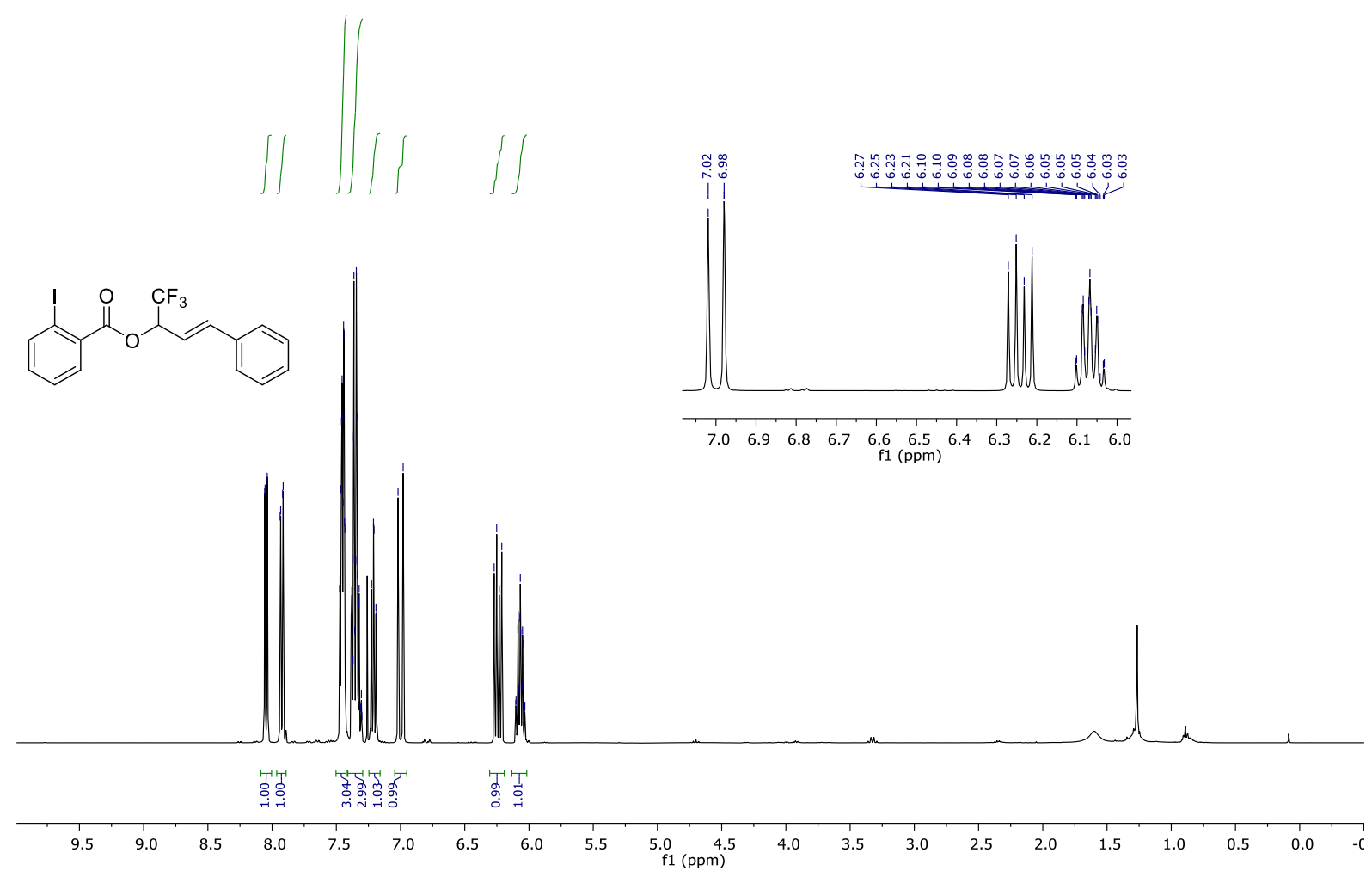

${ }^{13} \mathrm{C}-\mathrm{NMR}\left(101 \mathrm{MHz}, \mathrm{CDCl}_{3}\right.$ ) of compound 5 I

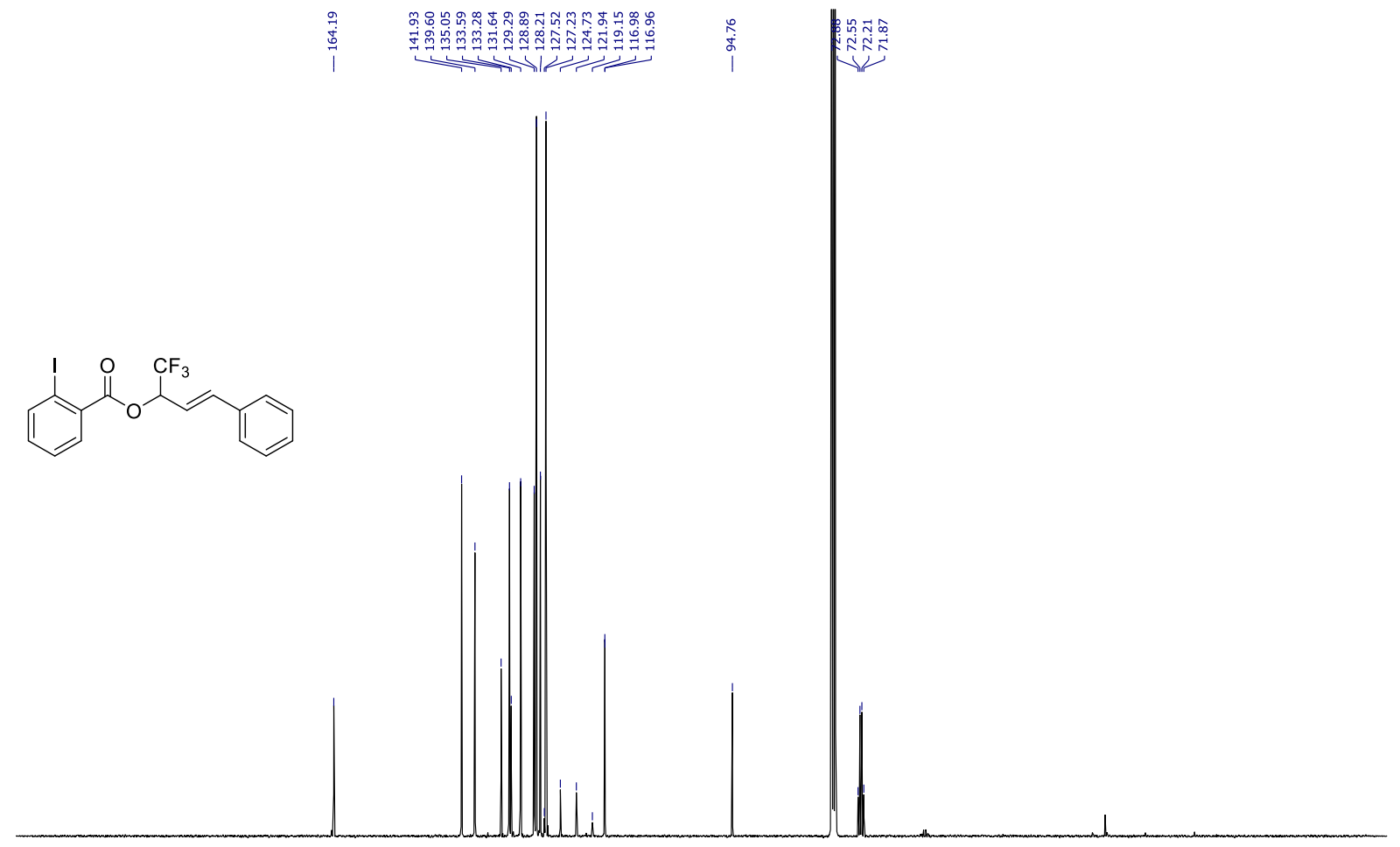

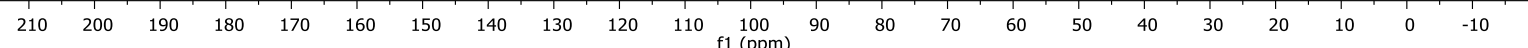


${ }^{19}$ F-NMR (376 MHz, $\mathrm{CDCl}_{3}$ ) of compound 5 I

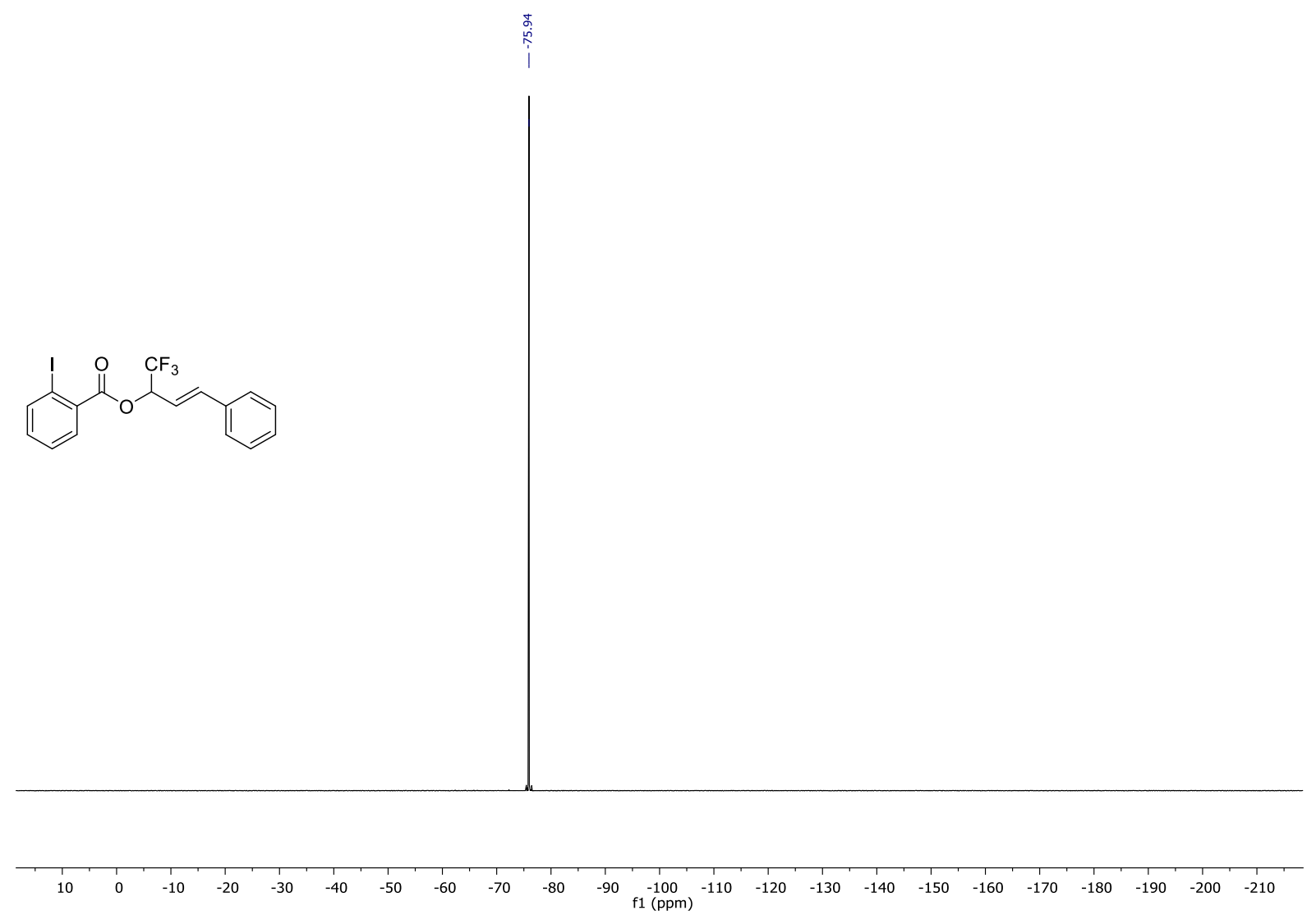


${ }^{1} \mathrm{H}-\mathrm{NMR}\left(400 \mathrm{MHz}, \mathrm{CDCl}_{3}\right.$ ) of compound $\mathbf{5 m}$

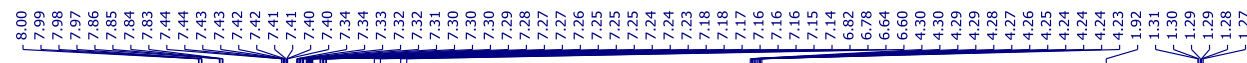

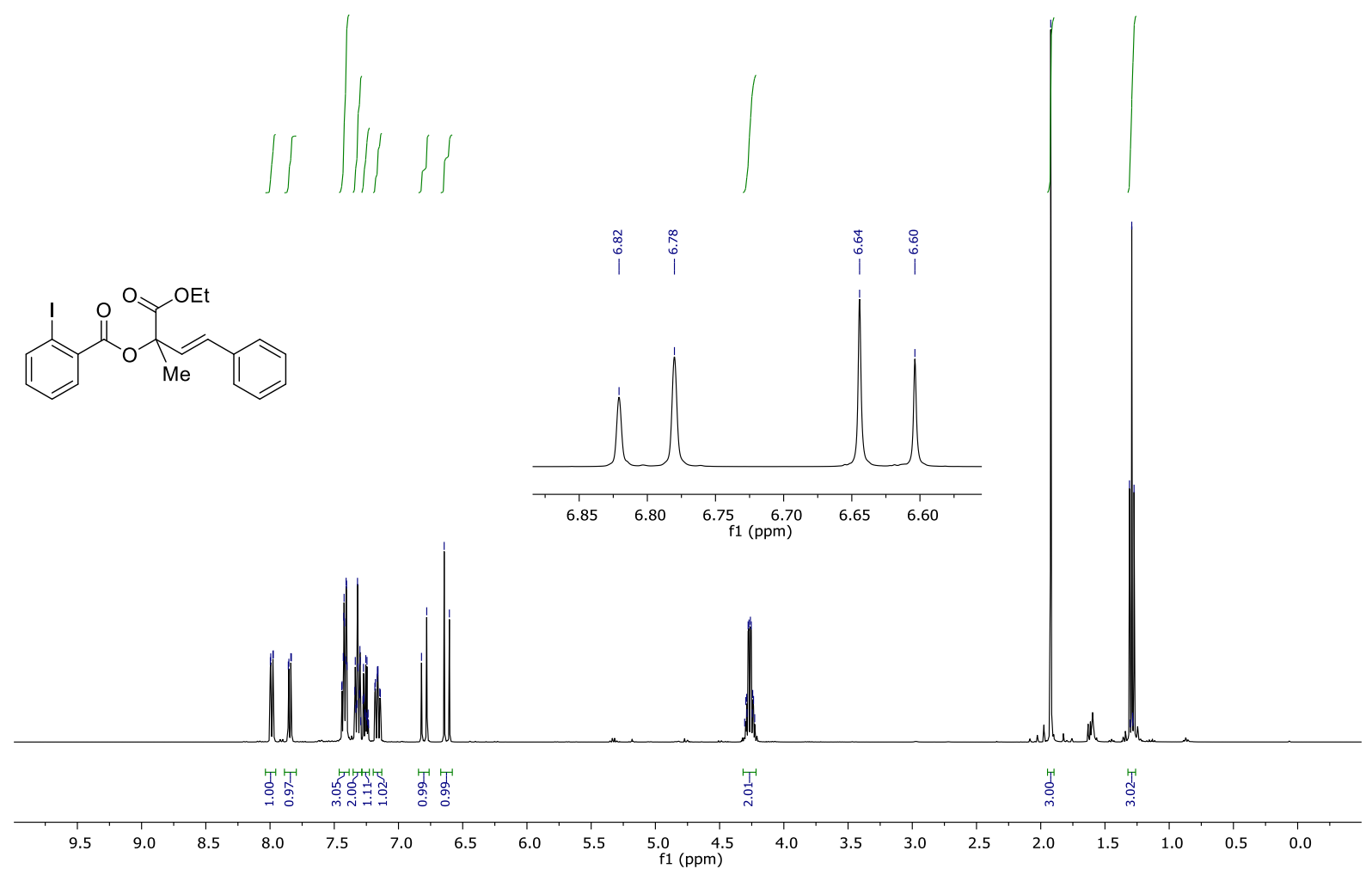

${ }^{13}$ C-NMR (101 MHz, $\mathrm{CDCl}_{3}$ ) of compound $\mathbf{5 m}$

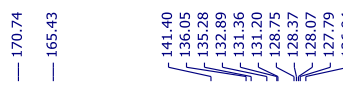

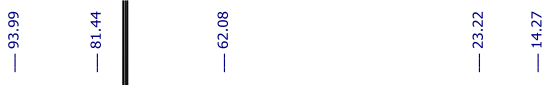
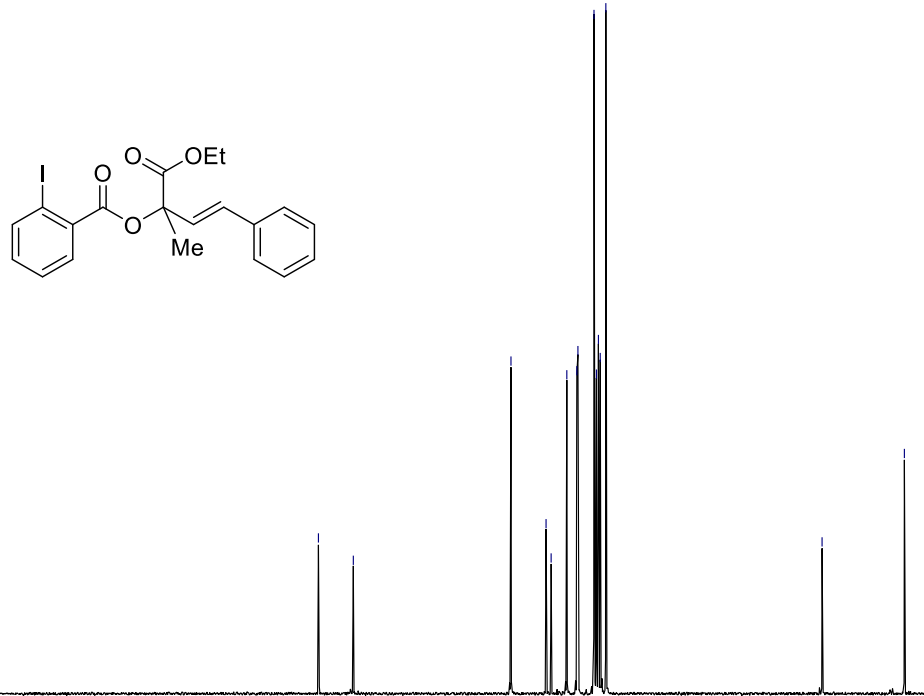

$\begin{array}{lllllllllllllllllllllll}210 & 200 & 190 & 180 & 170 & 160 & 150 & 140 & 130 & 120 & 110 & 100 & 90 & 80 & 70 & 60 & 50 & 40 & 30 & 20 & 10 & 0 & -10\end{array}$ 
${ }^{1} \mathbf{H}-\mathrm{NMR}\left(400 \mathrm{MHz}, \mathrm{CDCl}_{3}\right)$ of compound 50

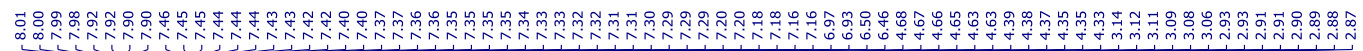
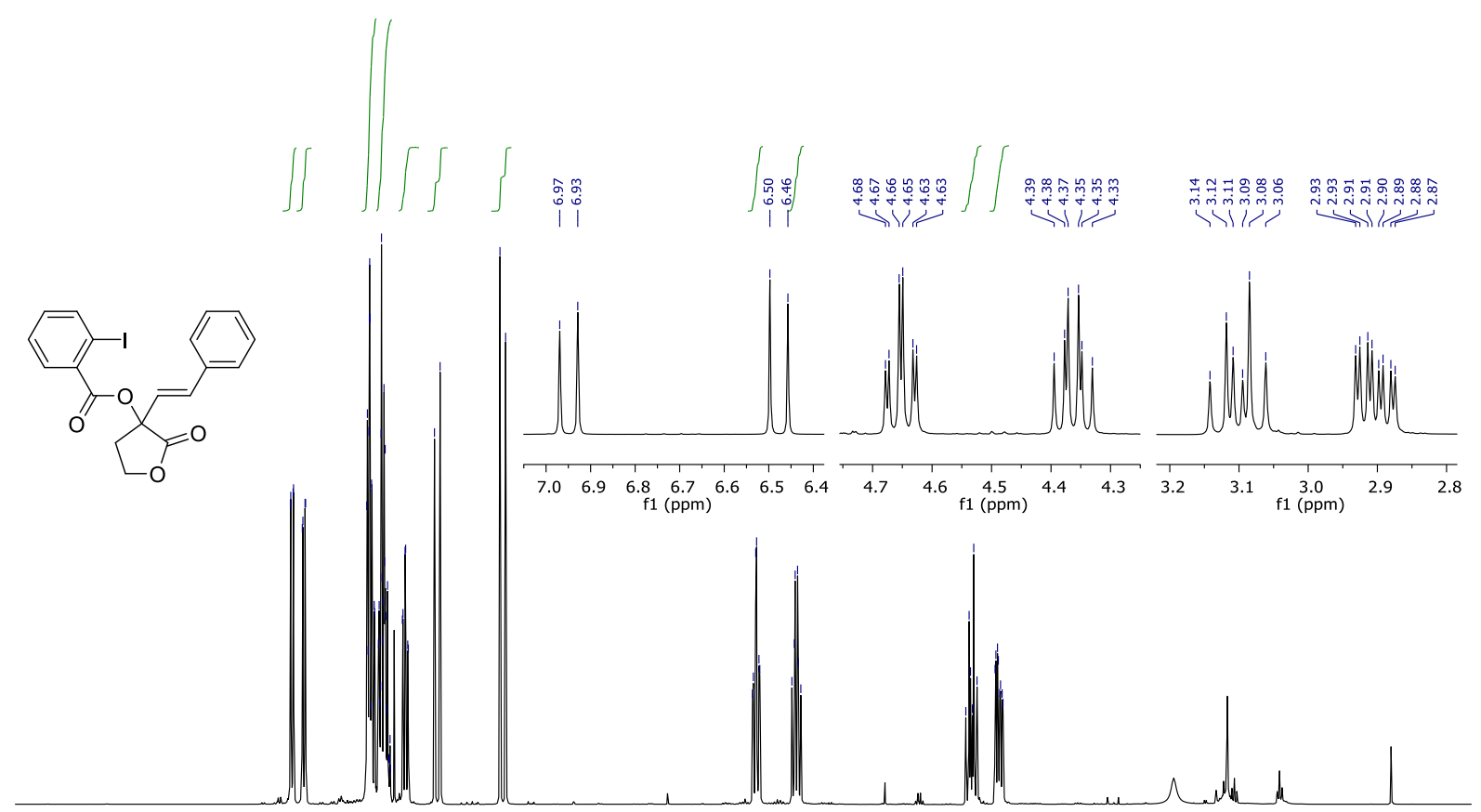

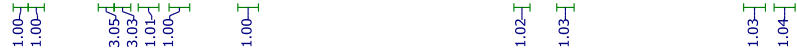

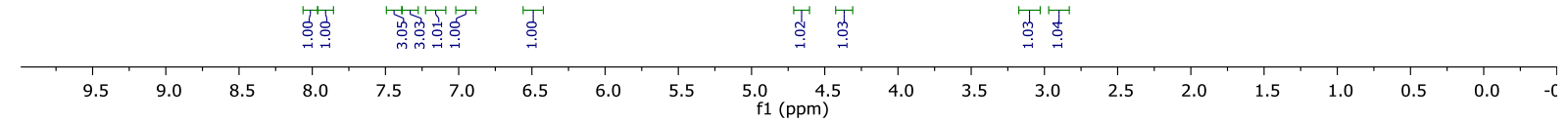

${ }^{13}$ C-NMR $\left(101 \mathrm{MHz}, \mathrm{CDCl}_{3}\right)$ of compound 50

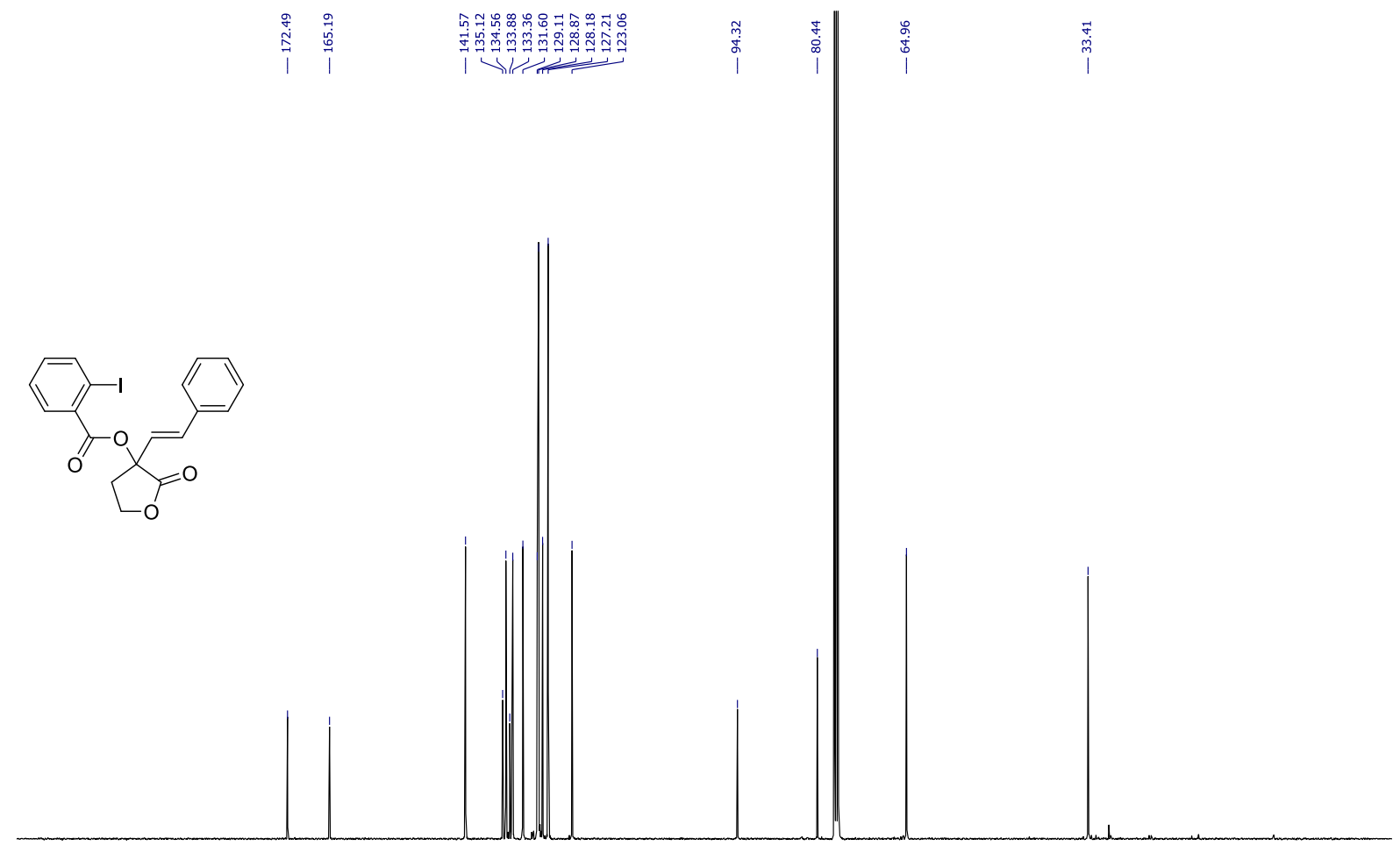

$\begin{array}{lllllllllllllllllllllll}210 & 200 & 190 & 180 & 170 & 160 & 150 & 140 & 130 & 120 & 110 & 100 & 90 & 80 & 70 & 60 & 50 & 40 & 30 & 20 & 10 & 0 & -10\end{array}$ 
${ }^{1} \mathbf{H}-\mathrm{NMR}\left(400 \mathrm{MHz}, \mathrm{CDCl}_{3}\right.$ ) of compound $\mathbf{5 p}$

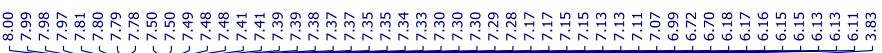

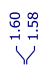

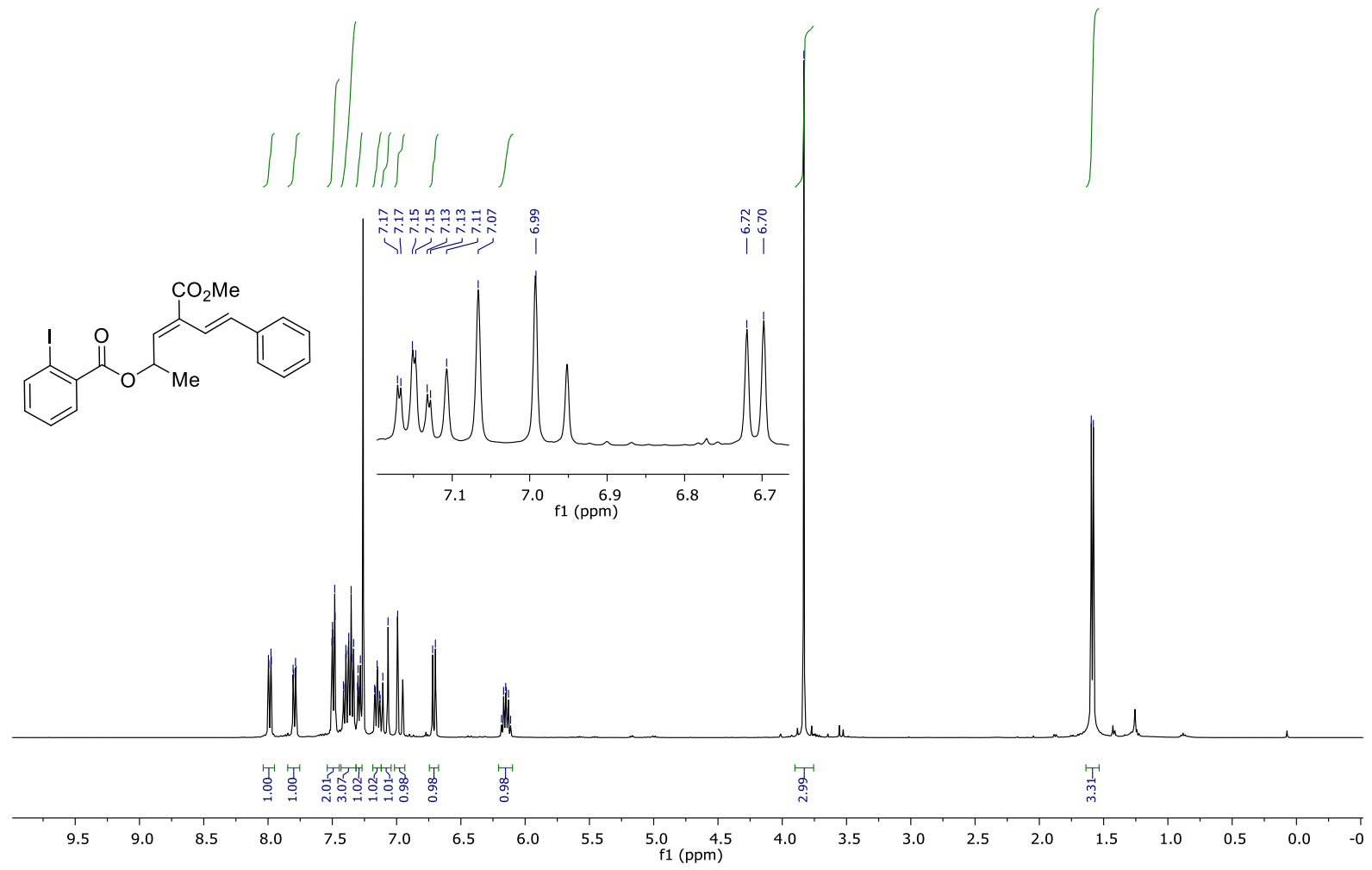

${ }^{13}$ C-NMR (101 MHz, $\mathrm{CDCl}_{3}$ ) of compound 5p

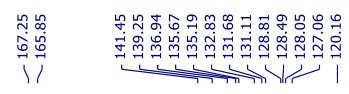
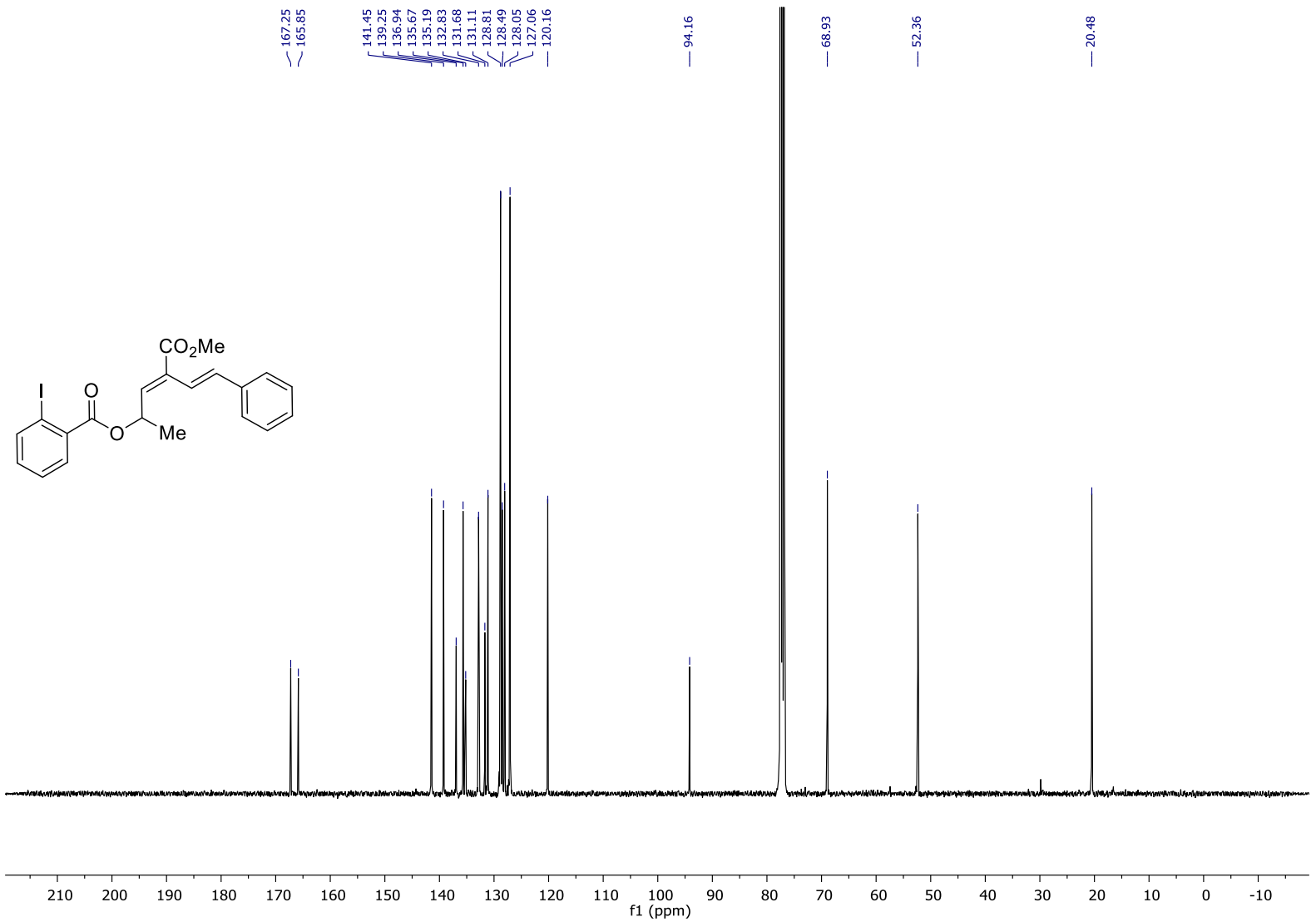

S143 
${ }^{1} \mathbf{H}-\mathbf{N M R}\left(400 \mathrm{MHz}, \mathrm{CDCl}_{3}\right.$ ) of compound $\mathbf{6 b}$

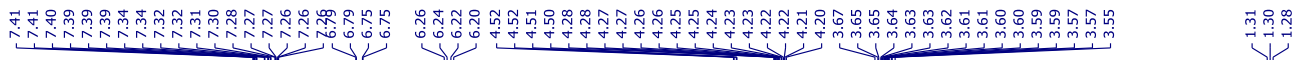

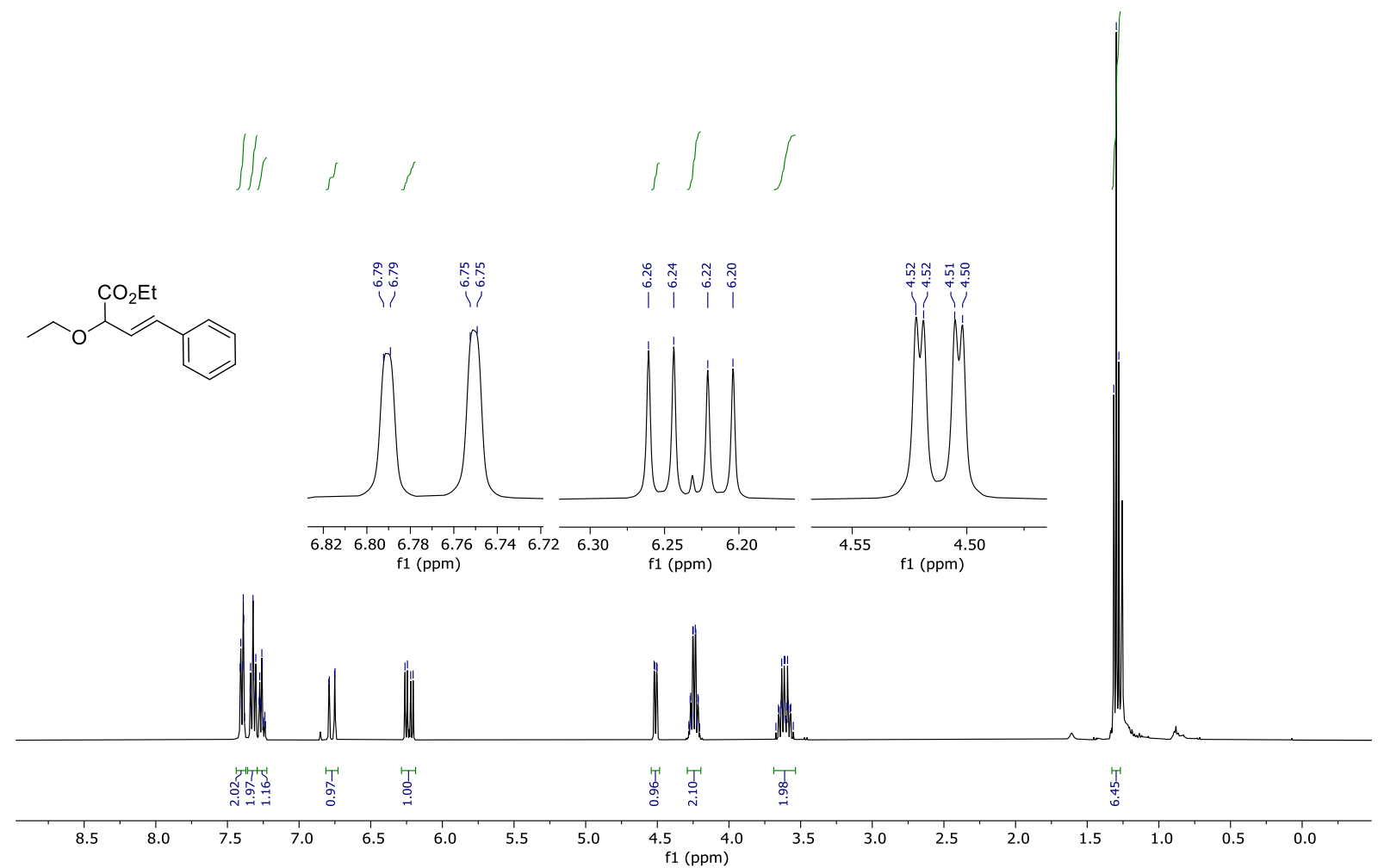

${ }^{13} \mathrm{C}$-NMR (101 MHz, $\mathrm{CDCl}_{3}$ ) of compound $\mathbf{6 b}$

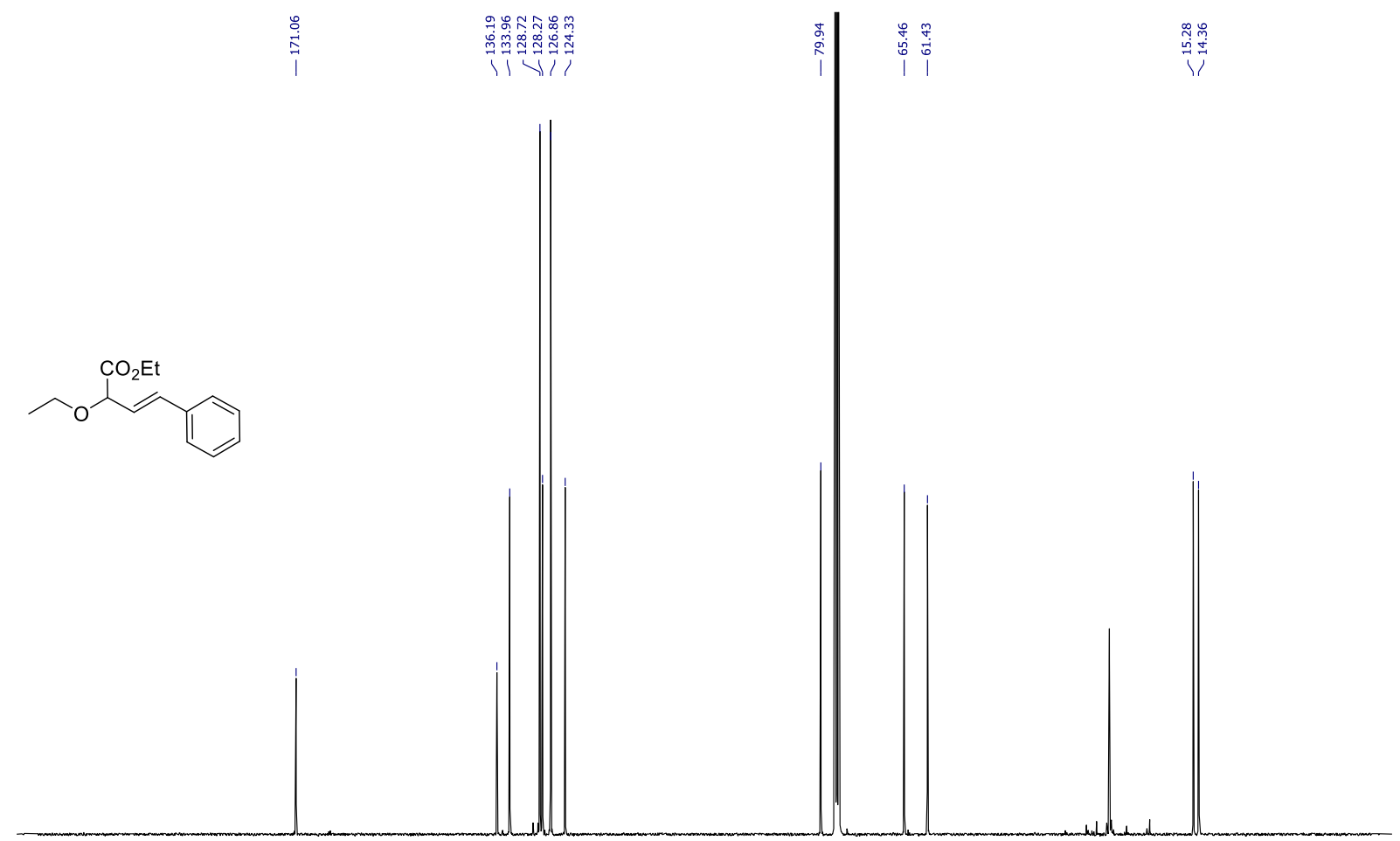

$\begin{array}{lllllllllllllllllllllllll}210 & 200 & 190 & 180 & 170 & 160 & 150 & 140 & 130 & 120 & 110 & 100 & 90 & 80 & 70 & 60 & 50 & 40 & 30 & 20 & 10 & 0 & -10 & \end{array}$ 
${ }^{1} \mathbf{H}-\mathrm{NMR}\left(400 \mathrm{MHz}, \mathrm{CDCl}_{3}\right.$ ) of compound $6 \mathbf{c}$

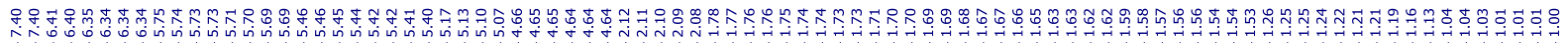

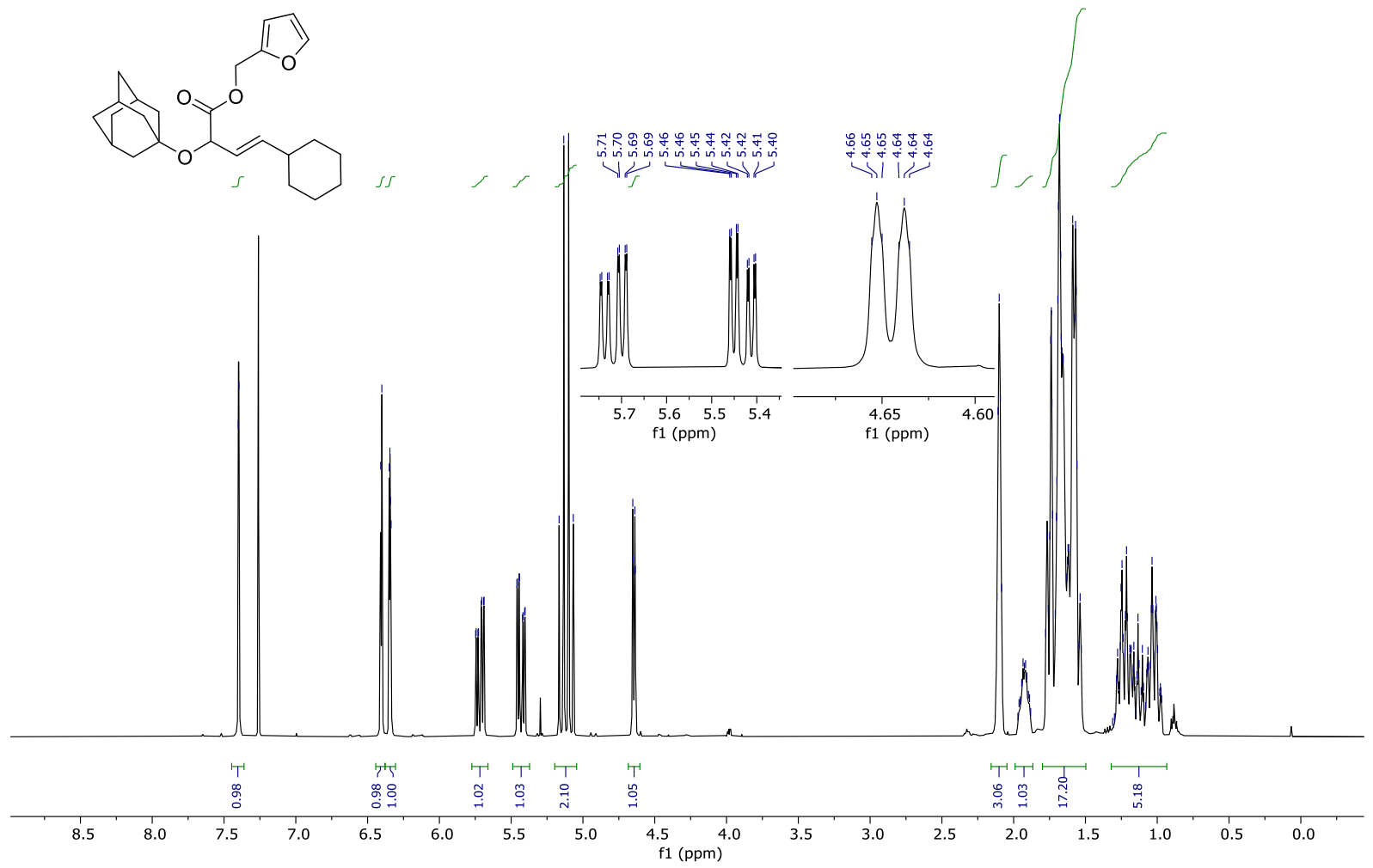

${ }^{13} \mathrm{C}-\mathrm{NMR}\left(101 \mathrm{MHz}, \mathrm{CDCl}_{3}\right)$ of compound $6 \mathrm{c}$

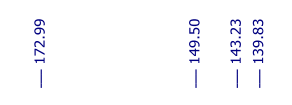

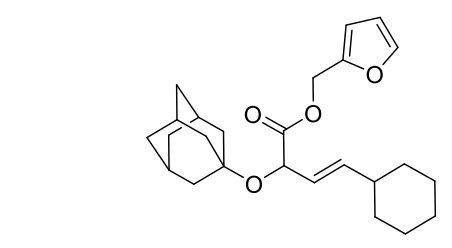
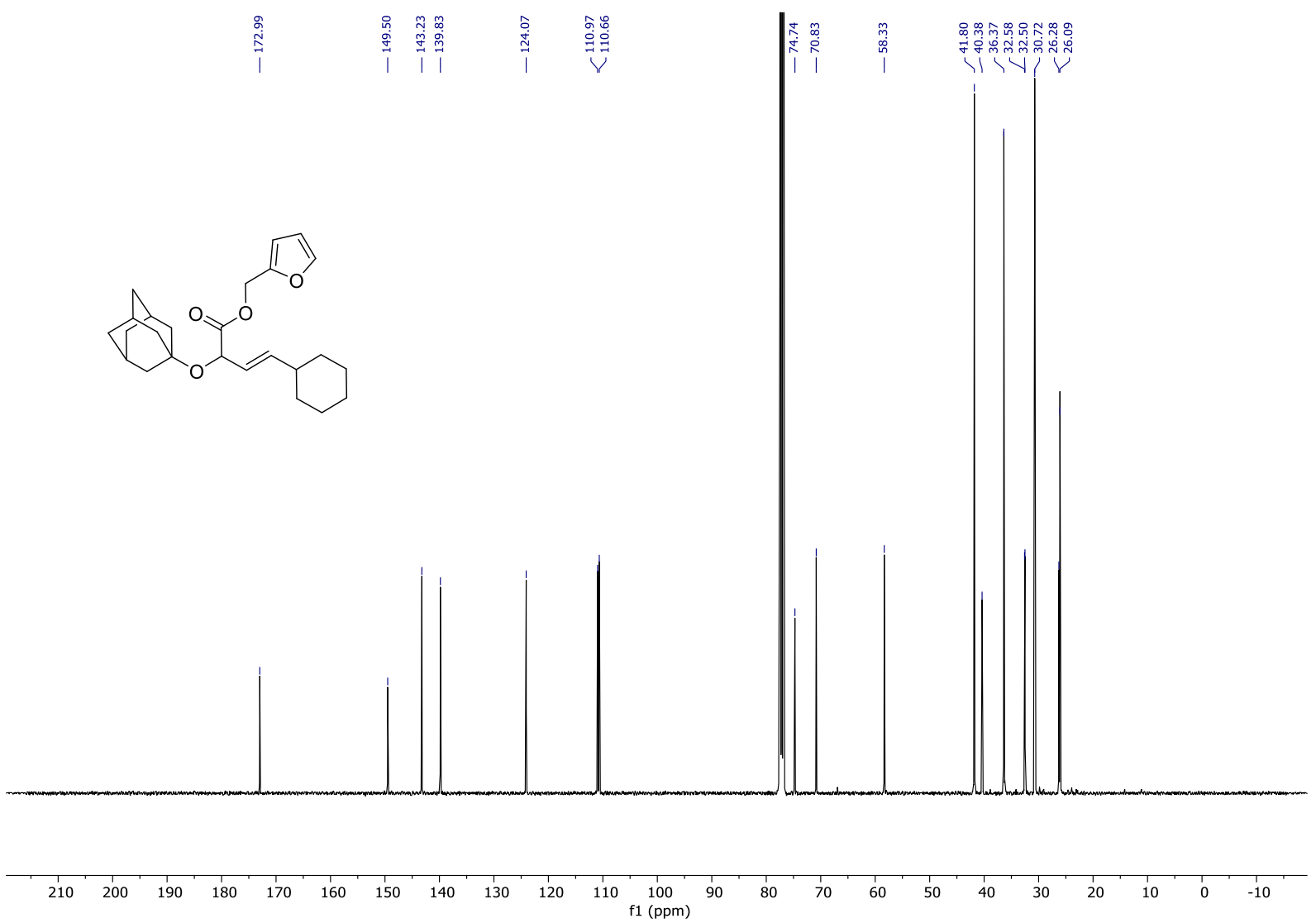

S145 
${ }^{1} \mathrm{H}-\mathrm{NMR}\left(400 \mathrm{MHz}, \mathrm{CDCl}_{3}\right.$ ) of compound $\mathbf{6 d}$

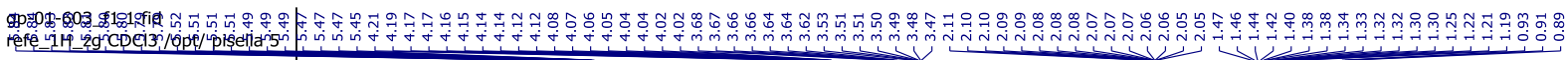

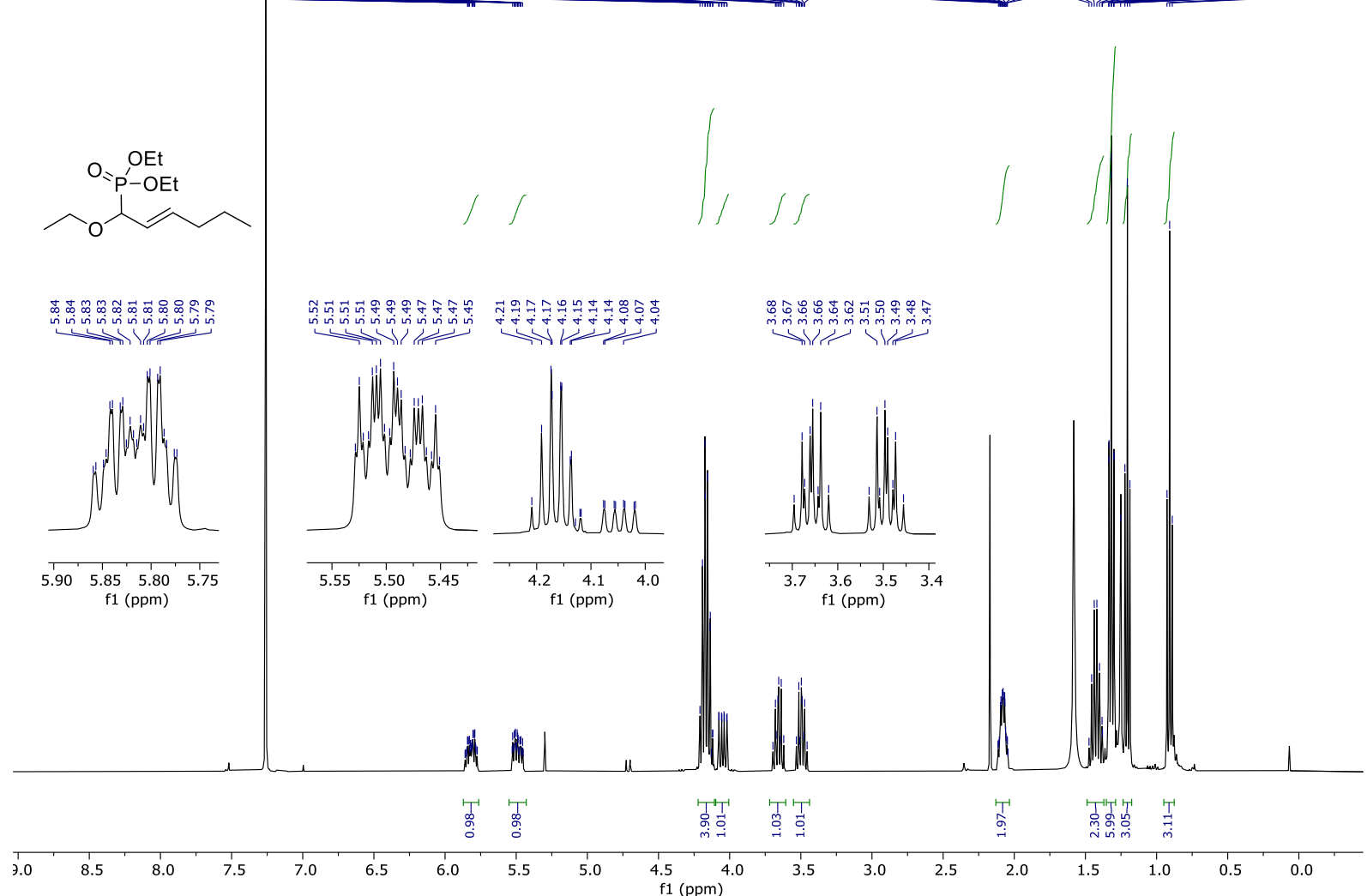

${ }^{13}$ C-NMR (101 MHz, $\mathrm{CDCl}_{3}$ ) of compound $\mathbf{6 d}$

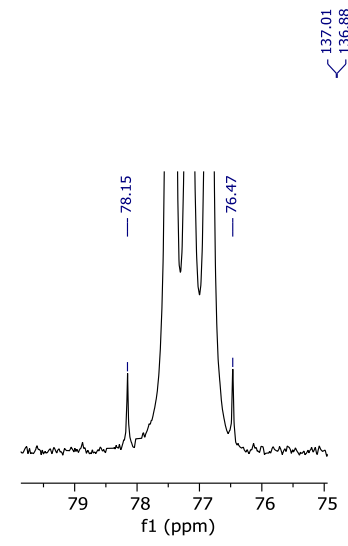

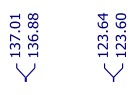

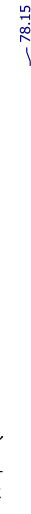

$\mid$

苜

O $\begin{gathered}\text { OEt } \\ \text { 'P-OEt }\end{gathered}$

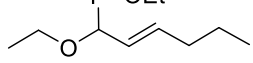
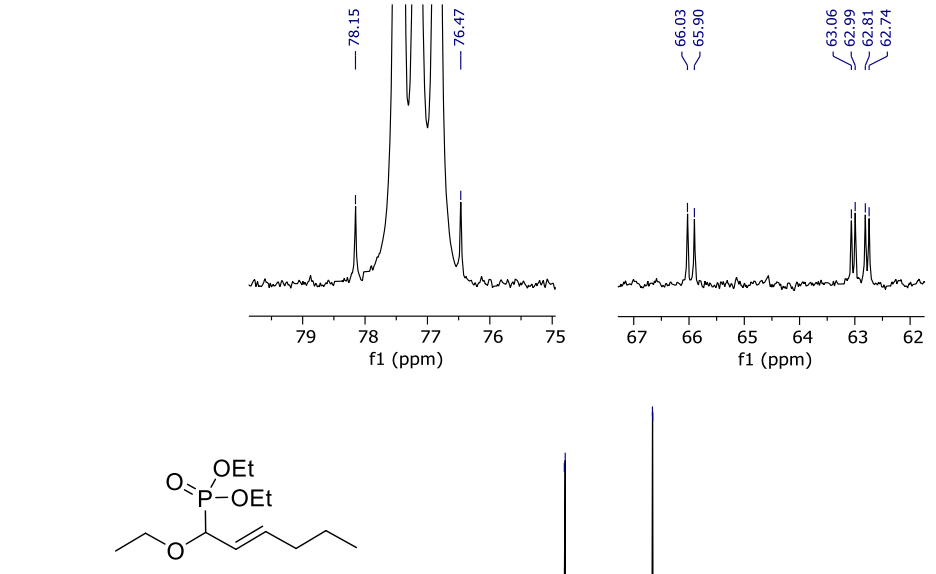

(1)

1

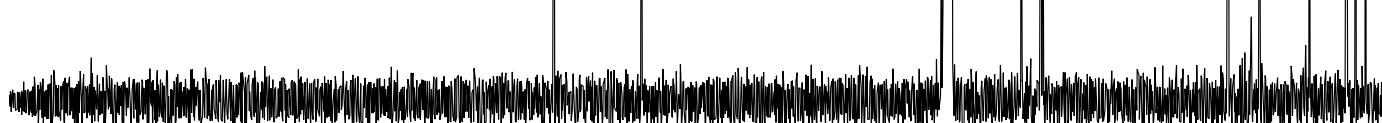

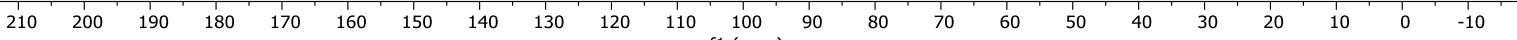


${ }^{31}$ P-NMR (162 MHz, $\mathrm{CDCl}_{3}$ ) of compound $\mathbf{6 d}$

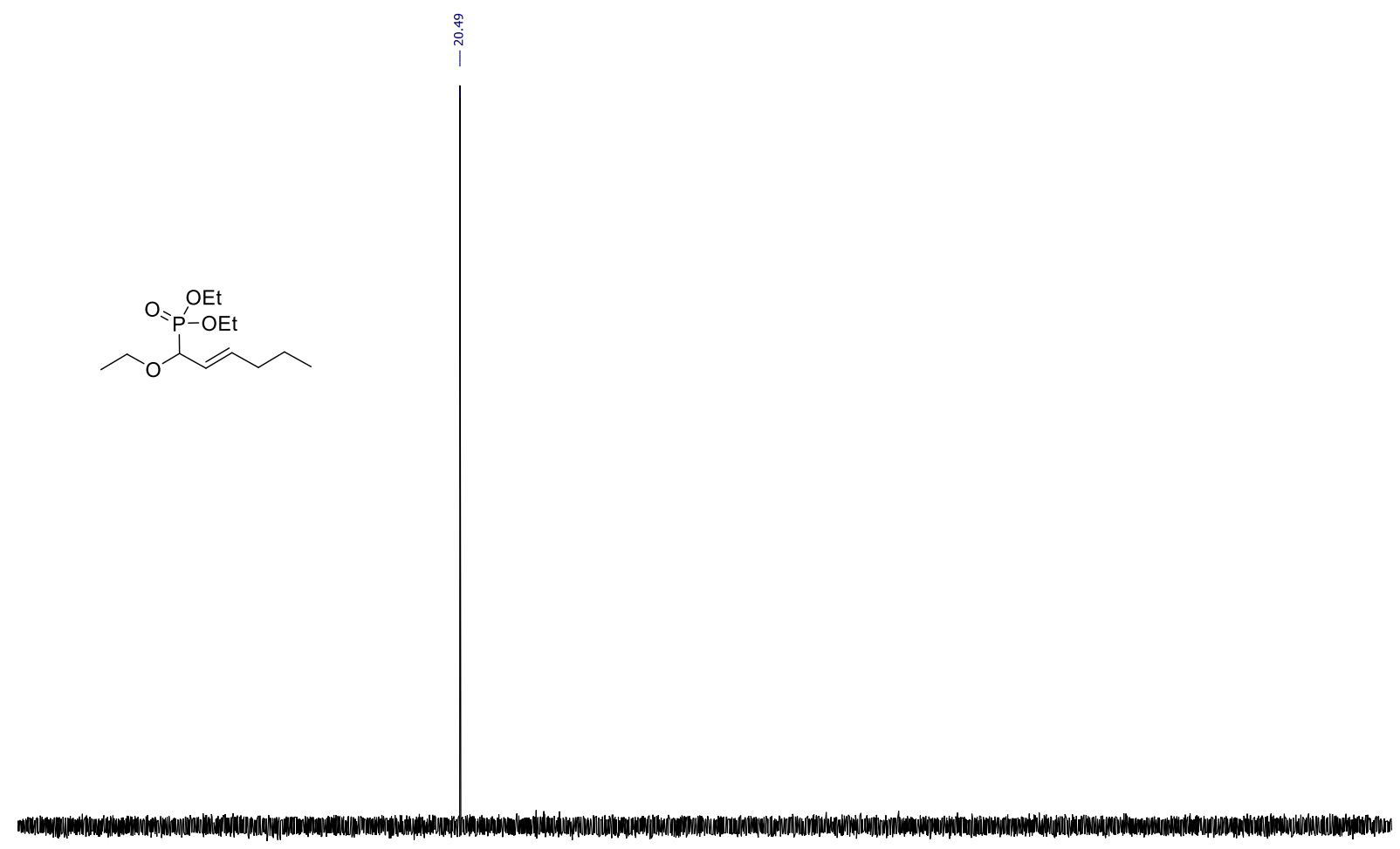

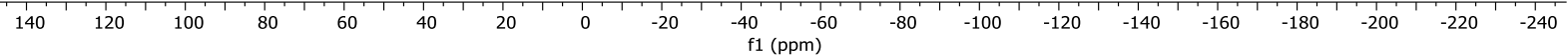


${ }^{1} \mathrm{H}-\mathrm{NMR}\left(400 \mathrm{MHz}, \mathrm{CDCl}_{3}\right)$ of compound $6 \mathrm{e}$

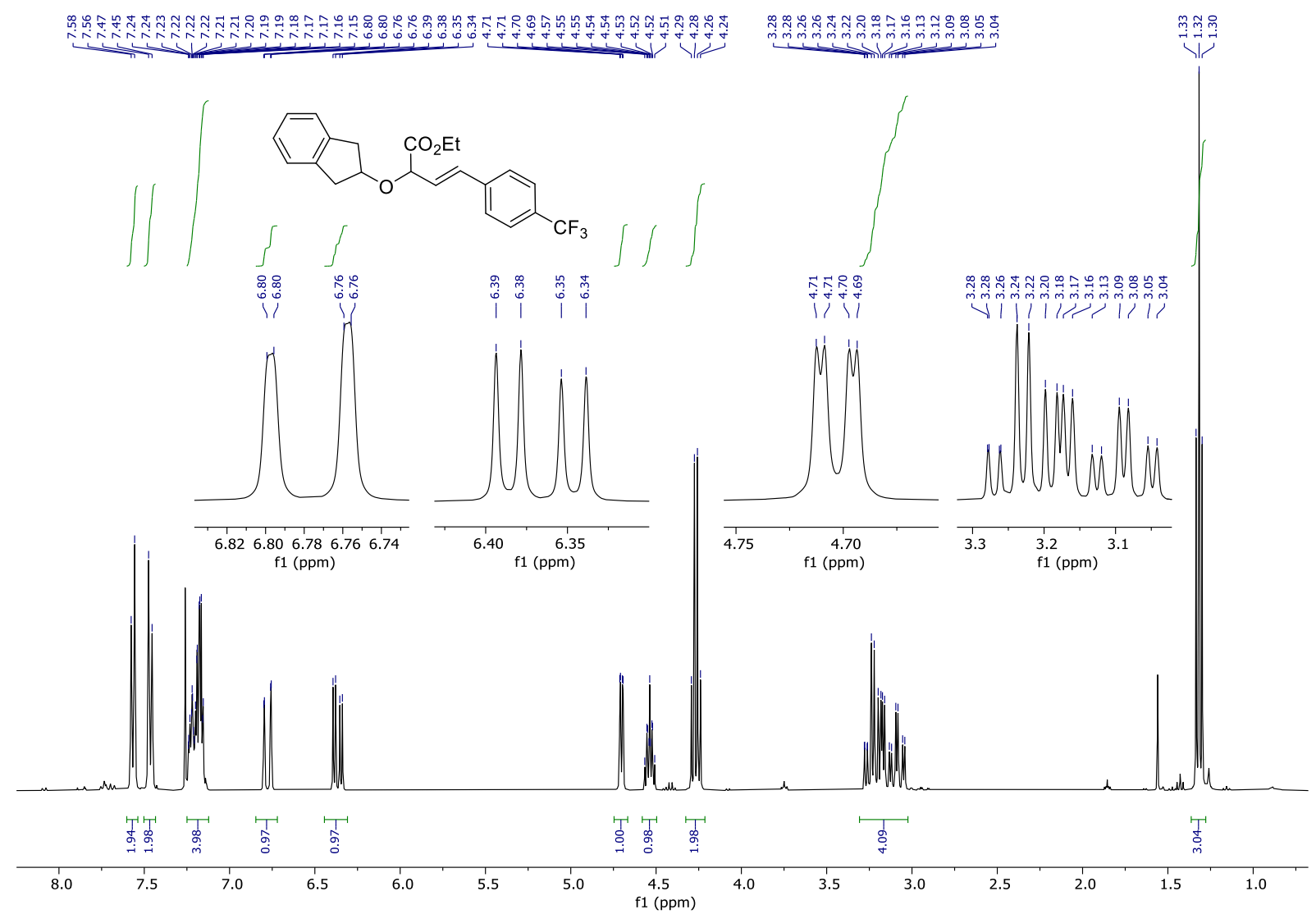

${ }^{13} \mathrm{C}-\mathrm{NMR}\left(101 \mathrm{MHz}, \mathrm{CDCl}_{3}\right.$ ) of compound $6 \mathbf{e}$
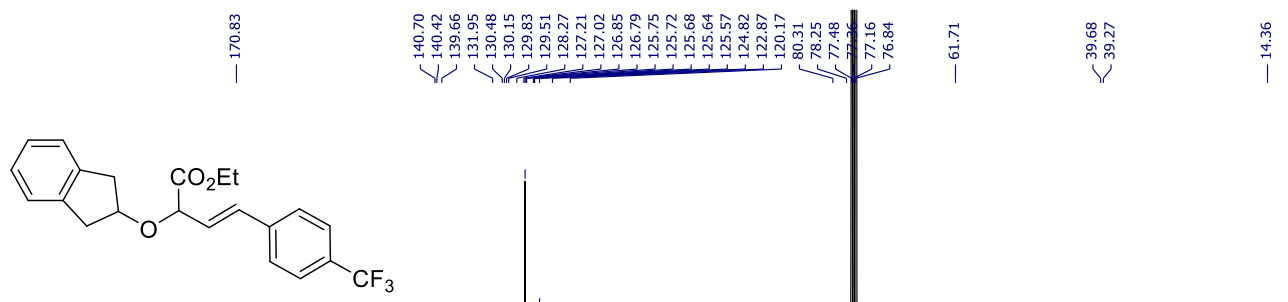

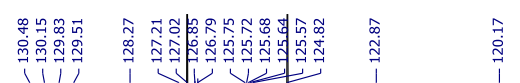

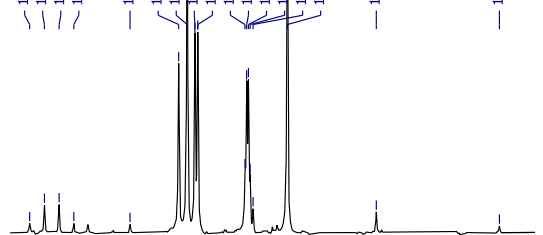

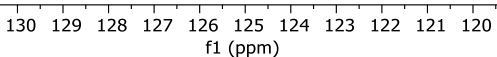
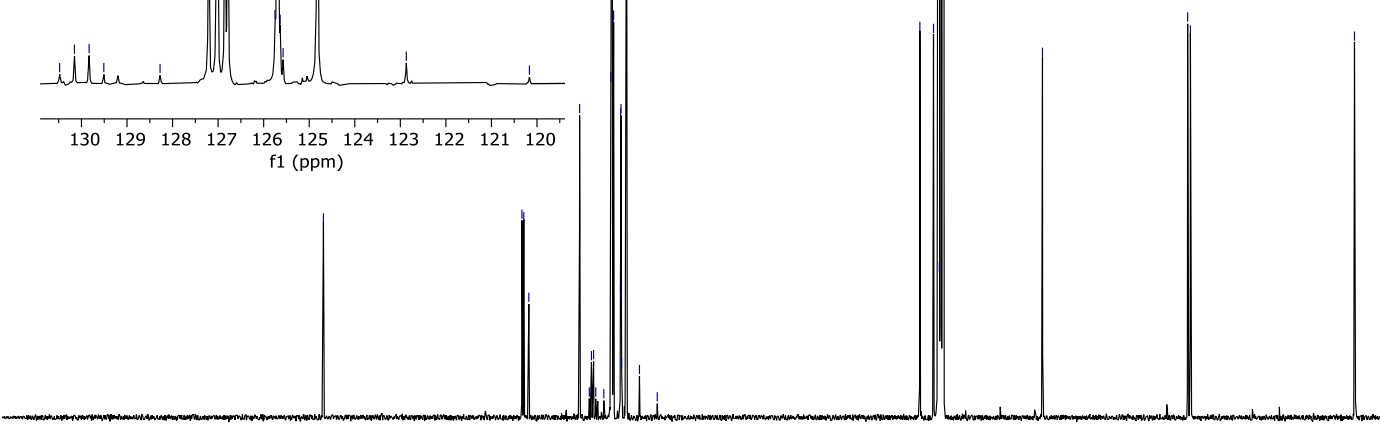

$\begin{array}{llllllllllll}210 & 200 & 190 & 180 & 170 & 160 & 150 & 140 & 130 & 120 & 110 & 100\end{array}$ 
${ }^{19}$ F-NMR (376 MHz, $\mathrm{CDCl}_{3}$ ) of compound $6 \mathrm{e}$

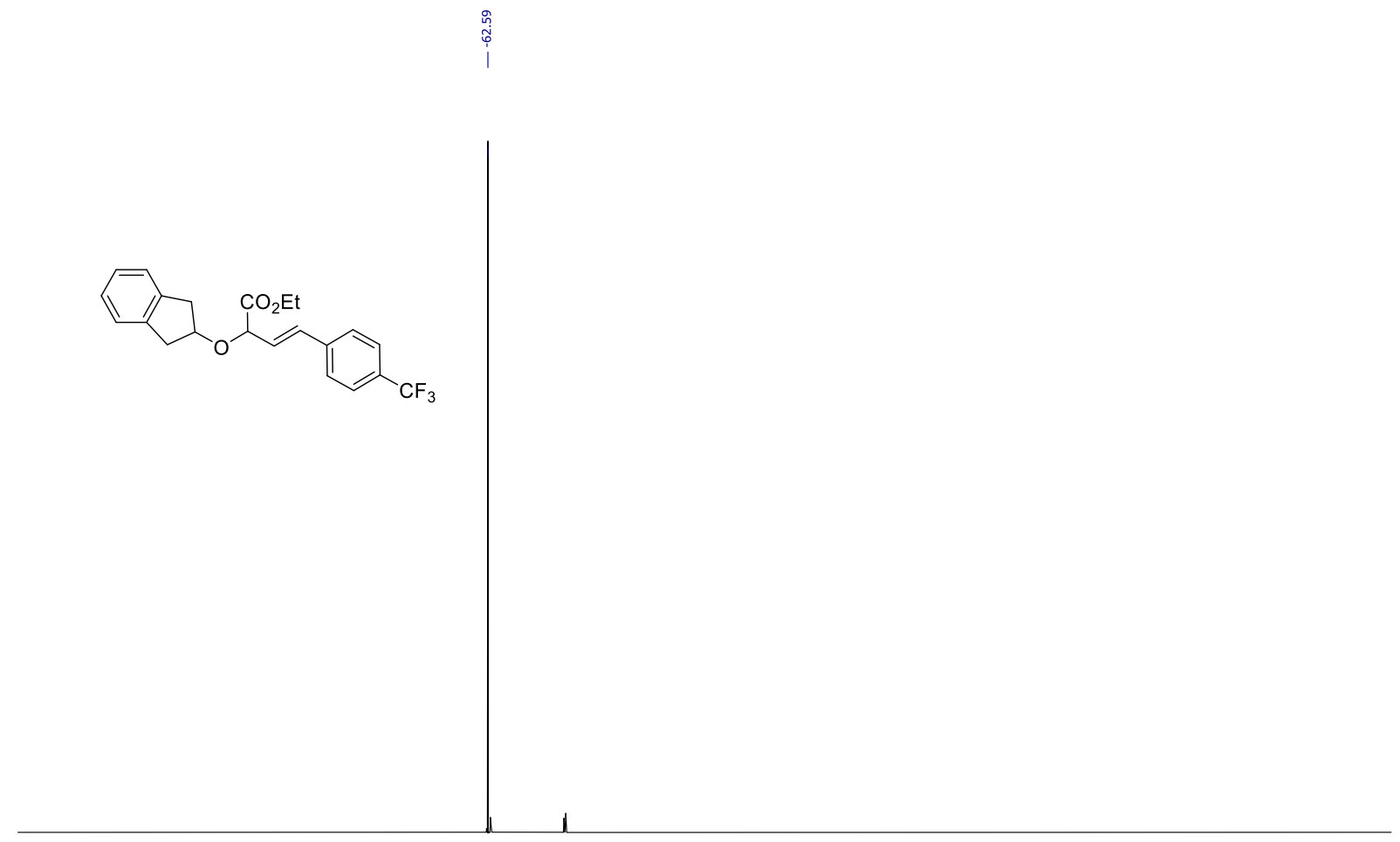

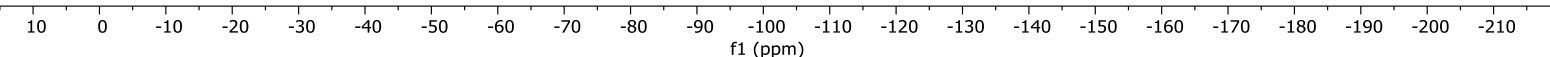


${ }^{1} \mathbf{H}-\mathrm{NMR}\left(400 \mathrm{MHz}, \mathrm{CDCl}_{3}\right)$ of compound $\mathbf{6 f}$

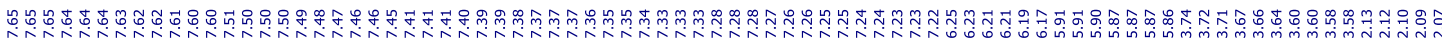

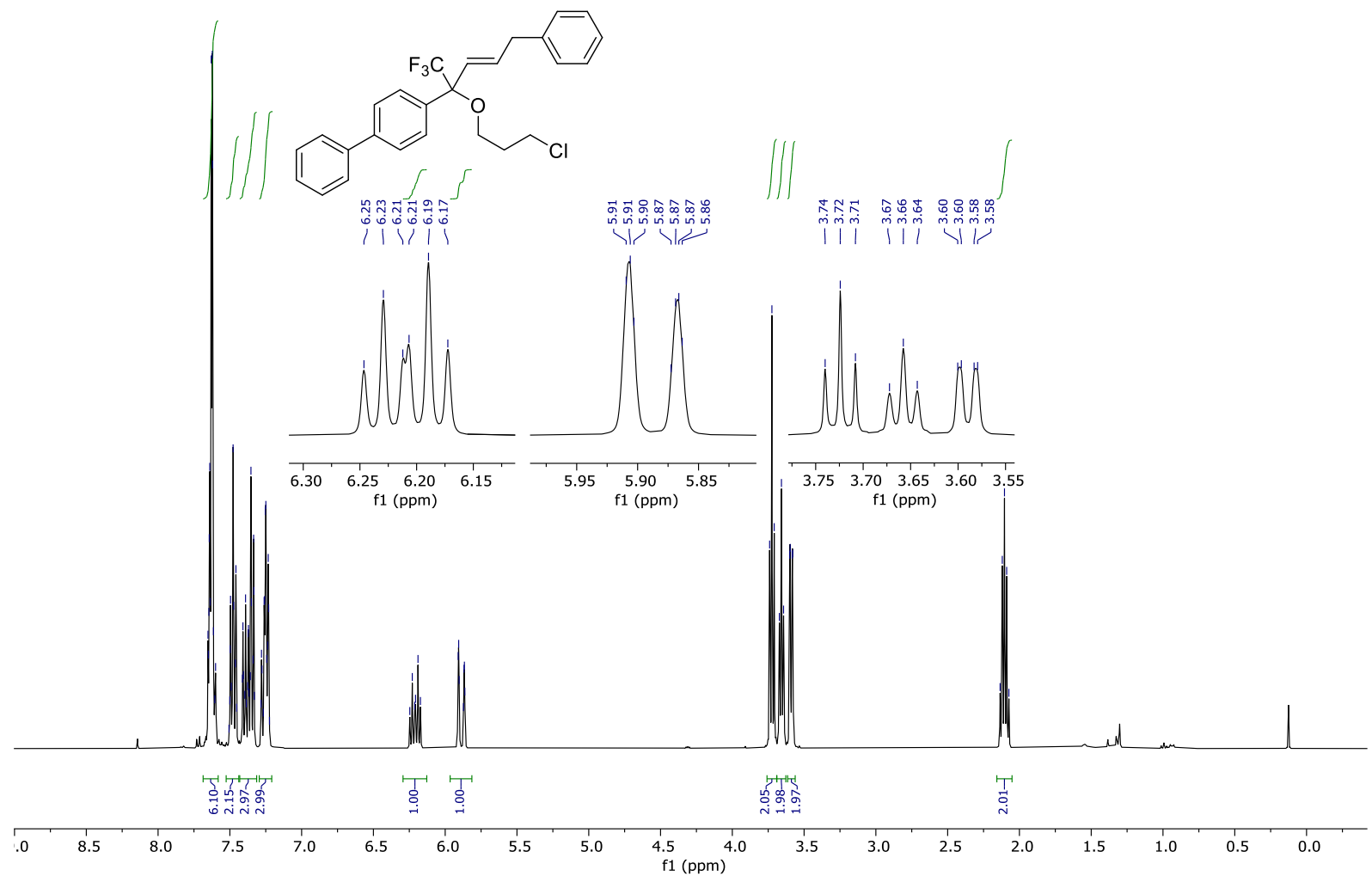

${ }^{13} \mathrm{C}-\mathrm{NMR}\left(101 \mathrm{MHz}, \mathrm{CDCl}_{3}\right)$ of compound $6 \mathrm{f}$

\begin{tabular}{|c|c|c|}
\hline 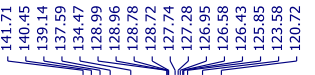 & 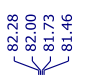 & $\begin{array}{l}\underset{1}{\pi} \\
\vdots \\
1 \\
1\end{array}$ \\
\hline
\end{tabular}
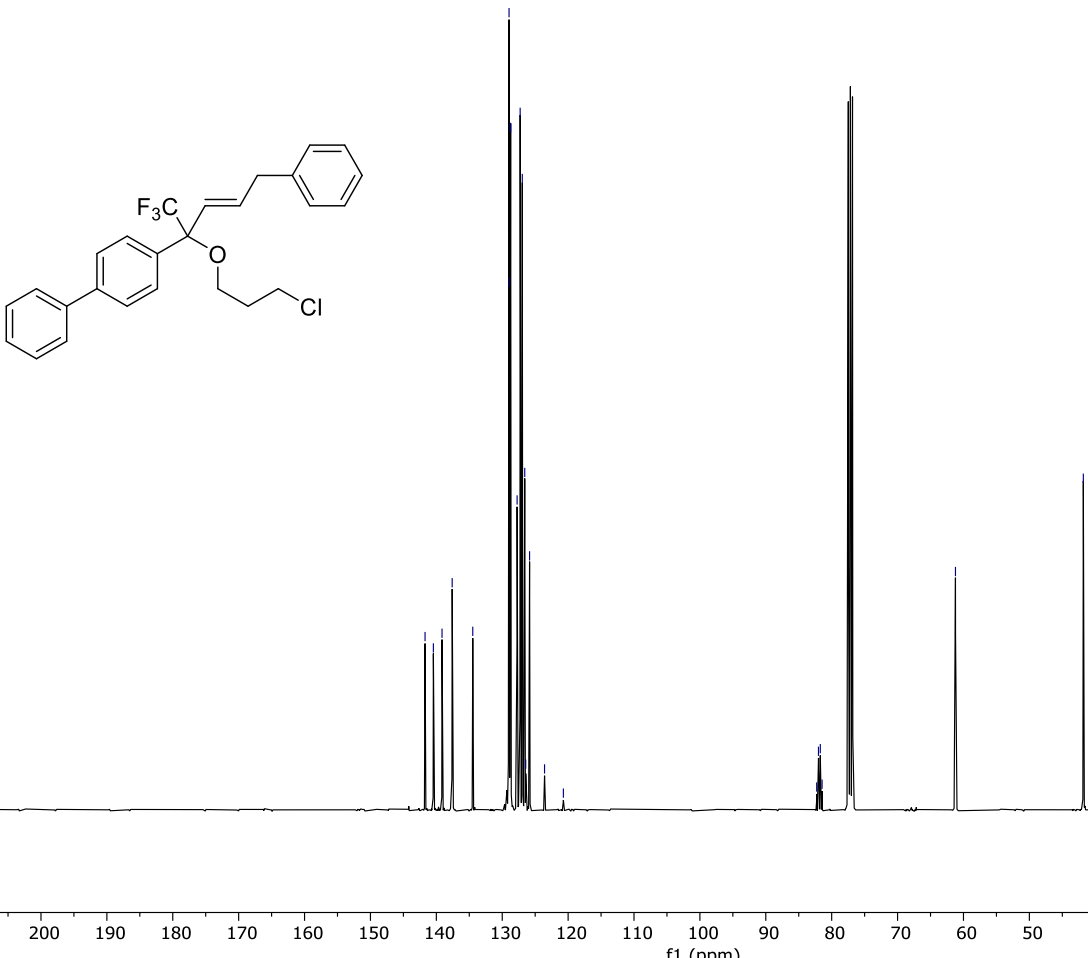

$1(\mathrm{ppm})$ 
${ }^{19}$ F-NMR (376 MHz, $\mathrm{CDCl}_{3}$ ) of compound $6 \mathbf{f}$

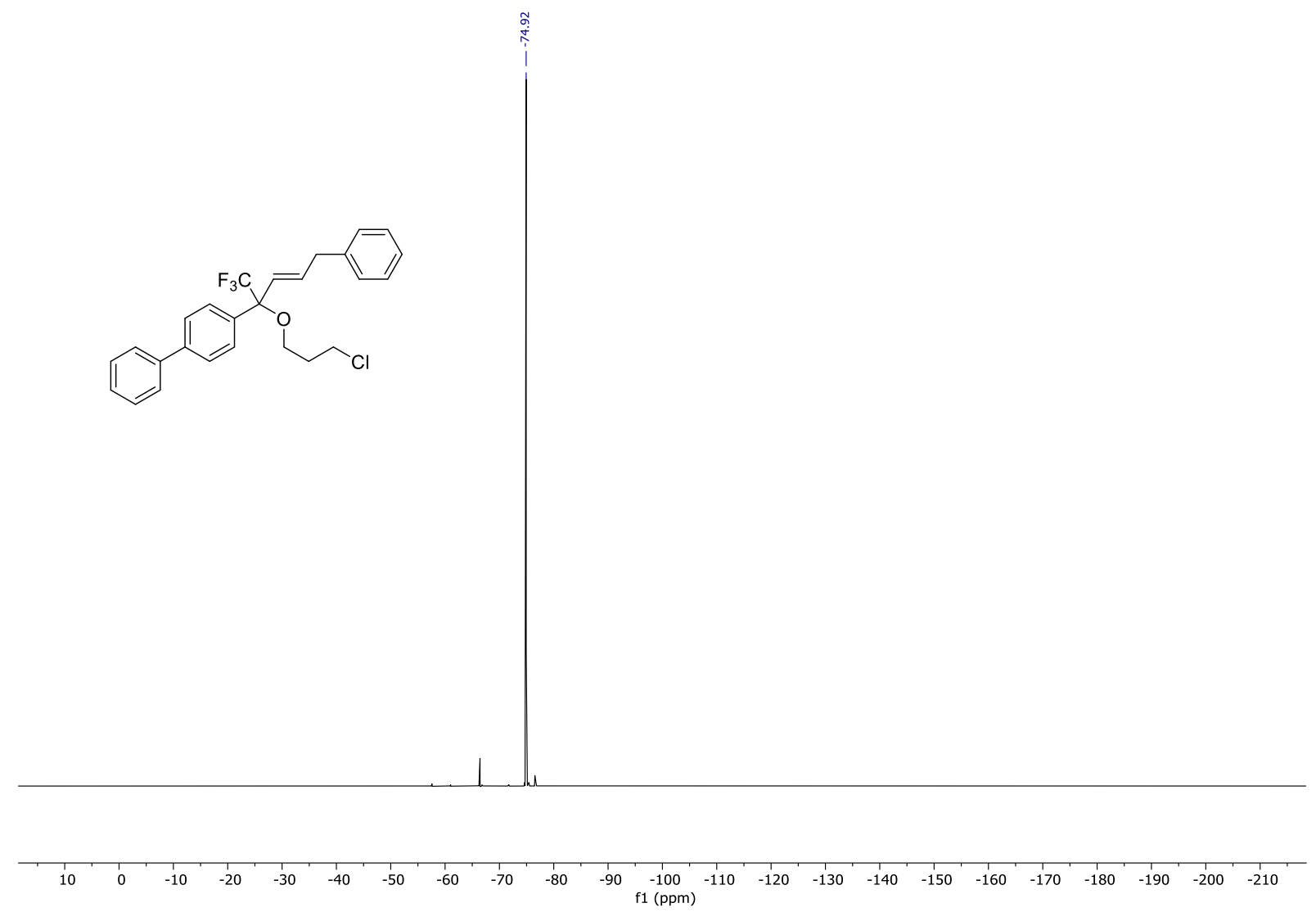


${ }^{1} \mathbf{H}-\mathrm{NMR}\left(400 \mathrm{MHz}, \mathrm{CDCl}_{3}\right.$ ) of compound $\mathbf{6 g}$

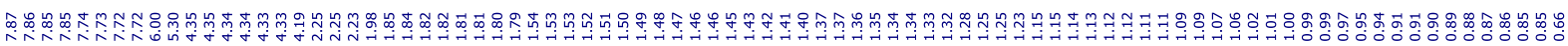

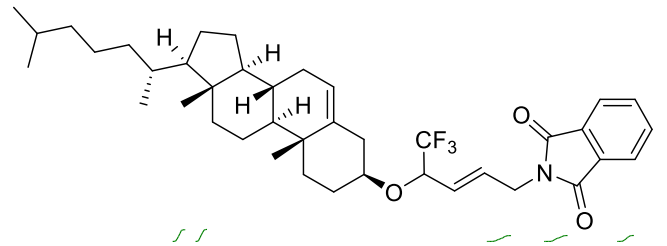

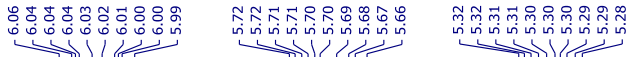

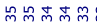

ilit

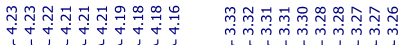
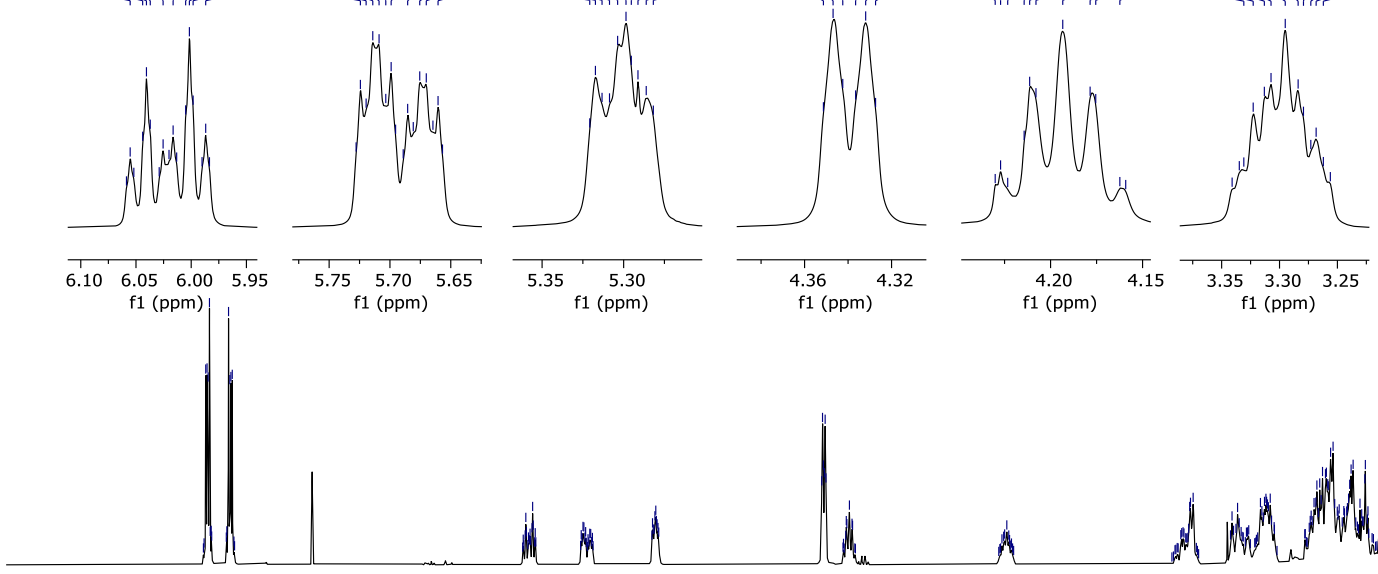$$
\text { f1 (ppm) }
$$
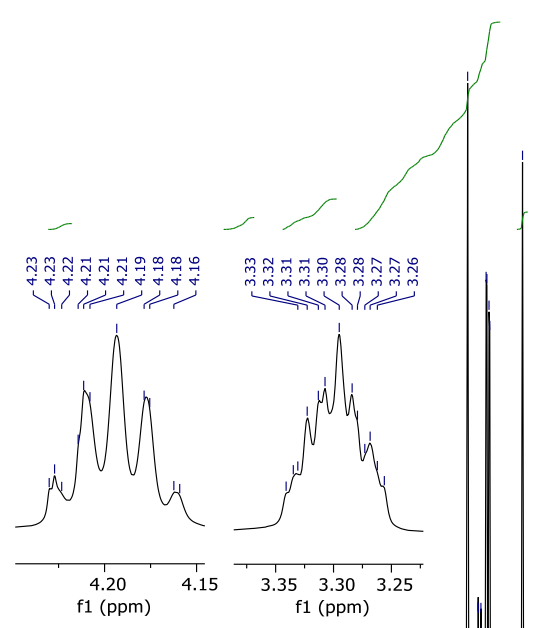

$$
\text { f1 (ppm) }
$$$$
\text { f1 (ppm) }
$$

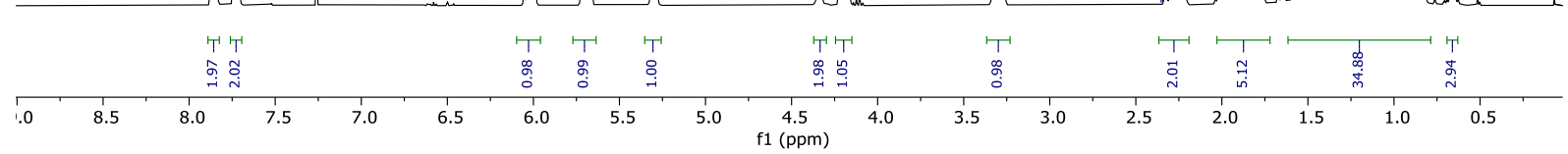

${ }^{13} \mathrm{C}-\mathrm{NMR}\left(101 \mathrm{MHz}, \mathrm{CDCl}_{3}\right)$ of compound $6 \mathrm{~g}$

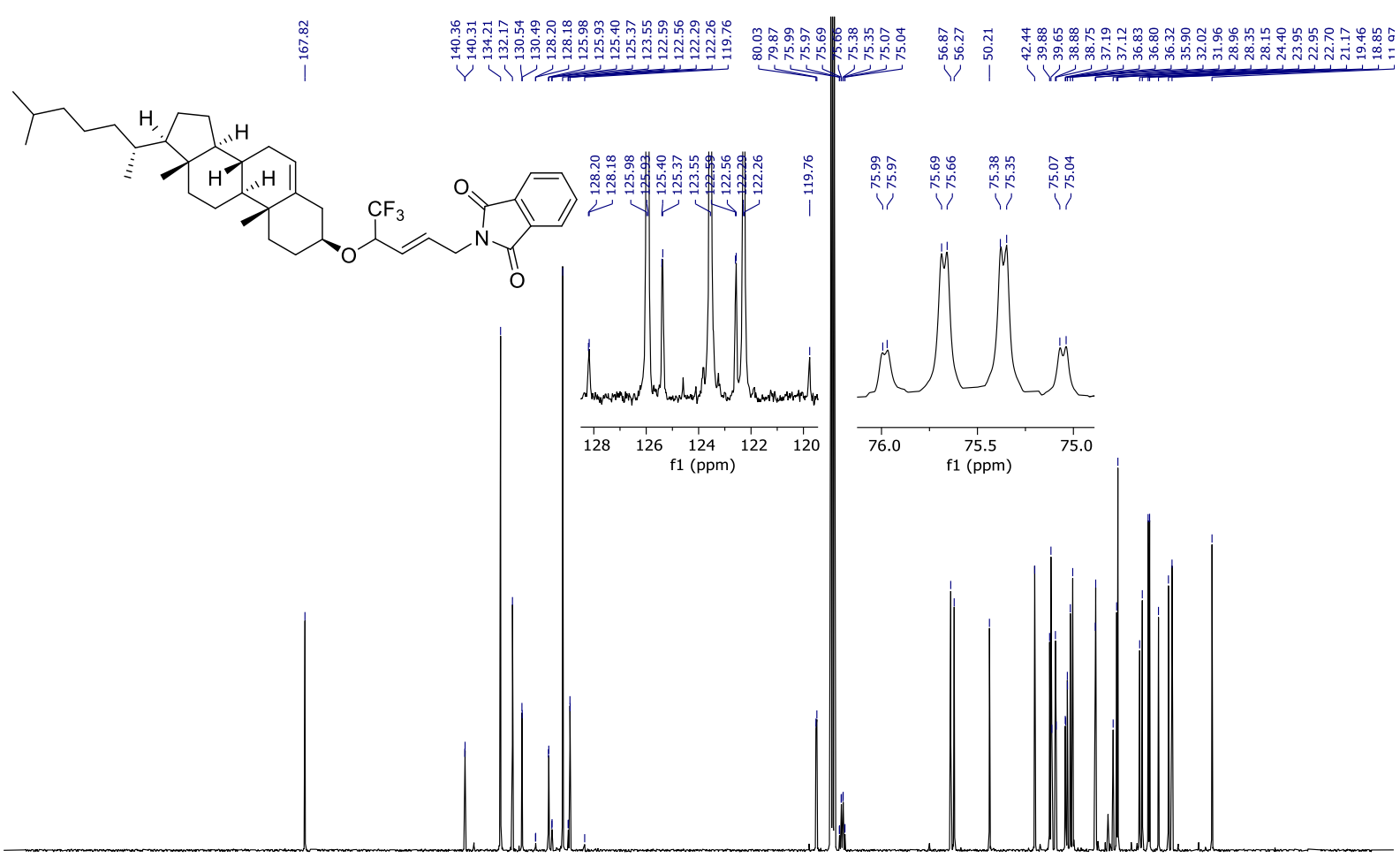

$\begin{array}{lllllllllllllllllllllllllllllllllll}210 & 200 & 190 & 180 & 170 & 160 & 150 & 140 & 130 & 120 & 110 & 100 & 90 & 80 & 70 & 60 & 50 & 40 & 30 & 20 & 10 & 0 & -10 & 10\end{array}$ 
${ }^{19}$ F-NMR (376 MHz, $\mathrm{CDCl}_{3}$ ) of compound $\mathbf{6 g}$

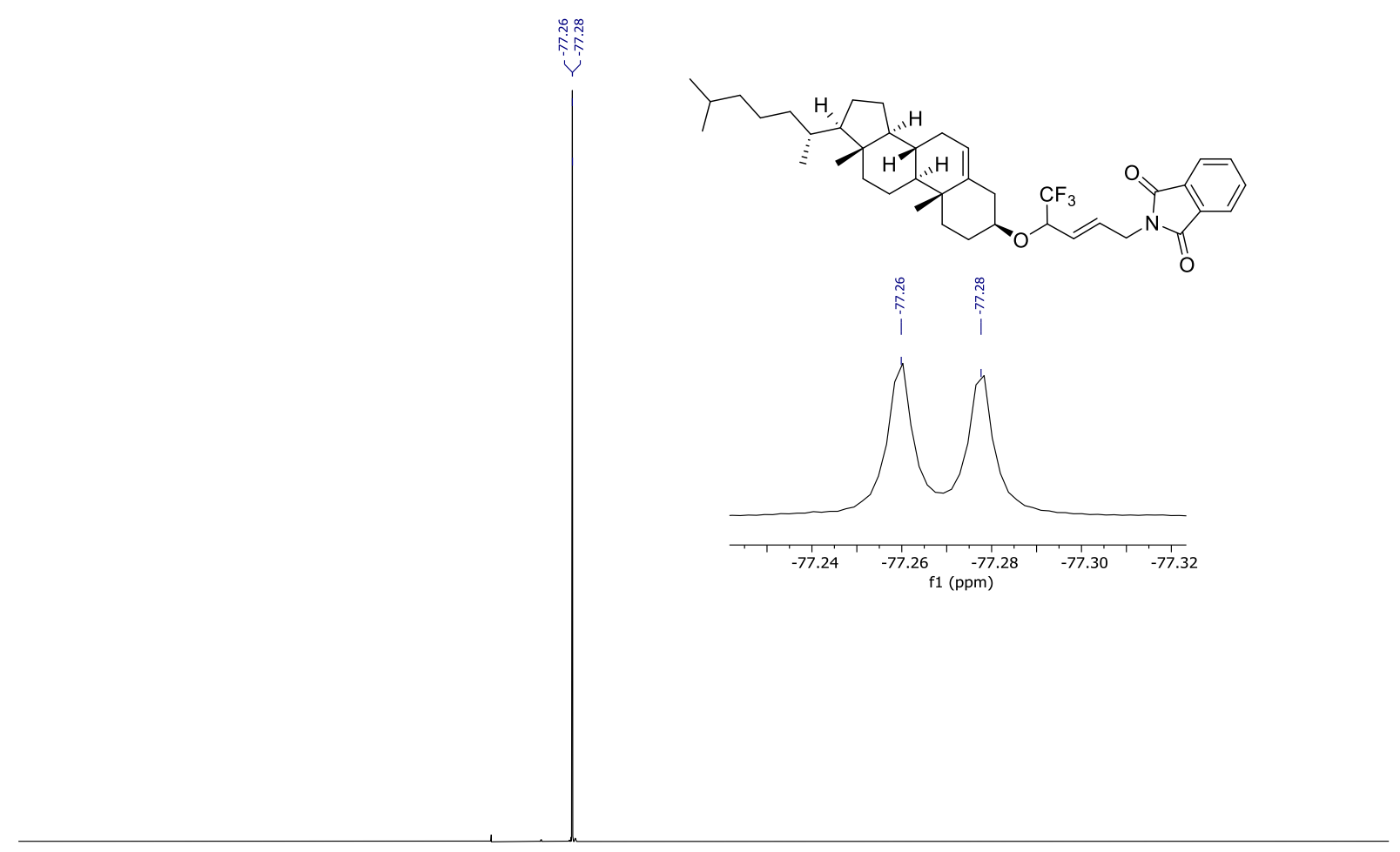

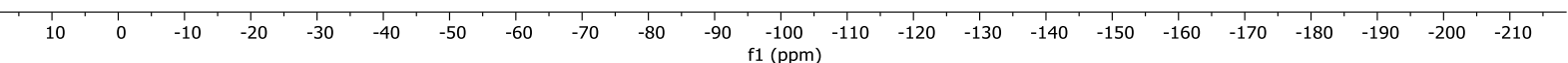


${ }^{1} \mathrm{H}-\mathrm{NMR}\left(400 \mathrm{MHz}, \mathrm{CDCl}_{3}\right.$ ) of compound 9

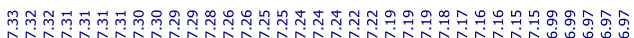

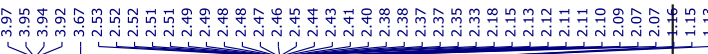
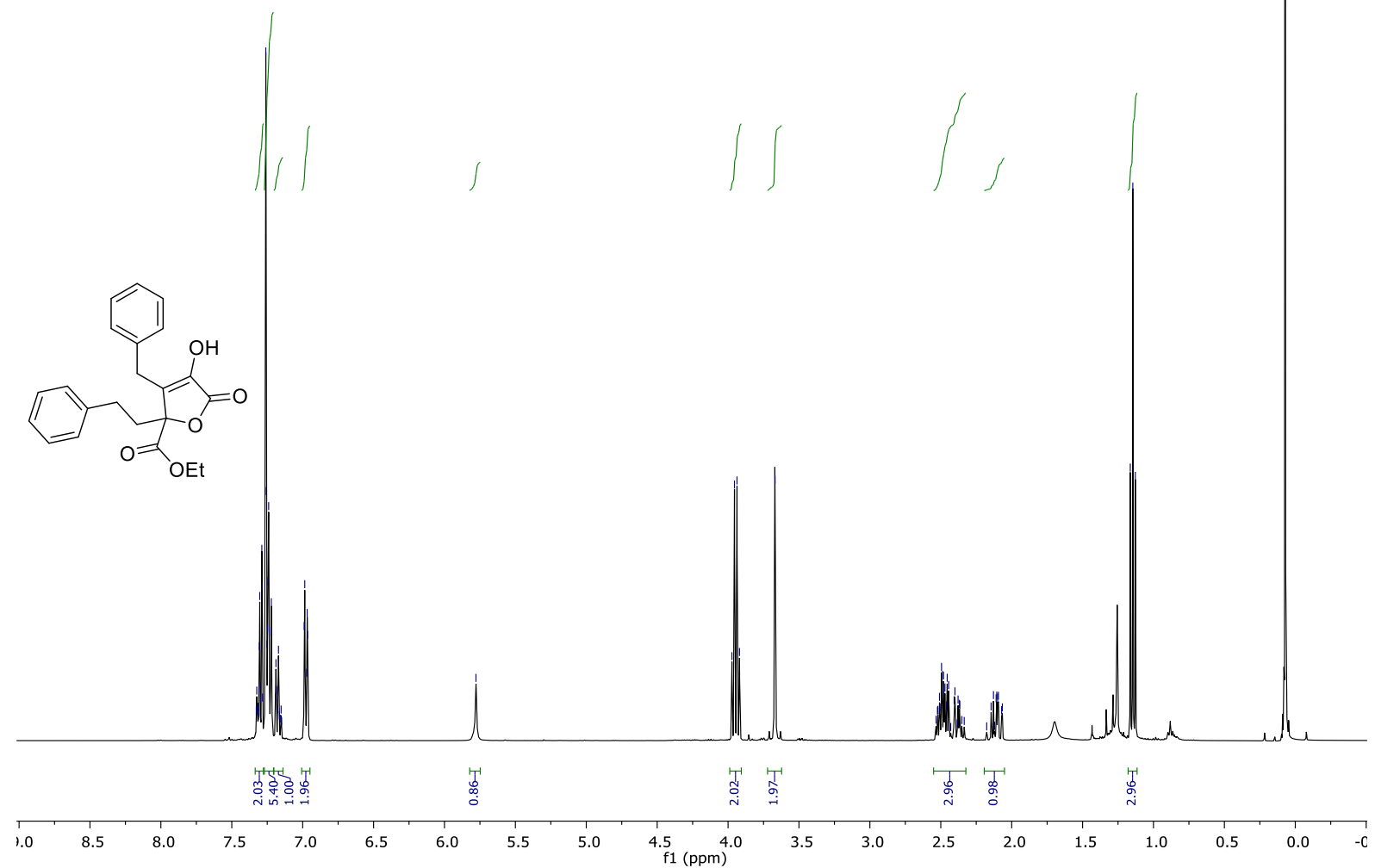

${ }^{13}$ C-NMR (101 MHz, $\mathrm{CDCl}_{3}$ ) of compound 9

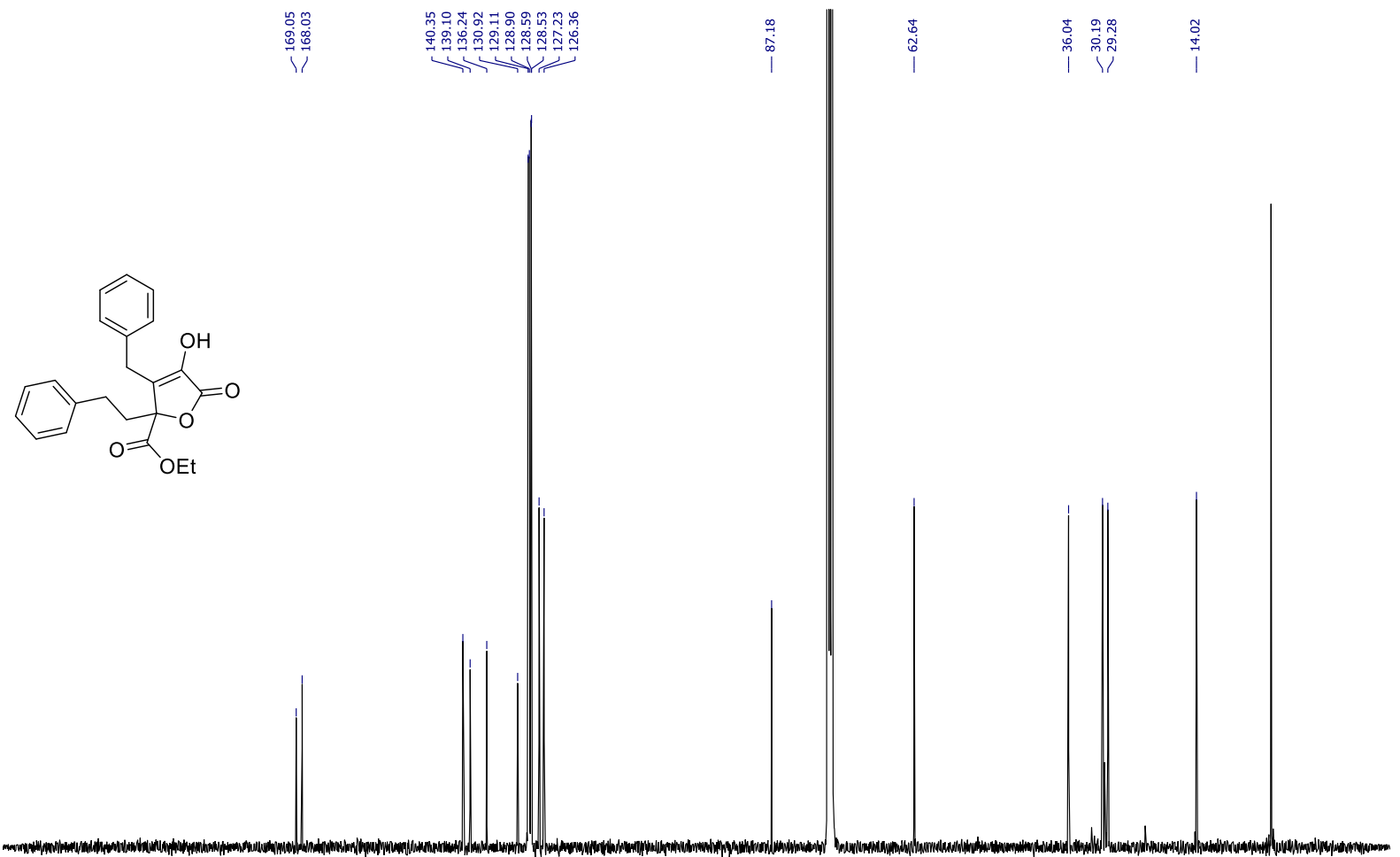

$\begin{array}{lllllllllllllllllllllll}210 & 200 & 190 & 180 & 170 & 160 & 150 & 140 & 130 & 120 & 110 & 100 & 90 & 80 & 70 & 60 & 50 & 40 & 30 & 20 & 10 & 0 & -10\end{array}$ 
${ }^{1} \mathbf{H}-\mathrm{NMR}\left(400 \mathrm{MHz}, \mathrm{CDCl}_{3}\right)$ of compound 10

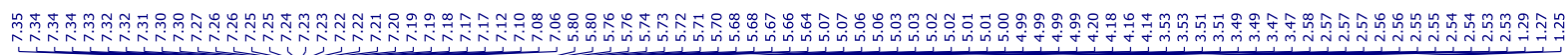

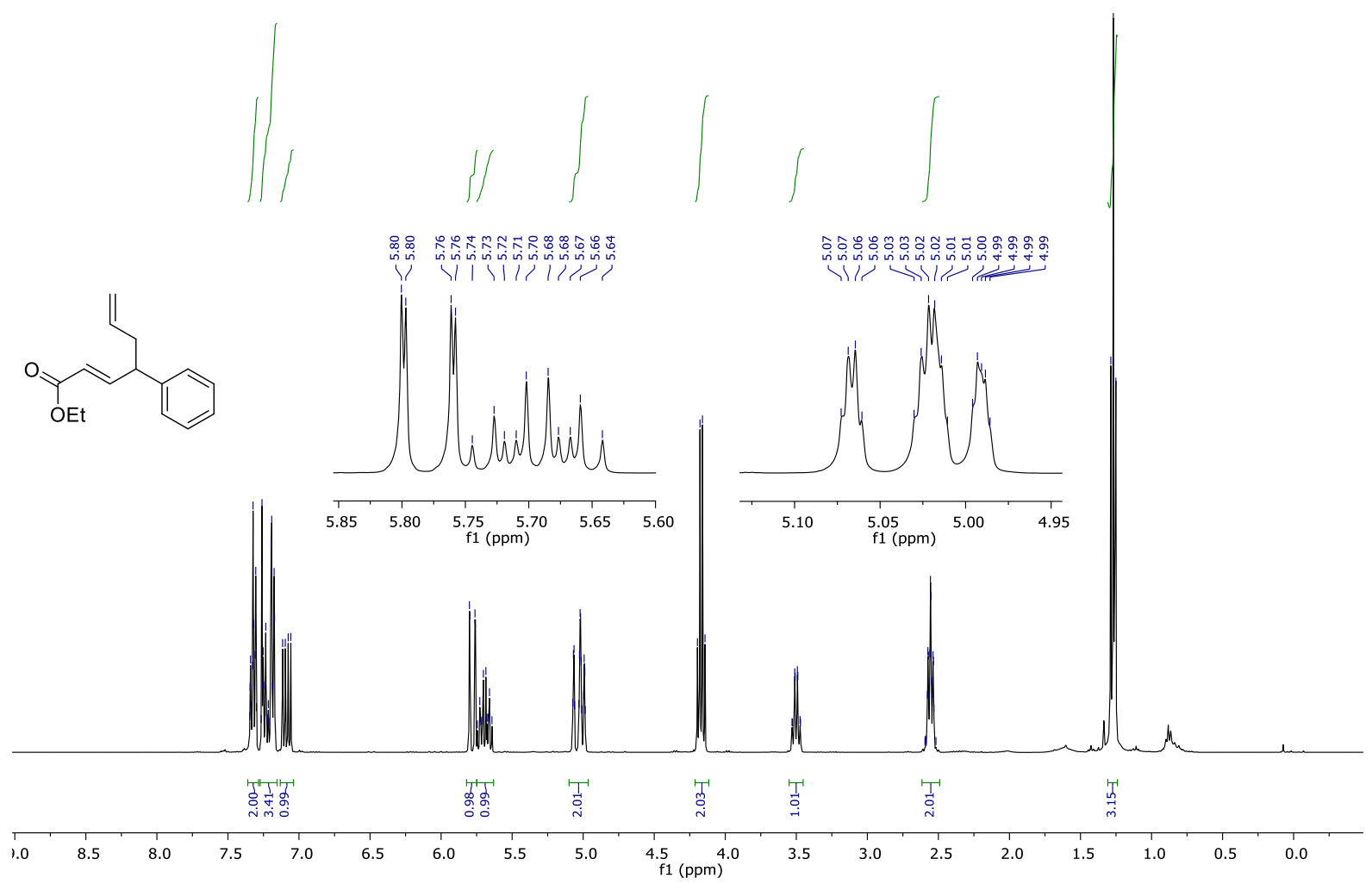

${ }^{13}$ C-NMR (101 MHz, $\mathrm{CDCl}_{3}$ ) of compound 10

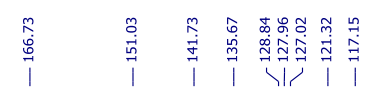
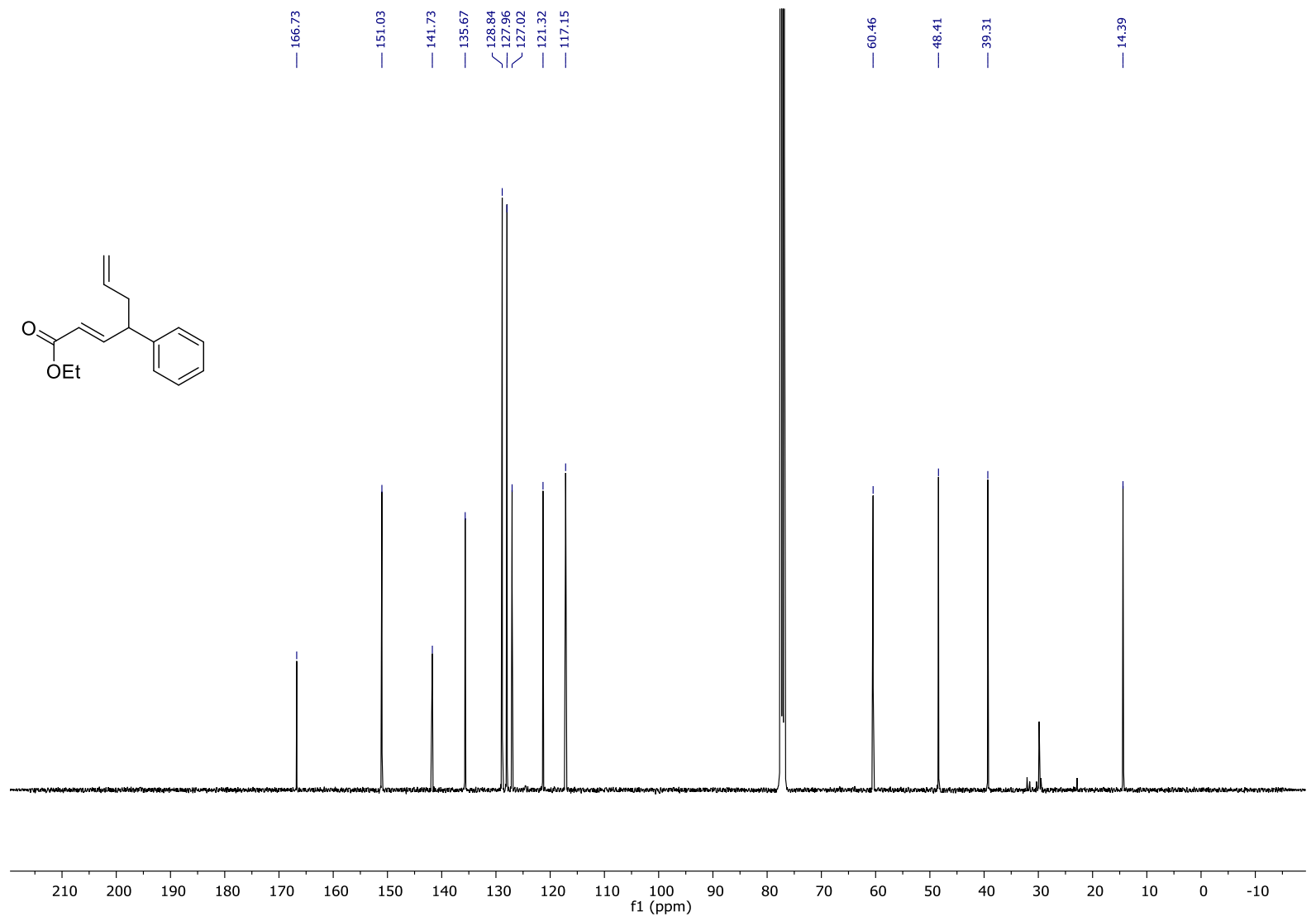

S155 
${ }^{1} \mathrm{H}-\mathrm{NMR}\left(400 \mathrm{MHz}, \mathrm{CDCl}_{3}\right.$ ) of compound $\mathbf{1 1}$

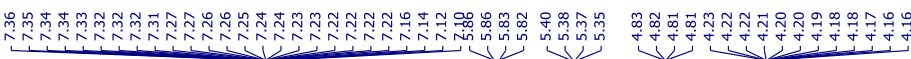

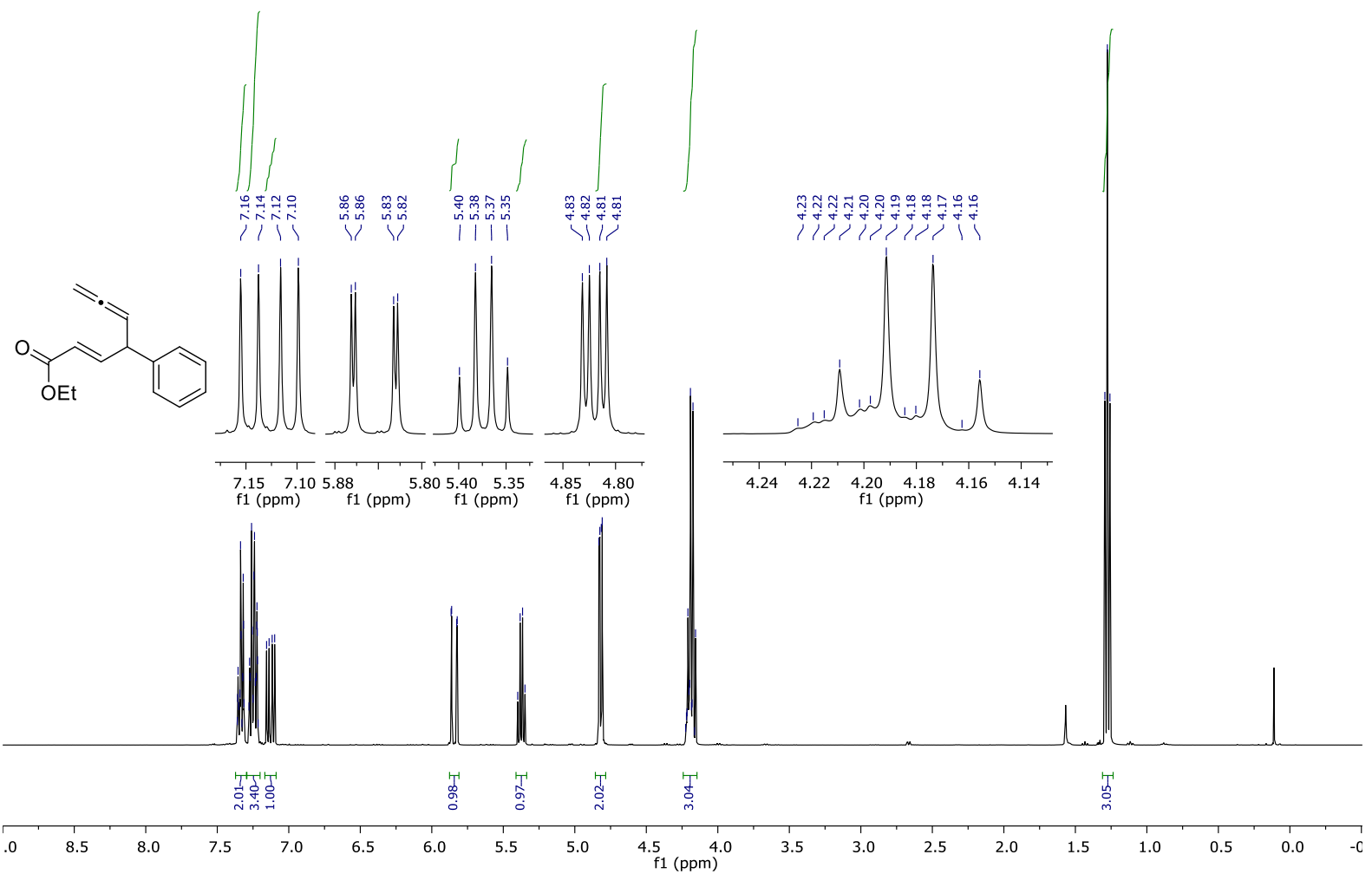

${ }^{13}$ C-NMR (101 MHz, $\mathrm{CDCl}_{3}$ ) of compound 11

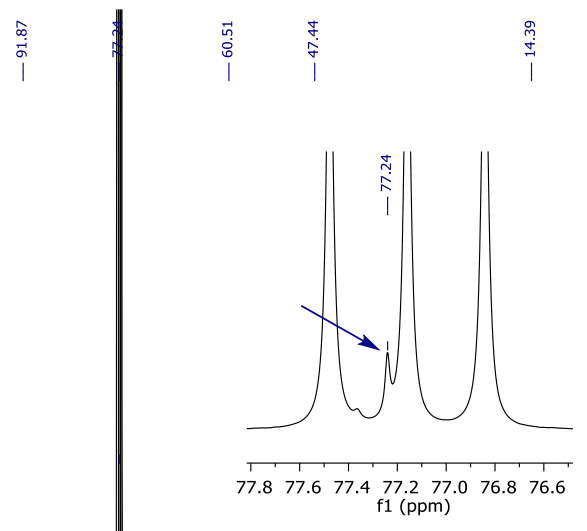<smiles>C=C/C(=C\C(=O)OCC)c1ccccc1</smiles>

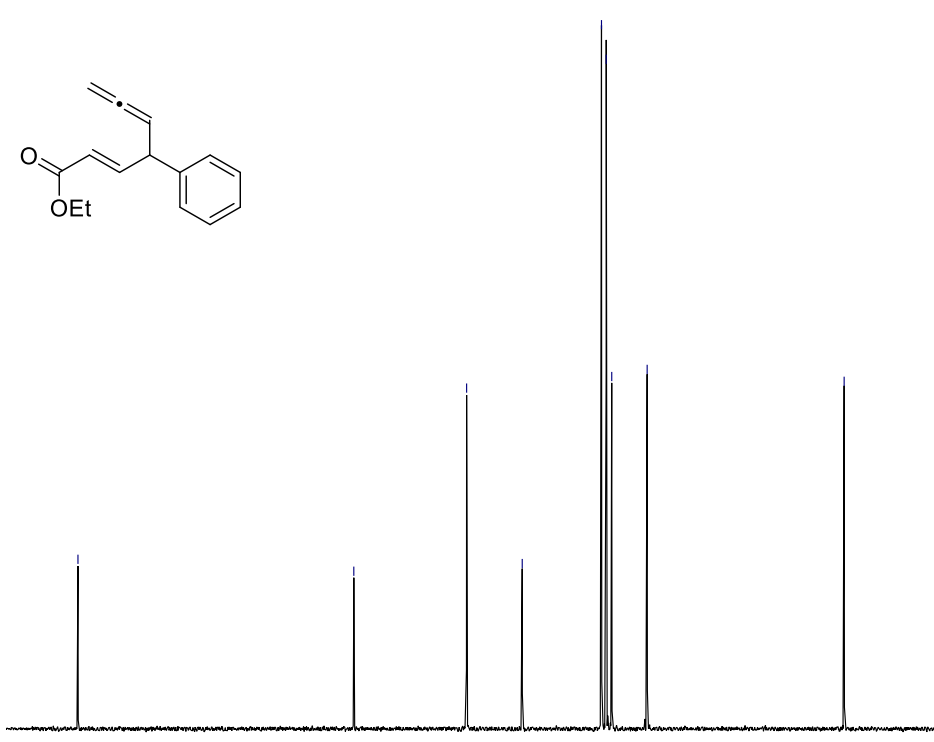

77.877 .677 .477 .277 .076 .876 .6

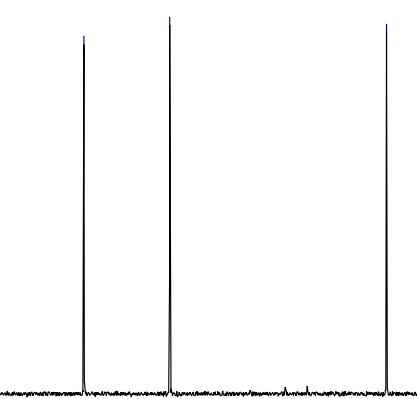

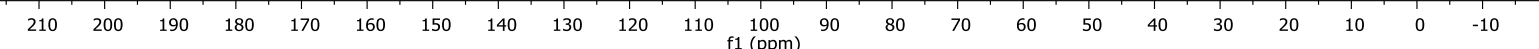


${ }^{1} \mathrm{H}-\mathrm{NMR}\left(400 \mathrm{MHz}, \mathrm{CDCl}_{3}\right)$ of compound 13

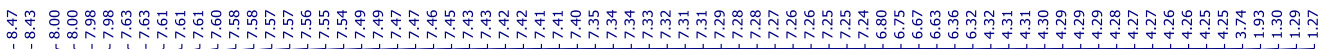

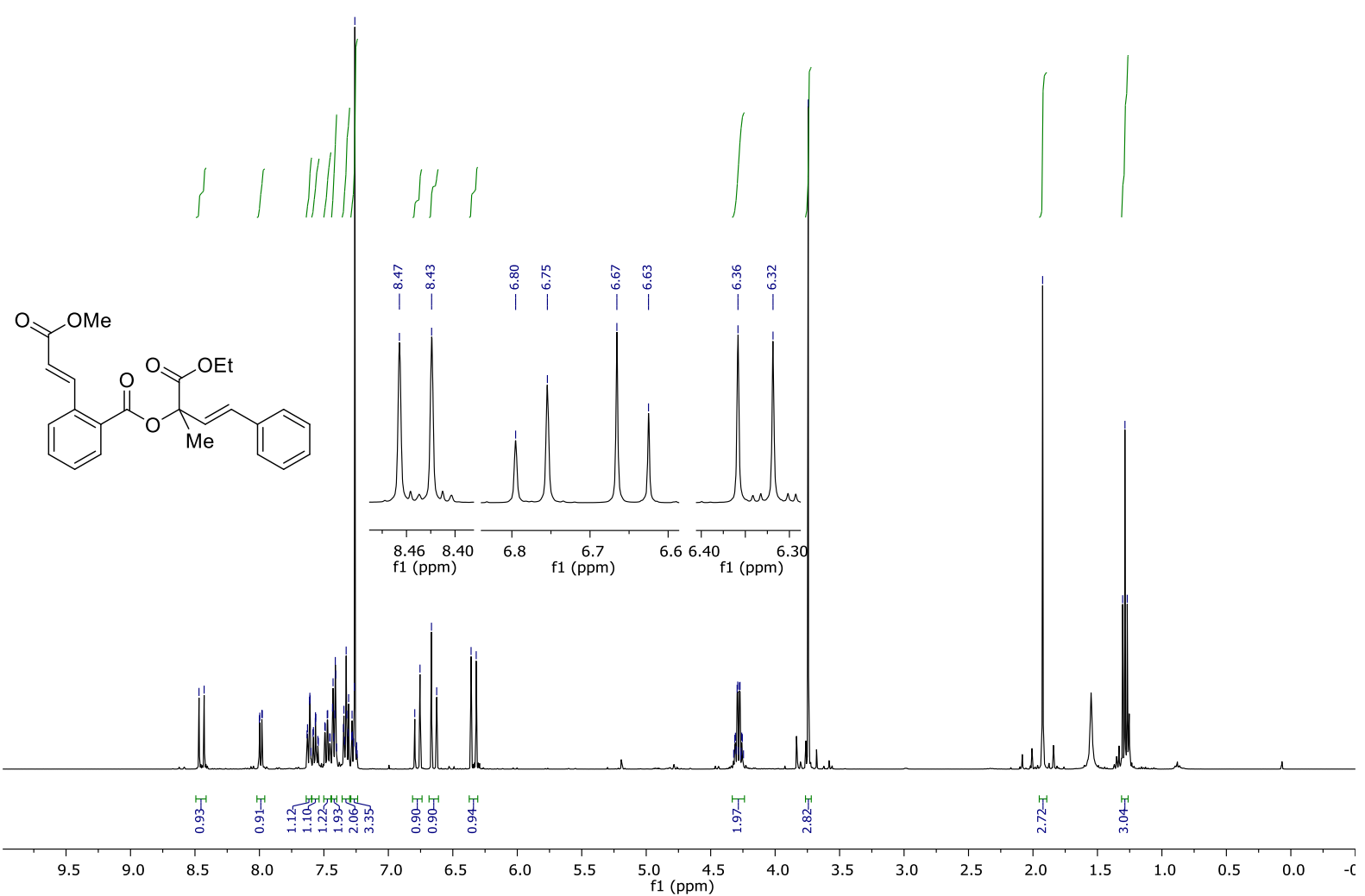

${ }^{13} \mathrm{C}-\mathrm{NMR}\left(101 \mathrm{MHz}, \mathrm{CDCl}_{3}\right)$ of compound 13

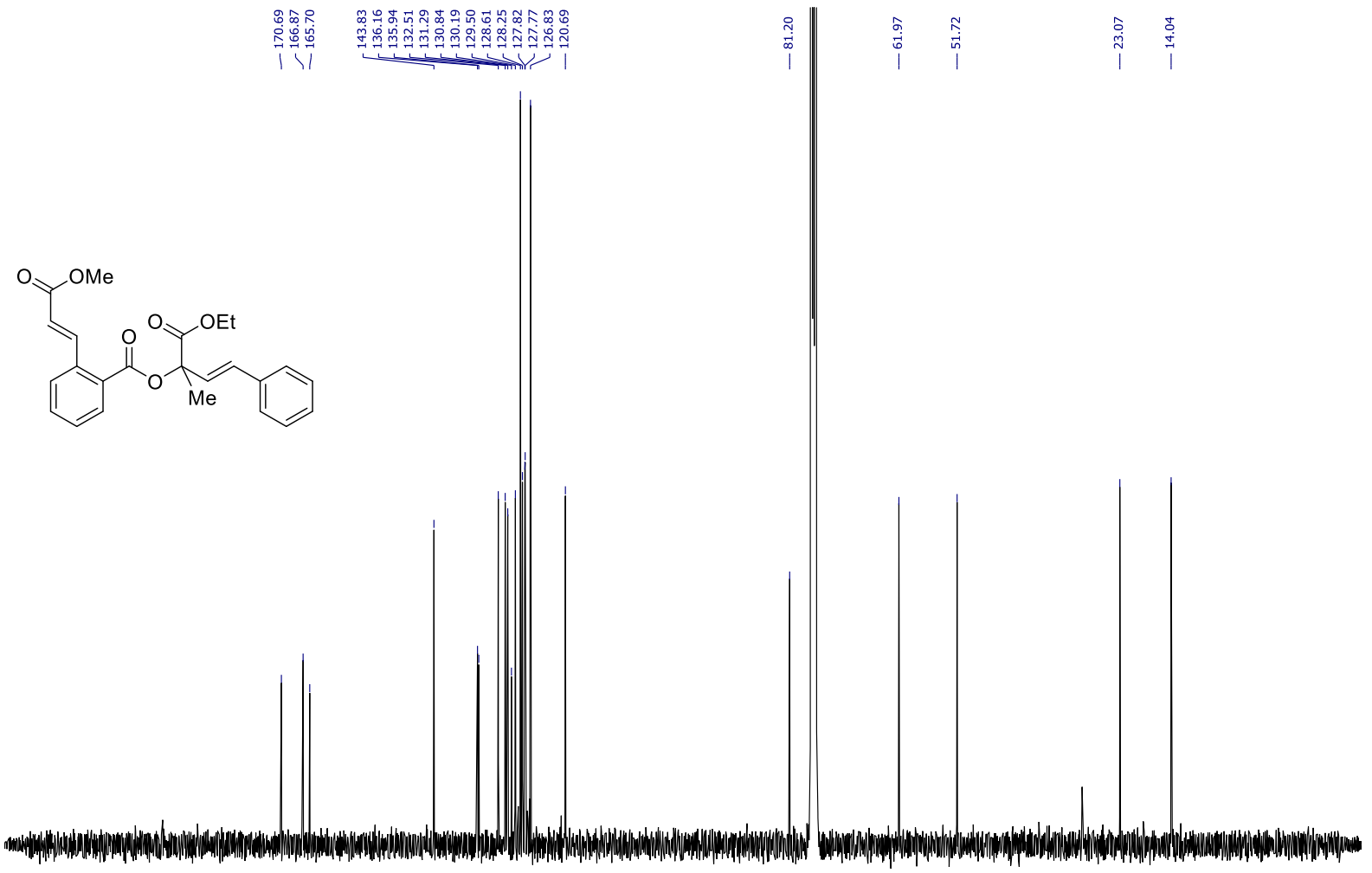

$\begin{array}{llllllllllllllllllllllll}210 & 200 & 190 & 180 & 170 & 160 & 150 & 140 & 130 & 120 & 110 & 100 & 90 & 80 & 70 & 60 & 50 & 40 & 30 & 20 & 10 & 0 & -10 & \end{array}$ 
${ }^{1} \mathbf{H}-\mathrm{NMR}\left(400 \mathrm{MHz}, \mathrm{CDCl}_{3}\right.$ ) of compound 14

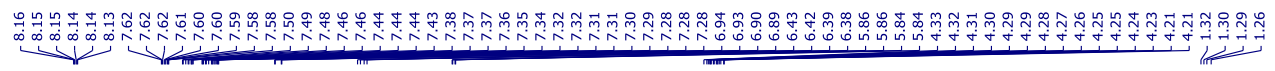

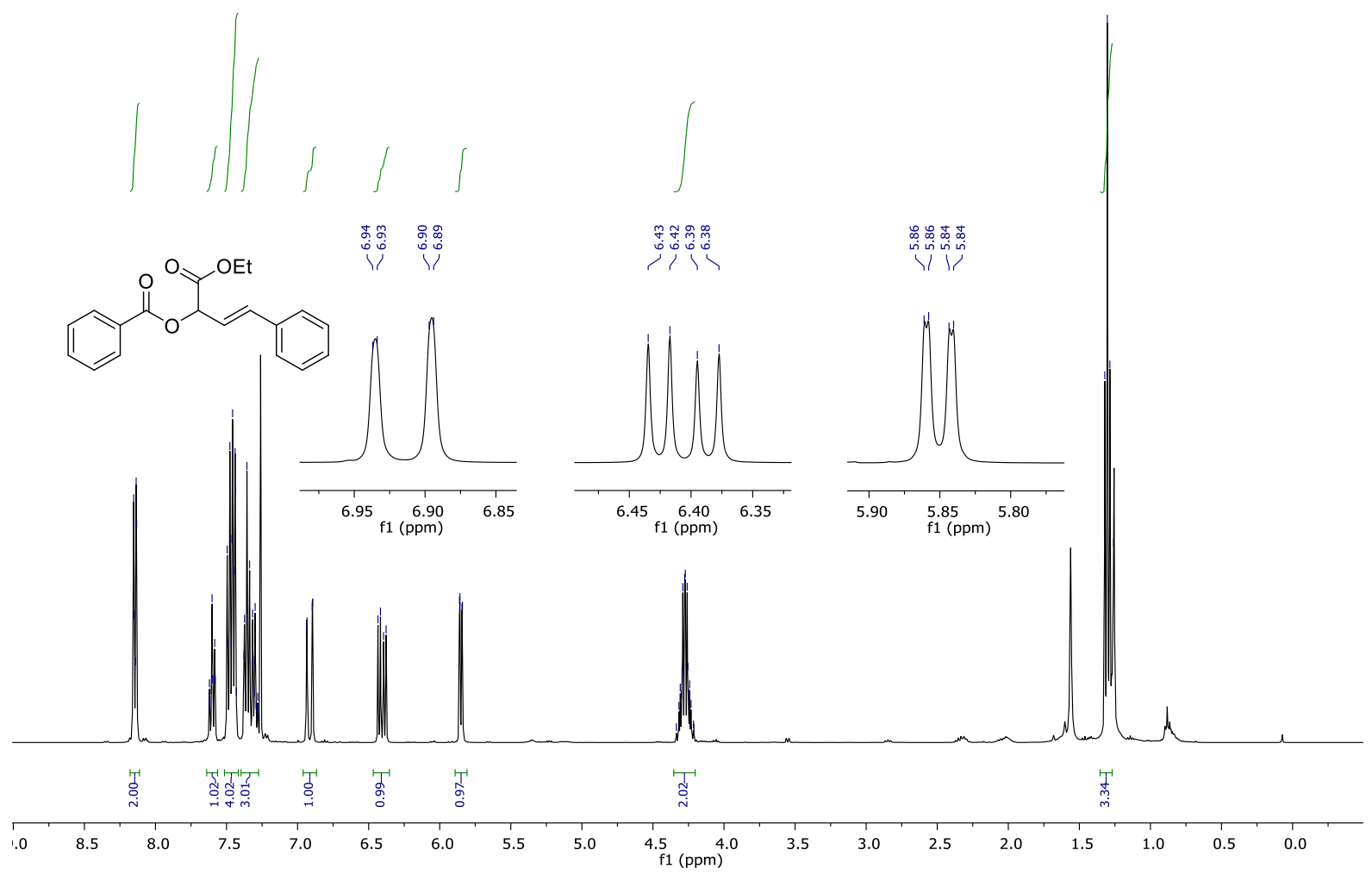

${ }^{13}$ C-NMR (101 MHz, $\mathrm{CDCl}_{3}$ ) of compound 14

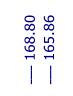

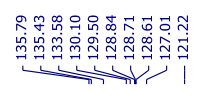
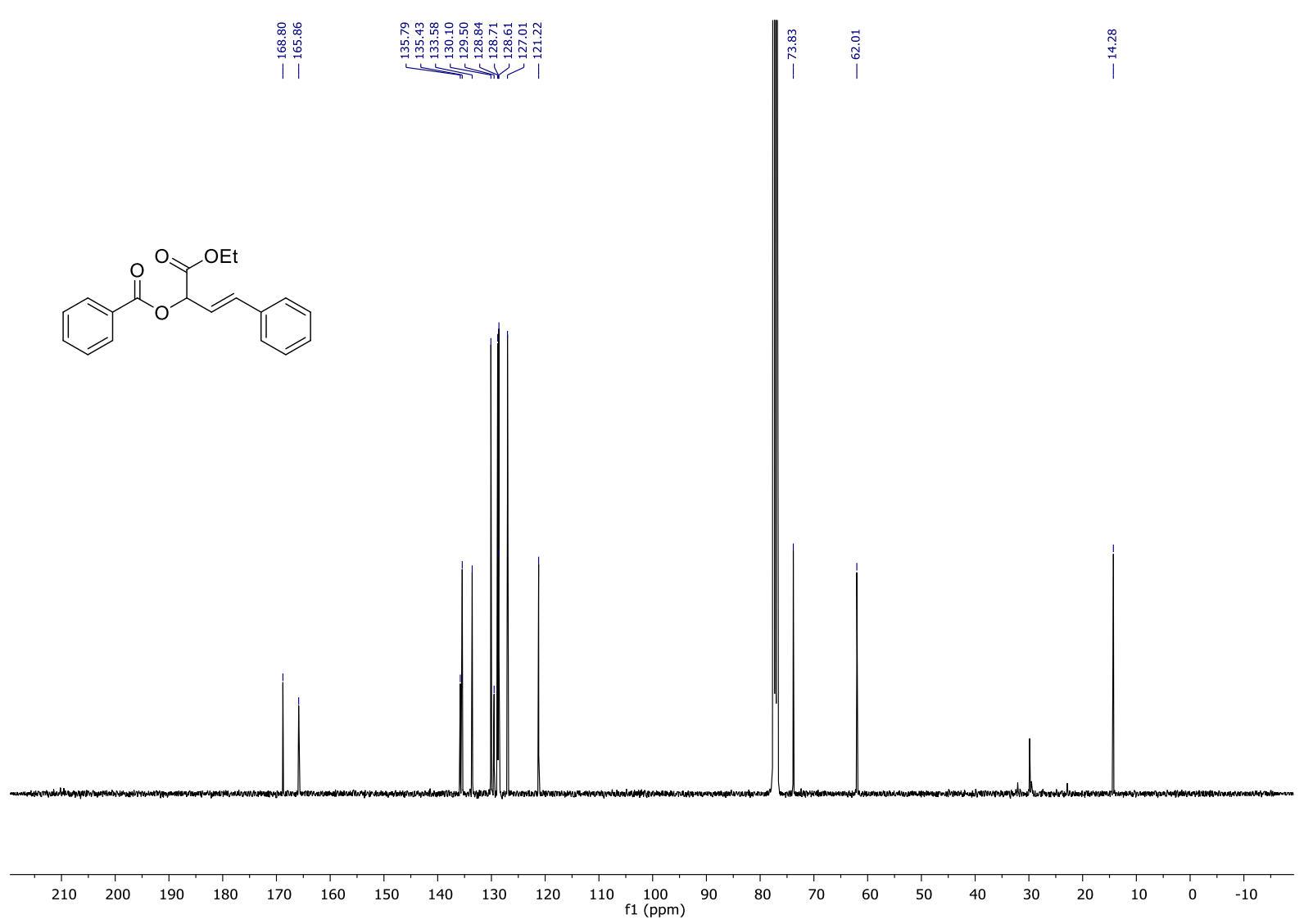

S158 
${ }^{1} \mathbf{H}-\mathrm{NMR}\left(400 \mathrm{MHz}, \mathrm{CDCl}_{3}\right)$ of compound 15

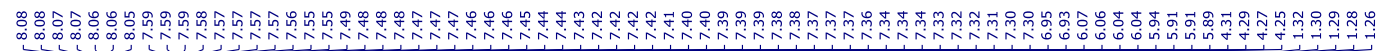

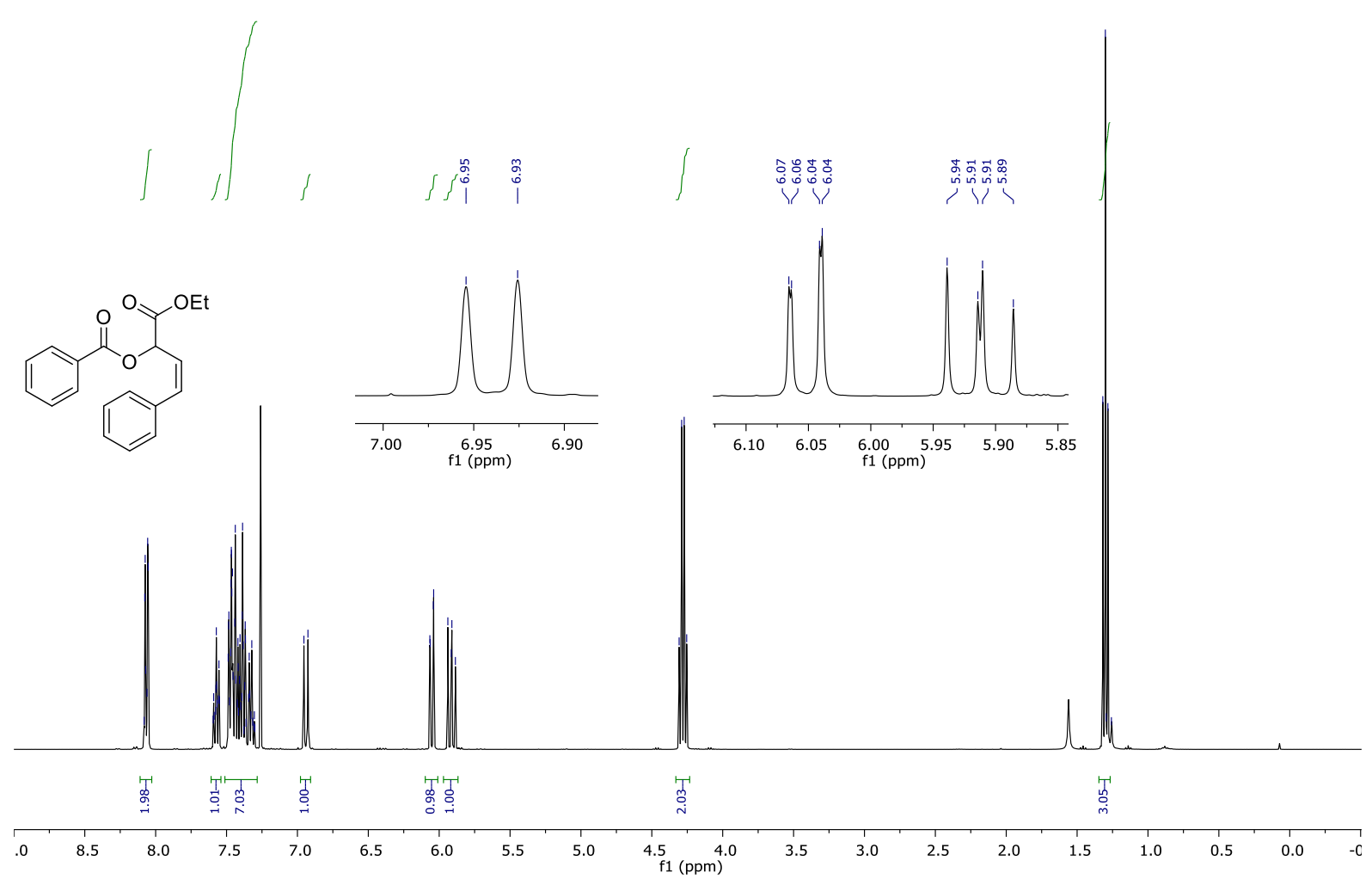

${ }^{13} \mathrm{C}-\mathrm{NMR}\left(101 \mathrm{MHz}, \mathrm{CDCl}_{3}\right.$ ) of compound 15

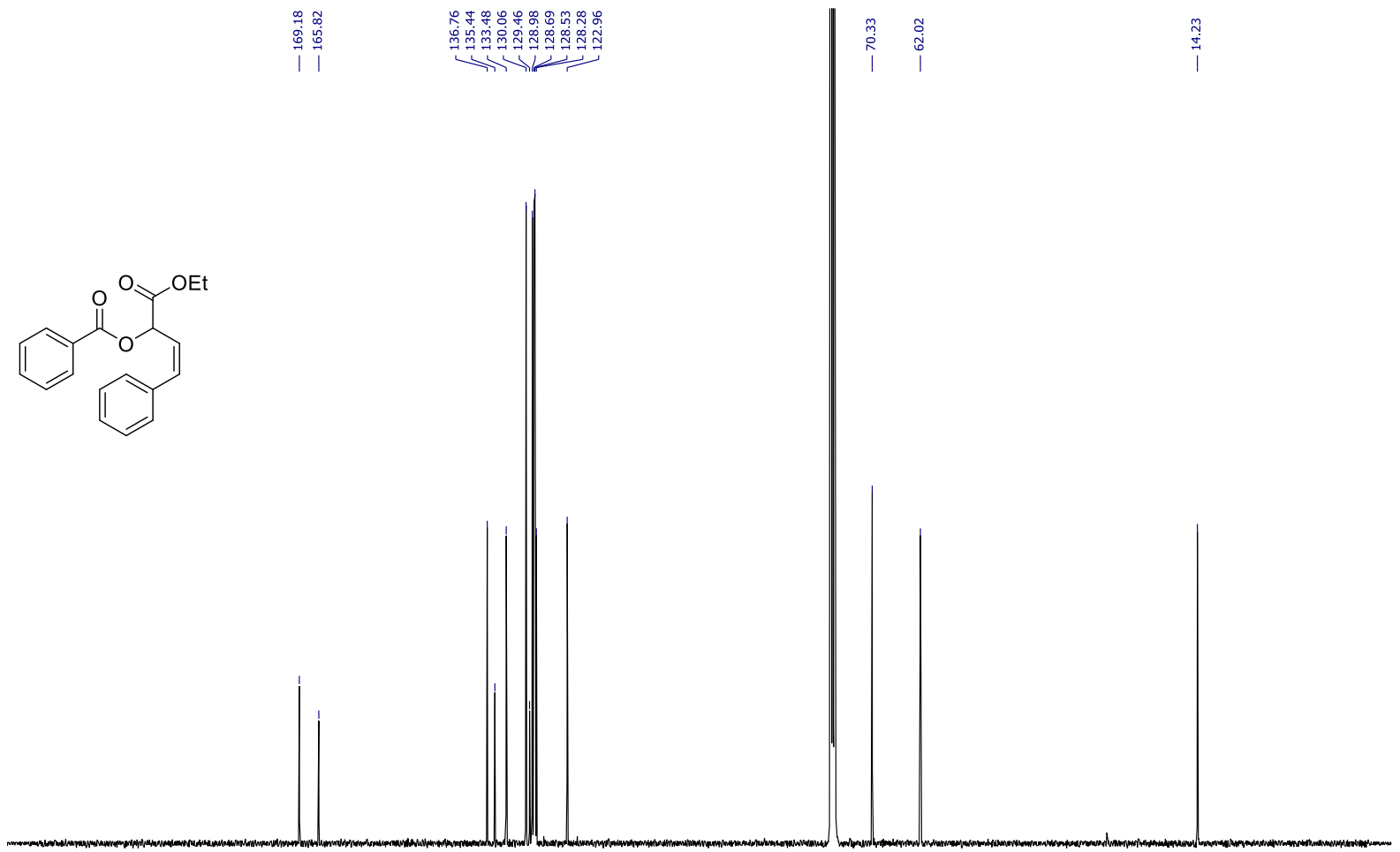

$\begin{array}{lllllllllllllllllllllll}210 & 200 & 190 & 180 & 170 & 160 & 150 & 140 & 130 & 120 & 110 & 100 & 90 & 80 & 70 & 60 & 50 & 40 & 30 & 20 & 10 & 0 & -10\end{array}$ 